HCP/T4024-01/15
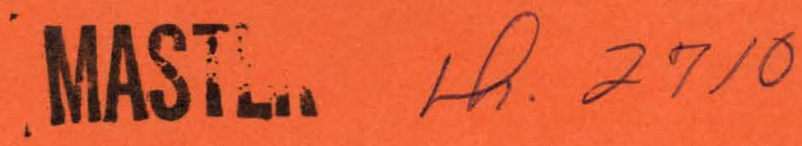

\title{
System Tests and Applications \\ Photovoltaic Program
}

Published May 1979

Prepared for:

U.S. Department of Energy

Assistant Secretary for energy Technology

Division of Central Solar Technology

Under Contract No. EG-77-C-01-4024 


\section{DISCLAIMER}

This report was prepared as an account of work sponsored by an agency of the United States Government. Neither the United States Government nor any agency Thereof, nor any of their employees, makes any warranty, express or implied, or assumes any legal liability or responsibility for the accuracy, completeness, or usefulness of any information, apparatus, product, or process disclosed, or represents that its use would not infringe privately owned rights. Reference herein to any specific commercial product, process, or service by trade name, trademark, manufacturer, or otherwise does not necessarily constitute or imply its endorsement, recommendation, or favoring by the United States Government or any agency thereof. The views and opinions of authors expressed herein do not necessarily state or reflect those of the United States Government or any agency thereof. 


\section{DISCLAIMER}

Portions of this document may be illegible in electronic image products. Images are produced from the best available original document. 


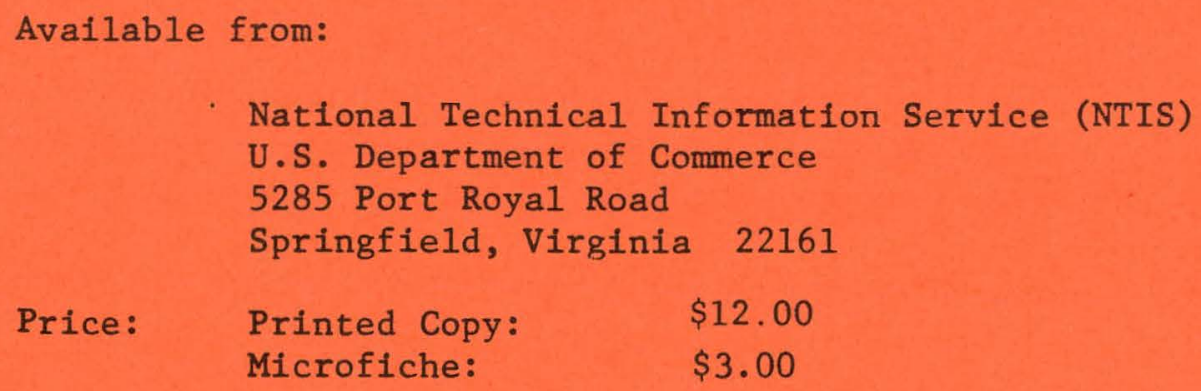




\section{System Tests and Applications Photovoltaic Program}

Published May 1979

Prepared for: U.S. Department of Energy

Assistant Secretary for Lnergy Techniöluyy Division of Central Solar Technology

Washington, D.C. 20585

Prepared by:

PRC Energy Analysis Company

McLean, Virginia 22102

Under Contract No. EG-77-C-01-4024 


\section{NOTICE}

This report was prepared as an account of work sponsored by the United States Government. Neither the United States nor the United States Department of Energy, nor any of their omployees, makes any warranty, express or implied, or ames any logal liability or responsibility for the accuracy. completeness, or usefulness of any information, apparatus, product, or process disclosed, or represents that its use would not infringe privately owned rights. Reference herein to any specific commercial product, process, or service by trade name, mark, manufacturer, or otherwise, does not necessarily constitute or imply its endorsement, recommendation, or fevoring by the United States Government or any ogency thereof. The views and opinions of authors expressed herein do not necessarily state or reflect those of the United States Government or any epency thereot. 


\section{PREFACE}

Photovoltaic Solar Energy Conversion Systems hold significant promise in reducing our dependence on fossil fuels by directly converting sunlight into electricity. When light energy, or photons, strike and penetrate certain materials called semiconductors, internal charges (positive and negative) are created. In devices specially designed for the purpose (i.e., solar cells) built-in "potential voltage barriers" separate the light generated charges and useful power (electricity) may be drawn off. This technology is a clean, simple method which requires no complex machinery or intermediate conversion to heat. In addition, photovoltaic systems are intrinsically modular which enables. them to be sized to fit any need, such as small remote, residential, industrial, or central station applications.

Photovoltaic conversion systems were first used extensively in the U.S. space program where they provided electricity for space craft and satellites. The basic technology has therefore been proven, and many terrestrial applications of photovoltaic systems already exist. These early applications are being implemented to develop information on operational costs, reliability, and performance and to acquaint potential customers with the characteristics and feasibility of such systems. Various medium to large-scale experiments will be installed to:

- Address technical questions relating to systems integration, performance, reliability, and maintenance;

- Gather data on photovoltaic systems energy costs; and

- Identify potential legal or institutional barriers.

Applications of increasing complexity will be implemented later

to:

- Incorporate technology advances from the ongoing research and development efforts;

- Provide potential users with system design, construction, and operational experience; and

- Stimulate a growing market for photovoltaic systems thus encouraging i.ndustry growth. 
This document is a summary of all the photovoltaic system tests and application experiments that have been initiated since the start of the program in 1975. They have been organized in the following manner for ease of reference:

- Application Experiments: These are independently designed and constructed projects which are funded by DOE;

- System Field Tests: Projects designed and monitored by the national laboratories involved in the photovoltaic program;

- Exhibits: Designed to acquaint the general public to photovoltaics;

- Component Field Tests: Real time endurance testing conducted to monitor module reliability under actual environmental condi'tions;

- Test Facilities: Descriptions of the four national laboratories involved in the photovoltaic program. 
Application Experiments

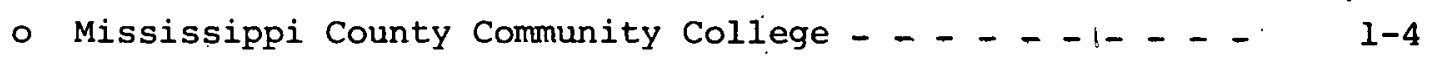

- PRDA-35 Concentrator Applications - . - . - . - . 5-42

- PRDA-38 Flat Panel Applications _ . . . . . . . . 43-70

\section{System Field Tests}

o Air Pollution Monitor _ _ _ _ _ . . . . . . $71-72$

- Agricultural Flexible Experiment - _ - _ - - - - 73-84

o Datléry Clarger txperıment _ _ . . . . . . . . 85-90

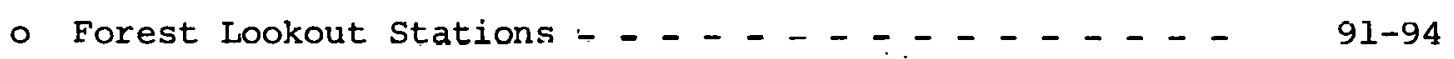

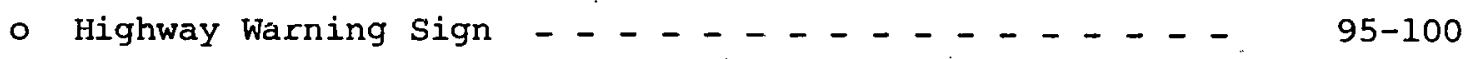

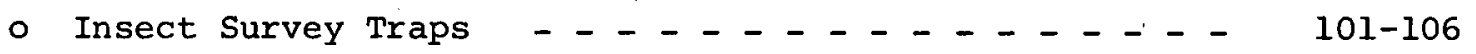

o Mt. Laguna Air Force Station Project - _ - - - - - 107-110

- Natural Bridges National Monument Project _ - _ - - 111-118

- Radar, DOD Remote Experiment _ - _ - _ - _ - - 119-122

- Radio

- Radio Relay Experiment _ _ - _ - _ - _ - - 123-126

- Radio Station Dispersed System - _ - _ . - _ - - 127-132

- RAMOS (Remote Automatic Meteorological Observation
Systems) Experiments

- Refrigerator Experiments

- Sil Nakya Indian Village _ - _ - _ . . . . - 141-144

- Isle Royale National Park _ _ _ . . . . . - 145-148

o Residential Hybrid Experiment _ _ . . . . . . 149-152

o Schuchuli Indian Village Power System _. . . . . . 153-160

- Seismic Sensor, USGS Experiment _ - _ - _ - - - - 161-162 


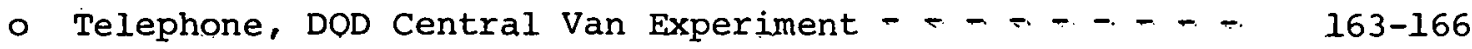

o Water purification System Experiment - +. - + - 167-170

\section{Exhibits}

o Chicago Museum Exhibit - - - - - - - - - - - 171-178

o Display Exhibits - - - - - - - - - - - 179-182

- Electric Vehicle Demonstrations

- Festival of American Folklife Exhibit - - - - - 183-186

- Lawrence Livermore Laboratory Solar Survey. - - - - 187-188

o Television Application Exhibit - - - - - - - - 189-192

o Water Cooler/Display - - - - - - - - - - 193-196

Component Field Tests

o Real Time Endurance Testing - - - - - - - - 197-204

- JPL Tests (4 sites) - - - - - - - 205-242

- NASA-LeRC (12 sites) - - - - - - - - - 243-256

- MIT-Lincoln Lab (7 sites) - - - - - - - - 257-265

- Mt. Washington Test Site - - - - - = - 266 -274

\section{Test Facilities}

o JPI - - - - - - - - - - - - -

$275-290$

0 MIT-Lincoln Laboratory _ _ . . . . . . . . . 291-300

- NASA-LeRC

- Systems Test Facility (STF) _ _ _ _ - . - . $301-304$

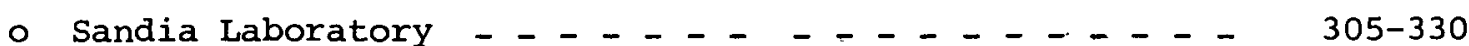




\begin{tabular}{|l|l|}
\hline LOCÁTION: Blythesville, Arkansas & OPERATIONAL DATE: August 1979 \\
\hline USER AGENCY: $\mathrm{MC}^{3}$ & DESIGNER: TEAM inc. \\
\hline
\end{tabular}

USE: Provide electrical power for entire college; also heating and cooling.

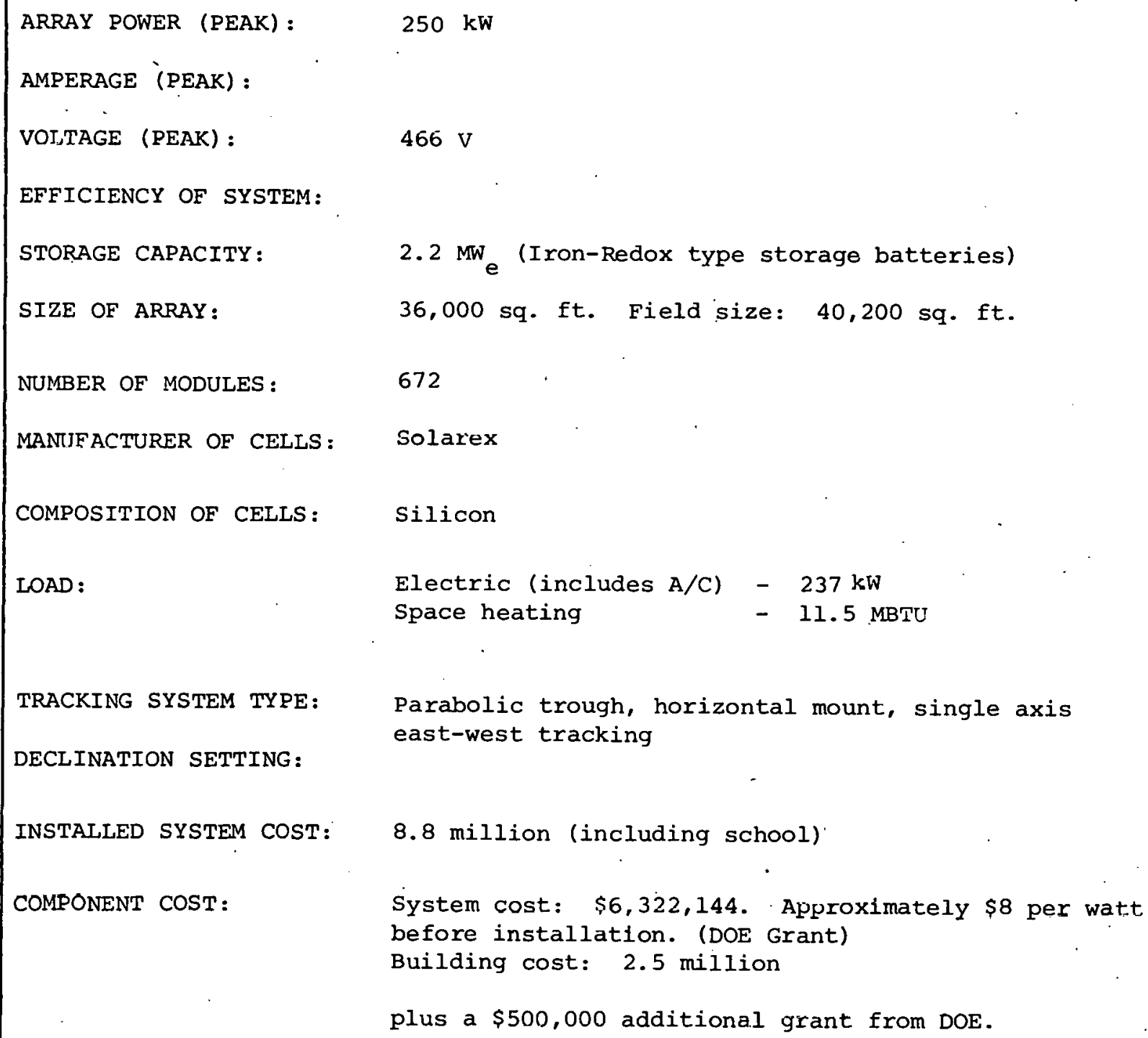

SPECJAL DESIGN FEATURES:

Building will not be completed until 1 year later (summer 1980), Honeywell and Acurex bids to manufacture the array were turned down in December 1978. A new RFP was issued in January 1979 with a contractor to be selected by March 1 st 1979. 
DATE :

TIME SINCE INSTALLATION:

CLEANING :

MODULE FAILURES (if any):

SYSTEM DEGRADATION (if any):

SPECIAL NOTES :

DATE:

TIME SINCE INSTALLATION:

CLEANING :

MODULE FAILURES (if any):

SYSTEM DEGRADATION (if any):

SPECIAL NOTES :

DATE :

TIME SINCE INSTALLATION:

CLLEANING:

MODULE FAILURES (if any):

SYSTEM DEGRADATION (if any):

SPECIAL NOTES : 


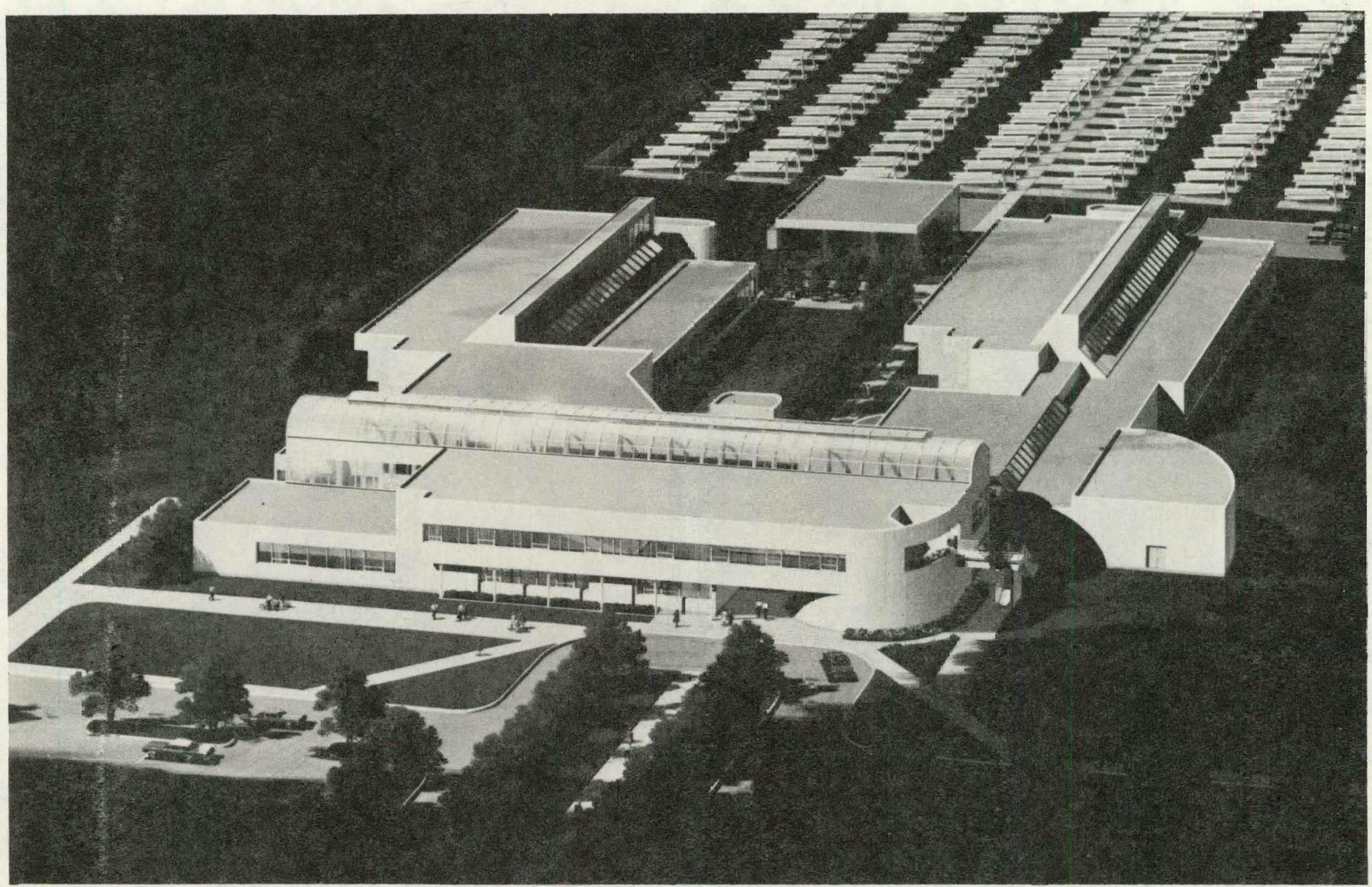

Mississippi County Conmunity College

B-ytheville, Arkansas 
THIS PAGE INTENTIONALLY LEFT BLANK 
Photovoltaic Concentrator Applications Experiments

Sandia Laboratories

(PRDA-35)

As part of the national program for technology development in solar photovoltaics, the U.S. Department of Energy (DOE) has initiated a three-phased plan to design, fabricate, and operate and evaluate several different onsite photovoltaic concentrator experiments. These systems, ranging from 20 to $500 \mathrm{~kW}$ peak electrical output, will be installed in a variety of applications. They will be operated for 1 to 2 years to obtain technical performance data and other non-technical data. Systems and applications were chosen from responses to a DOE Program Research and Development Announcement (PRDA) issued by the DOE Albuquerque Operations offlce. Seventy-seven proposals were received in response to the PRDA, and 17 experiments, representing $2.32 \mathrm{MW}$ of peak power, werc selected for Phase I, System Design. Sandia Laboratories provides technical assistance in project management.

Phase I was initiated June 1, 1978, and will be completed February 28, 1979. At that time the system designs will be evaluated and several projects selected for Phase II, System Fabrication. Phase II should start in June 1979. Up to 12 months will be required to complete system fabrication and checkout. Thus, the first largescale photovoltaic concentrator experiments should be operational by mid-1980. Phase III, Operation and Fivaluation, follows for a designated period up to 2 years.

The proposers were asked to provide budget estimates for Phase II. Using these estimates, which include program management and other nonsystem costs, Sandia calculated an installed cost for each selccted system. Distribution of these costs, in dollars per peak watt of installed system is shown in Figure 3. Custs range from $\$ 12 / \mathrm{w}$ to $\$ 36 / \mathrm{w}$, with an average of $\$ 17.50 / \mathrm{w}$. No distinction was made here between passively cooled systems and actively cooled or total-energy systems. In fact, there does not seem to be a trend of higher cost for actively cooled systems. Some correlation exists between system size and cost per watt; i.e., smaller systems tend to cost more per watt. 
Summary of 17 Photovoltaic Concentrator Applications Exper ments

\begin{tabular}{|c|c|c|c|c|c|c|c|c|c|}
\hline Pr ime Contractor & Site Owner & Location & Application & Size $(k W)$ & Totl. E & Optics & Track & CR & Cell \\
\hline Acurex Corp. & G. N. Wilcox Hosp. & Kaua i, HI & Hospital & 75 & Yes & Ref 1. Dish & $2-\mathrm{Ax}$ & 100 & $\mathrm{Si}$ \\
\hline Ariz. Public Svc. & Phoenix, Az & Phoenix, Az & Airport & 500 & No & Cassegrain & $2-\mathrm{Ax}$ & 70 & $\mathrm{Si}$ \\
\hline Battelle Columbus & C\&SO Electric & Columbus, $\mathrm{OH}$ & of $f / m a$ int. Bldg. & 150 & No & Ref 1 . Tr. & 2-Ax. & 20 & $\mathrm{Si}$ \\
\hline BDM Corp. & Craddock Dev. Co. & Albug., NM & Offize Bldg. & 50 & Yes & Refl. Tr. & $1-A x$ & 42 & $\mathrm{Si}$ \\
\hline Commonwealth of P.R. & v. Puerto Rico & San Juan, PR & Research Bldg. & 150 & Yes & Ref 1 . Slatts & $1-\mathrm{Ax}$. & 40 & $\mathrm{Si}$ \\
\hline E-Systems & Dallas-Ft. Worth, TX & DFW Airport & Airport & 20 & Yes & Lin. Fres. & $2-A x$ & 25 & $\mathrm{Si}$ \\
\hline General Electric & Sea world & Or lando, FL & Mar ine Exhibit & 305 & Yes & Refl. Tr. & $2-A x$ & 34 & $\mathrm{Si}$ \\
\hline InterTechnology & Warrenton, VA H.S. & Warrenton, VA & High: School & 20 & No & Refl. Tr. & $1-A x$ & 40 & $\mathrm{Si}$ \\
\hline Kaman Sciences & Kaman Sciences & Colo. Sprs, CO & Comput ing Ctr. & 54 & Yes & Cir. Fres. & $2-A x$ & 32 & $\mathrm{Si}$ \\
\hline LA Dept. Water/Power & LA Dept. Water/Power & Sun Valley, CA & Generating Plant & 200 & No & Refl. Tr. & $2-A x$ & 20 & $\mathrm{Si}$ \\
\hline Martin Mar ietta & State of $\mathrm{CO}$ & Roxborough Pk, CO & Park Visitor Ctr. & 80 & No & Cir. Fres. & $2-A x$ & 40 & $\mathrm{Si}$ \\
\hline RTI & RTI & Research Pk, NC & Resfarch Bldg. & 160 & No & Cassegrain & $2-A x$ & 70 & $\mathrm{Si}$ \\
\hline Solarex Corp. & Solarex Corp. & Rockville, MD & Solar Cell Mfg. & 200 & Yes & Ref1. Tr. & $2-A x$ & 40 & $\mathrm{Si}$ \\
\hline Sun Trac Corp. & McGraw-Edison & Racine, WI & Indust. Light. & 50 & No & 2-D CPC & $2-A x$ & 50 & $\mathrm{si}$ \\
\hline Texas Tech & G.G. Passmore & Reeves Co., TX & Irr -gation & 200 & No & Ref1. Tr. & $2-\mathrm{Ax}$ & 40 & $\mathrm{Si}$ \\
\hline Var ian Assoc. & Pacif ic G\&E & San Ramon, CA & Uti:ity sub. & 50 & No & Dir. Fres. & $2-\mathrm{Ax}$ & 500 & GaAs \\
\hline West inghouse & Georgia Power & Fulton Co., GA & Utility Sub. & 50 & No & Lin. Fres. & $2-\mathrm{Ax}$ & 20 & $\mathrm{Si}$ \\
\hline
\end{tabular}




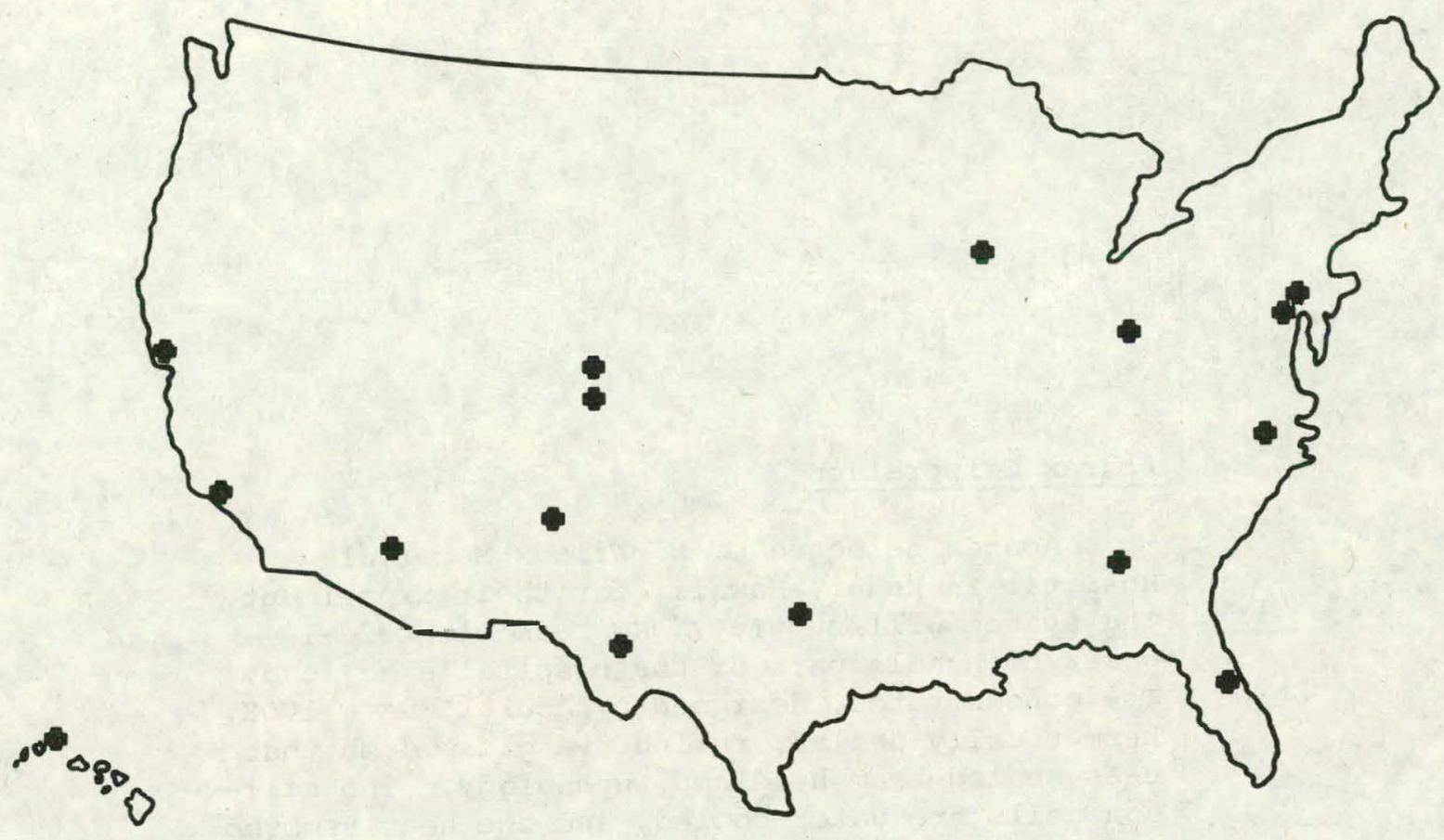

Figure 1 - Map showing site locations of the 17 photovoltaic concentrator applications experiments selected for Phase I, System Design.

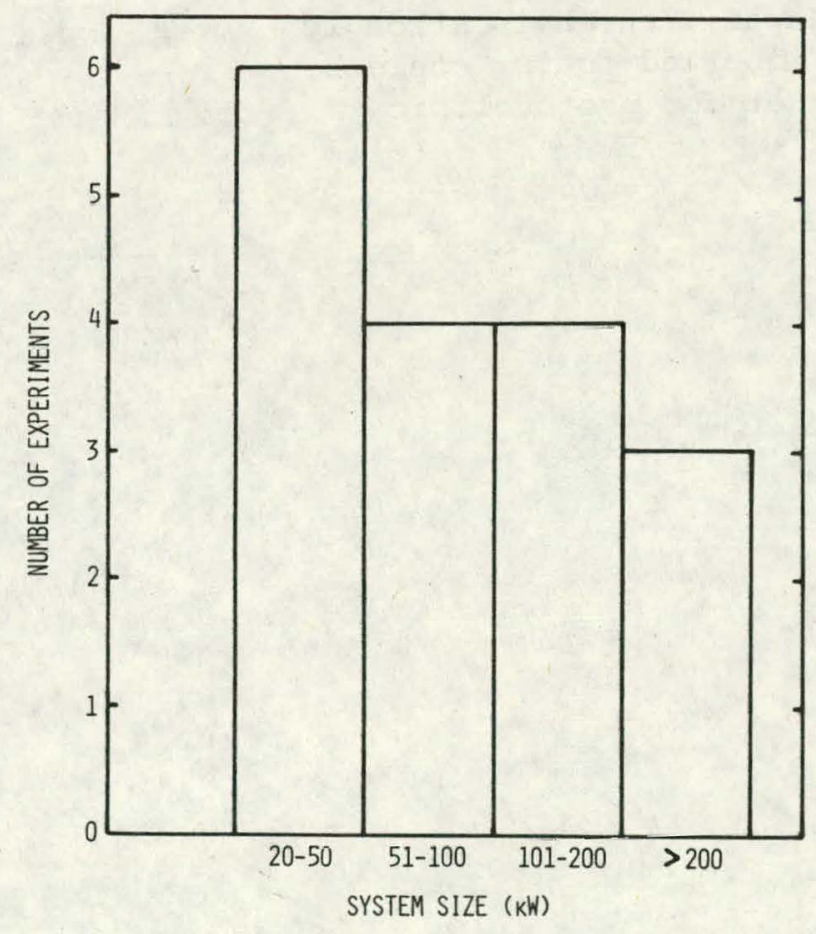

Figure 2 - Distribution of system size for the 17 photovoltaic concentrator applications experiments selected for Phase I, System Design.

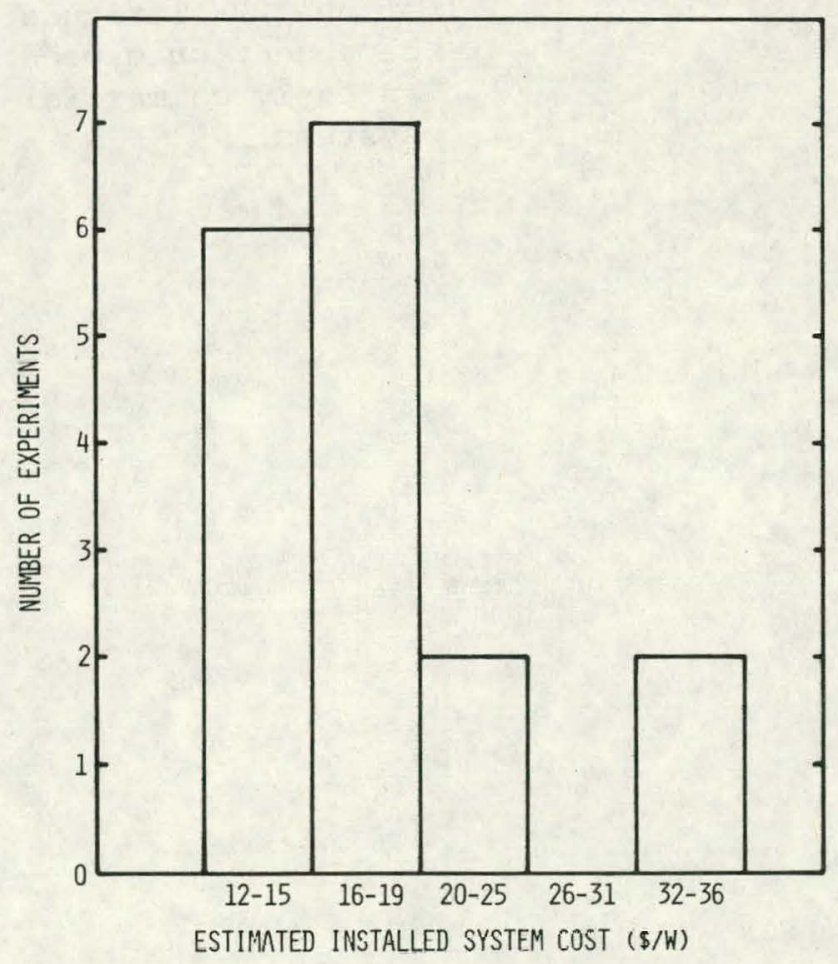

Figure 3 - Distribution of system costs for the 17 photovoltaic concentrator applications experiments selected for Phase I, System Design. 


\section{Acurex Corporation}

Acurex selected G. N. Wilcox Memorial Hospital in Kauai, Hawaii, for their experiment. The system will supply $75 \mathrm{~kW}$ peak electrical power to handle part of the hospital's ac load. The concentrator, designed by Acurex, is a 100x, hermetically sealed, reflective glass dish that uses sealed-beam headlamp technology. The silicon cells are water-cooled, and the heat removed is used to supply part of the hospital's hot water. Hospital air-conditioning and hot-water heating loads peak at midday and in the summer, providing a good match with solar availability at the $22^{\circ}$ latitude. Hawaii, which is strongly dependent on expensive imported fuels, could be an early commercial market for photovoltais systems. 


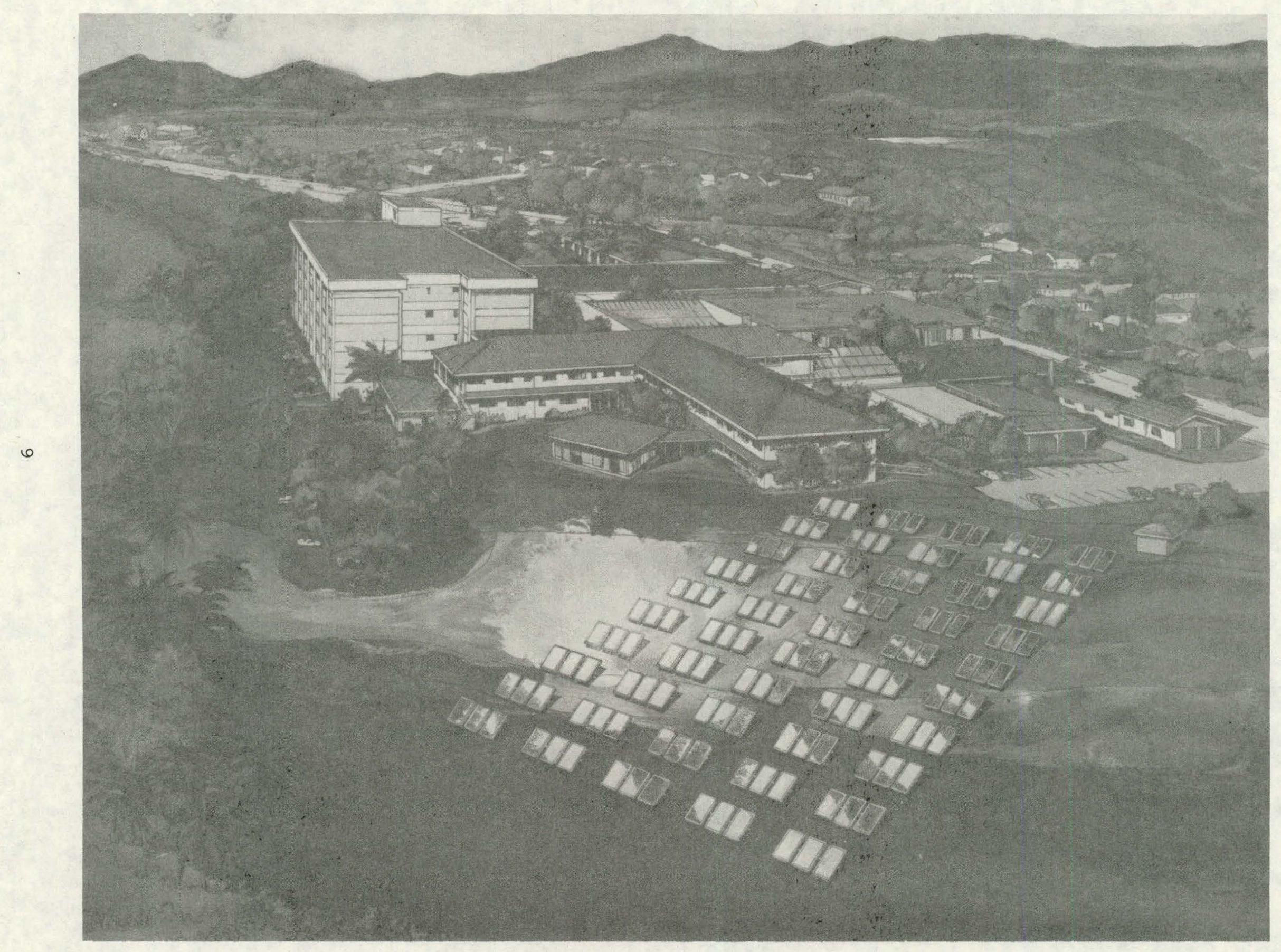




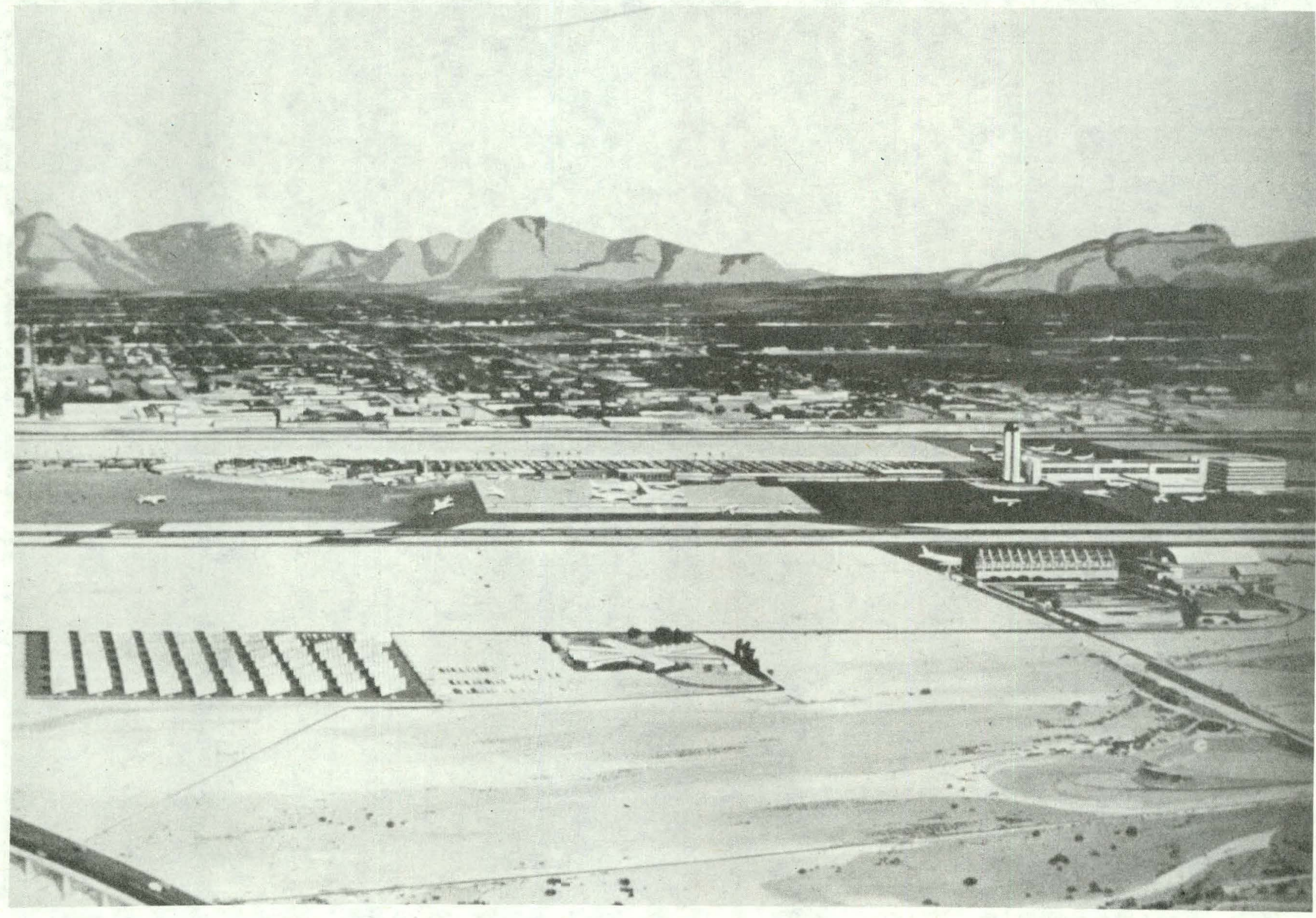




\section{Arizona Public Service Company.}

The Arizona Public Service Company, an electric utility, will design a 500-kw peak electric system for installation at the Phnenix Sky Harbor International Airport. The system, which will be tied directly to the utility's power grid in its primary operational mode, can be connected to an isolated load center in the airport terminal as an alternate operational mode. System size is large enough to be treated as a power generating plant on the grid-system by utility dispatch. A major subcontractor in this project is the Motorola Government Electronics Division for system and array designs. The concentrator will be Motorola's $70 x$ cassegainian module, which utilizes passively cooled silicon cells. 
Battelle Columbus Laboratories

The preliminary conceptual design for the Battelle Columbus Laboratories' experiment is to supply a peak output of $150 \mathrm{~kW}$ to an officemaintenance building in Columbus, $\mathrm{OH}$. The photovoltaic array, designed by spectrolab, will utilize $20 \mathrm{x}$ reflective parabolic troughs mounted on two-axis steerable turntables. The array will be located on a site owned by Columbus and Southern Ohio Electric Company next to the primary experiment load. Several modes of operation will be evaluated, including sinyle-luad opcration, loar-renter operation (multibuilding load) with and without onsite storage, feeding excess power to the utility grid, and parallel operation with the utility source. Nontechnical issues to be addressed include utility rate structure impacts and grid-feedback credits. 


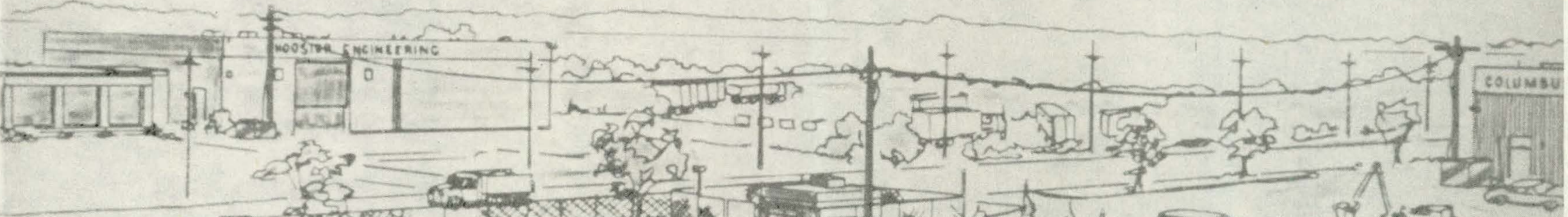

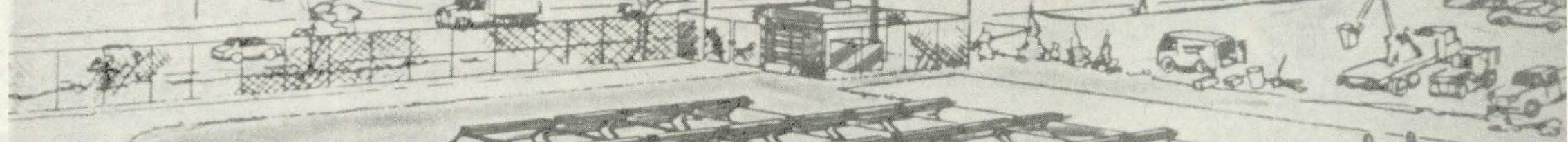

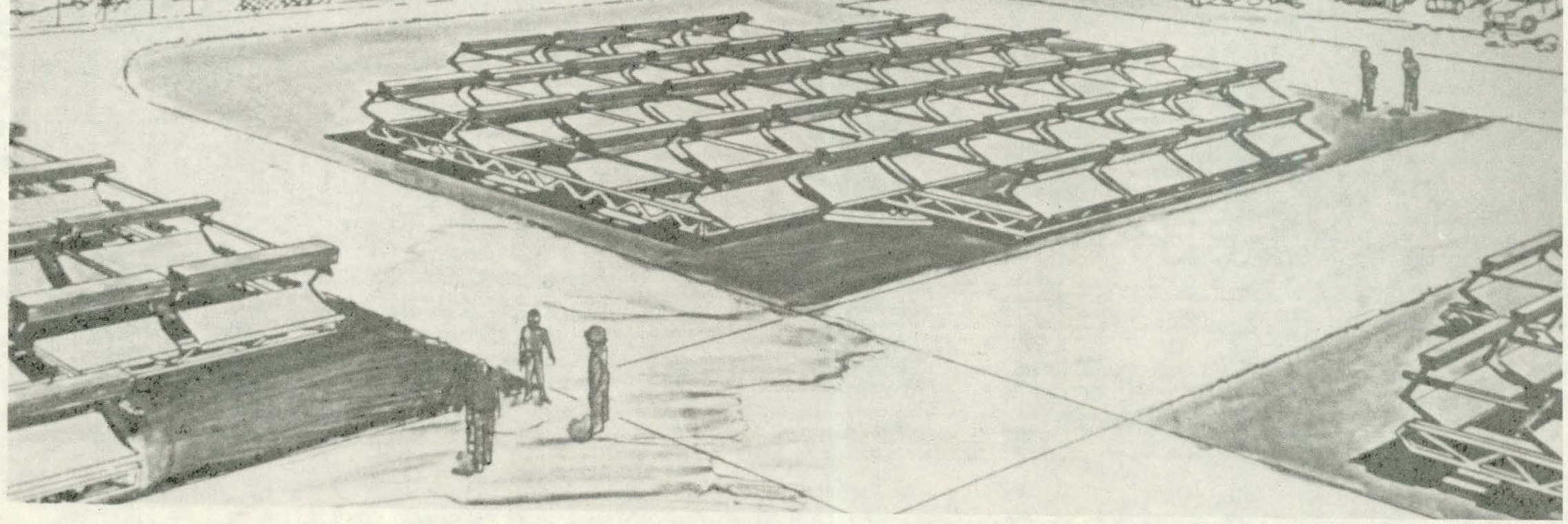




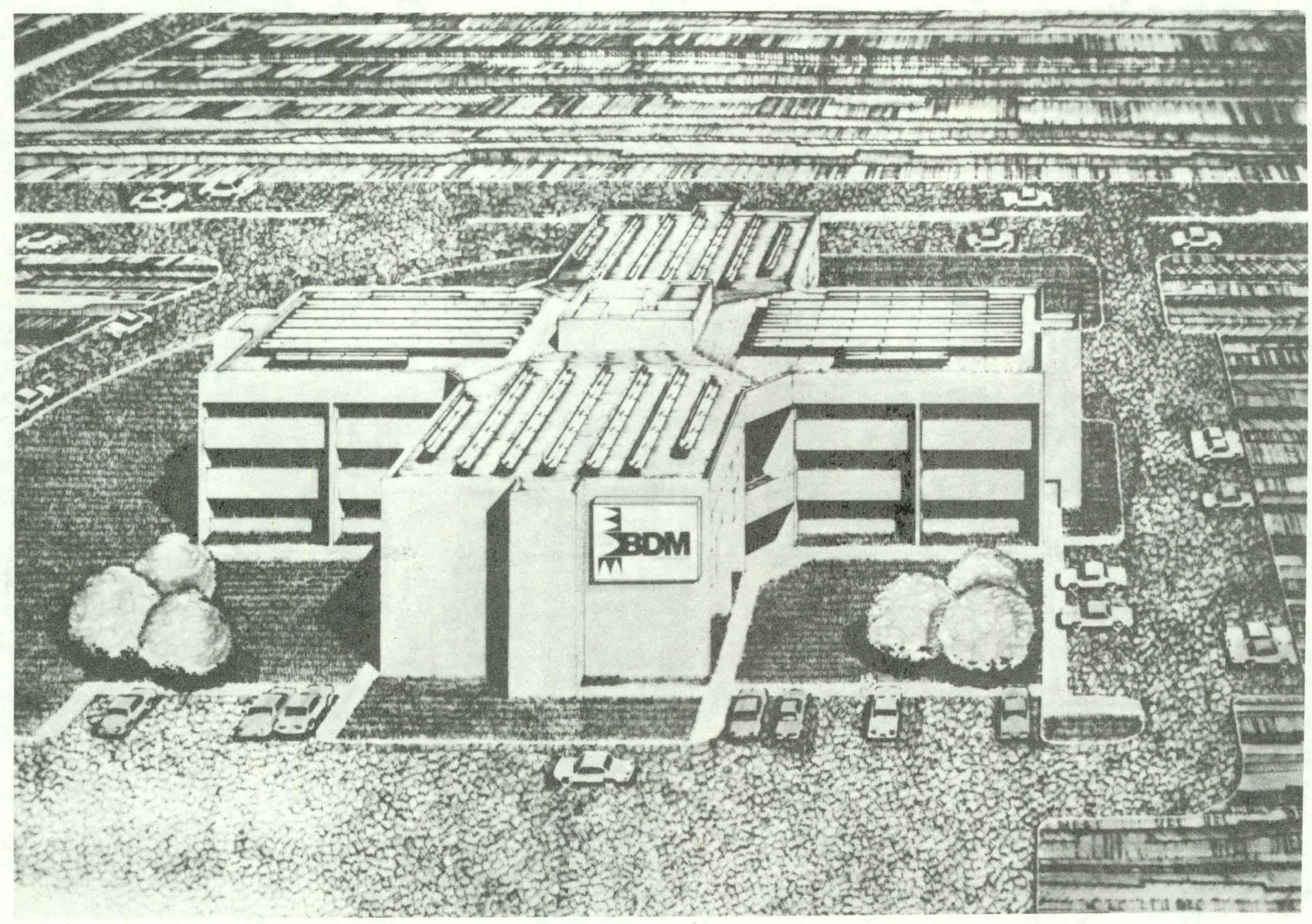




\section{BDM Corporation}

The BDM Corporation plans to design and install a $50-\mathrm{kW}$ system on their new headquarters building in Albuquerque, New Mexico. The system will supply at least $20 \%$ of the building electrical load. The collectors will be solar Kinetic's one-axis tracking reflective trough, thermal collectors modified to accept a siliconcell assembly receiver. The conceptual system design calls for half the array to be oriented east-west and half oriented north-south. This arrangement will provide a trade-off between the smaller seasonal output variation of the east-west array and the greater yearly energy generation of the north-south array. An optional mode of operation is to feed power back into the utility grid. 
Commonwealth of Puerto Rico

The Energy Office of the Commonwealth of Puerto Rico has chosen a load center application consisting of two research buildings on the San Juan campus of the University of Puerto Rico. The primary load is the Center of Energy and Environment Research, with a peak electrical demand of $84 \mathrm{~kW}$. The proposed system size is 77 or $150 \mathrm{~kW}$ peak, depending on option; surplus generated electrical energy will be supplied to the Cancer Research Hospital. The concentrating collector is an existing $24 \mathrm{X}$ slatLeflector, thermal system desiqned by AAI Corporation and modified with a $1.7 \mathrm{X}$ secondary concentrator to give an overall concentration ratio of $40 x$. The projected energy collection of $1500 \mathrm{~kW}_{\mathrm{th}}$ will supply the heating needs of the load center. 


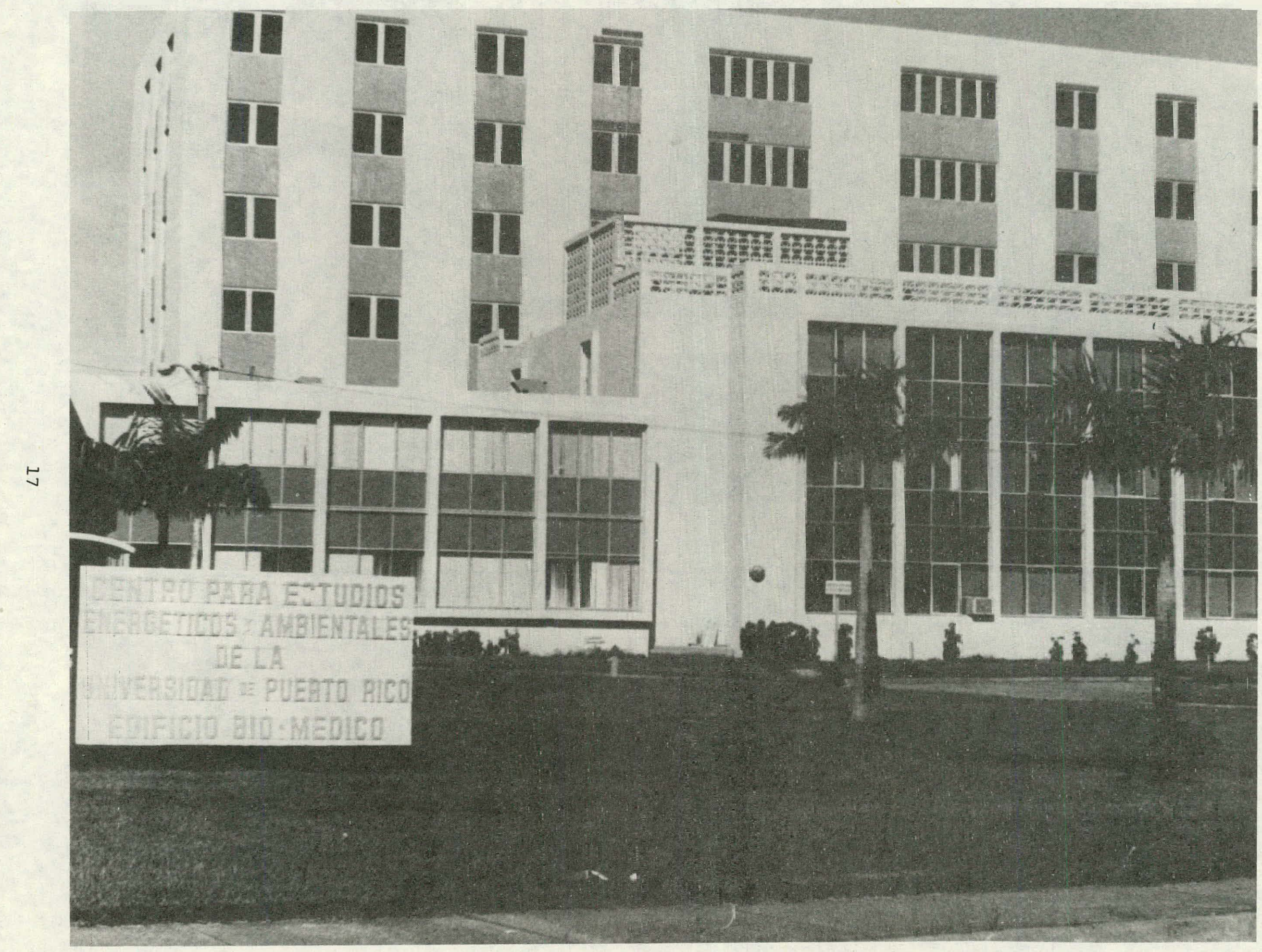




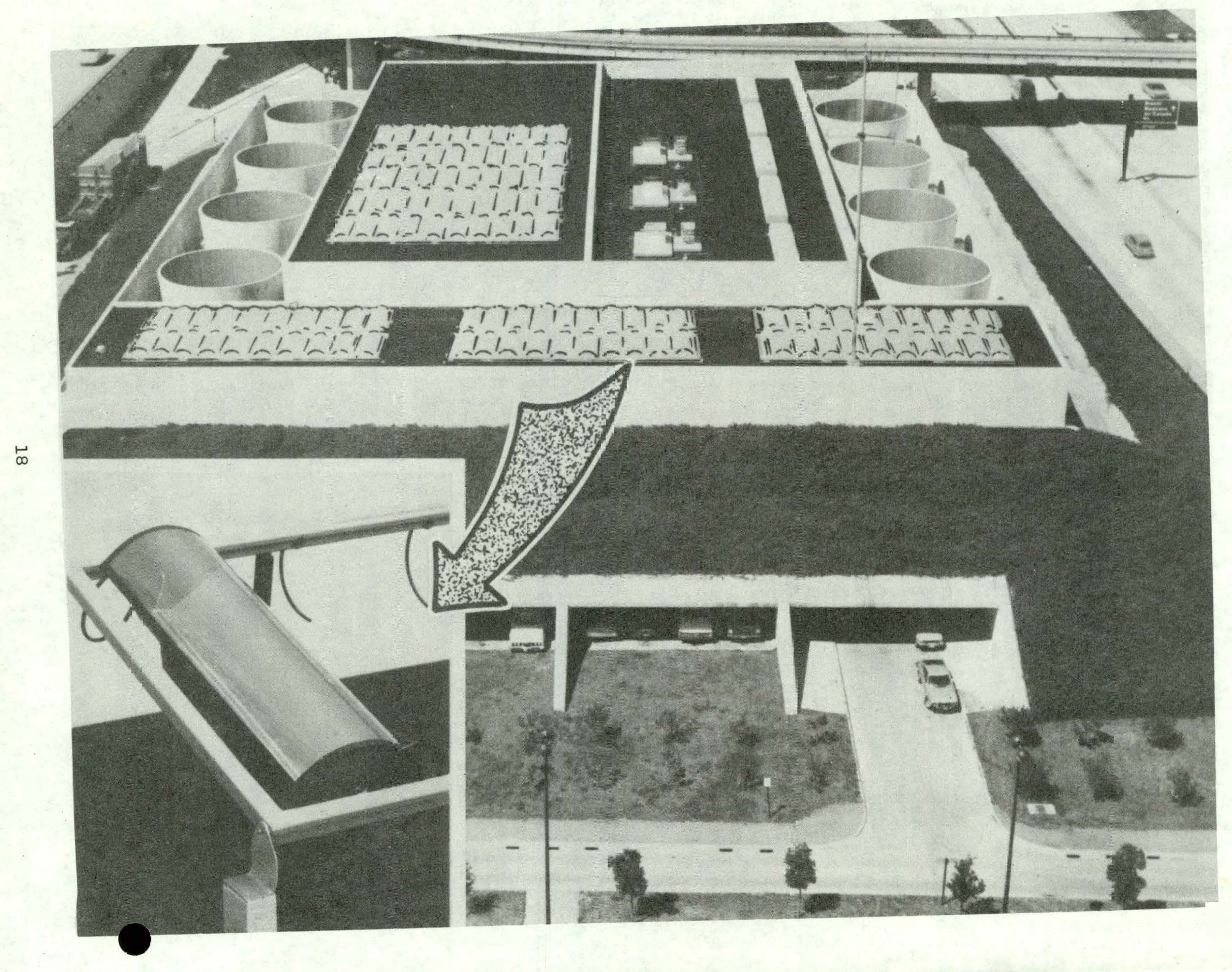


E-Systems, Inc.

E-Systems will use their linear Fresnel lens concentrator with a concentration ratio of $25 \mathrm{X}$ in conjunction with silicon solar cells to generate $20 \mathrm{~kW}_{\mathrm{e}}$ and $146.5 \mathrm{~kW}_{\mathrm{th}}$. This energy will be supplied to the central utility plant at the Dallas-Ft. Worth airport. Electricity from the array will be used by small motors and lights within the plant. Heat from the solar array will preheat boiler feedwater for the steam plant The feedwater is relatively cool, so that the solar cells will stay at a low mean temperature $\left(55^{\circ} \mathrm{C}\right)$ and hence have a relatively high conversion efficiency. About $60 \%$ of the available annual direct normal insolation will be effectively delivered to the plant as useful electrical and thermal energy. 
General Electric Company

The General Electric design will provide $305 \mathrm{~kW}$ peak electric power to a constant load for pumping water for the marine exhibits at Sea World in Orlando, FL. The photovoltaic collectors providing a concentration ratio of $34 \mathrm{X}$ are General Electric's recently designed, two-axis tracking, turntable-mounted, parabolic troughs. The silicon cells are water-cooled. More than 12 million visitors annually visit orlando, giving this project high public visibility. Special displays and educational programs provided by Sea World will further cnhance this visibility. 


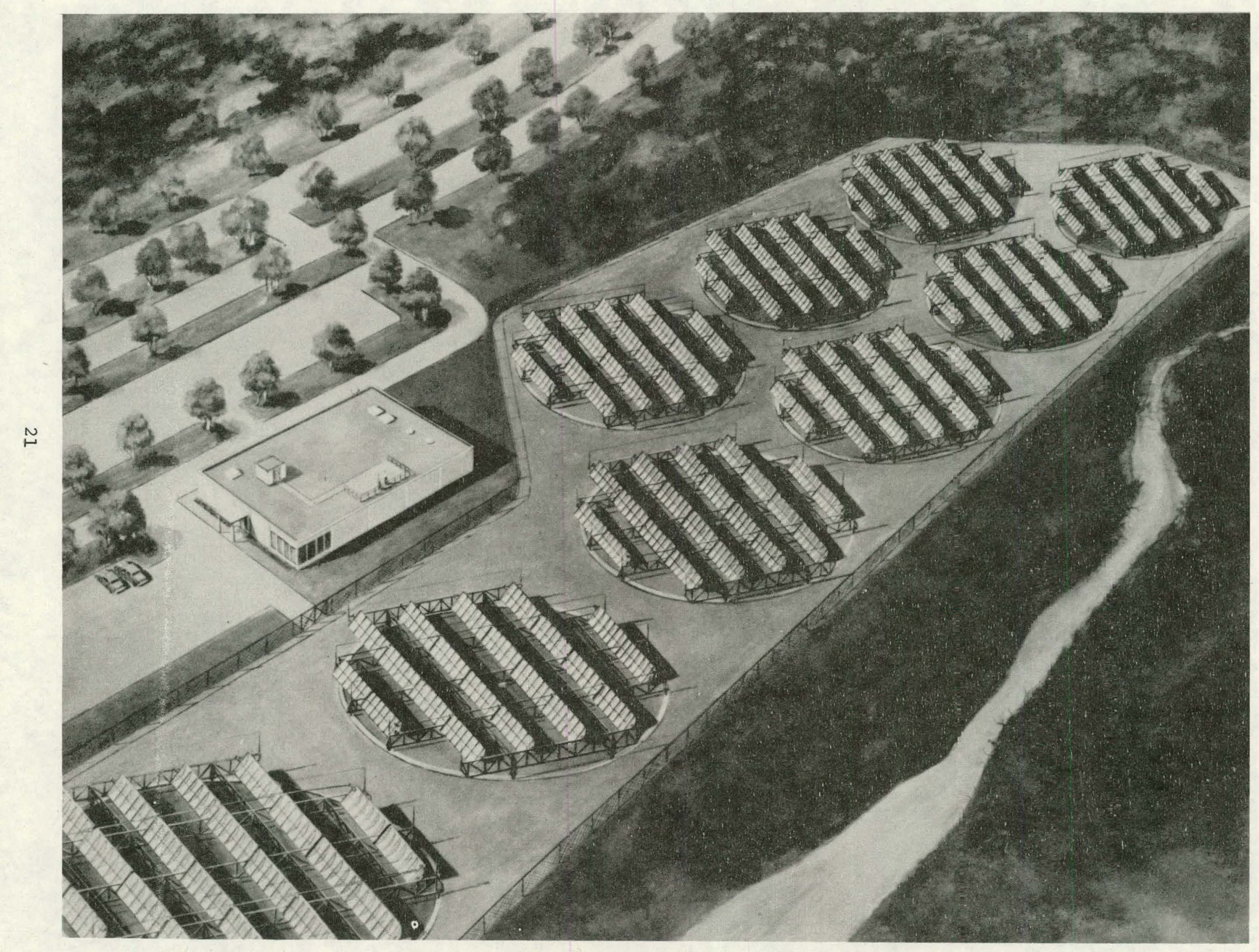


NO PICTURE AVAILABLE 


\section{InterTechnology/Solar Corporation}

Tle Fduquier High School in Warrenton, VA, will be the site for a $20-\mathrm{kW}$ electrical system being designed by InterTechnology/Solar. The photovoltaic concentrator system will be placed next to the existing solar thermal system designed and built by InterTechnology/Solar in 1974. The primary concentrator will be the Acurex parabolic trough designed for thermal applications and modified for photovoltaics. The Del thermal concentrator will be retained in the early design stages as an alternate collector. The cells will be actively cooled, but no use is planned for the thermal energy. 
Kaman Sciences Corporation

Electrical and thermal needs of Kaman Sciences computing center and manufacturing plant are the loads for this application. The array, sized at $54 \mathrm{~kW}$, is composed of heliostattype ground-mounted concentrators and roof-mounted solar-axis concentrators. These concentrators are designed by ARCO Solar and Northrup, respectively, and use Fresnel lenses with a concentration ratio of $32 \mathrm{x}$. The system will receive, condition, control, store, convert, and dispatch the electricity and heat in several operational modes. In particular, coloradu splinys City Utility and Public Service Company of Colorado will extensively study various utility rate structures. 


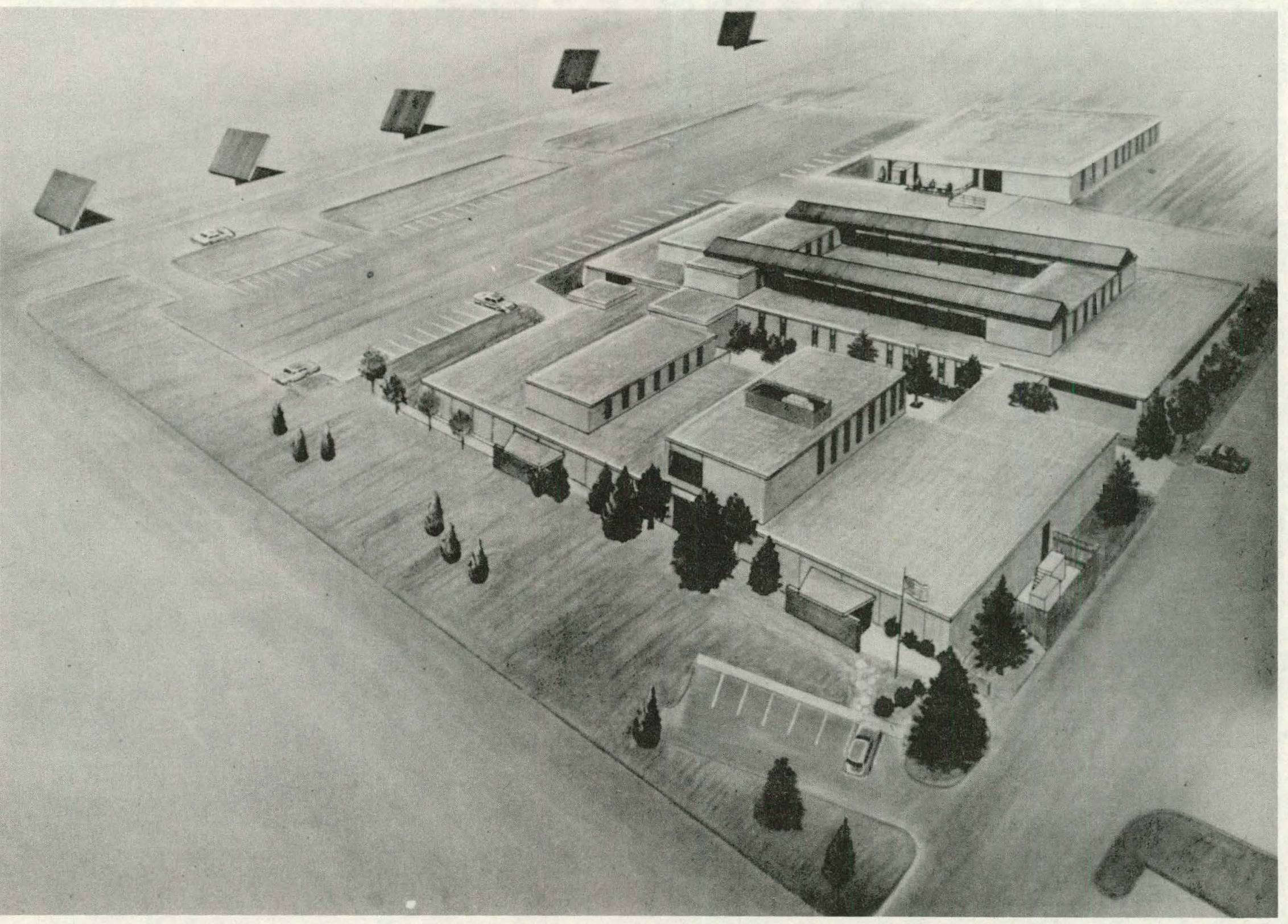




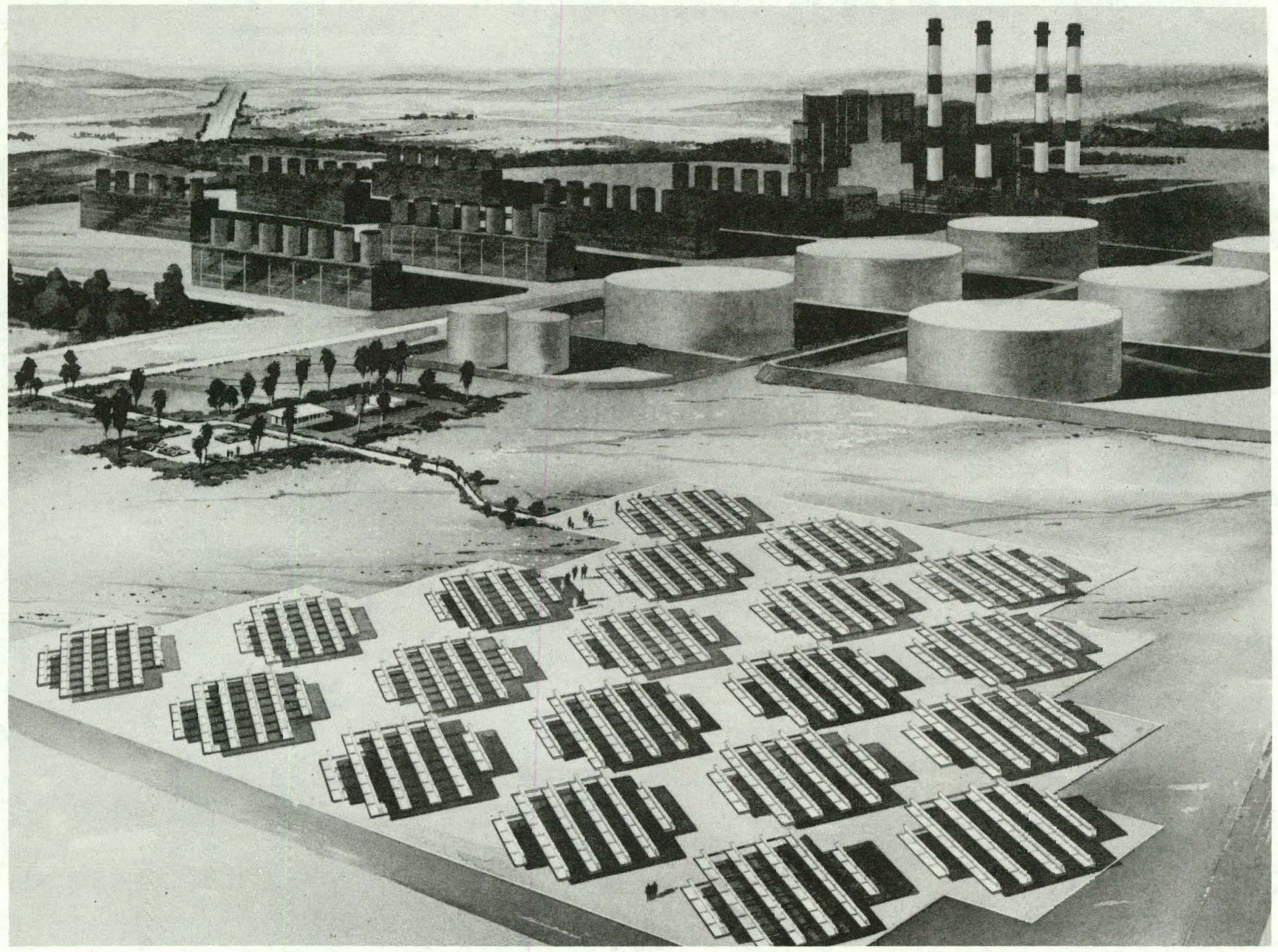


The Los Angeles Department of Water and Power

The Los Anyeles vepartment of Water and Power plans to connect their system to an electric motor load and the electric utility grid at their Sun Valley generating station near Los Angeles. Provisions will be made to supply the motor load with power from the array or the utility system. When the motor load demand is low, the photovoltaic system will deliver excess power to the utility grid. Spectrolab will provide the $200-\mathrm{kW}$ photo-. voltaic array, a $20 x$ turntable-mounted parabolictrough design. 


\section{Martin-Marietta Corporation}

The Roxborough State Park Visitors Center 25 miles south of Denver, $\mathrm{CO}$, is the site of the Martin-Marietta experiment. This project intends to make the Visitors Center completely energyindependent by combining the photovoltaic array with the already-existing active and passive solar heating and cooling system. The concentrator system is based on Martin-Marietta's existing Fresnel lens concentrator array design with a concentration ratio of $40 \mathrm{x}$. The overall electrical system size is $80 \mathrm{~kW}$. 


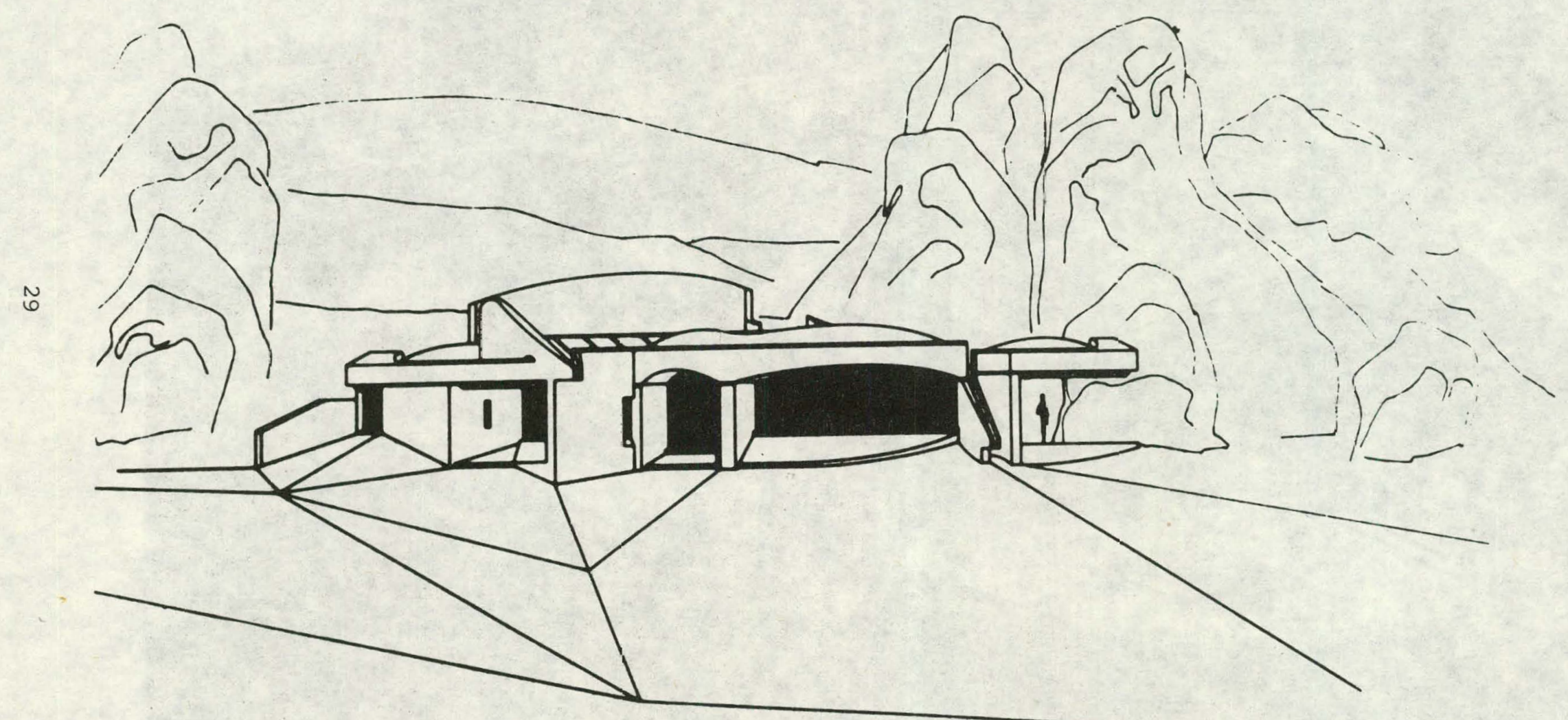




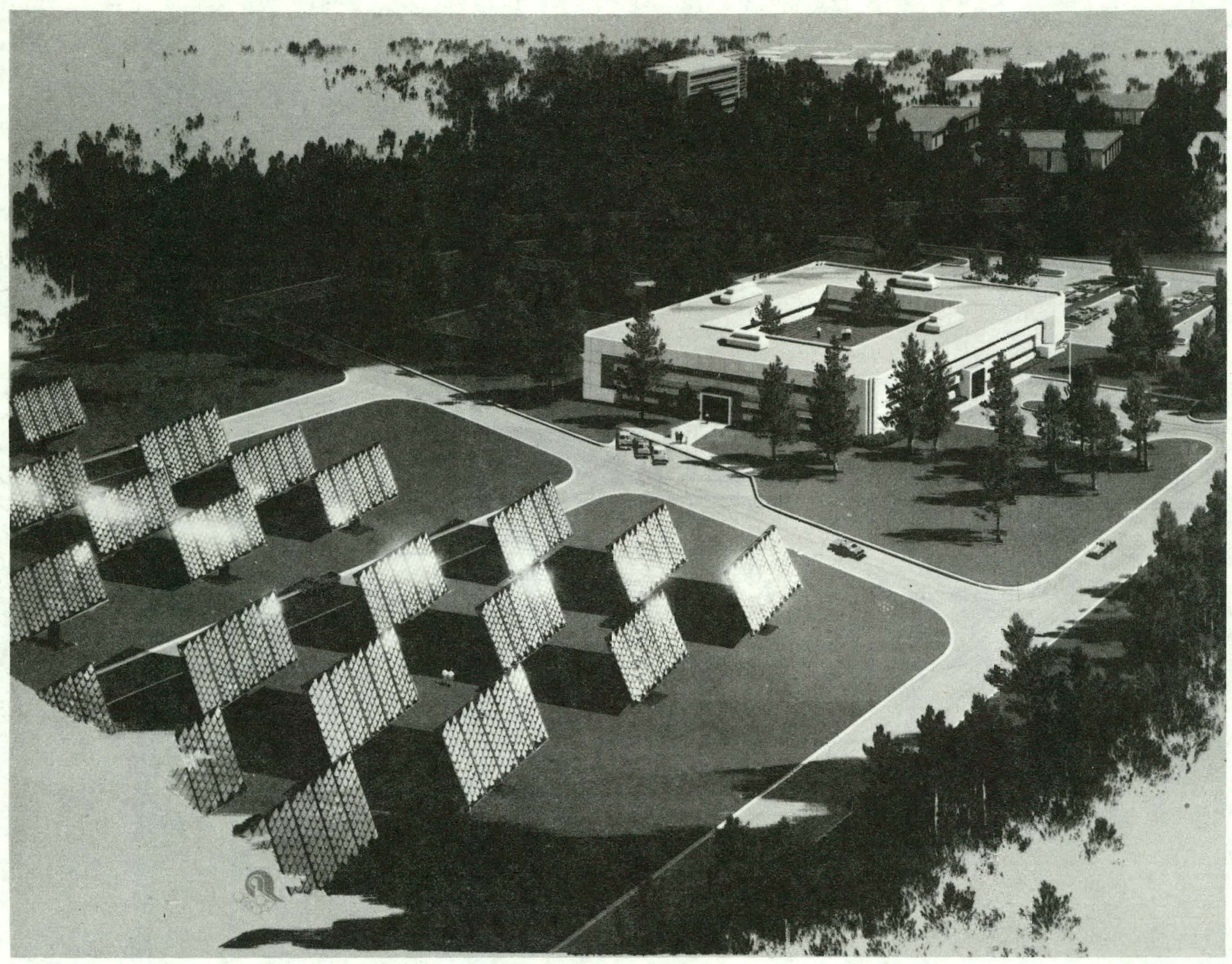


Research Triangle Institute (RTII)

RTI is designing a concentrator system to provide part of the electrical energy requirements for their new laboratory-office building at Research Triangle Park, North Carolina. The system size will be $160 \mathrm{~kW}$. Most of the building load will be direct current so that inversion to ac will be required for little, if any, of the solar-supplied power. The photovoltaic collectors will consist of Motorola's two-axis tracking paraboloid concentrators with a concentration ratio of $70 \mathrm{x}$. The cassegainian design of these concentrators offers the alternative of increasing the concentration ratio for incorporating solar cells with higher conversion efficiencies than silicon, such as the multi-bandgap cells under development at RTI. 


\section{Solarex Corporation}

The solar cell production line at Solarex's facility in Rockville, Maryland, was chosen as the load for the Solarex experiment. The 200-kW photovoltaic array, which is actively cooled, will provide all the electrical and thermal energy needs of the production line. The array utilizes $40 \mathrm{x}$ parabolic troughs with two-axis tracking. In addition to the "solar-breeder" aspect of this experiment, technical and magagerial practices that maximize the energy efficiency of the production operations (e.g., scheduling energy-intensive process steps tor hours of peak insolation and use of "floating holidays" to reduce energy demand during extended periods of low insolation) will be introduced. 


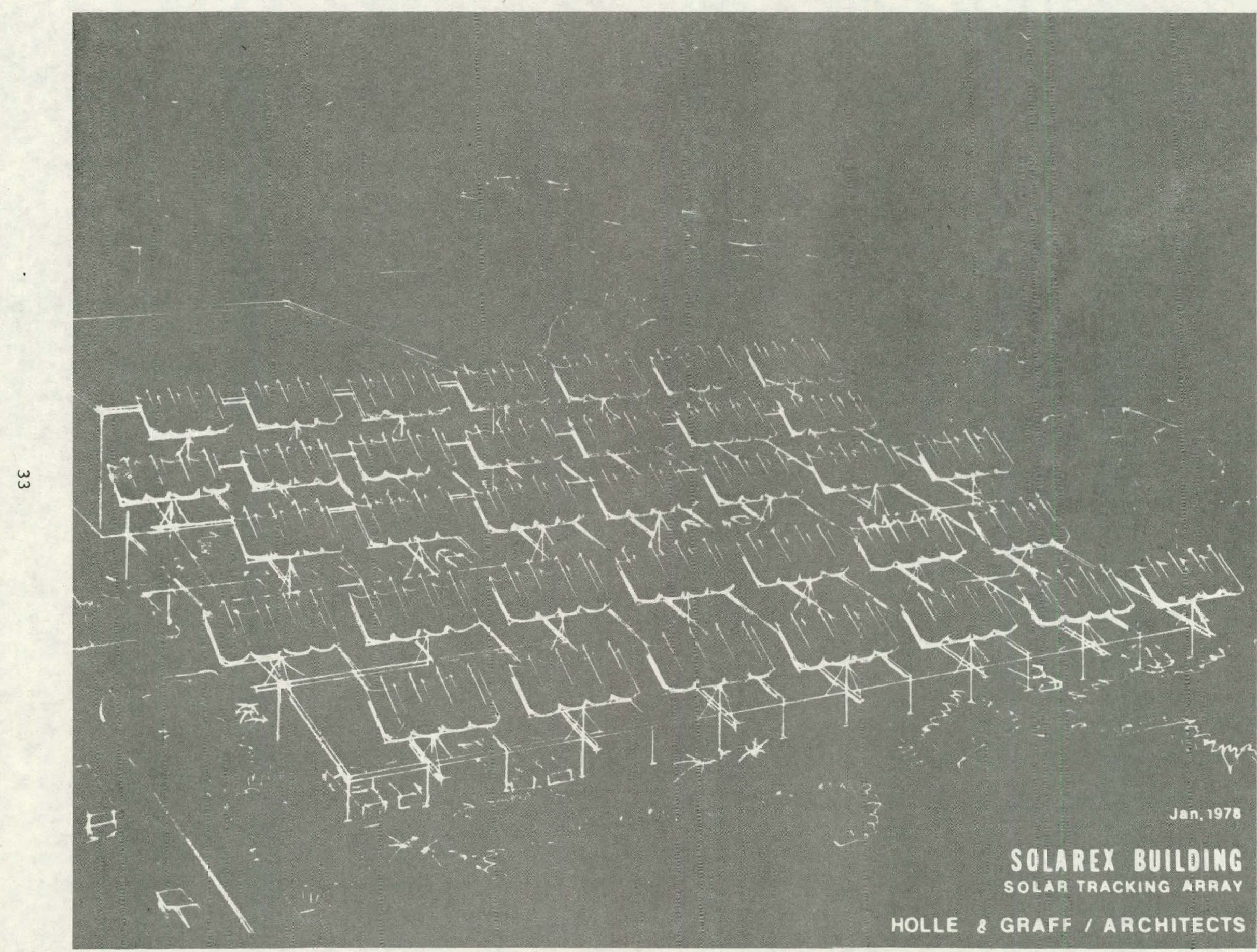


SUN TRAC /MCGRAW-EDISON

PHOTOVOLTAIC INSTALLATION

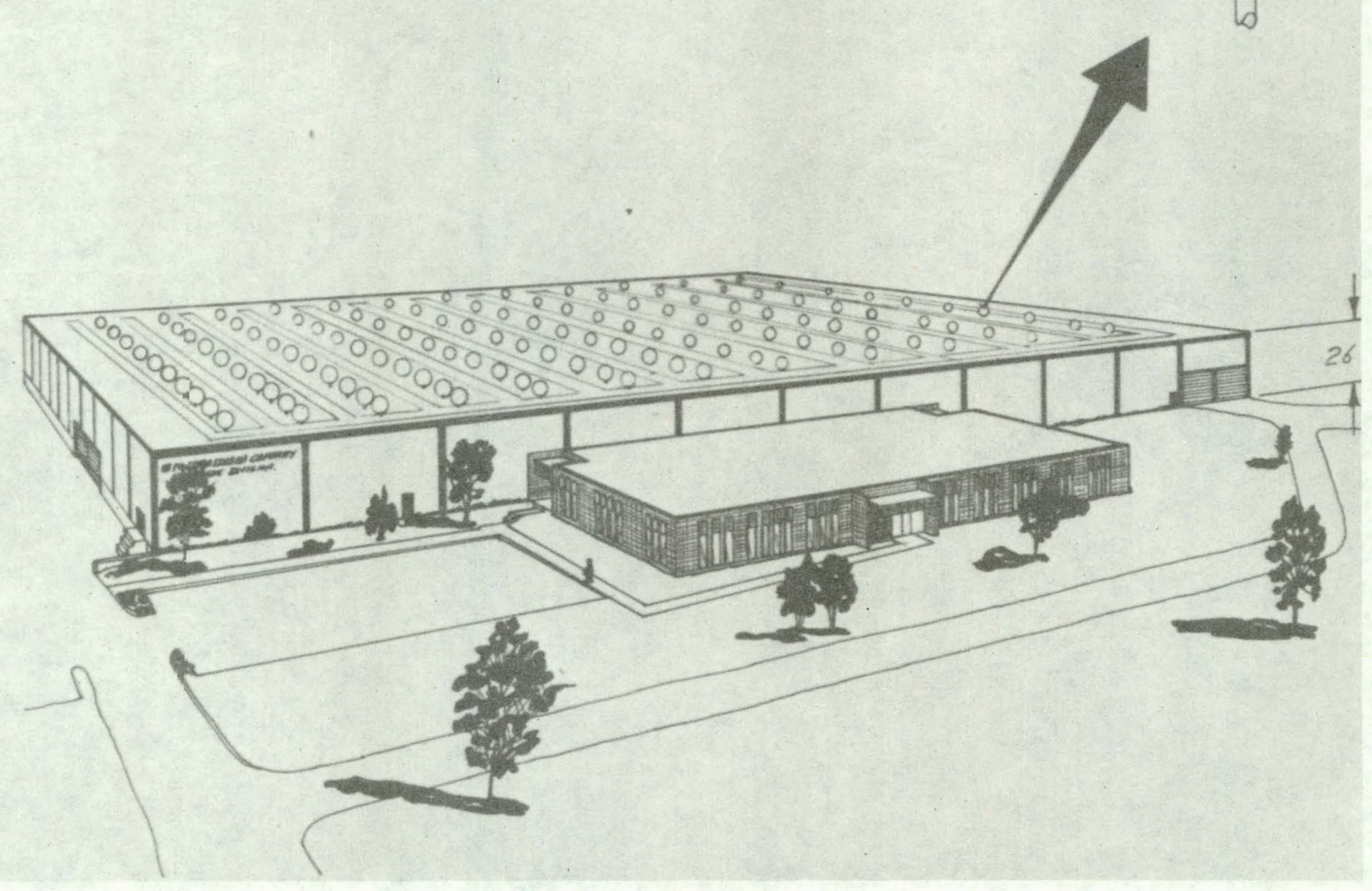




\section{Sun Trac Corporation}

Sun Trac Corporation selected an industrial lighting application. The site, an industrial plant operated by the Area Lighting Division of the McGraw-Edison Company, is located in Racine, WI. Sun Trac will utilize their unique bubble-enclosed modules with two-dimensional compound parabolic concentrators, giving a concentration ratio of $70 \mathrm{x}$ on 0.64 -in-diameter silicon cells. In the 50-kW experiment, sun Trac will investigate the impact of photovoltaic systems on time-of-day rates for industrial plants with one-shift daytime operations. McGraw-Edison, site owner and active participant in the system design, will investigate special luminaire and ballast design for photovoltaic lighting applications. 
Texas Tech University, Center for Energy Research

Texas Tech is planning an agricultural experiment involving deep-well irrigation in the Trans-Pecos Region of Texas. The site selected is representative of the deep-well irrigation problems of an agricultural region severely impacted by high energy costs. A 200-kW array will supply power in parallel with the utility grid to drive a 200-hp, three-phase pump motor to provide a lift of 540 feet. The collectors will be Honeywell's double-parabolic, two-axis tracking thermal design modified for photovoltaics. 


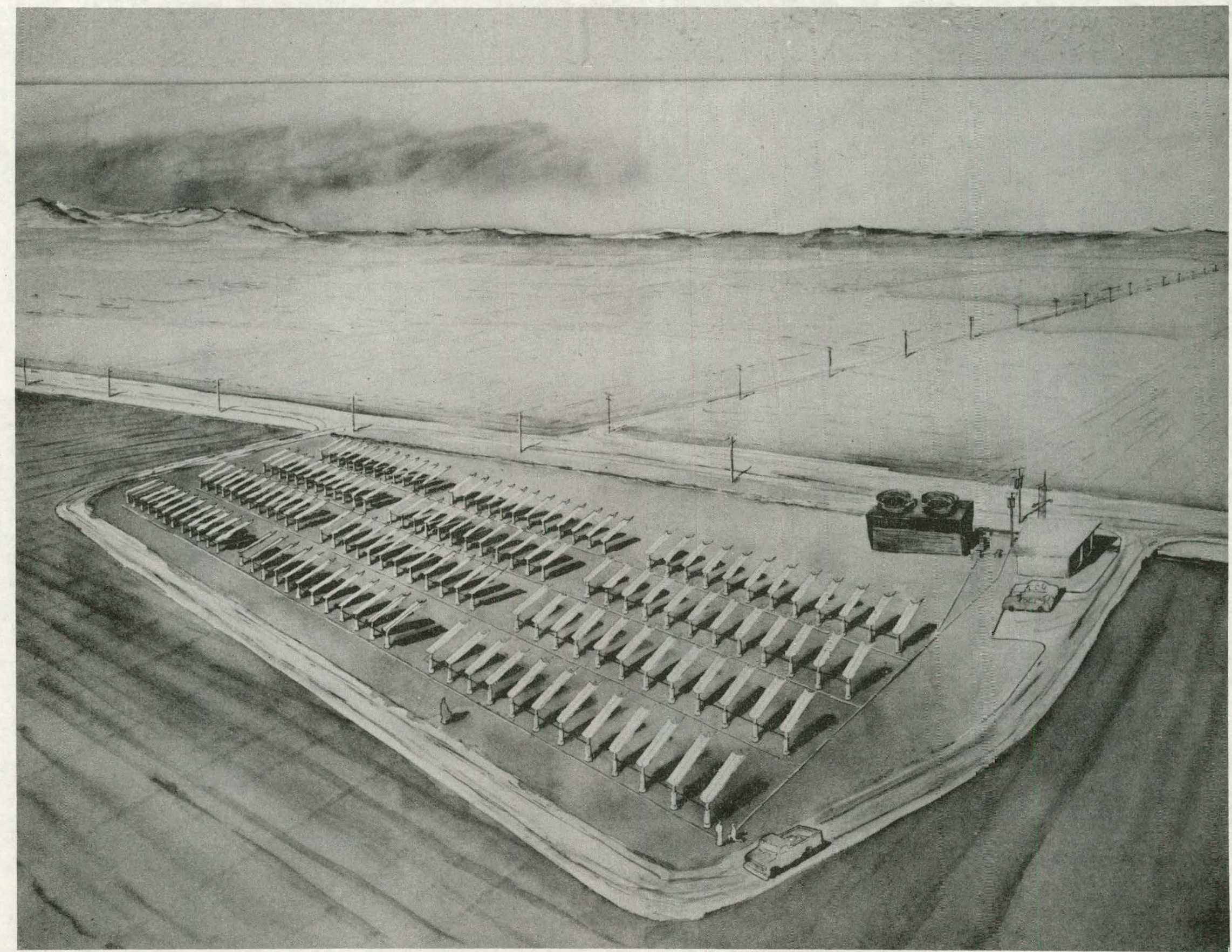




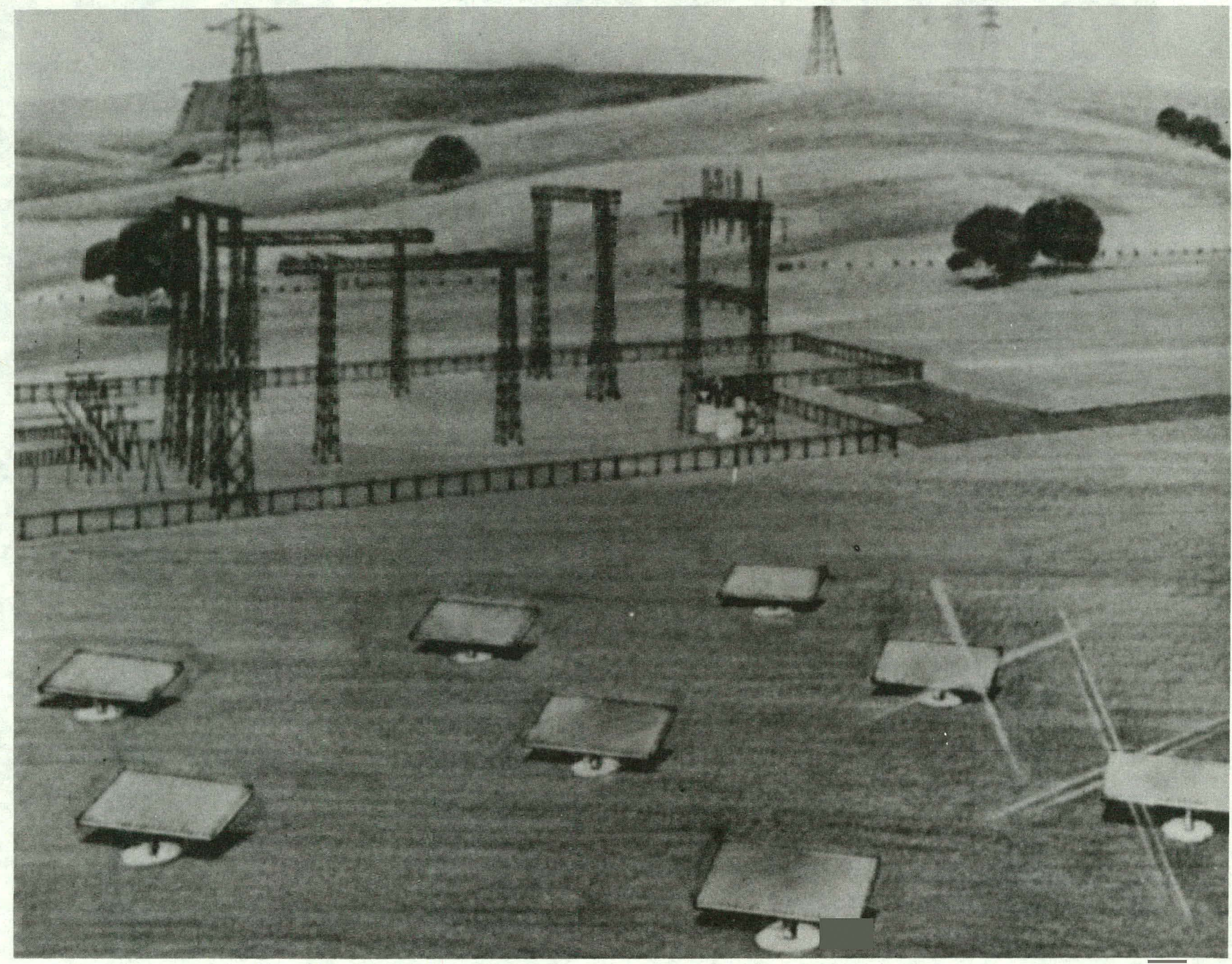




\section{Varian Associates Incorporated}

The Varian experiment represents the only gallium arsenide cell array. Fresnel lenses will provide a $500 x$ concentration ratio for the gallium arsenide cells. The system will supply power to a utility substation in San Ramon, CA, owned by the Pacific Gas and Electric Company. Experiment size is $50 \mathrm{~kW}$. The system is actively cooled. Possible uses of the thermal energy will be investigated; however, no thermal loads have yet been identified. 


\section{Westinghouse Electric Corporation}

The application to be served by the Westinghouse design is a local operating headquarters of the Georgia Power Company in Fulton County, GA. A 20X linear Fresnel lens concentrator array being designed by Westinghouse will be used in the application to provide $50 \mathrm{~kW}$ of peak electric power. Various modes of operation including utility-grid operation will be investigated. 


\section{SOUTH FULTON OPERATING HEADQUARTERS}

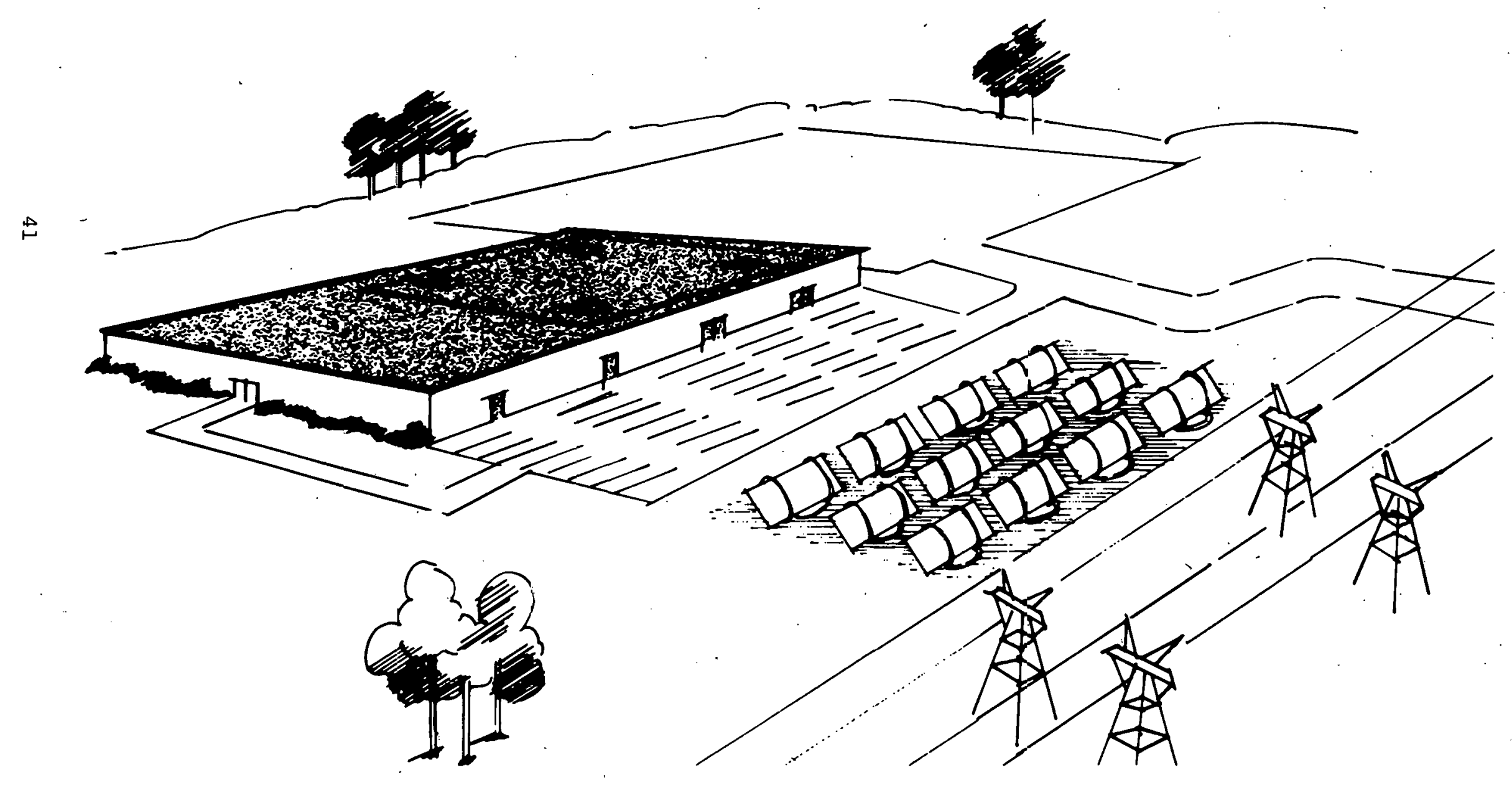


THIS PAGE INTENTIONALLY LEFT BLANK 
Following is a list of the twelve prime contractors conducting Phase I system design and brief summary information relating to each experiment project.

Prime Contractor/ Subcontractors

1. Acurex Corporation

2. BDM Corporation

Intertechnology/

Solar Corp.

OCLI

Windworks, Inc.

3. Battelle Columbus

Laboratories

Solarex Corp.

K\&S Engineers

Westinghouse

4. General Electric Co.

Busch Gardens

Tampa Electric Co.

Curry-Smith-Jaudon

Architects

Greiner Engr. Sciences, Inc.

5. Gilbert Associates, Inc.

Solarex Corp.

General Battery
Site Owner

\& Location

Sacramento Municipal Ụtility Sacramento, CA
Anheuser-Duseh
Tampa, FL

27Jkw

$100 \mathrm{~kW}$

Suburban Sanitary

Commission

Piscataway, MD

$\underline{\text { Size }}$

Application

$100 \mathrm{~kW}$

Utility Grid

Battelle

Columbus, $\mathrm{OH}$

$100 \mathrm{~kW}$

Industrial

Machine Shop

nmusement Park Amphitheater

6. Lea County Electric Cooperative, Inc.

NM State University stone and Webster Sollar Power Corp.

Reading, PA

Edison Shopping

Center

Lovington, NM
$210 \mathrm{~kW}$

Battery Mfg. and Charging

\section{$150 \mathrm{~kW}$}

Shopping Center 
Prime Contractor/

Subcontractors

7. A. D. Little, Inc.

Solarex Corp.

Refinement in Design

8. Lockheed Missiles and

Space Company

City of Santa Clara

Univ. of Santa Clara

Licciardello-Davis Assoc.

9. Mobil-Tyco Corp.

10. NM State University

El Paso Electric Co. Fout's Langford Gomez Moore, Inc.

Ponsford Brothers

11. Science Applications,

Inc.

Benham-Blair Assoc. OK Gas \& Elec. Co. Solarex Corp.

12. Solar Power Corp.

Stone \& Webster

Mass. Electric Co.
Site Owner

\& Location

Size Application

New England Tele. $\quad 30 \mathrm{~kW} \quad$ Telephone Switching

Co.

Wilmington, MA

City of Santa Clara 30kW Community Center

Santa Clara, CA

Mobil Oil Corp. McKinley Co., NM

20kW, Water Desalination

El Paso Electric 20kW

Generating Plant Computer Control

Co.

El Paso, TX

Oklahoma Center for $500 \mathrm{~kW}$

Science and Art Science and Art

Center

Beverly Public

Schools

$175 \mathrm{~kW}$

High School

Beverly, MA 


\section{PROJECT SCHEDULE FOR FLAT PANEL APPLICATIONS}

All Phase I contracts have a start date of September 30, 1978 and a completion date of March 31, 1979. System design reports and proposals for Phase II and III are due February 28, 1979 and final contract reports are due March $31,1979$.

A mid-point contract technical and progress review is tentatively scheduled in early January 1979 and a final design review in mid-March 1979.

Prototype array modules must be delivered to DOE. for qualification by February 28, 1979. The array test facility at JPL will accept prototype array hardware for performance qualification beginning in mid-November 1978 . Advance arrángement must be made with the JPL array test facility coordinator regarding specific delivery schedules and any special test requirements.

\section{PROJECT MANAGEMENT STRUCTURE}

Photovoltaic concentrator application experiments resulting from PRDA-38 will be managed by the DOE Albuquerque Operations office (ALO). The ALO Contracting officer will appoint a Government Technical Representative (GTR) who will coordinate with the Phase I contractors in administering the technical aspects of the contracts. The GTR will use technical support, assistance, and facilities of DOE laboratories and othẹ government laboratories as required. The GTR or his designate shall not make any commitments or authorize any changes which affect the contract price, terms, or conditions. Any such changes shall be reterred to the contraceing ufflce for action.

For PRDA-38 contracts, the GTR has designated Sandia Laboratories as the contract Technical Monitor. Sandia will maintain an overview of all contract work including schedules, system designs, and hardware development and will coordinate technical assistance as required from the other program prime contractors.

The Sandia Technical Coordinator for PRDA-38 contracts is E. I. Burgess. 


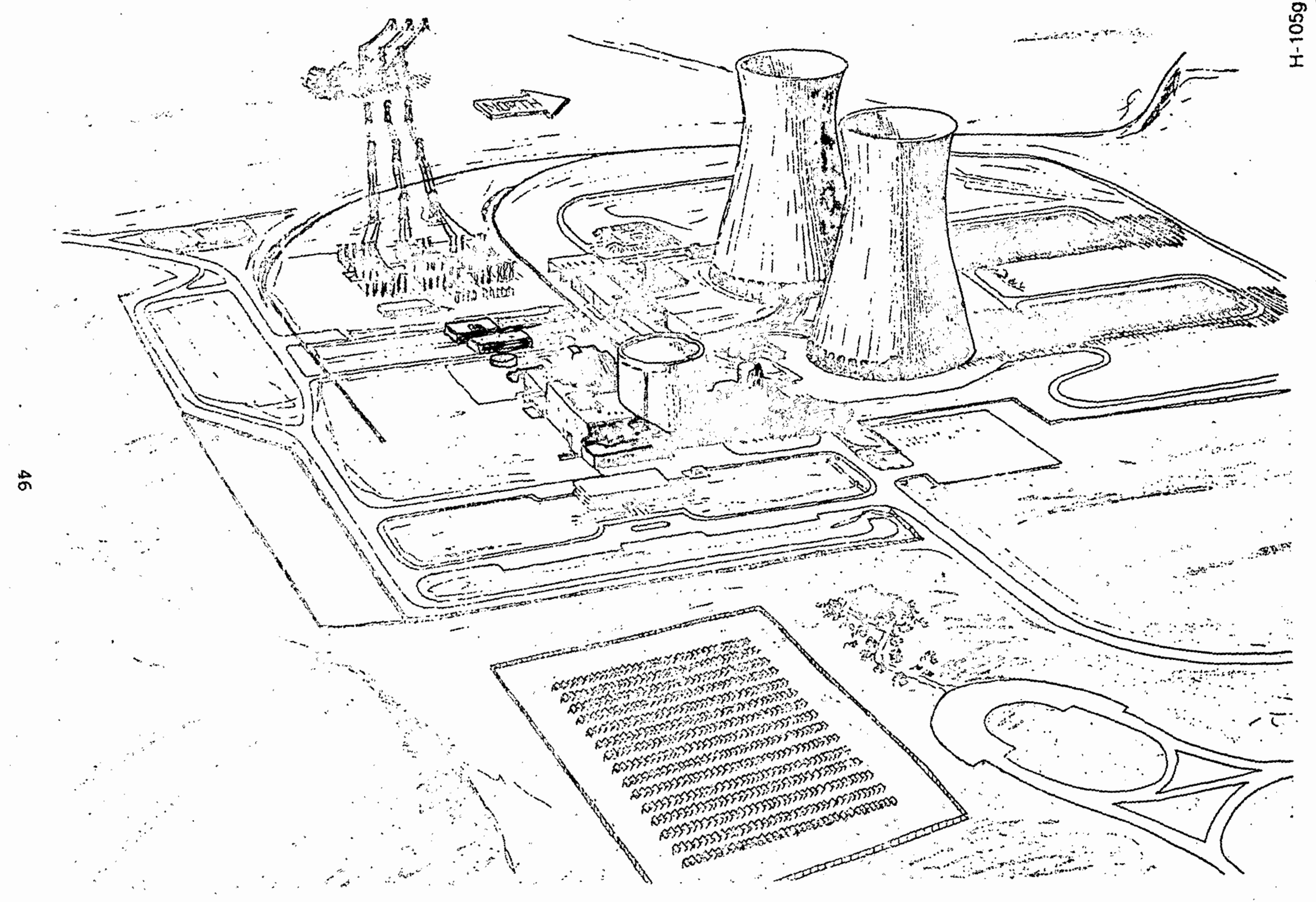

Aerial view of Rancho Seco site showing proposed solar system installation. 


\section{Acurex Corporation}

Acurex plans to design and install a $100 \mathrm{~kW}$ peak photovoltaic application experiment that will directly interface with the existing Sacramento Municipal Utility district's grid. This district has day peaking and summer peaking load characteristics. The PV system uses Motorola cells, packaged in $1 \times 4$ foot modules; eight modules are fastened together to form a 4 x $8 \mathrm{ft}$ center-slotted panel that is attached with 11 other panels to torque tube drive. North-south one-axis tracking is provided, using a simple clock type system to increase the energy collected. All electrical energy is supplied to the utility network and no storage is provided. 
The BDM Corporation has chosen to install a $100 \mathrm{~kW}$ 'flat panel photovoltaic system at a waste water treatment plant, south of Washington, DC. The PV array will provide electrical $A C$ power for the dewatering process which requires the use of approximately 30 motors between the hours of 7 am and $6 \mathrm{pm}$. BDM has selected high efficiency cells, manufactured by OCLI to meet this energy requirement. Four $2 \times 4 \mathrm{ft}$ modules are supported on a ground-mounted support structure. A very limited amount of storaye in vatteries will be provided, but no feed of excess power to a utility network will be provided. 
COPY NO. 5 OF 9

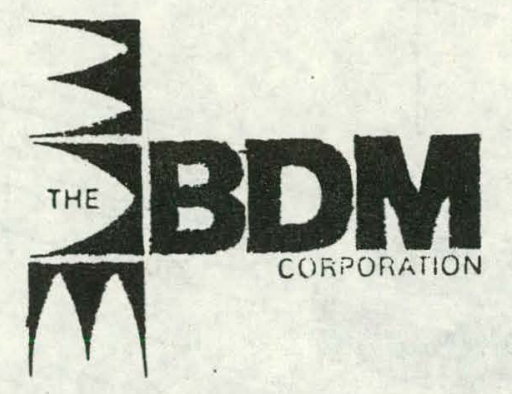

\section{KW FOTOVOLTAC FAT PAUEL SVSEM AT A WESWUGTON, D.C. AREA WASE TREATEET PLANT}

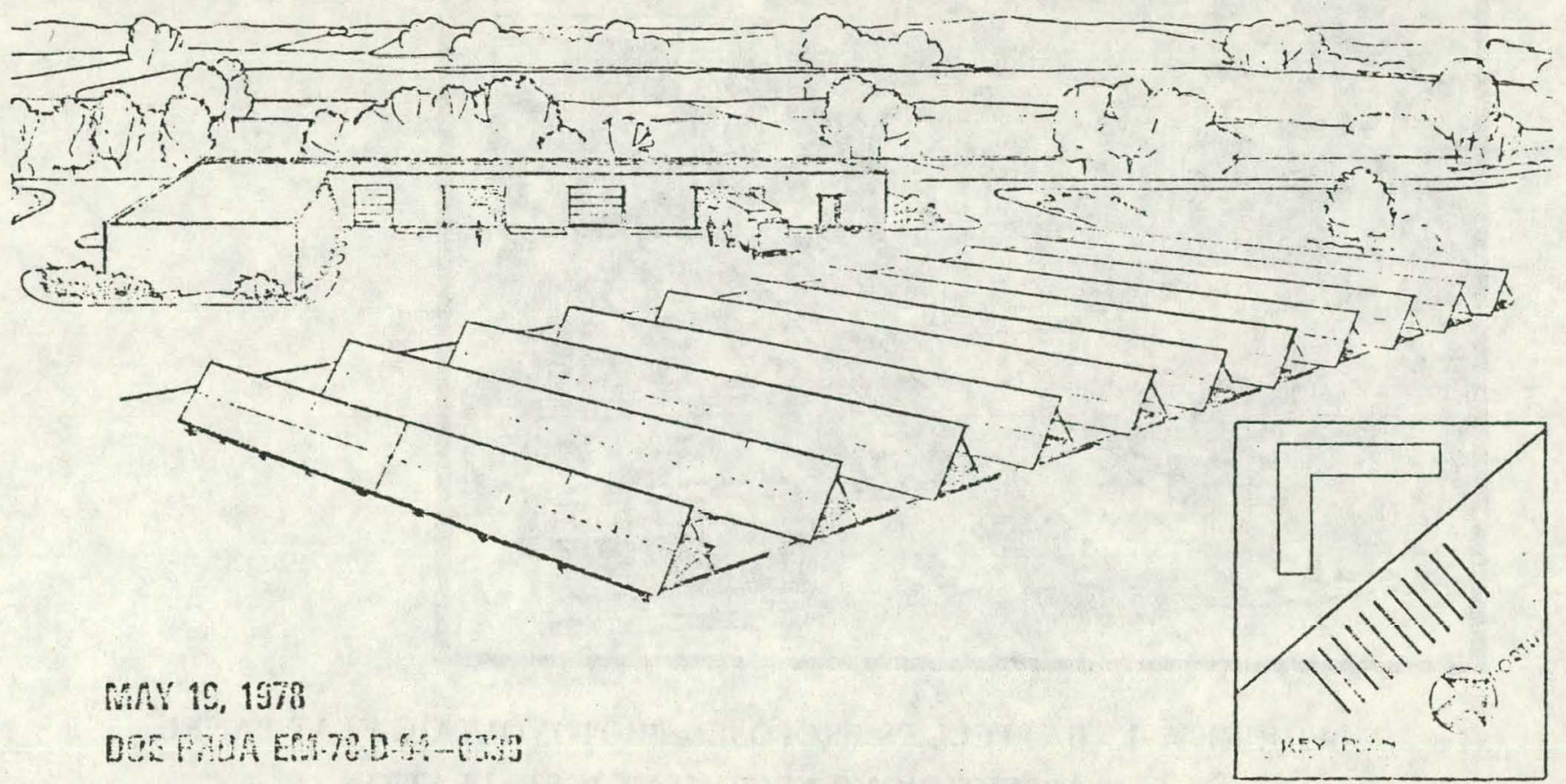




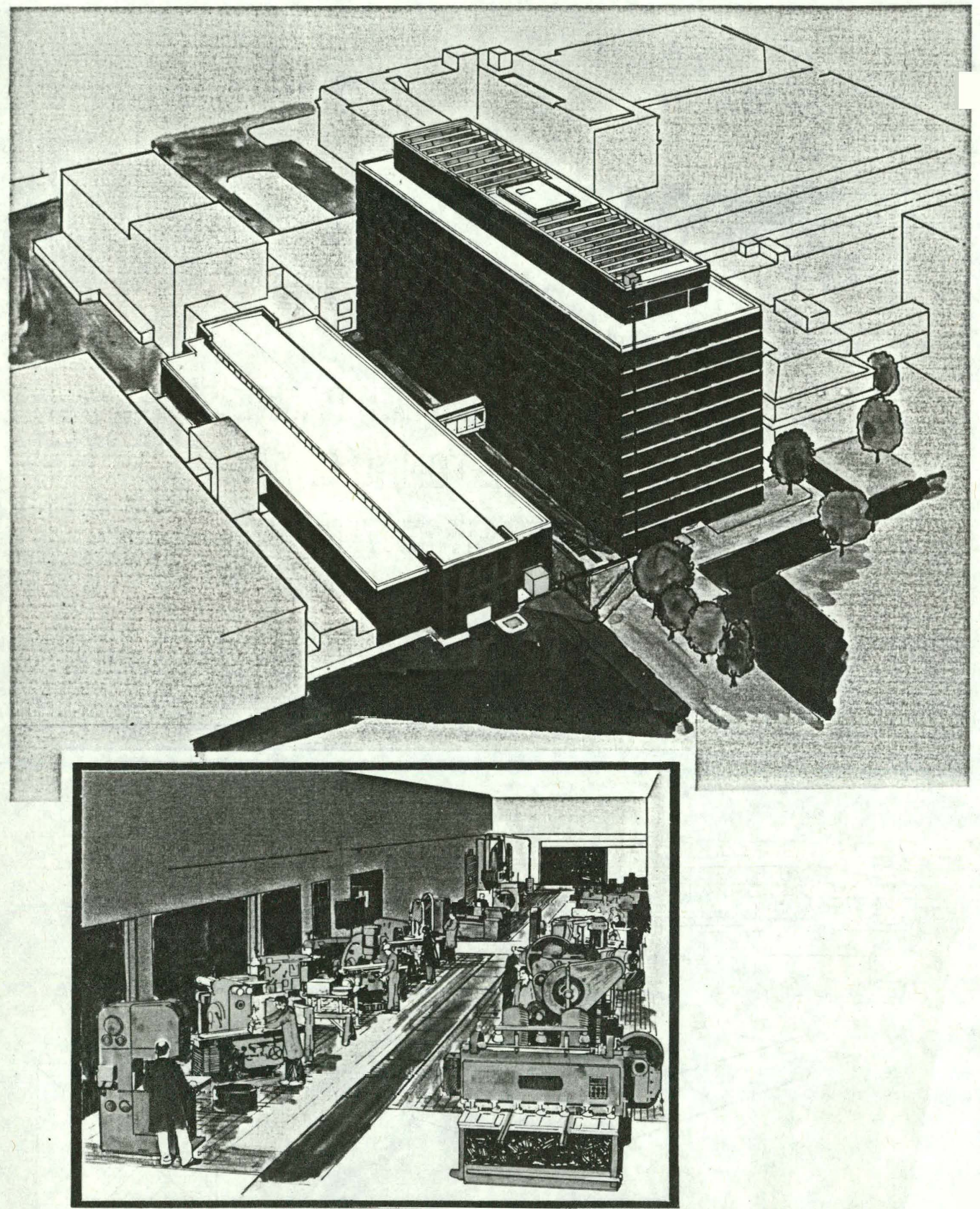

FIGURE A-1. BATTELLE'S PROPOSED PHOTOVOLTAIC FLAT PANEL APPLICATION EXPERIMENT INSTALLATION 
Battelle Columbus Laboratories

The preliminary Battelle conceptual design is to employ $100 \mathrm{~kW}$ of high power density flat panel modules to supply power to the Metals Fabrication and Machining Facility at Battelle. The roof-mounted Solarex arrays will be located on buildings adjacent to the Machine shop at Battelle in Columbus, $\mathrm{OH}$. In this experiment excess power will be delivered to alternate loads or storage which differs from the Battelle concentrator project which is utility interactive. Experience with large motor loads will be gained from this project. These represent a large portion of industrial energy use. A number of nontechnical issues including utility rate structure and electrical code will be investigated. 
General Electric

General Electric plans to design and install a $30 \mathrm{~kW}$ system on the south-facing roof of the stanleyville amphitheater in Busch Gardens, Tampa, FL. The power generated will be used for direct displacement of lighting and air handler loads within the amphitheater. A total of 4,312 shingle solar cell modules are to be interconnected in a matrix of 88 modules in series by 49 modules in parallel. The shingle module to be used is a second generation lowcost design using seven 4" cells connected in series. The array feeds a common DC bus at nominal 200 Vdc to provide the input to a $30 \mathrm{kVA}$ inverter which is controlled to operate at the instantaneous maximum power point of the array. The inverter supplies power in parallel with the output of a $75 \mathrm{kVA}$ transformer which rocoivcs its power from Tampa Electric Company. It is expected that the load will nearly always exceed the inverter output, but in the event that excess power does exist it will be fed back through the transformer to be available for other loads within the facility. 


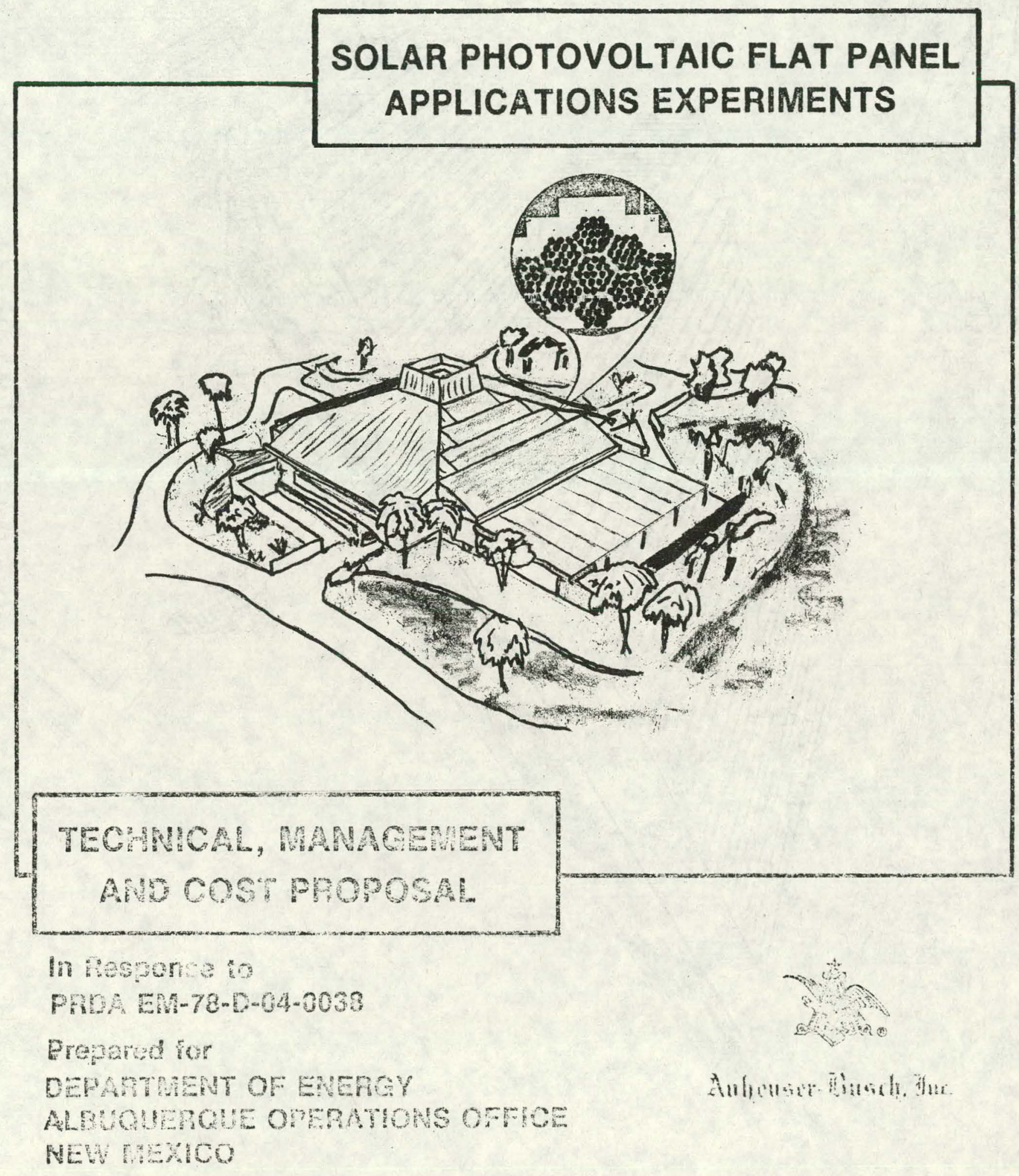




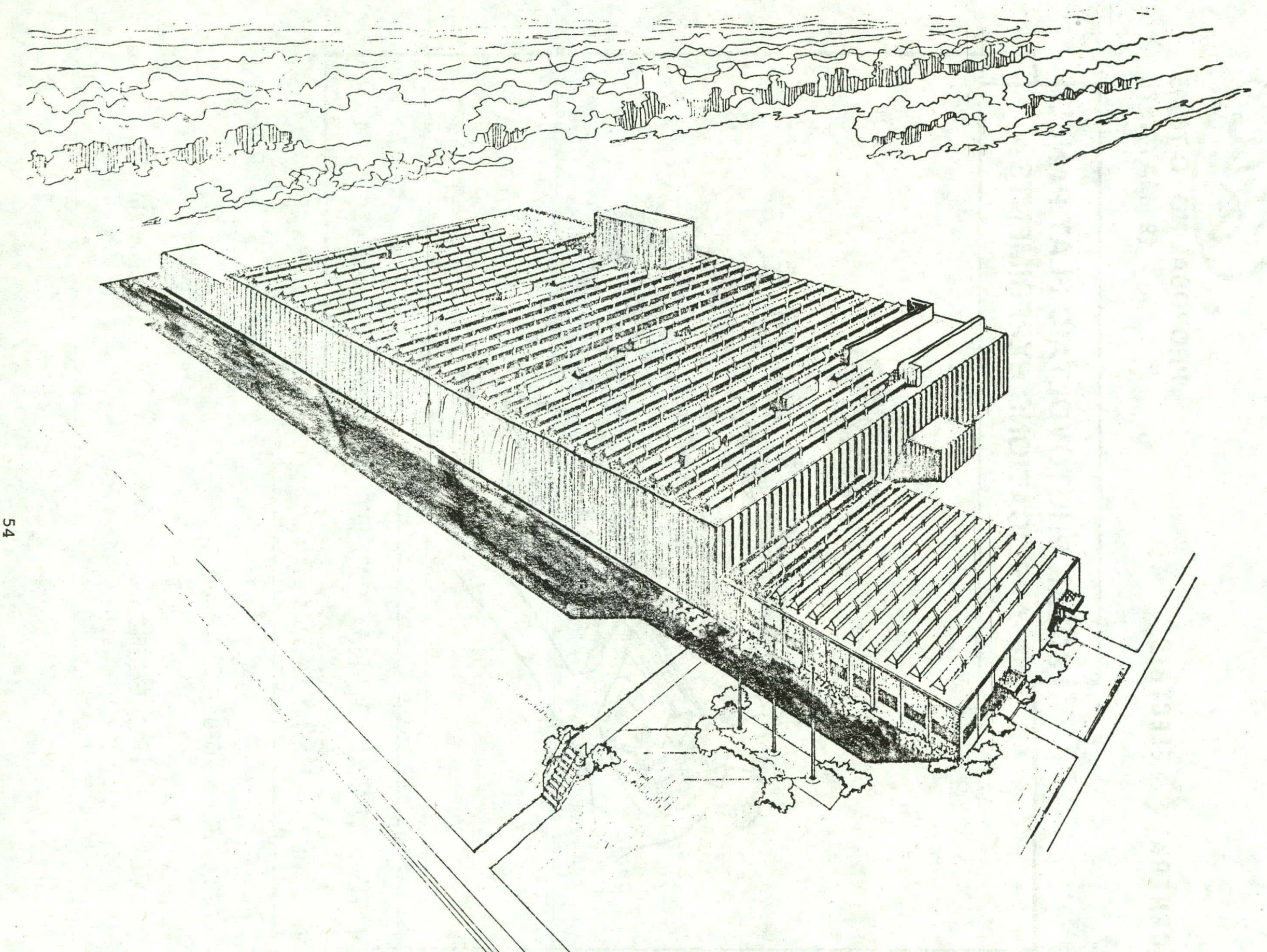

Genera Batery Photovoltaic Installation 
Gilbert Associates, Inc.

This large A\&E firm is wurking with the General Battery Company in Reading PA to install approximately $200 \mathrm{~kW}$ of photovoltaic flat panels on the roof of a new battery production building. Generated power would be used to "form" (place an initial DC charge) lead acid battery grids on one of their three production lines. Because forming occurs between $3 \mathrm{pm}$ and $8 \mathrm{am}$, it will be necessary to provide considerable storage capacity for this project. The array will use Solarex 2 x $4 \mathrm{ft}$ modules electrically connected so that each power unit (10 for $210 \mathrm{~kW})$ will produce approximately $20 \mathrm{~kW}$ of $240 \mathrm{Vdc}$ power. No feed-back of excess power to the utility system will be provided. 
Lea County Electric Cooperative, Inc.

The Lea County Electric Coop., with its subcontractors Stone and Webster, New Mexico Solar Energy Institute, and Solar Power Corporation (SPC), is designing a $150 \mathrm{~kW}$ flat panel photovoltaic facility for a new shopping center in Lovington, a small town in southeastern New Mexico. The system will utilize standard SPC modules and tentatively plans to use three $50 \mathrm{~kW}$ power conditioning units. It will interface with the local electric utility grid and will supply approximately one-fifth of the peak shopping center load. When the photovoltaic power exceeds the demand (e.g. on weekends) the excess will be fed back into the utility grid. The system will be passively cooled and will require no battery storaqe. Various trade-off studies are being performed during the desiqn phase, including fixed tilt vs seasonally adjusted tilts, and studies are underway to optimize the photovoltaic power system to its load in terms of life-cycle cost per kilowatt-hour delivered. 


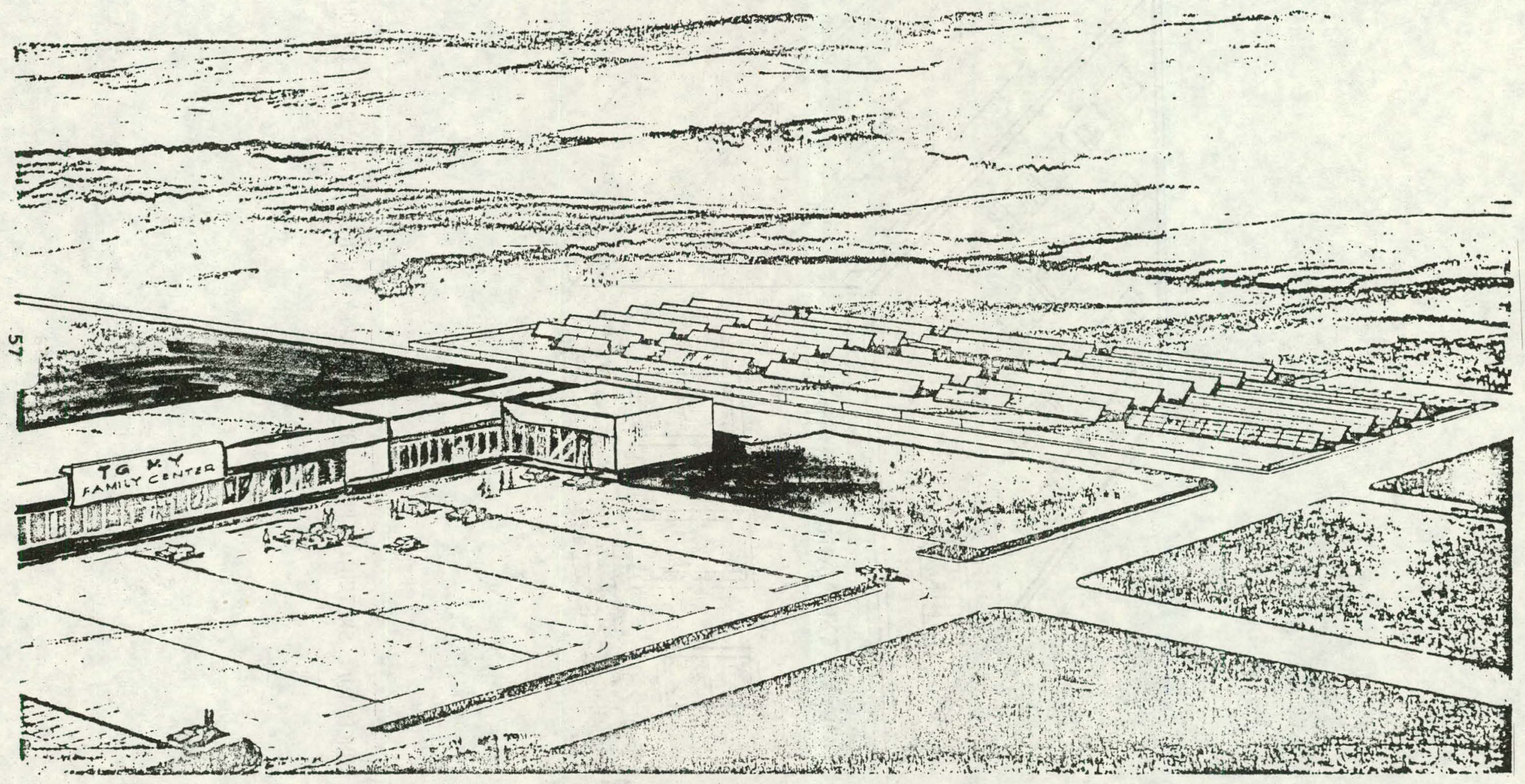

Artist's Concept of Photovoltaic Facility for Lovington, New Mexico Shopping Center. 


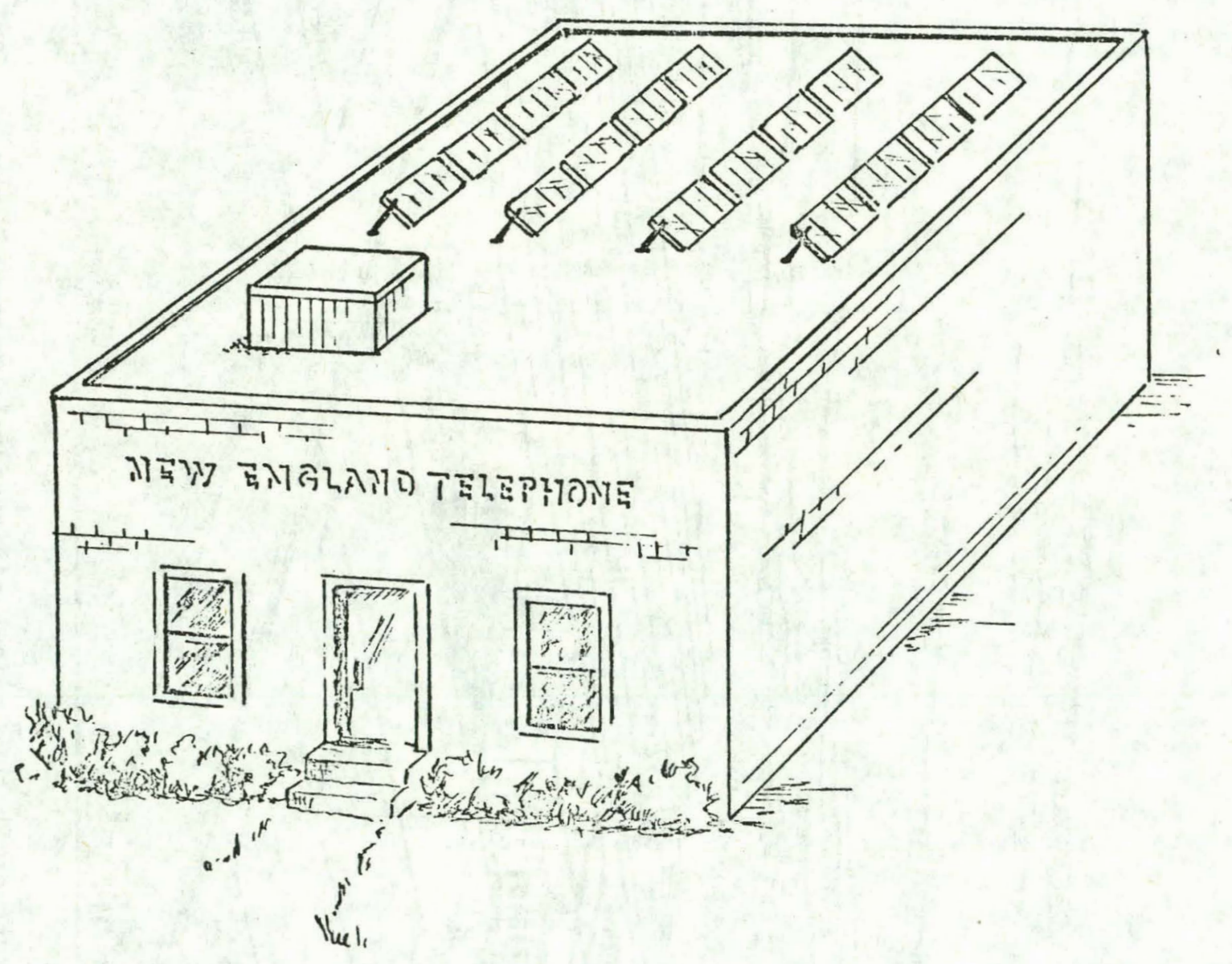

CONCEPTUAL SKETCH OF PHOTOVOLTAIC ARRAY ON NEW ENGLAND TELEPHONE BUILDING 
Arthur D. Little, Inc.

The system being designed by A. D. Little uses a fixed linear compound parabolic collector (CPC) of their own design. The cells on this 3-5x range collector will be manufactured by Solarex. The application selected is $48 \mathrm{Vdc}$ power to the switching equipment in New England Telephone Company's Wilmington, MA office. The switching equipment requires $30 \mathrm{~kW}$ to $50 \mathrm{~kW}$ of DC power depending on the time of day. The output of the photovoltaic system will be a maximum of $30 \mathrm{~kW}$ and may be connected, after regulation, in parallel with rectified utility power reducing utility requirements on an as available basis. 


\section{Lockheed Research Laboratory}

Lockheed has chosen to design, fabricate and evaluate a flat panel photovoltaic system to provide $30 \mathrm{~kW}$ of power to the Community Recreation Center in Santa Clara, CA. This electrical energy will be utilized to power the majority of the mid-day electrical demand of the recreation center, which includes pumps, blowers, and controls of the existing solar-thermal heating and cooling system. PV panels provided by OCLI or ARCO will be mounted on a lightweight structure that covers an existing play area, adjacent to llie seciedtion center building. It excess power is generated, this will be used by the building lighting load or returned to the Santa clara municipally owned utility through the utility grid. 

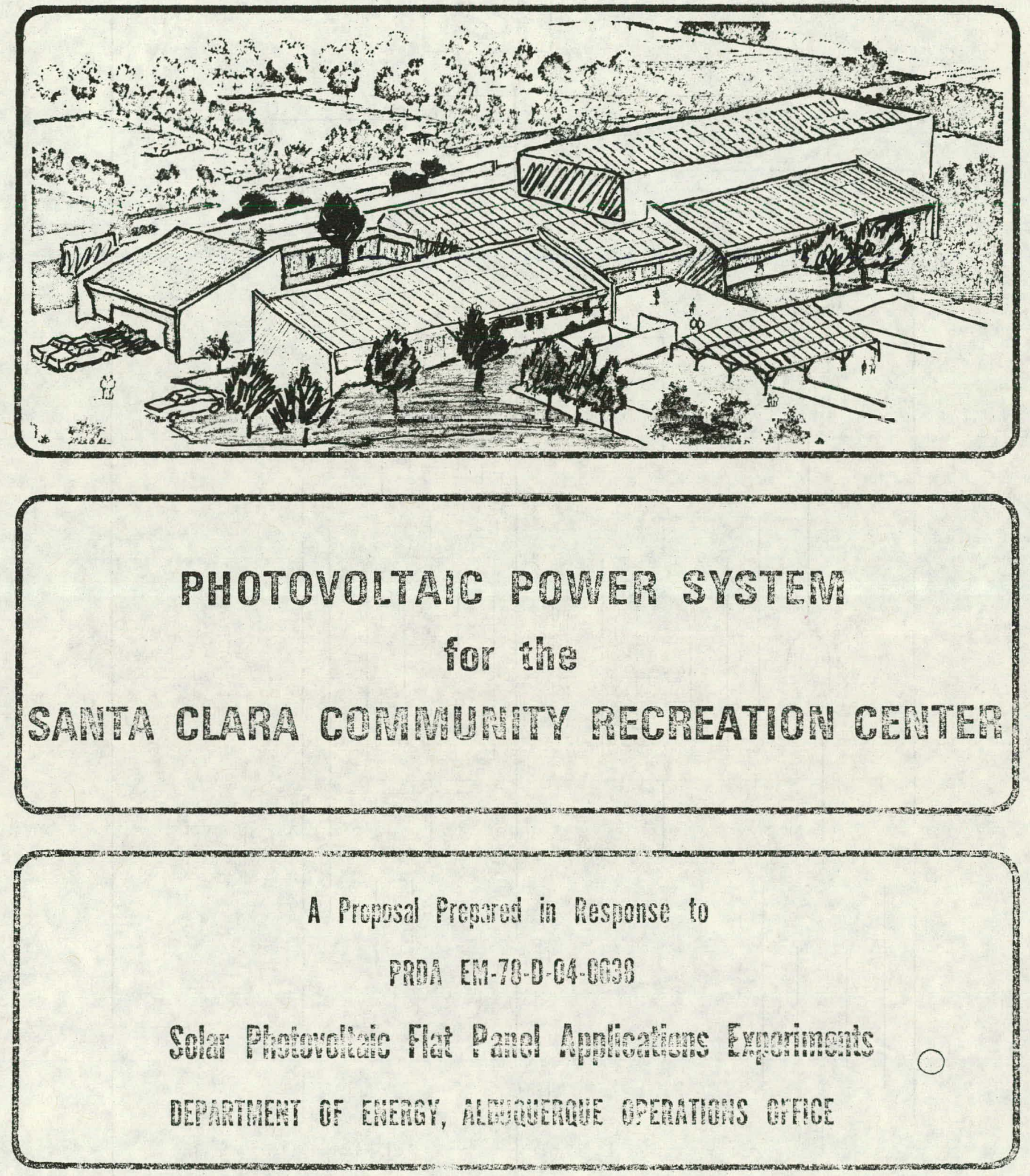

ROCWAEED

PALO ALTO RESEARCH I. ABORATORY 


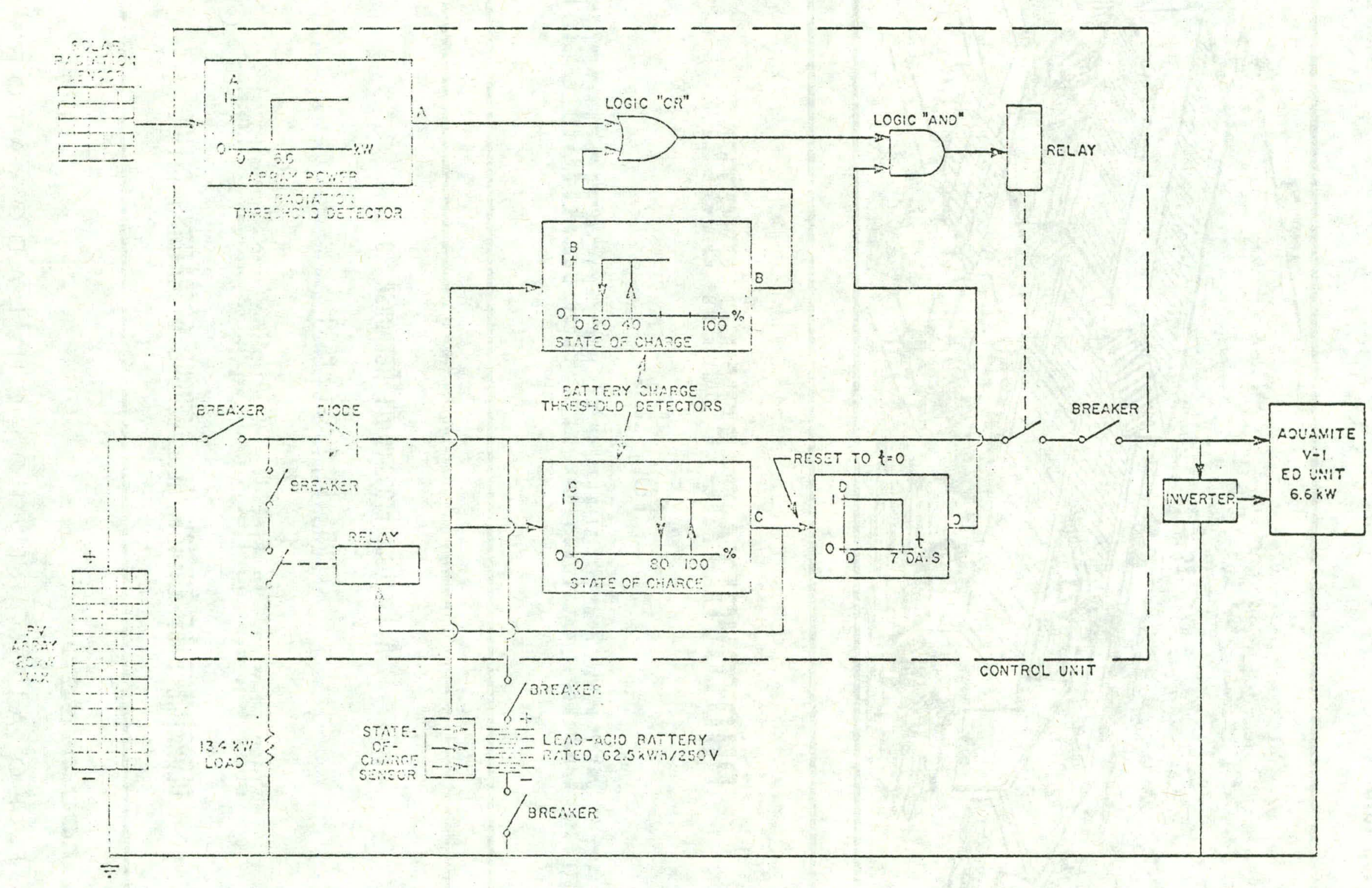


Mobil Tyco Solar Energy Corp.

This application provides $20 \mathrm{~kW}$ of DC power to operate an electrodialysis unit near Crownpoint, NM. The photovoltaic modules are of Mobil Tyco's own manufacture and use their ribbon-grown silicon cells. Approximately $60 \mathrm{kWh}$ of deep discharge lead acid battery storage will provide more or less continuous power to the commercial desalinization unit. A small inverter will be used to provide AC control voltages for the unit. While this particular application is restoring process water from uranium leaching, it is typical of any remote desalinization application such as water purification for drinking or irrigation. 


\section{New Mexico State University}

The New Mexico Solar Energy Institute will install a flat panel photovoltaic array of $20 \mathrm{~kW}$ DC peak output for use at El Paso Electric's Newman Power Station. Onehundred-twenty-five volt DC is required for the power company's computer and control system that adjusts electrical load demands. Approximately $80 \%$ of the daytime computer demand load will be satisfied. The photovoltaic panels to be used are produced at Photon Power, Inc. and consist of thin film cadmium sulfide cells, produced by spraying CaS onto 1/8" thick float glass. The panels are $20^{\prime \prime} \times 24 "$, and lend themselves to the possibility of lowcost, high-production photovoltaic output. A low-cost method of mounting the panels in a frame and then supporting the frame on ground level supports adjacent to the power plant will be used. 



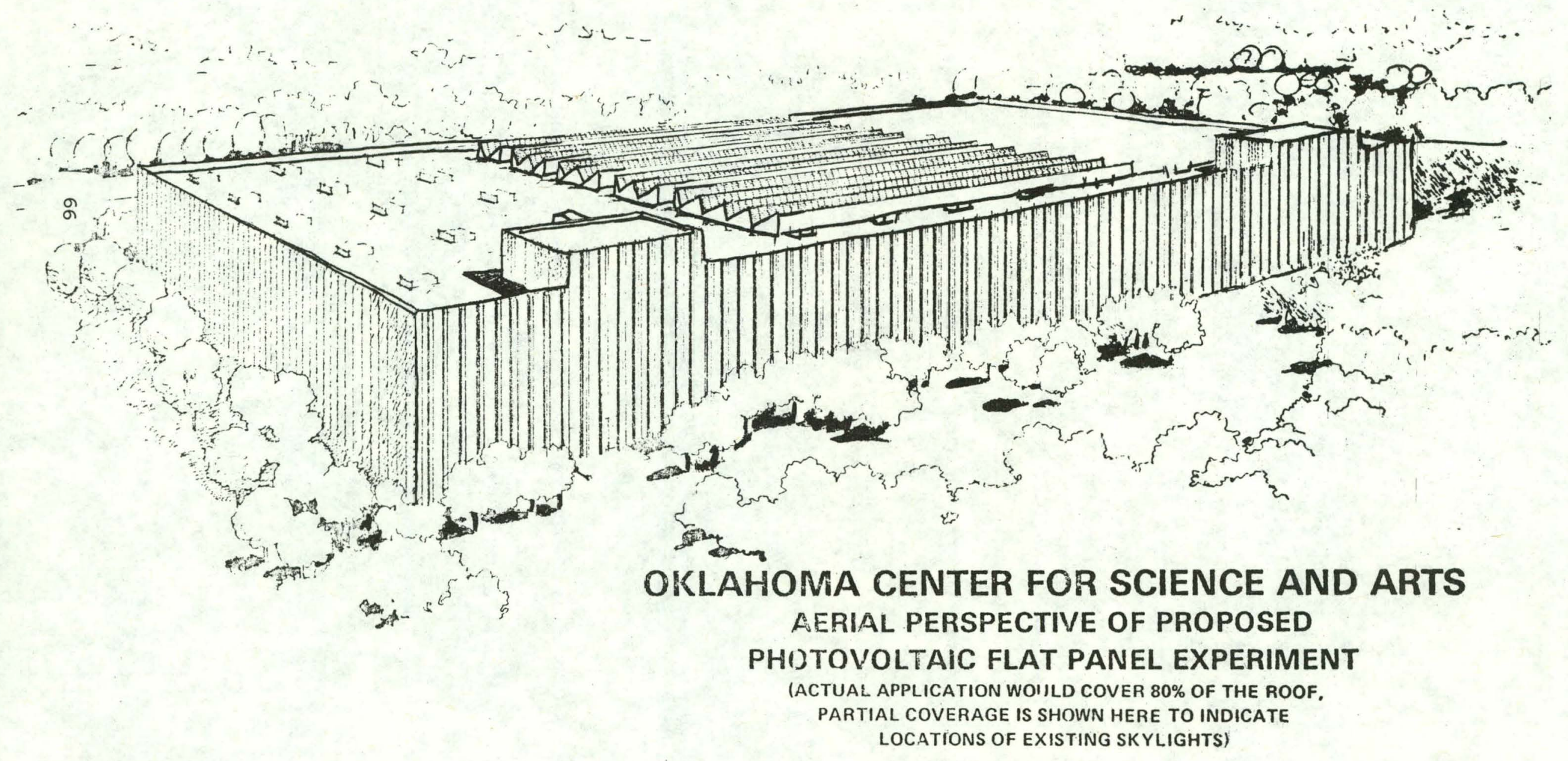


Scientific Analysis, Inc.

SAI is designing a nominal $500 \mathrm{~kW}$ peak photovoltaic flat panel array for installation at the oklahoma Center for Science and Art, Oklahoma City. The system will use a field of polycrystalline silicon solar cell arrays, rated at $400 \mathrm{~kW}$ peak, and reflector augmentation to enhance system output to approximately $500 \mathrm{~kW}$. A major exhibit of the science center is energy. The photovoltaic power would be used as a major source to power and light these exhibits. Any excess power generated by the PV field would either be fed to the Oklahoma Gas \& Electric utility grid or utilized in other on-site facilities. Solarex cast polycrystalline silicon cell modules are to be roofmounted; reflector augmentation is being used to reduce the total cost per $\mathrm{kW}$ of this project. 


\section{Solar Power Corporation}

Solar Power is designing a $175 \mathrm{~kW}$ system to provide AC power to the Beverly High School in Beverly, MA. This will allow peak load sharing of the normal $400 \mathrm{~kW}$ to $500 \mathrm{~kW}$ peak loads and lead excess power back into the Massachusetts Electric Company grid on weekends. The Beverly High School is a combined vocational school operating year-round with summer school in an air-conditioned 25,000 square foot wing of the school. The system will employ Solar Power's 30-watt modules arrayed over 82,000 sq $\mathrm{ft}$ of roof area on the school itself. One or more peak power tracking inverters will Lie 3-phase power into the existing distribution system. 


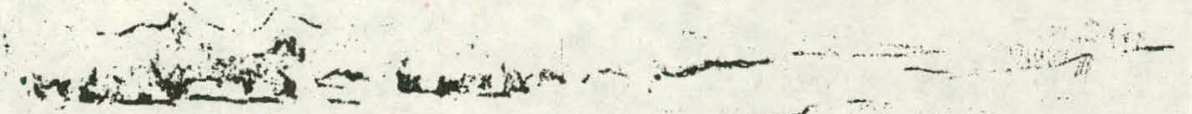

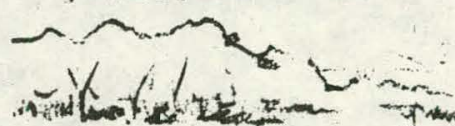

in
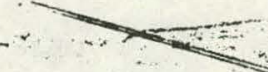
$\rightarrow-\infty-\infty$

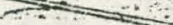

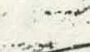

(2)

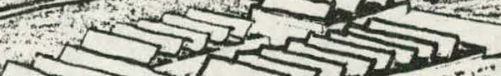

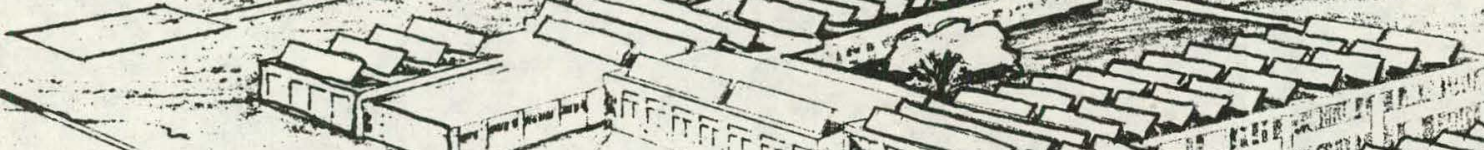

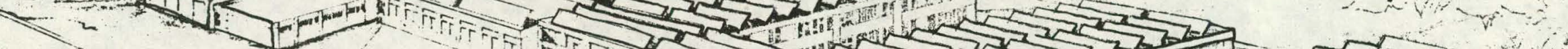

$\ldots$

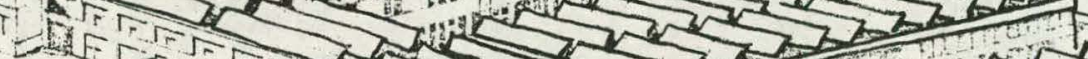
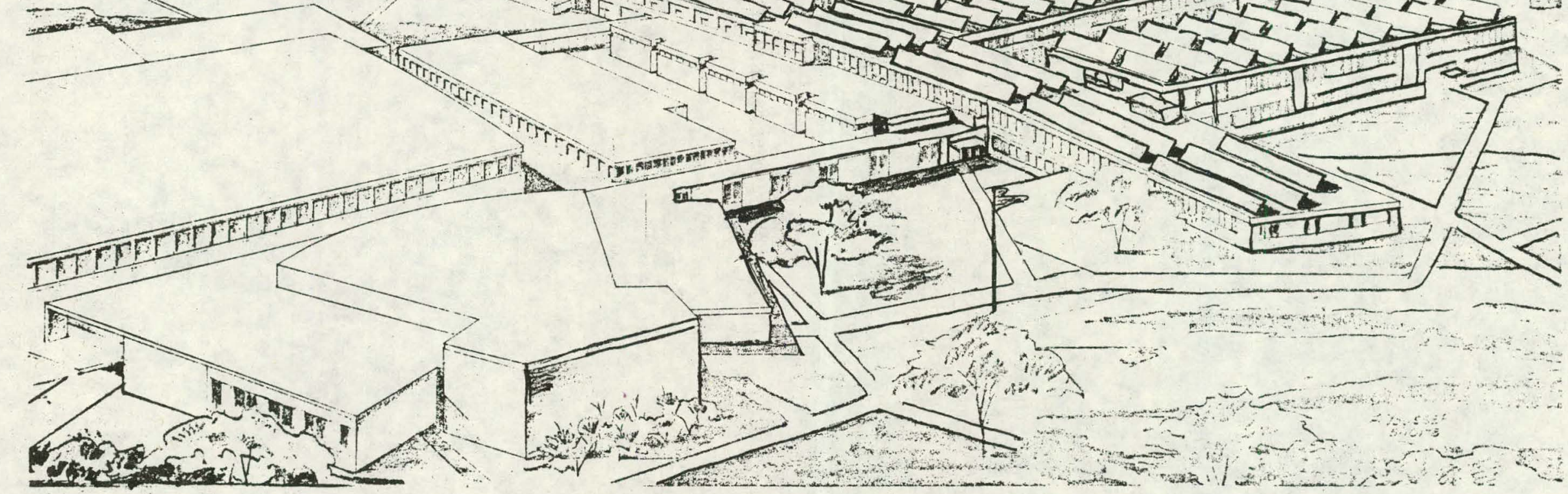
THIS PAGE INTENTIONALLY LEFT BLANK 


\begin{tabular}{|l|l|}
\hline LOCATION: $\begin{array}{l}\text { Liberty State Park. } \\
\text { New Jersey }\end{array}$ & OPERATIONAL DATE: Scheduled for mid-1979. \\
\hline USER AGENCY: $\begin{array}{l}\text { New Jersey Department of } \\
\text { Environmental Protection }\end{array}$ & DESIGNER: NASA Lewis Research Center \\
\hline
\end{tabular}

USE: Demonstration of Photovoltaic power for air pollution monitor.

$\begin{array}{ll}\text { ARRAY POWER (PEAK): } & 360 \text { watts } \\ \text { AMPERAGE (PEAK): } & 6.4 \text { amps } \\ \text { VOLTAGE (PEAK) : } & 60 \mathrm{~V} \mathrm{DC} \\ \text { EFFICIENCY OF SYSTEM: } & 561 \text { A-h } \\ \text { STORAGE CAPACITY: } & 59 \text { square feet } \\ \text { SIZE OF ARRAY: } & 20 \text { (Block III) } \\ \text { NUMBER OF MODULES: } & \text { ARCO } \\ \text { MANUFACTURER OF CELIS : } & \text { Silicon } \\ \text { COMPOSITION OF CELLS: } & \end{array}$

TRACKING SYSTEM TYPE: 、 Non-tracking

DECLINATION SETTING: $\quad 56^{\circ}$ year round

INSTALLED SYSTEM COST:

COMPONENT COST:

SPECIAL DESIGN FEATURES: 
DATE : TIME SINCE INSTALLATION:

CLEANING :

MODULE FAILURES (if any):

SYSTEM DEGRADATION (if any):

SPECIAL NOTES:

NO PICTURE AVAILAB்LE

DATE:

TIME SINCE INSTALLATION:

CLEANING :

MODULE FAILURES (if any):

SYSTEM DEGRADATION (if any):

SHEC $\perp A C$. NOTES :

DATE:

TIME SINCE INSTALLATION:

CLEANIN!G :

MODULE FAILURES (if any):

SYSTEM DEGRADATION (if anY):

SPECIAL NOTES: 
Agricultural Flexible Test Facility

\begin{tabular}{|l|l|}
\hline LOCATION: Mead, Nebraska & OPERATIONAL DATE: July 27, 1977 \\
\hline USER AGENCY: Farm & DESIGNER: MIT - Lincoln Lab \\
University of. Nebraska
\end{tabular}

USE: To be used as a flexible test bed in order to experiment with a variety of PV applications including irrigation, crop drying and fertilizer manufacturing.

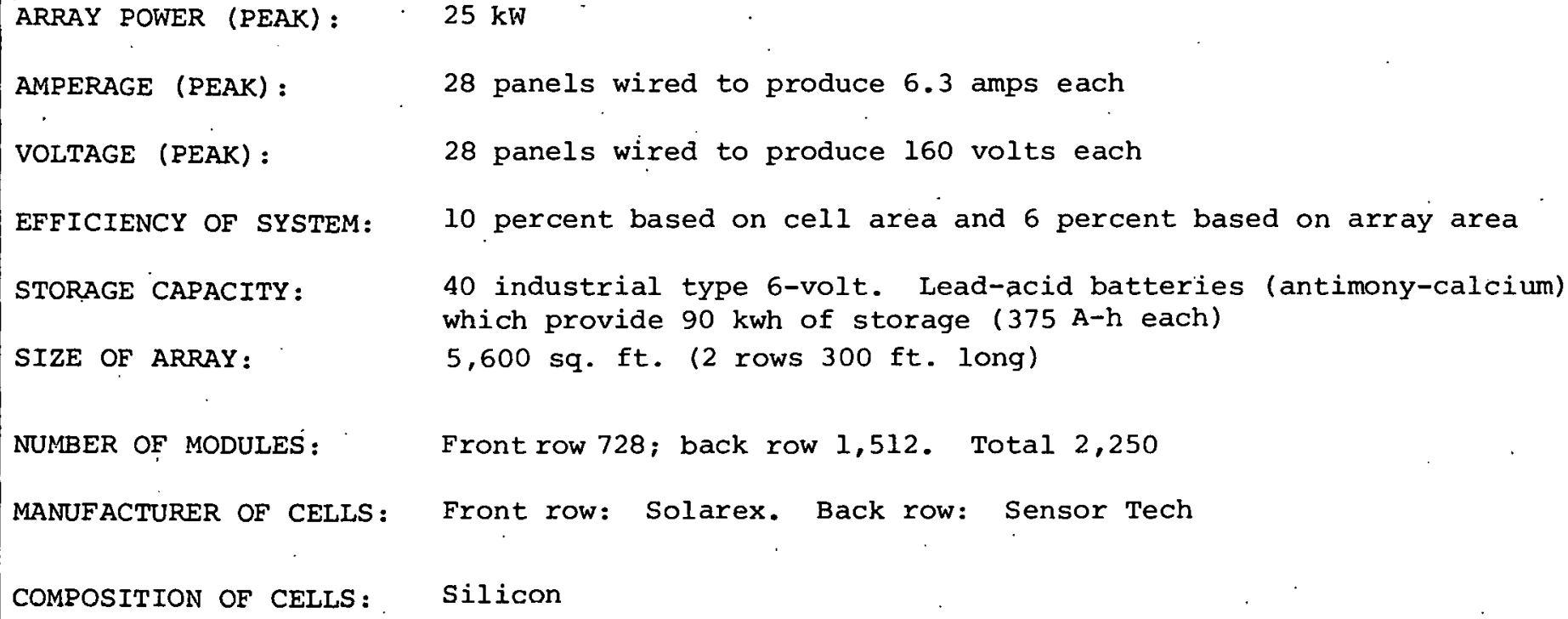

TRACKING SYSTEM TYPE: Non-tracking. Mounted on trunnions enabling individual control of panel elevation between 00 and 650 .

DECLINATION SETPING: 12 settings changed every month.

INSTALLED SYSTEM COST: \$l million

COMPONENT COST:

SPECIAL DESIGN FEATURES:

- The old center-pivot irrigation system required more than twice the energy. used by the gated-pipe system which is presently coupled to the PV power unit.

The 1,000 gallon-per-minute pump can be driven by either DC or AC electric motors. Individual hydraulic tilt control was provided on each of the 28 panels in order that additional experiments could be conducted. 
DATE : February 1978

CLEANING :

MODULE FAILURES (if any): Six

SYSTEM DEGRADATION. (if any):

SPECIAL NOTES:

To date the experiment has proven to be extremely successful. The photovoltaic system has consistently delivered electric power when needed, and the solar cell modules have exhibited an extremely low failure rate: only 6 modules out of 2,000 have failed to deliver electric power during the first six months of operation. Also, one of the lessons learned was that considerable utility energy was expended to provide heat for the battery subsystem in order to maintain rated battery capacity.

DATE: September 1978 TIME SINCE INSTALIATION: 1 year, 2 months

CLEANING: Twice, once in March and once in September.

MODULE FAILURES (if any): 19

SYSTEM DEGRADATION (if any); Less than 1 percent

SPECIAL NOTES:

- The RTV covered modules degraded from 1 to 10 percent.

- The most effective washing agent was found to be pummice (RTV only).

LA'L'H: March 1979

TIME SINCE INSTALLALIUN:

18 months

\section{CLEANING :}

MODULE FAILURES (if any): 24

SYSTEM DEGRADATION (if anY): $1 \%$

SPECIAL NOTES :

1000 cells were damaged due to a hail storm., 


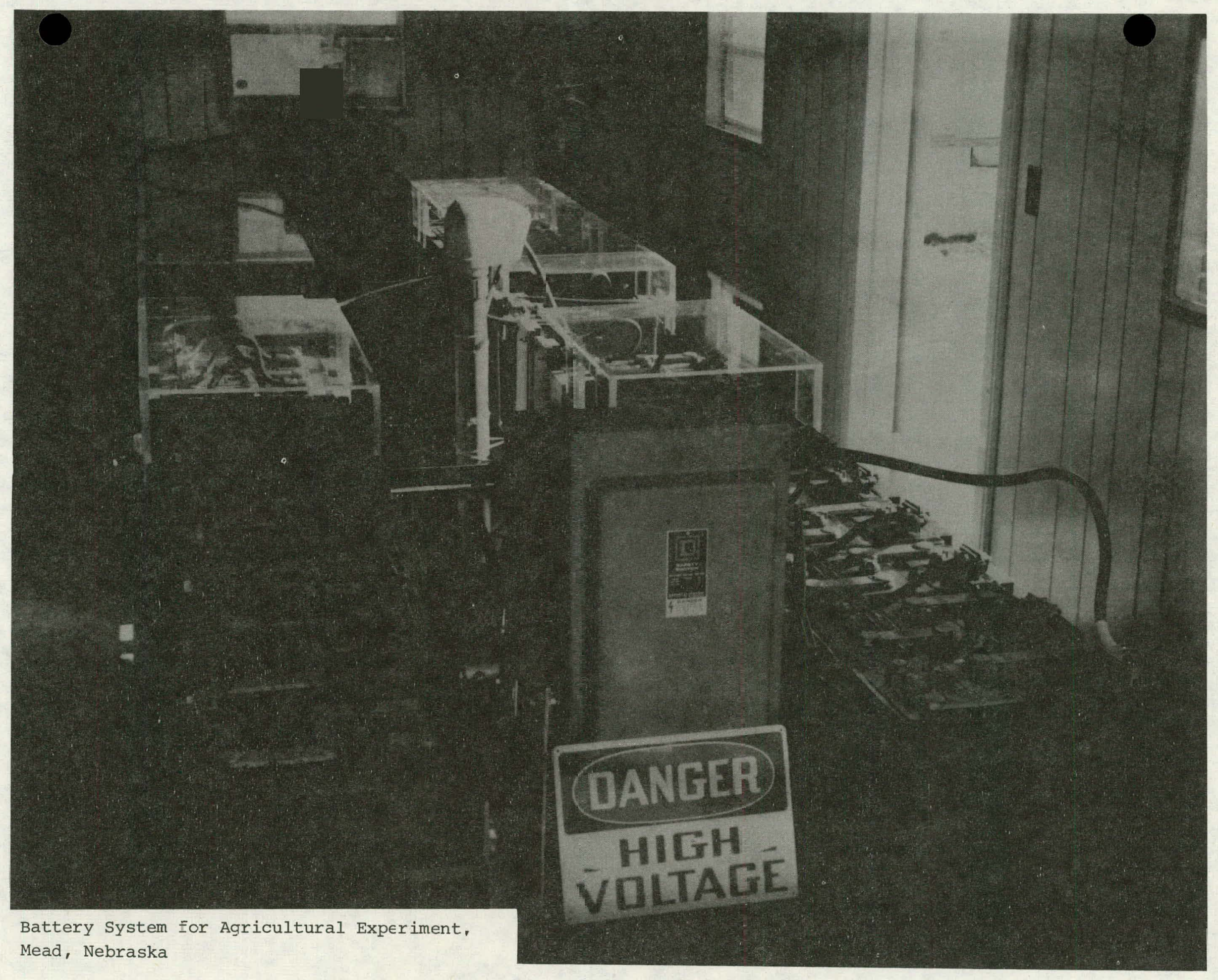


Aerial View of System

Aerial view of $25 \mathrm{~kW}$ Photovoltaic Agricultural Field Test System at Mead, Nebraska, showing arrays, irrigation reservoir (2 acre-feet capacity), trailers, grain drying bins and a portion of the 80 acres of corn which was irrigated by the photovoltaic system. Also seen in the background is a center-pivot irrigation system which requires more than twice the energy used by the more energy-conserving, gated pipe system which is coupled to the photovoltaic power unit. The system was turned on on $27 \mathrm{July} 1977$. The project is funded by the Energy Technology Office of the Department of Energy. The photovoltaic system was designed and constructed by MIT/Lincoln Laboratory. The agricultural elements of the system were provided by the University of NebraskaLincoln, which operates the Mead Agricultural Experiment Station. 


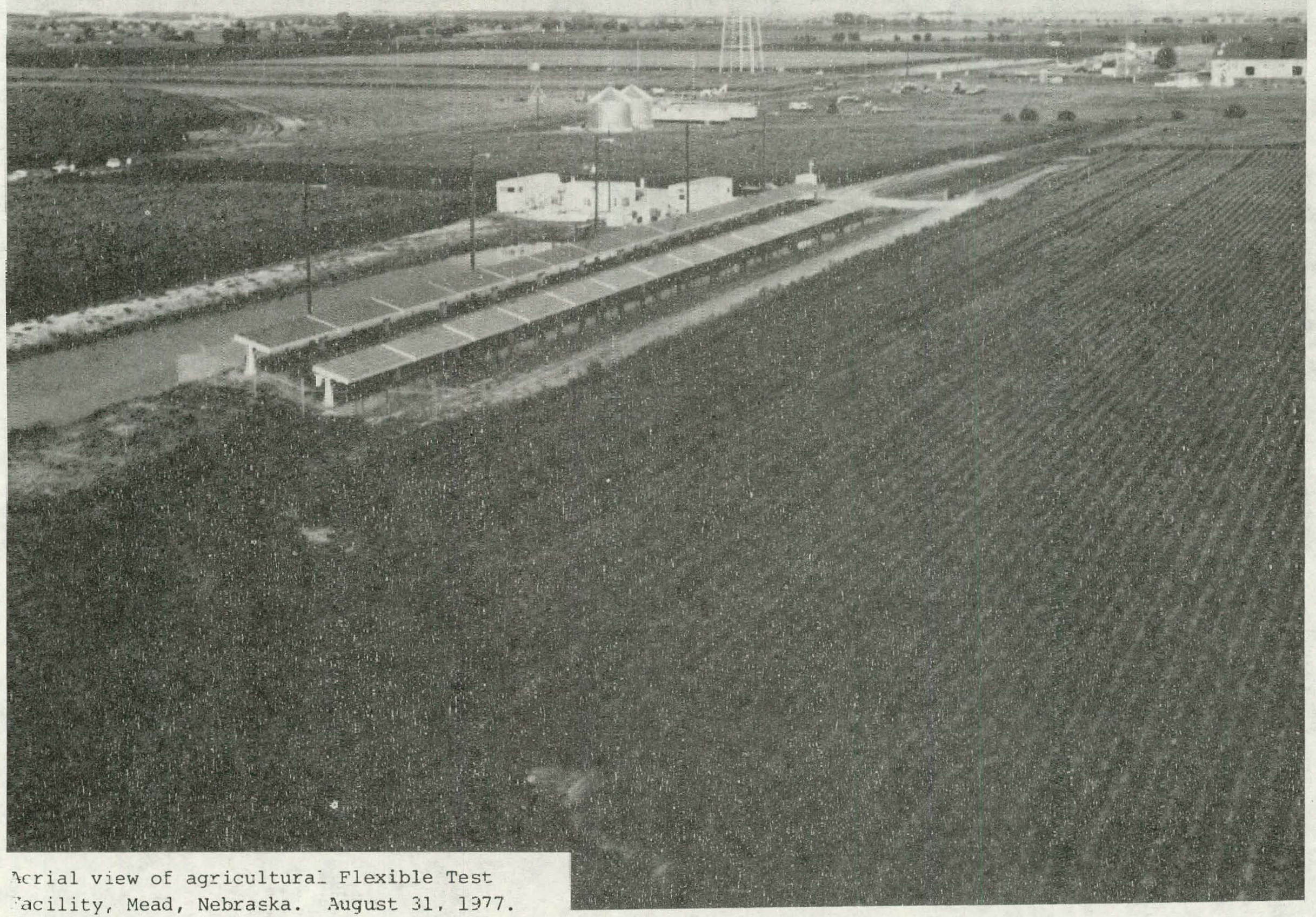




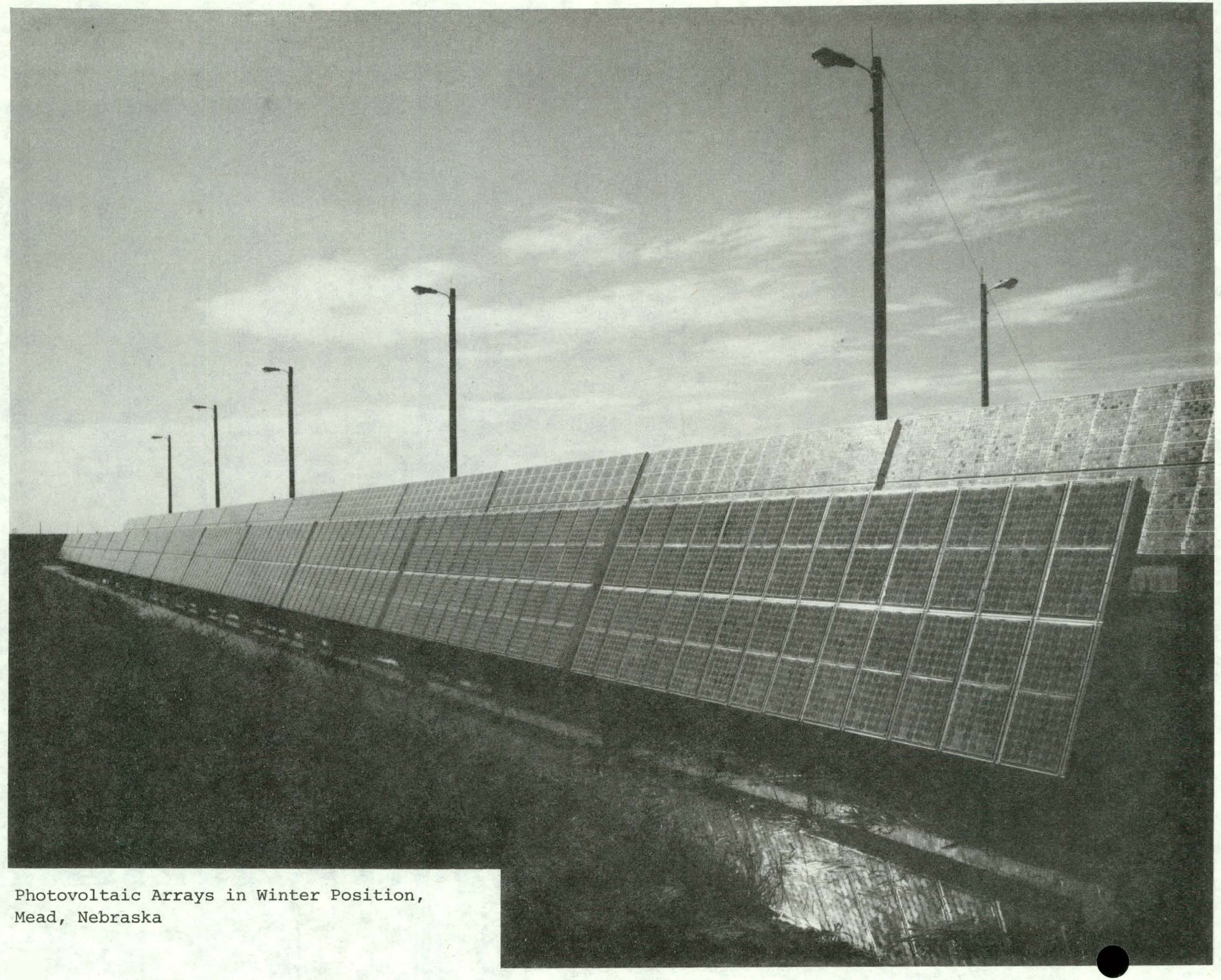




\section{Photovoltaic Arrays in Winter Position}

Another view of the array, with the panels tilted at a steep angle, which would be appropriate for winter operation. The arrays are located on the embankment which surrounds the reservoir and thus do not occupy valuable land which could otherwise be used for raising livestock or growing crops. The ditch seen in front of the lower row of panels is part of the run-off water return system mentioned previously.

Individual hydraulic tilt control was provided for each of the 28 panels in usder Lhal experlments could be conducted concerning the effect of tilt angle on dirt accumulation, self-cleaning during rainy weather and on snow-shedding, and also to permit quick stowing in the event of a severe hail storm. Two different manufacturers' solar cells were used: Solarex Corporation (foreground), and Sensor Technology Corporation (background). Lightning protection cables and a lighting system are seen on the tall poles situated behind the array. 


\section{Gated Pipe Irrigation}

A corn-borer's view of part of the gated pipe irrigation system. Water is distributed via buried pipes and risers to surface-sited pipes and valves of the type shown, which are located at the "high" end of a gently sloping field. Pneumatic pressure is used to actuate groups of valves. The excess water must, by law be collected at the lower end of the crop rows not only because it is valuable but because it contains fertilizers, herbicides and pesticides which are added to the irrigation water on a pre-programmed basis, and uncontrolled run-off would result in pollution. This run-off water is diverted to the two acre-ft. reservoir and is reused for irrigation purposes. 


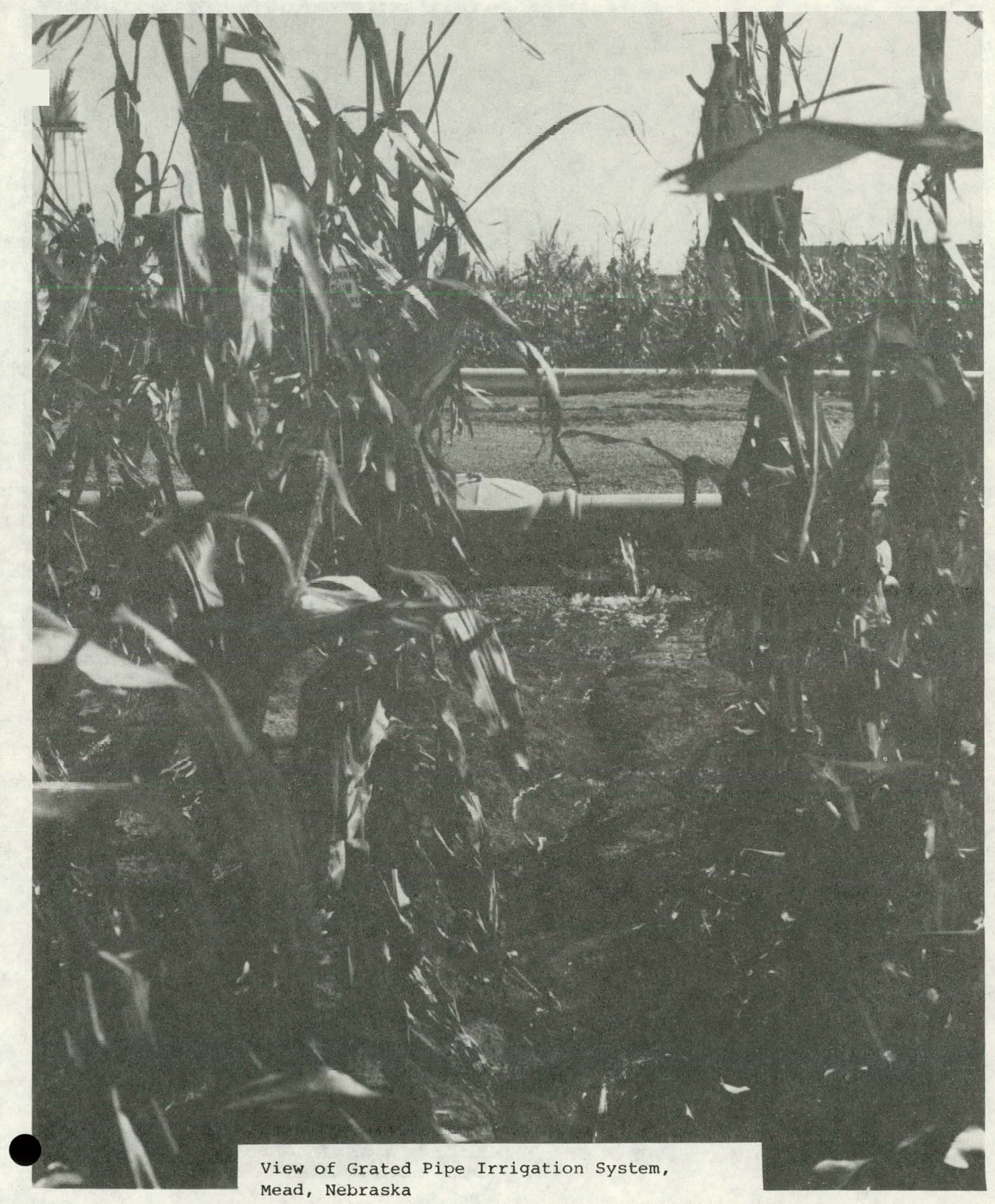




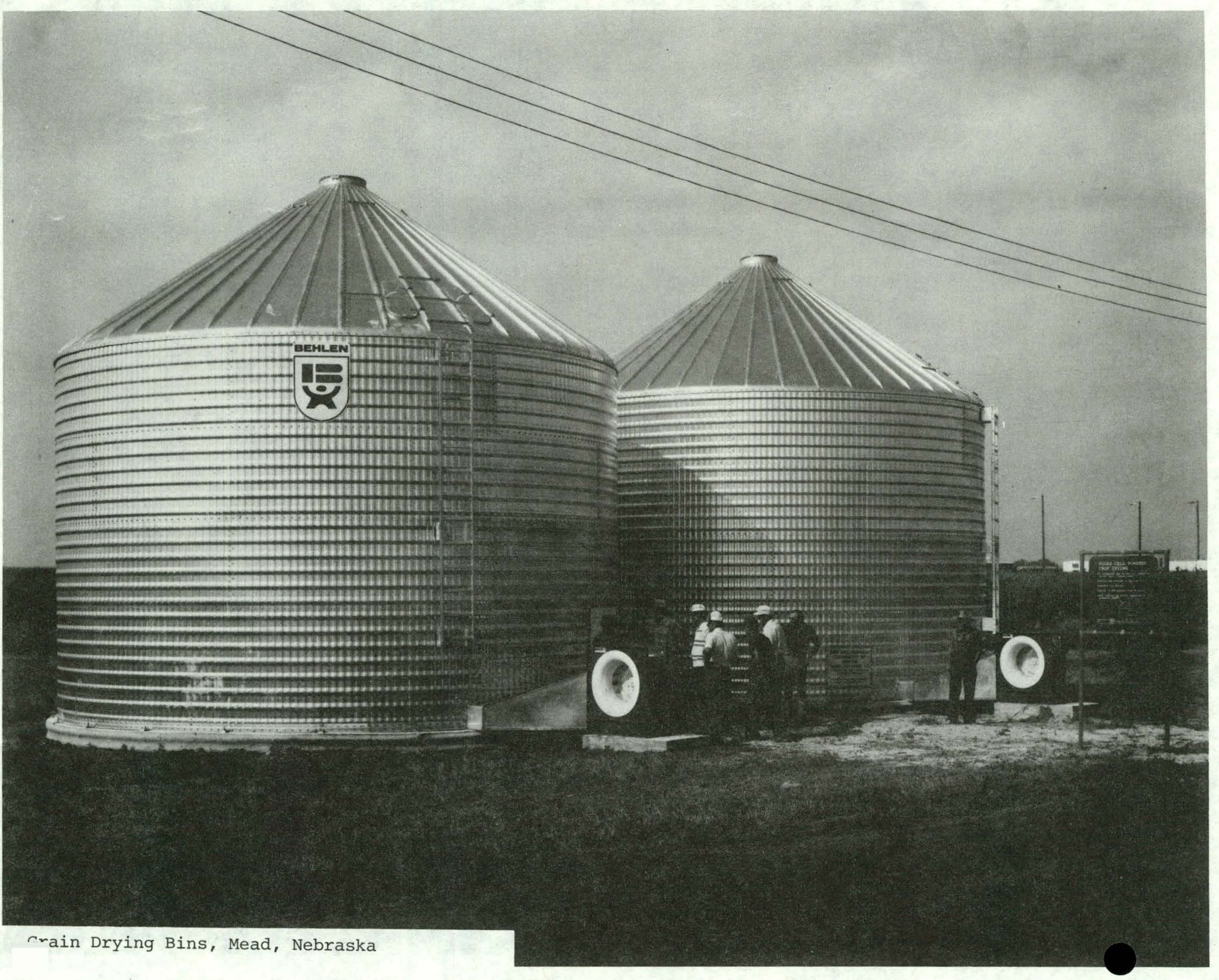




\section{Grain Drying Units}

The photovoltaic power system is now being used to dry grain. The two grain drying bins shown contain 12,000 bushels of corn which were harvested from the 80 acres irrigated by the PV system. The corn must be dried to about $15 \%$ moisture content so that it will not sprout nor rot when the weather becomes warm in the spring. In contrast to the practice of forcing heated air through the grain (which requires combustion of fuels or electric resistance heating), the approach used here entails forcing larger quantities of air at ambient temperature and humidity through the grain. The two approaches are roughly equivalent in terms of total energy consumption. Additional uses for the photovoltaic power system are presently being explored. These include: electric power for fans and lighting for animal husbandry, on-site production of fertilizer, and grain grinding. 


\section{Power Conditioning/Contro1}

A shelter houses switchgear, inverters, maximum power trackers, metering and control panels. A comprehensive data-logging system is also included. A 3-phase battery charger supplied from the utility is provided to supplement the array during cloudy weather periods. Also, a 25-kW power dump enables loading the DC bus in steps of 800 watts. It should be noted that the amount of control equipment in this unit exceeds that which would be required in an operational system purchased by a farmer due to the experimental nature of this system.

The three inverters are controlled by a single master circuit which maintains proper phase relationship and at the same time controls pulse widths to equalize voltage among the three phases. For motor starting, a variable frequency starting mode is provided, wherein both frequency and output voltage are linearly increased from around 30 Hertz and 120 volts to 60 Hertz and 240 volts (rms). Current limiting is provided for inverter protection.

Maximum power trackers are being provided for grouped panel outputs. These consist of DC-to-DC down-converters with pulse-width control of the silicon-controlled rectifiers in such a way as to present matched impedance to the array elements, thus enabling maximum power transfer.

Control of the converters is digital, with the pulse width stepped in successive increments. At each step the product of output current and voltage is checked. If the power increases, a further step is taken; if power decreases, the stepping process reverses.

Control of the system is being automated by means of a microprocessor which will be programmed to manage the battery state-of-charge, and at the same time extract maximum energy from the array under varying load conditions. 


\begin{tabular}{|l|l}
\hline OCATION: Nelis AFB, Nv.; Ft. Hood, Tx.; Ft. & OPERATIONAL DATE: July 1976 \\
Hunter, Ca.; Ft. Bragg, NC & DESIGNER: MERADCOM \\
\hline USER AGENCY: Department of Defense & \\
\hline
\end{tabular}

USE: Charge multiple "D" size Nicad Batteries. Utilized four systems, each capable of energizing 84 "D" batteries.

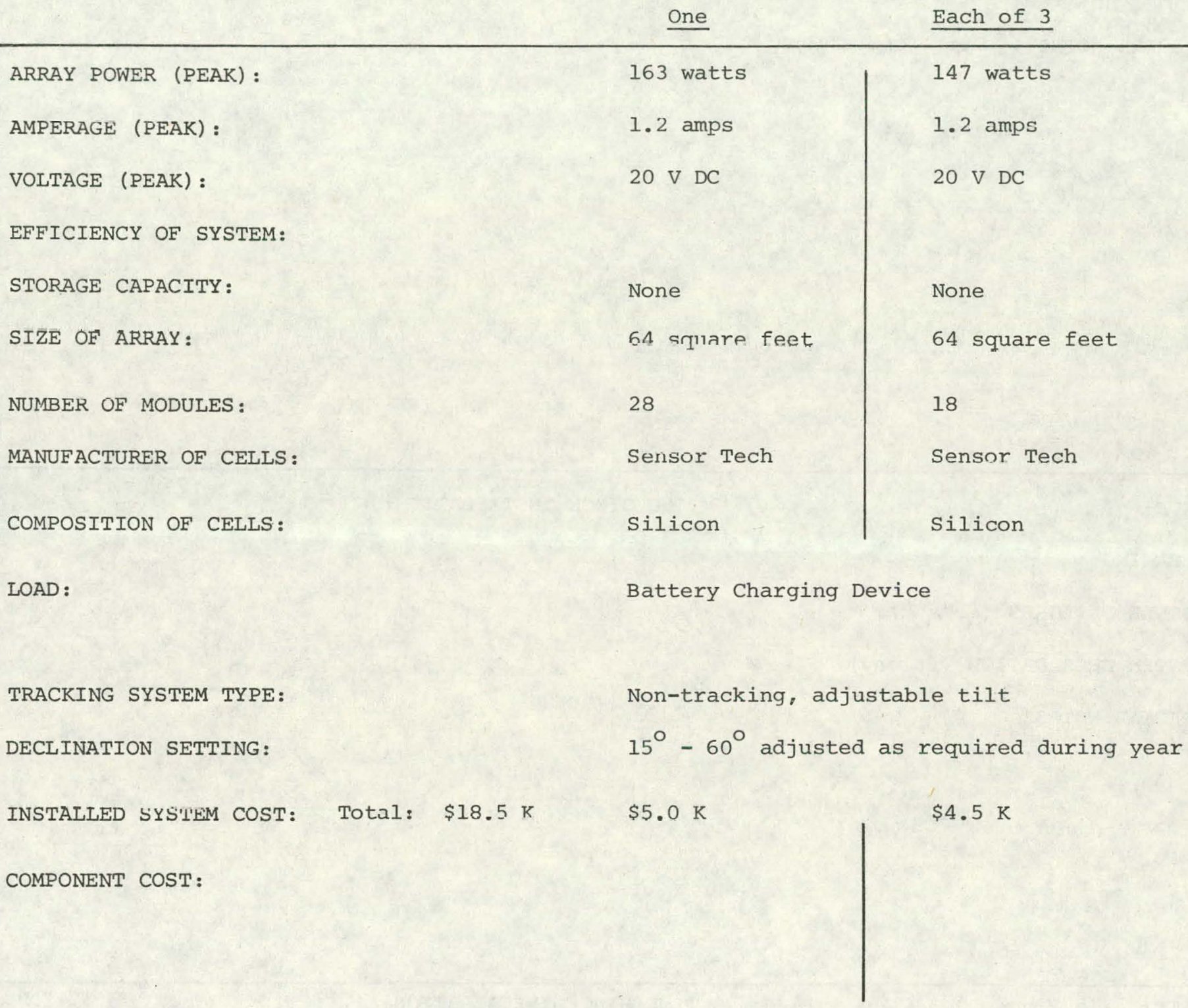

SPECIAL DESIGN FEATURES:

Part of JPL Block I modules. 


DATE: November 1978 TIME SINCE INSTALLATION: 2 years, 4 months
CLEANING: No
MODULE FAILURES (if any): None
SYSTEM DEGRADATION (if any): None
SPECIAL NOTES: Still operational

DATE:

TIME SINCE INSTALLATION:

CLEANING :

MODULE FAILURES (if any):

SYSTEM DEGRADATION (if any):

SPECIAL NOTES :

DATE:

TIME SINCE INSTALLATION:

CLEANIṆG :

MODULE FAILURES (if any):

SYSTEM DEGRADATION (if any):

SPECIAL NOTES: 


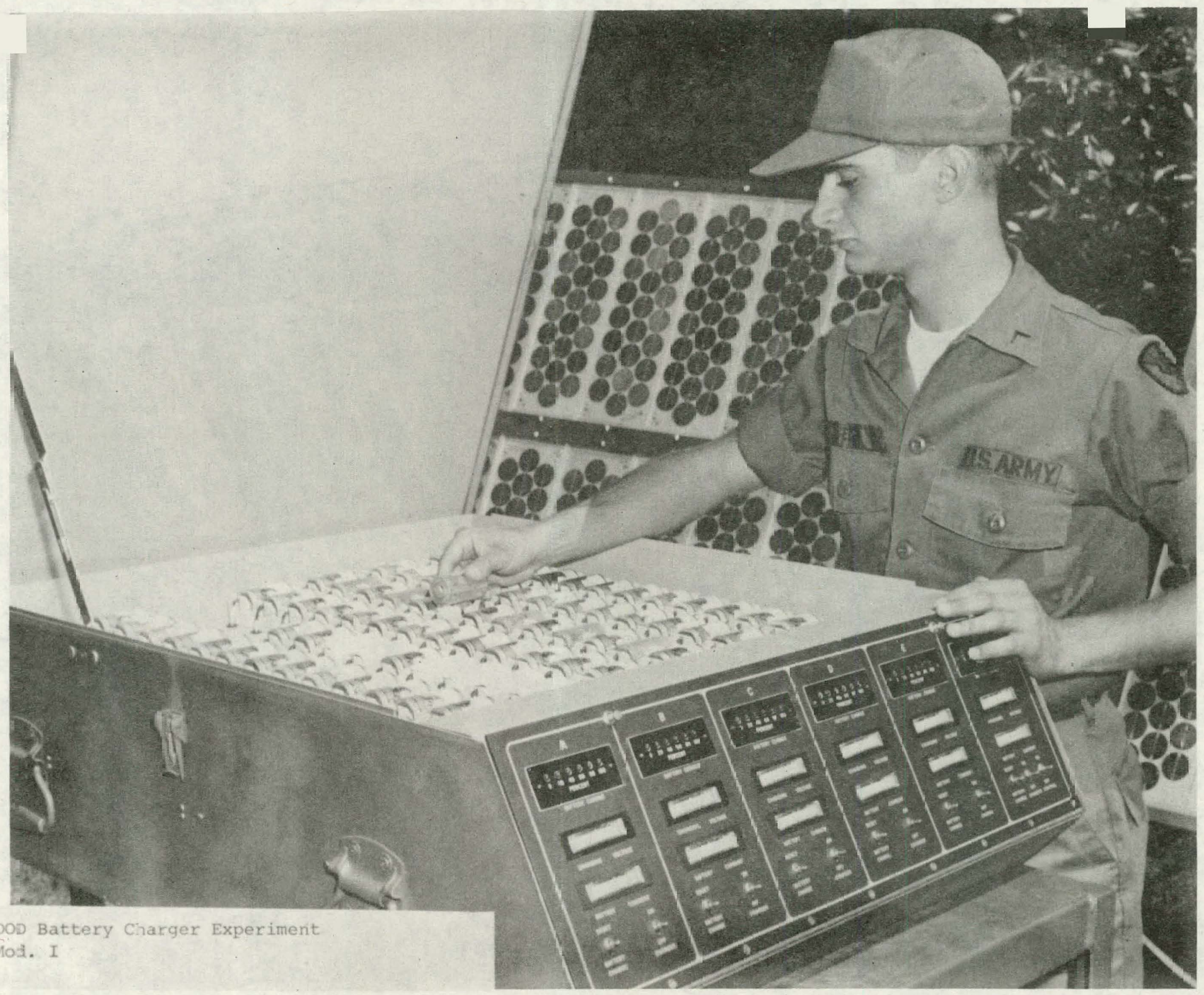




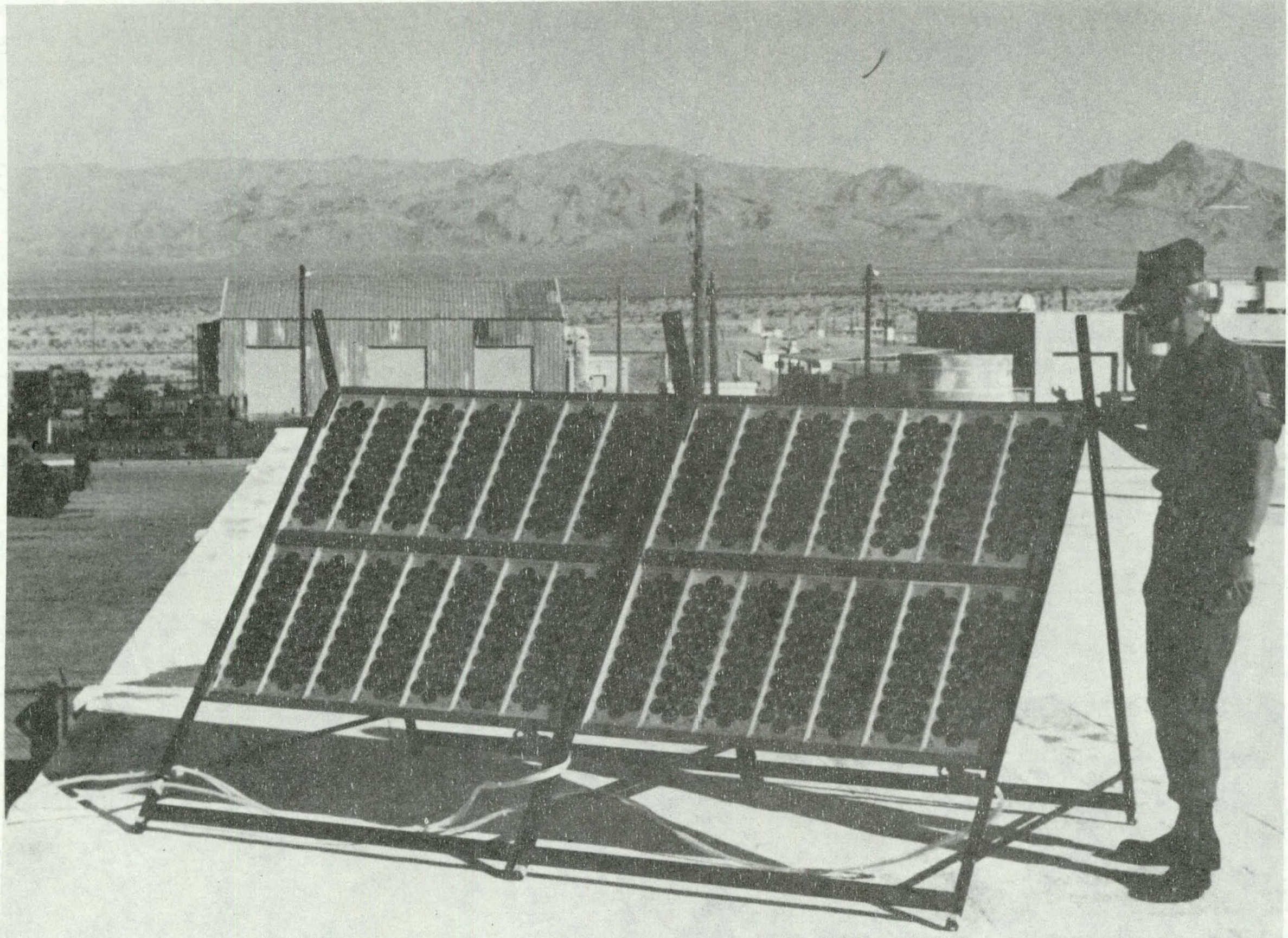

Ba ry Charter - Mod. II Array being checked out. 


\section{Battery Charger}

This low-power application was selected for use as a service indocLrination tool and to investigate the possibility of recharging "D" size nickel-cadmium batteries. It is intended to expose all branches of service to photovoltaic power supplies, investigate the characteristics of simple photovoltaic systems, and determine the military feasibility of a photovoltaic power source for recharging secondary batteries in the field. Four systems have been fabricated. Peak power is $147-163$ watts with a 20 volt DC system. A single 4-ft. $x$ 4-ft. solar cell panel weighing 120 lbs. is used. 


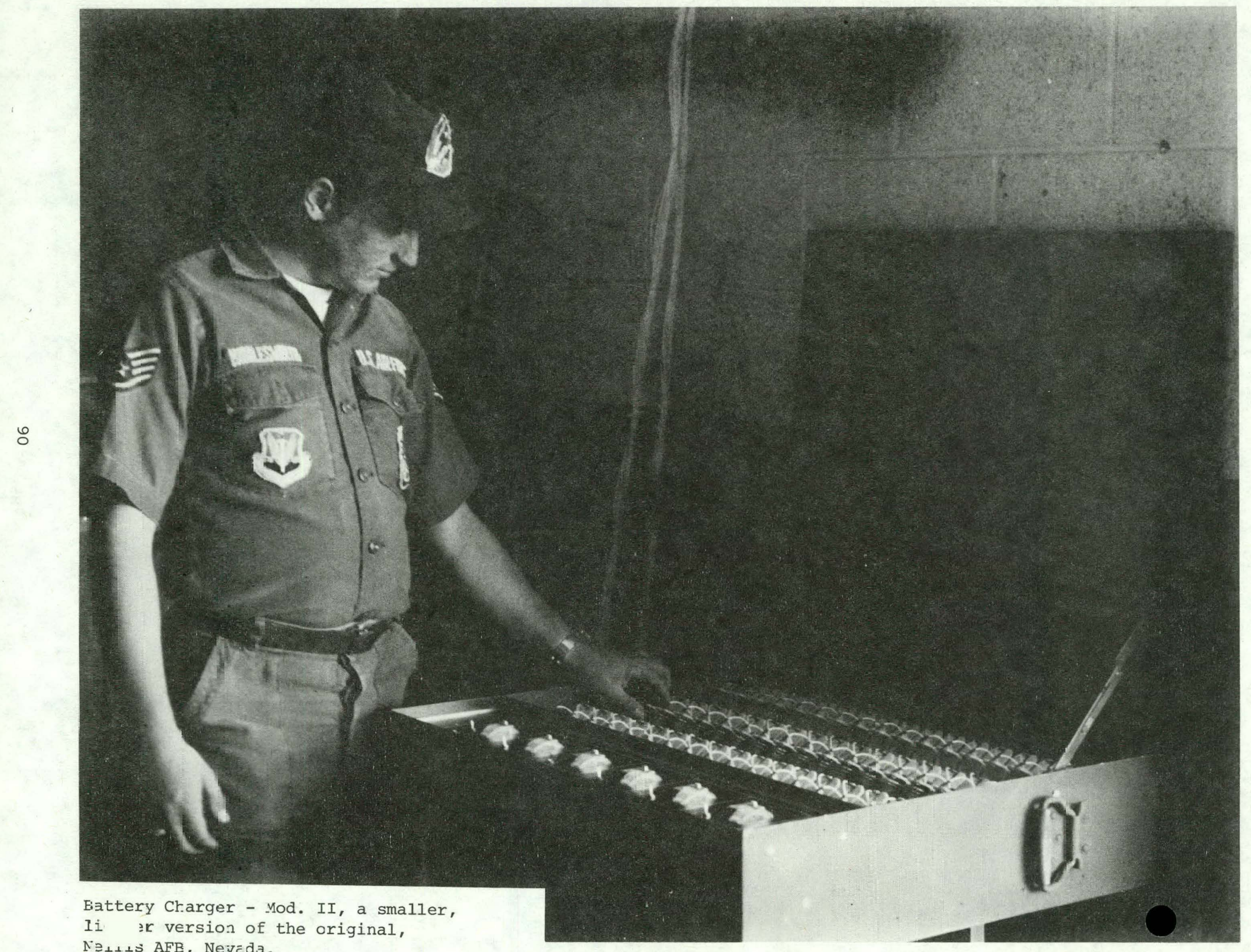

Ii $a$ version of the original,

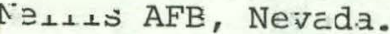


Forest Lookout Stations

Antelope Peak (A.P.) and Pilot Peak (P.P.)

LO ON: Lassen National Forest, Calif. (A.P.) OPERATIONAL DATE: October 1976
Plums National Forest, Calif. (P.P.)

USER AGENCY: United States Forest Service

DESIGNER: NASA Lewis Research Center

USE: PV array provides sufficient electrical energy to operate the tower's refrigeration, lights, water pump and radio communication equipment.

$\begin{array}{ll}\text { ARRAY POWER (PEAK): } & 294 \text { watts } \\ \text { AMPERAGE (PEAK): } & 16 \text { amps. } \\ \text { VOLTAGE (PEAK): } & 12 \mathrm{~V} \mathrm{DC}\end{array}$

EFFICIENCY OF SYSTEM:

STORAGE CAPACITY: $\quad 3,015$ amp hours

SIZE OF ARRAY: $\quad 66.67$ square feet

NUMBER OF MODULES: $\quad 32$ (9.2 watt, 6 volt modules - Block I)

MANUFACTURER OF CELLS: SOlarex

COMPOSITION OF CELLS: Silicon

LOAD :

Water pump, lights, refrigerator, USFS radio and private TV.

TRACKING SYSTEM TYPE: Non-tracking

DECLINATION SETTING: $\quad 36^{\circ}$ year round

INSTALLED SYSTEM COST: $\$ 19,690.00$ (includes modules @ $\$ 21.50 / \mathrm{W}$ plus balance-of-system costs a $\$ 45.47 / \mathrm{W}$, but not experiment related items).

COMPONENT COST:

SPECIAL DESIGN FEATURES:

System used continually from May to September each year. During winter months only batteries are kept charged by the system. 
DATE: April 30, 1978 TIME SINCE INSTALLATION: 1 year, 6 months

CLEANING: No

MODULE FAILURES (if any): None

SYSTEM DEGRADATION (if any): None

SPECIAL NOTES:

Both still operating satisfactorily, but closed for winter. However, PV still powering radio repeaters.

DATE: July 31,1978

TIME SINCE INSTALLATION: 1 year, 10 months

CLEANING: No

MODULE FAILURES (if any): None

SYSTEM DEGRADATION (if any): None

SPECIAL NOTES :

Both operating satisfactorily

DATE :

TIME SINCE INSTALLATION :

CLEANIṆG :

MODULE FAILURES (if any):

SYSTEM DEGRADATION (if any):

SPECIAL NOTES : 


\section{PHOTOVOLTAIC POWERED FOREST LOOKOUTS}

\section{LASSEN AND PLUMAS NATIONAL FORESTS, CALIFORNIA}

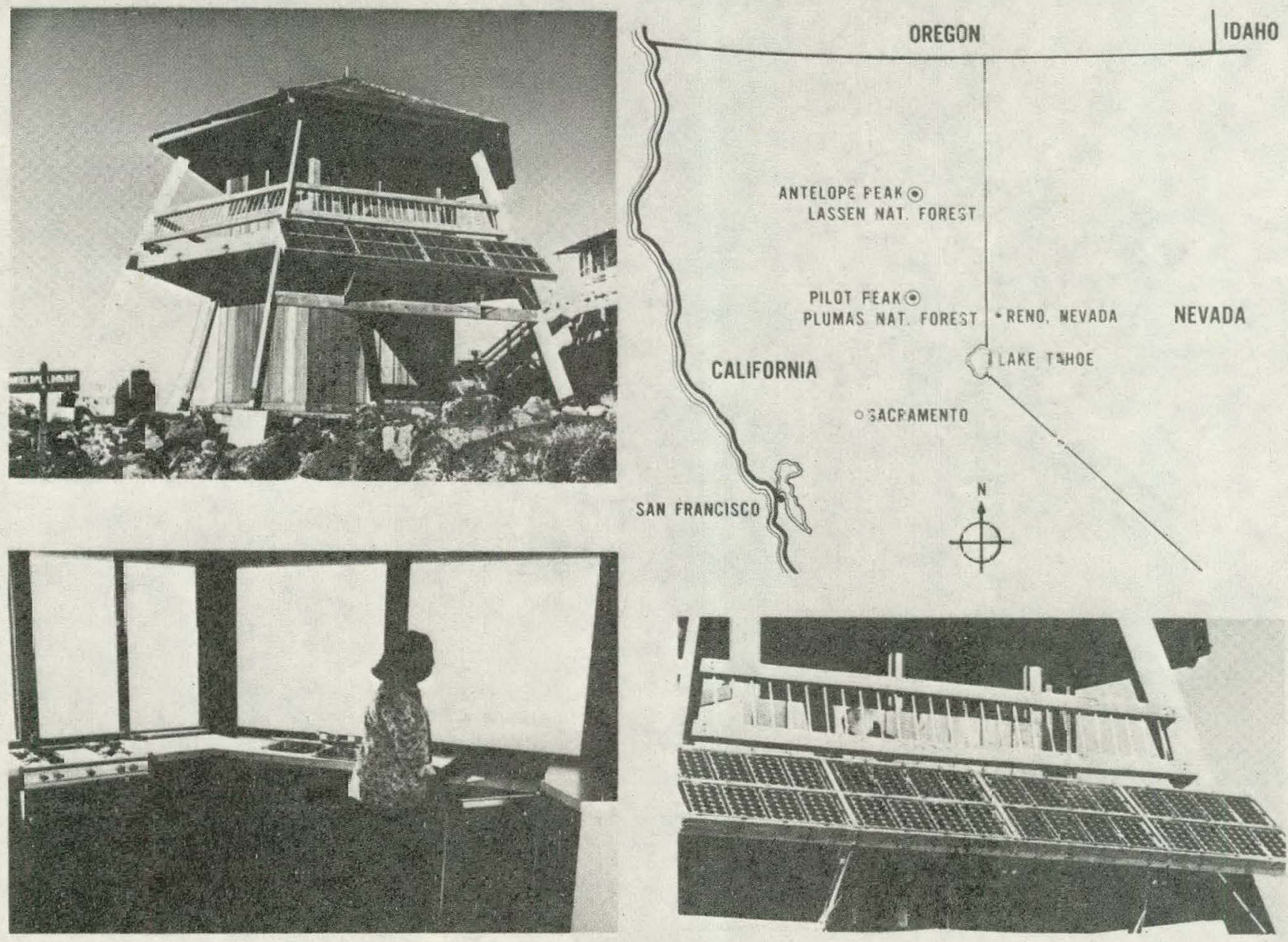




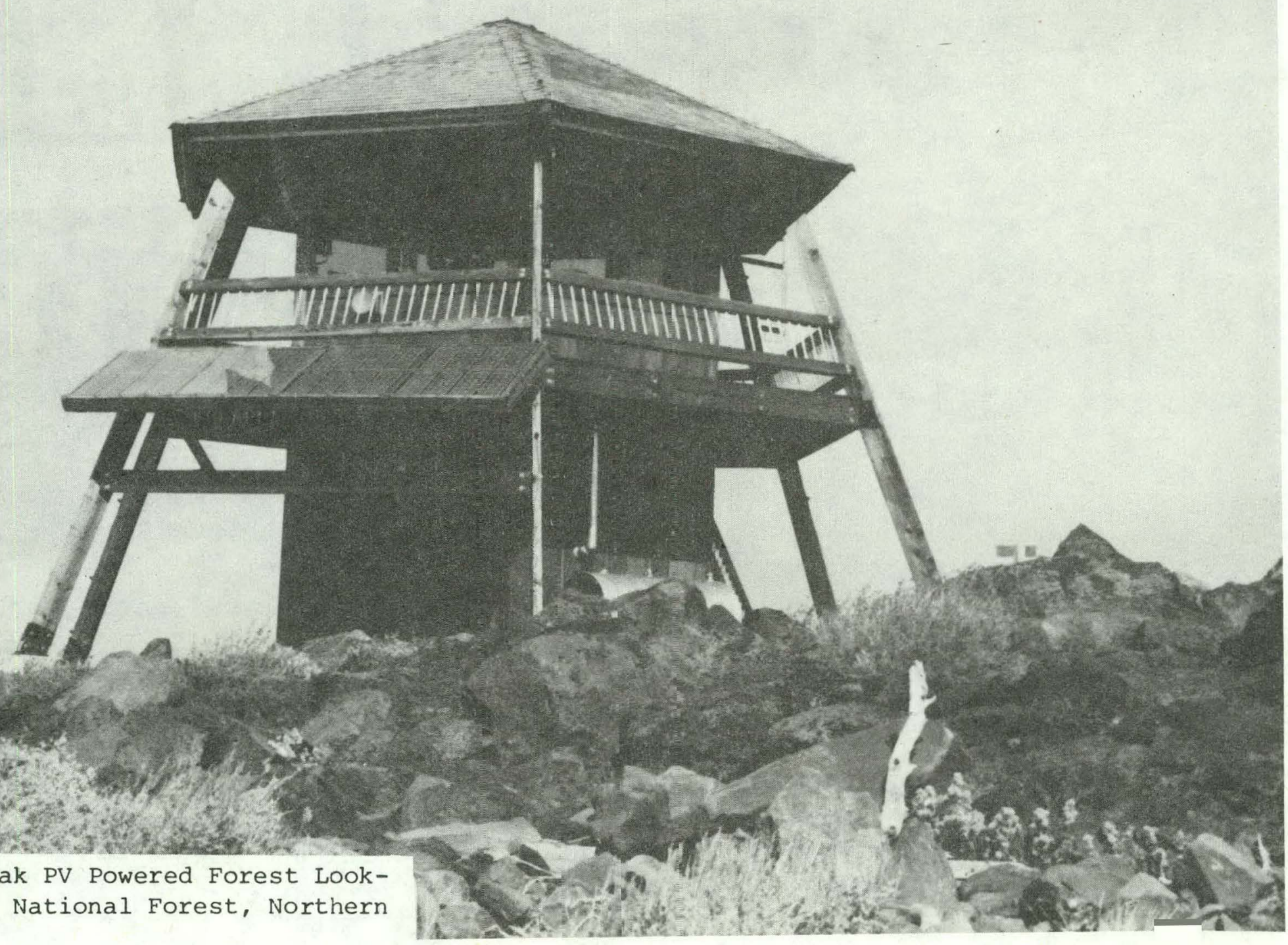


Highway Warning Sign Experiment

\begin{tabular}{l|l|l}
\hline OCATION: $\begin{array}{l}\text { Interstate } 10 \text { between Phoenix and } \\
\text { Tucson, Arizona }\end{array}$ & OPERATIONAL DATE: April 1977 \\
\hline USER AGENCY: Arizona Department of \\
\begin{tabular}{l} 
Transportation \\
\hline
\end{tabular}
\end{tabular}

USE: PV array provides electricity to power one dust storm warning sign.

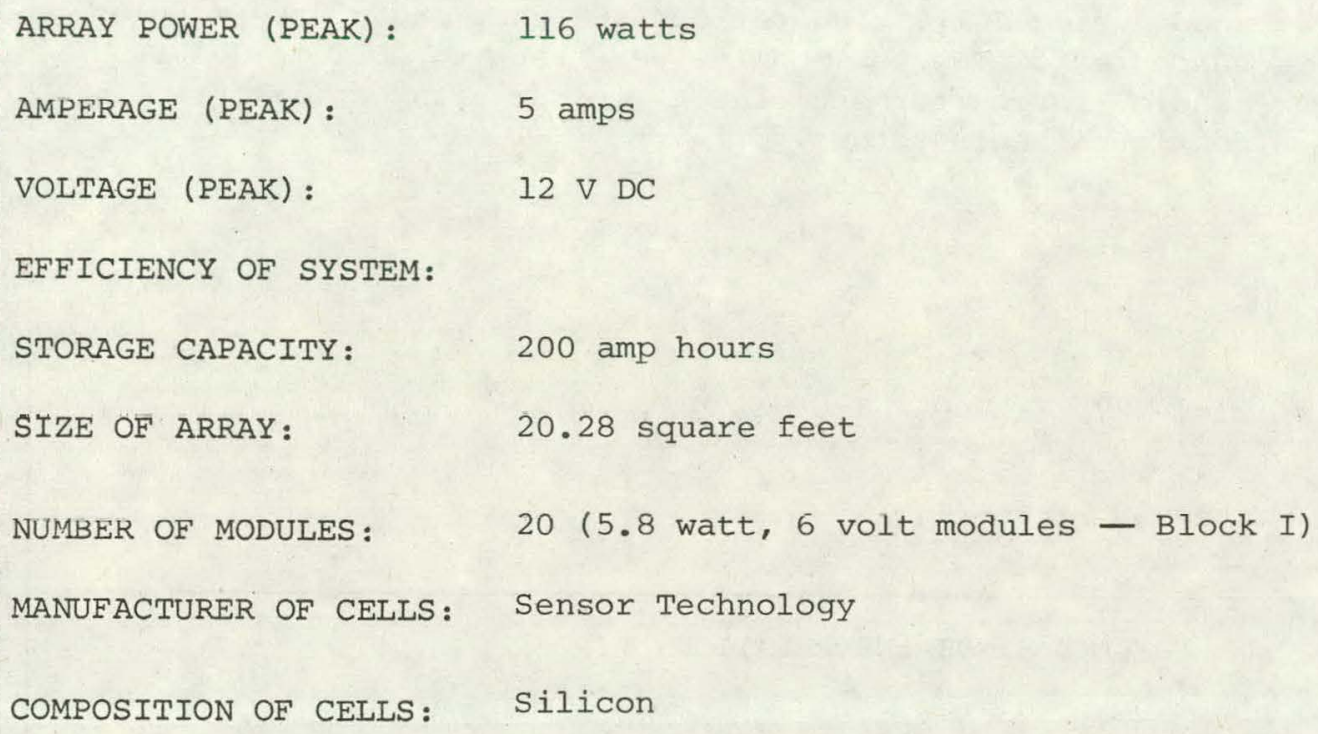

SPECIAL DESIGN FEATURES : 
DATE: July 31, 1978

CLEANING: Yes

MODULE FAILURES (if any): 1

SYSTEM DEGRADATION (if any): None

SPECIAL NOTES :

The highway sign PV array was damaged during July. Indications are that one of the modules was hit by a projectile (gunfire suspected). Two new modules were sent to ADOT in July. The damaged module and one other module (for performance check) in the array will be replaced. Operation of the sign continues satisfactorily.

DATE:

TIME SINCE INSTALLATION:

CLEANING :

MODULE FAILURES (if any):

SYSTEM DEGRADATION (if any):

SPECIAL NOTES:

CLEANIṆG :

MODULE FAILURES (if any):

SYSTEM DEGRADATION (if any):

SPECIAL NOTES: 
PHOTOVOLTAIC POWERED DUST STORM WARNING SIGN

ON INTERSTATE 10 MEAR CASA GRANDE, ARIZOMA

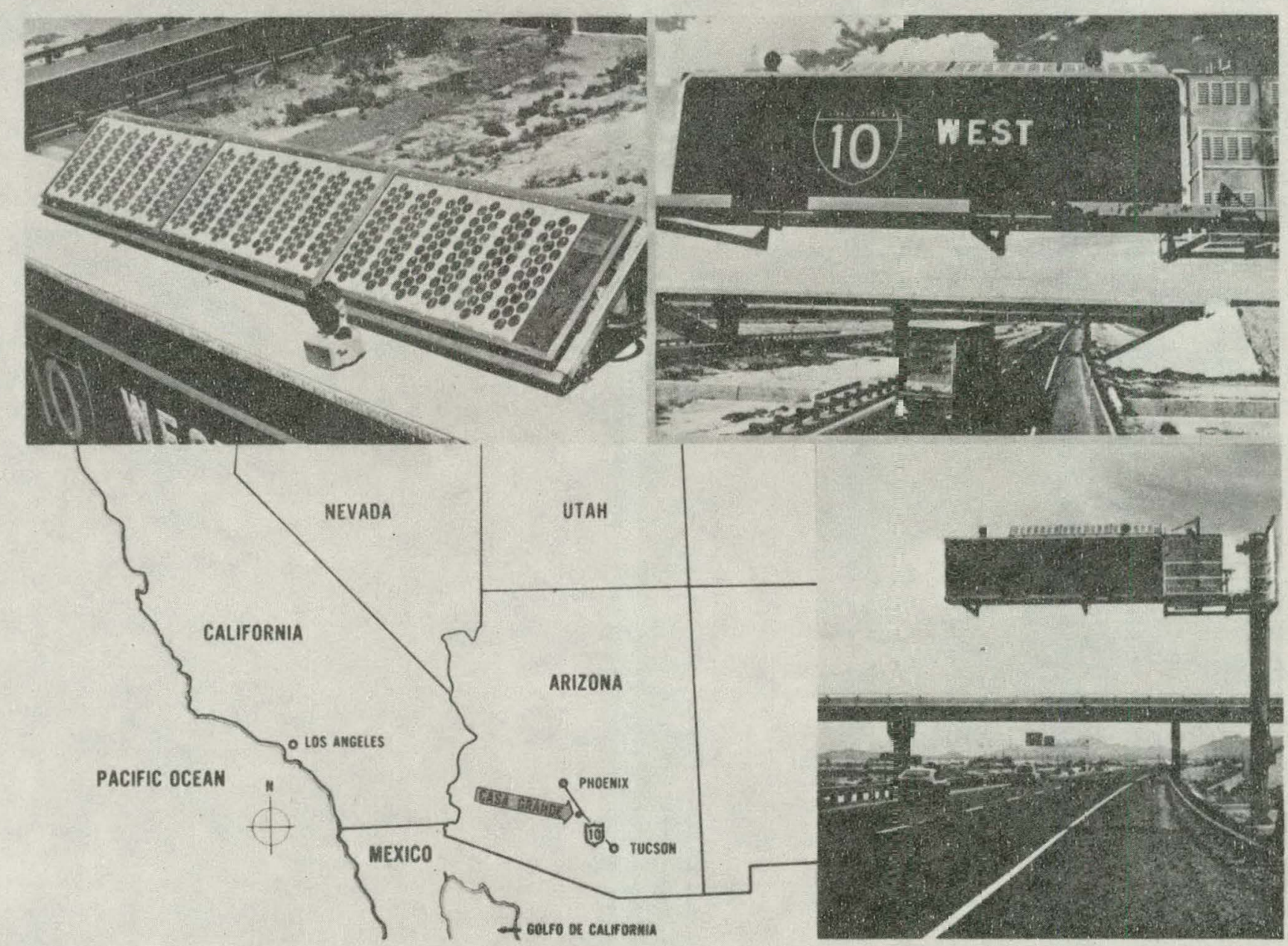




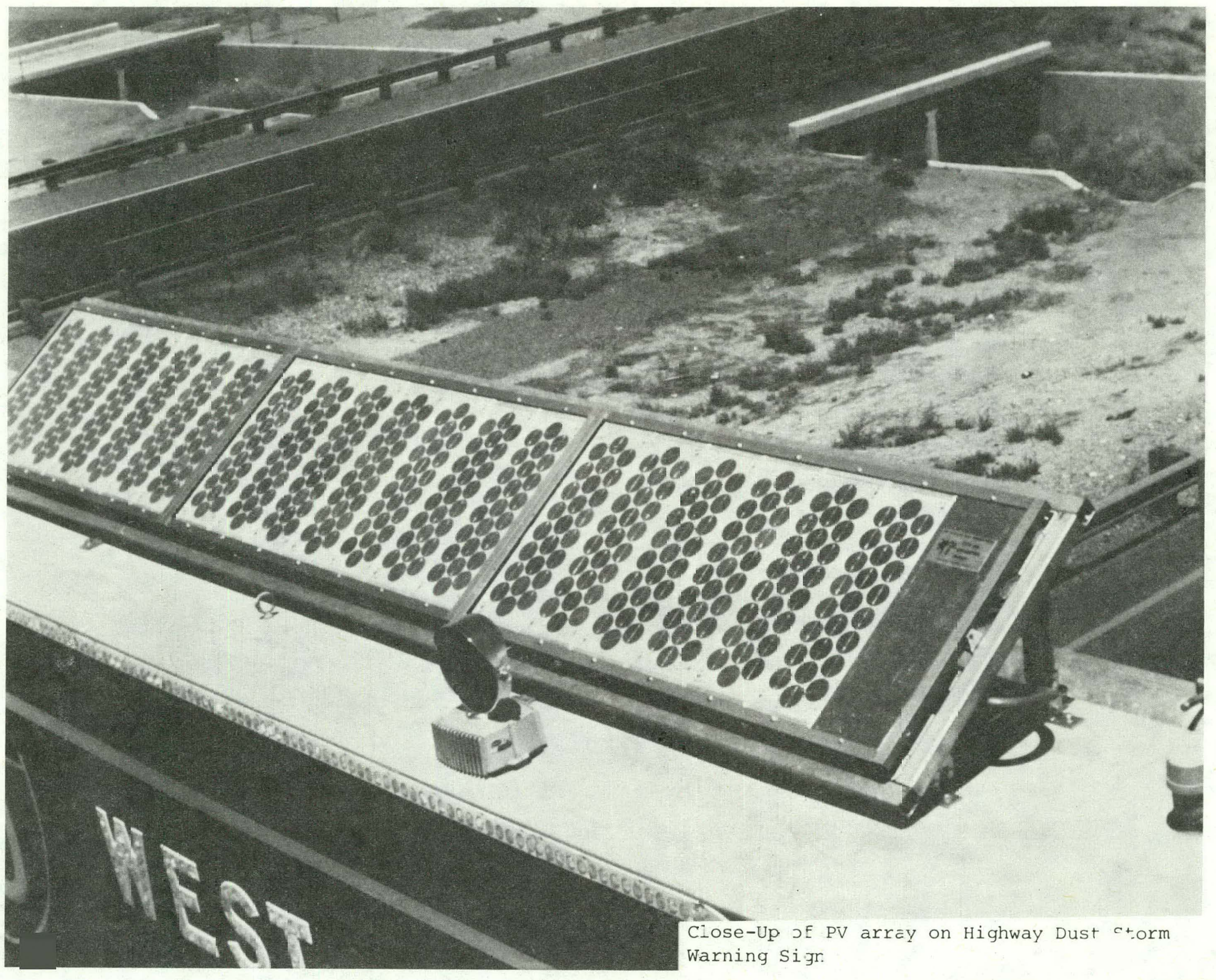




\section{Arizona Dust Storm Warning Sign}

The sign, operated by a 116 watt solar cell array, is one in a network of 40 radio-controlled highway signs in the Phoenix-Tucson-Gila Bend region erected 2 to 3 years ago by $A D O T$ to alleviate chain-reaction accidents caused by low visibility driving conditions resulting from blowing dust. When conditions are such that dust storms are possible, the warning system is activated by a radio control link from a Department of Public Safety dispatcher in Phoenix. On signal, the signs change from a normal "Interstate 10" directional information mode to "Dust Storm Alert, Radio $550 / 620 / 910 . "$ In addition to powering the changeable message feature, the photovoltaic power system also supplies electricity for sign lighting, and For radio communications.

The original power source for the sign was a propane fueled, 60-watt, thermoelectric generator. Now, solar cell power provides a more inexpensive operating system. Arizona Department of Transportation estimates that when all signs are converted to solar electricity they will save approximately $\$ 12,000.00$ a year in sign operating costs. 


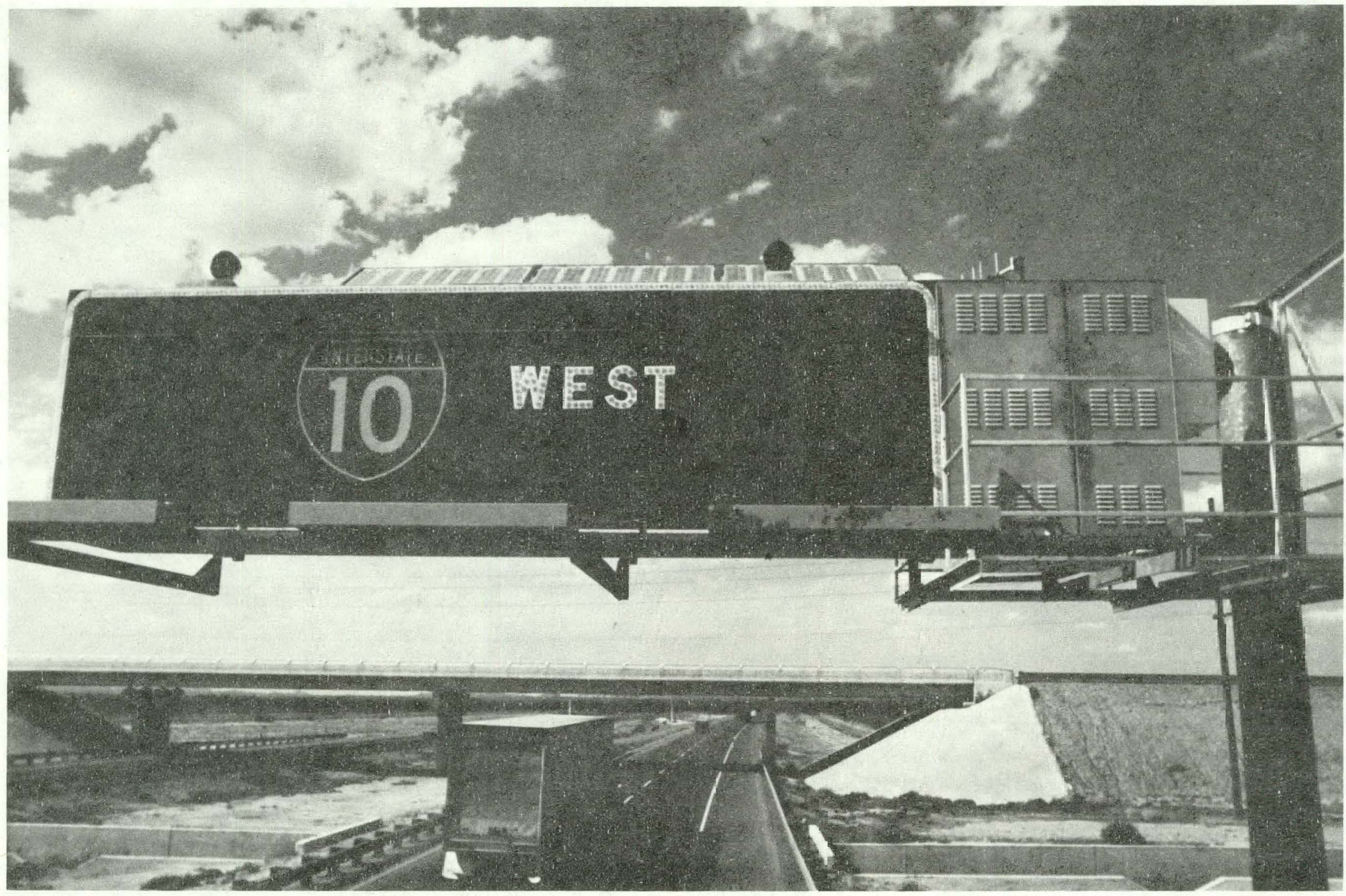

PV Powered Dust Storm Warning Sign on In=er-

state 10 Near Casa Grande, Arizona 
Insect Survey Trap Experiment

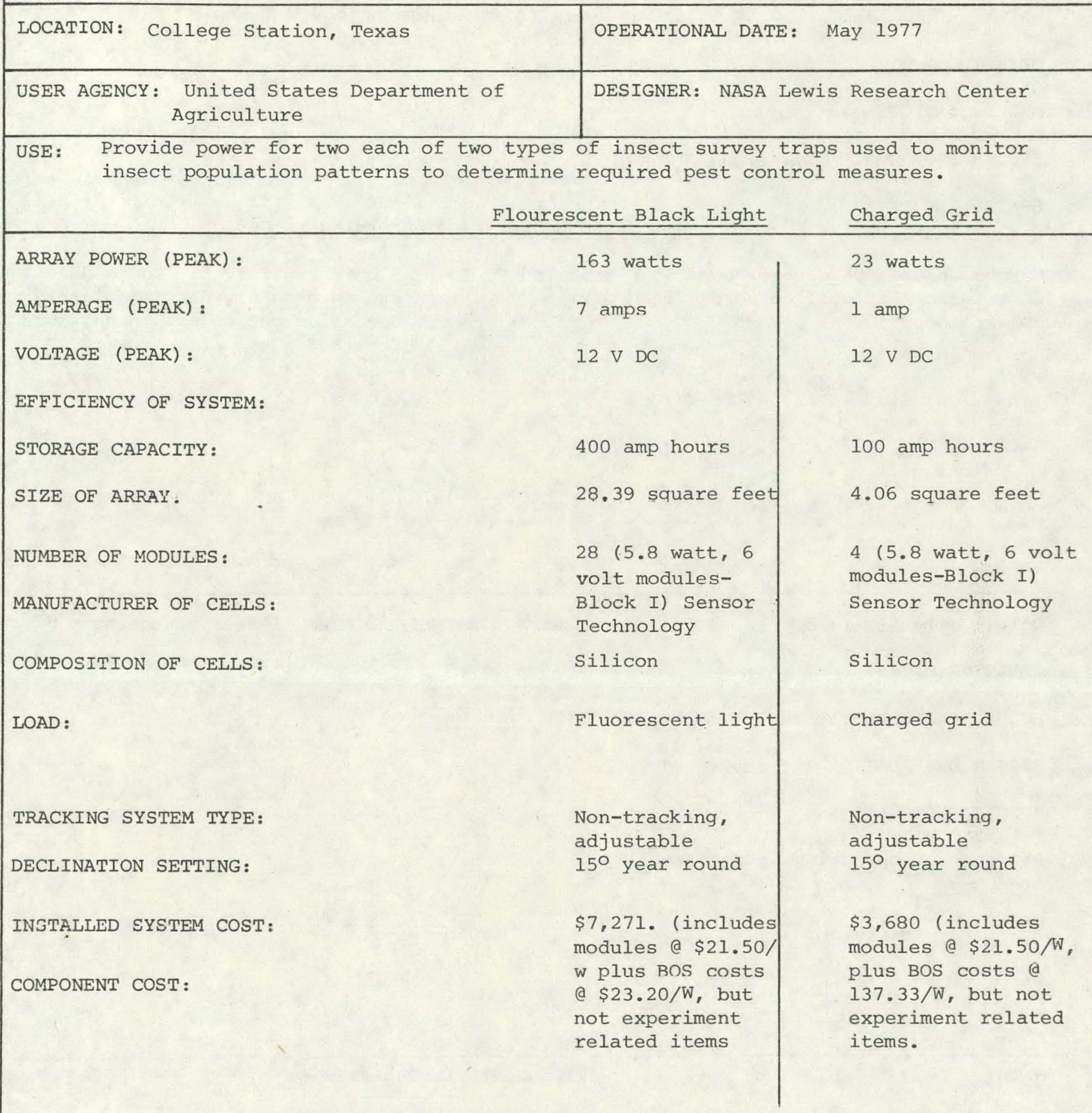

\section{SPECIAL DESIGN FEATURES:}

These types of traps have usually been utility-powered by means of long extension cords; consequently, flexibility of siting was greatly limited. With photovoltaic power, scientists are not constraincd in the conduct of insect studies; traps can be placed in the most advantageous and effective locations. 


\begin{tabular}{|c|c|}
\hline June 1977 & TIME SINCE INSTALLATION: \\
\hline CLEANING: No & \\
\hline MODULE FAILURES (if any): & \\
\hline SYSTEM DEGRADATION (if any): & None \\
\hline SPECIAL NOTES : & All Systems Operating According to Design \\
\hline $\begin{array}{l}\text { Charged Grid: Hi-Voltage Power } \\
\text { due to wasp nest buildup across } \\
\text { USDA replaced. }\end{array}$ & $\begin{array}{l}\text { Flourescent Light: One module failed } \\
\text { due to open circuit immediately after } \\
\text { operation commenced. Module was } \\
\text { replaced. }\end{array}$ \\
\hline
\end{tabular}

DATE: July 31,1978

TIME SINCE INSTALLATION: 1 year, 3 months

CLEANING: yes

MODULE FAILURES (if any): None

SYSTEM DEGRADATION (if any): None

SPECIAL NOTES :

All systems operating satisfactorily.

DATE :

TIME SINCE INSTALLATION:

\section{CLEANING :}

MODULE FAILURES (if any):

SYSTEM DEGRADATION (if any):

SPECIAL NOTES: 


\section{PHOTOVOLTAIC POWERED INSECT SURVEY TRAPS}

NEAR COLLEGE STATION AND NAVASOTA, TEXAS

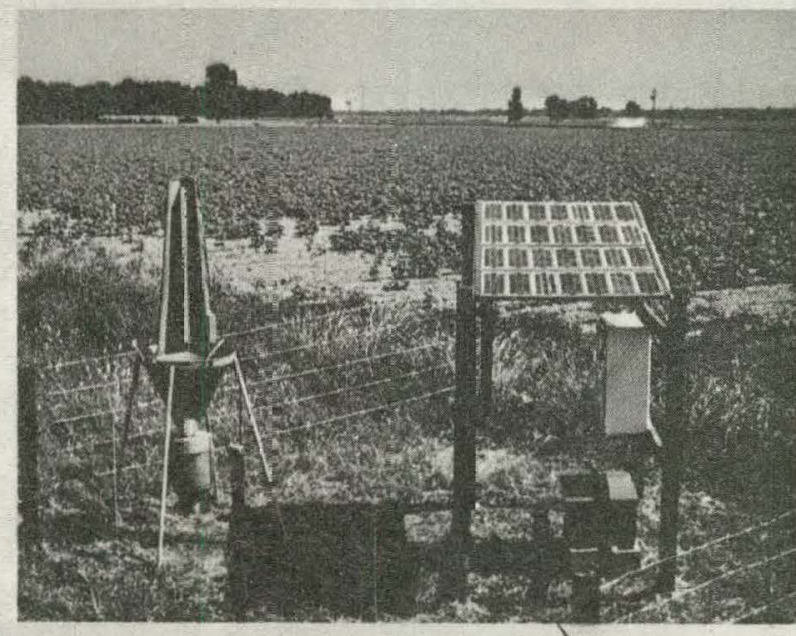

BLACKLIGHT TYPE

(140 PEAK WATT ARRAY)

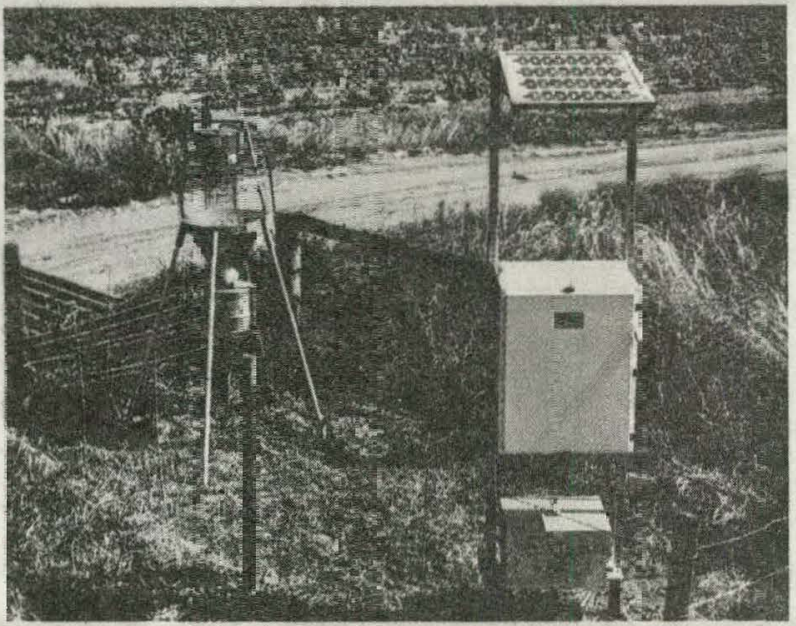

CHARGED GRID TYPE

20 PEAK WATT ARRAY)
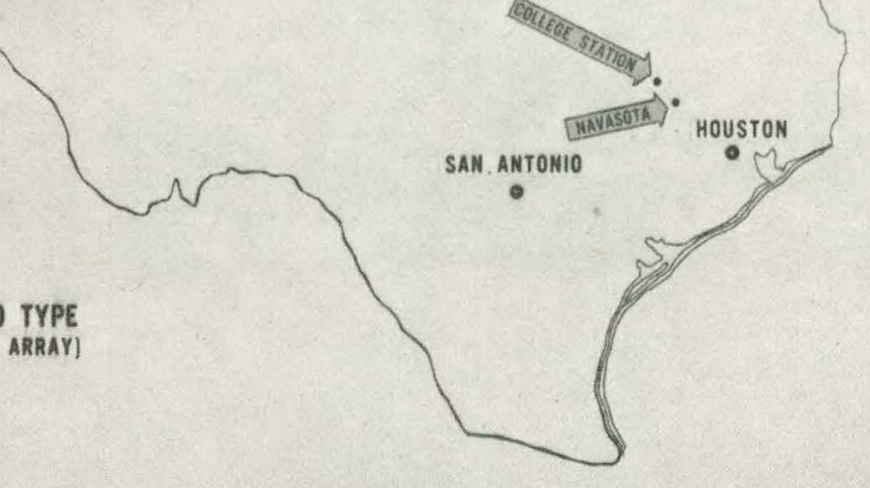


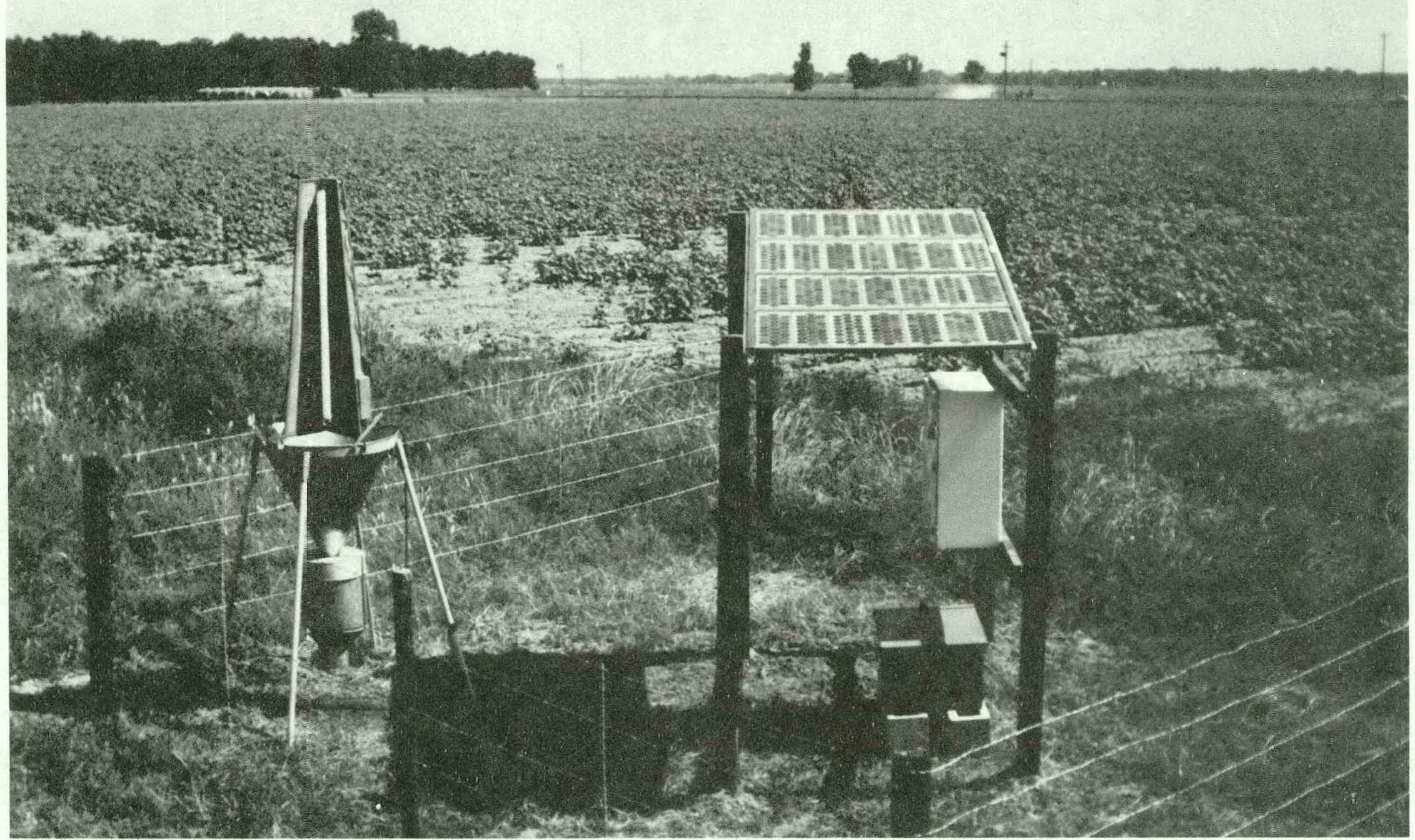

PV Powered Insect Survey Traps Near Co-lege

Station and Navasota, Texas. Summer 1977

(Blacklight Type, 140 watt array) 


\section{Insect Traps}

Solar cell arrays are now providing electric power for four insect survey traps near Texas A\&M University in College Station, Texas. The traps were designed and built by the Agricultural Research Service (ARSCotton Pest Control Equipment and Methods Research Unit) of the U.S. Department of Agriculture at College Station.

Inscct survcy traps ase used lo determine population patterns of harmful insects so that effective pest control programs can be initiated thereby reducing damage to crops. One type of trap utilizes a flourescent blacklight to attract insects; another kills the insects on an electric grid after they have been attracted by a synthetic pheromone (sex attractant). The data gathered on insects collected by the network of traps is used in computer programs which allow ARS scientists to predict future insect populations.

Although the insect survey trap network near Texas A\&M is concerned particularly with the cotton boll weevil, similar traps are also used for many other crop-destroying pests; consequently, the overall potential market for solar-powered units is believed to be significant. 

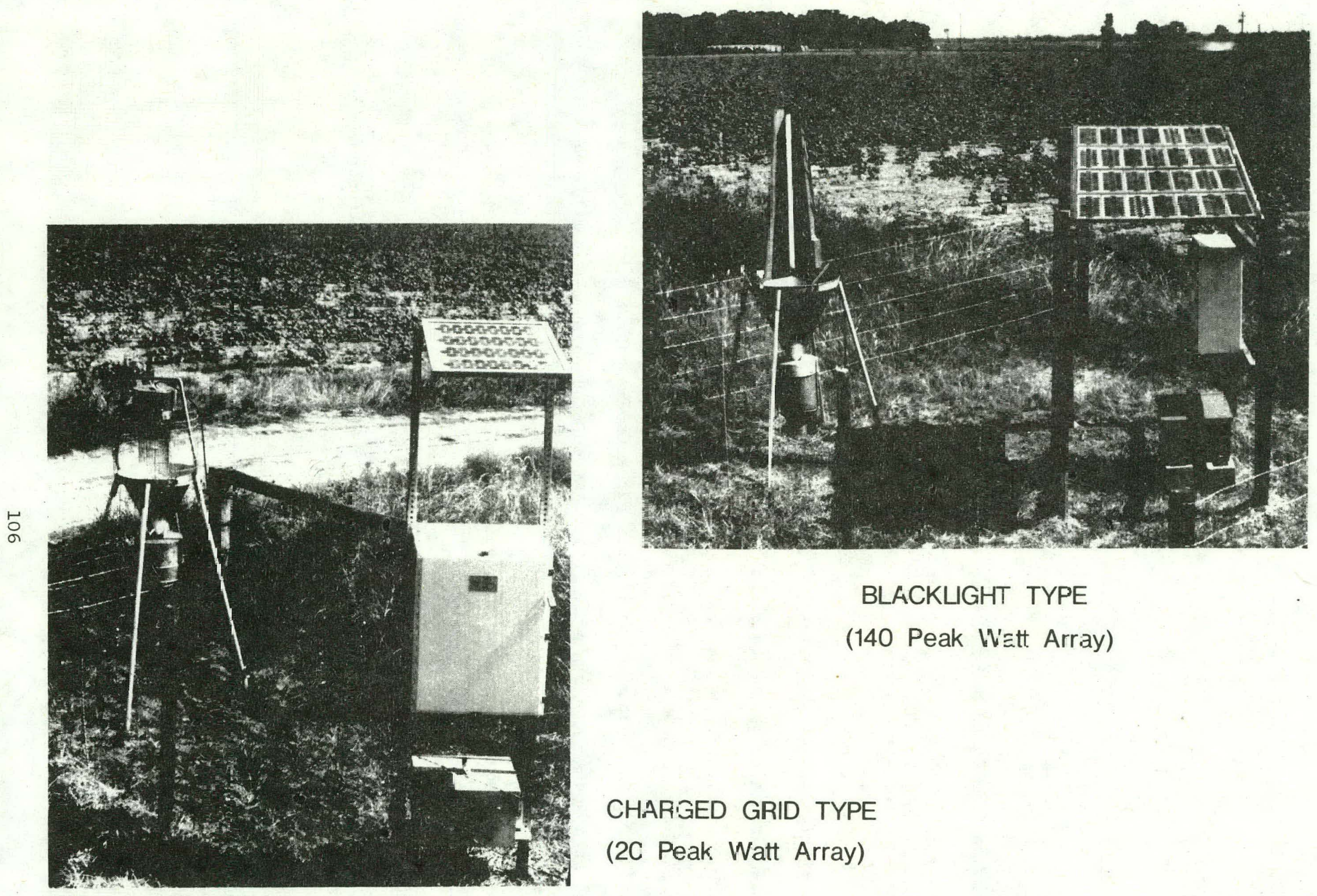

\section{BLACKLIGHT TYPE}

(140 Peak IV'att Array)

\section{CHARGED GRID TYPE}

(2C Peak Watt Array)

\section{INSECT SURVEY TRAPS}


Mt. Laguna Air Force Station Project

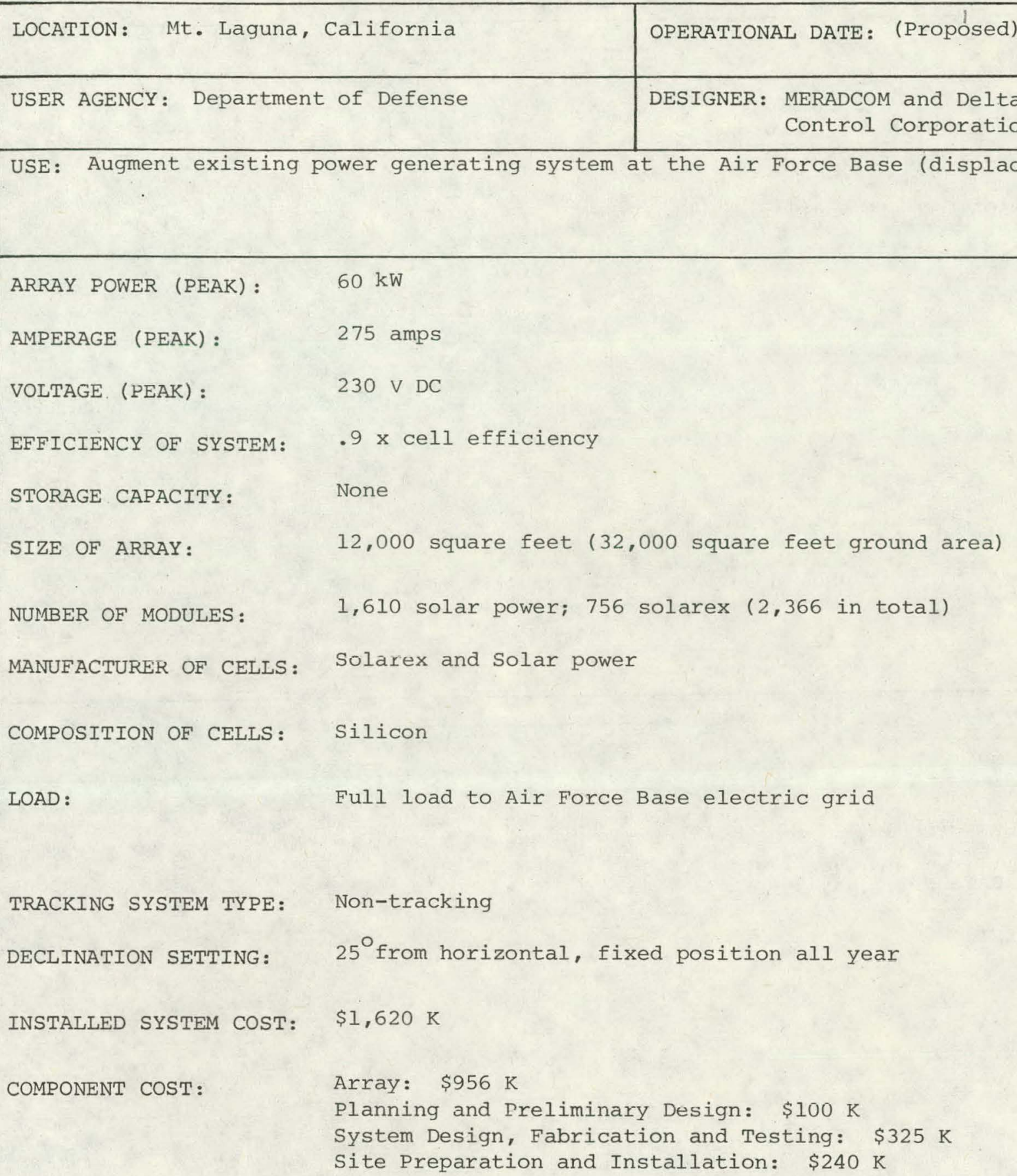


TIME SINCE INSTALLATION:

CLEANING :

MODULE FAILURES (if any):

SYSTEM DEGRADATION (if any):

SPECIAL NOTES:

DATE:

TIME SINCE INSTALLATION:

CLEANING:

MODULE FAILURES (if any):

SYSTEM DEGRADATION (if any):

SPECIAL NOTES:

DATE :

TIME SINCE INSTALLATION:

CLEANING :

MODULE FAILURES (if any):

SYSTEM DEGRADATION (if any):

SPECIAL NOTES: 
GOKW PHOTOVOLTAIC (SOLAR) AUGMENTATION SYSTEM
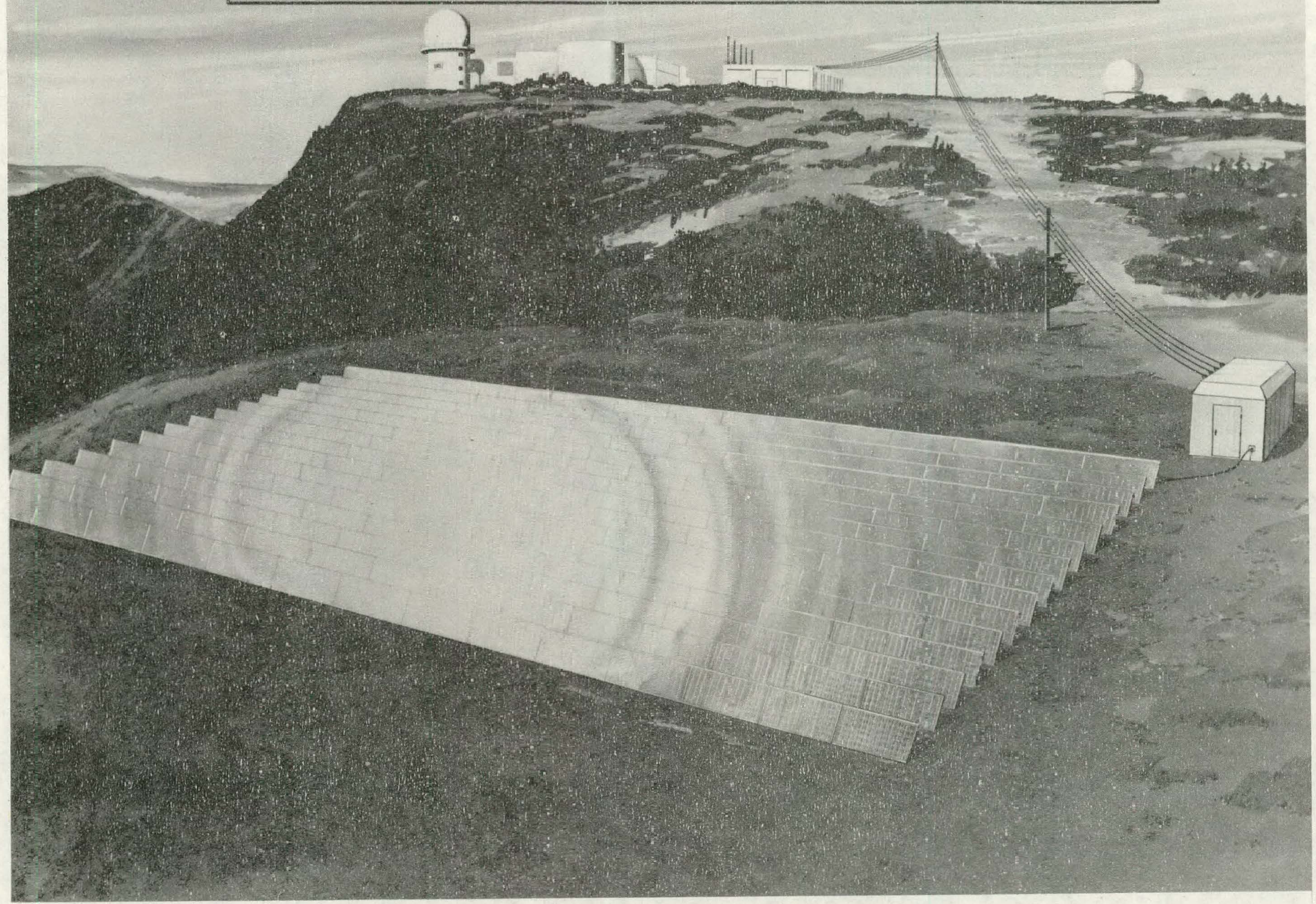


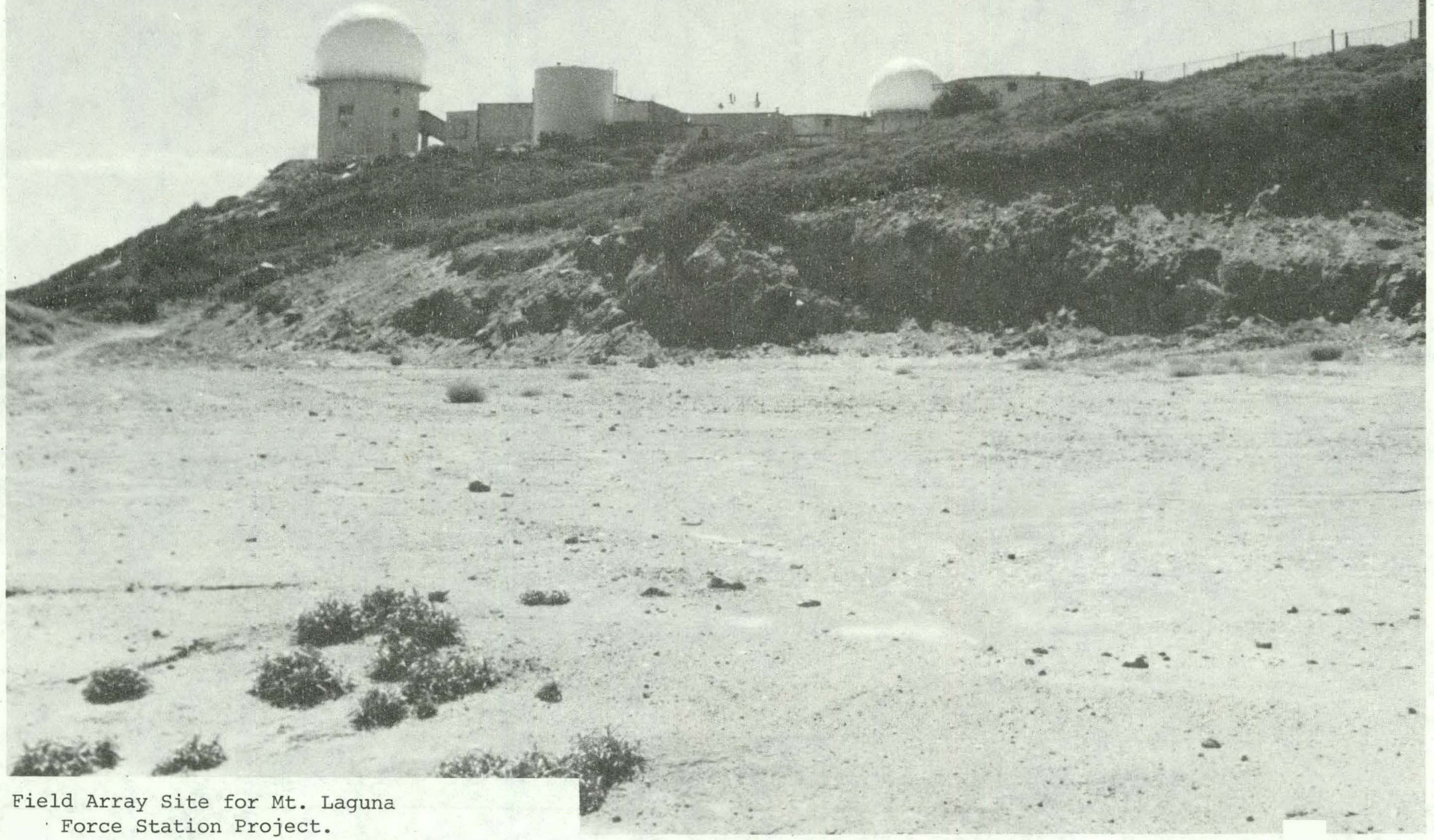


Natural Bridges National Monument Project

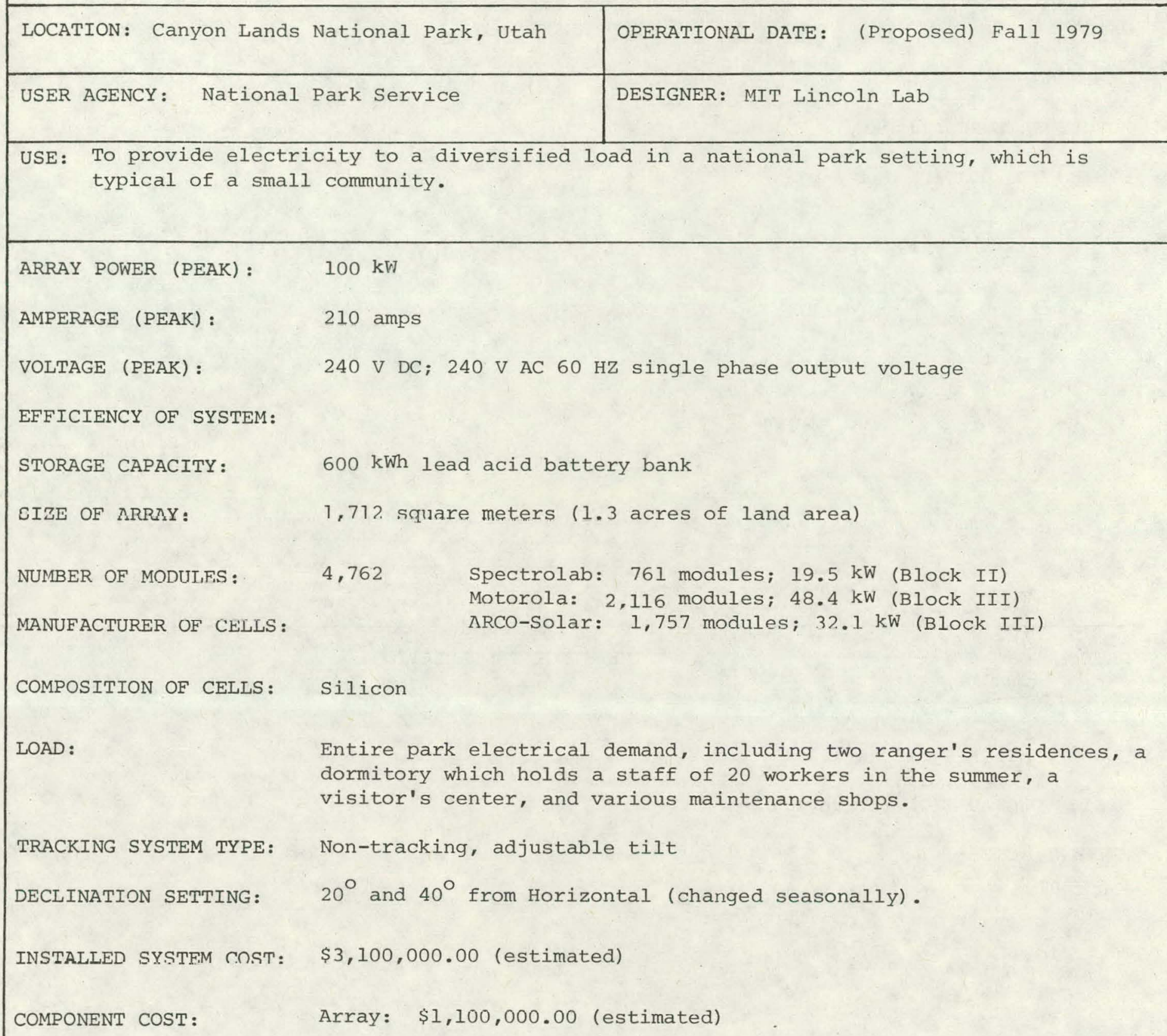

\section{SPECIAL DESIGN FEATURES :}

- To retain the park's aesthetics, the array will be designed so as not to protrude above the surrounding natural shrub growth. The vegetation consists mainly of shrubs being shorter than 15 feet.

- 40 KVA DIESEL GENERATOR Backup

- 2 field inspections, spring and Fall

- 2 complete washings, spring and Fall 
DATE :

TIME SINCE INSTALLATION:

CLEANING :

MODULE FAILURES (if any):

SYSTEM DEGRADATION (if any):

SPECIAL NOTES:

DATE :

TIME SINCE INSTALLATION:

CLEANING :

MODULE FAILURES (if any):

SYSTEM DEGRADATION (if any):

SPECIAL NOTES:

DATE :

TIME SINCE INSTALLATION:

CLEANING :

MODULE FAILURES (if any):

SYSTEM DEGRADATION (if any):

SPECIAL NOTES : 
$100 \mathrm{~kW}$ Load Center For The U.S. National Park Service (NPS)

Placement of a photovoltaic test bed in a U.S. National Park is of interest for several reasons. For one thing, the NPS offers a modest near-term market for solar cells at an array price of one to two dollars per peak watt. The initial size of this market is approximately 15 peak megawatts, and it should become realizable in the early $1980^{\prime} \mathrm{s}$ if the DOE price goals are met. This market size is conservatively based on utilizing PV only at those Park Service installations which are remotely located and presently use diesel-electric generators. (The total Park Service demand is much larger than this - in the range 200 to 300 megawatts peak - but is supplied largely from the electric utility grid.) An NPS experiment is also of interest because it typifies the use of photovoltaics in load center applications, both in the Service, Commercial and Institutional sectors of the U.S. economy, and in on-site generation systems for less developed countries. Finally, the large visitation to the National Parks offers good visibility to the general public for such an experiment.

Accordingly, a study was initiated in October, 1976, in conjunction with the Park Service to identify potential solar PV applications. By the end of November, more than 60 applications were found. Application selection criteria were developed and then applied to select the ten most promising applications for on-site visits. On the basis of further information gained from site visits, the Natural Bridges National Monument (NBNM), Utah, a remote portion of Canyonlands National Park located in southeastern Utah, was judged to be most attractive for the first PV system in the Park Service.

NBNM contains several huge stone arches which were carved by wind and water erosion from the surrounding sandstone rock. The park lies at an average elevation of 6,600 feet and is in a semi-arid region characterized by infrequent (but sometimes violent) rain and snow falls.

A preliminary sizing study for the power system has already been completed, along with an initial architectural study which verified that arrays could be sited in an aesthetically acceptable manner. The PV system is scheduled to be completed in 1979, with turn-on to take place in the summer of that year. 


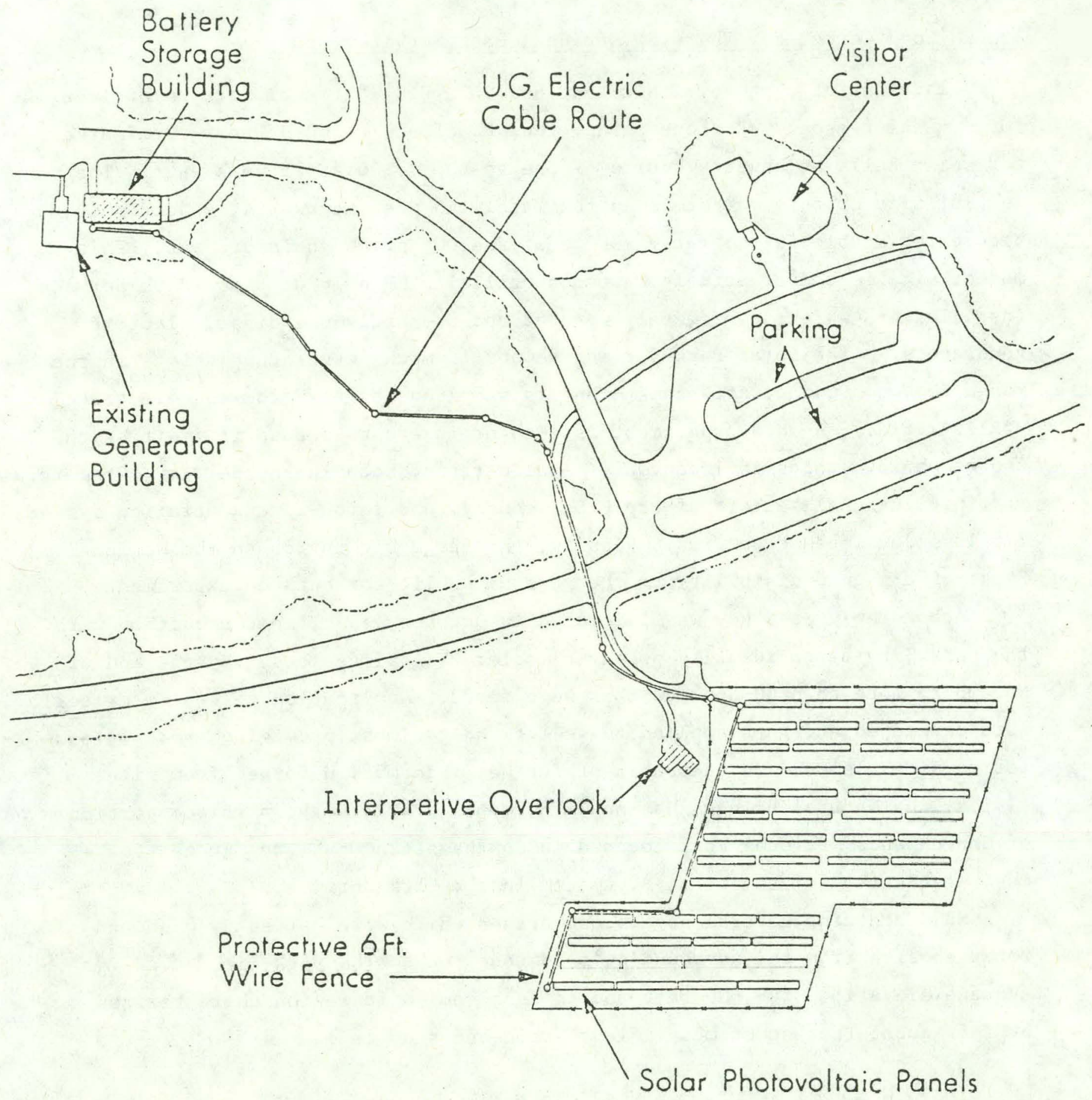

Site Plan for Natural Bridges National

Monument $100 \mathrm{~kW}$ Power System 


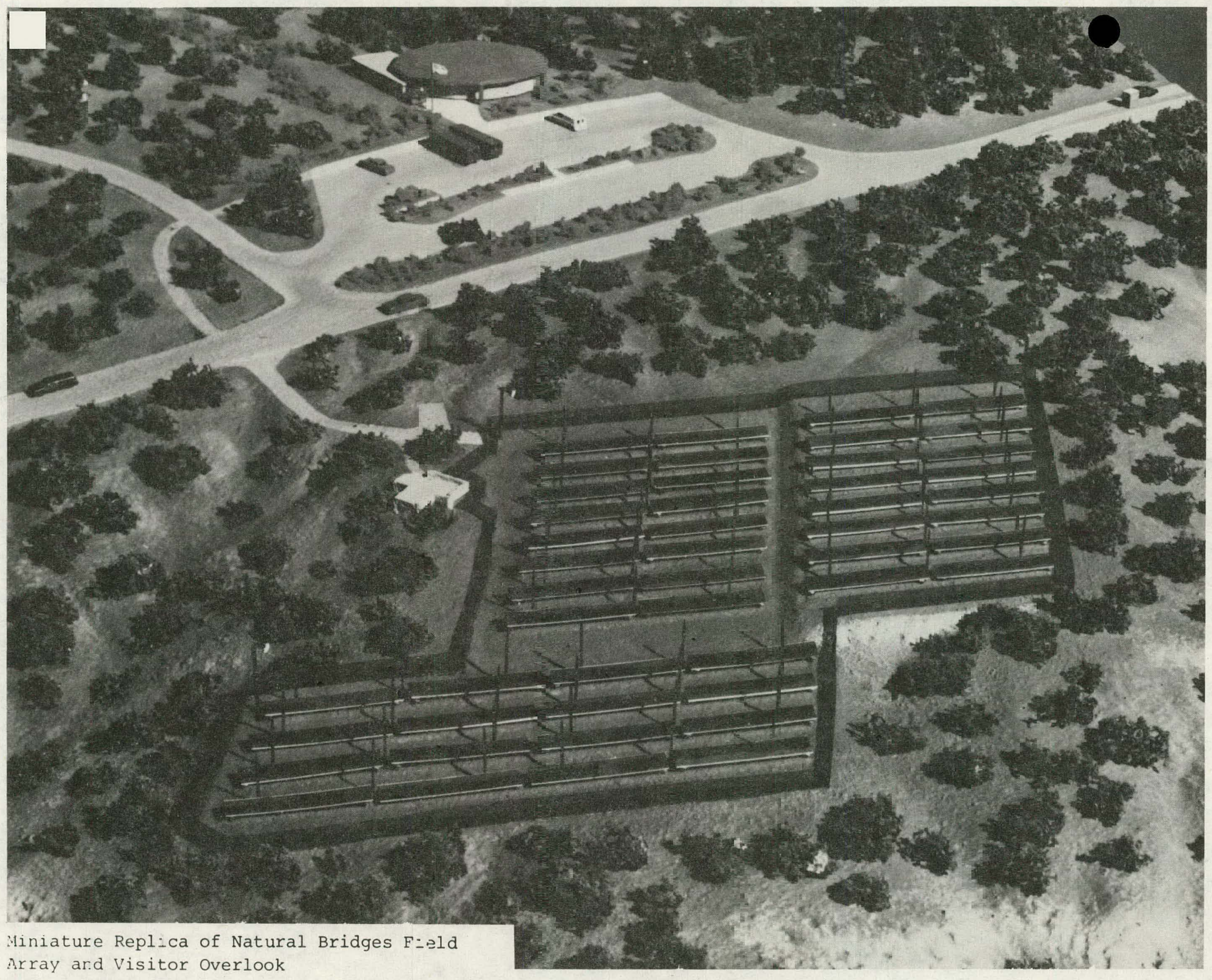




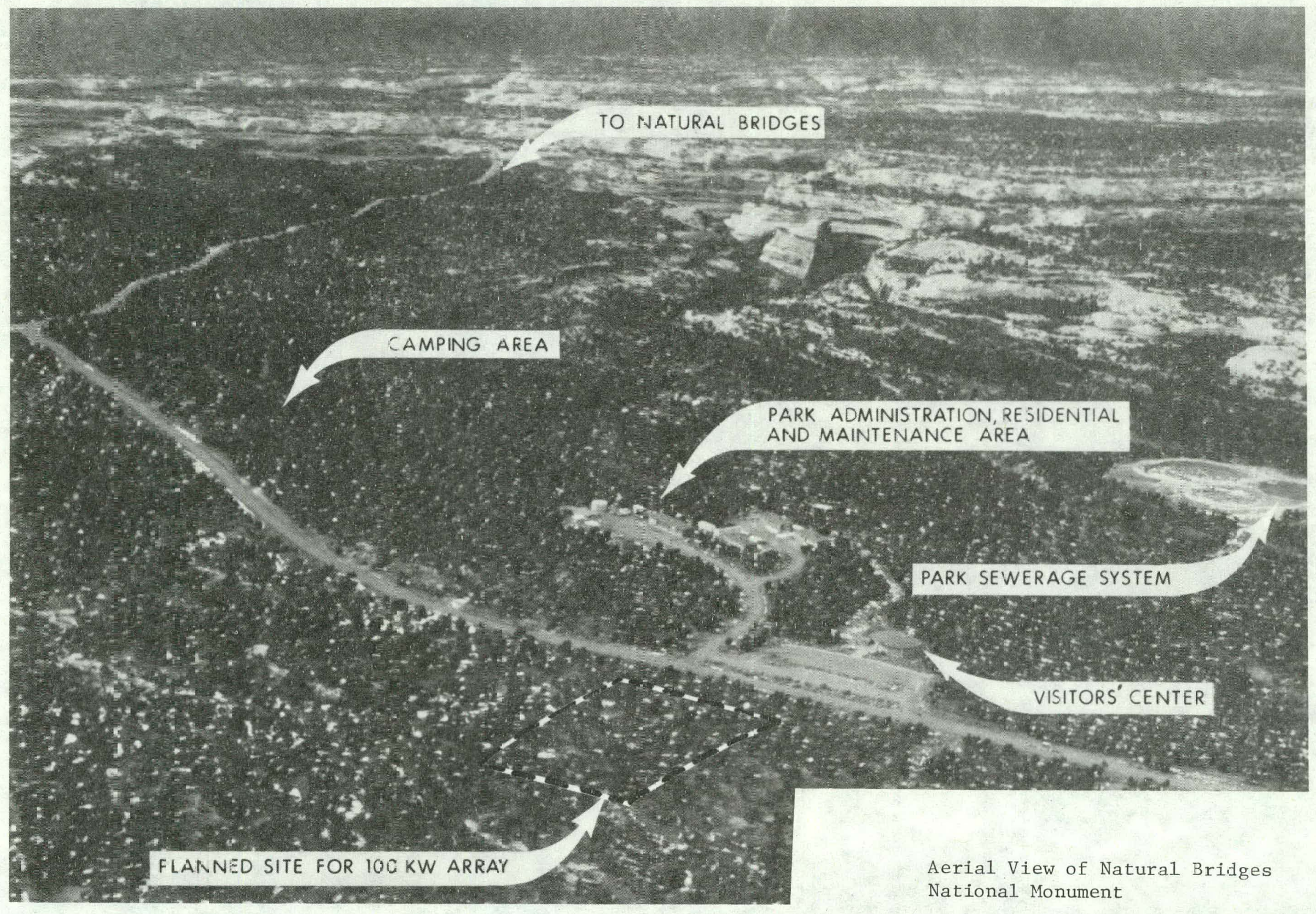


PLAN: This task, which was initiated in FY-78, has progressed from the conceptual design phase to the start of outside contractor activity. By the end of FY-78 contracts will have been awarded for the design and fabrication of four major subsystems: batteries, battery charger, and two inverters. In eariy FY-79 a system integration contractor will be selected. In addition, the NPS will award a contract (Department of Interior funds) in the fall of 1978 for site development work in support of the PV power system.

The system integration contractor will perform the detailed design, fabrication, installation, integration, and testing of the PV power system. This activity will include the array field structures (exclusive of foundations, which will be provided by the NPS), the module wiring and installation, the system wiring, switchgear, sensors, control, maintenance and repair equipment and an alarm subsystem. The four major subsystems referred to previously will also be developed by contractors and will then be provided to the system contractor by MIT/Lincoln Laboratory. In addition, a communication system will be procured by MIT/Lincoln Laboratory and supplied to the system contractor. This system is needed because of the extreme remoteness of NBNM and because there is no possibility of upgrading the limited radio telephone system presently in use at the Park. The system will be used for both voice comunication and for transmission of PV system performance data.

Site development work by the NPS at NBNM is expected to begin in October 1978 and to be completed in February 1979. The system integration contractor will perform an off-site system test in early 1979 and will install array field structures and modules in the spring of 1979. The final installation and testing of the PV power system will be completed in July 1979. 
MIT/Lincoin Laboratory will supervise the development of technical material and a training course for NPS personnel. This course will be designed to provide operation and matntenance personnel with a basis for dealing with PV power systems and w1ll support the NPS goal of evaluating the potential role of photovoltalcs in future IPS energy planning. Additionally, the training course will provide an opportunity to evaluate the problems of technology transfer of photovoltaics to the ranks of people who will be responsible for the daily operation and maintenance of PV power systems.

MAJOR RESUZTS/KEY MILESTONES:

- Final Design Review October 1978

- Site Development (by NPS) completed February 1979

- Begin artay field installation at NBNM March 1979

- Begin off-site system integration testing March 1979

- Begin power system installation at NBiM May 1979

- Begin acceptance testing June 1979

- Ded1cation July 1979 
Remote Radar Experiment

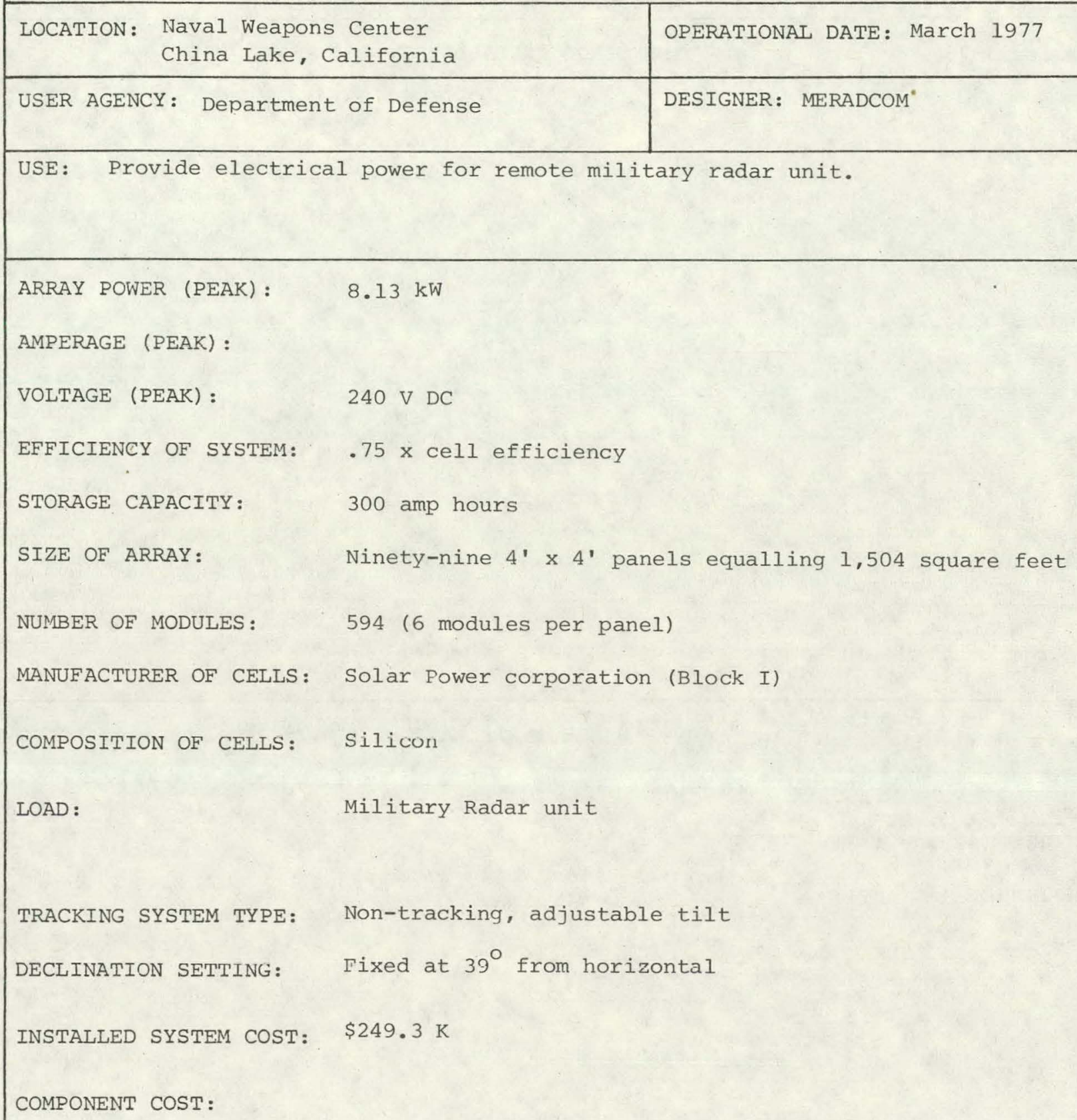

SPECIAL DESIGN FEATURES:

Has a motor generator enabling $\mathrm{DC}$ and $\mathrm{AC}$ power conditioning. 
DATE: November 1978

TIME SINCE INSTALLATION: 1 year, 8 months

CLEANING :

MODULE FAILURES (if any):

SYSTEM DEGRADATION (if anY):

SPECIAL NOTES:

Operating satisfactorily.

DATE:

TIME SINCE INSTALLATION:

CLEANING :

MODULE FAILURES (if any):

SYSTEM DEGRADATION (if any):

SPECIAL NOTES:

DATE :

'I'LME' SINCE INSTALLATION:

CLEANING :

MODULE FAILURES (if any):

SYSTEM DEGRADATION (if any):

SPECIAL NOTES: 


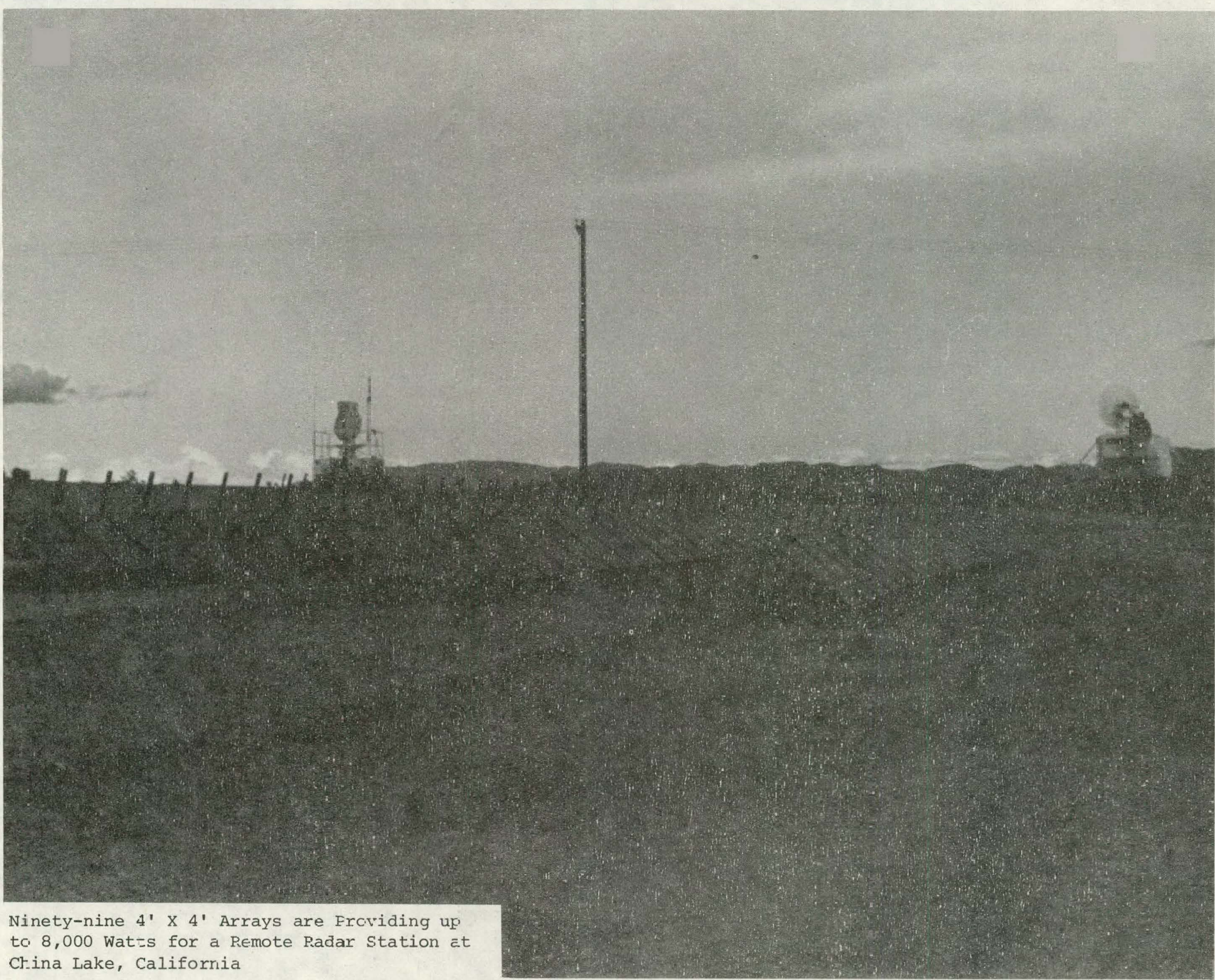



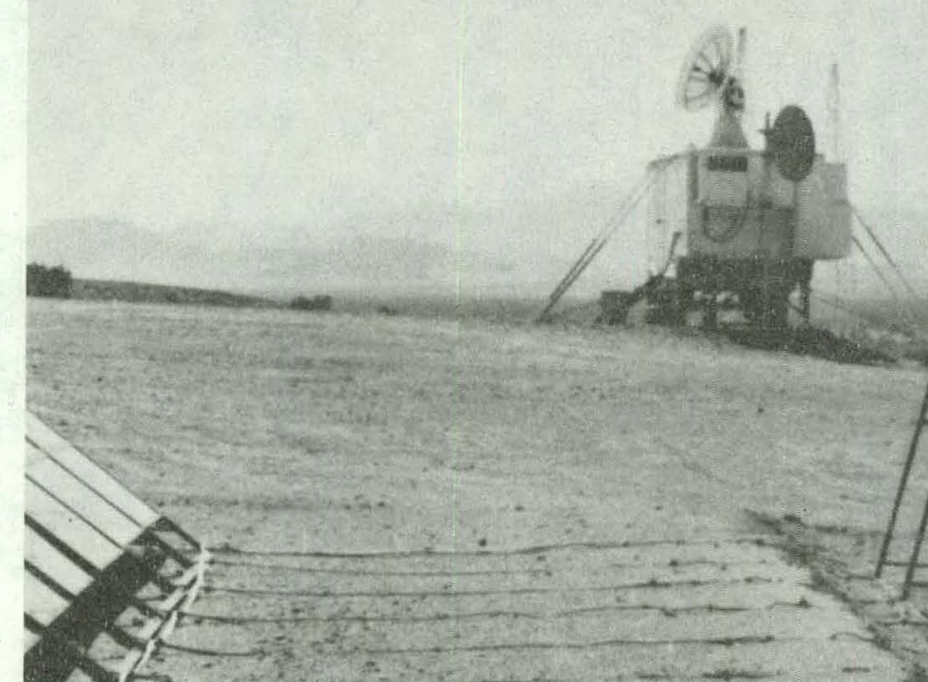

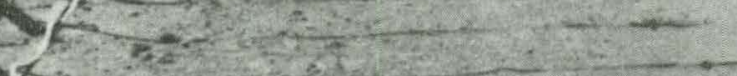
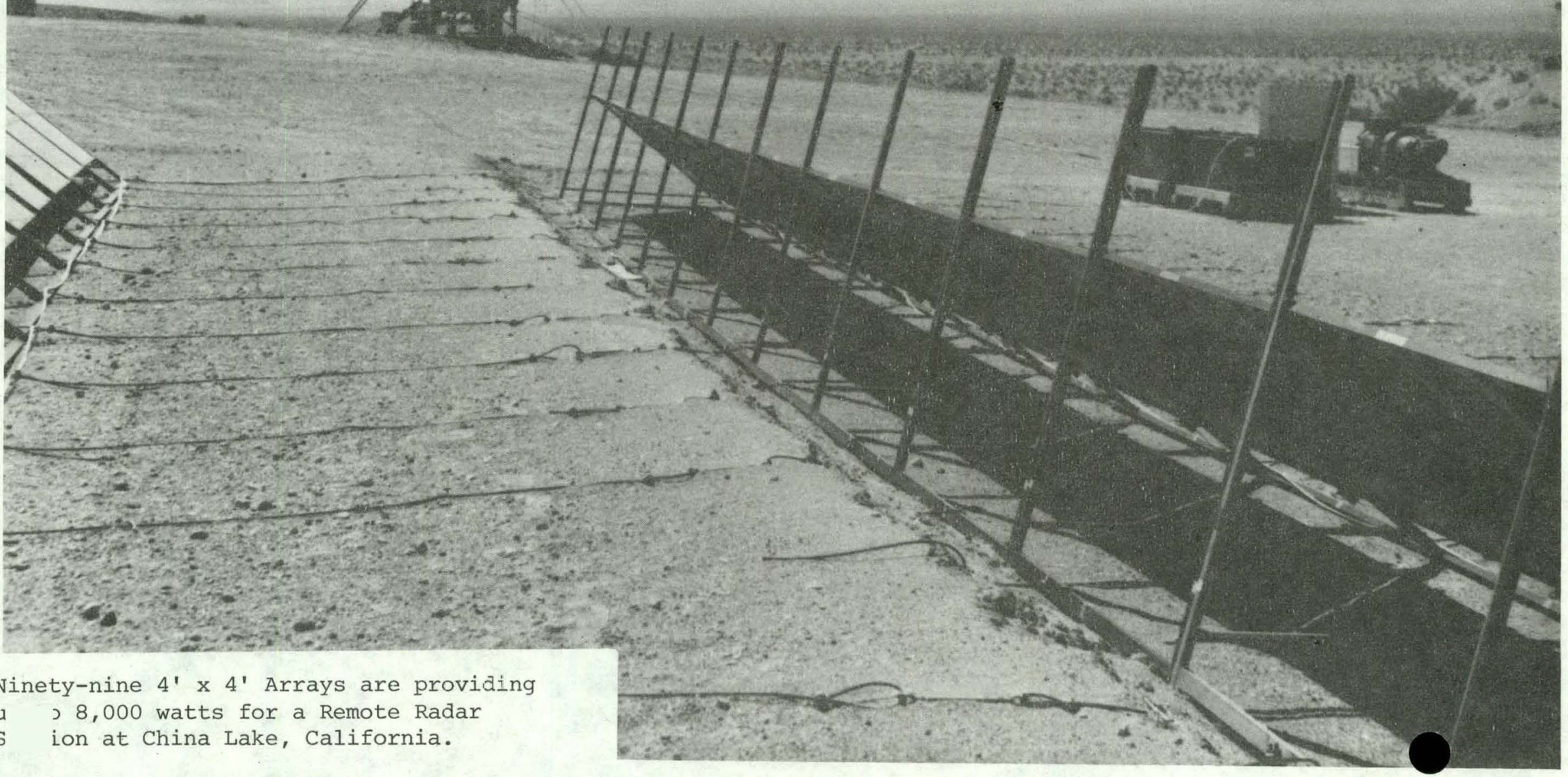


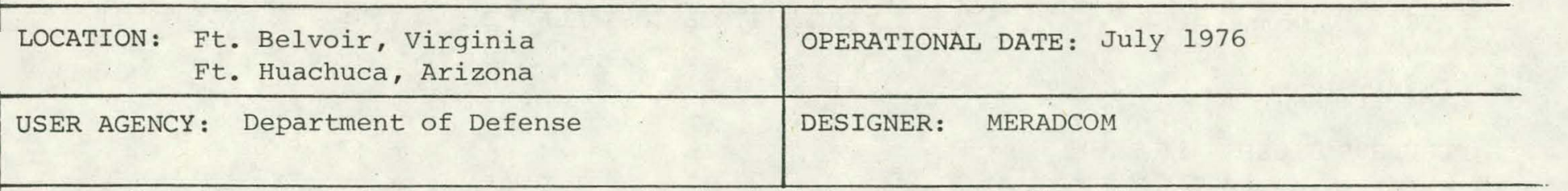

USE: Provide electrical power for each of eight low power Radio relay Systems.

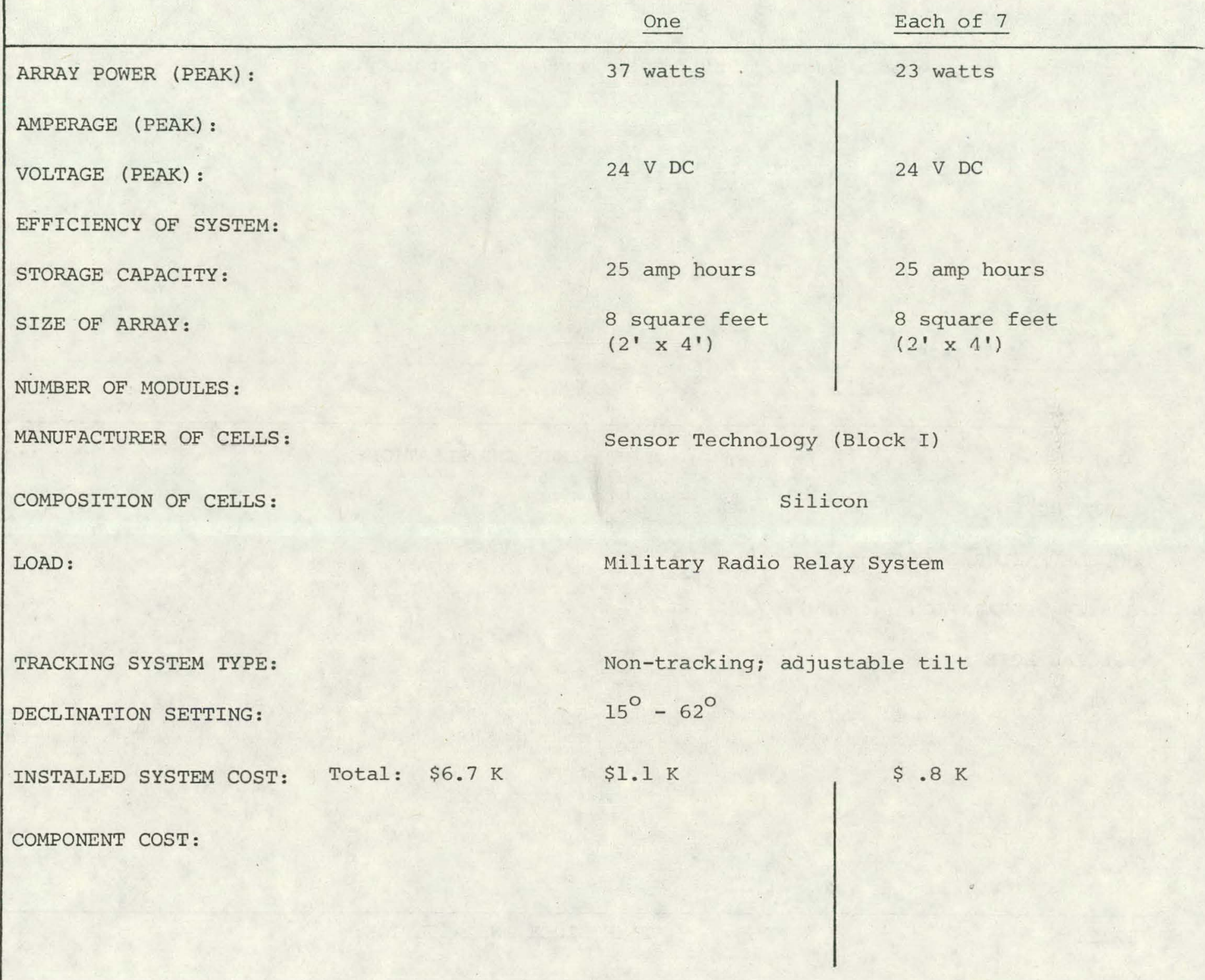

SPECIAL DESIGN FEATURES: 
DATE: November 1978

CLEANING : NO

MODULE FAILURES (if any): None

SYSTEM DEGRADATION (if anY):

SPECIAL NOTES:

Worked well with good results. Still operating satisfactorily.

DATE :

TIME SINCE INSTALIATION:

\section{CLEANING :}

MODULE FAILURES (if any):

SYSTEM DEGRADATION (if anY):

SPECIAL NOTES :

DATE :

TIME SINCE INSTALLATION:

CLEANING :

MODULE FAILURES (if any):

SYSTEM DEGRADATION (if any) :

SPECIAL NOTES: 


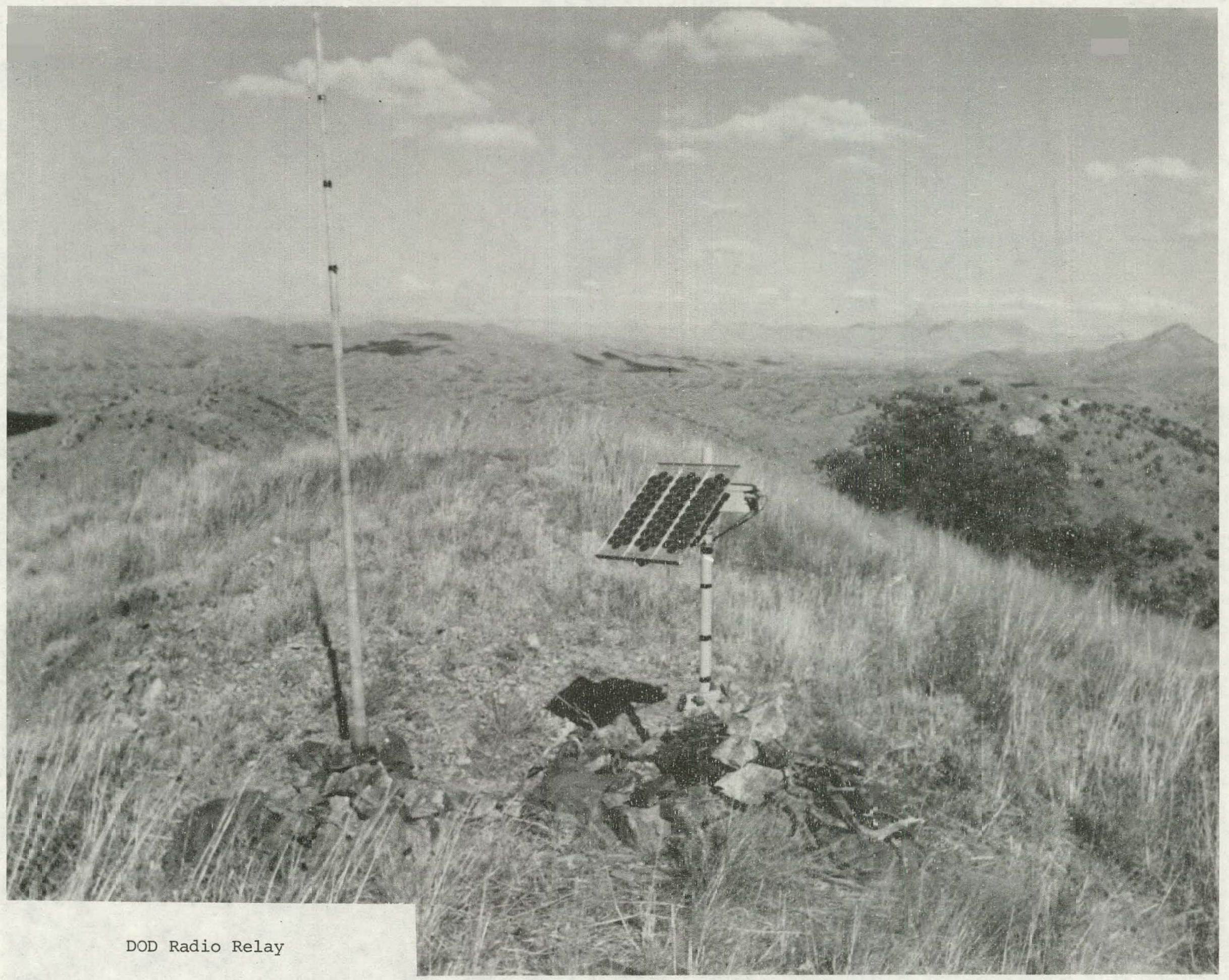




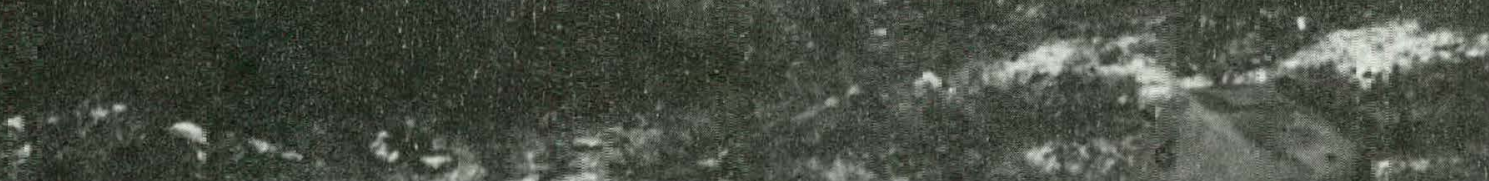

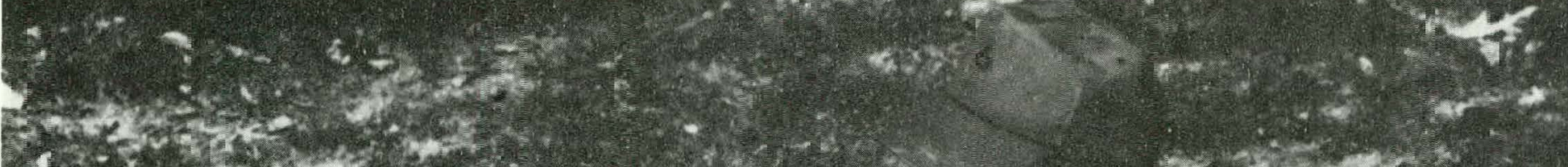

3.

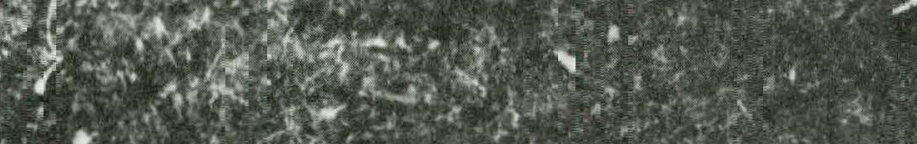

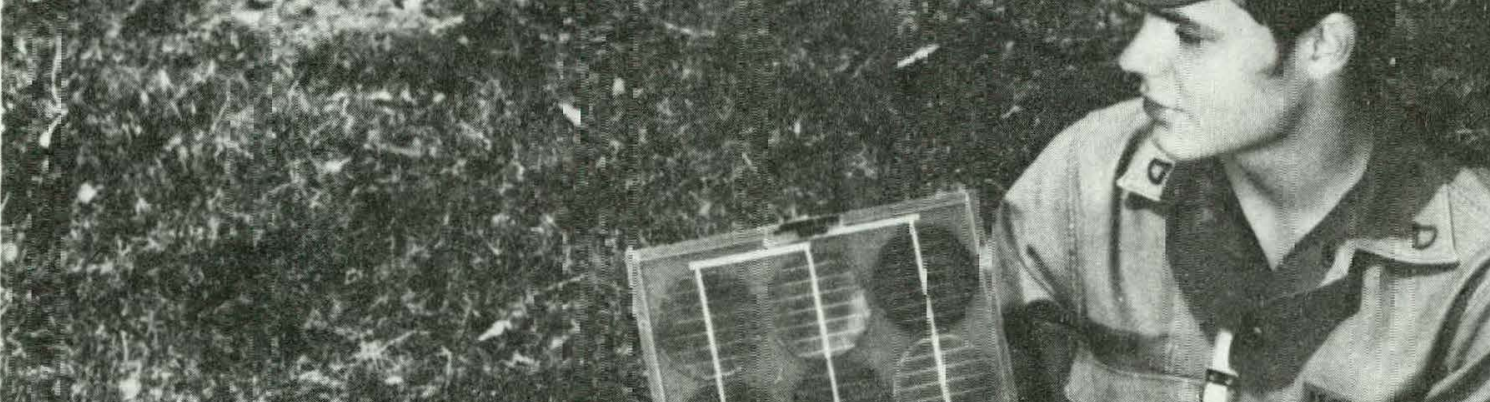

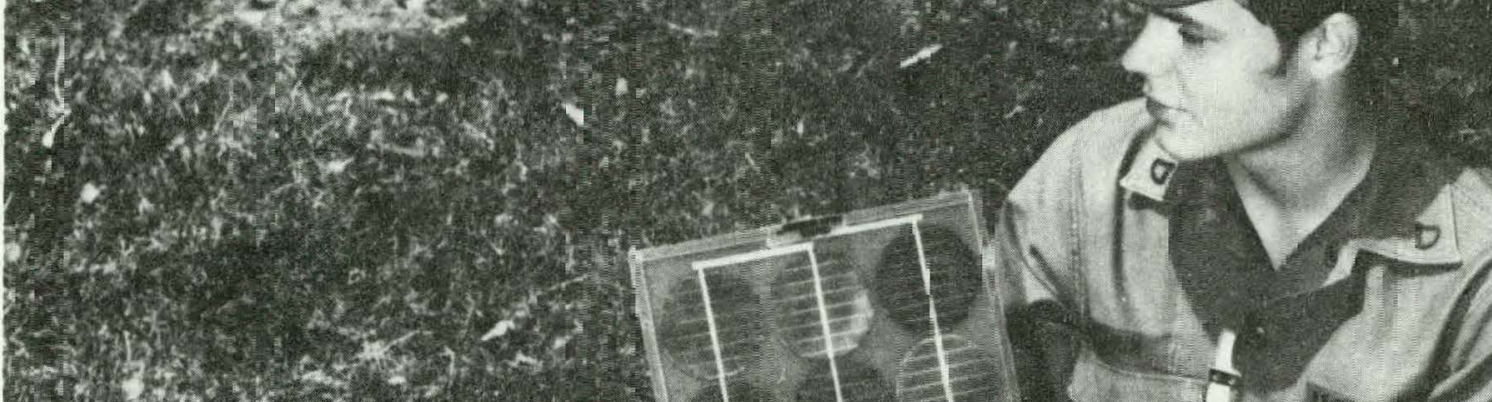

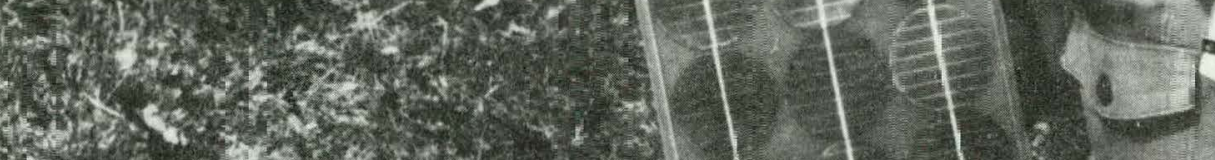

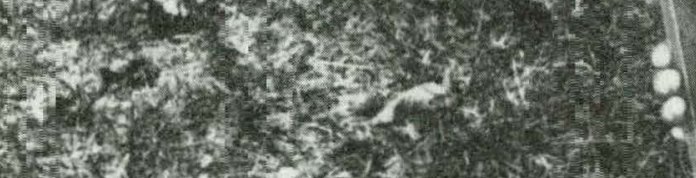

\section{1.}

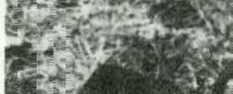

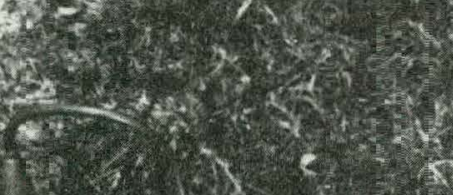

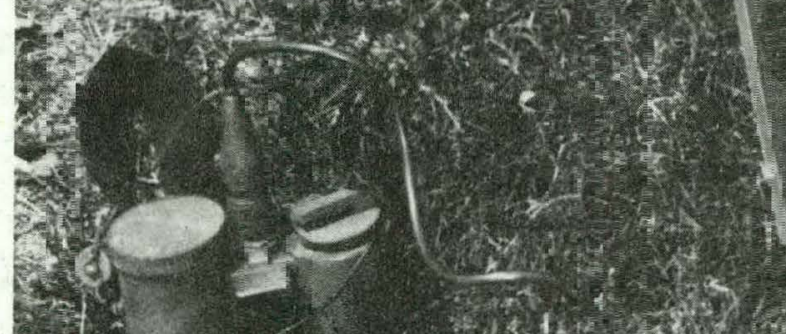

10.6. (2)

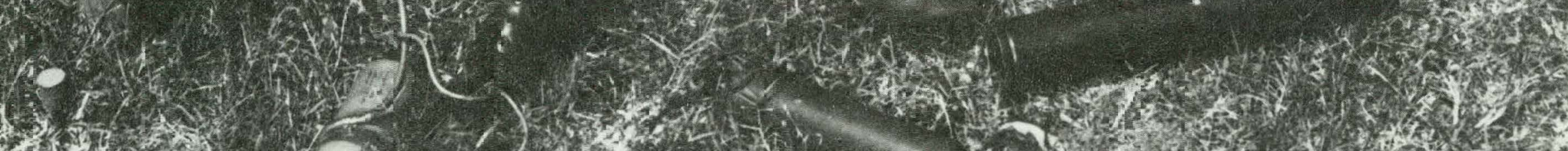

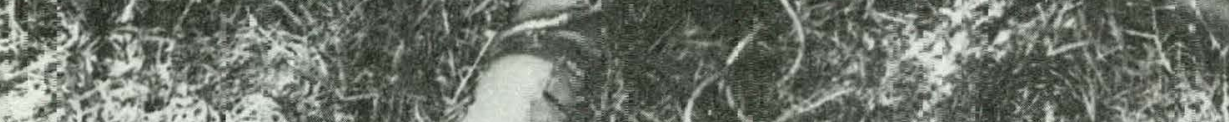
2.3.

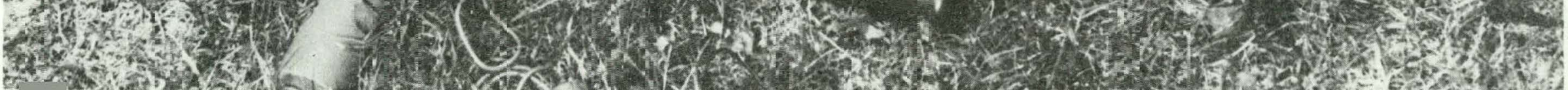

Ra Relay Equipment with Solar Cell Module

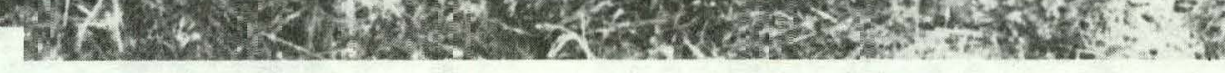




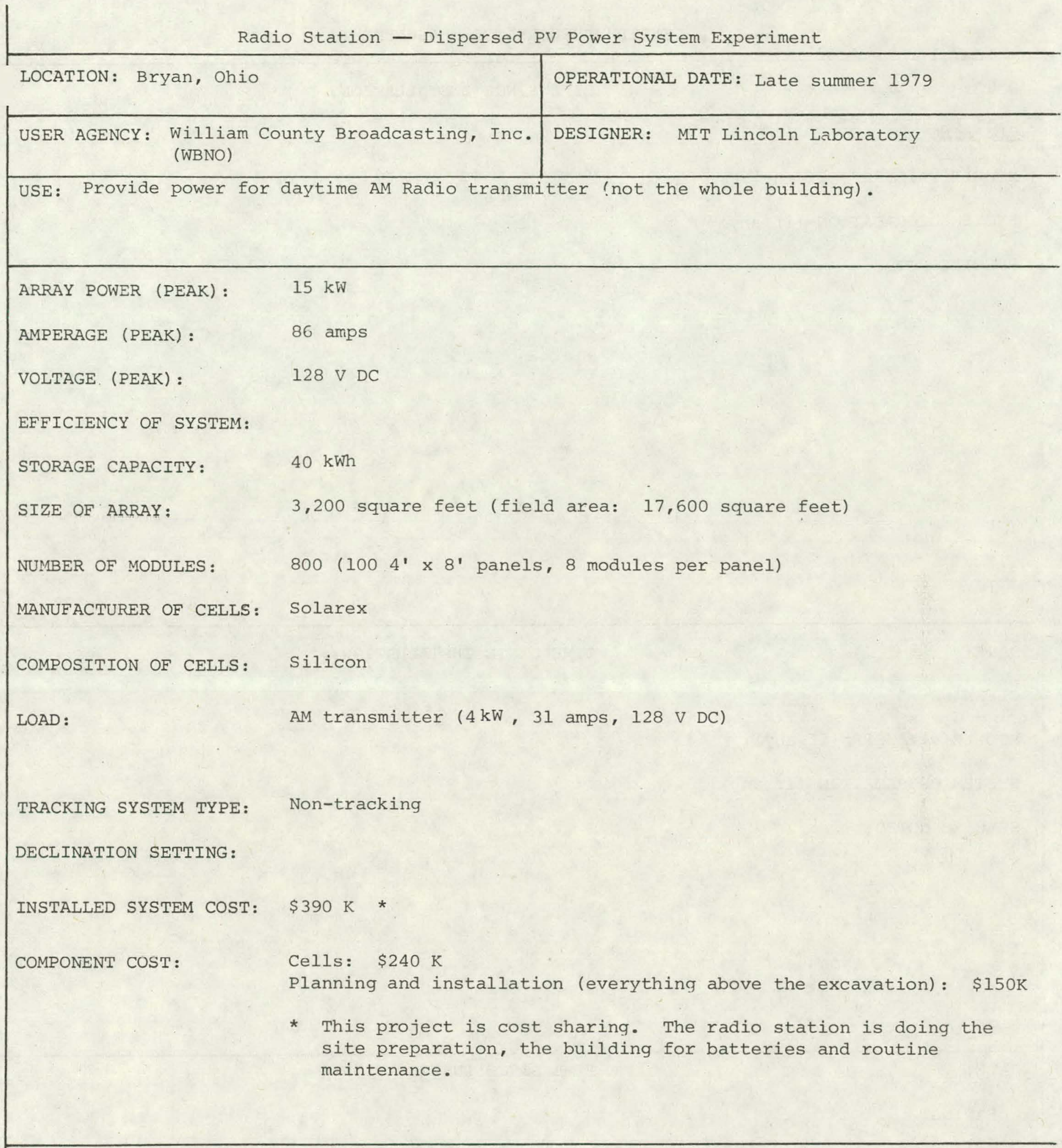

SPECIAL DESIGN FEATURES:

\section{Attractiveness}

- Daytime use

- DC loads (no inverters)

- Experienced personnel

\section{Special Features}

- Premanufactured components which will plug together on site

- Low-cost structure: Sheet steel frame, blocks instead of poured concrete. 
DATE :

TIME SINCE INSTALLATION:

CLEANING :

MODULE FAILURES (if any):

SYSTEM DEGRADATION (if any):

SPECIAL NOTES:

DATE:

TIME SINCE INSTALLATION:

CLEANING :

MODULE FAILURES (if any):

SYSTEM DEGRADATION (if any):

SPECIAL NOTES:

DATE:

TIME SINCE INSTALLATION:

CLEANING :

MODULE FAILURES (if any):

SYSTEM DEGRADATION (if any):

SPECIAL NOTES: 


\section{Dispersed PV Applications - A PV-Powered Radio Station}

The intent of this task is to develop a field test system based on concepts which, when physically realized in production quantities, will promise low cost for relatively small ( $20 \mathrm{~kW}$ ) systems. The key features for such a low-cost system are believed to be the following:

- The loads match well to the diurnal solar input, thus minimizing storage;

- The PV power system components and subsystems are manufactured (as opposed to constructed) and installed at the site with an absolute minimum of site work;

- The loads are primarily DC, thus eliminating or minimizing costs for $D C-$ to-AC inversion;

- The application is one for which the PV system design is not strongly driven by aesthetic and architectural considerations (as is the case for say, residences); and

- The PV system design is suitable for use in a variety of applications with little or no PV system design changes required, thus enhancing price reductions arising from accumulation of manufacturing experience.

Studies performed by MIT-LI indicate that a good candidate application is daytime-only, AM radio stations. There are about 2,000 AM stations in the U.S. which operate during the daylight hours only and which have transmitted power requirements in the range 250 to 5,000 watts. The use of PV for AM (as opposed to FM or TV) systems is especially attractive because these stations possess relatively large expanses of open land beneath their transmitter towers for providing an electrical ground plane and for siting their tower guy wires. This area is more than sufficient for a PV array. MIT-LI is presently preparing a specification and RFP for design, manufacture and installation of an AM radio station power system, with turn-on planned in the summer of 1979. 


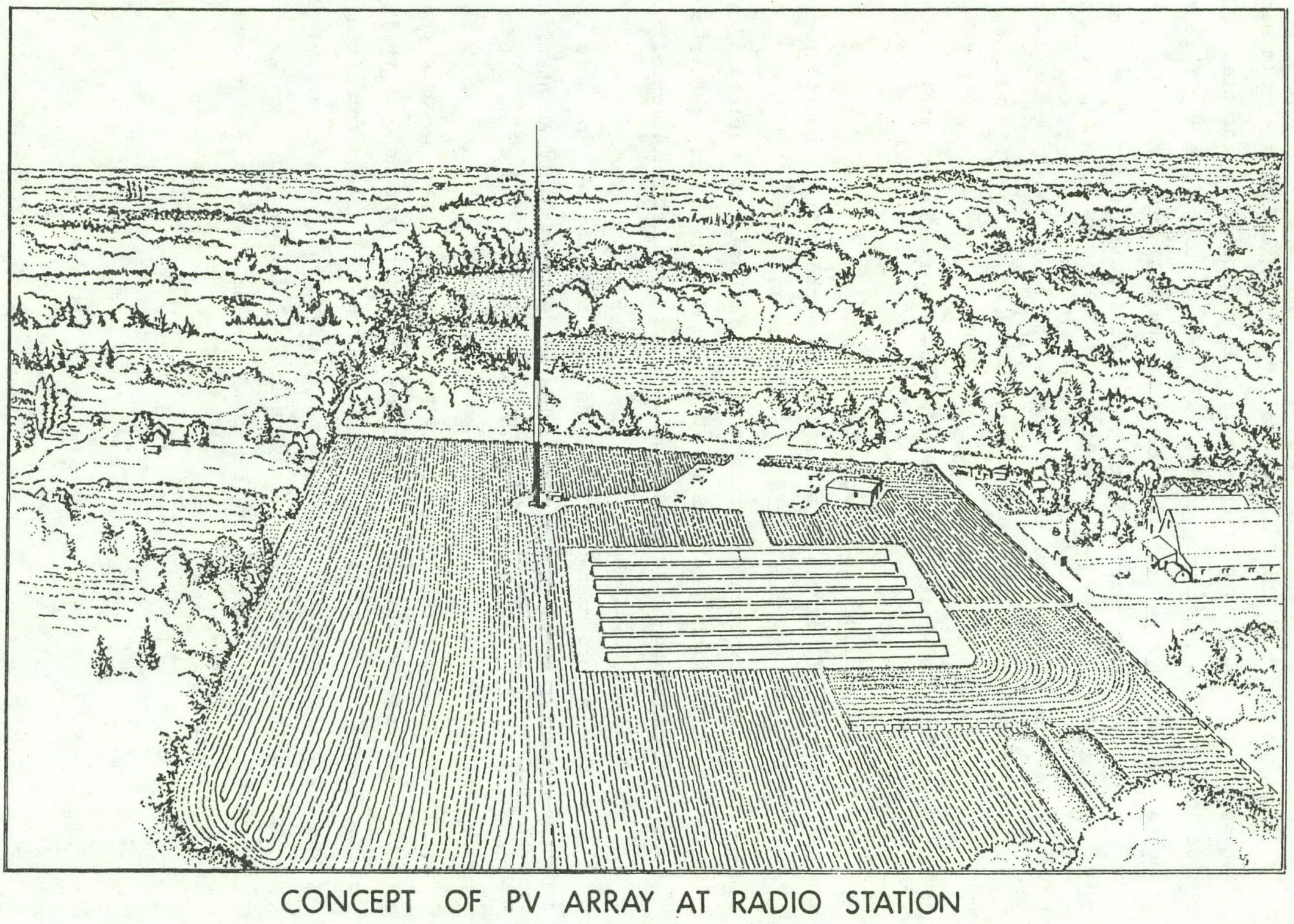



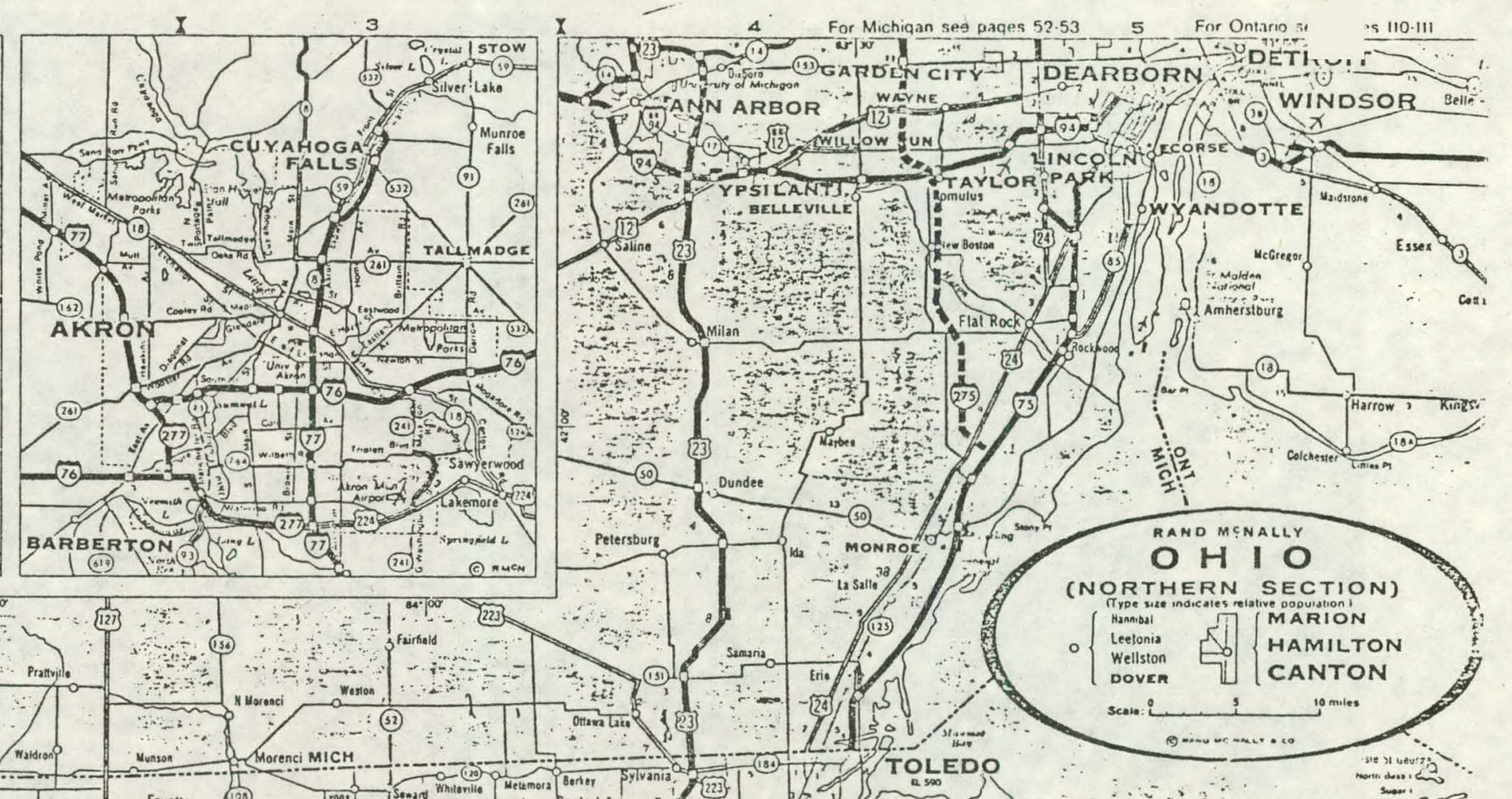

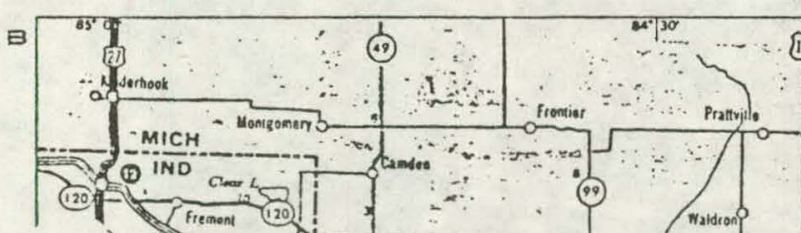

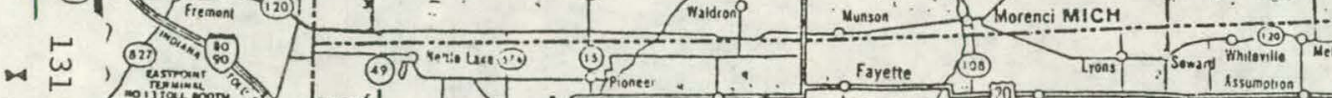

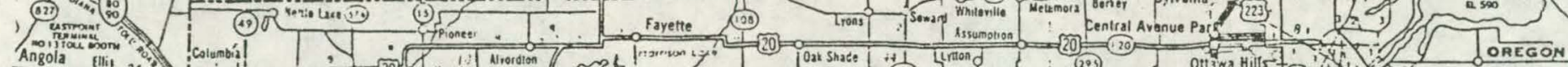

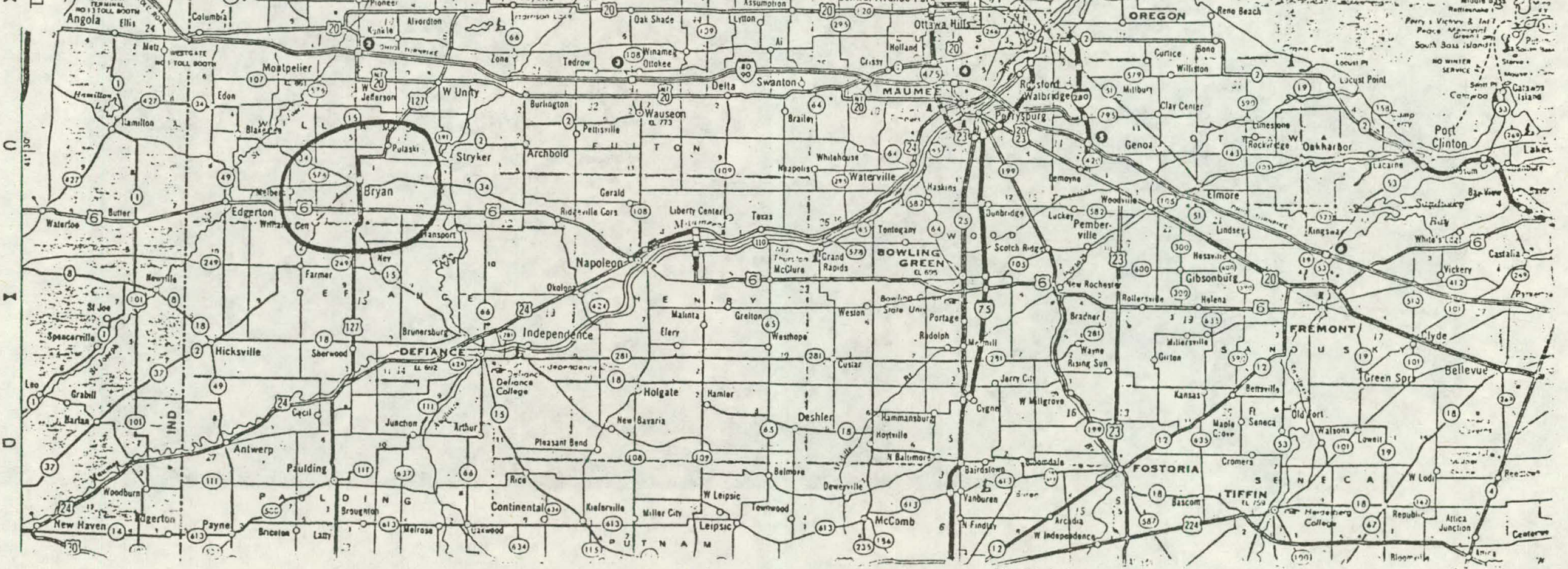




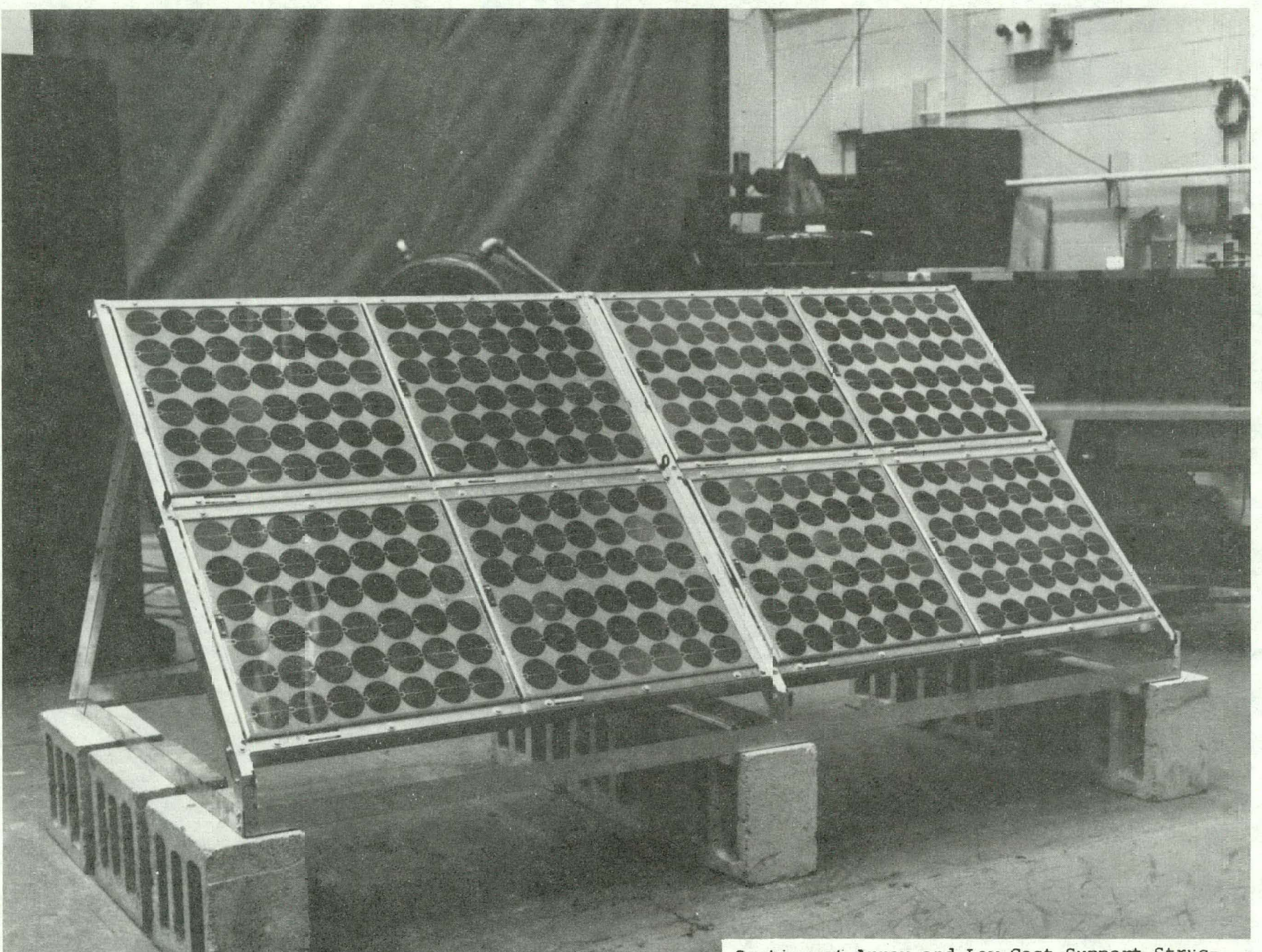

Section of Array and Low Cost Support Strlic-

ture to be Ised for the Dispersed Radio Station Power System 
Remote Automatic Meteorological Observation Systems (RAMOS)

Location:

(a) Halfway Rock, Maine

(b) Stratford Shoals, New York

(c) Loggerhead Key, Florida

(d) Clines Corners, New Mexico

(e) South Point, Hawaii

(f) Point Retreat, Alaska
Operational Date:

September 1977

May 1977

October 1977

April 1977

June 1977

July 1977

User Agency: National Weather Service (NOAA)

Designer: NASA Lewis Research Center

Use: Provide electrical power to meteorological instruments and data transmitters for six remote weather stations.

\section{System Characteristics:}

Array Power (Peak watts):

System Voltage (Peak):

Efficiency Rating of system:

Storage Capacity:

Size of Modules:

Number of Modules:

Manufacturer of Cells:

Composition of Cells

(a), (b)
111 watts
24 V DC
60 amp hours
9.2 watt, 6 volt
12 (Block I)
Solarex
Silicon

$$
\text { (a), (b) }
$$

111 watts

$24 \mathrm{~V} D \mathrm{DC}$

silicon (c), (d), (e)

74 watts

$24 \mathrm{~V}$ DC

60 amp hours

9.2 watt, 6 volt

8 (Block I)

Solarex

silicon (f)

148 watts

$24 \mathrm{~V}$ DC

1,065 amp hours

9.2 watt, 6 volt

16 (Block I)

Solarex

Silicon

Overall Installed System Cost:

$\$ 5563(\mathrm{a}, \mathrm{b}) ; \$ 4742(\mathrm{c}, \mathrm{d}, \mathrm{e}) ; \$ 9392$ (f) - costs include modules @ $21.50 / \mathrm{w}$ plus balance-of-system costs (BOS), but not experiment related itcms.

BOS Material and Labor Costs: $\$ 3160$ (Sites a-e); $\$ 6210$ (Site $\mathrm{f}$ ).

BOS \$ Watt:
(a),
(b) $-\$ 28$.
(c),
(d), (e),
(f) $-\$ 42$.

Tracking System Type: Non-tracking

$\begin{aligned} & \text { Declination Setting; Time of Year: } \text { Year Round }-0^{\circ} \text { (a), (b), } 56^{\circ} ;(\mathrm{c}), 41^{\circ} ;(d),(f), 48.5^{\circ} \text {; } \\ & \text { and }(e), 33.5^{\circ}\end{aligned}$

Load (all):

Instrumentation for wind speed and direction, dew point temperature, ambient temperature, atmospheric pressure, rainfall, rainfall last ten minutes; data transmitter. 
Special Design Features or Comments: The NWS has stated that in the most remote locations (such as Point Retreat, Halfway Rock and Loggerhead Key) the use of solar cells will save up to $\$ 150 /$ year/site in fuel costs and up to $\$ 3,000 /$ year/site in fuel transportation and maintenance costs which would normally be required for the leading competitor, a thermoelectric generator (TEG) system. Even more impressive is a comparison of 10 year life cycle costs for solar cells vs TEG which yields a 2:I cost advantage for photovoltaics.

\section{System Performance Measurements}

Date: April 30, 1978

Time Since Installation: (average) 9 months

Special Notes:

Operation of the Photovoltaic Systems in New Mexico, Hawaii and Florida was satisfactory. Entire station at Halfway Rock, Maine, destroyed in storm in February 1978. Stratford Shoals, New York, inoperative due to winter storm.

LeRC and NOAA personnel visited the Stratford Shoals RAMOS in April $1978.0 n 1 y$ one of the three series strings in the PV array was generating power. Six of the eighi modules in the two defective strings had some delamination with the encapsulant separating along the bottom edge of the module. Corrosion of the cell interconnects had occurred in these areas of delamination. The bottom row of the modules in the array was slightly buckled outward indicating wave and wind/or ice stress from the rear. Other damage to the installation included: NOAA loss of one-half of the VHF antenna, loss of ambient air and dew point air temperature sensors and supporting bracket and loss of the wind vane. Major repairs required to both NOAA RAMOS equipment and PY arraỹ.

Three modules at the Alaska site were damaged by vandalism in the fall of 1977 and were replaced. The Alaska system then operated satisfactory through the winter months.

Date: July 31,1978

Time Since Installation: (average) 1 year

Cleaning: No

Module Failure (if any): Noted above

System Degradation (if any): Noted above

Special Notes:

Halfway Rock, Maine Clines Corners, New Mexico

South Point, Hawaii

Point Retreat, Alaska

Loggerhead Key, Florida

Stratford Shoals, New York
- entire station destroycd by storm.

- operating satisfactorily

- operating satisfactorily

- operating satisfactorily

- inoperative due to NOAA equipment problems

- inoperative due to winter strom, awaiting USCG transportation for NOAA and LeRC personnel who will replace the array and check NOAA equipment. 


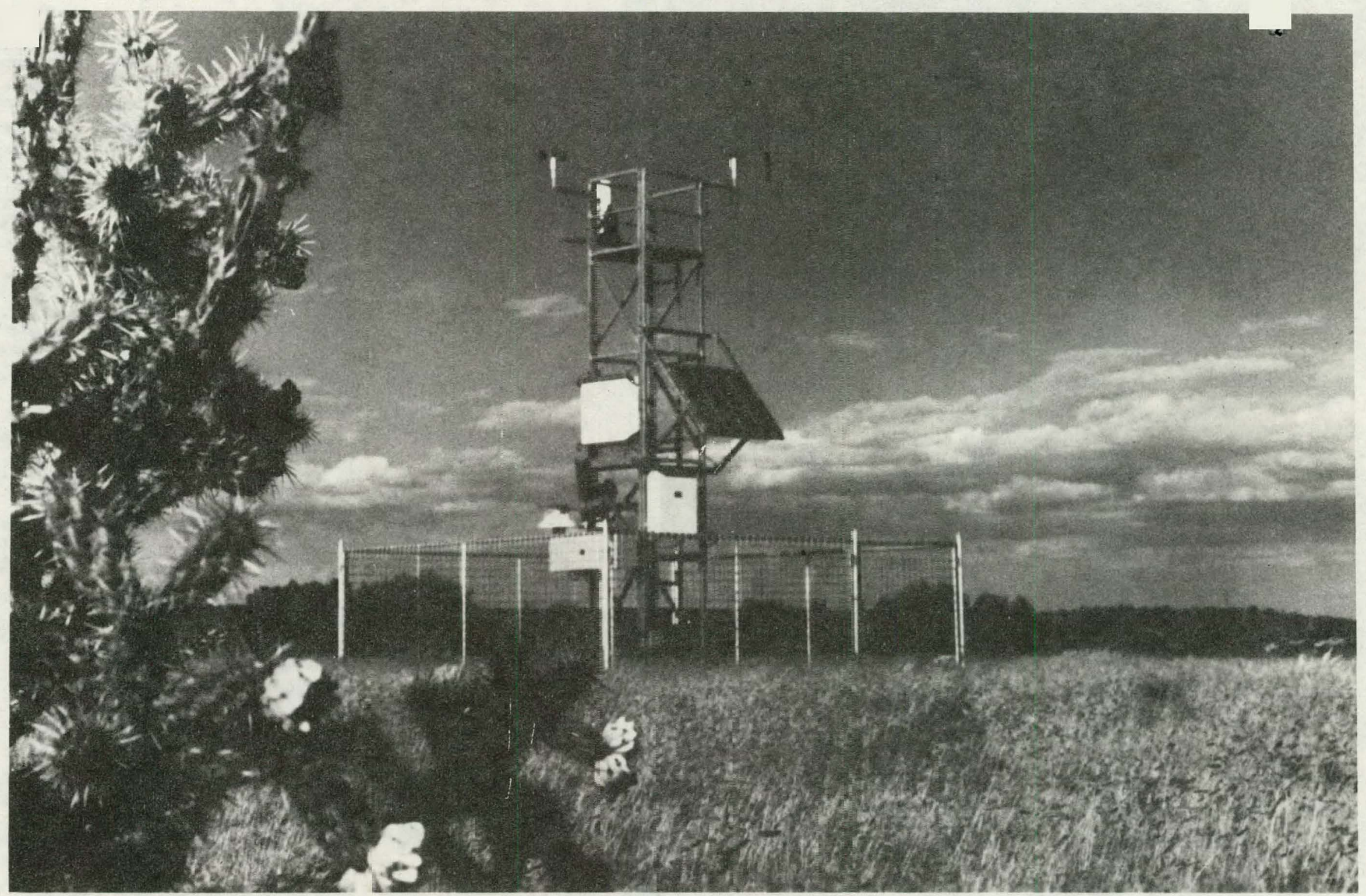

SILENT SENTINEL -- Located atop a snall, but meteorologically important ridge at the edge of New Mexico's vast eastern plains, the nation's first operational solar cell powered RAMOS weather station stands silently, reporting weather data hourly via satellite to National Weather Service (NWS) offices. The solar powəred RAMOS is designed to improve the weather forezasting capabilities of the NWS and provile loca- weather forecasters with advance storm warning $\mathrm{i}$ an area often hit the hardest by severe weather. 


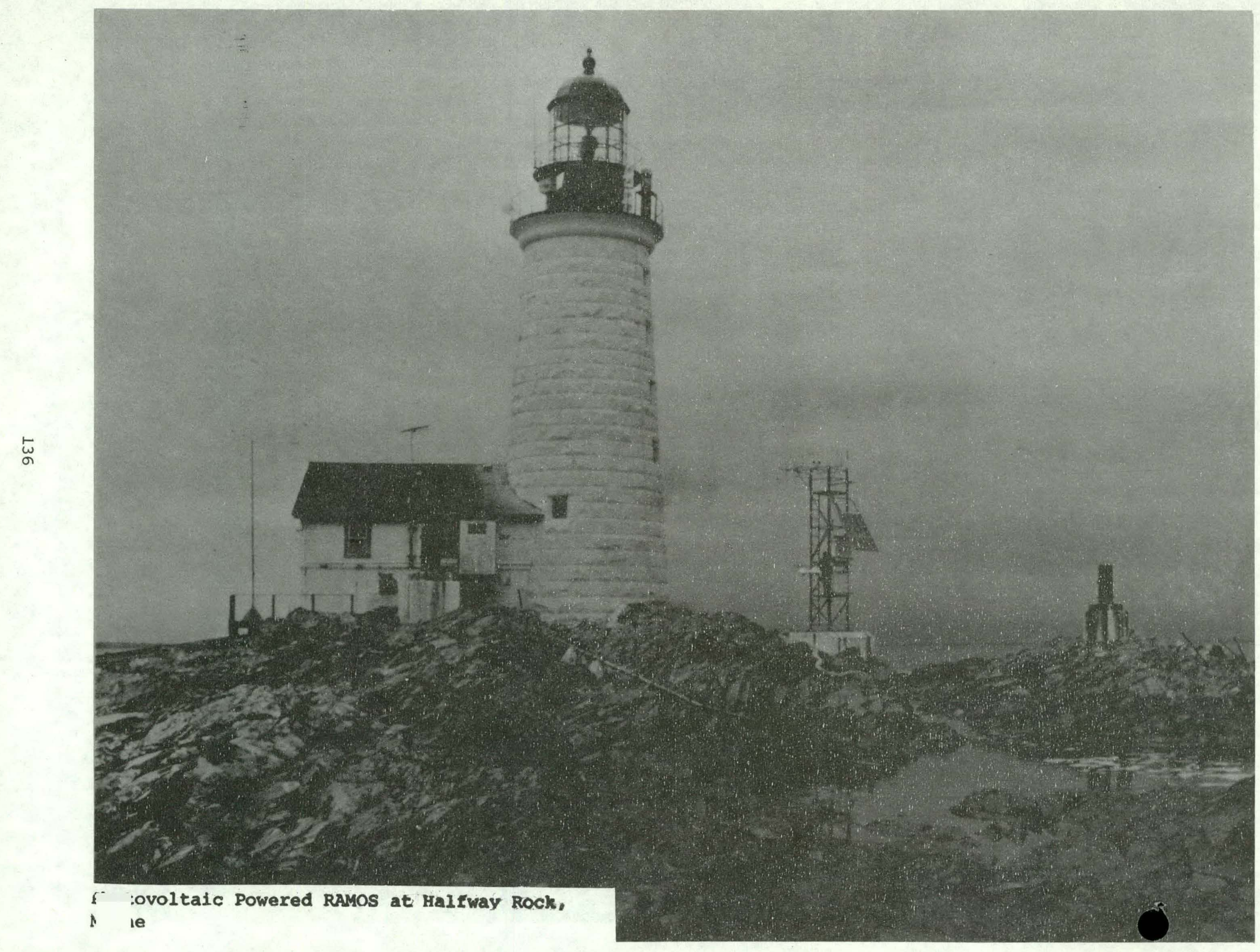




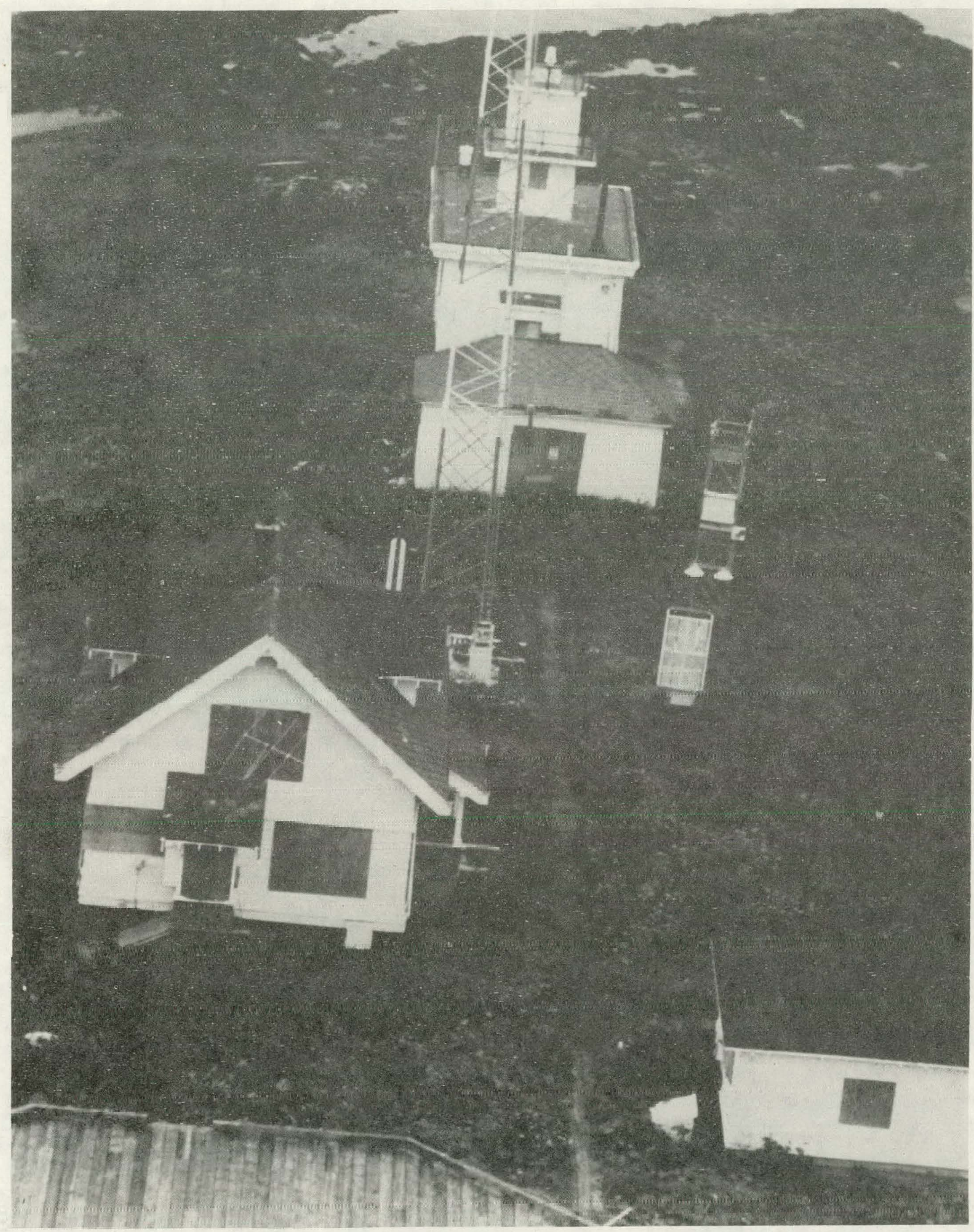

Photovoltaic Powered RAMOS Weather station, Point Retreat, AK. 


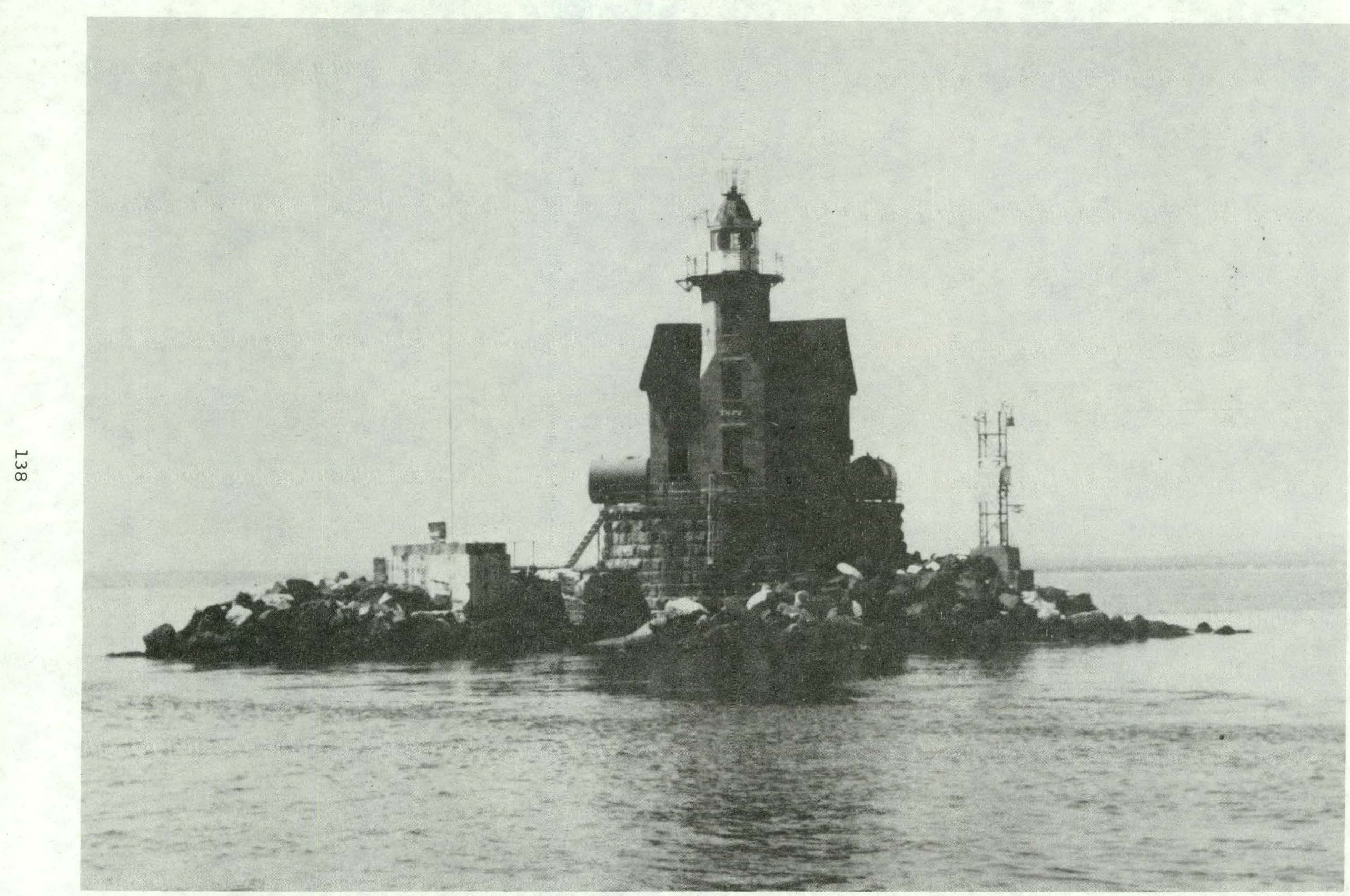

Photovoltaic Powered RAMOS at Stratford Shoals, $\mathrm{N}$ York 


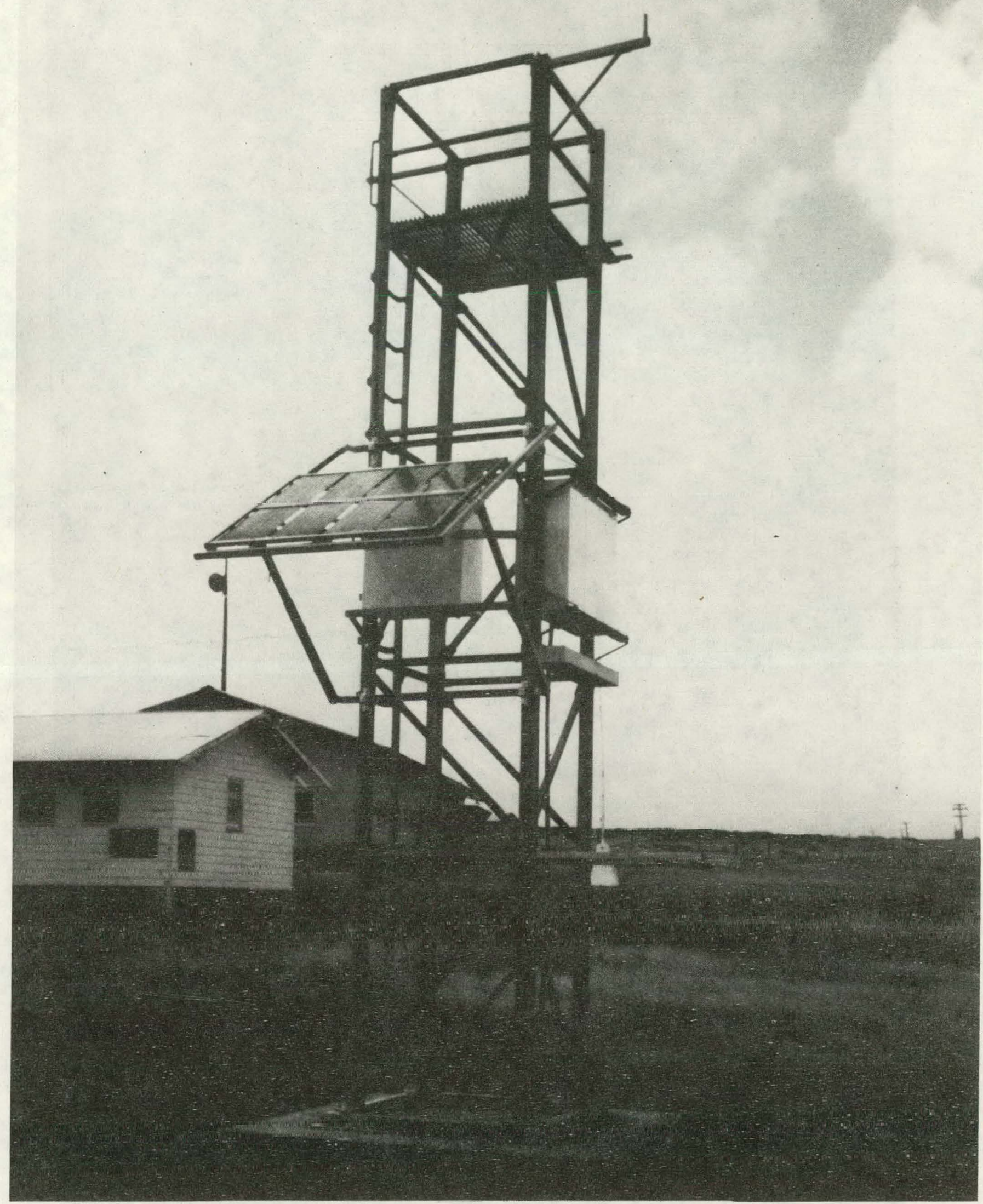

Photovoltaic Powered RAMOS Weather Station, South Pnint, Hawaii 


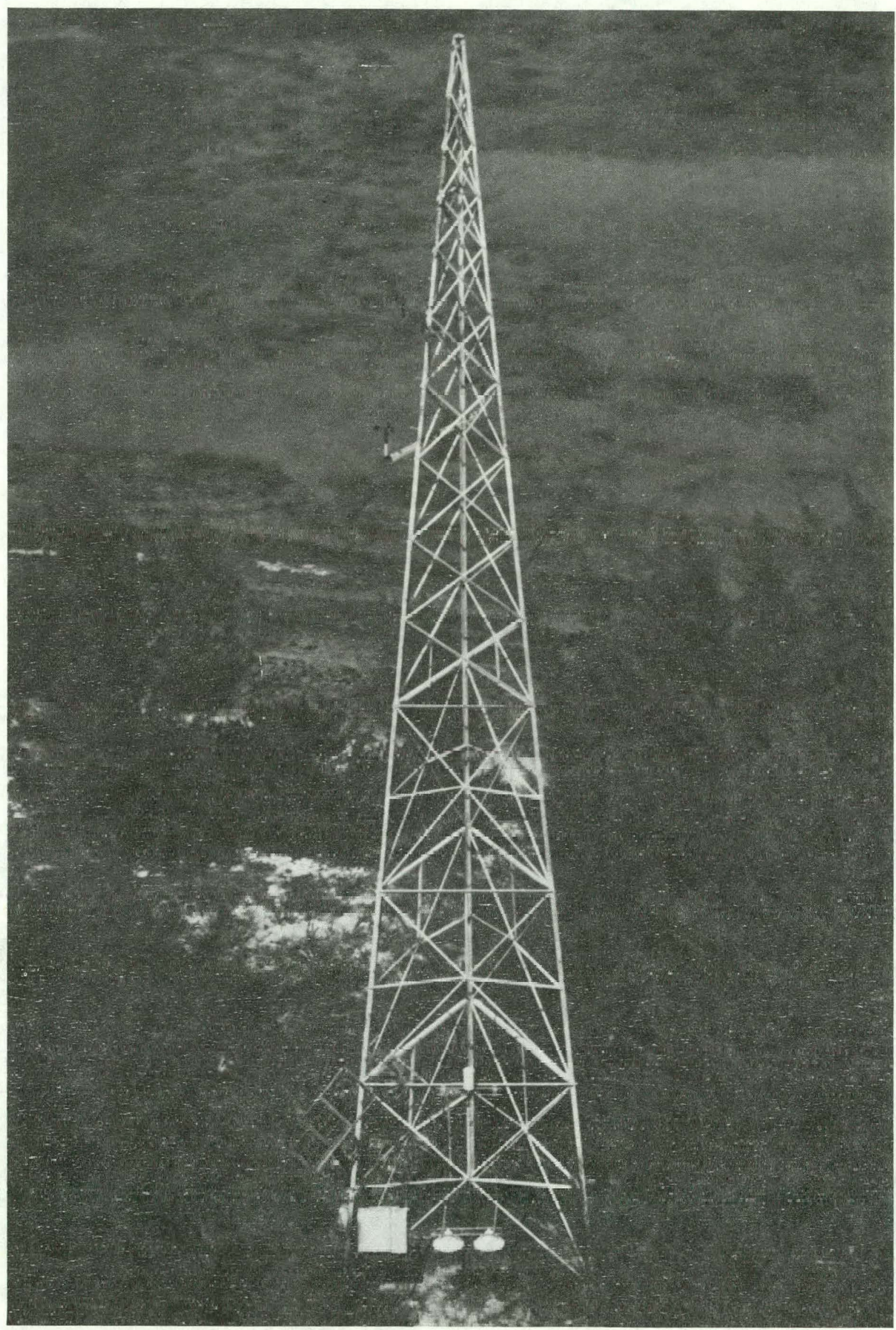

Photovoltaic Powered RAMOS Weather Station, Loggerhead Key, Florida 
Indian Village Refrigerator Experiment

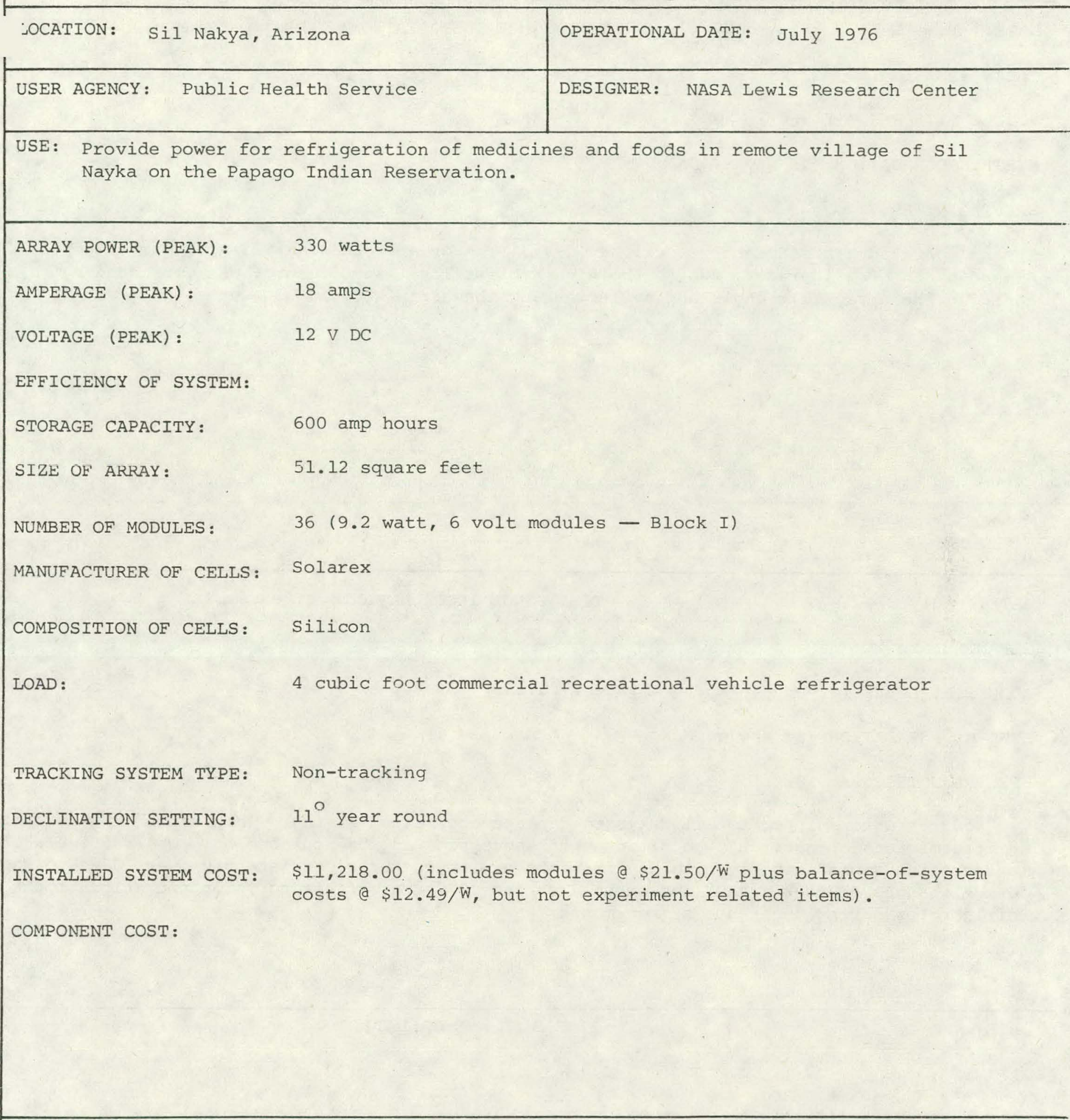

SPECIAI DESIGN FEATURES : 
DATE: June 1977

TIME SINCE INSTALLATION: 11 months

CLEANING: Yes

MODULE FAILURES (if any): None

SYSTEM DEGRADATION (if any): None

SPECIAL NOTES :

System operated satisfactorily until May 1977. The greater than anticipated summer power demand by the refrigerator, due to the high ambient local temperature, was corrected by changing the array tilt angle and by increasing the array size to 330 watts.

DATE: July 31,1978

TIME SINCE INSTALLATION: 2 years

CLEANING: Yes

MODULE FAILURES (if any): 1 intermittent failure

SYSTEM DEGRADATION (if any): None

SPECIAL NOTES :

Two modules were shipped to Sil Nakya to replace one failed string. This string had developed an intermittent open circuit condition which necessitated the replacement. The refrigerator is operating satisfactorily with daytime ambient temperatures consistently over 1000 F. The design changes (larger array) implemented during 1977 are satisfactory for operation of the refrigerator during their hot summer months.

\section{DATE :}

TIME SINCE INSTALLATION:

CLEANING :

MODULE FAILURES (if any):

SYSTEM DEGRADATION (if any):

SPECIAL NOTES: 


\section{PHOTOVOLTAIC POWERED REFRIGERATOR}

AT PAPAGO INDIAN VILLAGE OF SIL. NAKYA, ARIZONA

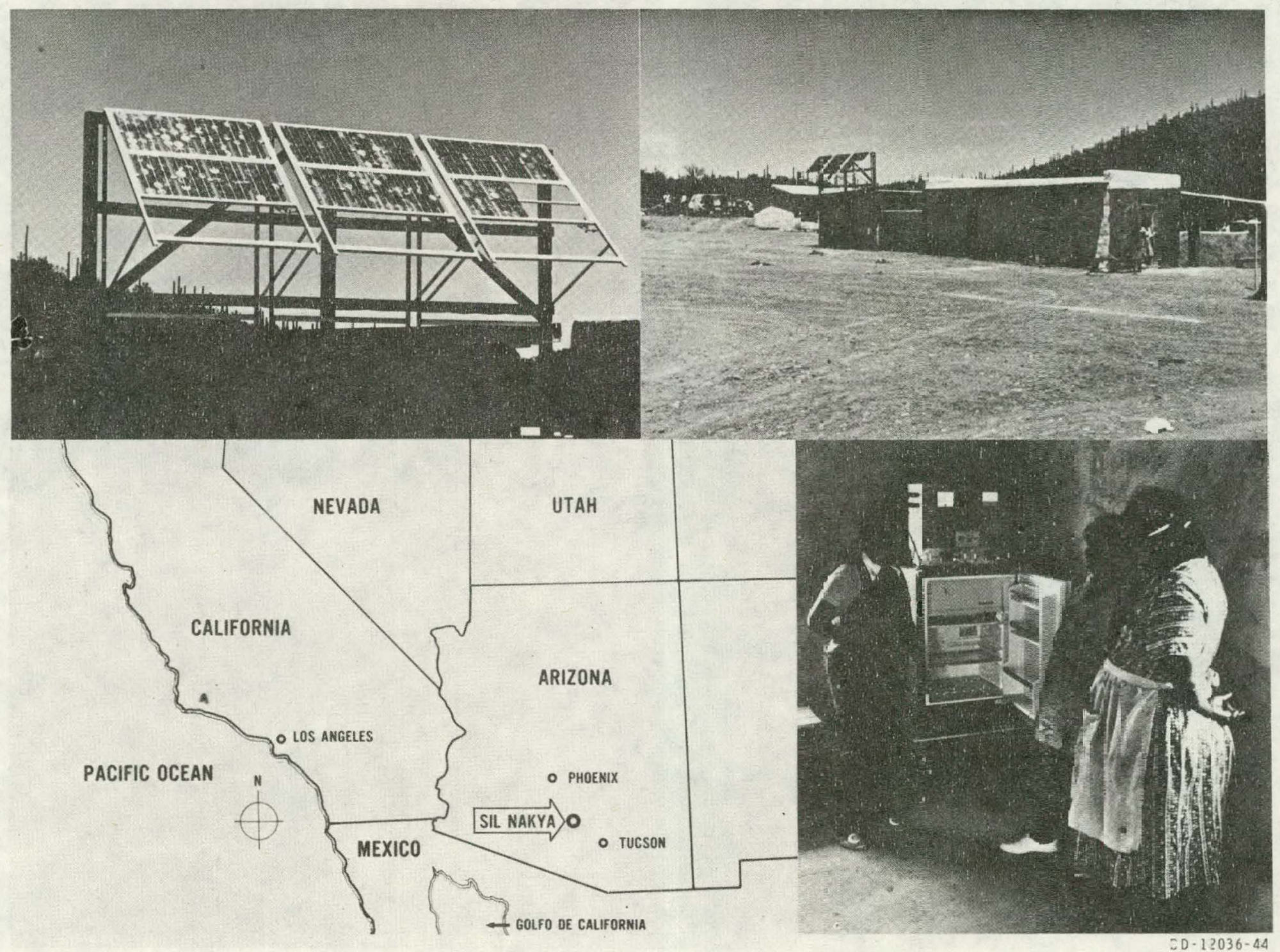




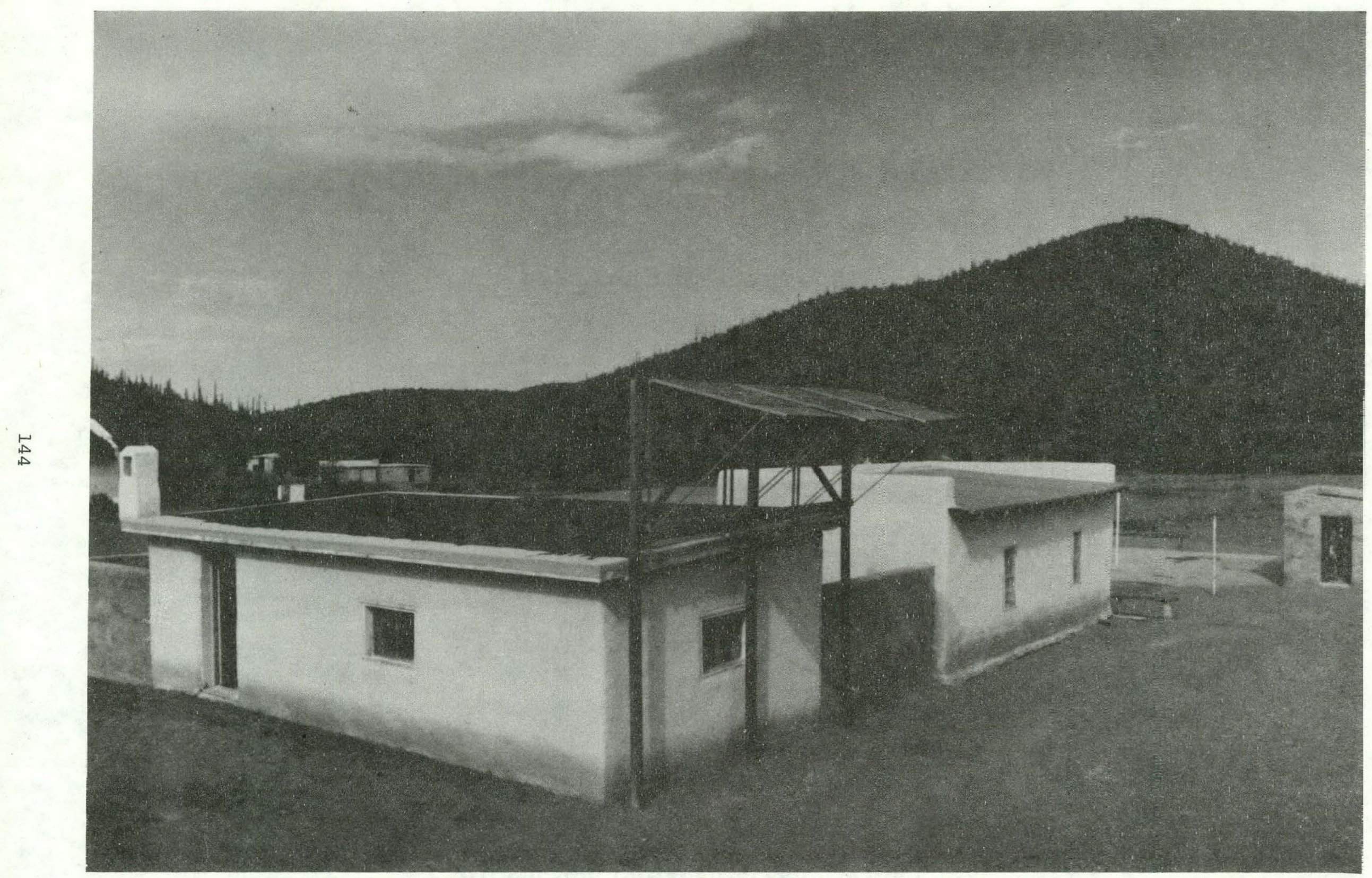

View of enlarged array which now powers the $r \in$ gerator at Sil Nakya Indian Village,

Ar _._una. Summer 1978. 


\begin{tabular}{|c|c|}
\hline $\begin{aligned} \text { LOCATION: } & \text { Isle Royale National Park } \\
& \text { Lake Superior, Michigan }\end{aligned}$ & $\begin{array}{l}\text { First - Summer of } 1976 \\
\text { Second - Summer of } 1978\end{array}$ \\
\hline $\begin{array}{l}\text { USER AGENCY: } \\
\qquad \text { National Park Service }\end{array}$ & $\begin{array}{l}\text { DESIGNER: } \\
\qquad \text { NASA Lewis Research Center }\end{array}$ \\
\hline
\end{tabular}

USE: Refrigeration of foodstuffs for trail crews constructing wilderness trails.

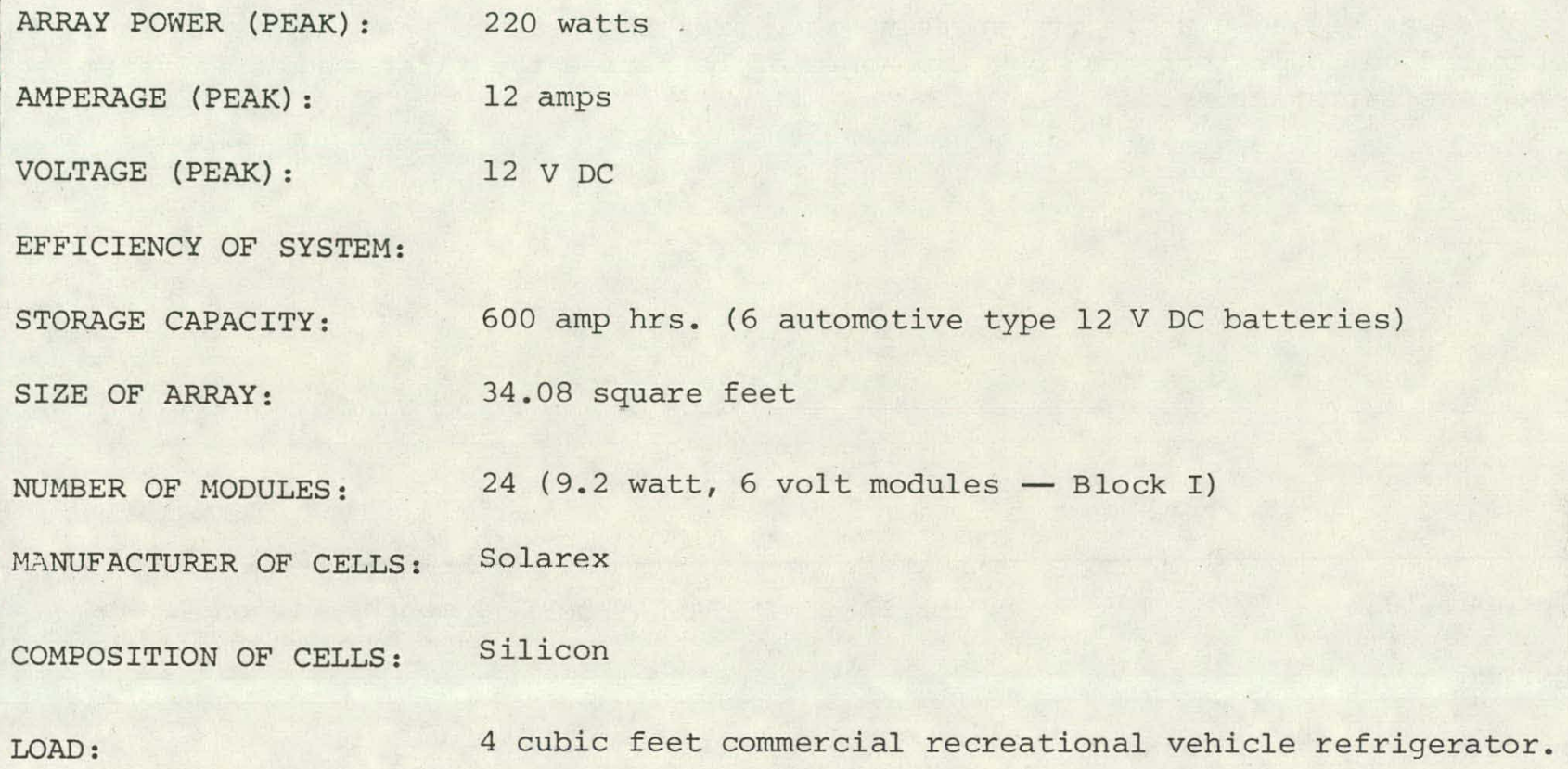

SPECIAL DESIGN FEATURES: 
DATE: June 1977

TIME SINCE INSTALLATION: 11 month (operational only 4 months during summer of

CLEANING: Occasionally with water only 1976)

MODULE FAILURES (if any): None

SYSTEM DEGRADATION (if any): None

SPECIAL NOTES:

Two batteries were damaged while transporting them from the boat to the campsite. Thus, the system operated on 400 rather than 600 amp hours of batteries the first summer. System performance was satisfactory.

DATE: October 1978 TIME SINCE INSTALLATION: 4 months (second summer)

CLEANING: NO

MODULE FAILURES (if any): None

SYSTEM DEGRADATION (if any): None

SPECIAI NOTES :

Operated satisfactorily while installed at back-country ranger station (different site than first summer).

object of considerable visitor interest (over 3,800 visitors at site during season).

DATF:

TTMF: STNCF: TNSTATITATTON :

CLEANINGG:

MODULE FAILURES (if any):

SYSTEM DEGRADATION (if any):

SPECIAL NOTES: 


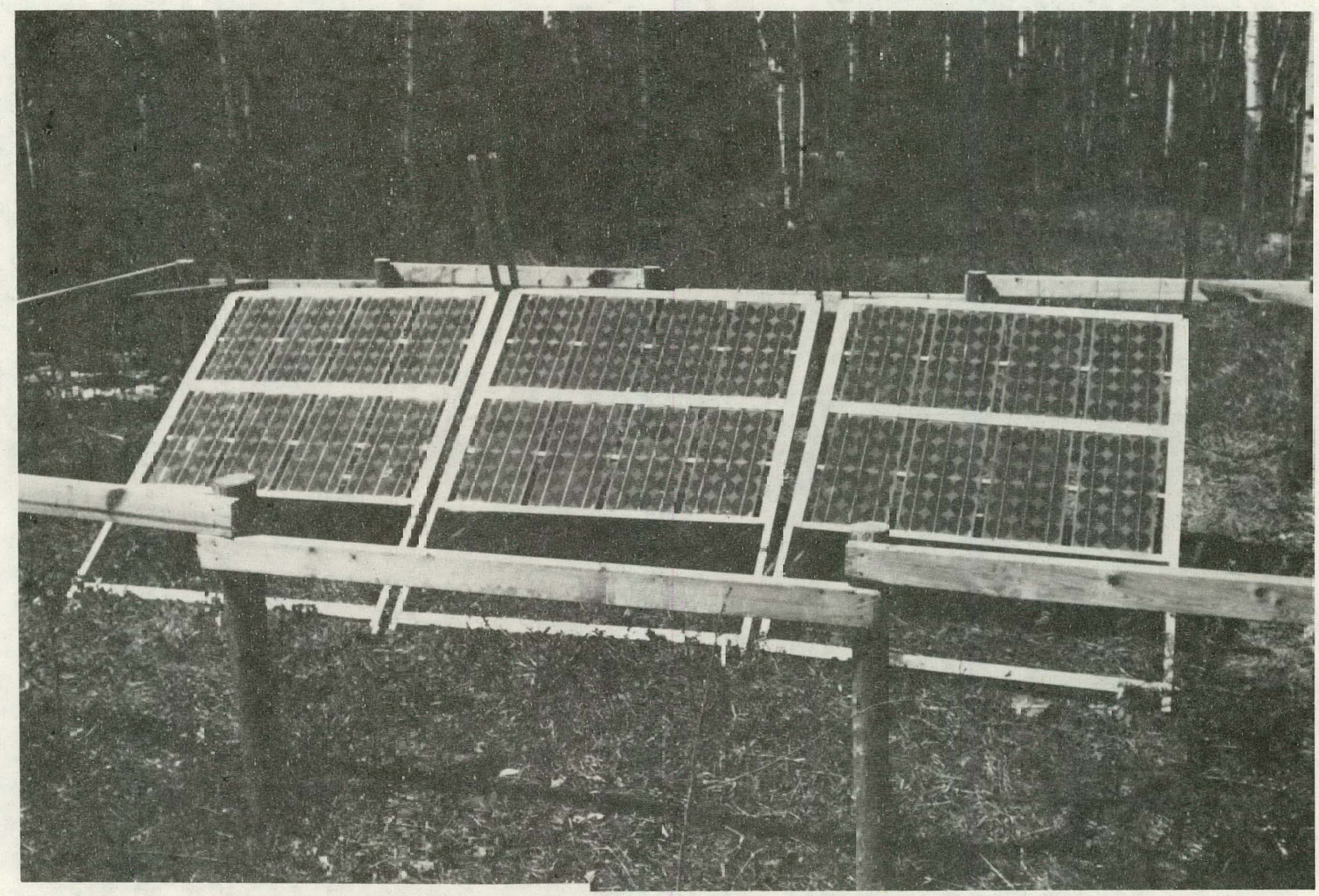

View of Array Whizh Powers a Refricerator at Isle Roya-e National Park, Michigar. 


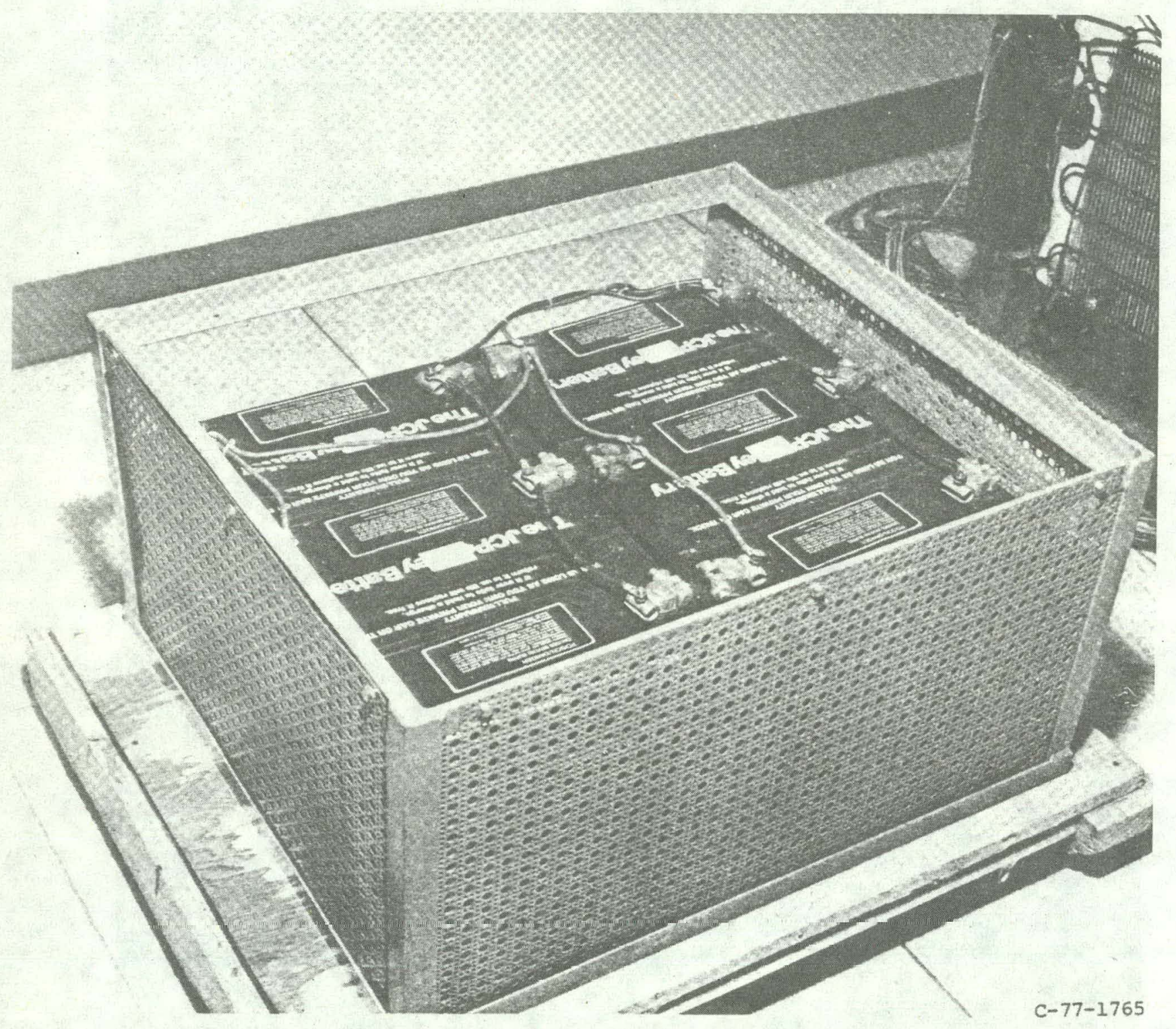

Figure 2 - Battery Pack and Refrigerator Stand for Isle Royale National Park P/V Powered Refrigerator System

Standard automotive type lead-acid maintenance-free batteries were selected for energy storage. Six 100 amp. hr. batteries connected in parallel provided capacity for up to 10 days of operation during cloudy weather. The batteries were packaged simply into a vented metal enclosure that served as a stand for the refrigerator. 


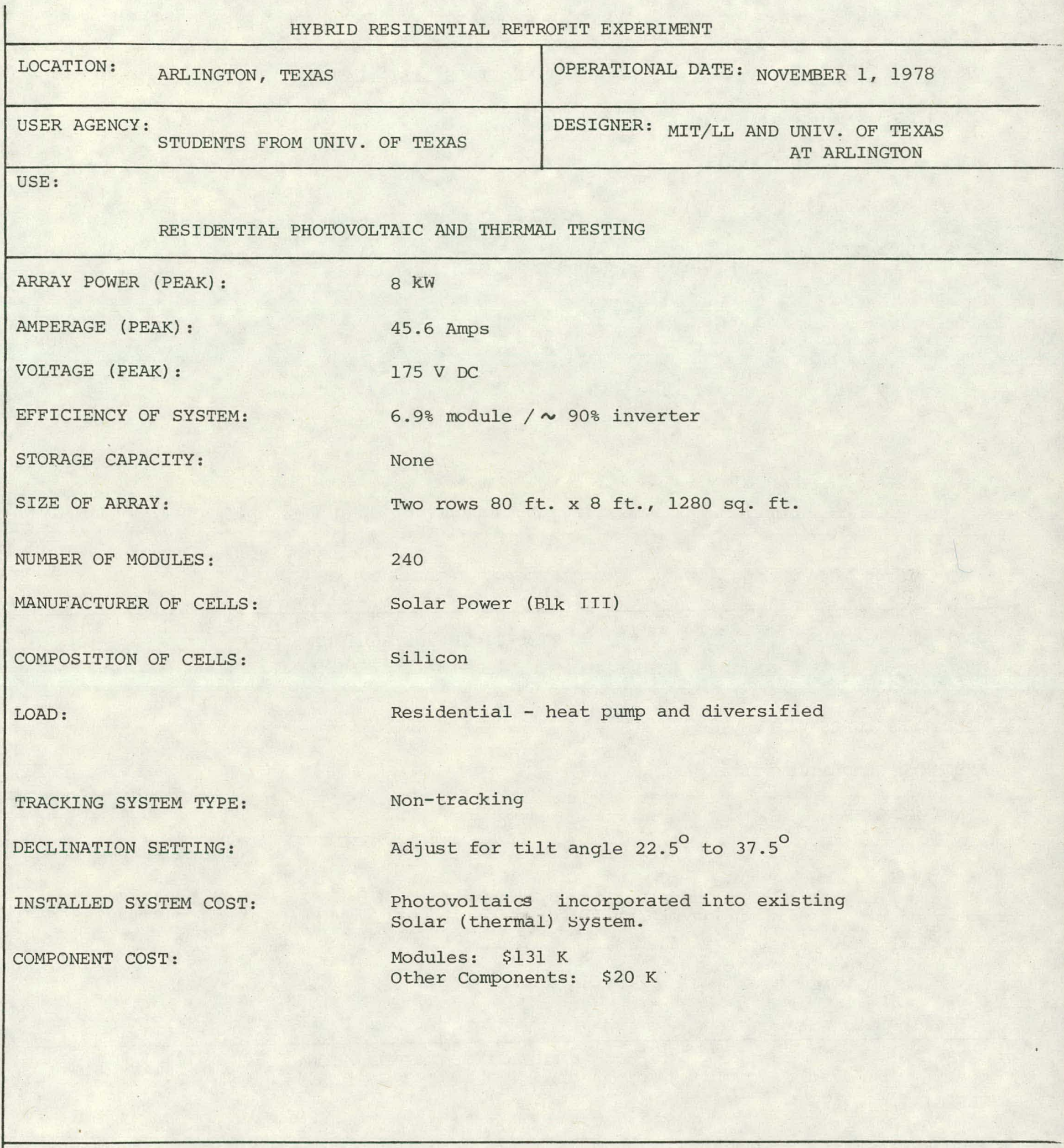

SPECIAL DESIGN FEATURES:

- Time commutated Gemini $8 \mathrm{~kW}$ inverter

- Utility two-way power flow

○ Extensive energy usage monitoring

- PV array mounted in backyard 
DATE :

TIME SINCE INSTALLATION:

CLEANING :

MODULE FAILURES (if any):

SYSTEM DEGRADATION (if any):

SPECIAI NOTES :

DATE :

TIME SINCE INSTALLATION:

CLEANING :

MODULE FAILURES (if any):

SYSTEM DEGRADATION (if any):

SPECIAL NOTES :

NATE:

CLEANING :

MODULE FAILURES (if any):

SYSTEM DEGRADATION (if any):

SPECIAL NOTES: 


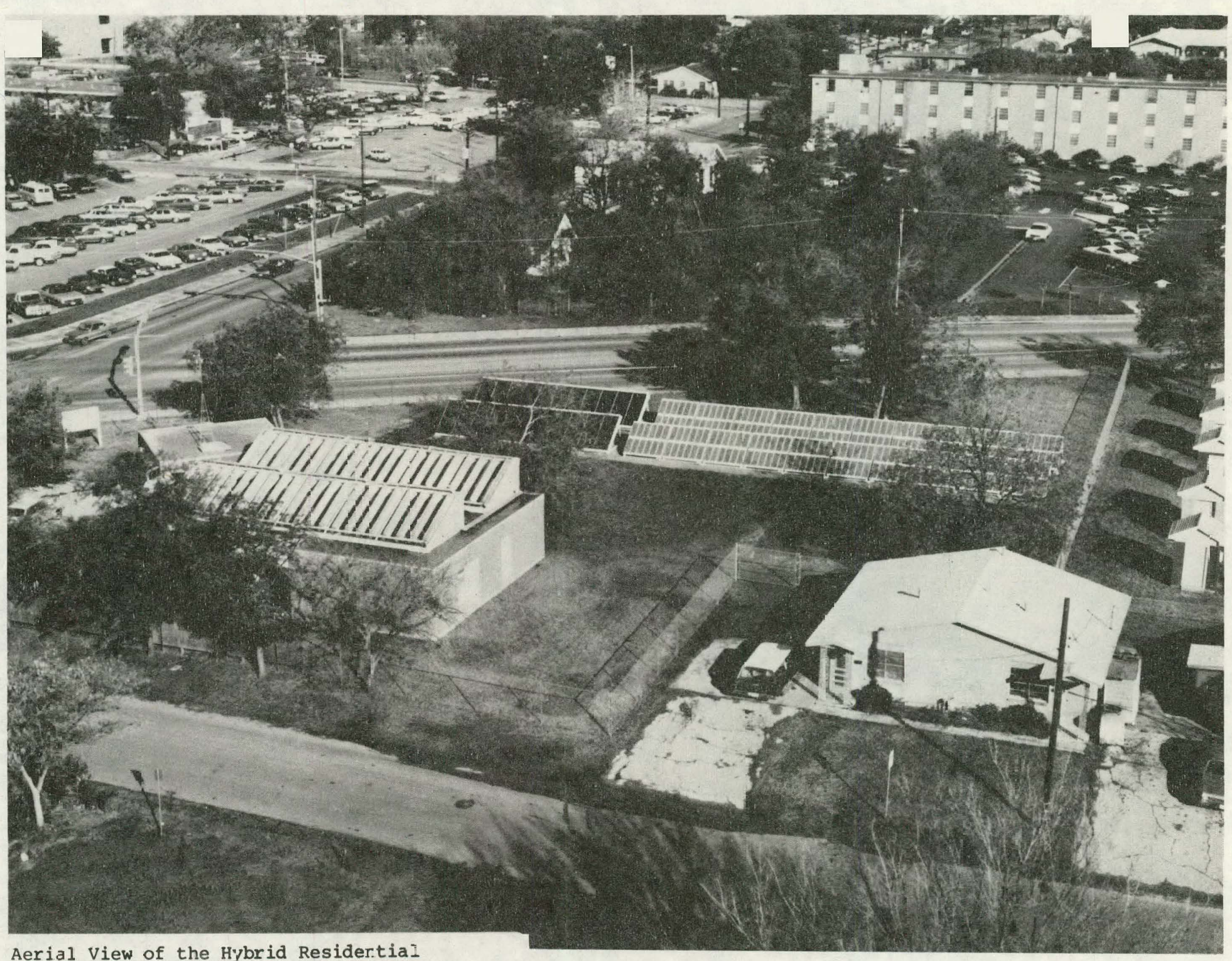

Aerial View of the Hybrid Resider.

Experiment in Arling=on, Texas, Nov. 1978 


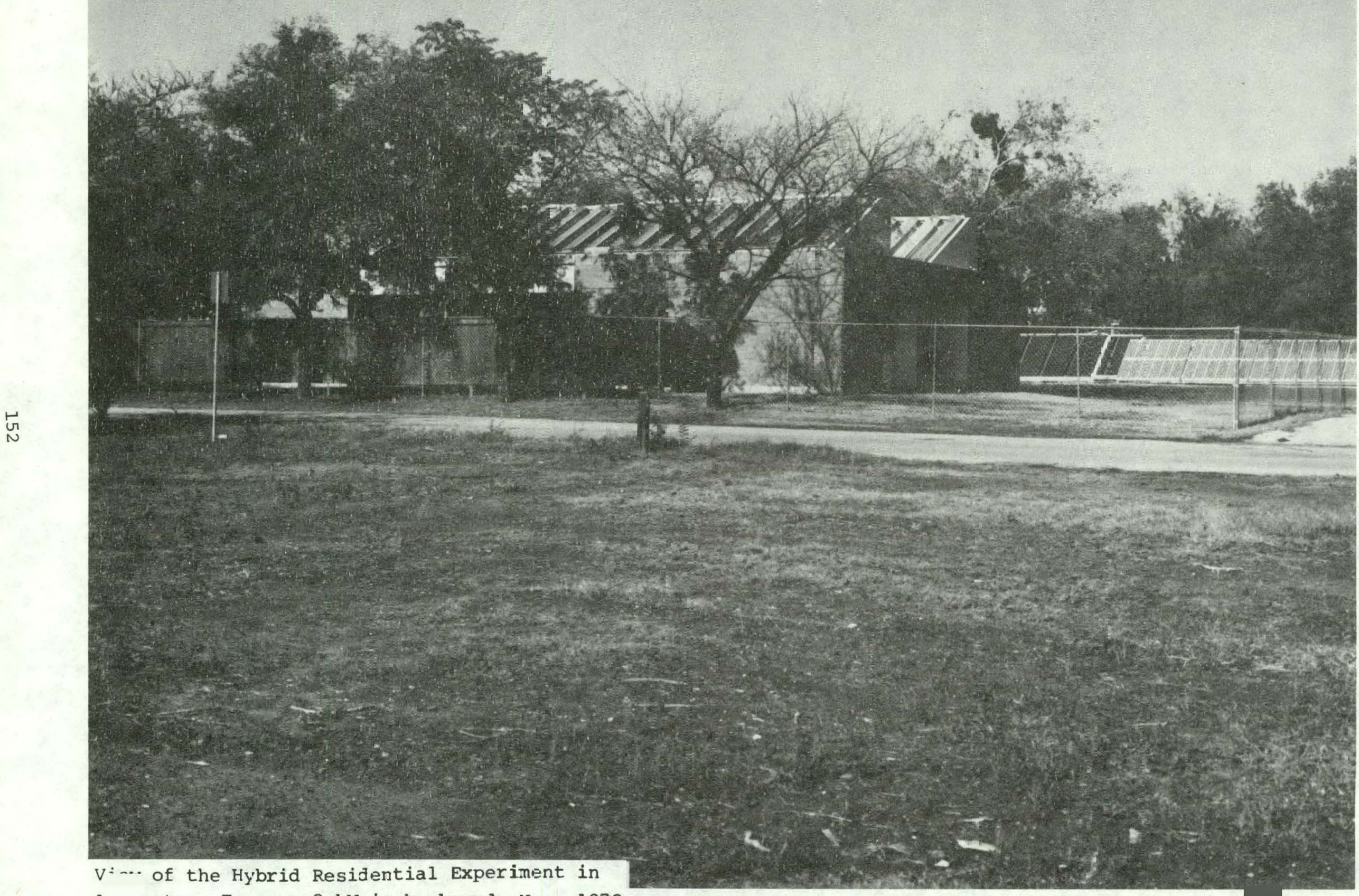

A gton, Texas. $8 \mathrm{~kW}$ in backyard. Nov. 1978 


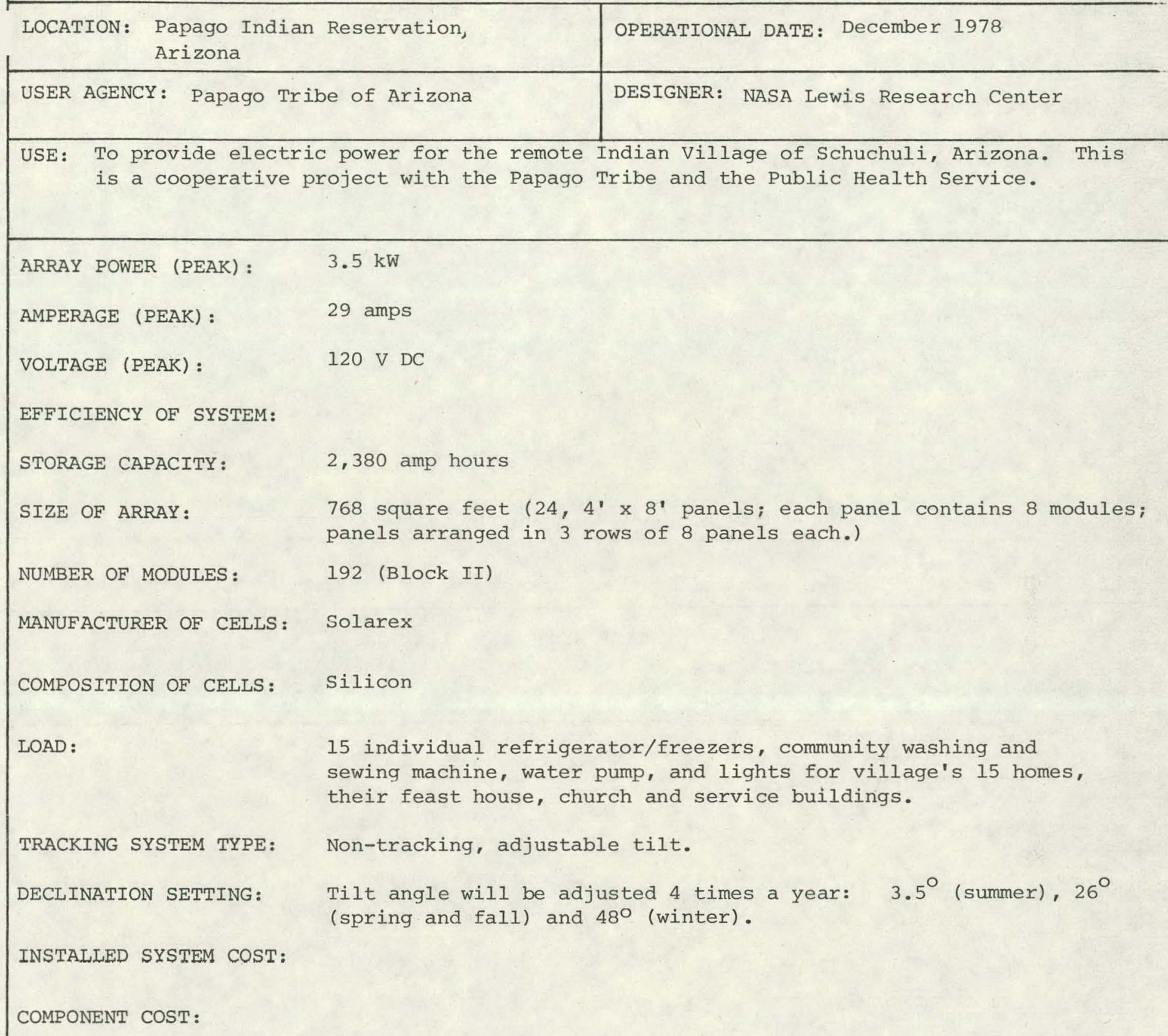

SPECIAL DESIGN FEATURES:

- An all DC system was selected to avoid the losses associated with commercially available $\mathrm{DC} / \mathrm{AC}$ inverters. 
DATE :

TIME SINCE INSTALLATION:

CLEANING :

MODULE FAILURES (if any):

SYSTEM DEGRADATION (if any):

SPECIAL NOTES:

DATE :

TIME SINCE INSTALLATION:

CLEANING :

MODULE FAILURES (if any):

SYSTEM DEGRADATION (if any):

SPECIAL INUTES:

DATE :

TIME SINCE INSTALLATION:

CLEANIN⿴G :

MODULE FAILURES (if any):

SYSTEM DEGRADATION (if any):

SPECIAL NOTES : 
Village of Schuchuli, Arizona, in tie Papago Indien Reservation.

Dəc. 1978

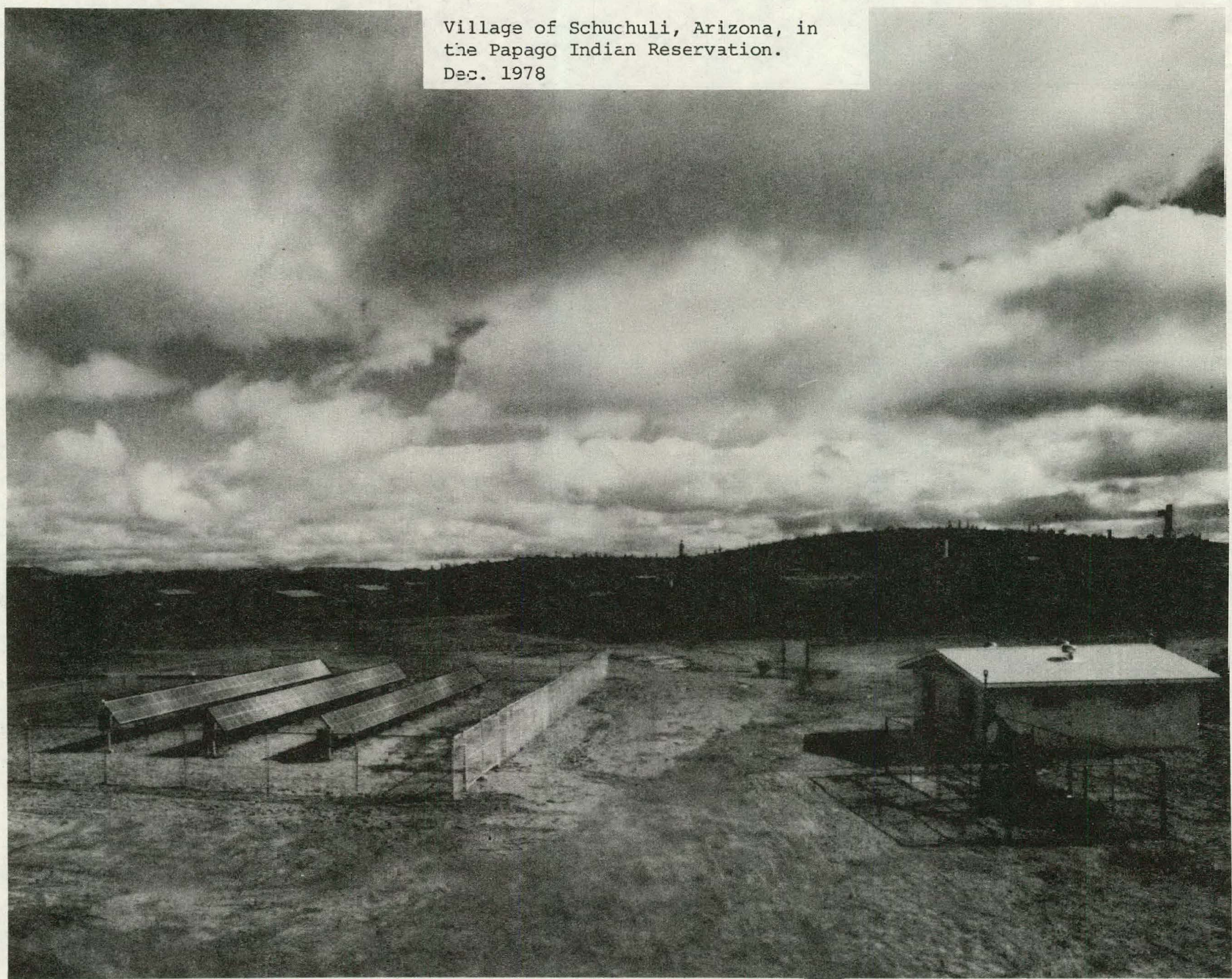


Loads and Load Profiles

Representatives of the Papago Tribe and the village approved the installation of the photovoltaic system for the villiage of Schuchuli. The selection of the loads to be powered was based on a prioritized list developed by the villagers. An electric motor to operate the existing water pump was an obvious choice to replace the $7 \mathrm{HP}$ diesel engine currently used. This will eliminate the cost burdens associated with diesel fuel and maintenance which place a strain on the financial resources of the village. In addition, the villagers agreed to use other load devices (appliances) in a communal fashion and approved the construction of a domestic services building to house the appliances. The other load devices chosen by the villagers based on power availability and need are listed below in order of priority:

1. A light in the kitchen of each house

2. A light in another room of each house

3. Lights in a community building, feast house, and church

4. Refrigerators in the community building

5. Washing machine in the community building

6. Sewing maching in the community building

Water Pump - a 2 III permanenL maynet 120 volt DC motor will be used to power an existing jack pump on the main well. The pump delivers approximately 1100 gal/hour into the village water distribution system which includes an 11,000 gallon storage tank located approximately 1200 feet from the well. LeRC and PHS personnel jointly estimated water consumption for villagers and livestock to range from $2500 \mathrm{gal} /$ day in the winter to $5000 \mathrm{gal} /$ day in the summer. An additional 960 gal/day was estimated by LeRC to be required for the clothes washer. Total pumping time therefore ranges from 3.1 hours/day in the winter to 5.4 hours/day in the summer. A control system limits pumping to daylight hours roughly 
centered about mid-day, except for emergency situations. Another well, powered by a gasoline engine, can provide water if problems occur with the main well or $\mathrm{P} / \mathrm{V}$ system.

Lights - A total of 44, 20-watt/120 VDC fluorescent lights will be installed in the village. The lights will employ a special design $120 \mathrm{VDC} / 23 \mathrm{kHz}$ inverter ballast which enables the lamp to produce the same number of lumens as a $120 \mathrm{VAC} / 60 \mathrm{~Hz}$ ballast. The lights will be distributed as follows: 2 in each of the 15 houses, 6 in the feast house, 2 in the domestic services building, 2 in the church, and 4 in the electrical equipment building.

Refrigeration Units - A total of fifteen (15) 4 cubic foot refrigerators (with a small freezing compartment) will be provided in the domestic services building. Each will have an automatic door closer and a key lock. These refrigerators are assembled in groups of three and powered as a unit from a single compressor with a $1 / 8$ HP 120 VDC permanent magnet motor. The duty cycle should be about $25 \%$ "on". in a $110^{\circ} \mathrm{F}$ ambient environment based on test results.

Clothes Washer - A standard wringer-type washer will be installed in the domestic services building. This washer has been fitted with a $1 / 4$ HP permanent magnet 120 VDC motor. A wringer-type washer was selected for overall simplicity and to reduce water consumption. The washer, operated from a clock timer, can be run for 12 hours/day, seven days a week. At $1 / 2$ hour/load, this provides for washing approximately 1.75 loads/person/ week. Water consumption was estimated at $40 \mathrm{gal} / \mathrm{load}$. Scwing Machine - A commercially available sewing machine with a variety of stitches, a light and a $1 / 8 \mathrm{HP}, 120 \mathrm{~V}$ universal motor will be 
installed in the domestic services building. For systeln sizing purposes, the unit was assumed to operate in the late afternoon for 3 hours/day. Load Management

Because of unknowns in the use of the loads and variations in insolation, a load managemet subsystem was incorporated into the design to (1) protect the batteries from excessive discharge and potential damage, and (2) to maintain operation of the more critical loads at the expense of. less critical loads. The load management subsystem sequentially disconnects loads as the battery capacity decreases to preset levels.

At $50 \%$ depth-of-discharge, the washing and'sewing machines are disconnected, at 60\%ithe lights, at $70 \%$ the water pump motor, and finally at $80 \%$ depth-of-discharge the refrigerators are disconnected. As the batteries are recharged, loads are sequentially reconnected into the system in reverse order. The four pilot cells provide-sensing of the depth-of-discharge. 


\section{BLOCK DIAGRAM OF SCHUCHULI VILLAGE POWER SYSTEM}

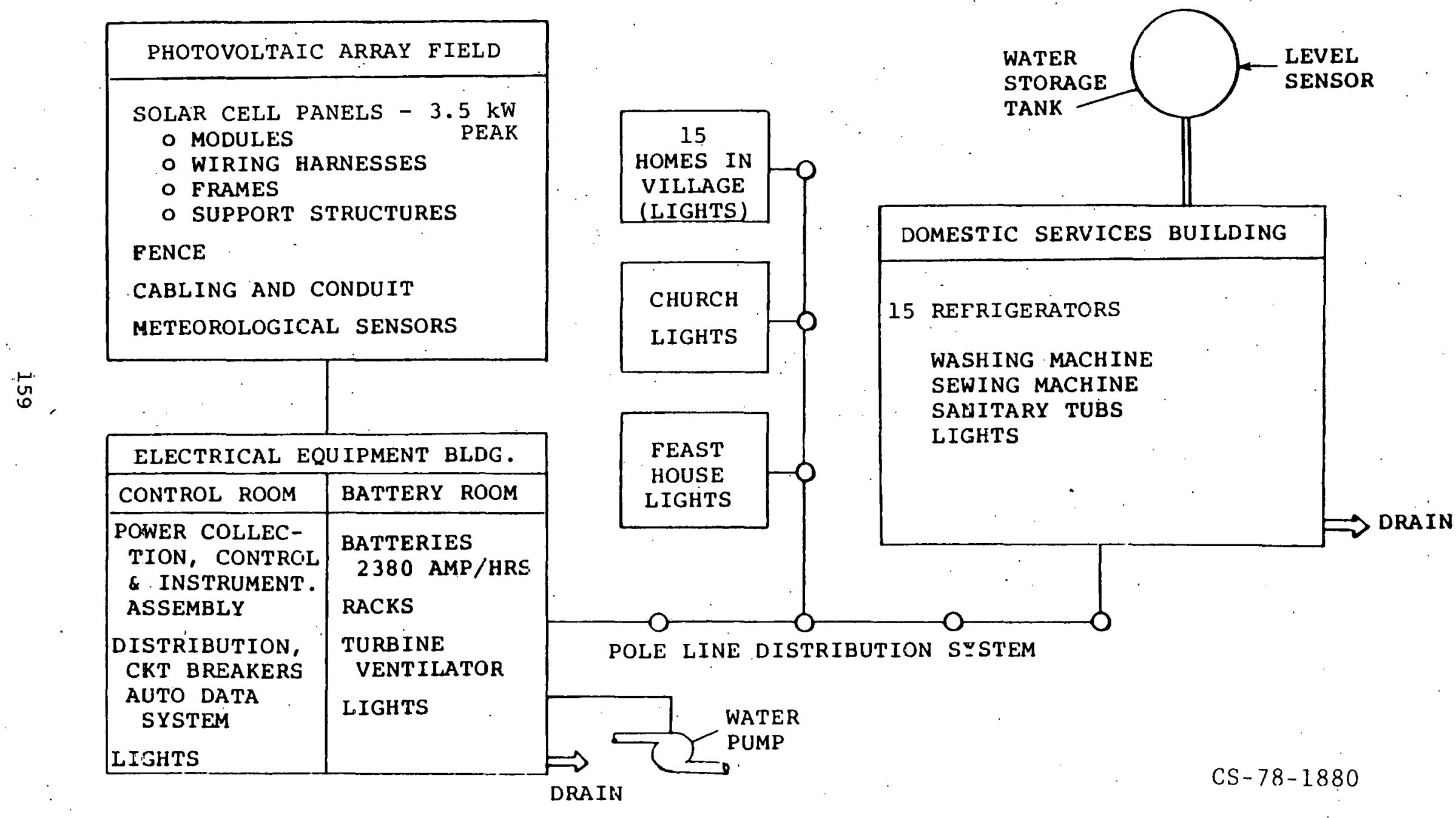




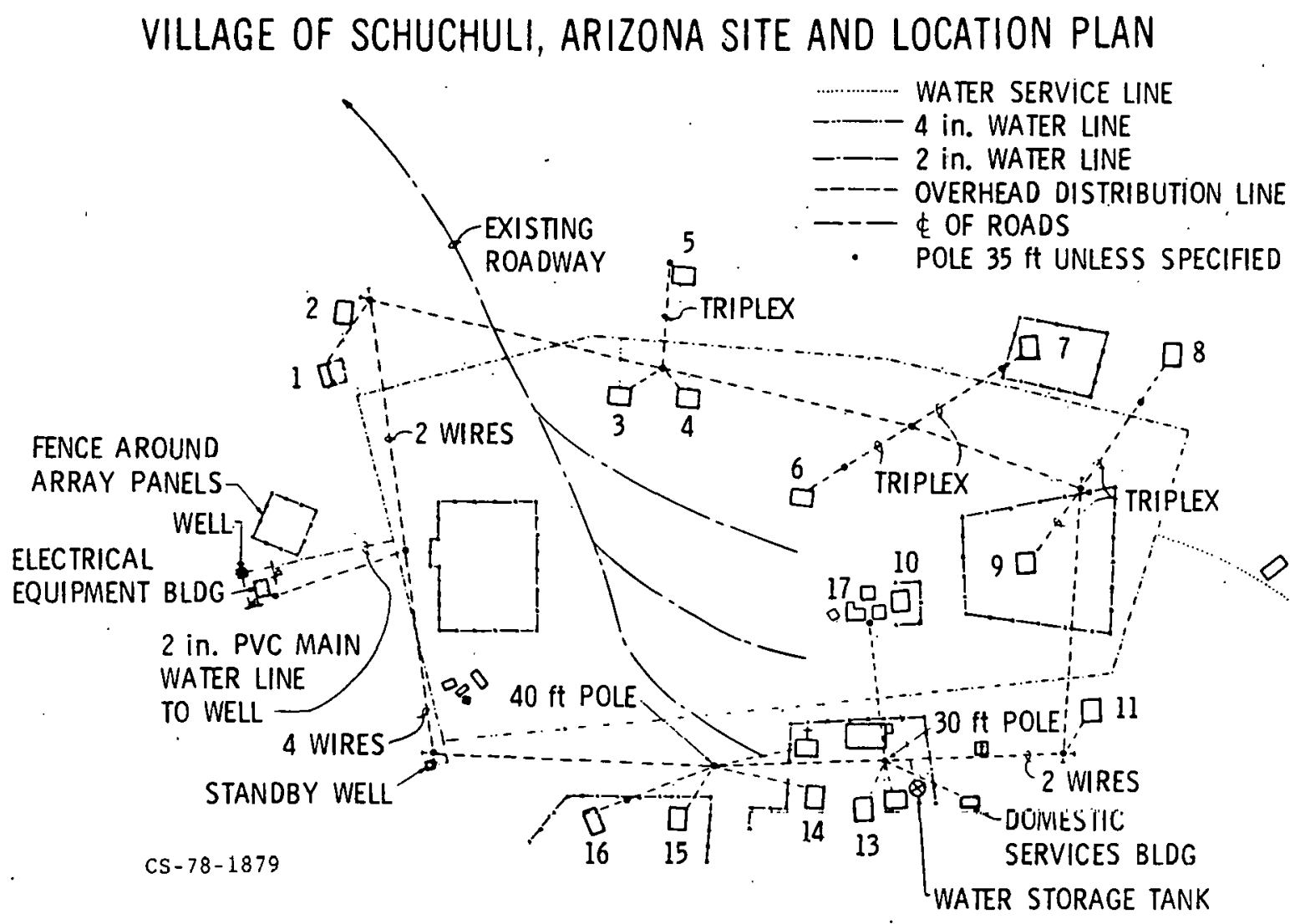




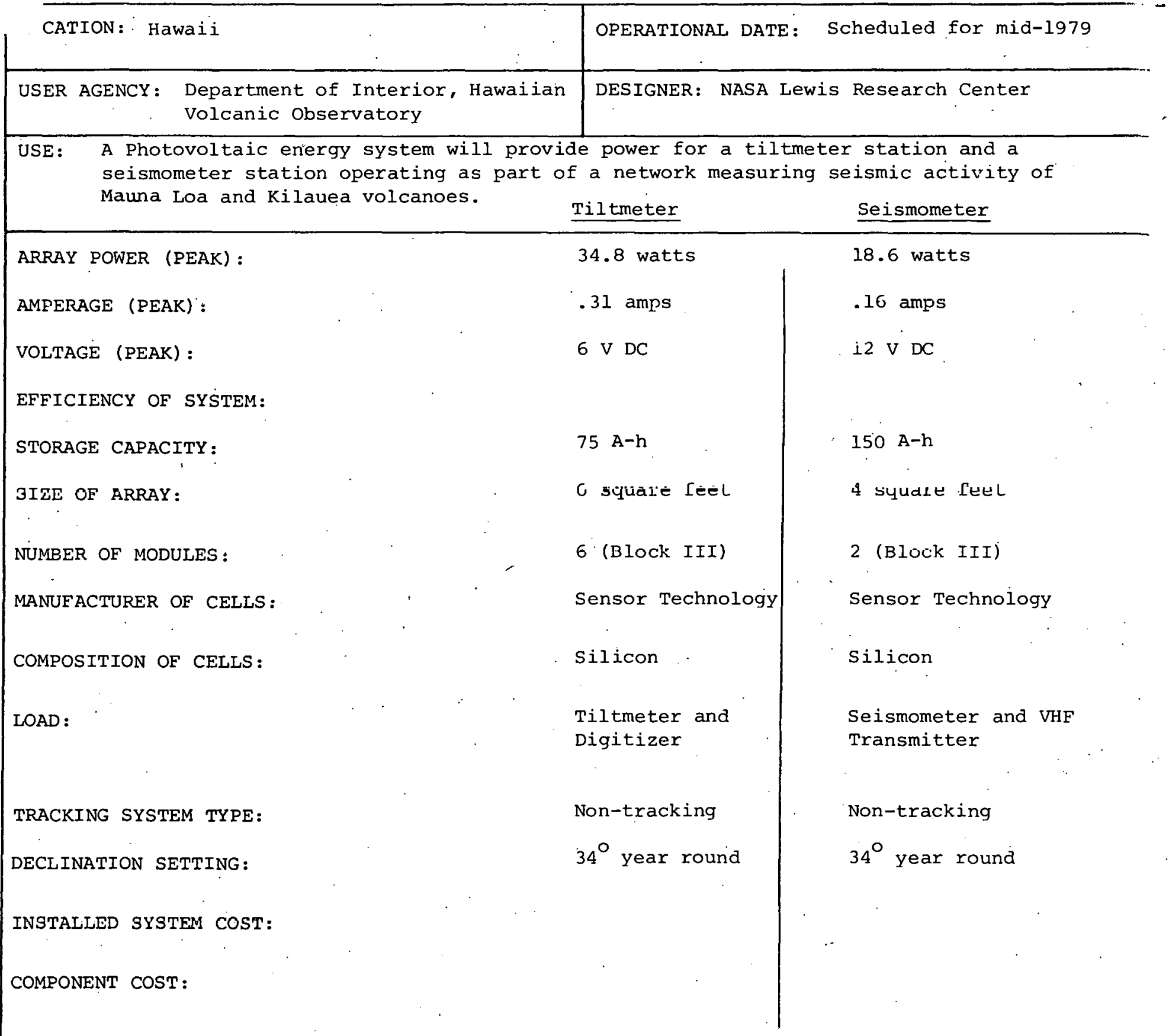


DATE:

CLEANING :

MODULE FAILURES (if any):

SYSTEM DEGRADATION (if any):

SPECIAL NOTES :
TIME SINCE INSTALLȦTION:

NO PICTURE AVAILABLE

DATE:

TIME SINCE INSTALLATION:

CLEANING :

MODULE FAILURES (if any):

SYSTEM DEGRADATION (if any):

SPECIAL NOTES:

DATE:

TIME SINCE INSTALLATION;

\section{CLEANING :}

MODULE FAILURES (if any):

SYSTEM DEGRADATION (if any):

SPECIAL NOTES: 
Telephone Central Van Experiment

LOCATION: Fort Belvoir; Fort Hood; Patrick OPERATIONAL DATE: July 1976

AFB, Florida; White Sands Missel Raqge

USER AGENCY: Department of Defense

DESIGNER: MERADCOM

USE: Provide electrical power for a mobile military. telephone van used as a central unit.

ARRAY POWER (PEAK): $2.65 \mathrm{~kW}$

AMPERAGE (PEAK): 22 amps

VOLTAGE (PEAK): $\quad 56 \mathrm{~V} \mathrm{DC}$

EFFICIENCY OF SYSTEM: $.8 \times$ cell efficiency

STORAGE CAPACITY: $\quad 375$ amp hours utilizing 32 electric vehicle type batteries

GIZE OF ARRAY, 48 S squa re feet. $\left(24,4^{\prime} \times 5^{\prime}\right.$ panels)

NUMBER OF MODULES: $\quad 288$

MANUFACTURER OF CELLS: SOlarex

COMPOSITION OF CELLS: Silicon

LOAD: Mobile field telephone exchange

TRACKING SYSTEM TYPE: Non-tracking, adjustable mounts on van

DEClinAtion Setting: $\quad 15^{\circ}-60^{\circ}$

INSTALLED SYSTEM COST: $\$ 81.2 \mathrm{~K}$

COMPONENT COST:

SPECIAL DESIGN FEATURES: 


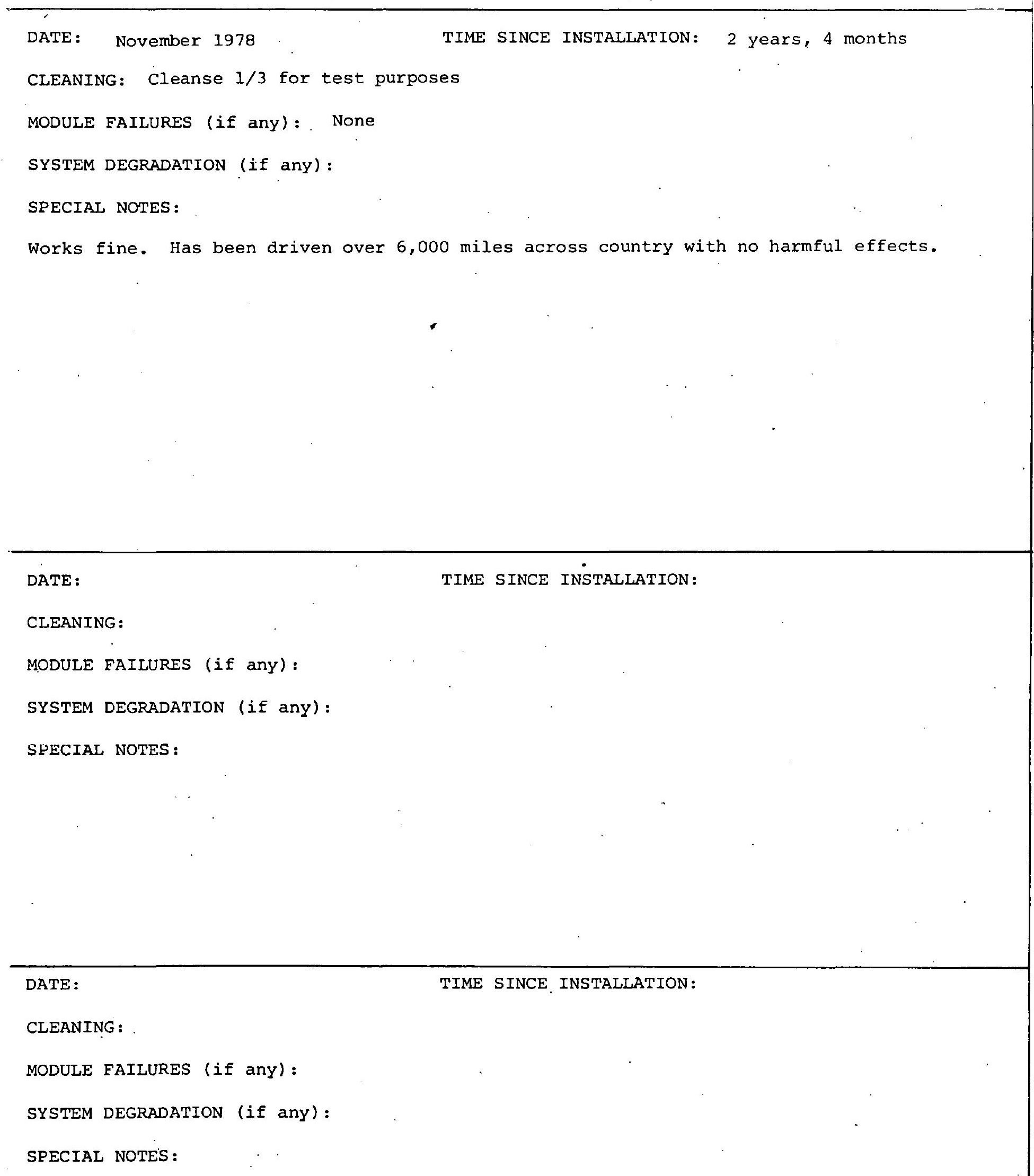




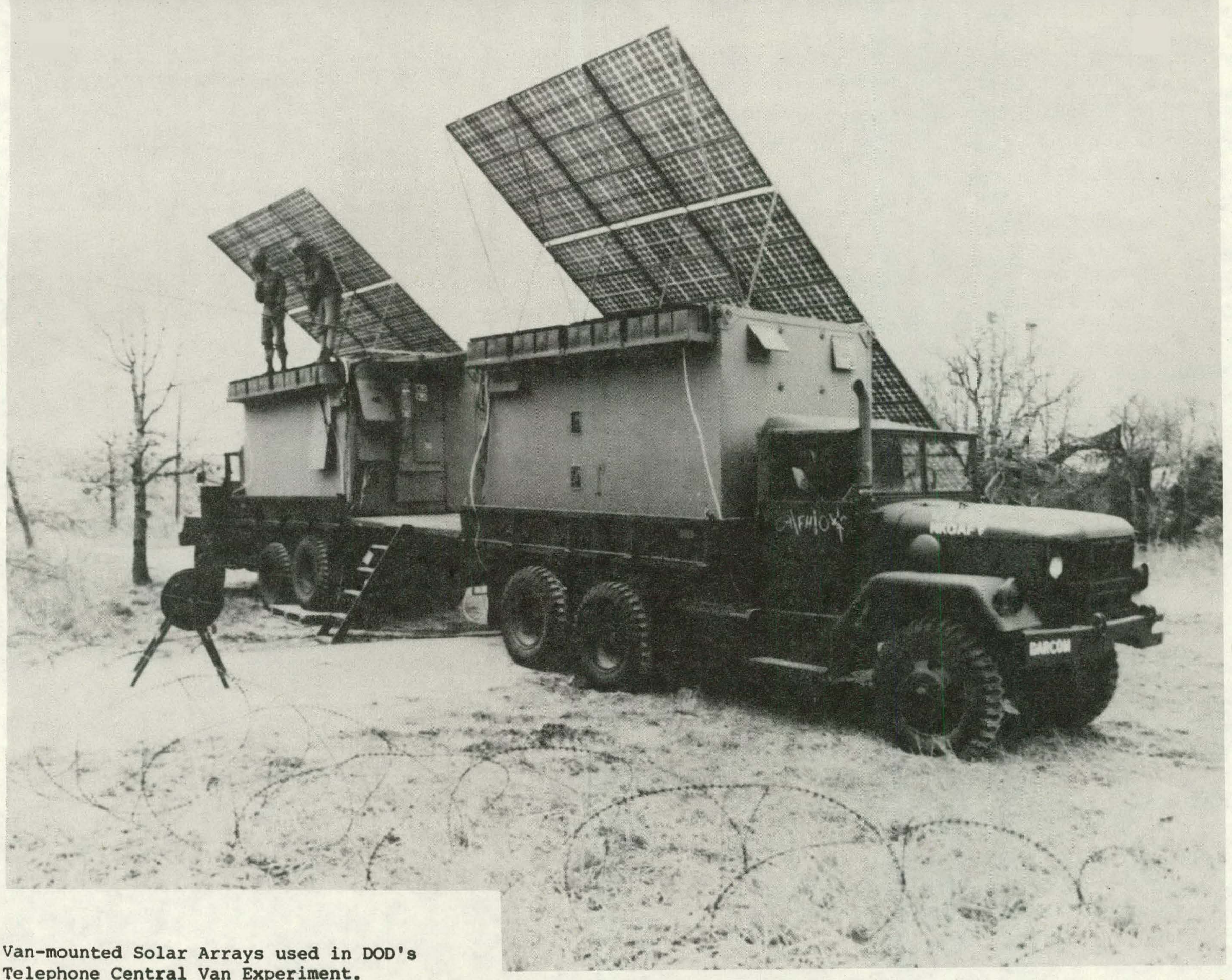
Telephone Central Van Experiment. 
Telephone Central Van

The objectives of the telephone central project are to:

- investigate the feasibility of permanently mounting a solar cell array on vehicles.

- determine the ability of a photovoltaic system to power an intermittent small load with a limited array.

- cvaluate the arequacy of the storage batteries and the need for a backup power source. 
Water Purification system Experiment

\begin{tabular}{|l|l}
\hline JCATION: Fort Belvoir, Virginia & OPERATIONAL DATE: April 1977 \\
\hline USER AGENCY: Department of Defense & DESIGNER: MERADCOM \\
\hline
\end{tabular}

USE: Provide electrical power for a DOD Mobile Reverse Osmosis Water Purification Unit

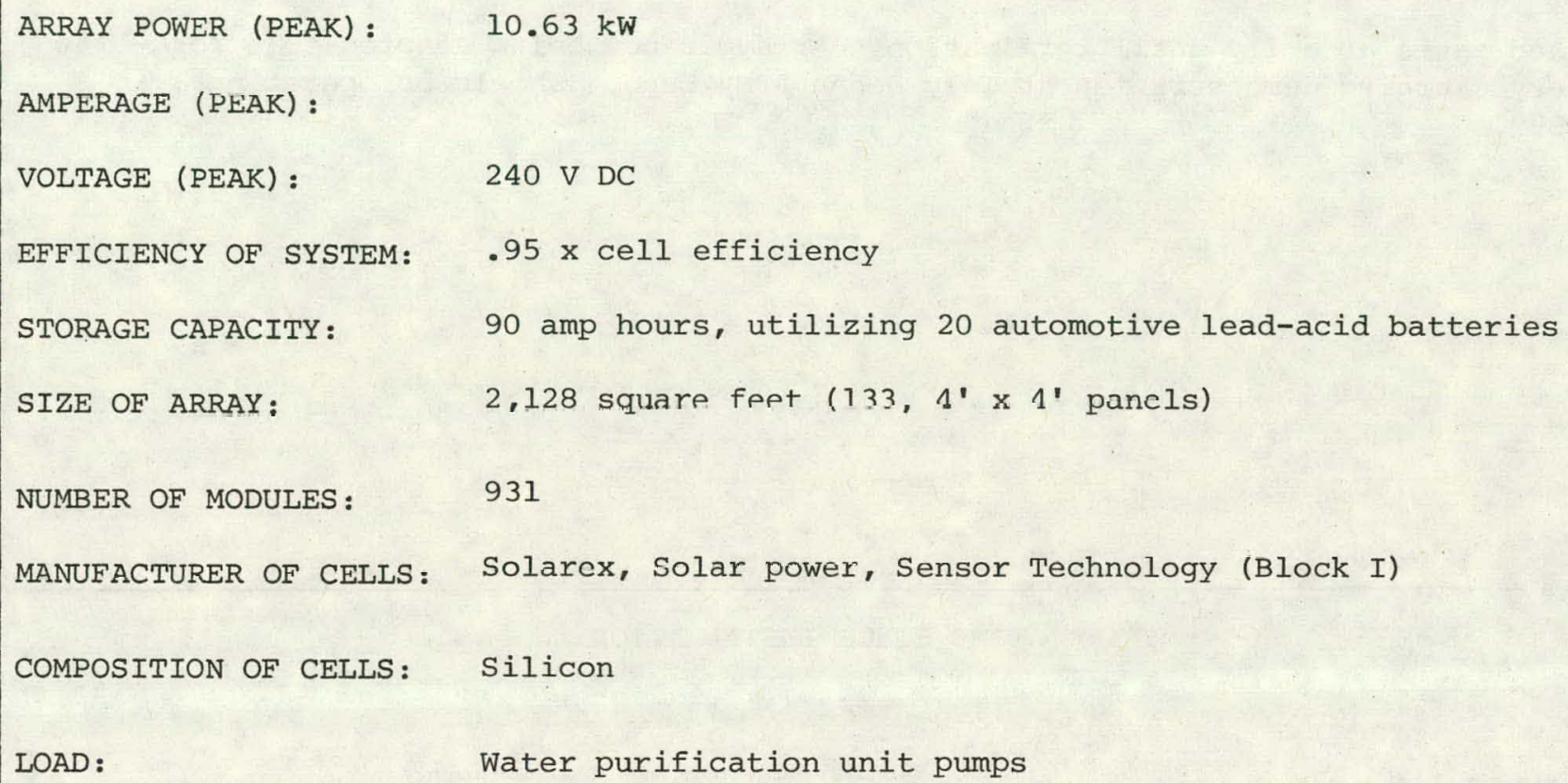


DATE: November 1978

TIME SINCE INSTALLATION: 1 year, 7 months

CLEANING: No (wanted to see how the degrade)

MODULE FAILURES (if any):

SYSTEM DEGRADATION (if any):

SPECIAL NOTES :

System worked satisfactorily until termination. Array is now being adapted to a fork-lift truck battery charging demonstration at Toly Hanna Army Depo. Should be operational in April of 1979 .

DATE :

TIME SINCE INSTALIATION:

CLEANING :

MODULE FAILURES (if any):

EYSTEM DEGRANATTON (if any):

SPECIAT, NOTES :

DATE :

CLEANING :

MODULE FAILURES (if any):

SYSTEM DEGRADATION (if any):

SPECIAL NOTES: 


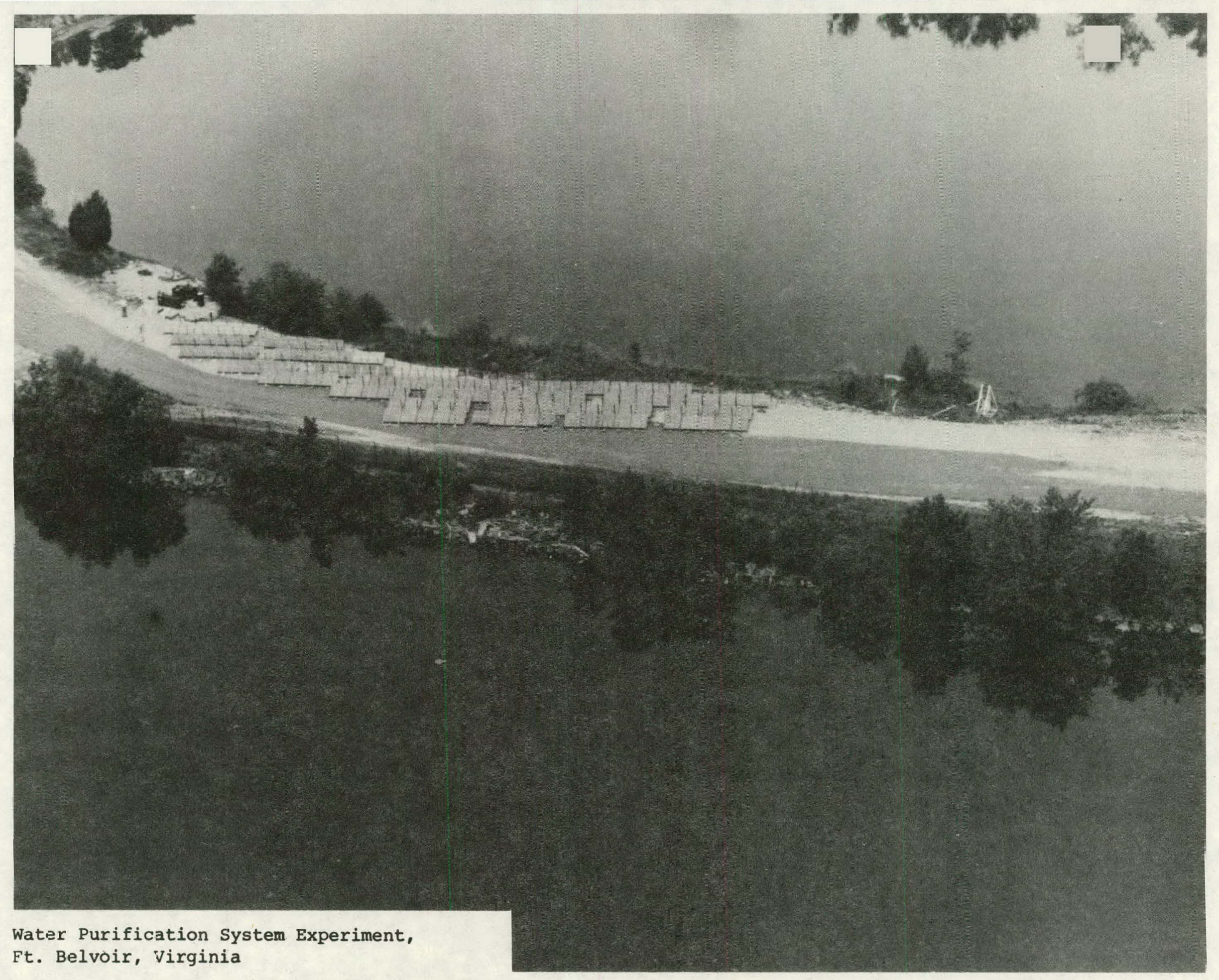




\section{Water Purification System}

This experiment involves a high power system for a large, mobile, reverse osmosis water purification unit. Design operating period is eight hours per day with a small storage capacity of two hours. This experiment is intended to:

- determine the feasibility of operating a semi-critical load with a photovoltaic array and product, i.e, purified water, storage

- evaluate the size and weight impact of photovoltaic systems used with large, mobile military applications

- investigate the adequacy of array and storage sizing

- determine if or how often a backup power source is needed Auring adverse weather conditions

The solar cell array consists of 1334 -ft. x 4-ft. panels providing about $10.6 \mathrm{~kW}$ (peak) power at 240 volts DC. Single panel weight is about 120 lbs. A 90 Ah storage capacity is provided. Storage batteries weigh $960 \mathrm{lbs}$. and have a volume of 5 cubic feet. 


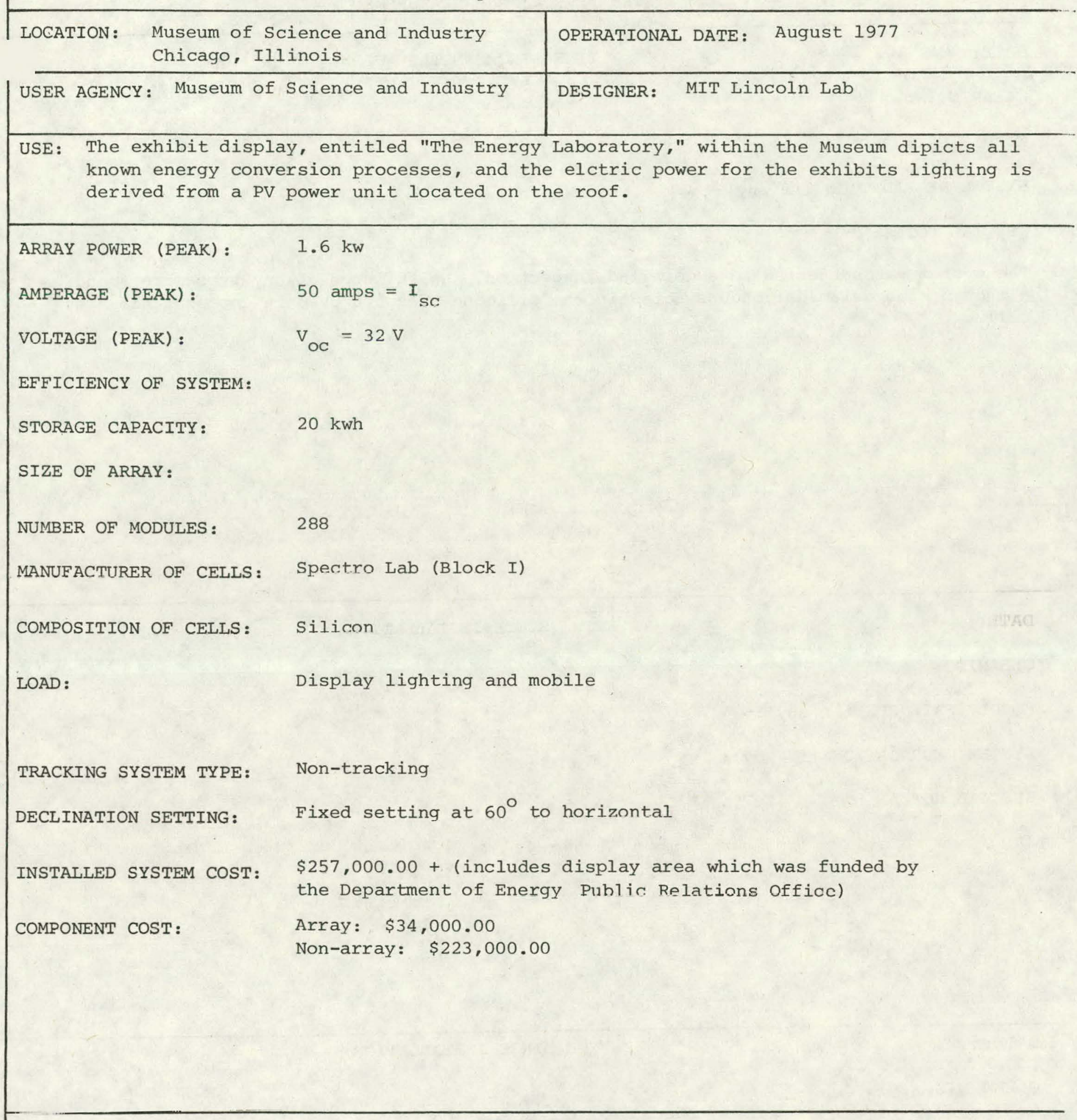

\section{SPECIAL DESIGN FEATURES:}

- All loads are DC which eliminates inverters

o Exhibits, Incorporated, from Chicago, Illinois, designed and built the display area. 
DATE: May 10, 1978 TIME SINCE INSTALLATION: 9 months

CLEANING:

MODULE FAILURES (if any):

SYSTEM DEGRADATION (if any):

SPECIAL NOTES:

The system was subjected to a detailed inspection. No failures of any type were found, although some delamination was noted in the silicone adhesive used in encapsulating the cells.

DATE :

TIME SINCE INSTALLATION:

CLEANING :

MODULE FAILURES (if any):

SYSTEM DEGRADATION (if any):

SPECIAL NOTES:

DATE :

CLEANIṆG :

MODULE FAILURES (if any):

SYSTEM DEGRADATION (if anY):

SPECIAL NOTES: 


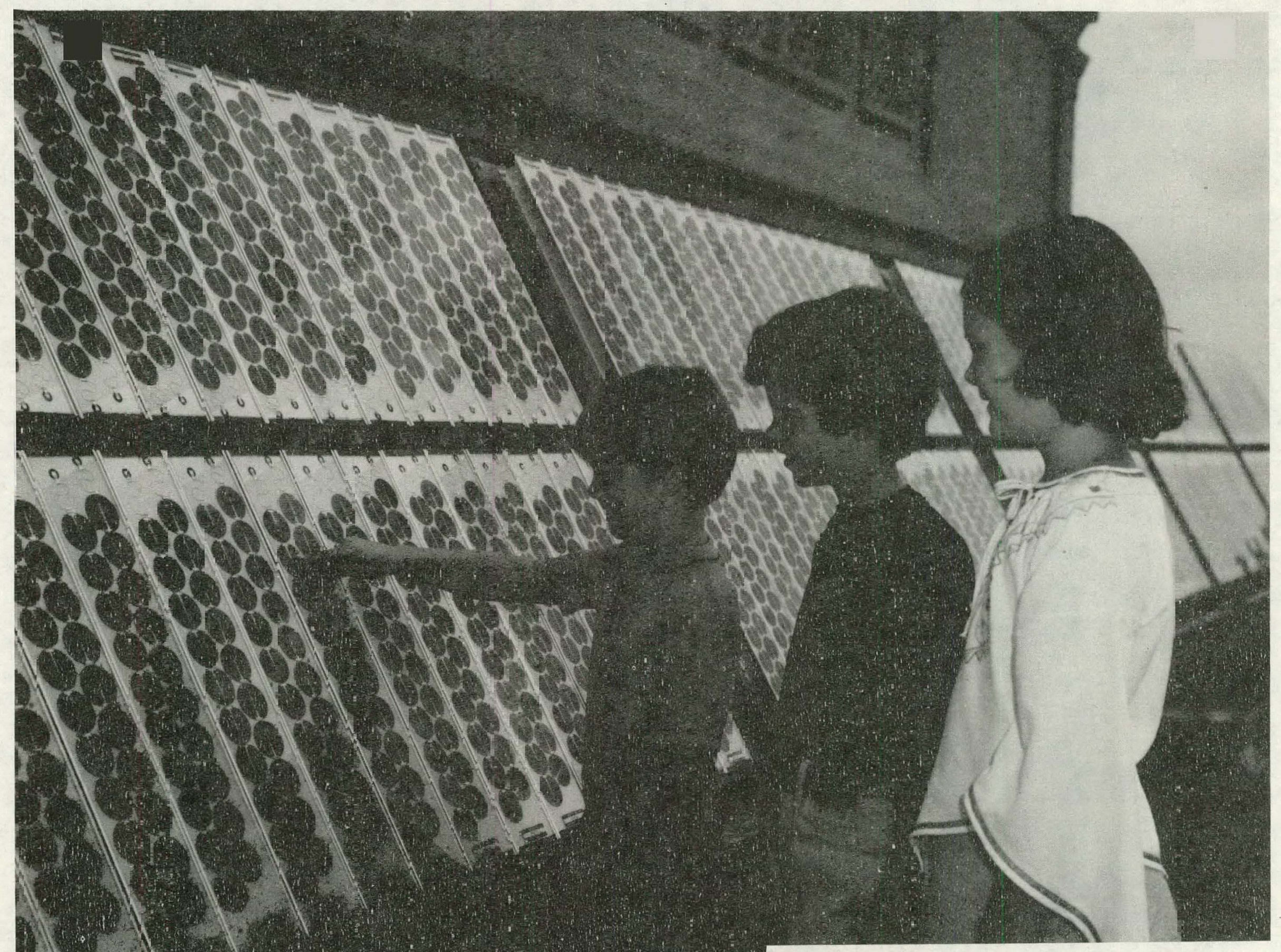

Chicago Muse um Exhibit,

Museum of science and Industry, Chicago, Illinois 


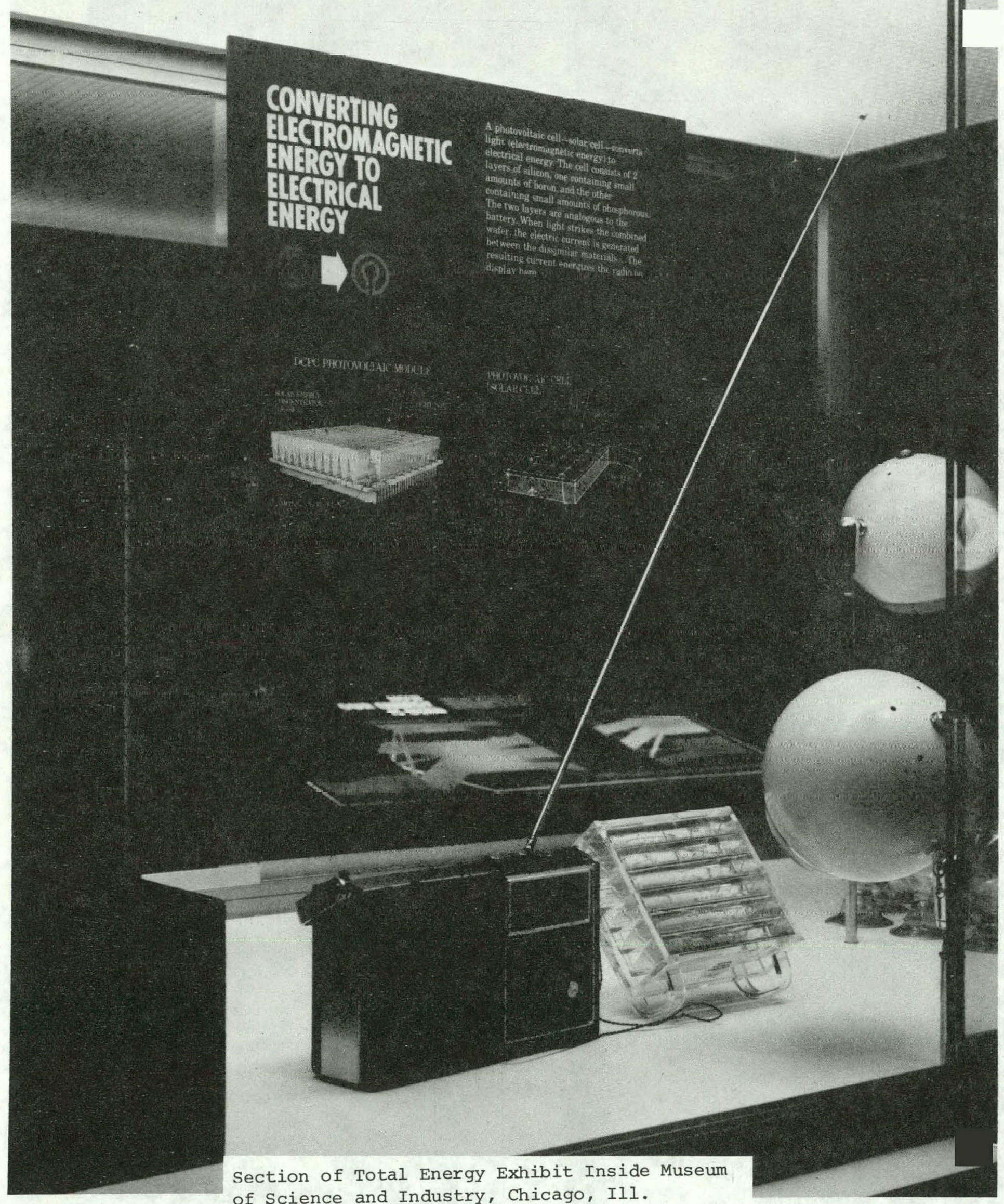


Photovoltaic Power for Energy Exhibit at Chicago Museum

In August 1977, the Museum of Science and Industry in Chicago opened a new display, entitled "The Energy Laboratory", which was funded by DOE (then ERDA). This exhibit depicts all known energy conversion processes and has a few booths explaining Photovoltaics, such as the one shown in the picture. The electric power for the exhibit's lighting is supplied by a photovoltaic array on the roof of the museum which visitors can see. A total of $1.6 \mathrm{~kW}$ peak power is provided, using solar cell modules from DOE's Low-Cost Solar Array Project.

This system utilizes an unregulated battery charger, which is feasible because both the charging rate and the array were sized to always prevent the possibility of overcharging.

Since the power was turned on in mid August the performance of the system has been monitored under incident sunlight conditions. The data were then adjusted to allow for the difference between the actual illumination and the reference value $\left(100 \mathrm{~mW} / \mathrm{cm}^{2}\right)$; and the theoretical and experimental values were compared (see figure on over-leaf)

In the future, additional performance data will be obtained with emphasis on detecting any degradation in performance resulting from exposure to the urban Chicago environment. 

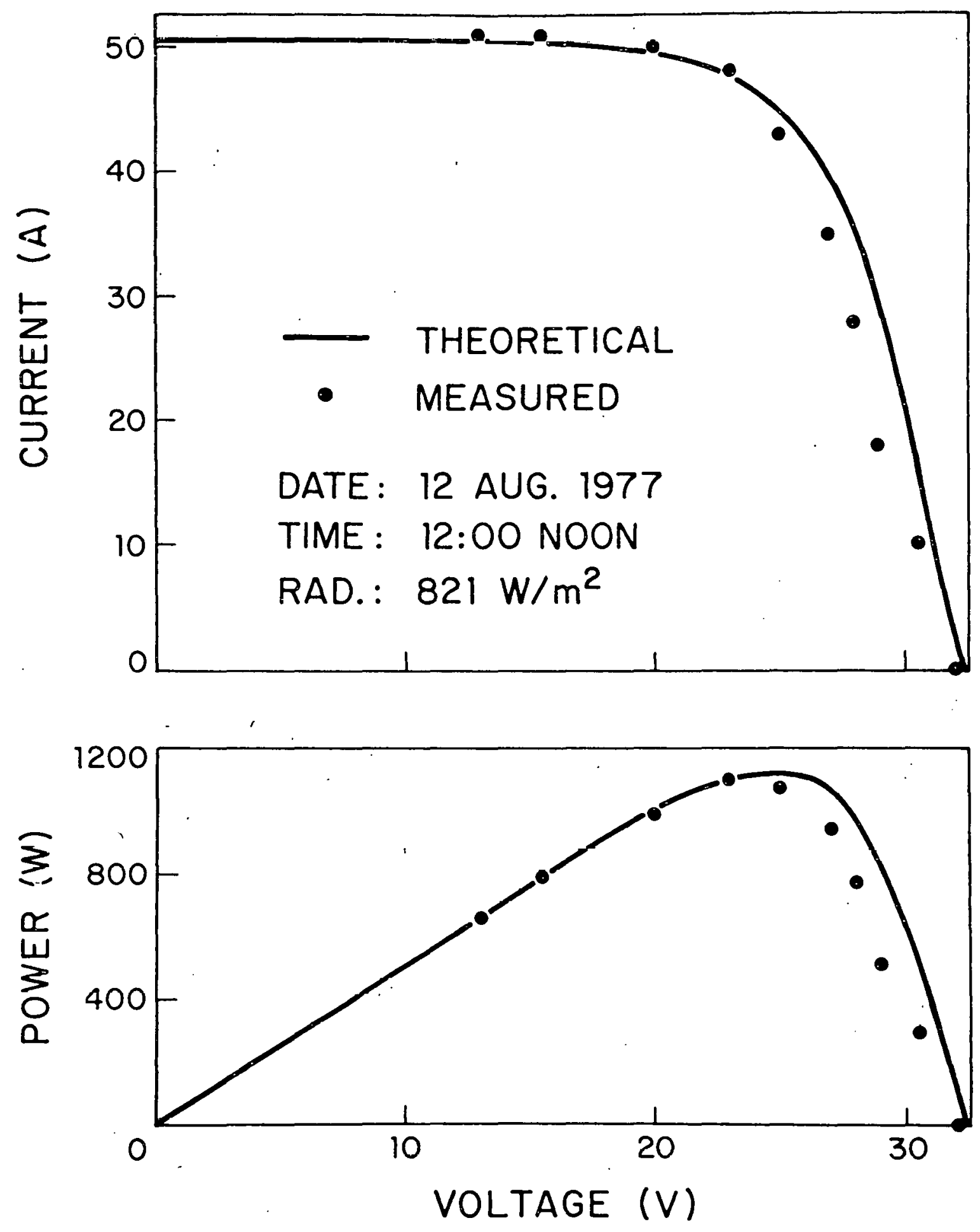

COMPARISON OF PREDICTIONS

AND MEASUREMENTS

FOR THE CHICAGO MUSEUM ARRAY 


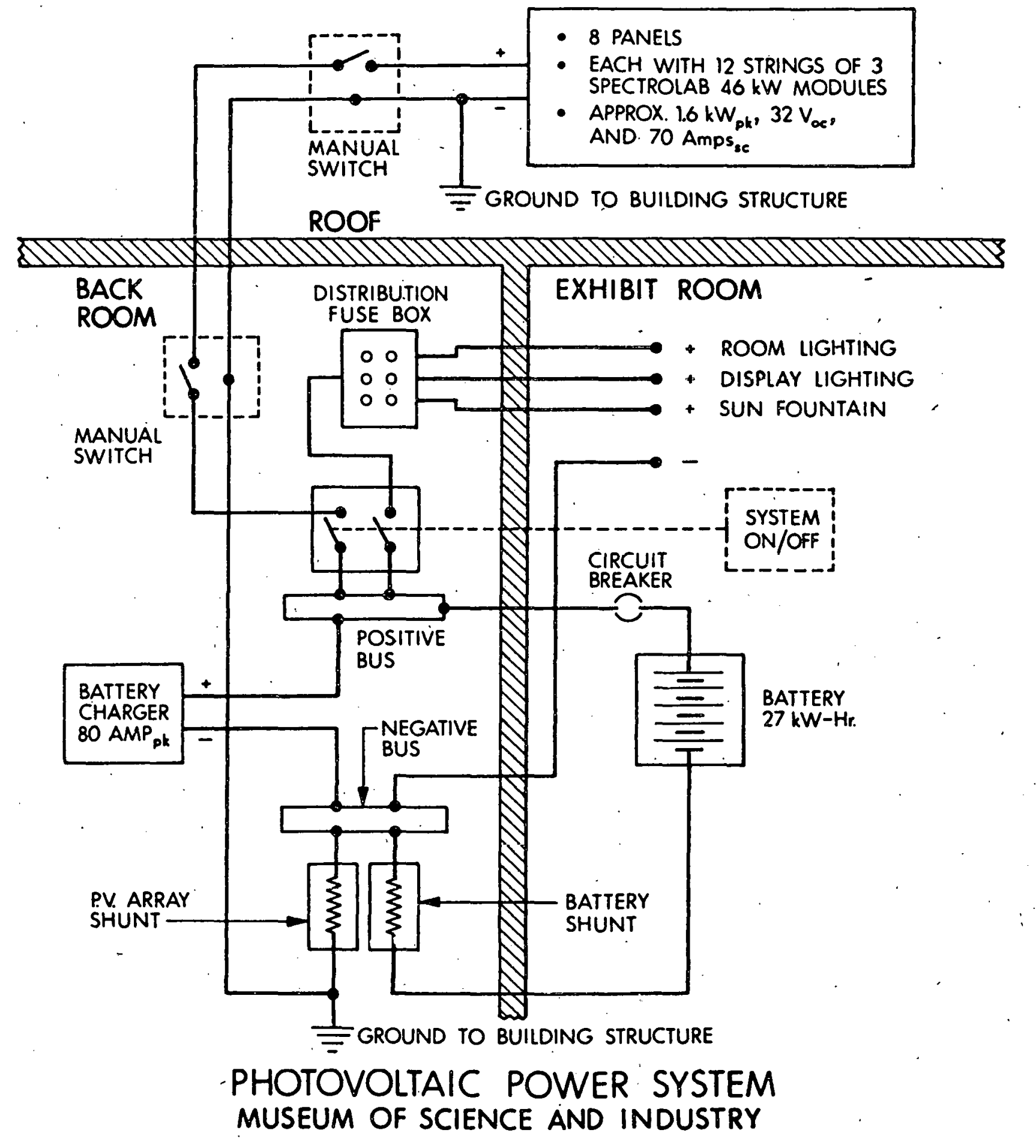


CHICAGO MUSEUM PHOTOVOLTAIC POWER SYSTEM
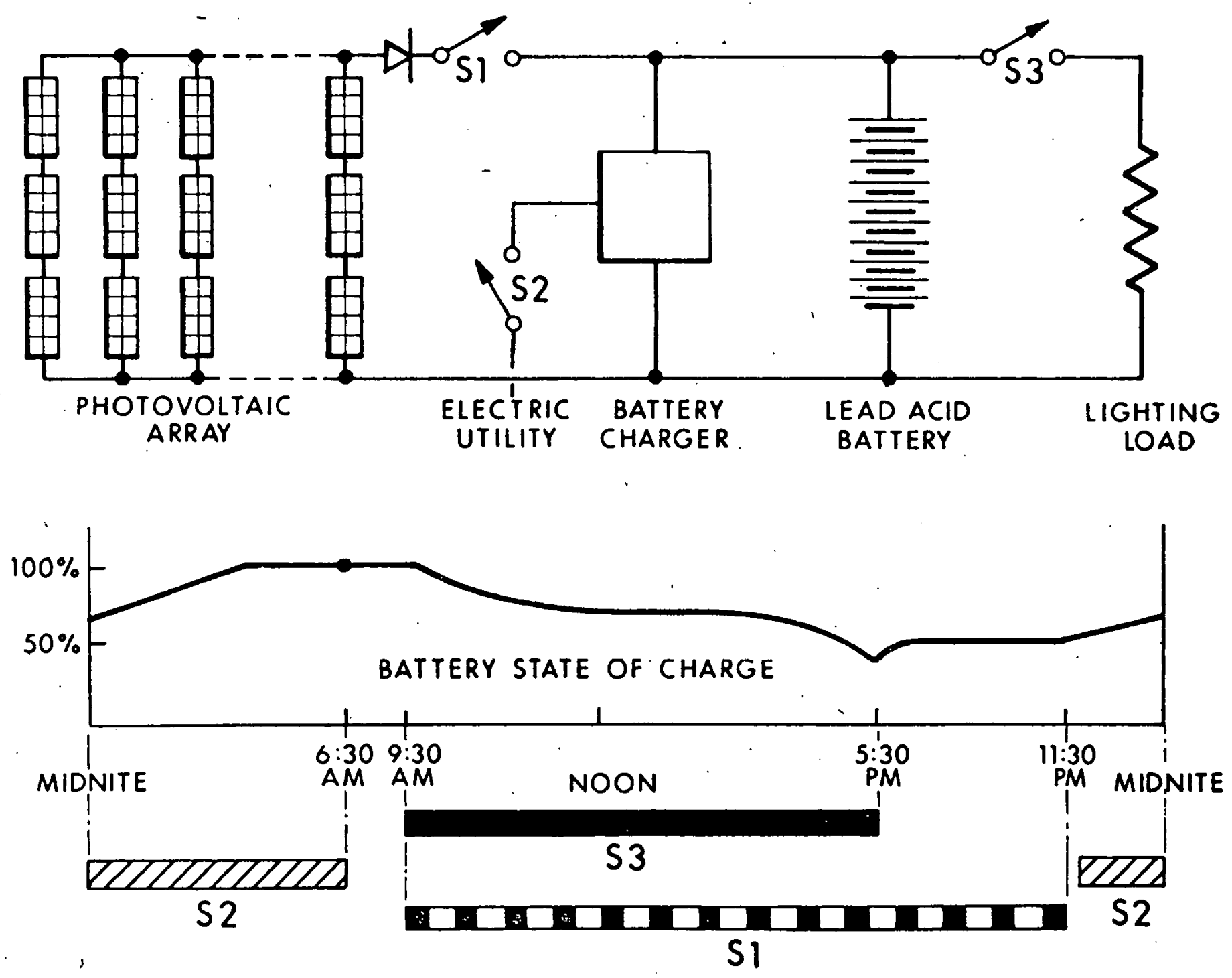
Both MIT-Lincoln Laboratory and Jet Propulsion Laboratory do work in designing and setting up display exhibits to be shown around the country at various conferences or at public points of interest such as museums or malls. At the time of this writing both have a display of some kind on photovoltaics which is portable and can be shown when necessary.

Listed are some of the displays each laboratory has shown at some time.

MIT-Lincoln Laboratory

- "Portable Micro-pumping Experiment/Display" This shows an inexpensive way for small farm irrigation in the field. Very portable; shown at the september IEEE conference in Washington, D. C.

- MIT-LL also has a portable display of their permanent display at the Mead Nebraska agrigultural test site. 'l'hls display is constantly touring to conferences courtesy of the University of Nebraska.

- "Photovoltaic Interpretive Center" This display was shown on Sun Day at the Boston Common. It's ready to tour anytime.

Jet Propulsion Laboratory

- "Solar Power Sun Fountain Display" Shown in Washington D. C.

- Display for WESCON 1976 "Electrical Energy from the Sun"

- Display for Exposition Park 8/10/77 - Space Day

- LSA Display - "New Ways of Meeting our Future Energy Needs Science \& Industry Make Electricity From Sunlight"

- 1978 Photovoltaic Public Display. This display shows how silicon flat plate modules are made from melting and purifing quartz to wiring cells in parallel and series. 


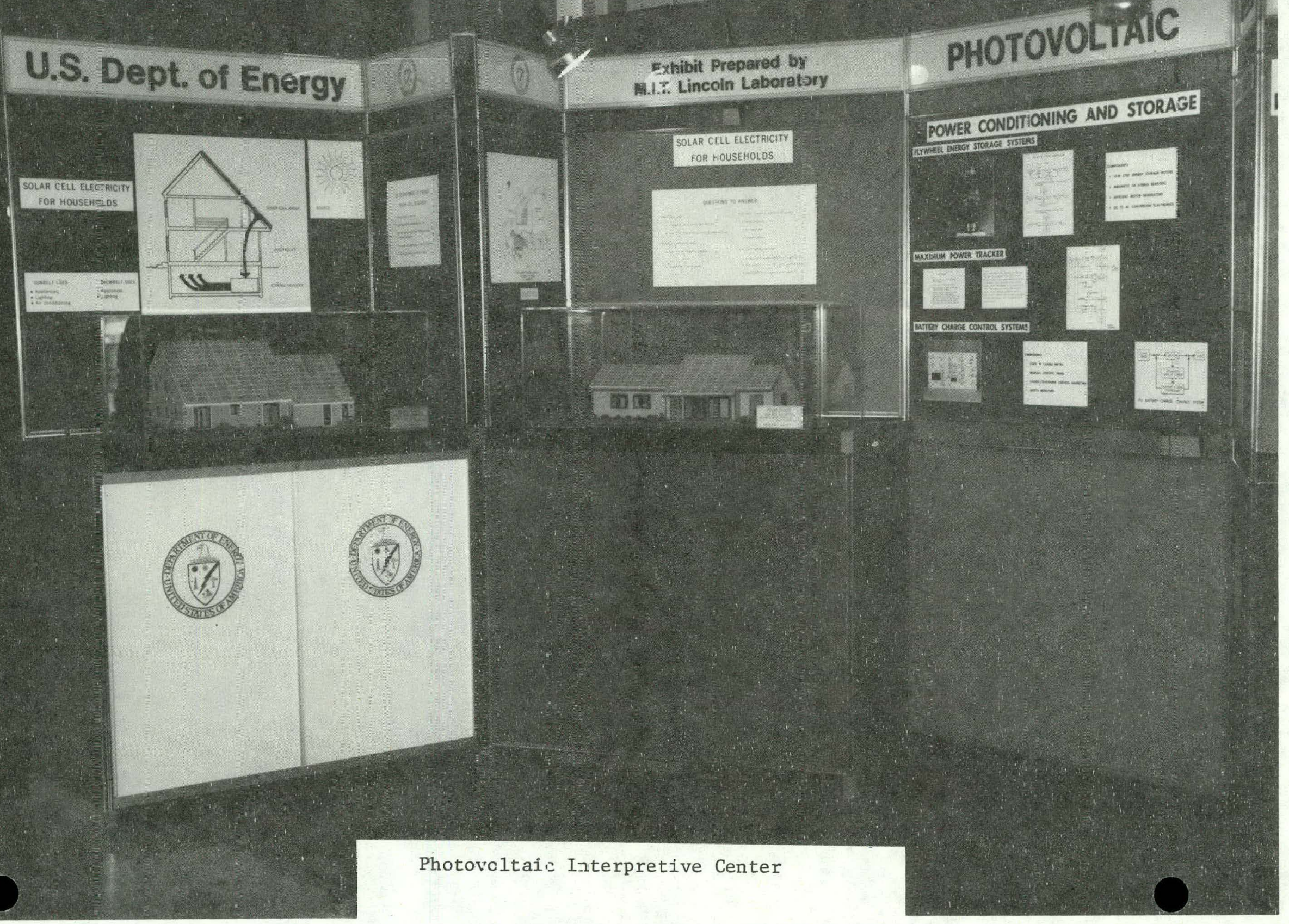




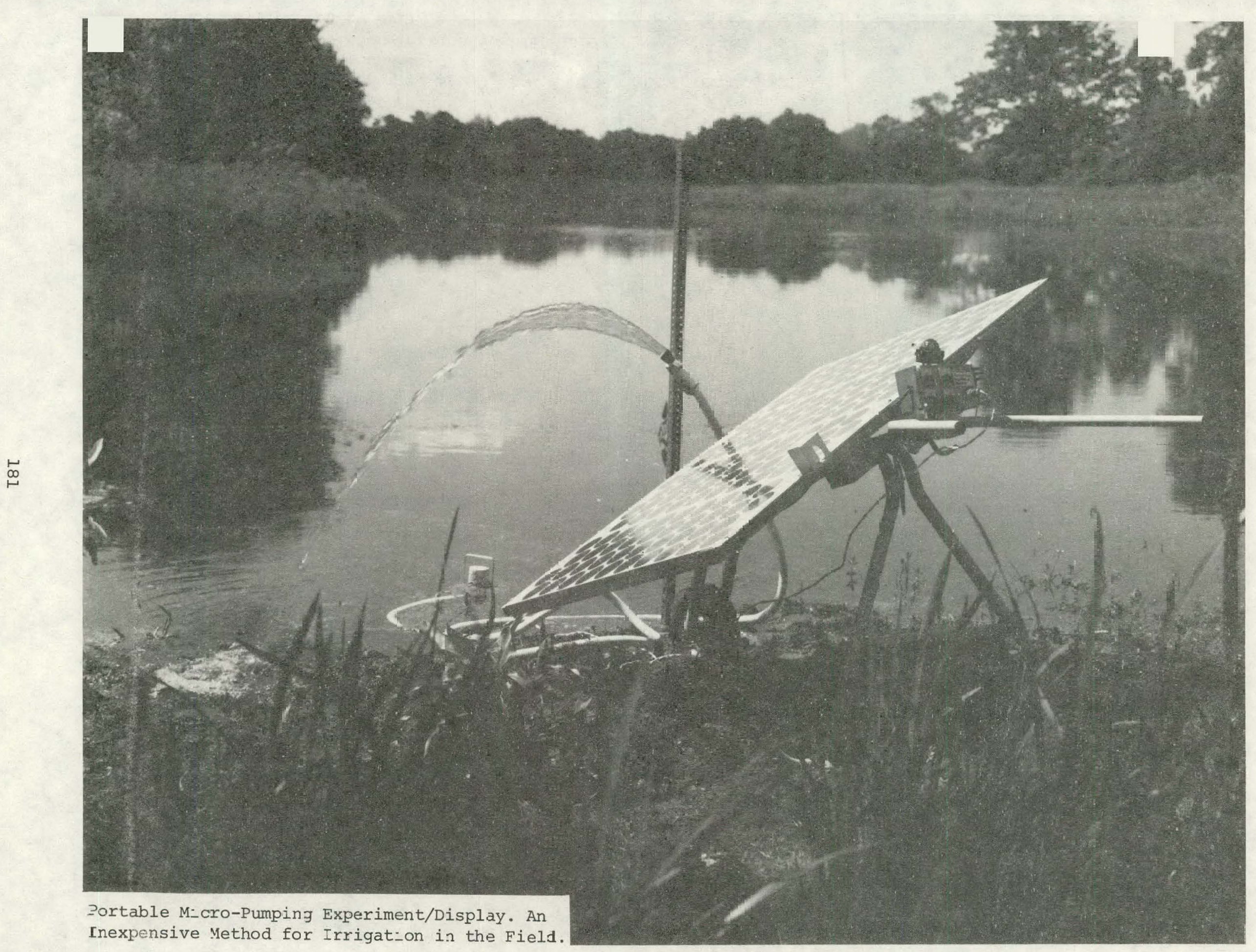




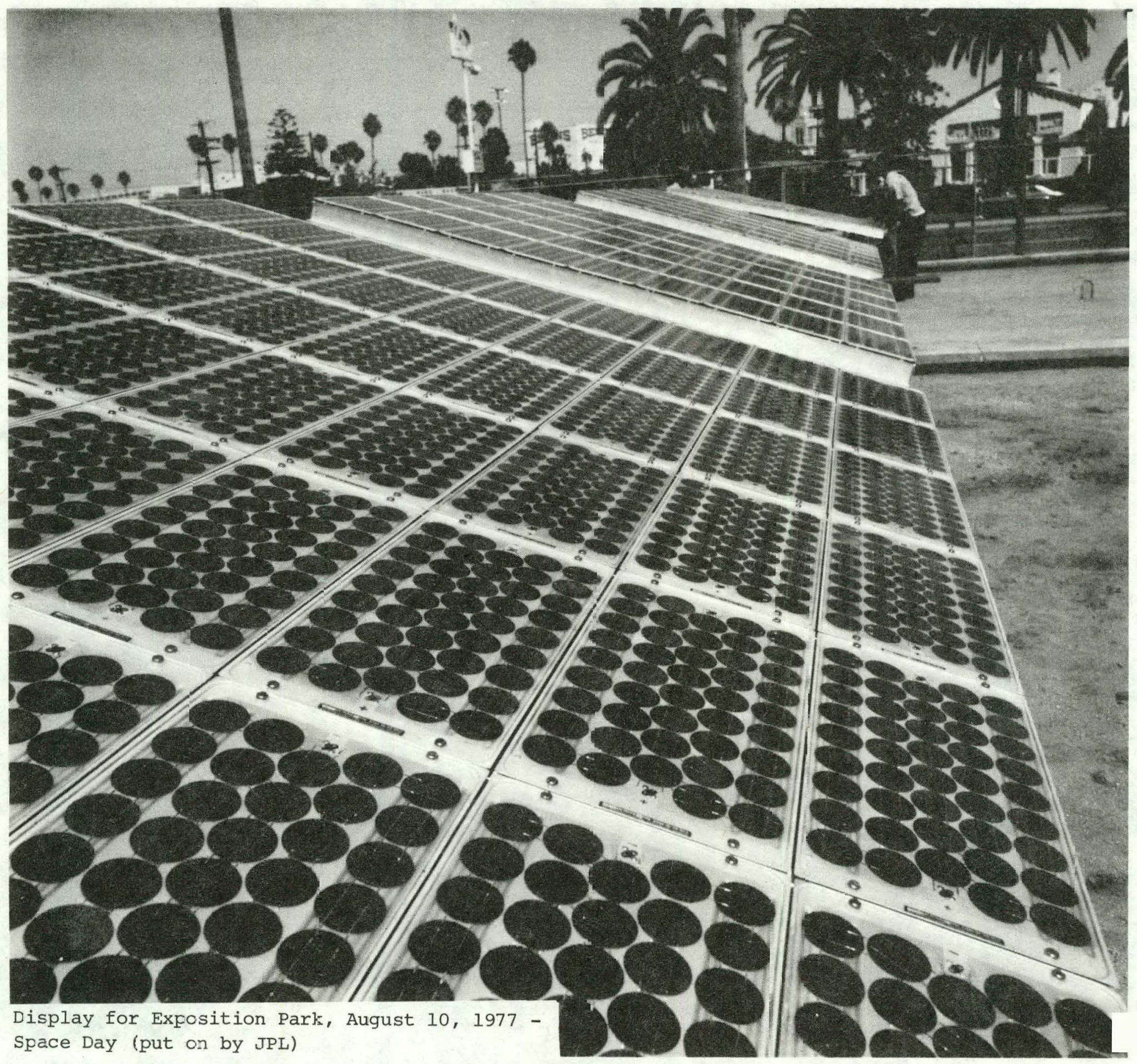




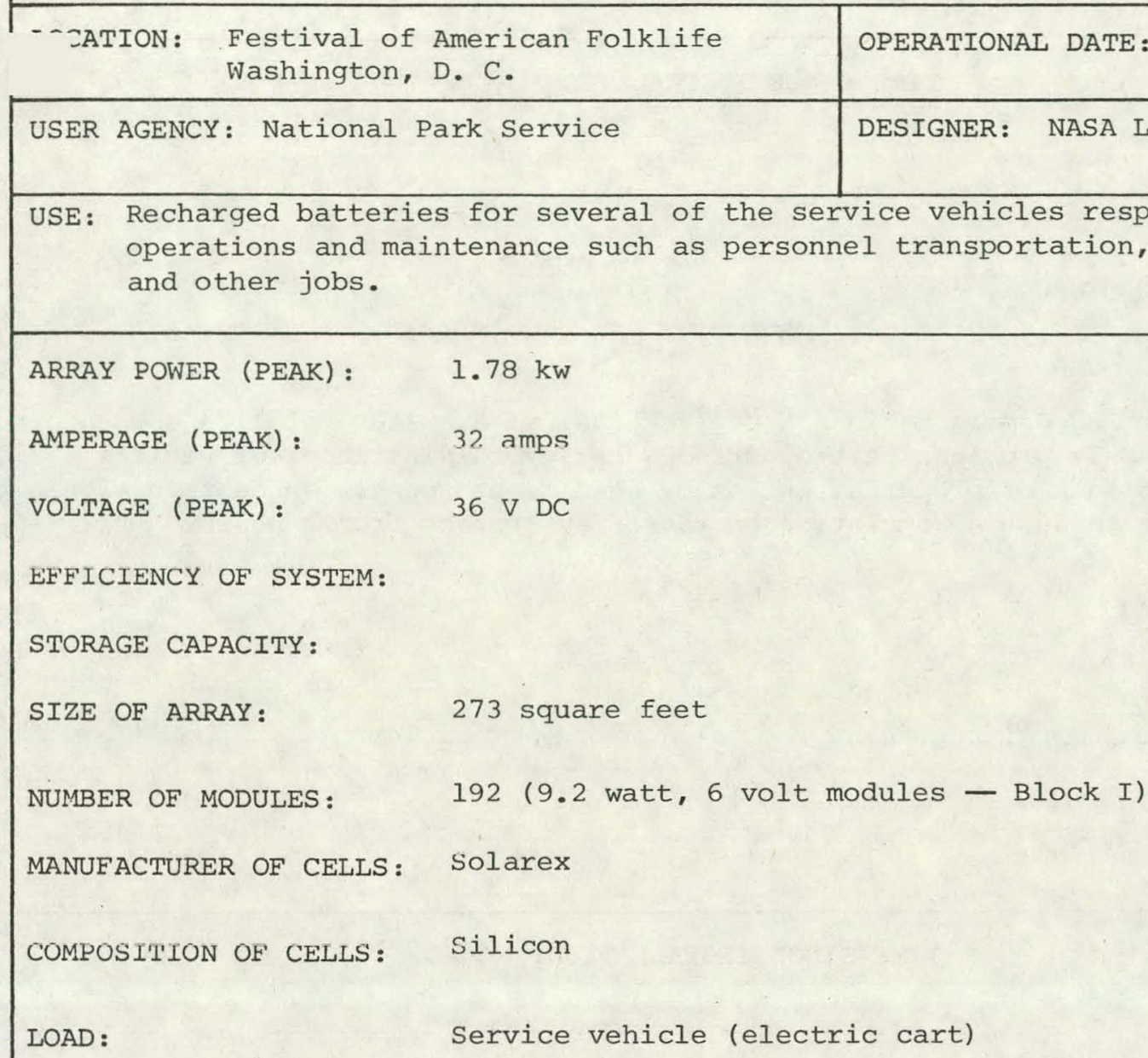
and other jobs.

$\begin{array}{ll}\text { ARRAY POWER (PEAK): } & 1.78 \mathrm{~kW} \\ \text { AMPERAGE (PEAK): } & 32 \text { amps } \\ \text { VOLTAGE (PEAK): } & 36 \mathrm{~V} \mathrm{DC}\end{array}$

EFFICIENCY OF SYSTEM:

STORAGE CAPACITY :

SIZE OF ARRAY:

273 square feet

NUMBER OF MODULES:

192 (9.2 watt, 6 volt modules - Block I)

MANUFACTURER OF CELLS: SOlarex

COMPOSITION OF CELLS: Silicon

LOAD :

Service vehicle (electric cart) operations and maintenance such as personnel transportation, security, trash pickup

TRACKING SYSTEM TYPE: Non-tracking, adjustable $15^{\circ}$ to $62^{\circ}$ from horizontal.

DECLINATION SETTING: $\quad 36^{\circ}$ from horizontal

INSTALLED SYSTEM COST:

COMPONENT COST: 
DATE: September 1976

TIME SINCE INSTALLATION: 2 months

CLEANING: None

MODULE FAILURES (if any): None

SYSTEM DEGRADATION (if any): None

SPECIAL NOTES :

The Electric Vehicle Recharging Demonstration at the Festival of American Folklife encountered no real difficulties. The only problems that occurred were several instances of vehicle battery overcharging due to lack of proper attention by on-site personnel, and a reduction in array output current due to dust accumulating on the array surface from a nearby unimproved road.

DATE:

TIME SINCE INSTALLATION:

CLEANING :

MODULE FAILURES (if any):

SYSTEM DEGRADATION (if any):

SPECIAL NOTES:

DATE :

TIME SINCE INSTALLATION:

CLEANING:

MODULE FAILURES (if any):

SYSTEM DEGRADATION (if any):

SPECIAL NOTES : 


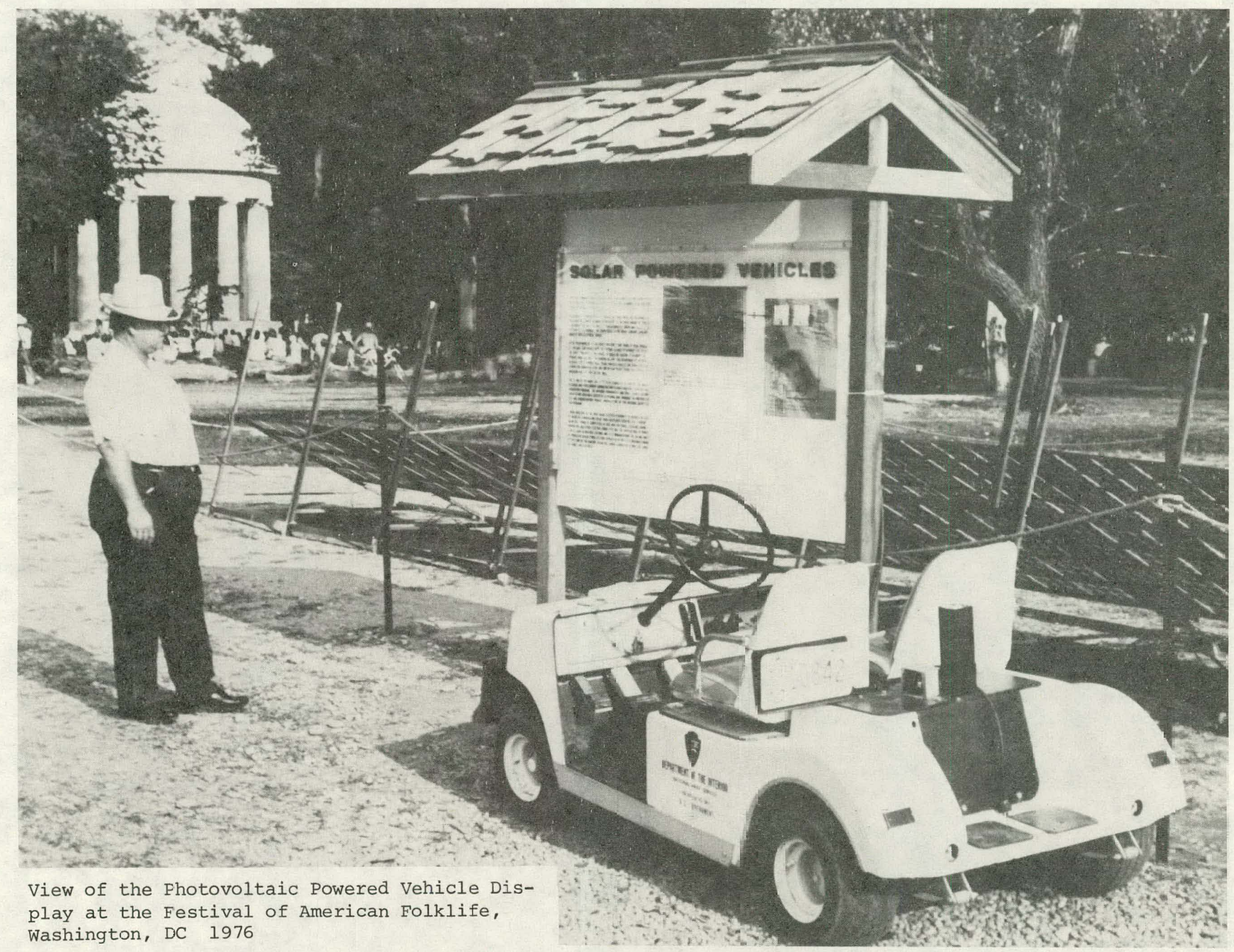


THIS PAGE INTENTIONALLY LEFT BLANK 
USER AGENCY: Cells under test for JPL

USE: To power electric powered cart.

ARRAY POWER (PEAK) : 190 watts

AMPERAGE (PEAK) :

VOLTAGE . (PEAK) :

$16.5 \mathrm{~V} \mathrm{DC}$

EFFICIENCY OF SYSTEM:

STORAGE CAPACITY:

Six 6-volt batteries

SIZE OF ARRAY :

NUMBER OF MODULES :

22 (each module is capable of 16.5 volts at 0.6 amps for a power output of 10 watts)

MANUFACTURER OF CELLS :

COMPOSITION OF CELLS: Silicon

LOAD: $\quad$ Electric motor

TRACKING SYSTEM TYPE: Non-tracking. Mounted on roof of cart

DECLINATION SETTING:

INSTALLED SYSTEM COST: Each module: \$133.00

Array: $\$ 3,000.00$

COMPONENT COST:

SPECIAL DESIGN FEATURES:

Cart speed: $11 \mathrm{mph}$

Cart range: Six miles per day if the sun shines. Fully charged batteries will carry the cart 30 miles, but 5 days are then required the charge the batteries.

Cart capability: Two passengers - 700 pound load 


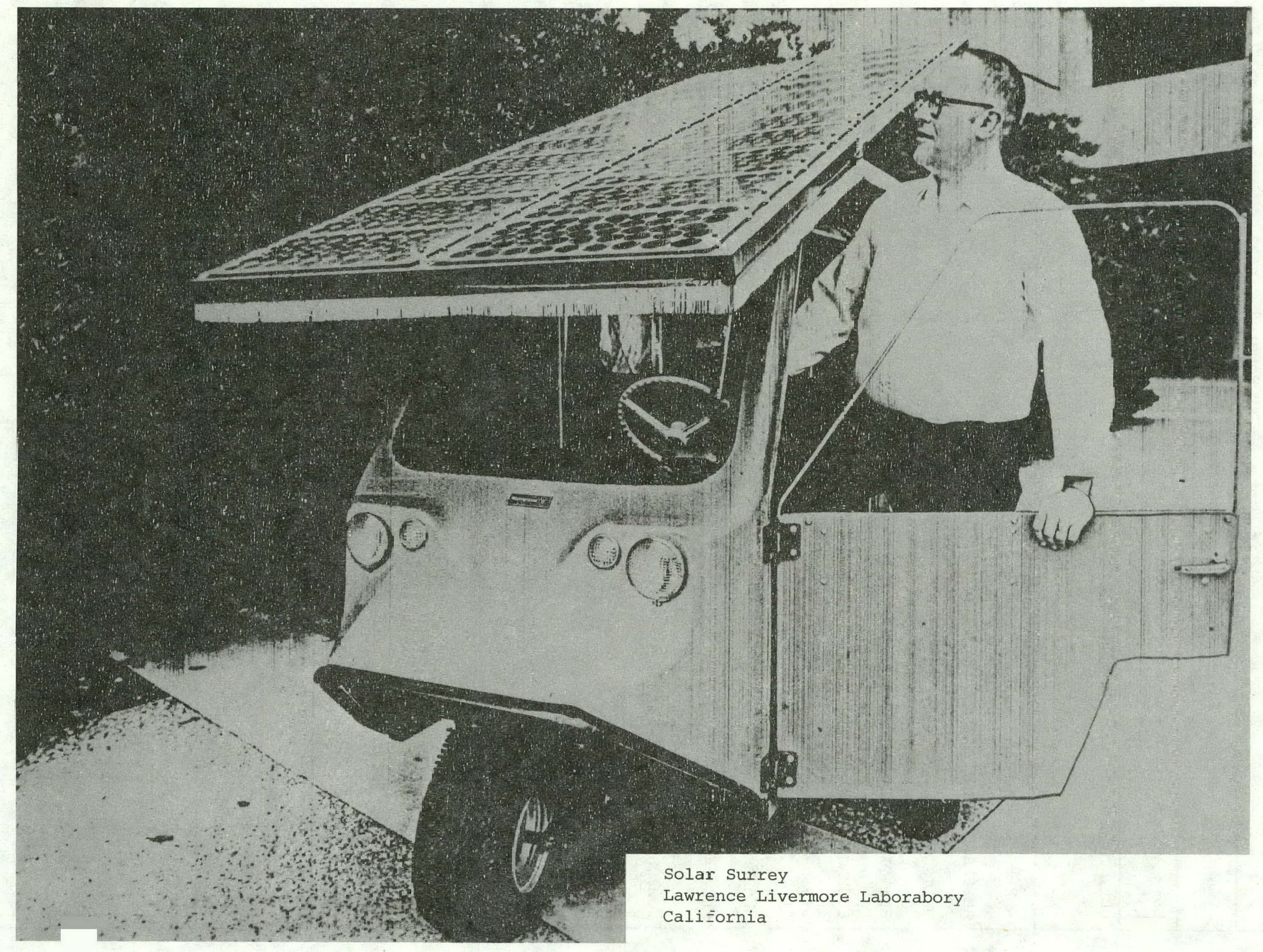




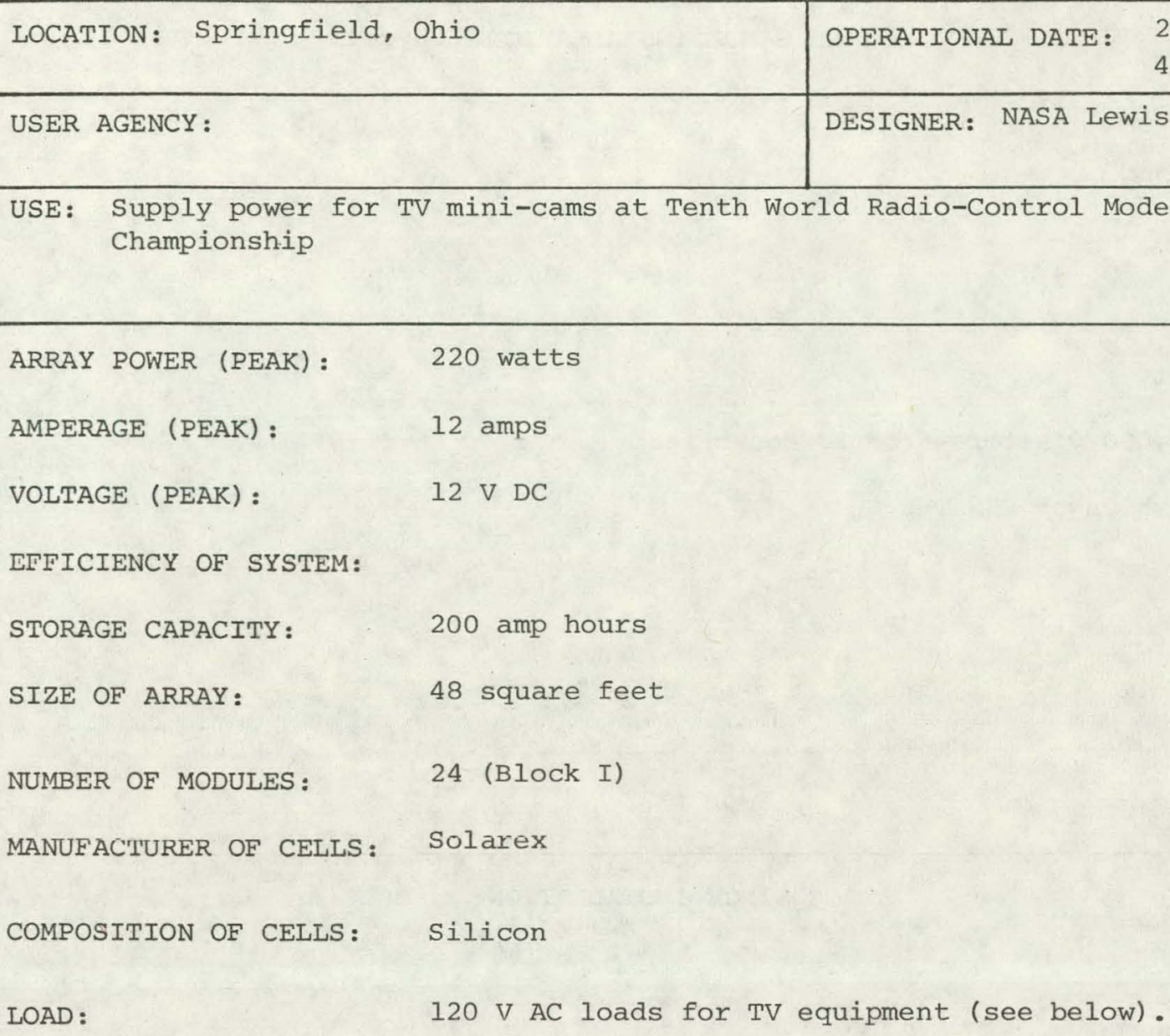

TRACKING SYSTEM TYPE: None

DECLINATION SETTING: $\quad 36^{\circ}$

INSTALLED SYSTEM COST:

COMPONENT COST:

SPECIAL DESIGN FEATURES:

- System was provided as a display of Solar Energy for this international model airplane event.

- Loads: TV monitor

Television mini-coms

TV video cassette recorder

TV mini-com battery pack charging

Laser transmitter 
DATE :

CLEANING :

MODULE FAILURES (if any):

SYSTEM DEGRADATION (if any):

SPECIAL NOTES :

Operated satisfactorily

- An estimated 50,000 visitors from 23 countries

- TV program was shown on PBS TV.

DATE:

TIME SINCE INSTALLATION:

CLEANING :

MODULE FAILURES (if any):

SYSTEM DEGRADATION (if any):

SPECIAL NOTES:

NATT:

TIME SINCE INSTALTATTON:

CLEANING :

MODULE FAILURES (if any):

SYSTEM DEGRADATION (if any):

SPECIAL NOTES: 


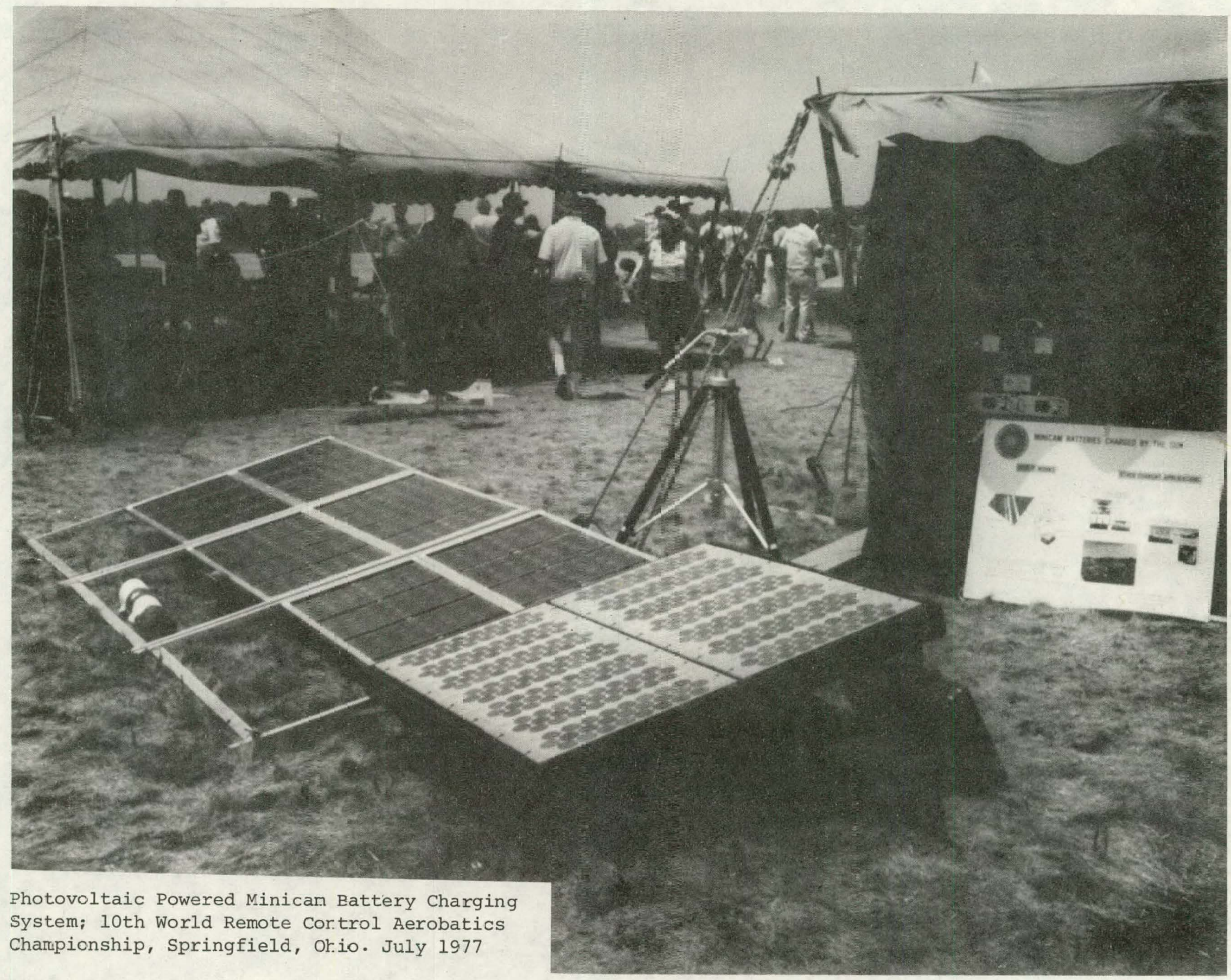


THIS PAGE INTENTIONALLY LEFT BLANK 


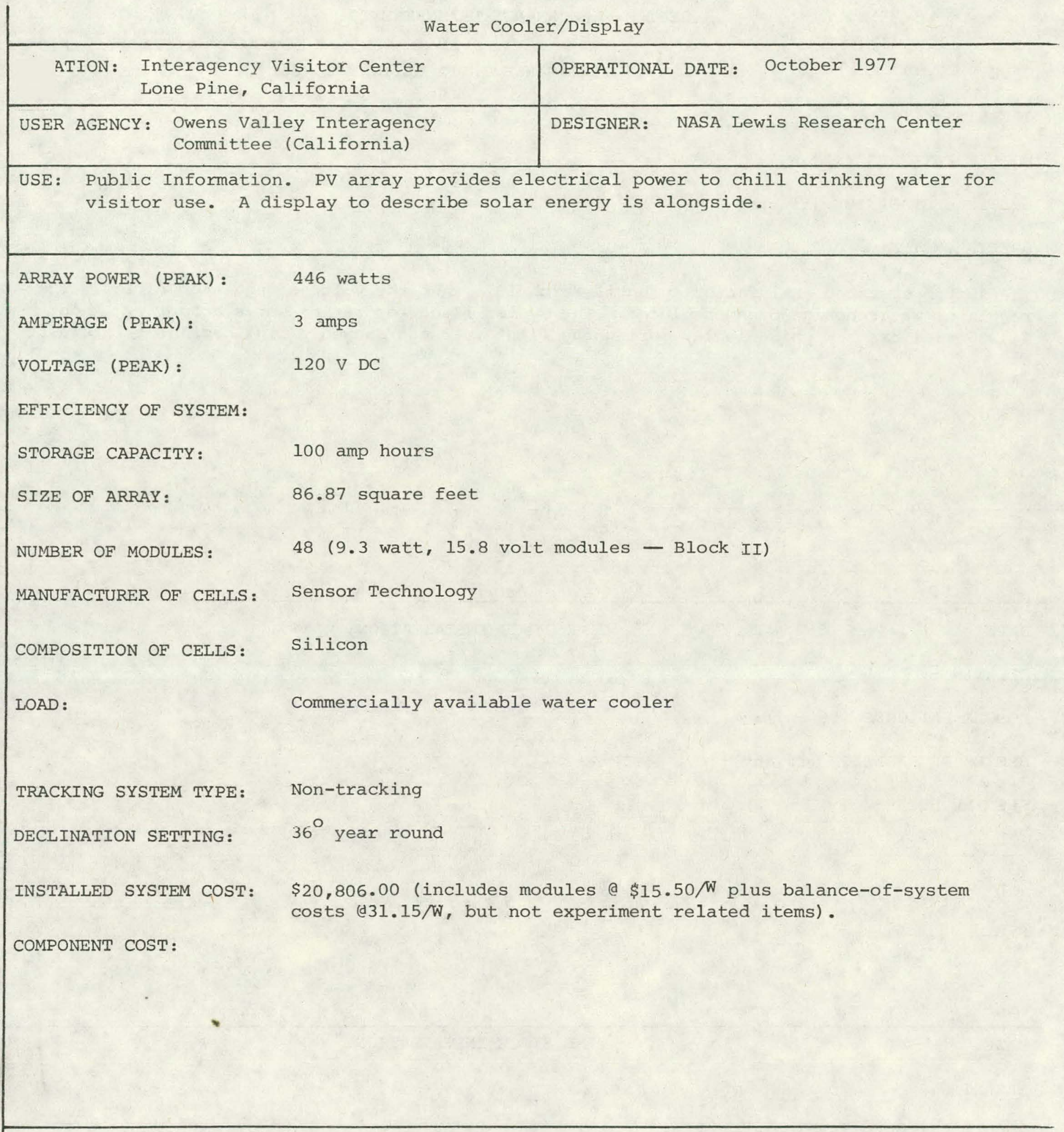

SPECIAL DESIGN FEATURES: 
DATE: November 1978

CLEANING: yes

MODULE FAILURES (if any): None

SYSTEM DEGRADATION (if any): As noted below

SPECIAL NOTES:

The system operated satisfactorily until March 1978 when the voltage regulator failed. The regulator was redesigned and replaced. The system is now operating satisfactorily. About 44,000 visitors saw this display during the first year and showed a high degree of interest.

DATE:

TIME SINCE INSTALLATION:

CLEANING :

MODULE FAILURES (if any):

SYSTEM DEGRADATION (if any):

SPECTAT, NOTES :

DATE :

TIME SINCE INSTALLATION

CLEANING :

MODULE FAILURES (if any):

SYSTEM DEGRADATION (if any):

SPECIAL NOTES: 


\section{PHOTOVOLTAIC POWERED WATER COOLER INTERAGENCY VISITOR CENTER \\ LONE PINE, CALIFORNIA}

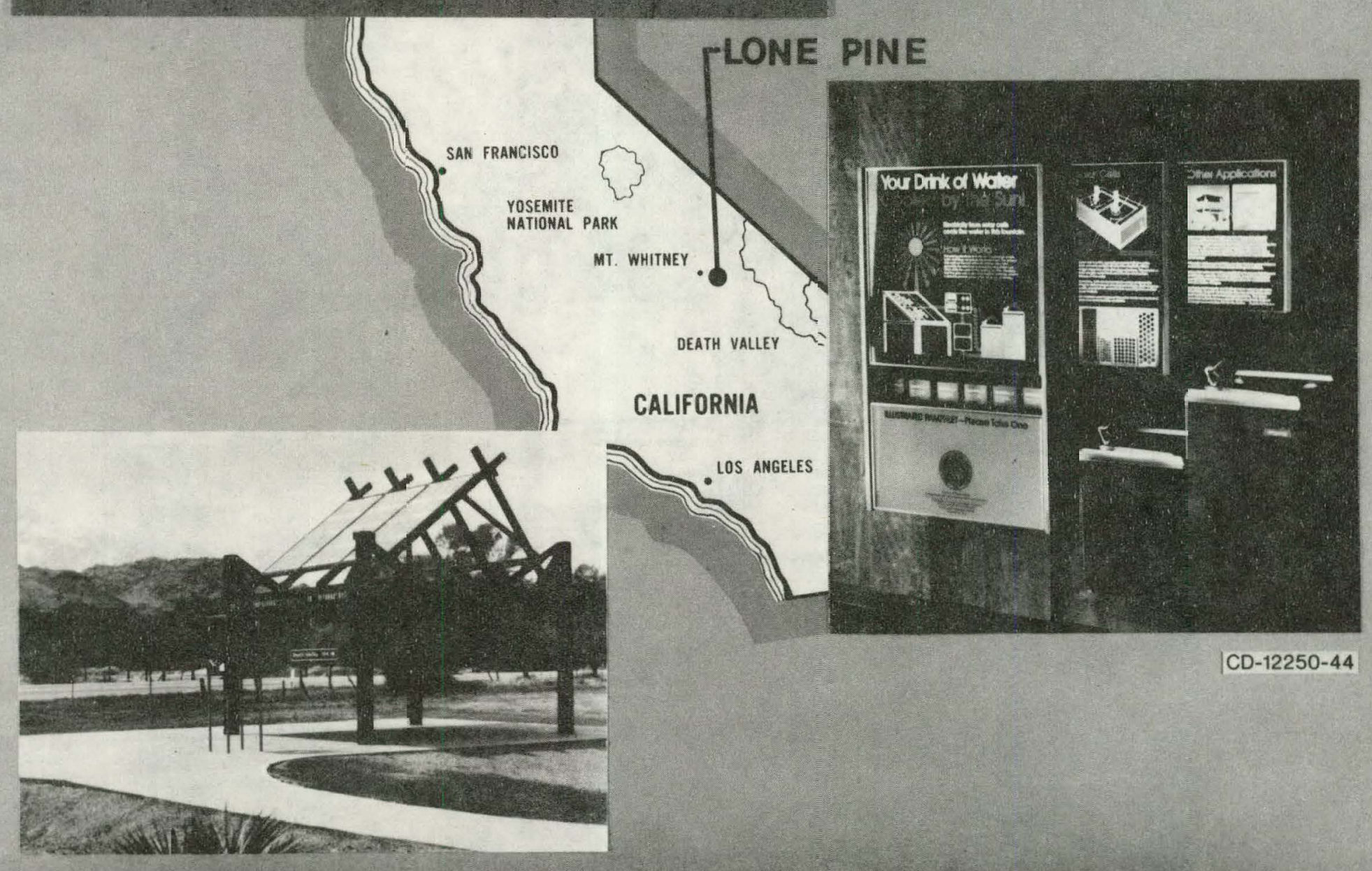



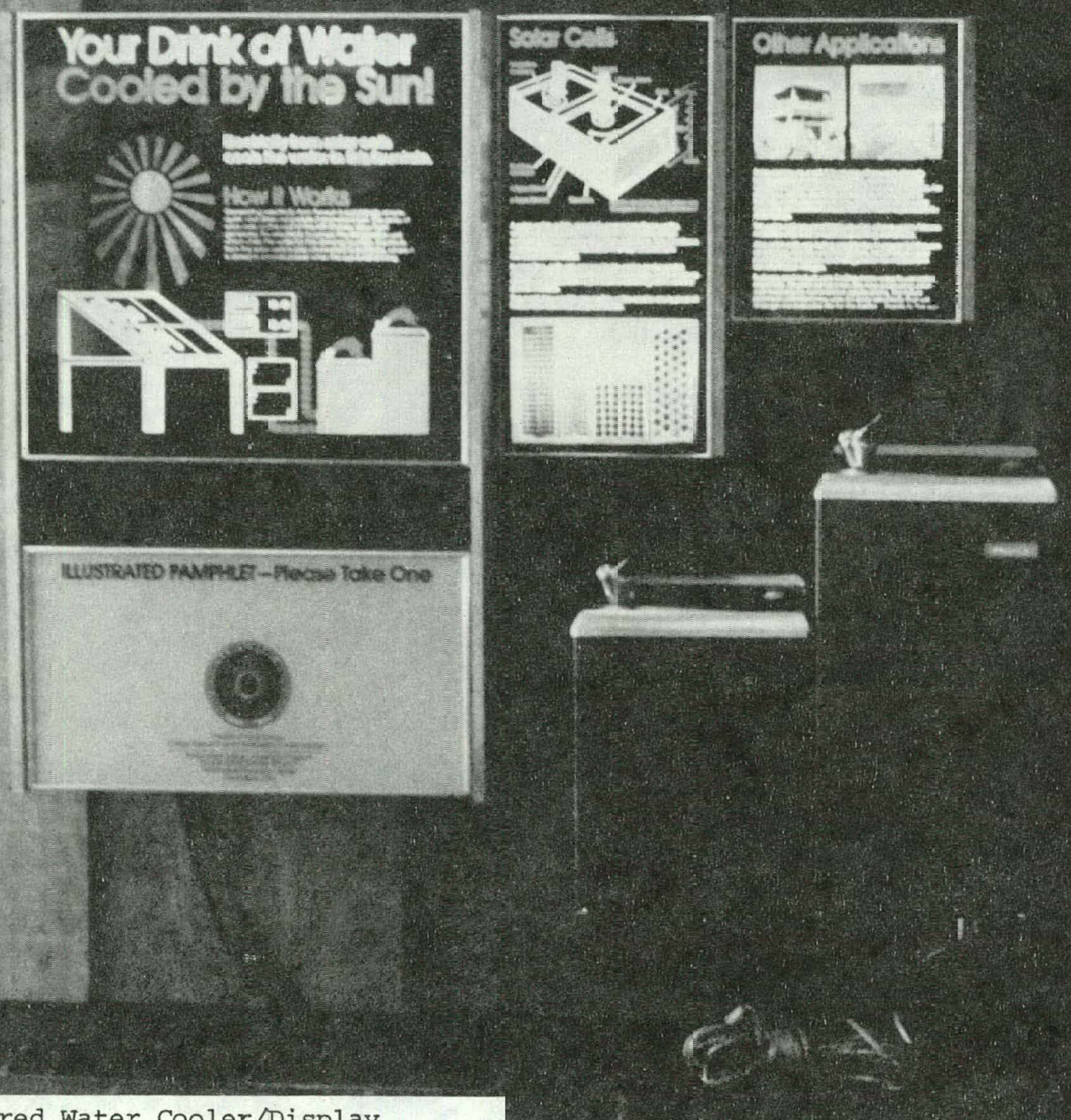


\section{Real Time Endurance Testing}

Three test facilities are currently undertaking real time endurance tests for the Department of Energy. They are: Jet Propulsion Laboratory (JPL), NASA-Lewis Research Center (LeRC) and MIT Lincoln Laboratory (MIT-LL). All totaled, there are 23 test sites located at various places across the country and in the Canal zone. JPL has responsibility for 4 sites, LeRC for 12 sites and MIT-LL for 7 sites. Their descriptions, locations and results will be presented by individual test facility on the following pages. 
The basic type of modules used for the endurance testing were Block I, II, and III modules purchased as part of the JPL Low-Cost Solar Array Project. A picture and milestone chart of the successive Block procurements are also shown on the following pages. 


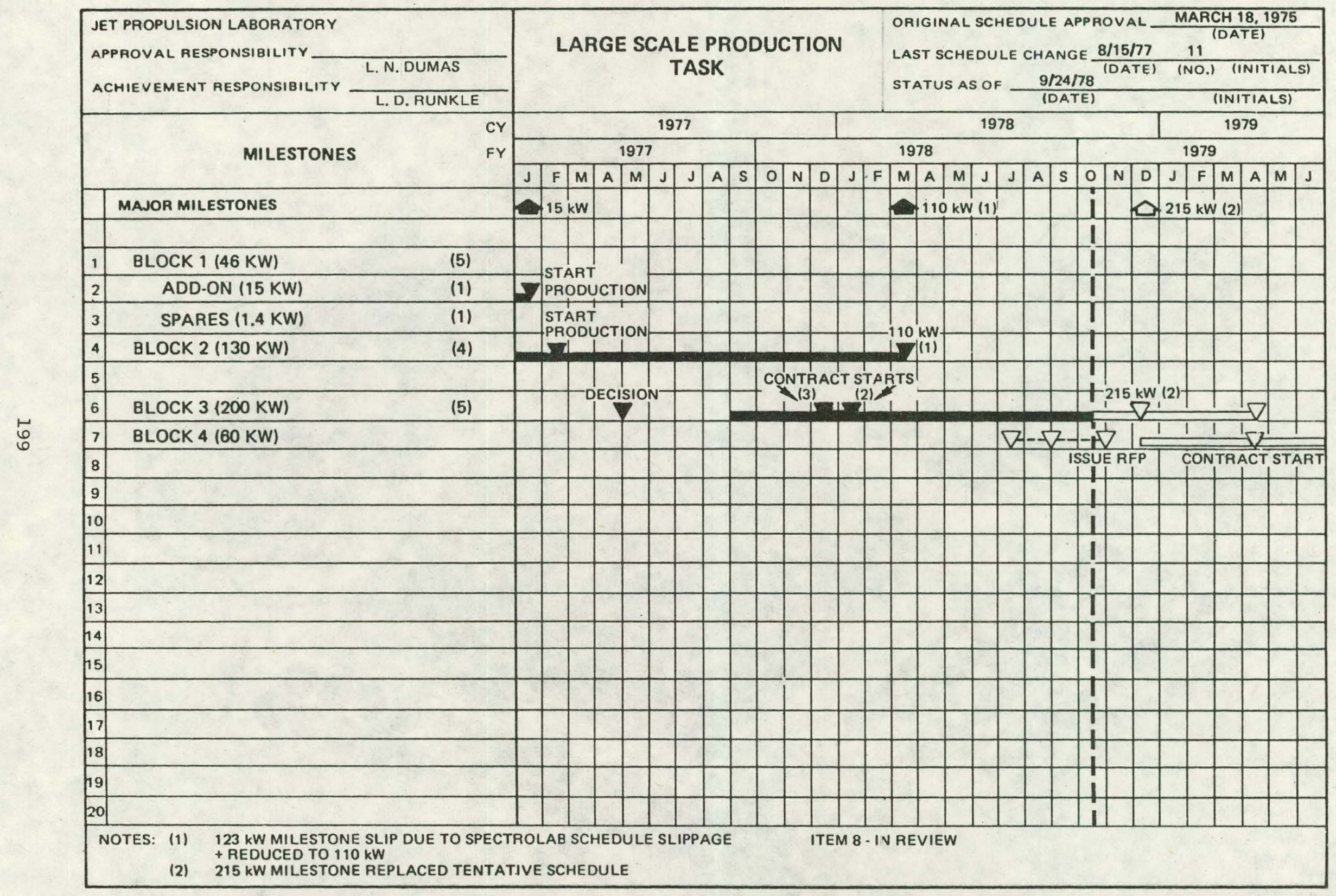




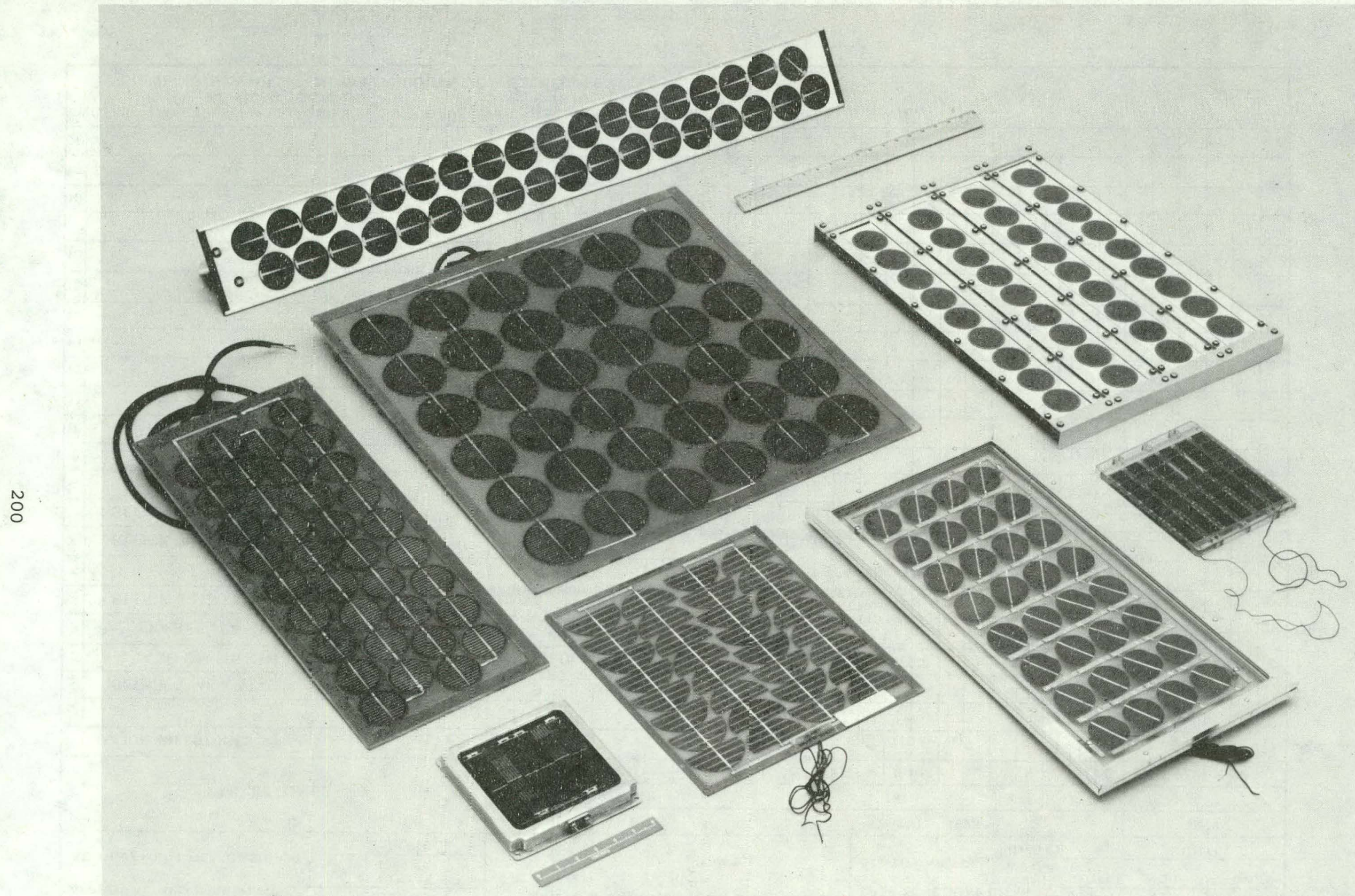




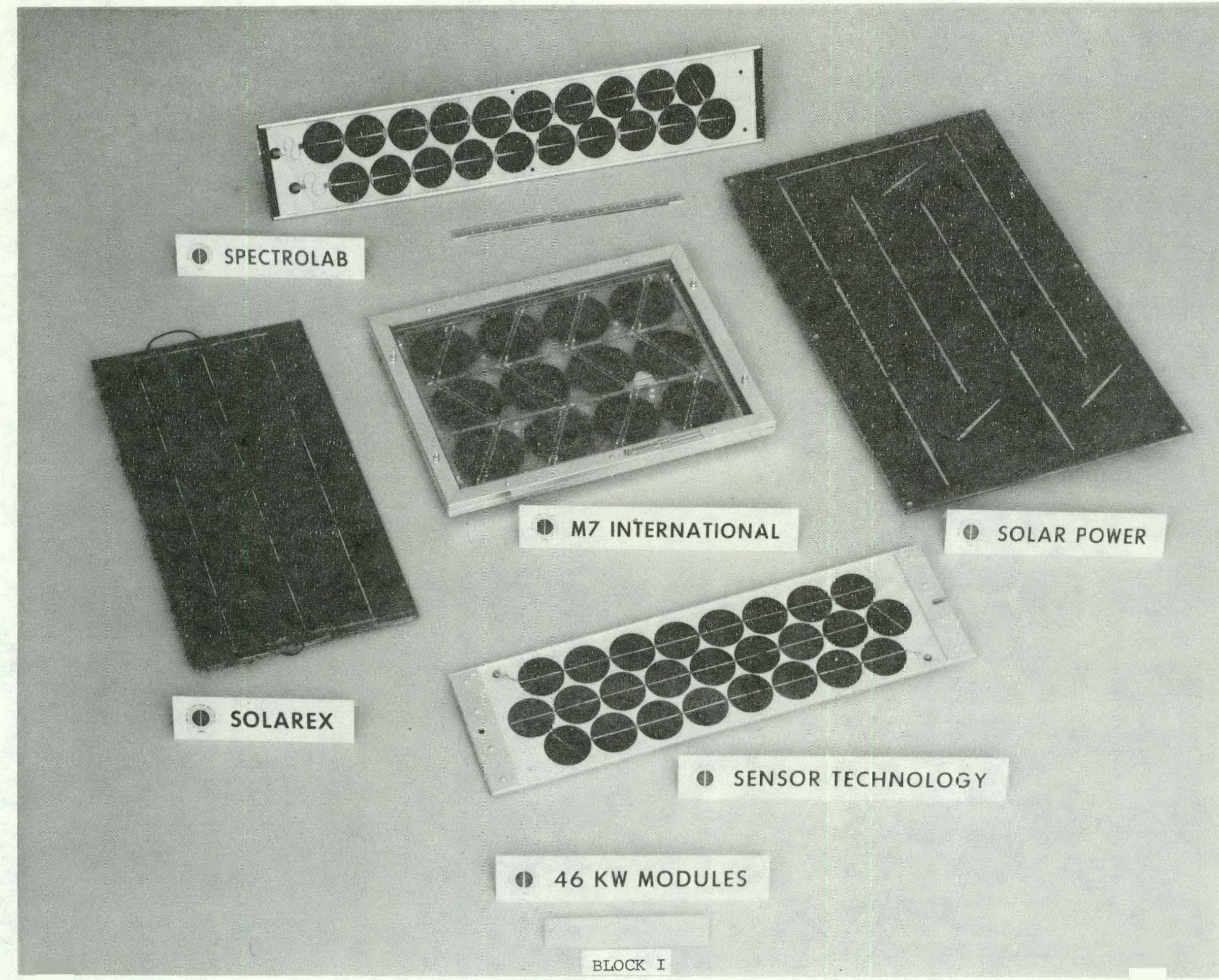

م 


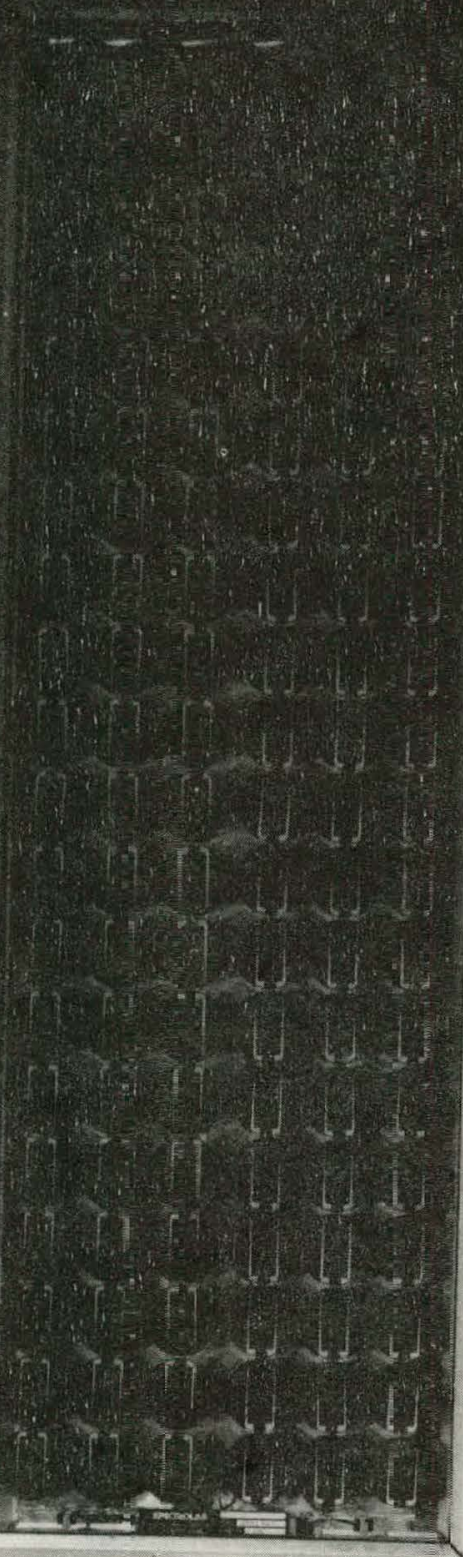

SPECTROLAB 23.3 WATTS

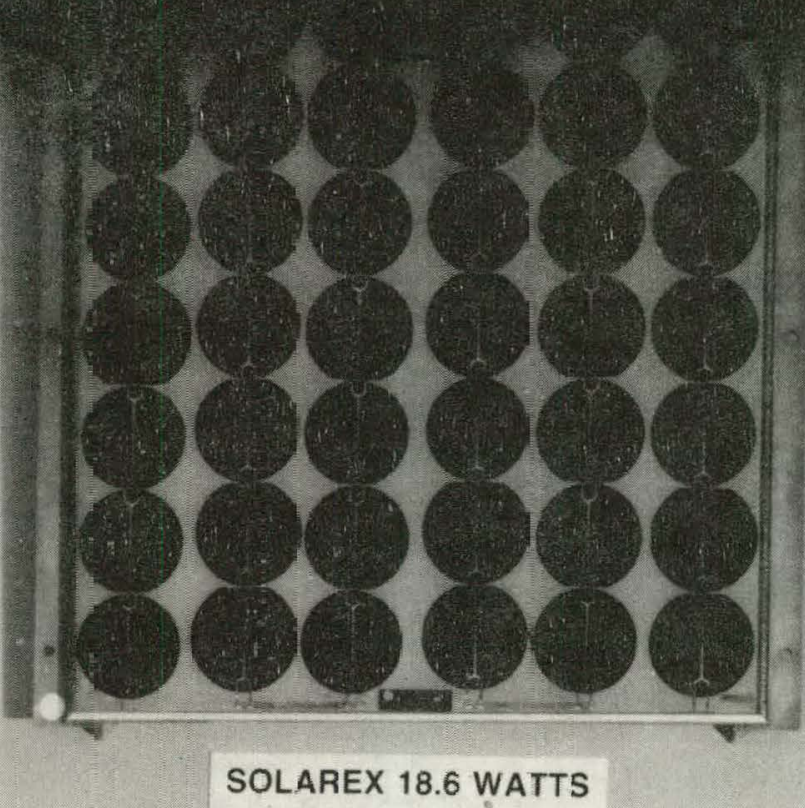

12 INCHES

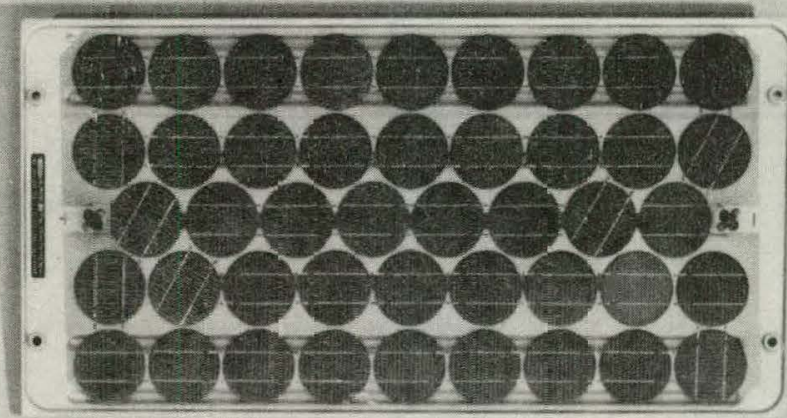

SENSOR TECHNOLOGY 9.7 WATTS

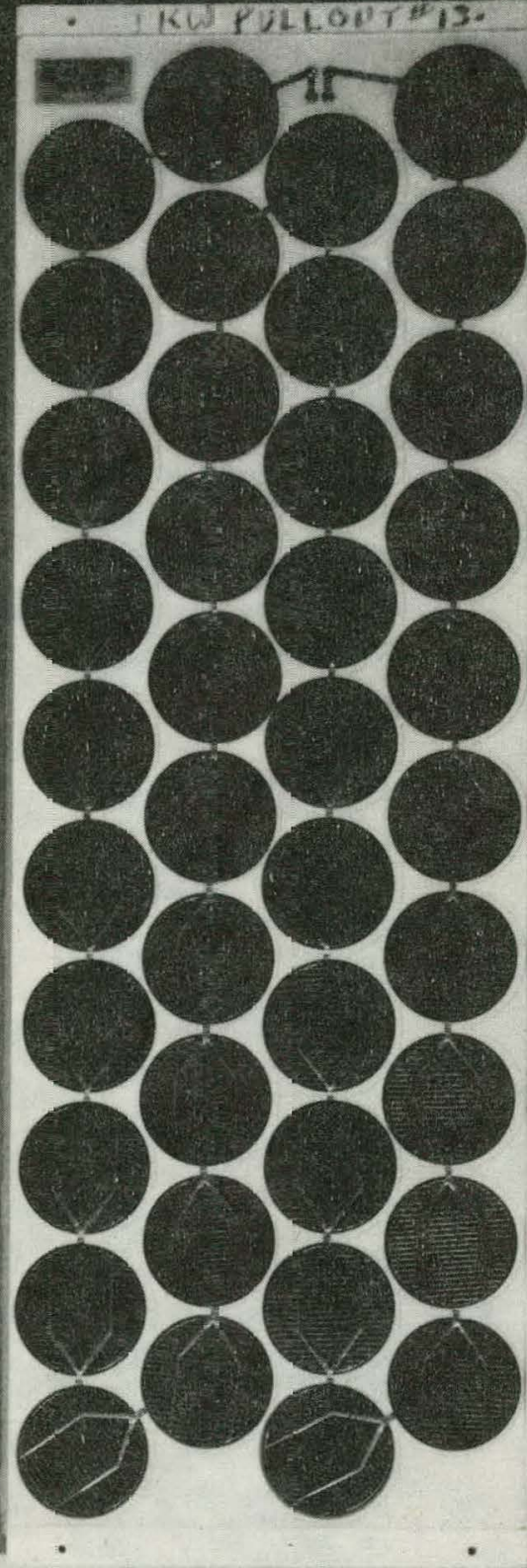

DOE BLOCK ॥ SILICON SOLAR CELL MODULES MODLLE PEAK POWER AT $50^{\circ} \mathrm{C}$ AND 15.8 VOLTS 


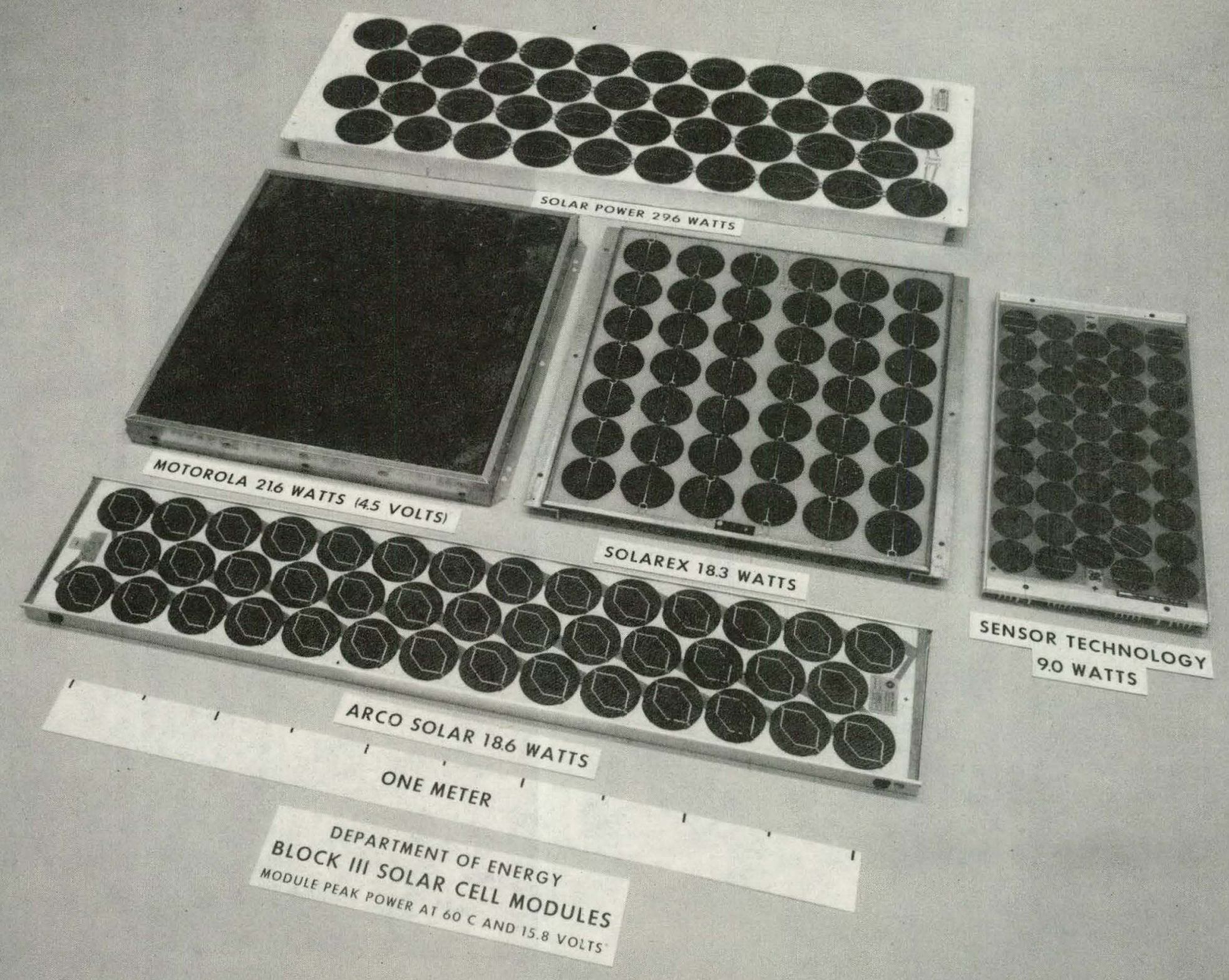




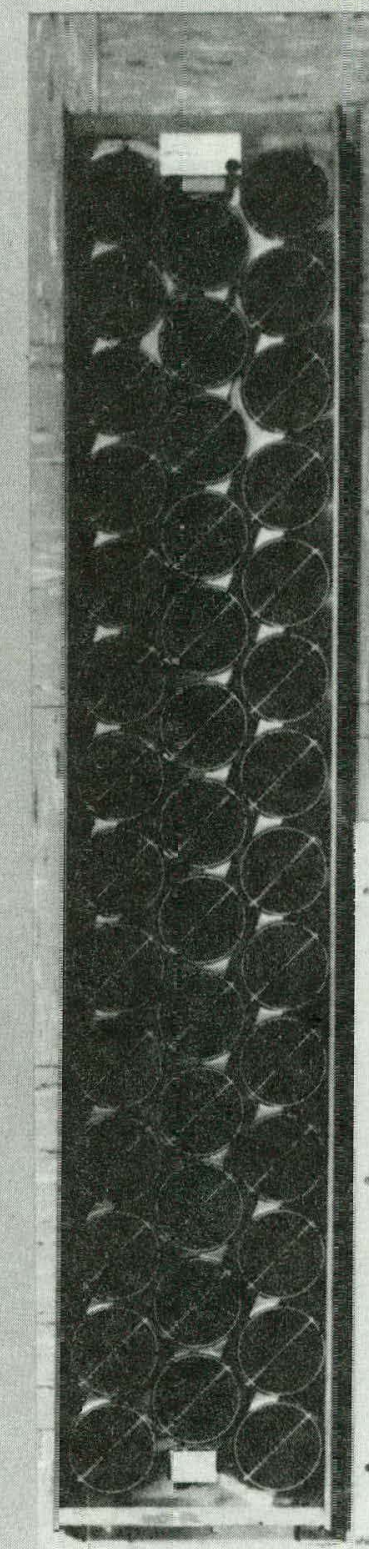

SOLAR TECHNOLOGY

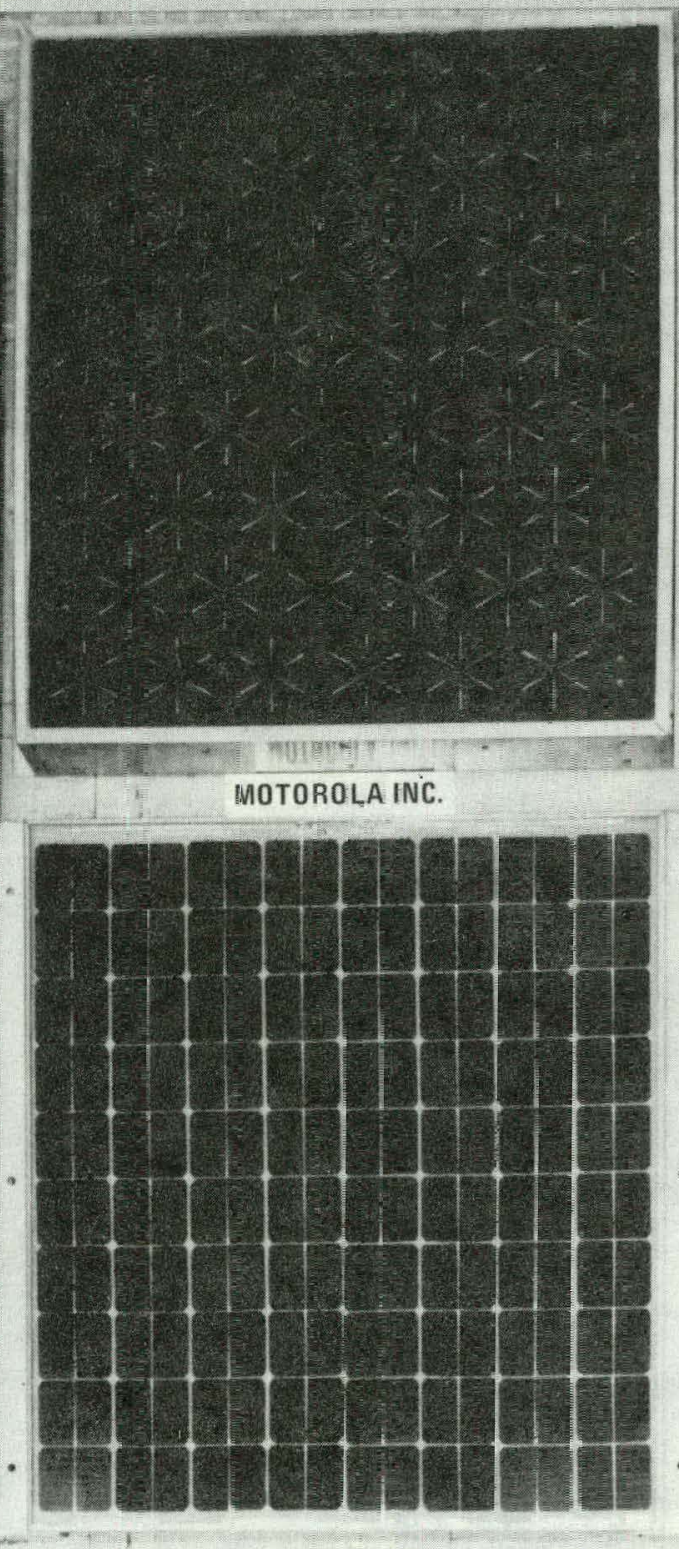

SOLAREX INC.

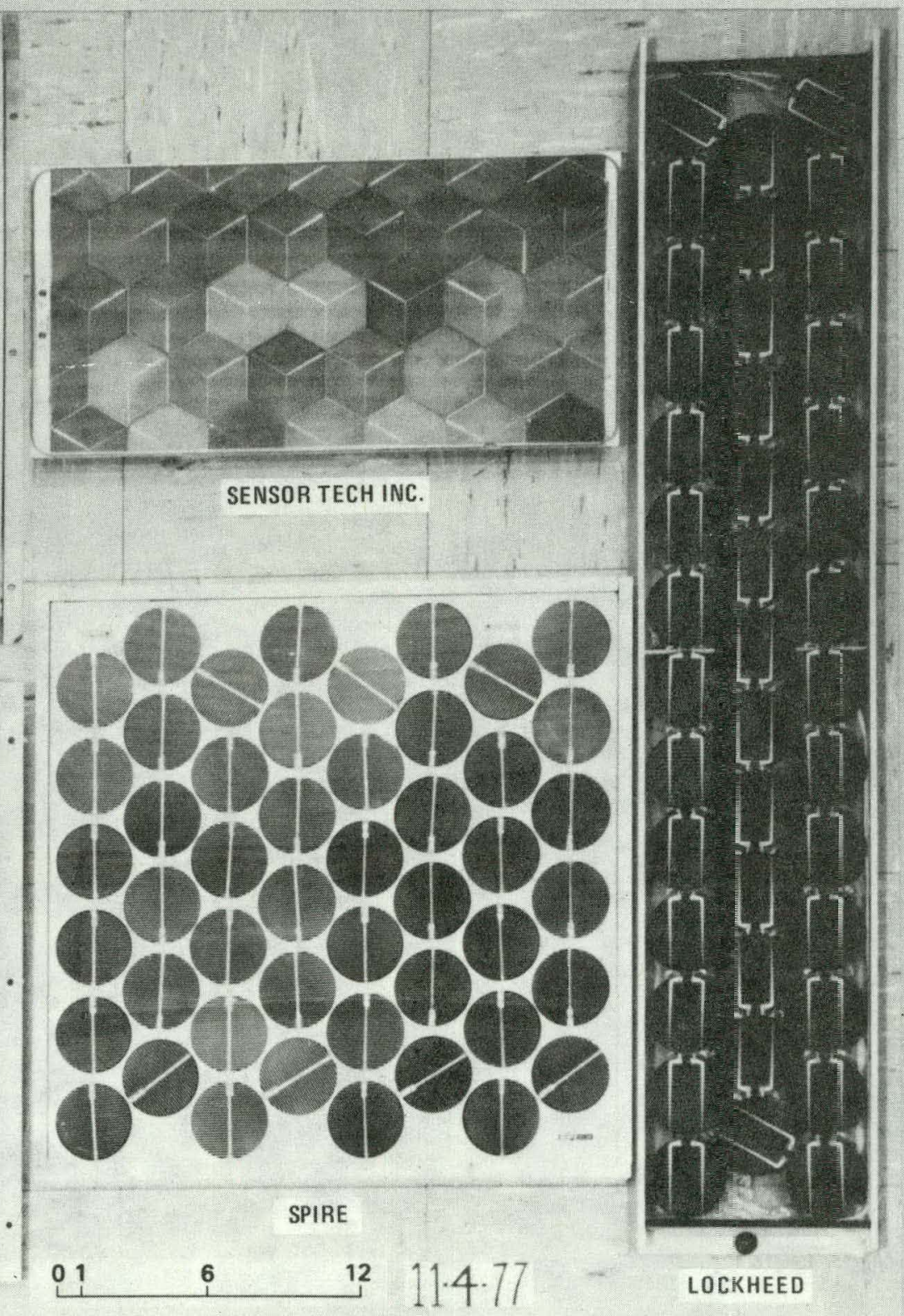




\section{FIELD TEST ACTIVITY}

The objectives of the Field Test Activity at JPL are:

(1) Obtain high quality continuous performance field data on a limited quantity of modules.

(2) Track module degradation to provide a base for the development of endurance projection techniques.

(3) Develop improved in-situ diagnostic testing tools and analytical techniques.

(4) Provide confirmation data for qualitication testing.

(5) Provide real-time/real-weather facilities for general project use.

*(6) Development of testing techniques, equipment, and procedures.

*(7) Performance of special purpose tests.

* Experience to date indicates that to accomplish the basic objective of the Activity, i.e., to acquire accurate real-time endurance data, some of the under-lying technical problems must be solved first. The "Performance of special purpose tests" focuses on specific problems that have emerged, and the object of "development of testing techniques" is to bring all the information together into a cohesive unit. 
Field Sites and Module Deployment

The Field Test Activity maintains four sites -- the principal site at JPL and three remote sites: one at Table Mountain in the San Bernardino Mountains; one in the desert at Goldstone near Barstow, California; and one by the ocean at the Coast Guard facility at Point Vicente on the Palos Verdes Peninsula. The Point Vicente Site, the most recent addition, was put into operation in early August 1978.

The JPL Site has 33 test stands, each capable of accommodating two $122 \times 122 \mathrm{~cm}$ ( $4 \times 4$ foot) subarrays. Each of the remote sites has eight test stands. All the stands at all the sites are identical. Data is obtained at the JPL Site by means of a fully automatic data system. At the remote sites, data is obtained with portable in-situ testing equipment.

JPL (PASADENA) SITE

Figure 1 shows Block I and Block II module deployment, and the recent and near future field additions, at the JPL Site. Typically the Block. I modules have been in the field about a year and a half and the Block II modules about one year. Included on the figure are the installation dates of the modules. The Block III modules designated for the site will be put on Stands 18 through 21. There will be eight $122 \times 122 \mathrm{~cm}(4 \times 4$ foot) subarrays in this group, two containing ARCO Solar modules, two containing Motorola modules, two containing high-density Solarex modules, and two containing glass-surfaced Sensor Technology modules. neployment of these mndilles is schediled for October.

An inventory of the modules at the Site including those that will be deployed in the near future are presented in Table 1. Parentheses around a number or comment means it is a planned deployment or activity. Modules temporarily assigned to the Site are not included in the inventory.

\section{REMOTE SITES}

A module inventory of the remote sites is presented in Table 2. The Block III modules that will be deployed at the remote sites will not be of the same type as those deployed at JPL because there will not be enough of each type of module available to provide a reasonable sample for all sites. It was decided to put those types that are the most different from the ones already deployed at the JPL Site and those that are the most similar at the remote sites. The result is that each of the remote sites will have one subarray of the following Block III modules: Sensor Technology, Solar Power, and Solarex. The modules will be deployed in October. 


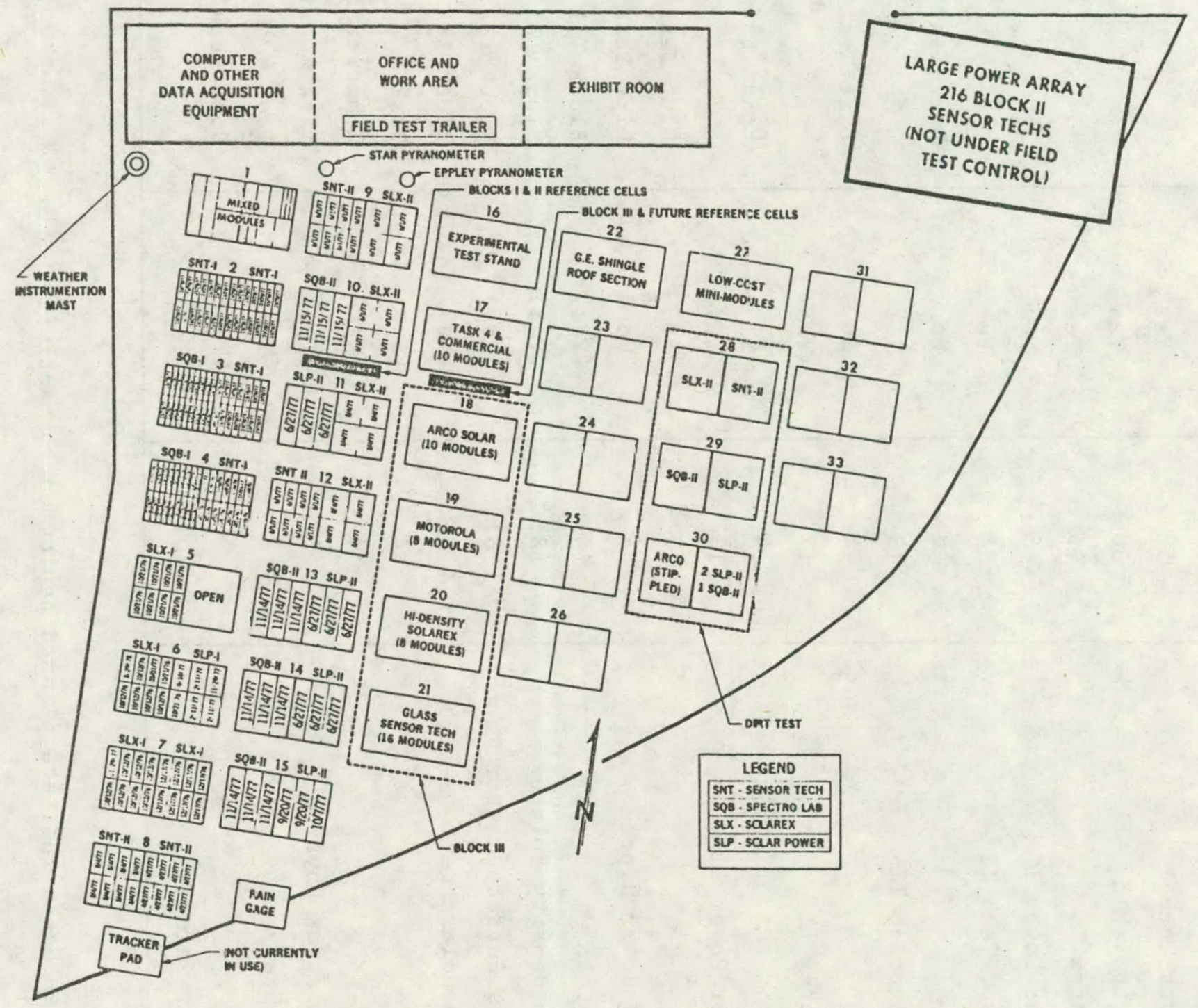

Figure 1. Layout of JPL S-te 
Table 1. JPL Site Module Inventory

\begin{tabular}{|c|c|c|c|}
\hline Module Type & Quantity & $\begin{array}{l}\text { Wired to } \\
\text { Data System }\end{array}$ & Remarks \\
\hline Sensor Tech I & 58 & Yes & \\
\hline Spectrolab I & 38 & Yes & \\
\hline Solarex I & 35 & Yes & \\
\hline Solar Power I & 8 & Yes & \\
\hline \multirow[t]{2}{*}{ Sensor Tech II } & 34 & Yes & \\
\hline & 8 & No & Dirt Test \\
\hline \multirow[t]{2}{*}{ Spectrolab II } & 13 & Yes & \\
\hline & 4 & No & Dirt Test \\
\hline \multirow[t]{2}{*}{ Solarex II } & 17 & Yes & \\
\hline & 4 & No & Dirt Test \\
\hline \multirow[t]{2}{*}{ Solar Power II } & 13 & Yes & \\
\hline & 5 & No & Dirt Test \\
\hline ARCo Solar Ripple & 5 & No & Dirt Test \\
\hline Motorola & $(8) *$ & $($ Yes $) *$ & Block III \\
\hline High Density Solarex & (8) & (Yes) & Block III \\
\hline Glass Surface Sensor Tech & $(16)$ & (Yes) & Block III \\
\hline ARCO Solar & (10) & (Yes): & Block III \\
\hline Xerux. & 2 & $(Y e c)$ & Task 4 \\
\hline Amperex & 2 & (Yes) & Conmescid \\
\hline Simulation Physics & 2 & (Yes) & Task 4 \\
\hline Lockheed & 2 & (Yes) & Task 4 \\
\hline Solec & 2 & (Yes) & Conmercial \\
\hline G. E. Shingle & $(40)$ & (Yes) & \\
\hline
\end{tabular}

*Parentheses indicate planned deployment or activity 


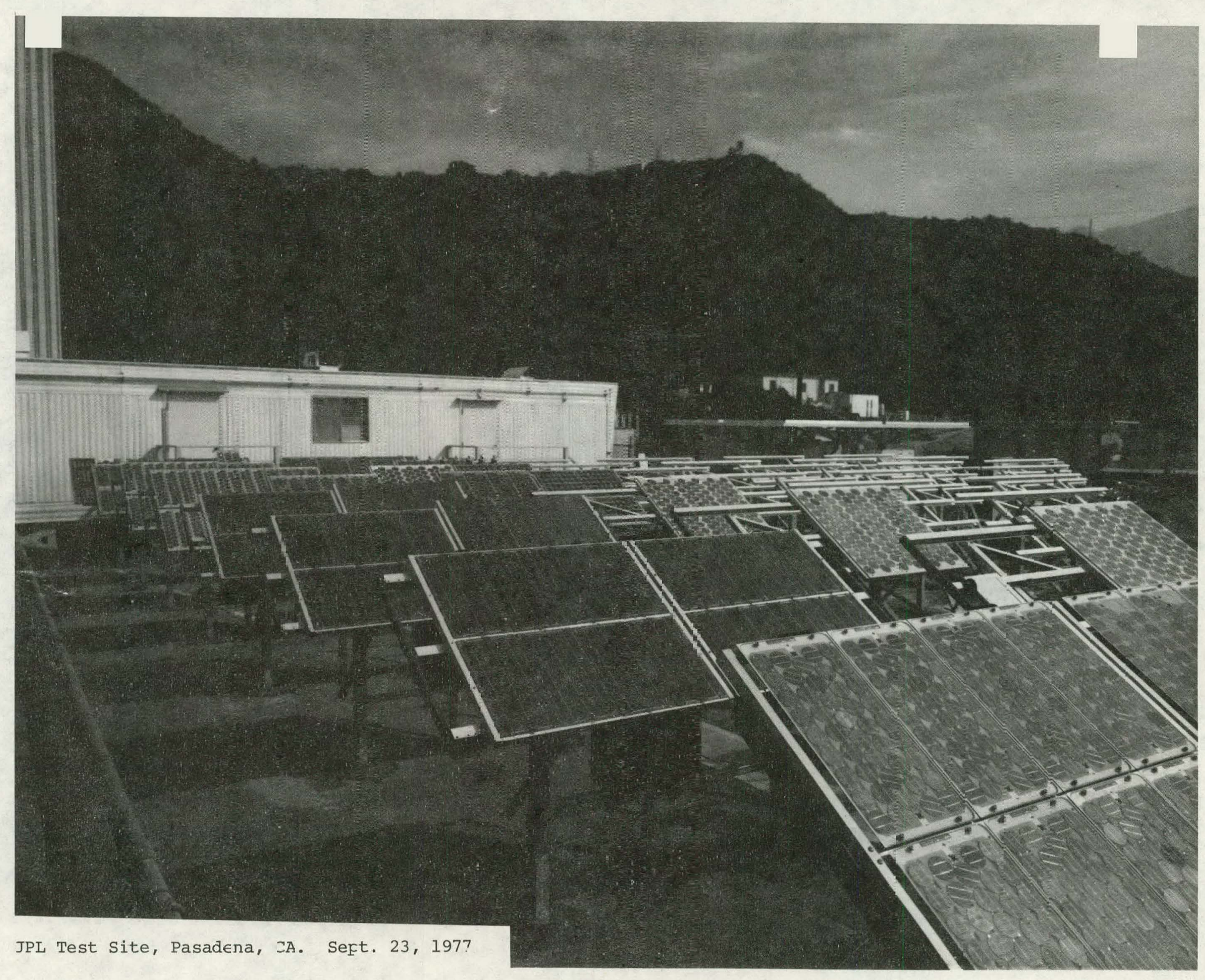




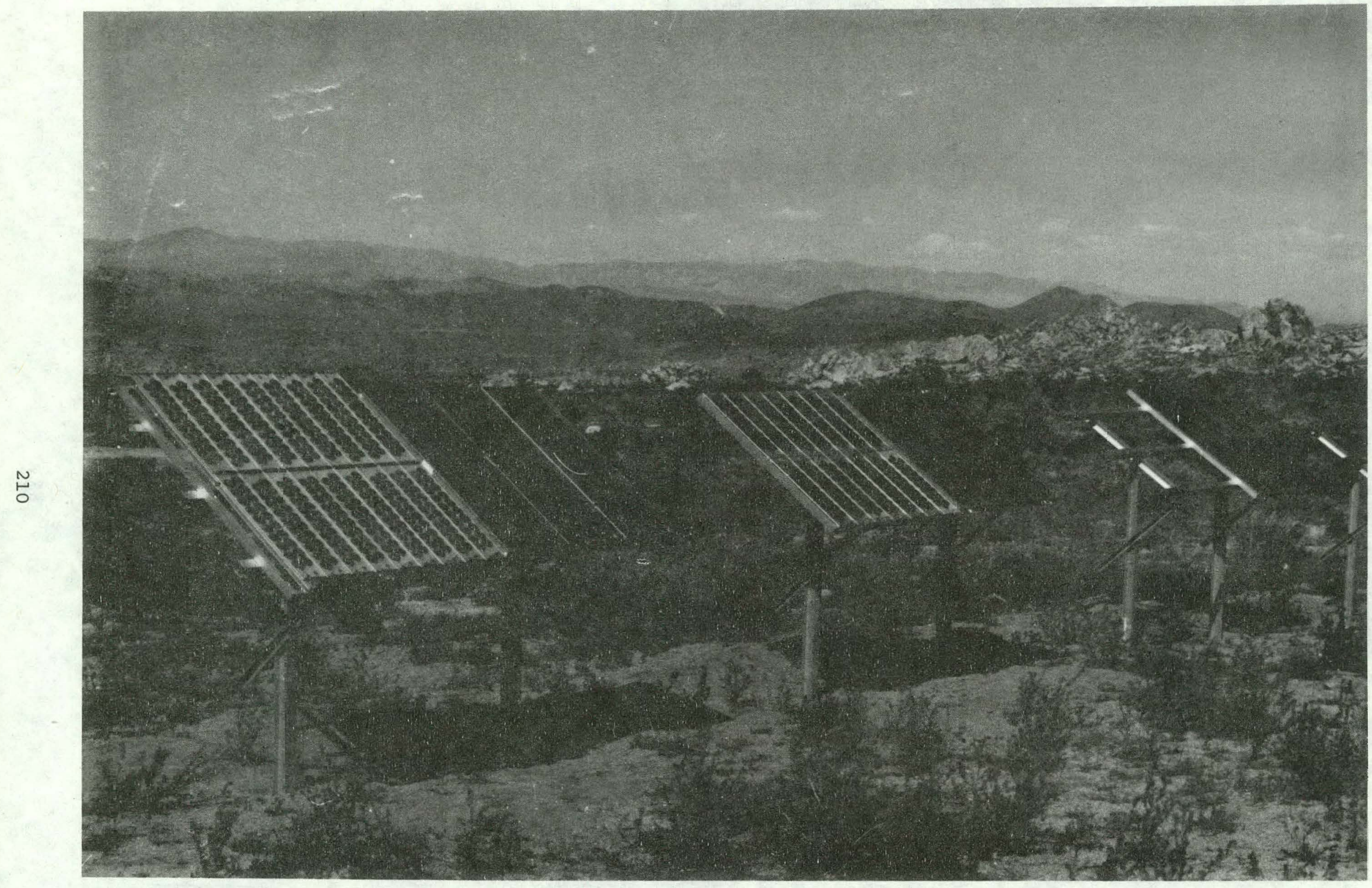

JPL Real Time Endurance Test Site, Goldstone DeeF Space Tracking Station, Mojave Desert, CA. Nov. 7, 1977 


\section{PASADENA FIELD TEST SITE}

The Pasadena Field Test Site provides an urban exposure environment for weathering tests of up to $334^{\prime} \times 3^{\prime}$ solar cell module arrays. This site is equipped with an automated data acquisition system with a mini-computer for data monitoring and reduction. The continuous surveillance of individual module performance in this field provides valuable data on performance trends which can be used to evaluate life prediction models, confirm the validity of accelerated testing techniques, and develop improved fieid service diagnostic test and analysis techniques.

The Goldstone Field Test Site is located in the upper Mojave Desert at the Goldstone Deep Space Tracking Station, operated by JPL for NASA. Temperature variations in this area are large, and wind-blown dust and sand are common. 


\section{TABLE MOUNTAIN TEST SITE}

The Table Mountain Field Test Site is located at 7500 foot elevation in an area characterized by bright, stable sunshine with high ultraviolet content; for this reason, the site has been used as a solar observatory for many years. Heavy snowfall and high winds occasionally occur during the winter months.

The Point Vicente field test site is the newest of JPL's real time test sites. It was put into operation in early August 1978. Point Vicente is located by the Pacific Ocean at the Coast Guard facility on the Palos Verdes Peninsula in California and provides a salt-air seashore environment. 


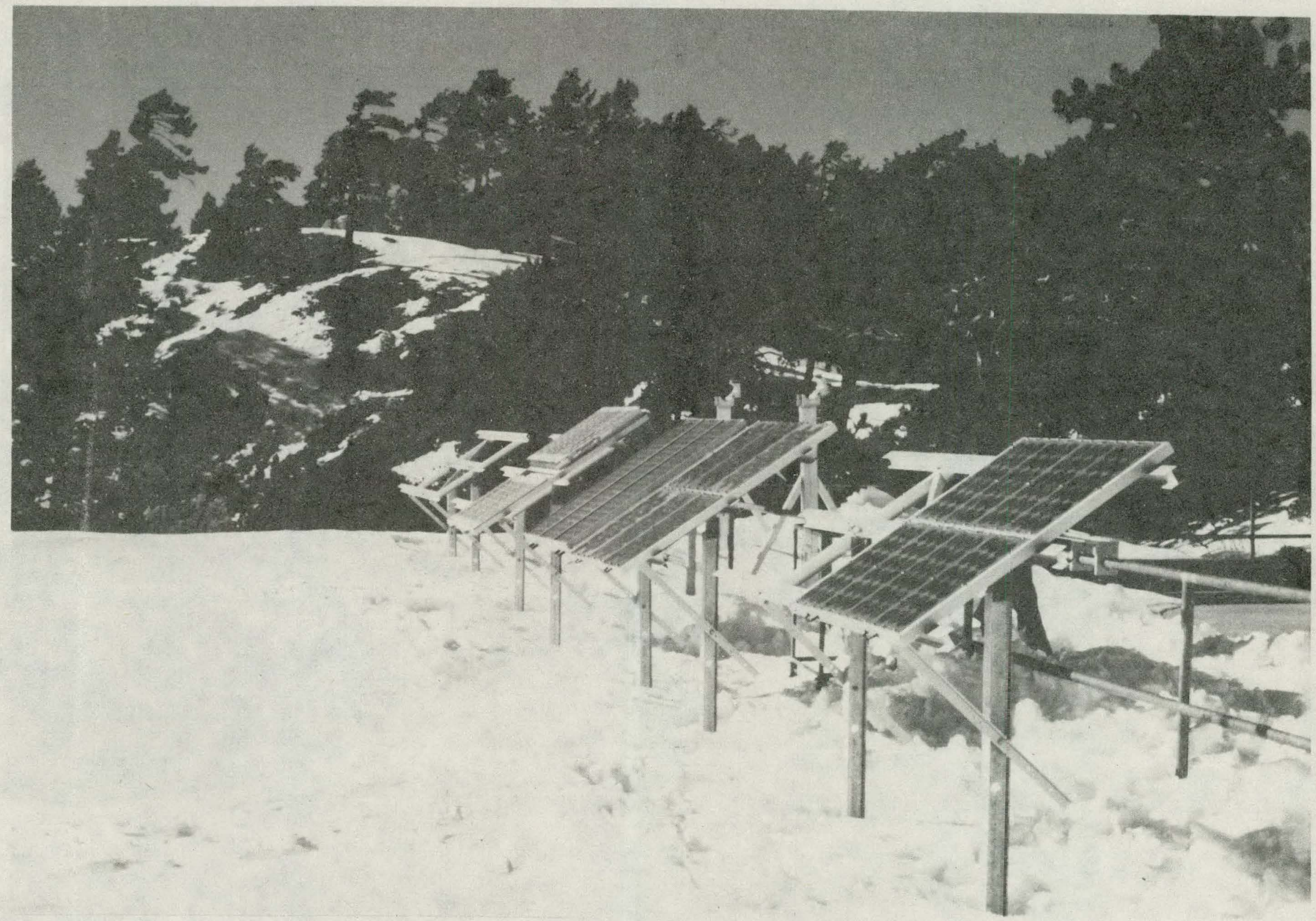

JPL Real Time Endurance Test Side. Table

Mountain. December 1977 


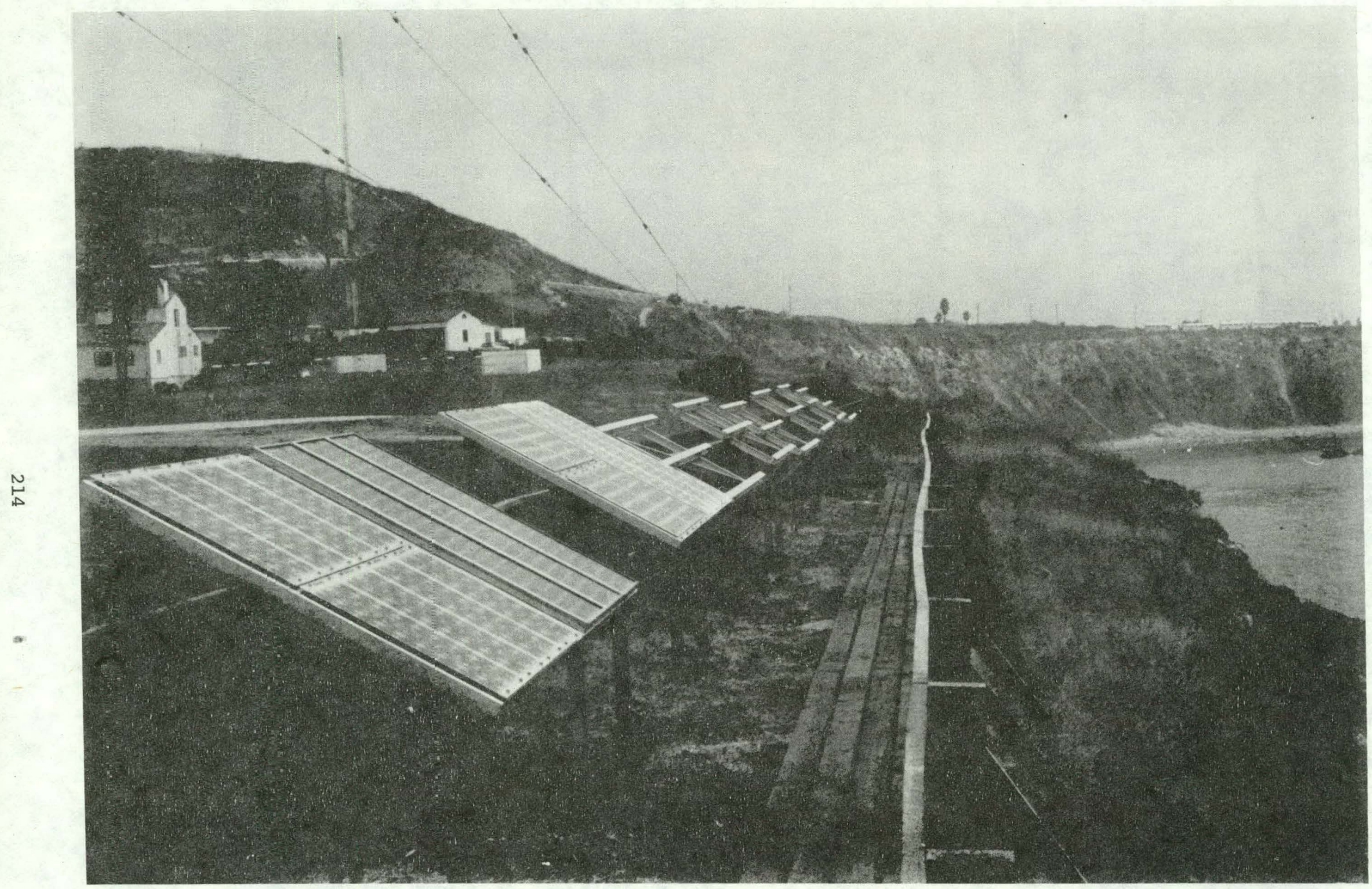

JFL Real Time Enzurance Test Szte

Pt. Vincente, CA 
Table 2. Remote Sites Module Inventory

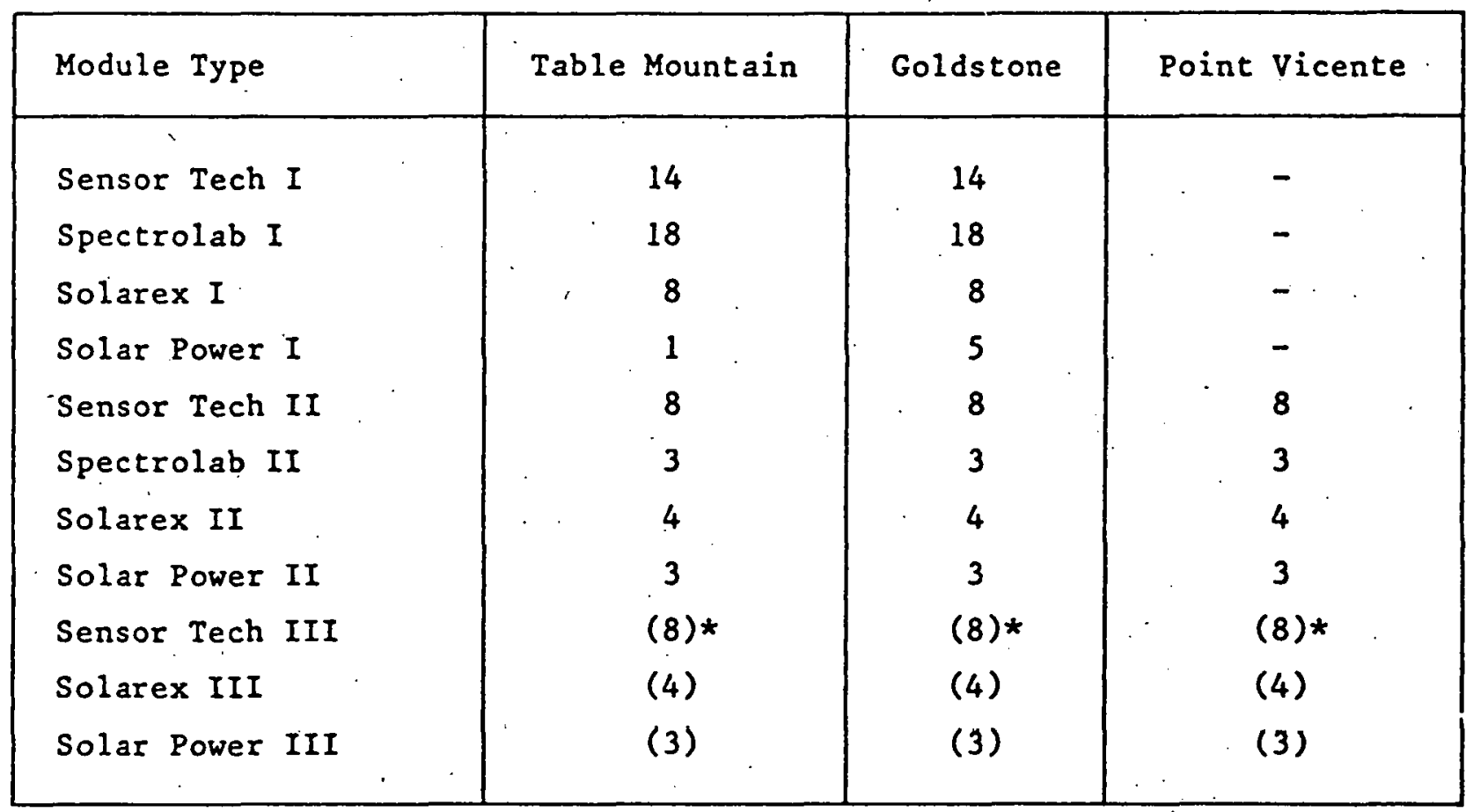

*Parentheses indicate planned deployment

To maintain the philosophy of testing the modules in a loaded condition, the modules at the remote sites will be loaded the same way as the modules at the JPL Site, i.e., all the modules in each subarray will be wired together in a series circuit with a resistor designed to dissipate peak power at $85 \mathrm{~mW} / \mathrm{cm}^{2}$. Currently all the modules at Table Mountain and Point Vicente are under load; installation of load resistors at Goldstone is scheduled for October. 
DATA ACQUISITION AND TEST PROCEDURE: JPL SITE

\section{HARDWARE}

Figure 2 contains a schematic of the data system. The system was accepted from Instrument Technology Corporation (ITC) on December 19, 1977, but persistant problems prevented the collection of $I-V$ data on a semi-routine basis until mid-February. In late March its capability was extended to a 24-hour-a-day; 7-daya-week operation.

In evaluating the data system, and specifically the dynamic load, prior to buy-off, it was subjected to several tests to determine if it was functioning according to the purchase specifications. The conclusion from these tests was that the system met or exceeded the purchase specifications. The specifications are as follows: current values below $200 \mathrm{~mA}$ are to be accurate to $\pm 1 \mathrm{~mA}$ and values above $200 \mathrm{~mA}$ are to be accurate to \pm 0.58 of the value; voltage values below 2 volts are, to be accurate to $\pm 10 \mathrm{mV}$ and values above 2 volts are to be accurate to \pm 0.58 of the voltage.

The data system has now been functioning on a routine basis for about six months. It is worthwhile to comment on its performance now to serve as a guide for the future, and for general knowledge for those contemplating systems of their own.

On the plus side, the arrangement of components is good and provides a great deal of flextbllity in the acquisition of data. Via the computer, single or sequential interrogations of devices in the field are possible. Having all the devices accessible to the computer allows changes to be made in the software by means of simple programming, rather than by complicated hardware changes.

On the minus side, an intermittent noise problem exists as a result of long lead wires to the multiplexors, many switching operations (many mechanical), and insufficient isolation of the electronic components. Sometimes the I-V curves look clean and other times very noisy. In a situation where the device (the module) is remote from the current sink (the dynamio load) and the voltage sensing and digitizing electronics (the dynamic load), extreme care must be exercised in both the design and wiring of the system. One goal of the Field Test Activity for the near future is to identify and minimize the noise problem. 


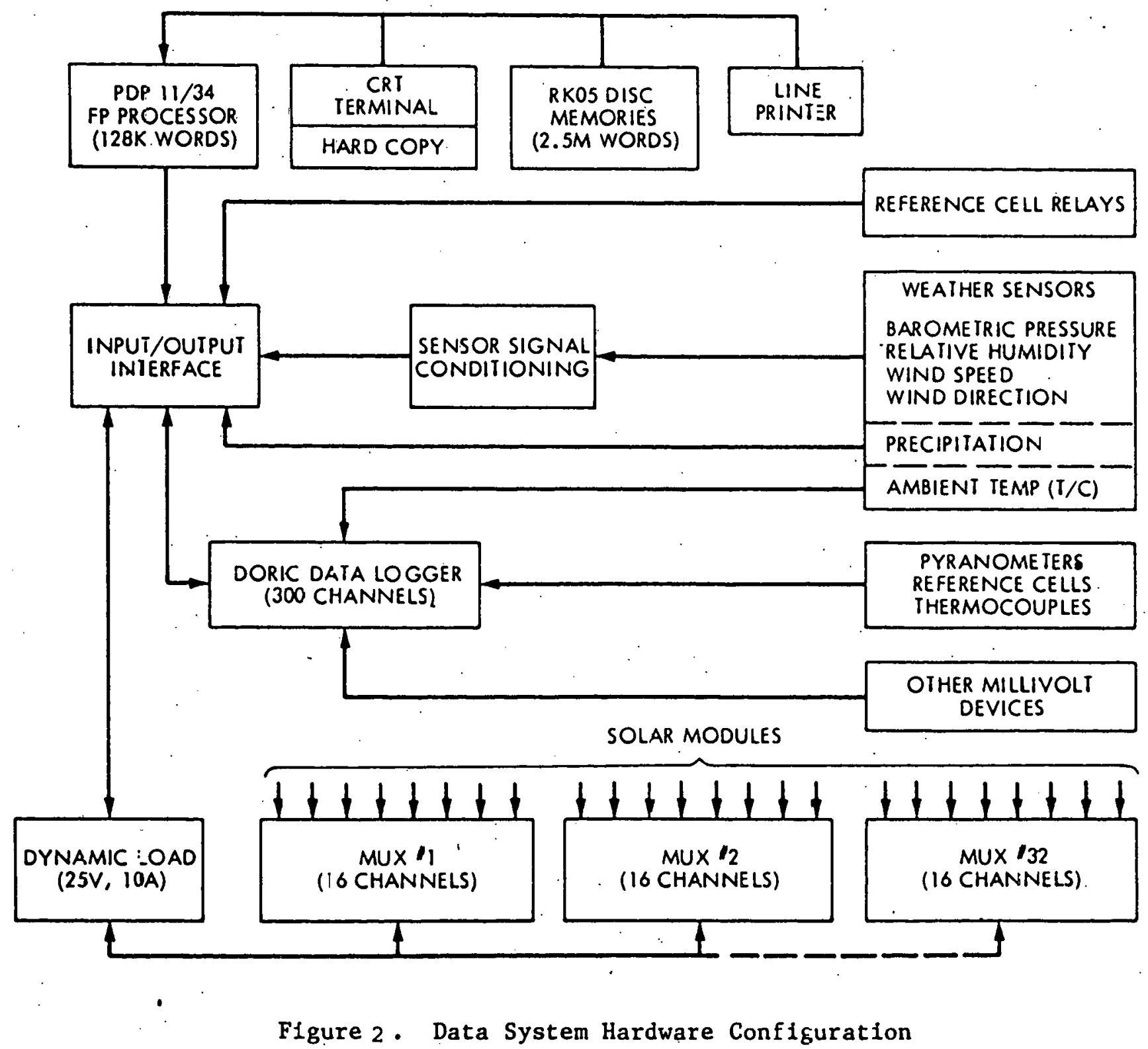




\section{SOFTWARE}

Figure 3 contains an updated schematic of the functional software configuration. There are two modes of operation, the dedicated and the interactive. The dedicated mode provides for the automatic acquisition of $I-V$, weather, and insolation data and is the primary operating mode. The interactive mode permits the selected acquisition of data from any single device by manual commands from the CRT. Within the scope of the interactive mode are the data archiving and file manipulation tasks which operate on data obtained in the dedicated mode.

All of the dedicated tasks are controlled by the Master Scheduler Task which oversees the whole operation. Figure 4 shows the data flow for the dedicated daily operations. A typical day goes as follows: At midnight, the Midnight Task, which is part of the Master Scheduler, is initiated. This Task determines what day of the week it is and whether it is a weekend day or holiday. When it is a weekend day or holiday, the printer is inhibited for most tasks and the summary tasks are rescheduled. It then calls up subroutine Sun, which calculates sunrise, sunset, and solar noon based upon the new declination angle and equation-of-time for the day. The Weather Data Acquisition Task is then initiated; weather data is taken every 15 minutes around the clock. A short time after sunrise, the Insolation Reading Task is started; insolation data is obtained every five minutes. The intervals of both these tasks can be changed by a simple override operation. When, the insolation level reaches a predetermined threshold $\left(85 \mathrm{~mW} / \mathrm{cm}^{2}\right.$. is currently being used) the Solar Module Data Acquisition Task will begin. If it is an overcast day and the threshold level is not reached by solar noon, the Task will be initiafed at that time. There is also a lower threshold of $40 \mathrm{~mW} / \mathrm{cm}^{2}$. No solar module data will be taken below that level.

All the modules in the field exist in a correlation table along with their associated reference cells and thermocouples. Another computer table, the Solar Module Sequence Table, is a listing of the order in which the modules are to be interrogated. For every module type in the field there is a reference cell enclosed in a weatherproof container with a pneumatically operated computer controlled door. When the module's number comes up on the sequence table, the routine checks to see if its reference cell door is open. If it is not, it opens the door. It next obtains the I-V data (typically 400 to 600 points are generated for each curve). After that, it obtains data from seven millivolt devices with the DORIC data logger: three for the array thermocouples, a fourth for the ambient air temperature thermocouple, a fifth for the reference cell reading, a sixth for the reference cell thermocouple, and a seventh for the Eppley pyranometer reading. It takes about one second per module. 
At a half hour after solar noon, the data obtained earlier goes through a correction, comparison, and storage process, followed by a hard copy sumary presentation. First, corrected curves are generated from the raw data based upon reference temperature and insolation values and the Sandstrom translation equations. This is performed in the I-V Data Correction Task. The corrected curves are then stored in a file capable of accomodating seven to ten days worth of data (the Corrected Data File). Also, the key parameters, such as $V_{\text {oc }}, I_{s C}$, and peak-power, are stored in a daily file known as the Permanent Daily Data File (PDDF). Second, the key parameters from these corrected curves are compared with data from a set of reference curves previously stored in the Reference I-V Curve File (RIVCF); the comparison is performed in Compare I-V Data Sumary Task. Finally, hard copy summaries of the daily data are presented in the form of two listings: a "Raw-I-V Curve Summary" and a "Comparison I-V Curve Summary." A typical set of summaries for July 5 is presented in Figures 5 and 6 . These figures show a portion of the first page of each of the five-page summaries. On weekends or holidays the Raw I-V Sumary is listed daily but the Comparison Summaries are delayed until the morning of the first working day. The nomenclature for these listings is given in the appendix. Approximately once a week, data in the Corrected Data File from one of the previous days is selected to be used for either the new Reference I-V Curve File, or to be put into the long-term archival file. This latter file is known as the Archived Reference I-V Curve File (RIVCFA). A second long-term archival file exists which contains the daily key parameters. This file is known as the Archived Permanent Daily Data File (PDDFA).

Hard copy summaries of the weather and pyranometer data are also listed daily. Currently this information is not archived; the hard copy records are the only ones that exist. Figures 7 and 8 contain a portion of the summaries for July 5. Heading the Pyranometer Data Summary is a listing of sunrise, sunset, and solar noon for the day, as well as the declination angle and the equation-of-time. The body of the sumbary contains the data from both pyranometers, the Eppley and the Star. The output is separated into groups of three columns. Each gruup is fui one pyranometer rcading the firct column is the time; the second indicates the pyranometer ( $120 /$ DL9 is the Eppley); and the third is the output in $\mathrm{mW} / \mathrm{cm}^{2}$. Data is obtained from both pyranometers at essentially the same time. The weather data presented in Figure 16 is self explanatory.

Several software tasks still remain to be completed. Work is currently in progress to develop software for the retrieval and manipulation of archived data. This utility software is necessary to provide the link between the archived data and all the analysis programs which will be written in the future. Other areas of activity are: completing the error logic rc -ines, writing a users guide, updating the Software Requirements vucument (SRD), and revising some of the older programs. 


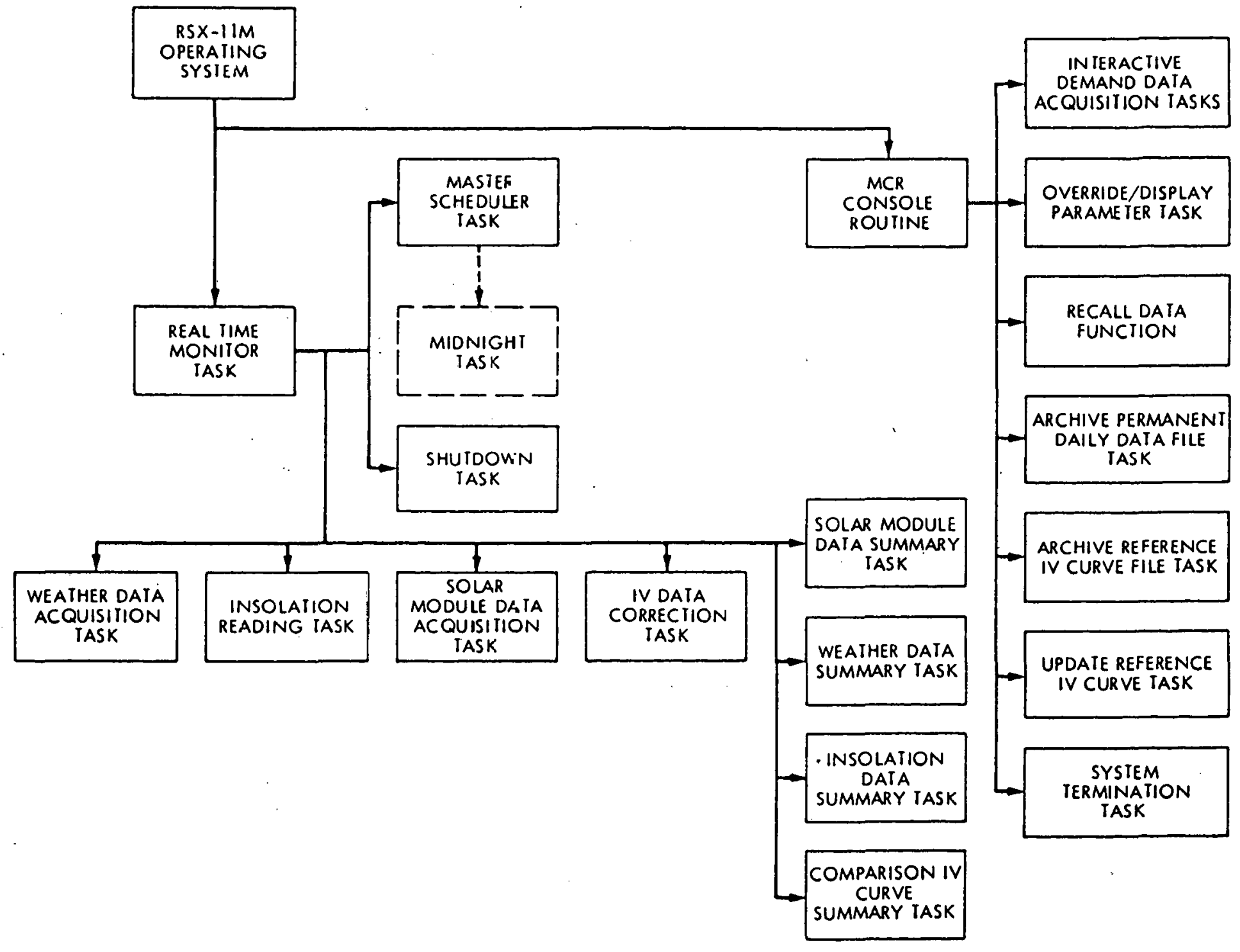

Figure 3 - Functional Software Configuration 

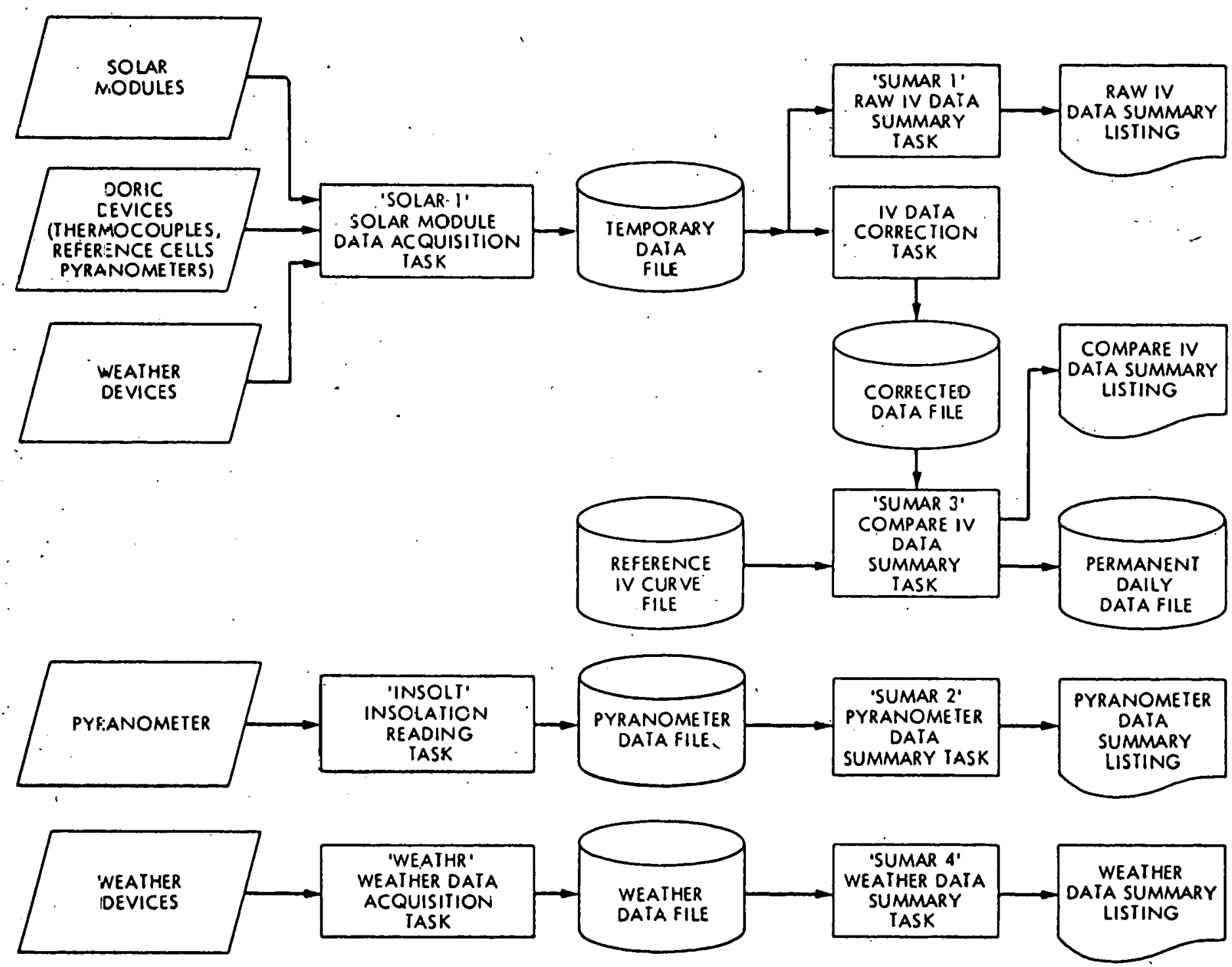

Figure 4. System Data Flow: Dafly Dperations 
RAW JU CURVE SUMMARY WEDNESDAY JUL 51978

REALIOUT
TIME
$\begin{array}{lrll}\text { SOLAR } & \text { TOTAL FILTEREI } & \text { ISC } & \text { VOC } \\ \text { MODULE } & \text { POINTS } & \text { POINTS } & \end{array}$

$17 / 5 E 6 / 1398$ $18 / 5 B 7 / 1393$ $19 / 5 \mathrm{k8/} 1397$ 20/5E9/ 1393 $21 / \mathrm{SCO} / 1390$ $22 / 5 C_{1} / 1380$ $23 / 5 C_{2} / 1376$ $24 / 5 C 3 / 1405$ $25 / 5 C 4 / 1388$ $26 / 5 C 5 / 1386$ $27 / 566 / 1405$ $28 / 5 C 7 / 1384$ $29 / 5 C 8 / 14418$ $30 / 5 C 9 / 1403$ $33 / 5112 /$ i 390 $34 / 503 / 1391$ $35 / 5[14 / 1394$ $36 / 5[15 / 1396$ $37 / 5116 / 1389$ $38 / 507 / 1403$ $30 / 5481$ 1 401 $40 / 5119 / 1404$ 41/SEO/ 1 435 42/SE1/ 1 405 43/SE2/ 1393 44/SE3/ 1385 45/SEA/ 1398 46/SES/ 1397 49/SEQ/ 1 421 50/SE9/ 1401 $51 / 5 F O / 1418$ $52 / S_{1} 1 / 1425$ S3/SF2/ 1416 $54 / S F 3 / 1421$ 55/SFA/ 1420

$\begin{array}{rll}95 & 0.397 & 12.761 \\ 92 & 0.392 & 12.743 \\ 82 & 0.396 & 12.810 \\ 87 & 0.392 & 12.907 \\ 83 & 0.389 & 12.743 \\ 84 & 0.379 & 12.700 \\ 83 & 0.375 & 12.761 \\ 88 & 0.404 & 12.755 \\ 91 & 0.387 & 12.694 \\ 86 & 0.385 & 12.712 \\ 96 & 0.404 & 12.883 \\ 84 & 0.383 & 12.840 \\ 94 & 0.418 & 12.877 \\ 91 & 0.402 & 12.767 \\ 91 & 0.389 & 12.712 \\ 91 & 0.390 & 12.639 \\ 90 & 0.393 & 12.804 \\ 90 & 0.395 & 12.749 \\ 89 & 0.388 & 12.682 \\ 89 & 0.402 & 12.773 \\ 96 & 0.400 & 12.608 \\ 96 & 0.403 & 12.749 \\ 109 & 0.434 & 12.791 \\ 94 & 0.404 & 12.736 \\ 97 & 0.392 & 12.578 \\ 90 & 0.384 & 12.749 \\ 93 & 0.397 & 12.749 \\ 92 & 0.396 & 12.749 \\ 97 & 0.420 & 12.486 \\ 88 & 0.400 & 12.810 \\ 95 & 0.417 & 12.816 \\ 89 & 0.424 & 12.913 \\ 94 & 0.415 & 12.834 \\ 98 & 0.420 & 12.852 \\ 90 & 0.419 & 12.859 \\ 108 & 0.441 & 12.822\end{array}$

FEAK IE FKFWR

$\begin{array}{llcc}\text { FEAK } & \text { IE } & \text { KEF } & \text { T/C } \\ \text { FOWEK } & \text { FKFWK } & \text { CEL } & \text { KEF-CE } \\ & & & \\ 3.792 & 0.381 & 81.195 & 31.9 \\ 3.788 & 0.363 & 81.049 & 32.0 \\ 3.920 & 0.379 & 81.112 & 32.0 \\ 3.900 & 0.371 & 81.319 & 32.0 \\ 3.864 & 0.373 & 81.257 & 32.0 \\ 3.736 & 0.363 & 81.319 & 32.1 \\ 3.704 & 0.353 & 81.402 & 32.1 \\ 3.944 & 0.388 & 81.340 & 32.1 \\ 3.684 & 0.357 & 81.299 & 32.1 \\ 3.712 & 0.367 & 81.319 & 32.1 \\ 3.900 & 0.374 & 81.423 & 32.1 \\ 3.792 & 0.357 & 81.381 & 32.1 \\ 4.088 & 0.389 & 81.465 & 32.1 \\ 3.820 & 0.373 & 81.340 & 32.1 \\ 3.740 & 0.369 & 81.361 & 32.1 \\ 3.732 & 0.366 & 81.278 & 32.2 \\ 3.844 & 0.373 & 81.402 & 32.2 \\ 3.820 & 0.366 & 81.236 & 32.2 \\ 3.748 & 0.361 & 81.506 & 32.3 \\ 3.900 & 0.378 & 81.361 & 32.3 \\ 3.780 & 0.373 & 81.444 & 32.3 \\ 3.808 & 0.373 & 81.465 & 32.3 \\ 4.012 & 0.391 & 81.174 & 32.3 \\ 3.808 & 0.372 & 81.465 & 32.3 \\ 3.572 & 0.363 & 81.547 & 32.3 \\ 3.680 & 0.359 & 81.340 & 32.3 \\ 3.792 & 0.376 & 81.423 & 32.3 \\ 3.796 & 0.364 & 81.568 & 32.3 \\ 3.932 & 0.388 & 81.444 & 32.4 \\ 3.940 & 0.381 & 81.236 & 32.4 \\ 4.024 & 0.388 & 81.340 & 32.4 \\ 4.124 & 0.393 & 81.402 & 32.4 \\ 4.052 & 0.389 & 81.319 & 32.4 \\ 4.060 & 0.391 & 81.423 & 32.5 \\ 4.092 & 0.388 & 81.444 & 32.5 \\ 4.056 & 0.400 & 81.299 & 32.5\end{array}$$$
T / C
$$$$
\begin{aligned}
& 44.5 \\
& 44.5 \\
& 44.6 \\
& 44.6 \\
& 44.6 \\
& 44.6 \\
& 44.6 \\
& 44.5 \\
& 44.5 \\
& 44.5 \\
& 44.5 \\
& 44.5 \\
& 44.5 \\
& 44.6 \\
& 45.5 \\
& 45.5 \\
& 45.5 \\
& 45.5 \\
& 45.5 \\
& 45.5 \\
& 45.5 \\
& 45.5 \\
& 45.5 \\
& 45.5 \\
& 45.5 \\
& 45.5 \\
& 45.5 \\
& 45.5 \\
& 44.0 \\
& 44.0 \\
& 44.1 \\
& 43.9 \\
& 43.9 \\
& 44.1 \\
& 44.1 \\
& 44.1
\end{aligned}
$$$$
\begin{aligned}
& 43.0 \\
& 43.1 \\
& 43.1 \\
& 43.1 \\
& 43.2 \\
& 43.2 \\
& 43.2 \\
& 43.2 \\
& 43.2 \\
& 43.2 \\
& 43.2 \\
& 43.2 \\
& 43.2 \\
& 43.2 \\
& 43.7 \\
& 43.7 \\
& 43.7 \\
& 43.7 \\
& 43.7 \\
& 43.7 \\
& 43.7 \\
& 43.7 \\
& 43.7 \\
& 43.7 \\
& 43.7 \\
& 43.8 \\
& 43.8 \\
& 43.8 \\
& 42.9 \\
& 42.9 \\
& 42.9 \\
& 42.9 \\
& 42.9 \\
& 43.0 \\
& 43.0 \\
& 43.0
\end{aligned}
$$

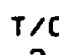

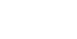

43.0
43.1
43.1
43.1
43.2
43.2
43.2
43.2
43.2
43.2
43.2
43.2
43.2
43.2
43.7
43.7
43.7
43.7
43.7
43.7
43.7
43.7
43.7
43.7
43.7
43.8
43.8
43.8
42.9
42.9
42.9
42.9
42.9
43.0
43.0
43.0

Figure 5. First Page of July 5 Raw I-V Curve Summary

\section{1}


COMPARISON IU CURVE SUMMARY WEDINESIIAY JUL 51978

\begin{tabular}{|c|c|c|c|}
\hline $\begin{array}{l}\text { RÉADUUT } \\
\text { TIME }\end{array}$ & $\begin{array}{l}\text { SOLAR } \\
\text { MODULE }\end{array}$ & ISC & voc \\
\hline $\begin{array}{l}10: 43: 18 \\
10: 43: 18\end{array}$ & $\begin{array}{l}17 / \text { SB } 6 / 1 \\
18 / S E 7 / 1\end{array}$ & $\begin{array}{l}0.418 \\
0.414\end{array}$ & $\begin{array}{l}13.214 \\
13.199\end{array}$ \\
\hline $\begin{array}{l}10: 43: 21 \\
10: 43: 23 \\
10: 43: 25\end{array}$ & $\begin{array}{l}19 / \text { SE8/ } \\
20 / 589 / 1 \\
21 / 500 / 1\end{array}$ & $\begin{array}{l}0.418 \\
0.413 \\
0,410\end{array}$ & $\begin{array}{l}13.263 \\
13.361 \\
13.198\end{array}$ \\
\hline $\begin{array}{l}10: 43: 26 \\
10: 43: 27 \\
10: 43: 28 \\
10: 43: 29\end{array}$ & $\begin{array}{ll}22 / S C 1 / & 1 \\
23 / S C 2 / 1 & 1 \\
24 / S C 3 / & 1 \\
25 / S C 4 / & 1\end{array}$ & $\begin{array}{l}0.399 \\
0.394 \\
0.425 \\
0.407\end{array}$ & $\begin{array}{l}13.152 \\
13.209 \\
13.205 \\
13.143\end{array}$ \\
\hline $\begin{array}{l}10: 43: 30 \\
10: 43: 31\end{array}$ & $\begin{array}{l}26 / \text { SC5/ } 1 \\
27 / \text { SC } 6 / 1\end{array}$ & $\begin{array}{l}0.405 \\
0.425\end{array}$ & $\begin{array}{r}13.165 \\
13.333\end{array}$ \\
\hline $10: 43: 32$ & $28 / S C>1$ & 0.403 & 13.283 \\
\hline $\begin{array}{l}10: 43: 33 \\
10: 43: 34\end{array}$ & $\begin{array}{l}29 / \text { SCB/ } \\
30 / \text { SC } 9 / 1\end{array}$ & $\begin{array}{l}0.439 \\
0.423\end{array}$ & $\begin{array}{l}13.324 \\
13.227\end{array}$ \\
\hline $10: 43: 35$ & $33 / 5512 / i$ & 0.410 & 13.218 \\
\hline & $34 / 5[13 /$ & 0.411 & 13.140 \\
\hline $10: 43: 37$ & $35 / 5[14 /$ & 0.413 & 13.298 \\
\hline $10: 43: 38$ & $36 /$ SIIS/ 1 & 0.416 & 13.248 \\
\hline $\begin{array}{l}10: 43: 39 \\
10: 43: 40\end{array}$ & $\begin{array}{l}37 / \text { SDi6/ } 1 \\
38 / \text { SD7/ } 1\end{array}$ & $\begin{array}{l}0.408 \\
0.423\end{array}$ & $\begin{array}{l}13.174 \\
13.268\end{array}$ \\
\hline $10: 43: 41$ & $39 / 518 / 1$ & 0.421 & 13.101 \\
\hline $10: 43: 42$ & $40 / 5[19 /$ & 0.424 & 13.252 \\
\hline $43: 43$ & $41 /$ SEO & 0.458 & 13.299 \\
\hline $10: 43: 43$ & 42/SE1/ 1 & 0.425 & 13.232 \\
\hline $\begin{array}{l}10: 43: 45 \\
10: 43: 46\end{array}$ & A3/SE2/ & & $\begin{array}{l}13.072 \\
13.249\end{array}$ \\
\hline & & & 13.249 \\
\hline $10: 43: 47$ & 45/SEA/ 1 & 0.418 & 13.254 \\
\hline $\begin{array}{l}10: 43: 48 \\
10: 43: 49\end{array}$ & $46 /$ SES/ 1 & 0.416 & 13.244 \\
\hline $10: 43: 49$ & 49/SE8/ & 0.441 & 12.917 \\
\hline $10: 43: 50$ & SO/SE9/ & 0.421 & 13.240 \\
\hline $10: 43: 51$ & S1/SFO/ 1 & 0.439 & 13.245 \\
\hline $10: 43: 53$ & $53 / 5 F 21$ & 0.443 & $\begin{array}{l}13.042 \\
13.264\end{array}$ \\
\hline $10: 43: 53$ & $54 / S F 3 /$ & 0.441 & 13.284 \\
\hline $10: 43: 54$ & SE/SFA/ 1 & 0.440 & 13.292 \\
\hline $10: 43: 56$ & $56 / 5 F 5 /$ & 0.464 & 13.270 \\
\hline $10: 43: 57$ & $57 / 5 F 6 /$ & 0.438 & 13.271 \\
\hline
\end{tabular}

$\begin{array}{llll}\text { FEAK } & \text { IE } & \text { FILL } & \text { AKEA/ } \\ \text { FOWER } & \text { FKFWR } & \text { FACTOR } & \text { ISC*VOC } \\ & & & \\ 4.144 & 0.392 & .7503 & .9119 \\ 4.152 & 0.388 & .7598 & . .9126 \\ 4.288 & 0.399 & .7735 & .9251 \\ 4.248 & 0.394 & .7698 & .9232 \\ 4.212 & 0.392 & .7784 & .9239 \\ 4.076 & 0.373 & .7767 & .9217 \\ 4.040 & 0.372 & .7763 & .9263 \\ 4.296 & 0.406 & .7655 & .9228 \\ 4.024 & 0.377 & .7523 & .9156 \\ 4.060 & 0.386 & .7615 & .9125 \\ 4.260 & 0.386 & .7518 & .9162 \\ 4.140 & 0.376 & .7734 & .9208 \\ 4.456 & 0.409 & .7618 & .9176 \\ 4.164 & 0.392 & .7442 & .9134 \\ 4.100 & 0.391 & .7568 & .9180 \\ 4.104 & 0.387 & .7599 & .9207 \\ 4.204 & 0.384 & .7655 & .9340 \\ 4.192 & 0.383 & .7606 & .9214 \\ 4.104 & 0.389 & .7635 & .9228 \\ 4.256 & 0.390 & .7583 & .9192 \\ 4.136 & 0.384 & .7499 & .9128 \\ 4.172 & 0.391 & .7425 & .9122 \\ 4.408 & 0.412 & .7237 & .9050 \\ 4.172 & 0.393 & .7419 & .9135 \\ 3.912 & 0.380 & .7264 & .9028 \\ 4.044 & 0.379 & .7555 & .9176 \\ 4.144 & 0.385 & .7480 & .9149 \\ 4.148 & 0.376 & .7529 & .9035 \\ 4.280 & 0.409 & .7514 & .9157 \\ 4.288 & 0.398 & .7693 & .9223 \\ 4.380 & 0.410 & .7533 & .9205 \\ 4.480 & 0.419 & .7546 & .9169 \\ 4.400 & 0.407 & .7591 & .9207 \\ 4.412 & 0.408 & .7531 & .9183 \\ 4.452 & 0.413 & .7612 & .9183 \\ 4.436 & 0.421 & .7204 & .9017 \\ 4.360 & 0.403 & .7501 & .9212 \\ & & & \\ 4.3196 & \end{array}$

Figure 6 - Comparison I-V Curve Summary for Data on Figure 5 
F.PFANIJMETER: [IATA SUMMAFY

WELINESLIAY

JUL $\$ 1978$

SUNFISE SOLAFNOOH SUHSET [IECLINATIOH EON DF TIME

4:50:47 11:57:9 19:3:31 N $2247.6 \quad 4: 27$

\begin{tabular}{|c|c|c|}
\hline $\begin{array}{l}\text { REALIOUT } \\
\text { TIME }\end{array}$ & $\begin{array}{l}\text { DORIC } \\
\text { DEUIEE }\end{array}$ & $\begin{array}{l}\text { REATIUU] } \\
\text { SIATA }\end{array}$ \\
\hline $\begin{array}{l}8: 11: 19 \\
8: 19: 55 \\
\theta: 29: 55\end{array}$ & $\begin{array}{l}120 / \mathrm{ML} \\
120 / \text { ILS? } \\
120 / \mathrm{ML} 9\end{array}$ & $\begin{array}{l}53.056 \\
54.387 \\
58.458\end{array}$ \\
\hline $\begin{array}{l}8: 39: 56 \\
8: 49: 56 \\
8: 59: 55\end{array}$ & $\begin{array}{l}120 / 0109 \\
120 / \text { IIL } 9 \\
120 / \text { IIL9 }\end{array}$ & $\begin{array}{l}60.271 \\
61.190 \\
65.869\end{array}$ \\
\hline $\begin{array}{l}9: 9: 55 \\
9: 18: 15 \\
9: 28: 16 \\
9: 38: 15 \\
9: 48: 15 \\
9: 58: 16\end{array}$ & 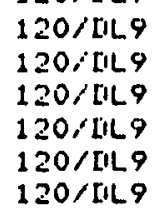 & $\begin{array}{l}58.110 \\
70.718 \\
72.146 \\
75.718 \\
76.548 \\
78.852\end{array}$ \\
\hline $\begin{array}{l}10: 8: 15 \\
10: 18: 15 \\
10: 28: 16 \\
10: 38: 15 \\
10: 48: 15 \\
10: 58: 16\end{array}$ & $\begin{array}{l}120 / \text { ILG } \\
120 / \mathrm{LL} 9 \\
120 / \mathrm{LL} 9 \\
120 / \text { IIL9 } \\
120 / \text { IIL9 } \\
120 / \text { IIL9 }\end{array}$ & $\begin{array}{l}80.799 \\
80.816 \\
82.584 \\
84.620 \\
85.165 \\
86.218\end{array}$ \\
\hline $\begin{array}{l}11: 8: 15 \\
11: 18: 15\end{array}$ & $\begin{array}{l}120 / 0 \mathrm{LL} 9 \\
120 / \mathrm{OL} 9\end{array}$ & $\begin{array}{l}88.067 \\
88.504\end{array}$ \\
\hline $\begin{array}{l}11: 28: 16 \\
11: 38: 15\end{array}$ & $\begin{array}{l}120 / \text { ILL } \\
120 / \text { UL } 9\end{array}$ & $\begin{array}{l}89.710 \\
86.727\end{array}$ \\
\hline $11: 48: 15$ & $120 /$ IIL 9 & 89.549 \\
\hline $\begin{array}{l}11: 58: 16 \\
12: 8: 15\end{array}$ & $\begin{array}{l}120 / \text { LL } 9 \\
120 / \text { L } 9\end{array}$ & $\begin{array}{l}87.799 \\
88.165\end{array}$ \\
\hline $\begin{array}{l}12: 18: 15 \\
12: 28: 17\end{array}$ & $\begin{array}{l}120 / \text { LL } 9 \\
120 / \text { LIL } 9\end{array}$ & $\begin{array}{l}87.174 \\
87.343\end{array}$ \\
\hline $\begin{array}{l}12: 38: 15 \\
12: 48: 15 \\
12: 58: 16 \\
13: 8: 15 \\
13: 18: 15 \\
13: 28: 16\end{array}$ & $\begin{array}{l}120 / \text { IIL9 } \\
120 / \text { IIL9 } \\
120 / \text { IIL9 } \\
120 / \text { ILL } \\
120 / \text { ILL } \\
120 / \text { IIL9 }\end{array}$ & $\begin{array}{l}87.763 \\
87.558 \\
84.933 \\
82.808 \\
81.495 \\
79.941\end{array}$ \\
\hline & na & \\
\hline
\end{tabular}

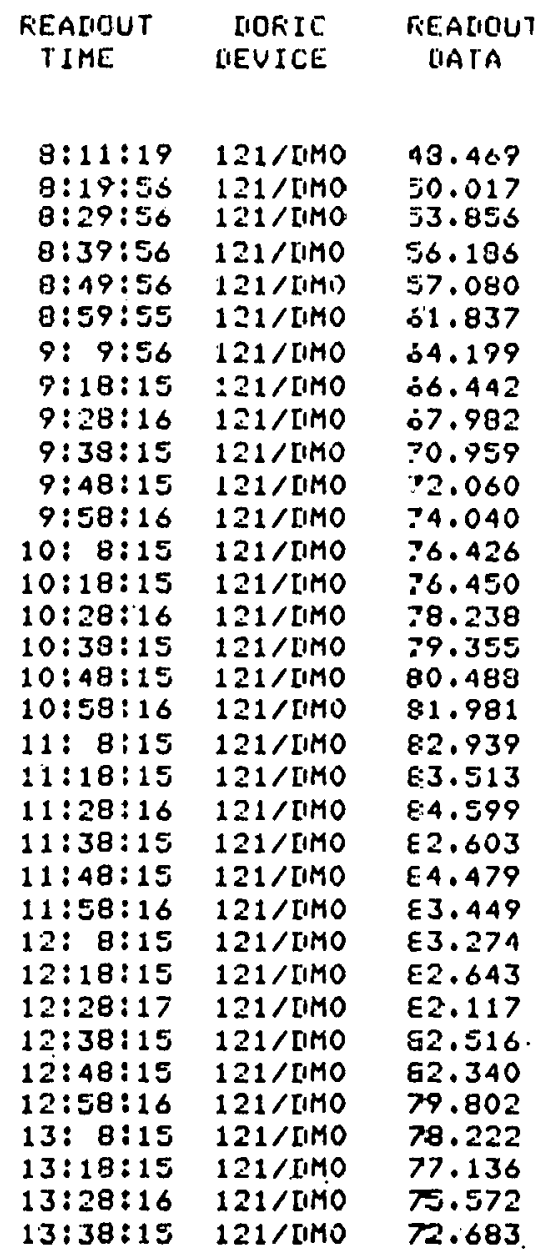

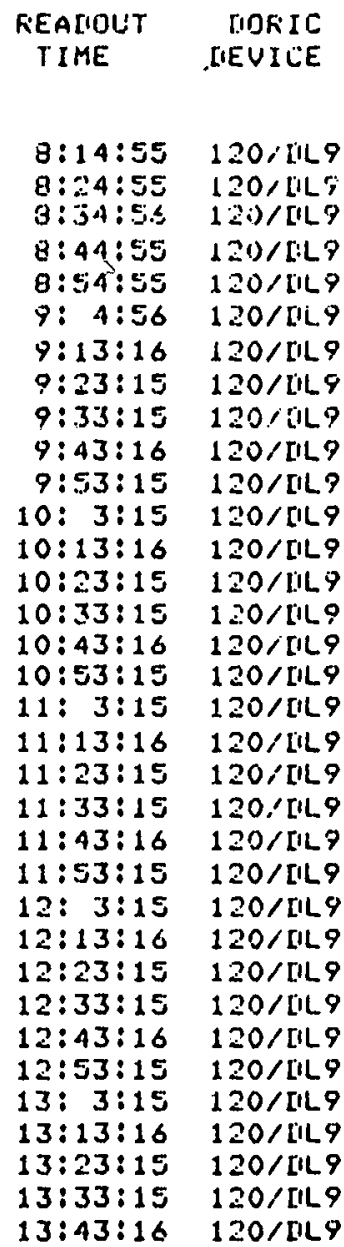

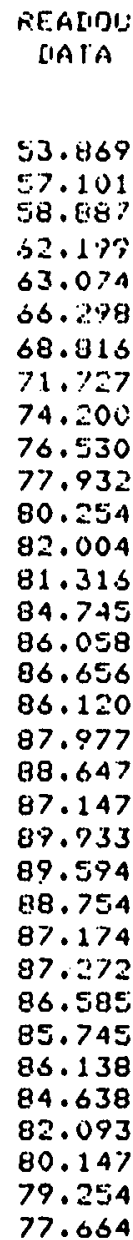

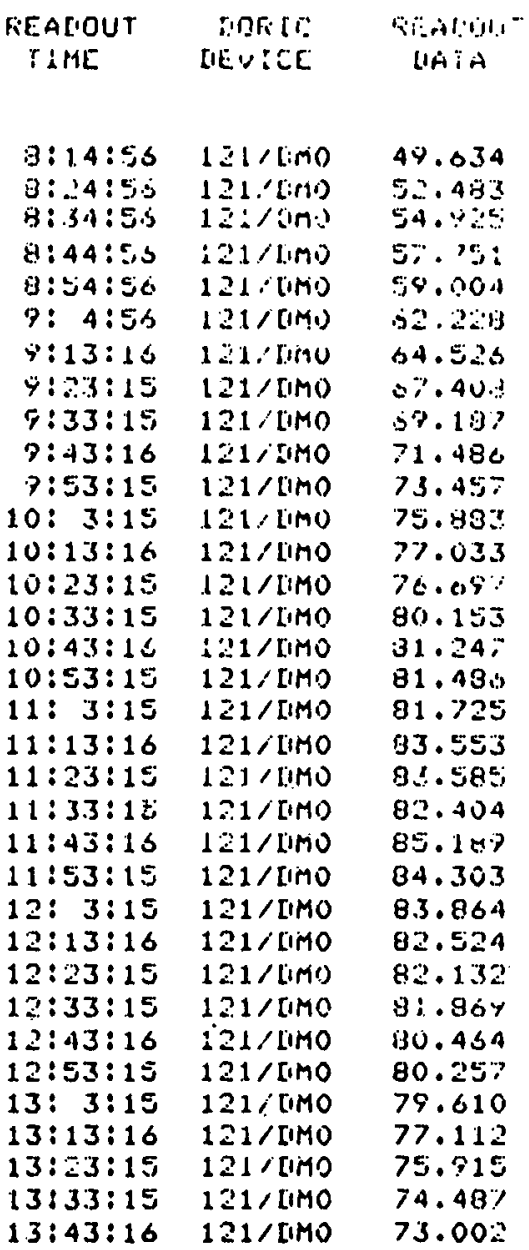

Figure 7 . Portion of Pyranometer Data Summary for July 5 
WEATHER IIATA SUMMARY

$$
\begin{aligned}
& \text { WEIINESLIAY } \\
& \text { JUL } 51978
\end{aligned}
$$

\begin{tabular}{|c|c|c|c|c|c|c|c|}
\hline $\begin{array}{l}\text { REALOUT } \\
\text { TIME } \\
\text { HH:MM:SS }\end{array}$ & $\begin{array}{l}\text { AIR } \\
\text { TEMP } \\
\text { (LEG C) }\end{array}$ & $\begin{array}{l}\text { WINII } \\
\text { SPEEII } \\
\text { (MFH) }\end{array}$ & $\begin{array}{c}\text { WINI } \\
\text { IIRECTION } \\
(N=0, W=90)\end{array}$ & $\begin{array}{l}\text { F'RECI - } \\
\text { F'ITATION } \\
\text { (INCHES) }\end{array}$ & $\begin{array}{c}\text { FELATIUE } \\
\text { HUMI IITY } \\
(\%)\end{array}$ & $\begin{array}{l}\text { BAROMETKIC } \\
\text { FRESSURE } \\
\text { (ME) }\end{array}$ & $\begin{array}{l}\text { TKAILEK } \\
\text { TEMF } \\
\text { (IIEG C) }\end{array}$ \\
\hline $\begin{array}{l}8: 30: 10 \\
8: 45: 10 \\
9: 0: 10 \\
9: 13: 16 \\
9: 28: 16 \\
9: 43: 16\end{array}$ & $\begin{array}{l}20.50 \\
21.00 \\
20.80 \\
21.90 \\
22.00 \\
22.40\end{array}$ & $\begin{array}{l}0.00 \\
0.90 \\
2.90 \\
2.90 \\
0.40 \\
2.90\end{array}$ & $\begin{array}{l}200.16 \\
172.08 \\
184.32 \\
147.60 \\
147.60 \\
165.24\end{array}$ & $\begin{array}{l}0.00 \\
0.00 \\
0.00 \\
0.00 \\
0.00 \\
0.00\end{array}$ & $\begin{array}{l}62.5 \\
62.5 \\
62.5 \\
60.0 \\
58.1 \\
54.6\end{array}$ & $\begin{array}{l}965.5 \\
980.6 \\
965.9 \\
965.0 \\
964.0 \\
965.5\end{array}$ & $\begin{array}{l}23.90 \\
24.10 \\
24.20 \\
24.60 \\
24.70 \\
24.80\end{array}$ \\
\hline $\begin{array}{r}9: 58: 16 \\
10: 13: 16 \\
10: 28: 16 \\
10: 43: 16 \\
10: 43: 32 \\
10: 43: 42 \\
10: 43: 52 \\
10: 44: 1 \\
10: 44: 11 \\
10: 44: 21\end{array}$ & $\begin{array}{l}23.20 \\
23.20 \\
24.10 \\
24.60 \\
24.50 \\
24.60 \\
24.60 \\
24.80 \\
24.40 \\
24.20\end{array}$ & $\begin{array}{l}1.90 \\
2.40 \\
0.90 \\
4.30 \\
5.30 \\
5.80 \\
4.80 \\
3.40 \\
6.80 \\
6.80\end{array}$ & $\begin{array}{l}173.88 \\
128.16 \\
150.84 \\
144.00 \\
133.56 \\
140.40 \\
131.76 \\
131.76 \\
133.56 \\
126.36\end{array}$ & $\begin{array}{l}0.00 \\
0.00 \\
0.00 \\
0.00 \\
0.00 \\
0.00 \\
0.0 .0 \\
0.00 \\
0.00 \\
0.00\end{array}$ & $\begin{array}{l}54.2 \\
52.7 \\
51.2 \\
50.7 \\
50.2 \\
50.2 \\
50.2 \\
50.2 \\
50.2 \\
49.8\end{array}$ & $\begin{array}{l}965.9 \\
964.5 \\
964.5 \\
965.9 \\
965.5 \\
964.5 \\
965.0 \\
965.9 \\
964.0 \\
964.0\end{array}$ & $\begin{array}{l}24.60 \\
25.00 \\
24.10 \\
21.90 \\
22.00 \\
21.90 \\
21.90 \\
21.90 \\
21.90 \\
21.90\end{array}$ \\
\hline $\begin{array}{l}10: 44: 32 \\
10: 44: 42\end{array}$ & $\begin{array}{l}24.20 \\
24.20\end{array}$ & $\begin{array}{l}5.80 \\
6.80\end{array}$ & $\begin{array}{l}126.36 \\
115.92\end{array}$ & $\begin{array}{l}0.00 \\
0.00\end{array}$ & $\begin{array}{l}49.3 \\
49.3\end{array}$ & $\begin{array}{l}964.5 \\
964.0\end{array}$ & $\begin{array}{l}21.90 \\
21.90\end{array}$ \\
\hline $\begin{array}{l}10: 44: 53 \\
10: 45: 3 \\
10: 45: 13\end{array}$ & $\begin{array}{l}24.20 \\
24.00 \\
23.90\end{array}$ & $\begin{array}{l}6.30 \\
4.80 \\
4.30\end{array}$ & $\begin{array}{l}117.72 \\
114.12 \\
114.12\end{array}$ & $\begin{array}{l}0.00 \\
0.00 \\
0.00\end{array}$ & $\begin{array}{l}49.3 \\
49.3 \\
49.3\end{array}$ & $\begin{array}{l}.965 .5 \\
964.0 \\
964.0\end{array}$ & $\begin{array}{l}21.90 \\
21.80 \\
21.70\end{array}$ \\
\hline $\begin{array}{l}10: 45: 23 \\
10: 45: 34 \\
10: 45: 44\end{array}$ & $\begin{array}{l}23.90 \\
24.10 \\
24.00\end{array}$ & $\begin{array}{l}3.90 \\
3.90 \\
2.90\end{array}$ & $\begin{array}{l}115.92 \\
115.92 \\
115.92\end{array}$ & $\begin{array}{l}0.00 \\
0.00 \\
0.00\end{array}$ & $\begin{array}{l}48.8 \\
49.3 \\
48.8\end{array}$ & $\begin{array}{l}964.0 \\
964.5 \\
964.0\end{array}$ & $\begin{array}{l}21.80 \\
21.80 \\
21.80\end{array}$ \\
\hline $\begin{array}{l}10: 45: 54 \\
10: 46: 4 \\
10: 46: 14 \\
10: 46: 25 \\
10: 46: 36 \\
10: 46: 46 \\
10: 46: 56 \\
10: 58: 16 \\
11: 13: 16\end{array}$ & $\begin{array}{l}24 \cdot 00 \\
24 \cdot 10 \\
24.30 \\
24.30 \\
24.20 \\
24.20 \\
24.30 \\
24.50 \\
25.20\end{array}$ & $\begin{array}{l}2.90 \\
4.30 \\
4.80 \\
4.30 \\
2.40 \\
2.90 \\
2.90 \\
4.30 \\
0.90\end{array}$ & $\begin{array}{l}120.96 \\
120.96 \\
119.52 \\
117.72 \\
120.96 \\
126.36 \\
147.60 \\
112.32 \\
110.52\end{array}$ & $\begin{array}{l}0.00 \\
0.00 \\
0.00 \\
0.00 \\
0.00 \\
0.00 \\
0.00 \\
0.00 \\
0.00\end{array}$ & $\begin{array}{l}48.8 \\
49.3 \\
49.8 \\
50.2 \\
50.2 \\
50.2 \\
50.2 \\
47.8 \\
45.9\end{array}$ & $\begin{array}{l}964.0 \\
965.0 \\
964.0 \\
965.5 \\
965.0 \\
964.0 \\
965.0 \\
965.5 \\
965.5\end{array}$ & $\begin{array}{l}21.80 \\
21.80 \\
21.80 \\
21.80 \\
21.60 \\
21.70 \\
21.80 \\
21.80 \\
21.60\end{array}$ \\
\hline $\begin{array}{l}11: 28: 16 \\
11: 43: 16 \\
11: 58: 16 \\
12: 13: 16\end{array}$ & $\begin{array}{l}26.30 \\
25.60 \\
25.80 \\
26.30\end{array}$ & $\begin{array}{l}3.90 \\
3.40 \\
2.90 \\
3.90\end{array}$ & $\begin{array}{l}170.28 \\
177.48 \\
112.32 \\
145.80\end{array}$ & $\begin{array}{l}0.00 \\
0.00 \\
0.00 \\
0.00\end{array}$ & $\begin{array}{l}44.4 \\
43.9 \\
43.4 \\
42.9\end{array}$ & $\begin{array}{l}964.5 \\
963.5 \\
965.0 \\
963.5\end{array}$ & $\begin{array}{l}21.50 \\
21.80 \\
21.80 \\
21.80\end{array}$ \\
\hline
\end{tabular}

Figure 8 . Portion of Weather Data Summary for July 5 
The test procedure for a typical weekday is as follows:

(1) First thing in the morning the pyranometers are cleaned:

(2) At 8:00 a.m. (PST) Summaries 2 and 4, the Insolation and Weather Task Summaries, automatically run; the data is listed on the line printer. An inspection of this data is made to see if everything is working correctly, and specifically to see if the determination of solar noon appears correct.

(3) Sometime before the triggering insolation level of 85 $\mathrm{mW} / \mathrm{cm}^{2}$, an interactive program called WARMUP is run. WARMUP exercises all the devices that are used in the daily acquisition.

(4) At either an insolation level of $85 \mathrm{mH} / \mathrm{cm}^{2}$ or solar noon, whichever comes first, SOLARI is automatically run. If the insolation level does not get above $40 \mathrm{~mW} / \mathrm{cm}^{2}$ before solar noon or if it has rained since midnight, SOLARl will not run.

(5) At 30 minutes after solar noon the Corrected Data Task and Summaries 2 and 4 , the Raw $I-V$ and Comparison $I-V$ Sumary Tasks, are automatically run; the data is listed on the line printer. Raw $I-V$ data is retained in a file until it is superceded by another set of data, probably the following day.

(6) A careful inspection of the I-V Summary data is made to determine if the modules are behaving normally. This iuspection is faclilcaced by looking at delta values in the Comparison I-V Summary. Modules that are not performing properly can usually be detected here. Once these modules are flagged, the data from them is retrieved using the RECALl functions and a hard copy of the I-V curve plot is made on the CRT. These I-V curves are then put into a log. Often the anomalous behavior does not recur. When a module is flagged several times a thorough examination, both physical and electrical, of the module, the wiring, and the multiplexor is made to determine if the problem is within the module or the instrumentation. When a module exhibits chronic problems (or if it fails outright) it is removed from the field and a Problem/Failure Report (PFR) written on it.

Once a week, usually Tuesday morning before the acquisition of data, the field is washed. The modules are washed with a solution of Tide and Labtone (a laboratory glass cleaner). The cleaning solution is applied with a combination sponge and squeegee. The modules are then rinsed with a hose and squeegeed dry, followed by a thorough wiping with a chamois. The data obtained just after washing is usually selected in the weekly archiving process for the archived Reference I-V Curve File. Therefore, the records in this file are consistently for clean modules. 
Test Results

For quick reference a condensed summary is given below. A detailed summary is given on the following pages.

(1) Data from the field indicates that the Block II modules are superior, across the board, to the Block I modules. To date, there have been no Block II failures and no significant degradation patterns emerging. In the same length of time as the Block II modules have been in the field, some of the Block I modules had already shown chronic problems and greater degradation patterns.

(2) The JPL dirt data, taken under conditions of inactive weather and small tilt angle, showed no difference between glass and silicone rubber. A representative 30-day, short-circuit current dirt degradation value for JPL in the summer is $7 \%$. The test results also confirm what was already suspected, i.e., that the effects of dirt on performance are highly dependent upon the local dirt condition and the availability of natural cleaning: rain and wind. 
TEST RESULTS

A. JPL SITE

1. Electrical Degradation

As indicated earlier the Block I modules have typically been in the field for a year and a half and the Block II modules a year. Until August 1977, module performance was tracked with the LAPSS system across the road in Building 248. About every two months, the modules were taken down, carried across the street, and interrogated with the LAPSS system. Except for modules that eventually failed and were removed from the field, the power degradation from the time they were placed there was generally less than $8 \%$. Usually those modules in the $5 \%$ to $8 \%$ category were those that had undergone severe environmental testing.

Module "dedicated" data has been obtained with the in-situ field test data system on a semi-regular basis since mid-February. In order to provide data continuity between when the modules were first put there and when the data system. took over, a comparison between the LAPSS data and the data system data had to be made. Ideally, one would like to take the data obtained with the data system, apply temperature and insolation corrections, and derive a set of data directly comparable to the LAPSS data. Unfortunately, this procedure has been found to yield data scatter which masks the change in module output. The problem appears to relate both to the algorithms used to correct the data (Sandstrom equations) and to the necessary test charactcrisation, specifically the means of deterwining the appropriate test insolation level for data correction purposes. This can be made clearer by looking at the Comparison I-V Data presented in Figure 6. The $I_{s c}$ of the whole family shows an increase in performance of about $5 \%$ when compared with the Reference I-V Data, which was obtained about a week before. It is inconceivable that all members of the family would physically experience the same kind of change. A comparison between the corresponding pyranometer data and the reference cell data shown in the Raw I-V Data Summary (see Figure 5) also shows a difference of about the same amount. If, as a matter of fact, the pyranometer data had been used to correct the data, instead of the reference cell data, the delta $I_{s c}$ values would have been much closer. The example presented here is not unusual but is a common observation from the data obtained over the past several months. An investigation of this problem is currently being undertaken and is discussed later.

An alternative approach to comparing the LAPSS data with data system data, which does not have the problems discussed above, is to use the fill-factor as a measure of the health of the modules since many important degradation modes result in a change in the shape of the I-V curve and, therefore, the fill-factor. Furthermore, for a module whose short-circuit current under test accurately describes the test insolation level, a change in the fill-factor is directly 
proportional to a change in the maximum power output, at least to the first order. To establish the repeatability of this parameter under various test conditions, five Block II modules (two Sensor Tech and one from each of the other manufacturers) were tested. After interrogation under different conditions with the field test data system, each module was interrogated three times with the LAPSS system, then returned to the field where another set of data was obtained. These were then plotted as a function of insolation level; the results are shown in Table 3.

These results show that the mean field test data system fillfactors compare with the LAPSS data by $1 \%$ or better; the corresponding data scatter ranges from $1 \%$ to $2 \%$. Some of the differences and scatter can possibly be attributed to temperature differences between the LAPSS and the test data, and between the data points themselves, but additional information is required to quantify these effects. The test data also show an interesting relationship between insolation level and fill-factor (last column in Table 3). The results indicate that there is no universal pattern for the different types of modules. Future work is being planned to investigate these relationships. Taking everything into account, the results indicate that for the sarde module the fill-facluss ullained with the LAPSS system and field test system data should agree by $2 \%$ to $3 \%$. Therefore, as an example, if the measured fill-factor obtained with the field test data system differs by 67 from the fill-factor obtained with the LAPSS system prior to placing a module in the field, the module fill-factor has degraded by at least $3 \%$.

An initial field status survey was made using this concept in mid-February; these results were presented at the 9 th Project Integration Meeting in April. Since then the process has been upgraded and during the period May 11 to May 31 an extensive survey was made of the modules in the field. A special computer program was written (FLDLPS) which makes five consecutive interrogation loops of the total field and stores the complete $I-V$ curve for each module for. the fifth loop. It also stores the fill-factors for the previous four loops and the pyranometer readings for all modules during all five loops. Figure 9 presents the first page of the program output for May 18. At the heading is the starting and finishing time for each loop and the corresponding pyranometer readings. Typically a loop took three minutes. Below this heading is a presentation of the module data for the fifth loop, and a fill-factor summary of the five loops. The five columns at the right contain this summary. The first two columns identify the module and the next two are status codes. The fifth contains the number of raw data points and the next four are peak-power, current at peak-power, short-circuit current, and open-circuit voitage, respectively. The PYRO column is the Eppley pyranometer reading.

Twelve similar interrogations were made during the period stated above. These results were then fed into an analysis program (FLDLPR) which summarized each interrogation, corrected the fifth loop data to a common insolation level, and compared the 12 interrogations. Figure 10 contains the sumary listing for module 41 ( $M u x 3$, Module 9). The date and time are self explanatory; NLP is the number of loops - 
Table 3. Fill-Factor Correlation

\begin{tabular}{|c|c|c|c|c|c|}
\hline Module & $\begin{array}{c}(1) \\
\text { LAPSS } \\
\text { Fill-Factor }\end{array}$ & $\begin{array}{l}\text { (2) } \\
\text { Mean Field* } \\
\text { Fill-Factor }\end{array}$ & $\begin{array}{c}(3) \\
\text { Difference } \\
(\%)\end{array}$ & $\begin{array}{c}(4) \\
\text { from Mean } \\
(\%)\end{array}$ & $\begin{array}{l}\text { Trend with Decreas- } \\
\text { Ing Insolation }\end{array}$ \\
\hline $\begin{array}{c}\text { Sensor Tech } \\
\text { (1) }\end{array}$ & 0.758 & 0.751 & 0.9 & \pm 1.5 & $\begin{array}{l}\text { Linear to } 50 \mathrm{~mW} / \mathrm{cm}^{2} \\
\text { then decreasing }\end{array}$ \\
\hline $\begin{array}{c}\text { Sensor Tech } \\
\text { (2) }\end{array}$ & 0.754 & 0.749 & 0.7 & \pm 1.2 & $\begin{array}{l}\text { Linear to } 50 \mathrm{~mW} / \mathrm{cm}^{2} \\
\text { then decreasing }\end{array}$ \\
\hline Spectrolab & 0.711 & 0.714 & 0.4 & \pm 1.8 & $\begin{array}{l}\text { Increasing then level } \\
\text { after } 60 \mathrm{~mW} / \mathrm{cm}^{2}\end{array}$ \\
\hline Solarex & 0.628 & 0.621 & $i .1$ & \pm 1.0 & $\begin{array}{l}\text { Linear to } 60 \mathrm{~mW} / \mathrm{cm}^{2} \\
\text { then decreasing }\end{array}$ \\
\hline Solar Power & 0.741 & 0.741 & 0.4 & \pm 2.0 & $\begin{array}{l}\text { Increasing then level } \\
\text { after } 60 \mathrm{~mW} / \mathrm{cm}^{2}\end{array}$ \\
\hline
\end{tabular}

*In the 60 to $100 \mathrm{~mW} / \mathrm{cm}^{2}$ range

Note: The first column contains the average of the three LAPSS flashes; the LAPSS data scatter was less than $0.5 \%$. The second column contains the mean fill-factor from the many data system interrogations in the 60 to $100 \mathrm{~mW} / \mathrm{cm}^{2}$ range. The third column compares the first two. Column four is the scatter of the values in column two. 


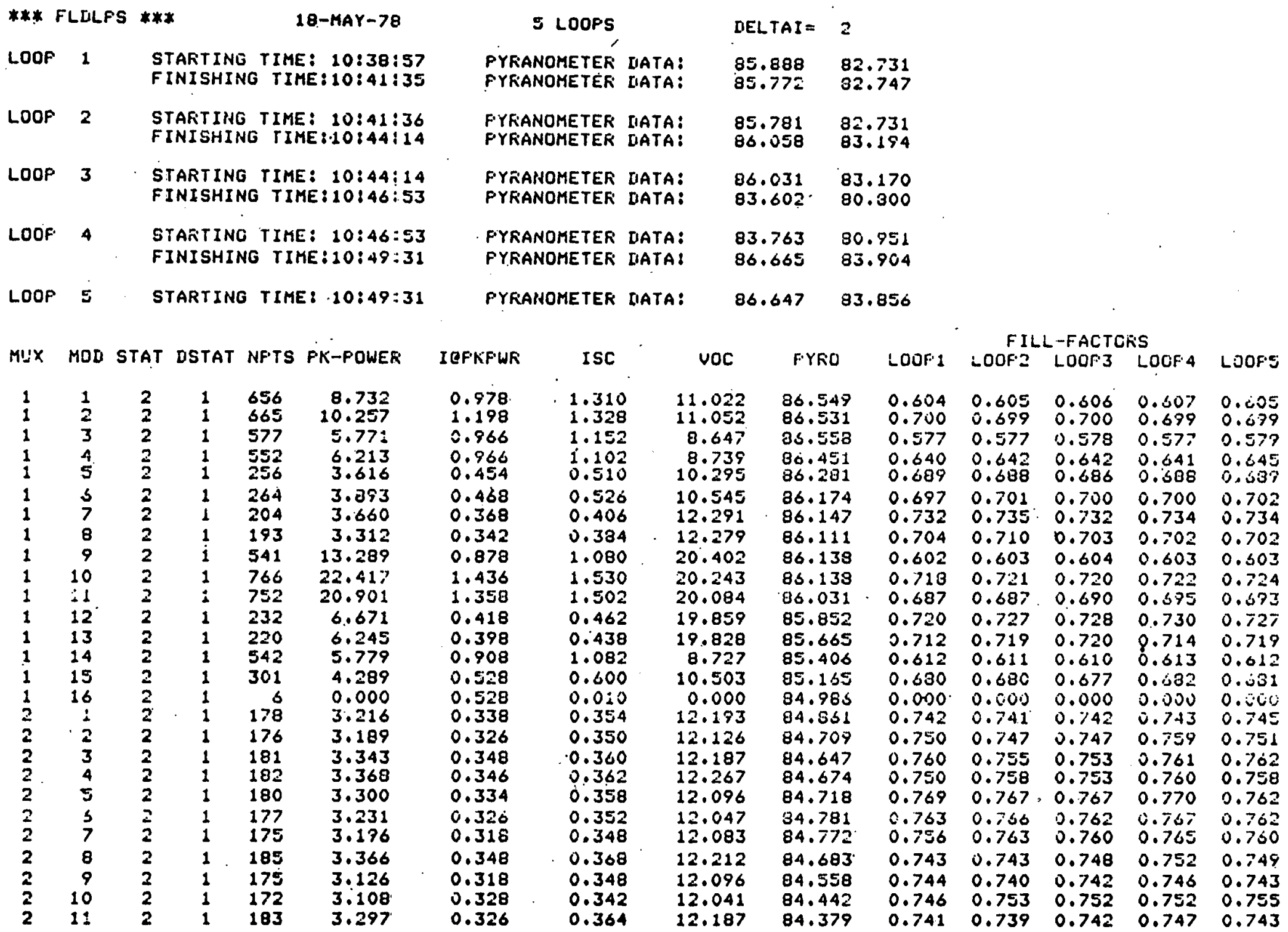

Figure. 9. Portion of FLDLPS Listing for May 18 
SUMMAFY FOK MUX '3 MOIIULE' 9. 12-JUN-78

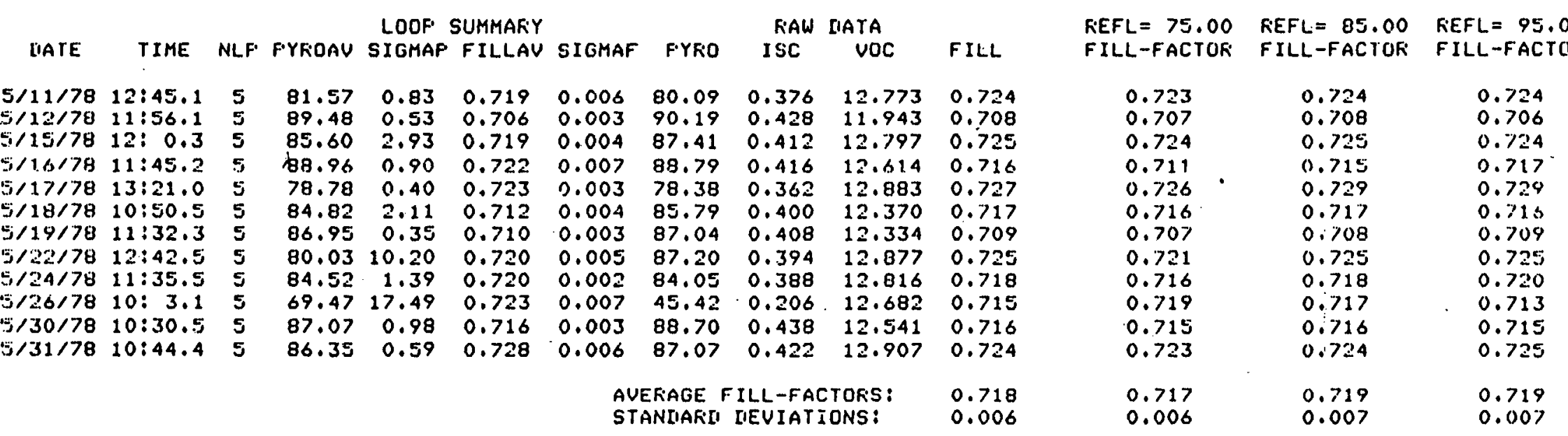

SUMMAKY FOK MUX 3 MOIIULE 10, 12-JUN-78

\begin{tabular}{|c|c|c|c|c|c|c|c|c|c|c|c|c|c|}
\hline IIATE & TIME & $N L F$ & F'YKODAU & $\begin{array}{l}\text { LOOF } \\
\text { SIGMAF }\end{array}$ & $\begin{array}{l}\text { SUMMARY } \\
\text { FILLAV }\end{array}$ & SIGMAF & FYYKOO & $\begin{array}{l}\text { KAW } \\
\text { ISC }\end{array}$ & $\begin{array}{l}\text { DATA } \\
\text { VOC }\end{array}$ & FILL & $\begin{array}{l}\text { REFL }=75.00 \\
\text { FILL-FACTOF }\end{array}$ & $\begin{array}{l}\text { KEFL }=85.00 \\
\text { FILL-FACTOK }\end{array}$ & $\begin{array}{l}\text { FEFL }=95.00 \\
\text { FILL-FAC TOF }\end{array}$ \\
\hline $\begin{array}{l}5 / 11 / 78 \\
5 / 12 / 78 \\
5 / 15 / 78 \\
5 / 16 / 78 \\
5 / 17 / 78 \\
5 / 18 / 78 \\
5 / 19 / 78 \\
5 / 22 / 78 \\
5 / 21 / 78 \\
5 / 26 / 78 \\
5 / 30 / 78 \\
5 / 31 / 78\end{array}$ & $\begin{array}{l}12: 45.1 \\
11: 56.1 \\
12: 0.3 \\
11: 45.2 \\
13: 21.0 \\
10: 50.5 \\
11: 32.3 \\
12: 42.6 \\
11: 35.5 \\
10: 3.1 \\
10: 30.6 \\
10: 44.4\end{array}$ & $\begin{array}{l}5 \\
5 \\
5 \\
5 \\
5 \\
5 \\
5 \\
5 \\
5 \\
5 \\
5 \\
5\end{array}$ & $\begin{array}{l}81.56 \\
89.47 \\
85.62 \\
88.96 \\
78.77 \\
84.81 \\
86.95 \\
79.92 \\
84.51 \\
69.58 \\
87.09 \\
86.36\end{array}$ & $\begin{array}{r}0.82 \\
0.54 \\
2.94 \\
0.89 \\
0.40 \\
2.13 \\
0.34 \\
10.29 \\
1.39 \\
17.76 \\
0.98 \\
0.57\end{array}$ & $\begin{array}{l}0.743 \\
0.722 \\
0.740 \\
0.743 \\
0.749 \\
0.731 \\
0.730 \\
0.744 \\
0.744 \\
0.745 \\
0.738 \\
0.749\end{array}$ & $\begin{array}{l}0.005 \\
0.002 \\
0.005 \\
0.002 \\
0.001 \\
0.005 \\
0.003 \\
0.003 \\
0.003 \\
0.005 \\
0.003 \\
0.004\end{array}$ & $\begin{array}{l}80.10 \\
90.19 \\
87.55 \\
88.80 \\
78.35 \\
85.80 \\
87.06 \\
87.18 \\
84.07 \\
44.99 \\
88.70 \\
87.05\end{array}$ & $\begin{array}{l}0.344 \\
0.396 \\
0.380 \\
0.380 \\
0.334 \\
0.370 \\
0.374 \\
0.366 \\
0.356 \\
0.188 \\
0.406 \\
0.390\end{array}$ & $\begin{array}{l}12.700 \\
11.882 \\
12.718 \\
12.584 \\
12.810 \\
12.279 \\
12.267 \\
12.810 \\
12.767 \\
12.578 \\
12.492 \\
12.852\end{array}$ & $\begin{array}{l}0.749 \\
0.724 \\
0.741 \\
0.740 \\
0.751 \\
0.731 \\
0.731 \\
0.742 \\
0.741 \\
0.740 \\
0.732 \\
0.743\end{array}$ & $\begin{array}{l}0.749 \\
0.726 \\
0.740 \\
0.739 \\
0.750 \\
0.731 \\
0.730 \\
0.742 \\
0.740 \\
0.733 \\
0.733 \\
0.745\end{array}$ & $\begin{array}{l}0.748 \\
0.725 \\
0.740 \\
0.740 \\
0.749 \\
0.731 \\
0.730 \\
0.742 \\
0.741 \\
0.729 \\
0.733 \\
0.744\end{array}$ & $\begin{array}{l}0.747 \\
0.723 \\
0.741 \\
0.740 \\
0.746 \\
0.729 \\
0.730 \\
0.741 \\
0.742 \\
0.723 \\
0.731 \\
0.743\end{array}$ \\
\hline & & & & & & \multicolumn{4}{|c|}{$\begin{array}{l}\text { AVEFIAGE FILL-FACTOKS: } \\
\text { STANIIARII IIEUIATIONS: }\end{array}$} & $\begin{array}{l}0.740 \\
0.008\end{array}$ & $\begin{array}{l}0.738 \\
0.008\end{array}$ & $\begin{array}{l}0.738 \\
0.008\end{array}$ & $\begin{array}{l}0.736 \\
0.009\end{array}$ \\
\hline
\end{tabular}

Figure 10. FLDLPR Listing for Module 41 (Mux 3, Module 9) 
there is an option for less than five loops. PYROAV is the average pyranometer value for the five loops and SIGMAP is the standard deviation of the five loops. Looking down the column it is apparent that on the $22 \mathrm{nd}$ and $26 \mathrm{th}$ the sky condition was changing during the interrogation. FILLAV and SIGMAF are the average fill-factors and fill-factor standard deviation for the five loops. Typically, for the whole field, the standard deviations were less than $1 \%$. Often when the insolation level varied greatly, as it did on the 22 nd and $26 \mathrm{th}$, the fill-factor standard deviation was also large. For this particular module this was not true.

The next four columns -- PYRO, ISC, VOC, and.FILL -- contain the raw data sumary for the fifth loop. And the next three contain the raw data corrected to the insolation levels (REFL) indicated. At the bottom of the summary are the average fill-factors and their standard deviations. During the 12-day interrogation period the standard deviation for the whole field usually fell between $1 \%$ and $2 \%$. These fill-factors were then compared with those obtained on the modules with the LAPSS just prior to their installation in the field, and the differences tabulated; the results are summarized in Table 4. Included at the right is a tabulation of the modules that have failed. These numhers are included in the "Quantity" column. The manufacturing and design deficiencies which led to these failures have been identified and corrected by the manufacturers, as is apparent by comparison of the results for Block I and II modules.

The modules in the less than $3 \%$ category can be classified as experiencing no degradation. Those in the $3 \%$ to $6 \%$ category show a small or marginal amount of degradation. The modules in this category appear to be stable and showed no abnormalities. The modules in the $6 \%$ to $10 \%$ category, generally speaking, are either bad or are going bad. A more detailed examination of the fill-factors of these modules shows them to be more erratic than the others.

No Block II modules have failed and none show degradations greater than $6 \%$. Furthermore, the majority of the Block II modules are in the zero to $6 \%$ or no. degradation category. In the same length of time that the Block II modules have been in the field, the Block I modules had already shown some chronic problems and greater degradation patterns. The Block II modules, across the board, appear superior to the Block I modules.

\section{Physical Change}

From experience to date, there is no apparent correlation between electrical failure and physical change. There are modules in the field exhibiting extensive delamination that are still functioning satisfactorily and, on the other hand, many of the modules that have failed looked good at the time of their failures. In the long term, however, correlations between physical changes and failure mechanisms must be developed if degradation models are ever to be formulated. In order to standardize the measuring and recording of physical change, an Ad Hoc Committee on Inspection Standards was formed in the LSA Project. Table 5 contains the recomended catagory list produced by the Committee. The Committee is now endeavoring to establish 
Table 4. Performance Summary of the Modules at the JPL Site as of May 31, 1978

\begin{tabular}{|c|c|c|c|c|c|c|c|c|}
\hline & \multirow{2}{*}{ Module Type } & \multirow{2}{*}{ Quantity } & \multirow{2}{*}{$\begin{array}{l}\text { Avg. Tine } \\
\text { In Field } \\
\text { (Months: }\end{array}$} & \multicolumn{4}{|c|}{$\%$ Fill-Factor Decrease In Fleld } & \multirow{2}{*}{ Falled* } \\
\hline & & & & $<3$ & $<6$ & $<10$ & $>10$ & \\
\hline \multirow{4}{*}{$\begin{array}{l}H \\
\text { H } \\
\text { Ü } \\
\text { - }\end{array}$} & $\mathrm{V}$ & 62 & 16 & 50 & 5 & 2 & 1 & 5 \\
\hline & w & 39 & 17 & 14 & 18 & 4 & 1 & 2 \\
\hline & $\mathrm{Y}$ & 38 & 20 & 24 & 8 & 3 & & 4 \\
\hline & $z$ & 21 & 17 & 5 & 1 & & 2 & 14 \\
\hline \multirow{4}{*}{ 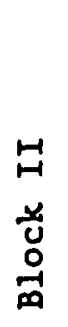 } & $\mathrm{v}$ & 34 & 12 & 31 & 3 & & & \\
\hline & W & 13 & 9 & 13 & & & - & \\
\hline & $Y$ & 17 & 11 & 8 & 9 & & & \\
\hline & $z$ & 13 & 11 & 9 & 4 & & & \\
\hline
\end{tabular}

* As of August 31 
Table 5. Inspection Categories

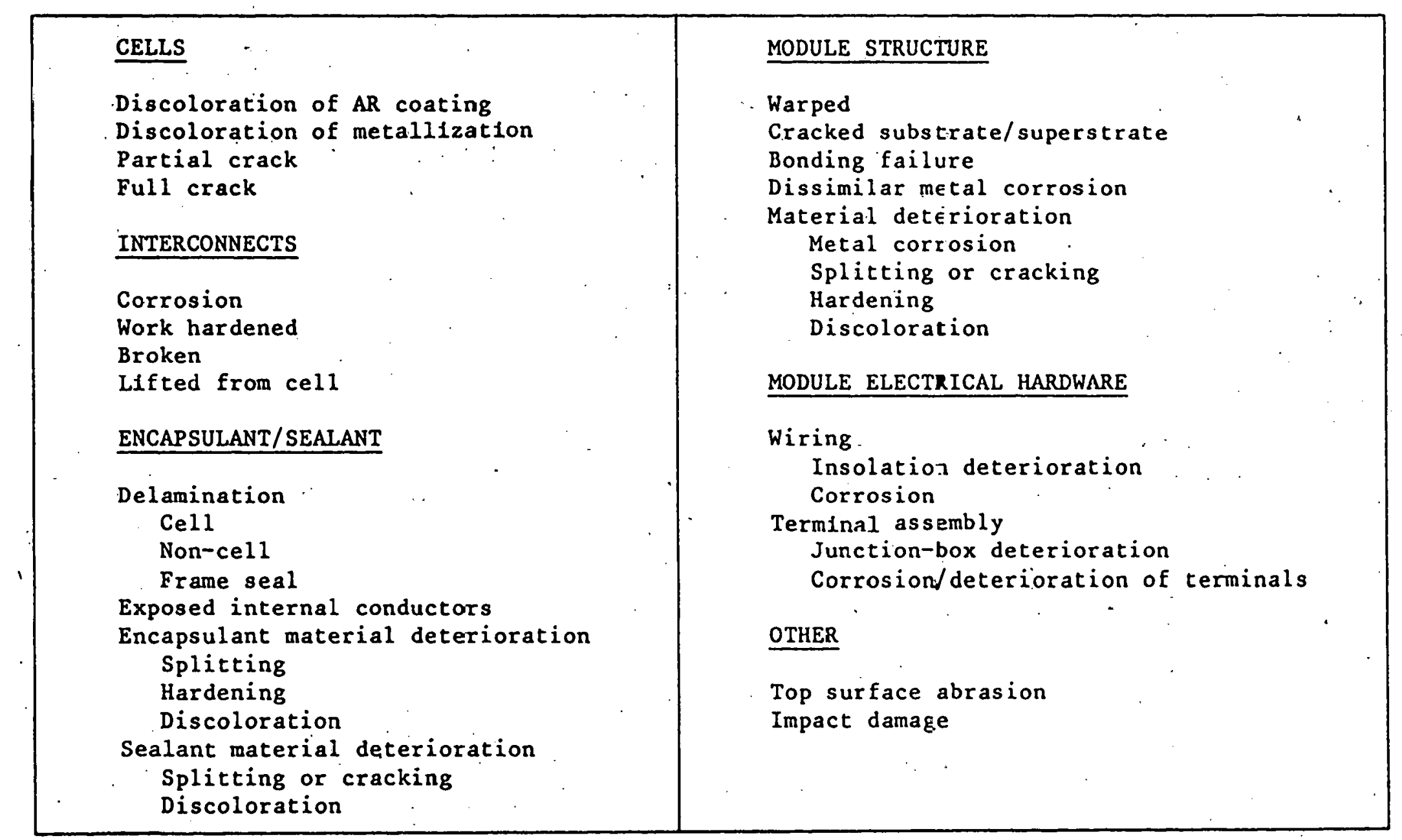


appropriate numerical tables for all these catagories into which the inspection data can be synthesized.

Concurrent with the development of reporting inspection standards, inspections of the modules at all four sites are being performed by the JPL Quality Assurance group. Current plans call for inspections at all the sites every three to six months.

3. Dirt Tests

Several dirt tests were performed about a year ago and have been reported on in previous publications and meetings. A summary of those data is presented in Table 6. Although the quality of the experiments was not as high as those performed more recently, the results are fairly consistent and indicate that short-circuit current decreases about $5 \%$ in a one month period, due to dirt (at the JPL Site), and that the cumulative effect of dirt levels out over longer periods of time.

Recently, a more controlled experimental program for obtaining dirt data was inaugurated at the JPL Site. Six $122 \times 122 \mathrm{~cm}(4 \times 4$ foot) subarrays of modules in good condition were specifically dedicated for this function; Section III of this Report describes the make-up of this set and Figure shows their locations in the field. Five of the six subarrays are being left in the field undisturbed for a month. They are then taken down and interrogated with the LAPSS system, washed, and then interrogated again. This cycle is being repeated monthly. The washing procedure is, described in Section IV-C, Test Procedure. The sixth subarray (Subarray 30 East) is designated for long-term dirt testing. It is also being interrogated monthly with the LAPSS, but is not washed. To date, two sets of data have been obtained from this toot program. The firsc test perıod was from June 5 to July 10 ( 35 days) and the second from July 11 to August 7 (26 days).

Two additional complementary tests were performed using essentially the whole field and the field test data system. The procedure was as follows: At the beginning of the test period the modules were washed. On the day at the end of the test period, at shortly before solar noon, the field was interrogated with a stand-alone program which corrects the data to $100 \mathrm{~mW} / \mathrm{cm}^{2}$. The modules were then washed and shortly after solar noon interrogated again. The short-circuit current of the clean modules was then compared with the dirty modules. The first of these tests was performed during the period May 25 to June 15 (20 days) and the second during the period June 30 to July 31 (30 days).

During the period when all four sets of data were obtained the weather was calm: no rain and very little wind movement. Also during this period the modules were tilted to the summer tilt angle of 15 degrees to the horizontal. Tables 7 and 8 contain the results from these tests in the form of percent changes in the short-circuit current between dirty and clean modules. The consistency of data within each test was very good; the delta short-circuit data scatter was less than $1 \%$ in almost all cases. A before and after delta 
Table 6. Early Dirt Tests

\begin{tabular}{|c|c|c|c|c|c|c|c|c|}
\hline \multirow{2}{*}{$\begin{array}{l}\text { Module Type } \\
\text { (Block I) }\end{array}$} & \multicolumn{2}{|c|}{2 Week Test } & \multicolumn{2}{|c|}{1 Month Test } & \multicolumn{2}{|c|}{1 Month Test } & \multicolumn{2}{|c|}{$41 / 2$ Month Test } \\
\hline & Quantity & ${ }^{\Delta I_{S C}}, \%$ & Quantity & ${ }^{\Delta \mathrm{I}_{\mathrm{SC}}}, \%$ & Quantity & $\Delta I_{S C}, \%$ & Quantity & ${ }^{\Delta \mathrm{I}_{\mathrm{SC}}, \%}$ \\
\hline Sensor Tech & 12 & -4 & 2 & -6 & 14 & -4 & 2. & -12 \\
\hline Spectrolab & 8 & -2 & 1 & -2 & 18 & $\sim 3$ & 0 & - \\
\hline Solarex & 31 & -4 & 3 & -5 & 8 & $\sim 5$ & 2 & $\sim 13$ \\
\hline Solar Power & 12 & -4 & 1 & $\sim 5$ & 6 & -4 & 1 & -13 \\
\hline
\end{tabular}


Table 7. Controlled Dirt Test

\begin{tabular}{|c|c|c|c|c|}
\hline Module Type & Encapsulant Surface & $\begin{array}{c}\text { Sample } \\
\text { Size }\end{array}$ & $\begin{array}{c}\text { June } 5-\text { July } 10 \\
\Delta I_{S C^{*}}^{*} \%\end{array}$ & $\begin{array}{c}\text { July } 11 \text { - Aug. } 7 \\
\Delta \mathrm{I}_{\mathrm{SC}}, \%\end{array}$ \\
\hline Sensor Tech II & Silicone rubber & 8 & 7.4 & 5.1 \\
\hline Spectrolab II & Glass & 3 & 8.8 & 6.5 \\
\hline Solarex II & Stlicone rubber & 4 & 7.7 & 5.6 \\
\hline Solar Power II & Silicone rubber (hard coat) & 3 & 6.8 & 5.0 \\
\hline ARCO & Glass (stippled) & 5 & 7.7 & 6.1 \\
\hline
\end{tabular}

${ }^{*}$ At an Insolation level of $100 \mathrm{~mW} / \mathrm{cm}^{2}$. 
Table 8. Whole Field Dirt Test

\begin{tabular}{|c|c|c|c|}
\hline Module Type & Sample Size & $\begin{array}{c}\text { May } 25 \text { - June } 15 \\
\Delta I_{\mathrm{SC}}^{*} \%\end{array}$ & $\begin{array}{c}\text { June } 30-\text { July } 31 \\
\Delta \mathrm{I}_{\mathrm{SC}}^{*}: \%\end{array}$ \\
\hline Sensor Tech I & 57 & 2.3 & 6.6 \\
\hline Spectrolab I & 38 & 2.7 & 6.5 \\
\hline Solarex I & 34 & 3.2 & 7.0 \\
\hline Solar Power I & 7 & 3.7 & 6.8 \\
\hline Sensor Tech II & 34 & 2.0 & 6.1 \\
\hline Spectrolab II & 13 & 2.4 & 7.1 \\
\hline Solarex II & 17 & 2.1 & 6.8 \\
\hline Solar Power II & 13 & 2.8 & 7.1 \\
\hline
\end{tabular}

${ }^{*}$ At an Insolation level of $100 \mathrm{~mW} / \mathrm{cm}^{2}$ 
peak-power comparison was also made with the Controlled Dirt Test data. The results were almost identical; the same delta values were evident using the peak power. It is felt, however, that the short-circuit current is a better and more direct indicator of the effects of dirt on module output.

An investigation of the residual effects of dirt, i.e., the persistence of the dirt to adhere to the module after washing, was also made. This was accomplished by comparing the initial clean with the after-the-wash-clean, short-circuit current data from the Controlled Dirt Tests. The Sensor Technology and ARCo module data showed essentially no-changes for both tests, whereas the Solarex and Solar Power data showed degradations of $1 \%$ and $3 \%$, respectively, for the first test, diminishing to a negligible increase for the second. The Spectrolab data indicated short-circuit current increases of about $1.5 \%$ for the first test and a slight decrease (using the first test as the reference for the second). Increases from Spectrolab II modules have been observed in the past so this was no surprise. Except for the Solar Power modules, where it appears there may be some residual dirt adhering to the modules, the differences were too small to state anything conclusive.

An examination of the data brings out the following points:

(1) The glass modules did not fare any better than the silicone rubber modules. The data scatter from all four tests, regardless of module type, was no greater than $\pm 1 \%$.

(2) Taking the two Controlled tests and the second Whole Field test as a group, and linearly extrapolating the results from those tests to a 30-day period, yields a delta $I_{s c}$ value of $7 \%, \pm 1 \%$.

(3) Regarding the first whole Field.Test, there is no reason to believe that the data from that test is any less valid than the second Whole Field Test, yet its extrapolated 30 -day mean value is only $4 \%$, slightly more than half the 7\% value. The only reasonable conclusion is that the air was cleaner during the first period. This brings out the somewhat obvious point that the effects of dirt depend not only on location but also on time of year.

\section{B. REMOTE SITES}

There is no resident data gathering equipment at any of the remote sites nor are there plans to install any. Electrical testing of the modules at Table Mountain and Goldstone was initially performed by removing them from the field, transporting them back to JPL, interrogating them with the LAPSS system, and then returning them to the sites. This practice has been suspended and will be replaced with in-situ testing. Portable $I-V$ equipment is being developed for this purpose, but it is not yet ready for field use. 
The last degradation data, when the modules were cycled back to JPL, was obtained last fall. However, functional in-situ inspection of the modules has been made since that time. The last time the modules were cycled back to JPL, all of the modules were performing satisfactorily (less than $5 \%$ degradation in peak-power), with the exception of one module type (Block I) at Table Mountain. One of these had failed and several showed degradations up to $8 \%$. Since that time, four more of this type at Table Mountain have failed. These failures were mostly caused by interconnect problems, which have since been corrected.

An arrangement has been made for acquiring weather data from the Table Mountain Site. Every four hours a member of the staff records the percent cloud cover, wind speed and direction, air temperature, relative humidity; atmospheric pressure, precipitation, and module oriented insolation measurement. This information is sent to JPL once a month where it is keypunched and 1 isted. Arrangements are being made to obtain weather data from Goldstone and Point Vicente. 
One of the most significant results to date is the realization that it is considerably more difficult to obtain high quality degradation data than originally thought. However, the Field Test Activity now has a much better idea of what problems must be solved to accomplish this goal, and furthermore, it has a unique testing capability for investigating them. The combination of a real time data system with several input options, a flexible wiring arrangement, and ready access to a LAPSS system all contribute to provide a powerful capability. During the next year the major goale of the Activity will be to: (1) improve the quality of the data, (2) enhance. testing procedures, and (3) increase the ability to analyze the data. The following is a list of tasks that will be undertaken. The order of the list generally reflects priority.

(1) Development of a method for determining the test insolation level suitable for correcting the module daily data.

(2) Determination of improved insolation/temperature translation equations and constants.

(3) Development of portable I-V equipment for in-situ testing.

(4) Development of an understanding of the relationship between fill-factor, insolation, and other parameters.

(5) Development of I-V curve fitting techniques.

(6) Development of techniques for the analysis of archived data.

(7) Development of refined testing strategy(s). 


\section{NASA LEWIS RESEARCH CENTER \\ Real Time Endurance Testing}

NASA Lewis Research Center currently has a network of twelve different test sites to obtain endurance data from a wide range of environmental conditions. The climatic conditions at these sites range from the arctic cold of Alaska to the hot, tropical weather of the Canal Zone.

The endurance data for these sites are still being compiled and therefore is not available at the time of this writing. Their site location, latitude, climate and installation dates are given in Table I.

NASA Lewis Research Center has. conducted real time endurance testing at different sites prior to their current network. This series of endurance testing was concluded at the end of 1977, and the results have been compiled and analyzed. 


\section{Site Location}

US Army Cold Region Test Center Fort Greely, AK

USDAFS Forest Engineering Laboratory Houghton, MI

US Army Tropical Test Center Fort Clayton, Canal zone

\section{Naval Air Station}

Key West, FL

Naval Weapons Support Center Crane, IN

US Army 9th Infantry Division Fort Lewis, WA

NASA Michoud New Orleans, IA

Sandia Labs. Albuquerque, NM

Pacific Missile Test Center San Nicolas Island, CA

USDAFS Rocky Mountain Experiment Station Mines Peak, CO

Approximate

Latitude

Climate

Testing Started

$64^{\circ}$

$47^{\circ}$

$9^{\circ}$

$25^{\circ}$

390

$41^{\circ}$

$40^{\circ}$

$47^{\circ}$

$30^{\circ}$

$35^{\circ}$

$34^{\circ}$

$40^{\circ}$
Arctic

North Central Great Lakes

Tropical

Humid Marine

Midwest Humid, Low Pollution

Marine

High Desert

Very Humid, Cloudy, Mild

Humid, High Pollution.

High Desert

Intense Marine

Mountain
Oct. 1,1977

Nov. 20,1977

Dec. 2, 1977

Dec. 7, 1977

Dec. 30,1977

Jan. 6,1978

Jan. 13, 1978

Jan. 18,1978

Feb. 16,1978

Feb. 23, 1978

Apr. 3, 1977

May 23,1978 


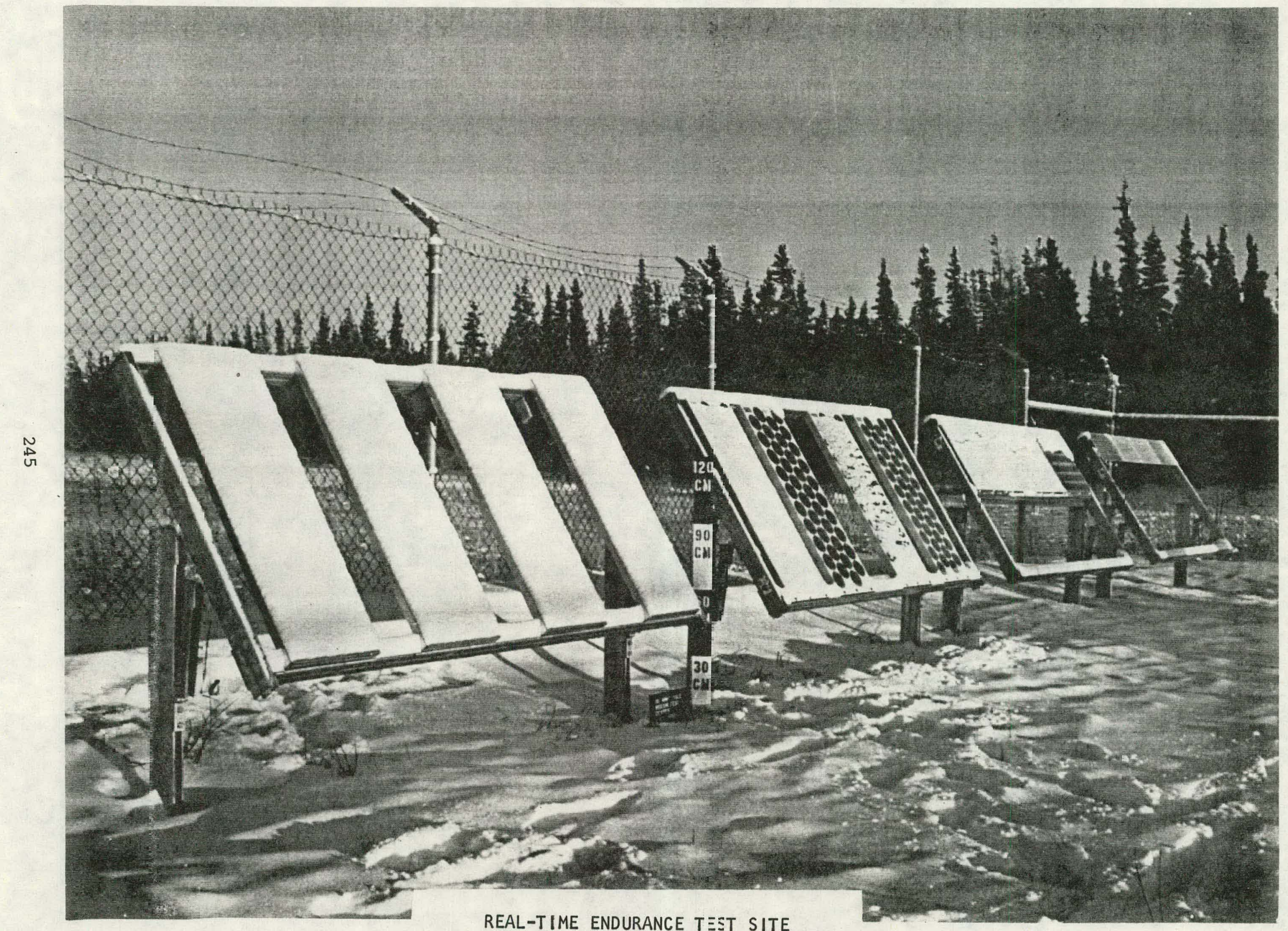

REAL-TIME ENDURANCE TEST SITE

FORT GREELY, ALAS \& 


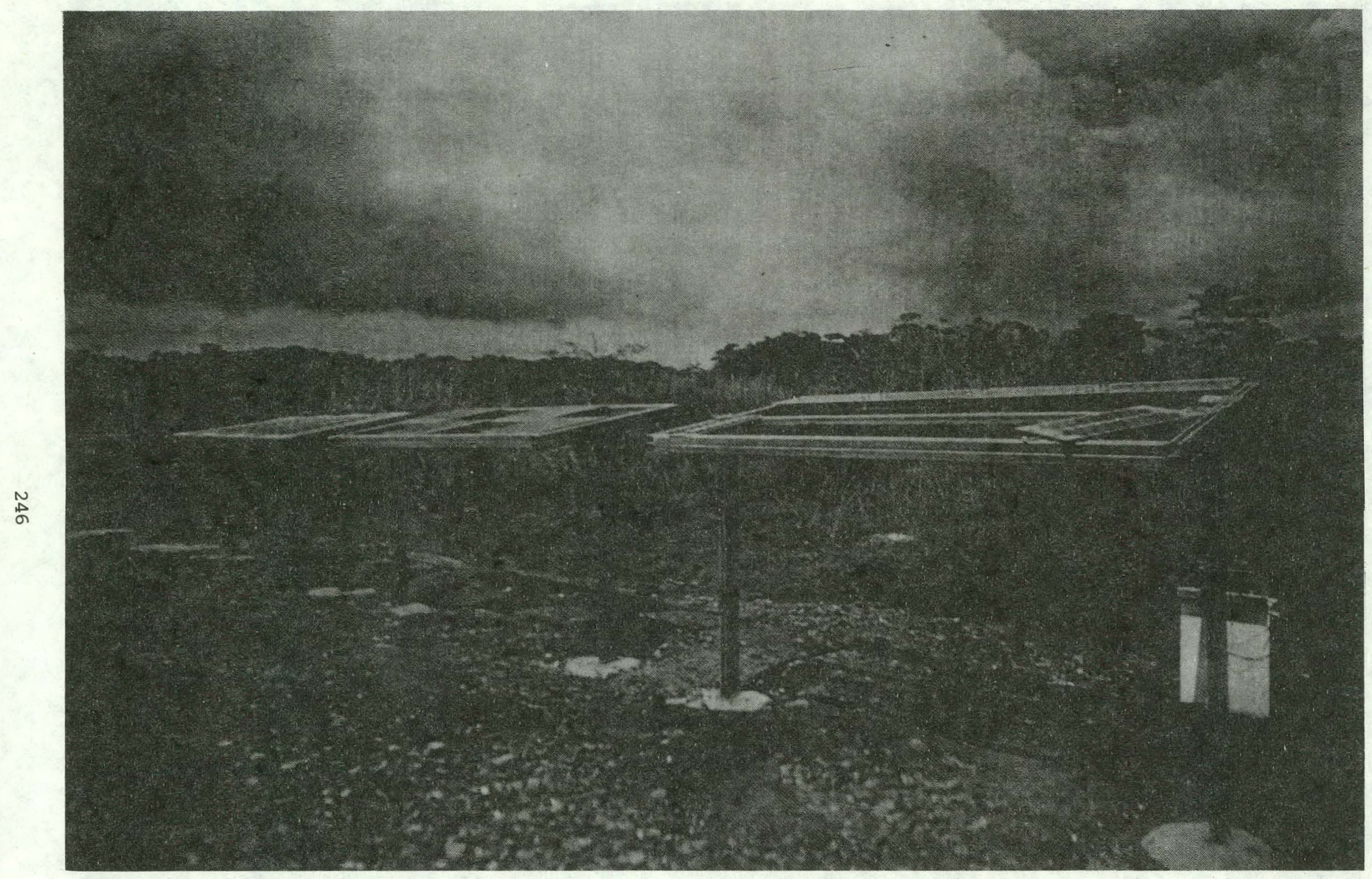

REAL-TIME ENDURANCE TEST SITE

FORT CLAYTON, CANAL ZONE 


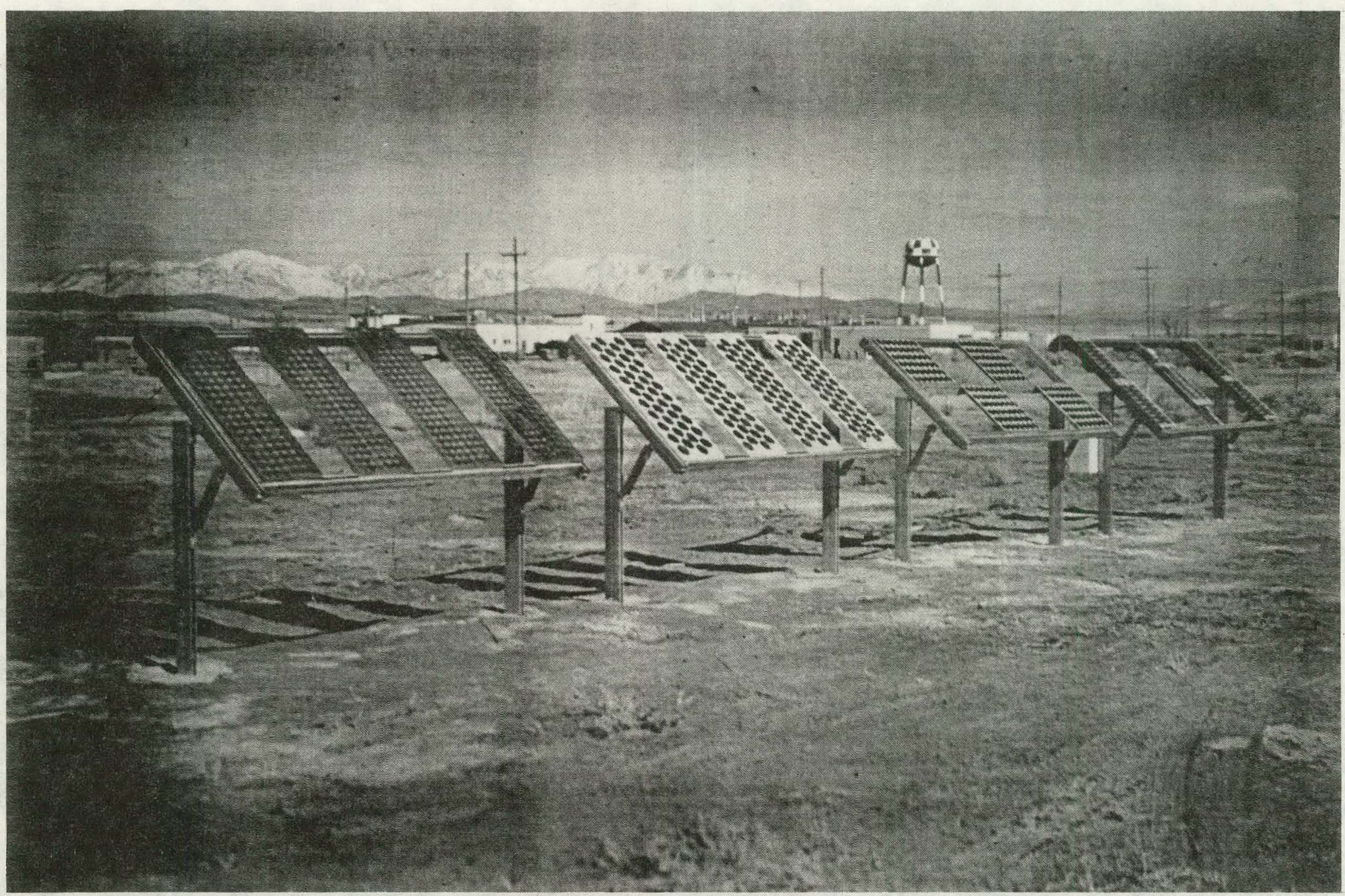

REAL-TIME ENDURANCE TEST SITE DUGWAY, UTAH 


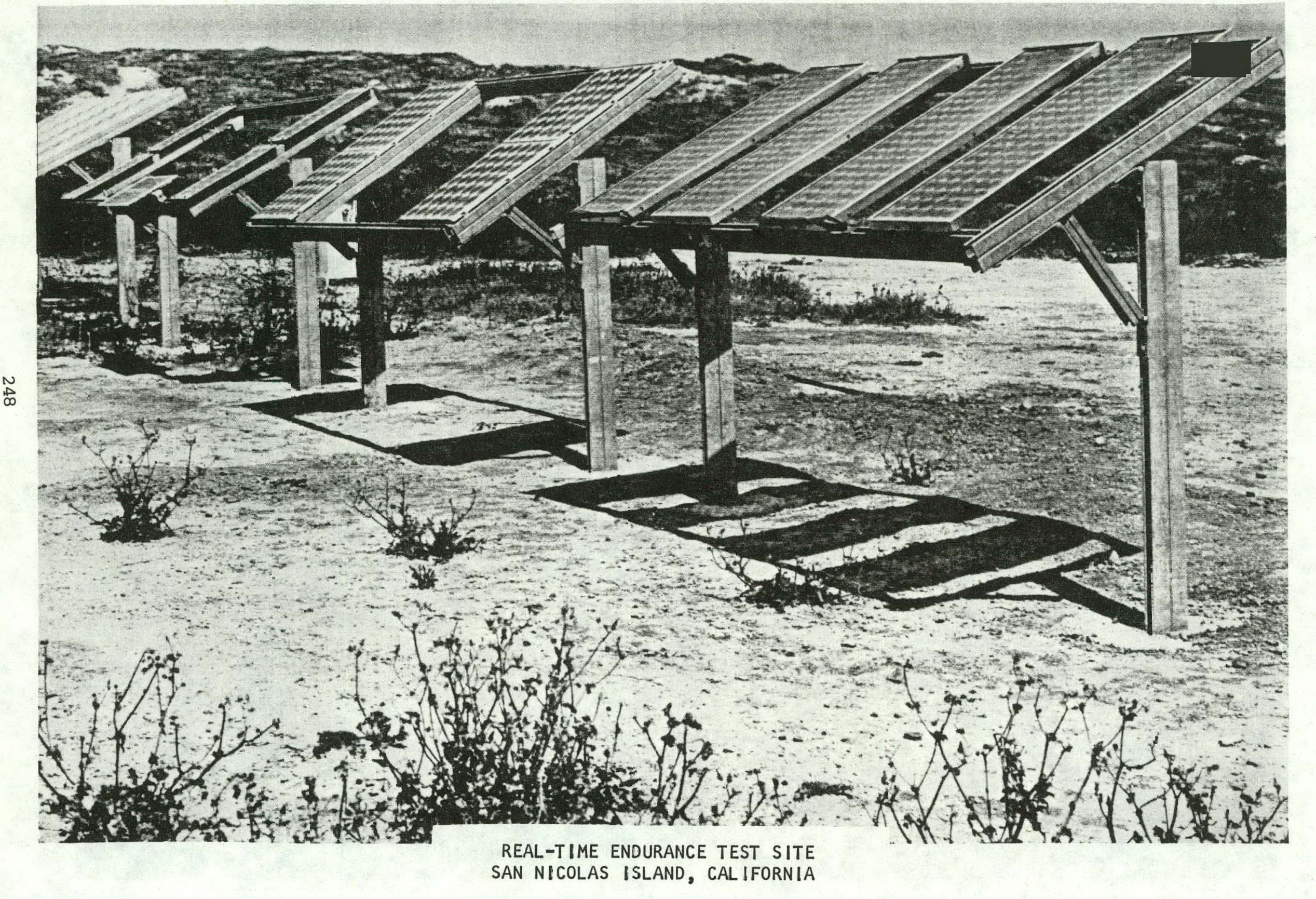


The sites of the first series of tests conducted by NASA-LeRC are listed below along with a general description of the local exposure conditions:

1. Desert Sunshine Exposure Tests, Inc., Phoenix, Arizona. Southfacing panels, inclined at $45^{\circ}$. Desert conditions.

2. Caribbean Testing, Inc., Caguas, Puerto Rico. South-facing panels inclined at $5^{\circ}, 18^{\circ}$ and $45^{\circ}$. A fourth panel has its inclination angle changed by $5^{\circ}$ approximately every two weeks to follow the sun. The maximum angle is $40^{\circ}$ and the minimum is $0^{\circ}$. Tropical, rain forest conditions.

3. Solar Testing Service, Inc., Pompano Beach, Florida. Southfacing panels inclined at $5^{\circ}$ and $45^{\circ}$. Sub-tropical conditions.

4. Sub-Tropical Testing Service, Miami, Florida. South-facing panels inclined at $5^{\circ}$ and $45^{\circ}$. Sub-tropical conditions.

5. South Florida Testing Service, Miami, Florida. South-facing panels inclined at $5^{\circ}$ and $45^{\circ}$. Sub-tropical, sea air atmosphere.

6. Air Pollution Control Center, Cleveland, Ohio. South-facing panels inclined at $40^{\circ}$. A very heavy industrial environment.

7. NASA-Lewis Research Center, Cleveland, Ohio. South-facing panels inclined at $40^{\circ}$. Ordinary urban environment (commercial/ business residential areas in prevailing upwind direction).

Modules from four manufacturers were used and are denoted as Block I modules. They were exposed at a variety of test sites with different environments for periods up to 1 year. At some sites, modules were removed periodically and the effect of the environment was determined by the measurement of the electrical characteristics. At other sites, the modules were left undisturbed until the tests were terminated after which time the electrical characteristics were measured. Some modules from each site were washed and remeasured to determine the effects of dirt and other environmental fallout on performance.

A description of the construction of the module from each manufacturer is given below.

Spectrolab Aluminum backed; 2 in. diameter cells completely encapsulated in silicone; covered with glass sheet $1 / 8$ in. thick.

Sensor Tech Aluminum backed; 2 in. diameter cells completely encapsulated in silicone.

Solarex Fiberglass-epoxy composite backed; 3 in. diameter cells completely encapsulated in silicone.

Solar Power Fiberglass-epoxy composite backed; 3 in. diameter cells completely encapsulated in silicone. 
Descriptions of Encapsulant

At Site 1, 7 different plastics and 31 five-cell sub-modules were tested. The plastics were FEP-A, acrylic, perfluoroalkoxy (PFA), Mylar, polyester, Aclar 22A and Tefzel. The sub-modules were covered with FEP-A (heat bonded or glued), FEP-C (head bonded or glued), acrylic, clear silicons rubber, UV-stabilized Lexan, polyether-sulfone and PFA (heat bonded or glued). A more detailed listing of these samples is given in Tables II and III.

At Site 2, 97 samples of types described in Table IV, numbers 1 through 13, are being exposed along with 9 sub-modules of tyoe number 14 .

At Site 3, 54 samples of types $1-13$ in Table III are being exposed. Again, only qualitative comments can be made for these samples.

At Site 4, 53 samples of types $1-13$ and 11 sub-modules, type 14, as described in Table III are being exposed.

At Site 5, 61 samples of types $1-13$ and 13 sub-modules, type 14, as described in Table III are being exposed.

At Sites 6 and 7, modules from four manufacturers have been exposed for approximately two months outdoors. These modules were manufactured in 1976 for the 46-kW purchase of the ERDA/JPL LOW Cost Silicon Solar Array Project. The manufacturers are Spectrolab, Sensor Technology, Solar Power and Solarex.

The washing was done using an Alconox-Tide solution and light hand scrubbing until the scrub cloth appeared clean. However, there was no hard rubbing of the module surface. The modules were well rinsed with tap water and then dried.

Summary of Results

that:

Endurance testing of Block I modules at selected sites has indicated

1. For silicone-covered modules made by Solarex, Solar Power and Sensor Tech:

a. Outdoor exposure causes a similar decrease in performance for these brands.

b. The degradation is site dependent with the Cleveland Air Pollution Control Center causing the most degradation because of heavy industrial pollution. Puerto Rico was next because of the tropical rain-forest conditions of its climate.

c. The degradation is apparently not dependent on insolation alone.

d. Washing does not remove all of the degradation. The permanent loss in maximum power reaches a steady value after several hundred days exposure. 
2. For glass-covered, silicone potted modules made by Spectrolab:

a. Outdoor exposure is much less damaging than for the other modules tested because of less dirt attraction and retention.

b. Washing the modules recovers the performance loss completely.

3. The effect of local conditions is most damaging where some type of chemical interaction can occur with the module surface as with chemically active particulates and moist mossy growth compared to dry desert sand and field soil.

\section{Conclusions}

Limited real time outdoor exposure has shown that some materials are not suitable for solar cell module construction. These are polyurethane, polyester, Kapton, Mylar and UV-stabilized Lexan. Polyvinylidene fluoride may be suitable, but because different formulations are available, each must be evaluated. Acrylic, FEP-A and glass appear to be good candidates for module covers. RTV silicone rubber (clear) appears to pick up and hold dirt both as a free film and as a potting medium for modules. These results indicate that dirt accumulation and cleanability are important factors in the selection of solar cell modules covers and encapsulants. 
TABLE II

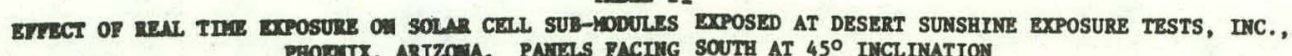

\begin{tabular}{|c|c|c|c|c|c|c|c|c|c|}
\hline $\begin{array}{l}\text { sus- } \\
\text { movere } \\
\text { iD wo. }\end{array}$ & SUE-MODULE COVER & $\begin{array}{l}\text { Construetiol } \\
\text { süSTRATE }\end{array}$ & $\begin{array}{r}\text { TEST TIRE } \\
\text { \& EXPOSURE } \\
\end{array}$ & $\begin{array}{r}\text { SEC } \\
\text { CIrCuIT } \\
\text { Isc, } \\
\text { IMIIILL } \\
\end{array}$ & $\begin{array}{l}\text { CUT } \\
\text { CURBSTr } \\
\text { AMPS } \\
\text { MHALL } \\
\end{array}$ & $\begin{array}{l}\text { Maxnan } \\
\text { Paax, } \\
\text { IIIIIIL }\end{array}$ & $\begin{array}{l}\text { MOUIRR } \\
\text { WATIS } \\
\text { THSAL } \\
\end{array}$ & $\Delta P_{\max }, \mathrm{z}$ & OBSERVATIOANS \\
\hline 84 & FEP-A, heat bonded (a) & aluginum & 6 months; & .128 (b) & .130 (b) & $.266(b)$ & $.268(b)$ & +.7 & slight delamination at end interconnect \\
\hline 85 & & & 97,652 langleys & .131 & .134 & .277 & .282 & +1.8 & some edge delamination \\
\hline 105 & & & & .128 & 127 & .276 & .280 & +1.4 & discolorated \\
\hline 114 & & & & .128 & .131 & .270 & .274 & +1.5 & edge delamination \\
\hline 117 & & $\downarrow$ & & .131 & .136 & .276 & .278 & +.7 & sone edge delamination \\
\hline & & fiberglas & & .136 & .138 & .280 & .279 & -.4 & good appearance \\
\hline 116 (c) & & aluninum & 2 months; & .128 & .134 & .227 & .234 & +3.1 & edge delamination \\
\hline $121(c)$ & $\downarrow$ & fiberglas & 34,612 langleys & .130 & .128 & .253 & .266 & +5.1 & interconnects cut through \\
\hline 195 & .159 cacrylic senled at & the edges & & .136 & .134 & .231 & .232 & +.4 & good appearance; some wilkiness at edge \\
\hline 198 & cast XR-63489 (clear & 111cone) & & .143 & .140 & .251 & .225 & -10 & dulled surface \\
\hline 201 & UV stabilized Lexan & polyatyrene & & .127 & .106 & .220 & .099 & -55 & good appearance \\
\hline 202 & $\begin{array}{l}\text { FBP-A, heat bonded, no } \\
\text { primer attached with } \\
\text { Mystak tape }\end{array}$ & aliainue & & .139 & .144 & .255 & .170 & -33 & one cell delaminated \\
\hline 206 & FEP-C, att. w/Myatik tape & aluminum & & $.121(d)$ & $.122^{(d)}$ & .201 (d) & $.183^{(d)}$ & -8.9 & delaminated \\
\hline 211 & FEP-C, GE 585 adhesive & aluminum & & .123 & .124 & .223 & .225 & +.9 & bubbling at cell edges \\
\hline 214 & $\begin{array}{l}\text { UV otabilized Lexon with } \\
\text { GE } 585 \text { adhesive }\end{array}$ & aluentnum & & - & -- & - & - & - & broken cell; delanination, bubbles \\
\hline 217 & $\begin{array}{l}\text { Polyether sulfone with } \\
\text { GI } 585 \text { adhesive }\end{array}$ & aluminum & & .123 & .110 & .235 & .192 & -18 & yellow, brittle, pulling off at edges \\
\hline 222 & PYA, heat bonded & fiberglas & & .120 & .075 & .243 & .142 & -42 & some delamination there bubbled; interconnects are thite \\
\hline 223 & FEP-A with GE 585 adhes:ve & alueinum & & .126 & .128 & .240 & .234 & -2.5 & delamination at edges and interconnects \\
\hline 226 & FEP-A with GE 585 adhes:ve & Pornica & & .124 & .127 & .243 & .245 & +.8 & bubbled at cell edges \\
\hline 229 & PFA with GE 585 adhesive & Pornica & & .134 & .130 & .237 & .234 & -1.3 & bubbled at cell edges and on one cell \\
\hline 234 & FBP-A with GE 585 adhes:ve & aluminum & & .132 & .128 & .241 & .234 & -2.9 & unstuck at cell edges \\
\hline 237 & FEP-A with GE 585 adhes:ve & Tapton & & .127 & .128 & .251 & .251 & 0 & slight bubbling at several cell corners \\
\hline 250 & FEP-A with GE 574 adhesive & aluainume & & .124 & .130 & .247 & .249 & +.8 & edges unstuck \\
\hline 252 & FEP-A with GE 574 adhesive & Kapton & & .121 & .124 & .201 & .204 & +1.5 & cracked cell; bubbles at cell edge \\
\hline 253 & FEP-C with GE 574 adhesive & Rapton & & .128 & 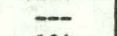 & .239 & - & -- & bubbling at interconnects \\
\hline 259 & FEP-A with GB 574 adhesive & fiberglas & & .122 & .124 & .224 & .224 & 0 & some discoloration on cell back \\
\hline 260 & FEPP-C with GB 574 adhesive & fiberglas & & .129 & $\overline{-1}$ & .191 & -- & - & good appearance \\
\hline 267 & FEP-A with GB 574 adhesive & " \& Kapton & & .129 & .132 & .207 & .207 & 0 & good appearance; some discoloration on cell back \\
\hline 271 & PFA with GE 574 adhesive & Kapton & & .127 & $-\overline{130}$ & .191 & $\overline{102}$ & $\overline{0-1}+$ & good appearance; some discoloration on cell back \\
\hline 276 & PFA with GE 574 adhesive & fiberglas & & .125 & .132 & .187 & .183 & -2.1 & good appearance; some discoloration on cell back. \\
\hline PFA-X & PFA with GE 585 adhesive & aluminum & $\downarrow$ & .126 & -- & .222 & - & - & delamination at several areas; lead tab off \\
\hline
\end{tabular}

(a) These sub-modules were made using front and bacix contact cells. All others had uraparound contact ce11s.

(b) These parameters through sample number 202 were measured at AnO, $25^{\circ} \mathrm{C}$

(c) Samples were placed on real time test after fou: months of accelerated exposure. Init1al parameters are those measured prior to real time test.

(d) These parameters for this and all subsequent samples measured at AM1, $28^{\circ} \mathrm{C}$. 


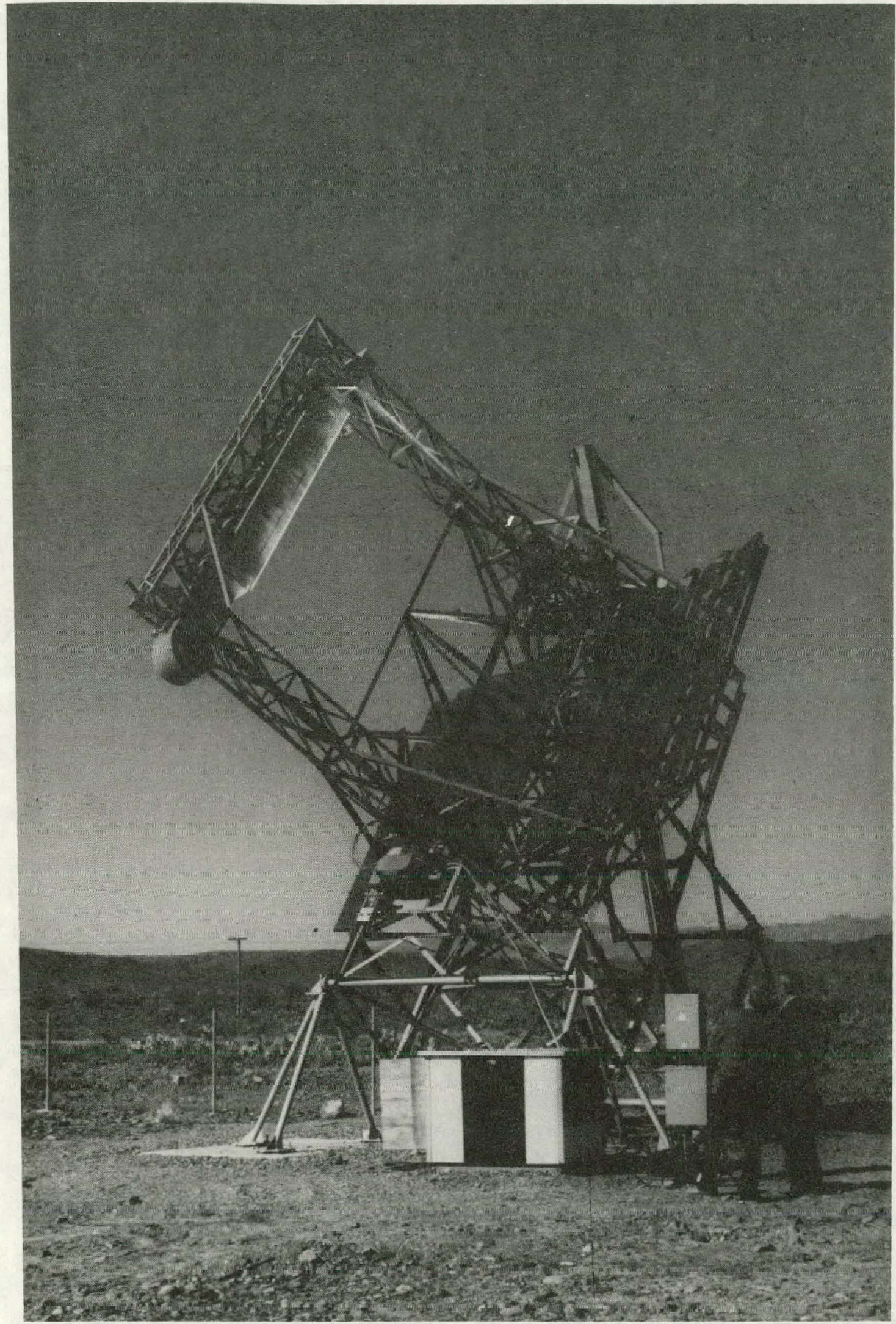

Desert Sunshine Accelerated Exposure Testing, Phoenix, Arizona. Summer 1978 


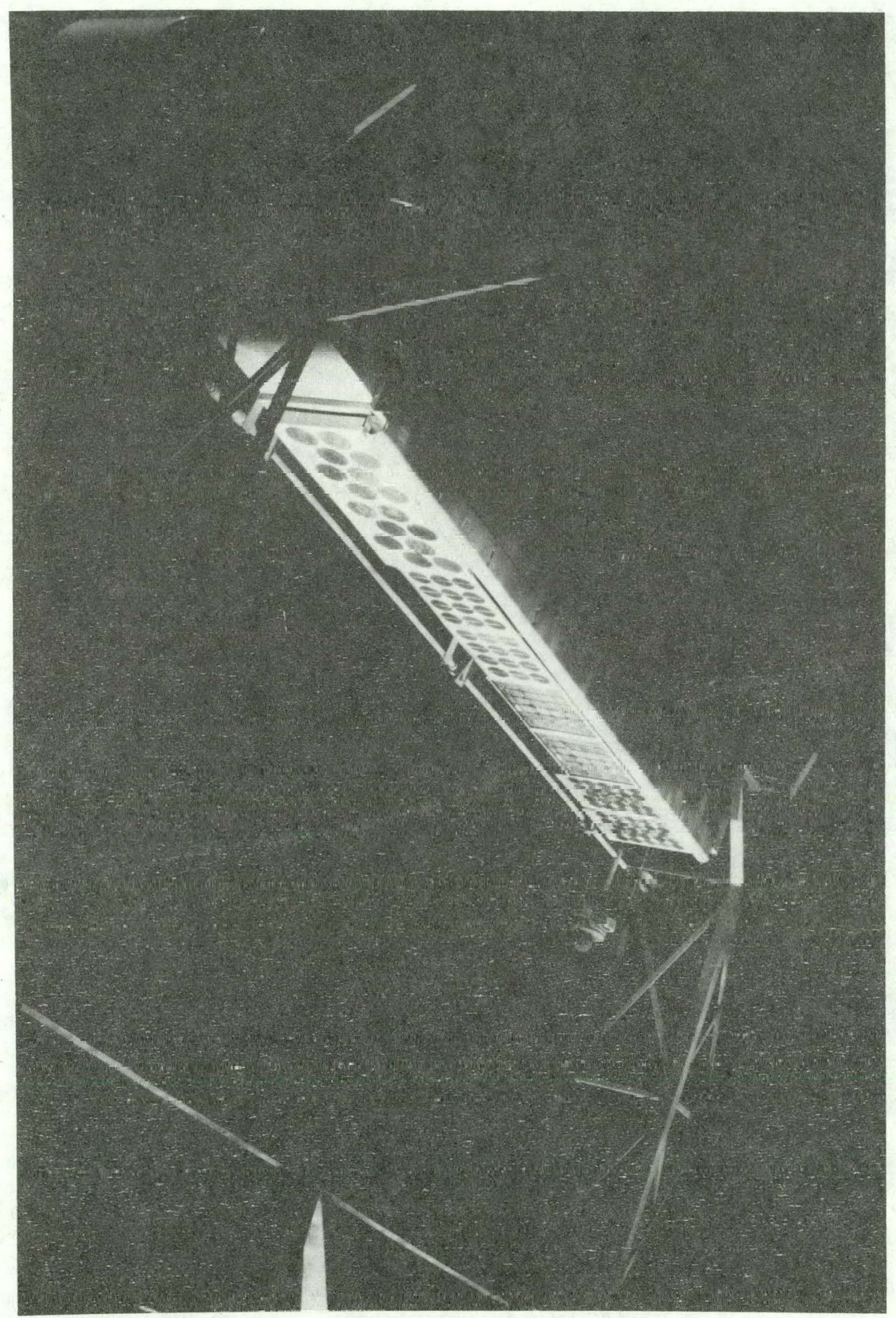

Desert Sunshine Accelerated Exposure Testing, Phoenix, Arizona. Summer 1978 


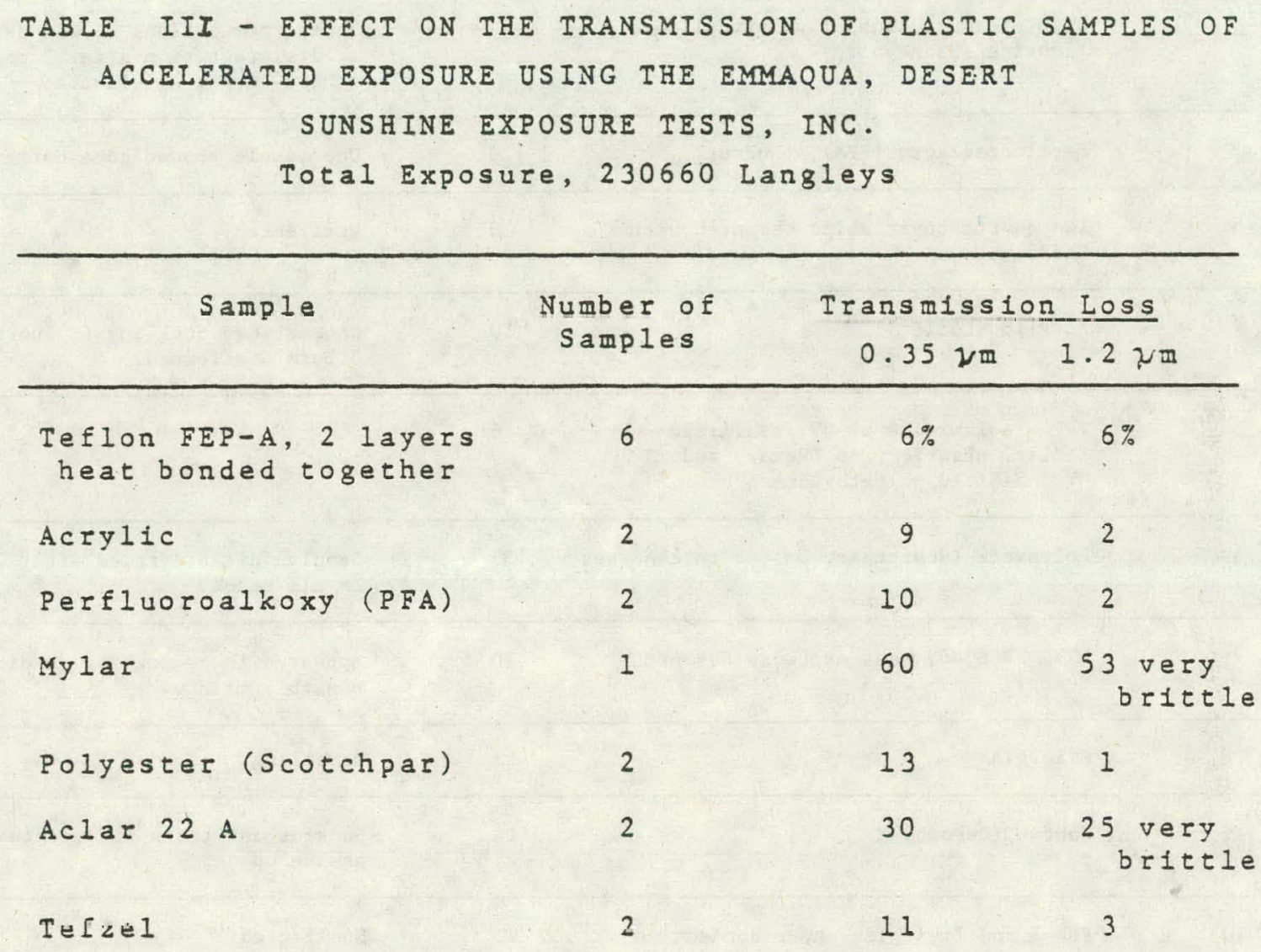




\section{TABLE IV. - QUALITATIVE EFFECTS OF REAL TIME EXPOSURE IN FLORIDA AND PUERTO RICO}

TOTAL TIME, 6 MONTHS

\begin{tabular}{|c|c|c|c|}
\hline $\begin{array}{l}\text { Identification } \\
\text { Number }\end{array}$ & Sample Description & $\begin{array}{l}\text { Number of } \\
\text { Samples }\end{array}$ & Observations \\
\hline 1 & $\begin{array}{l}\text { Eight formulations of polyvinylidene } \\
\text { fluoride (Pennevalt) }\end{array}$ & 64 & $\begin{array}{l}\text { Three formulations showed darkening } \\
\text { or disintegration after } 3 \text { months; } \\
\text { others showed no effects. }\end{array}$ \\
\hline 2 & Perfluoroalkoxy (PFA), (DuPont) & 10 & One sample showed some darkening. \\
\hline 3 & $\begin{array}{l}\text { Two quartz cover slips cemented with } \\
\text { GE585 }\end{array}$ & 10 & Unaffected. \\
\hline 4 & Acrylic (Lucite) & 10 & $\begin{array}{l}\text { Showed some buckling in Puerto Rico. } \\
\text { others unaffected. }\end{array}$ \\
\hline 5 & $\begin{array}{l}\text { TVP - a laminate of UV stabilized } \\
\text { Tedlar, plastic grid (Vexar) and } \\
\text { UV inhibited polyethylene }\end{array}$ & 6 & $"$ \\
\hline 6 & Polyester (Scotchpar, 3M), 2 thicknesses & 33 & $\begin{array}{l}\text { Samples disintegrated after } 2 \text { months } \\
\text { in all cases. }\end{array}$ \\
\hline 7 & $\begin{array}{l}\text { RTV, XR } 63489 \text { cast at Lewis Research } \\
\text { Center }\end{array}$ & 10 & $\begin{array}{l}\text { Appeared to be picking up dirt or } \\
\text { possibly mildew. }\end{array}$ \\
\hline 8 & F1berglas & 15 & Ravelling \\
\hline 9 & Kapton (DuPont) & 14 & $\begin{array}{l}\text { Buckles and tears and eventually } \\
\text { breaks up. }\end{array}$ \\
\hline 10 & $\begin{array}{l}\text { FEP-A and fiberglas, heat-bonded } \\
\text { together }\end{array}$ & 20 & Unaffected \\
\hline 11 & FEP-A & 32 & $\begin{array}{l}\text { Some samples in Puerto Rlco curling } \\
\text { and slightly yellow. }\end{array}$ \\
\hline 12 & FEP-C & 24 & $"$ \\
\hline 13 & UV stabilized Lexan & 17 & $\begin{array}{l}\text { Buckling and cracking of several } \\
\text { samples. }\end{array}$ \\
\hline 14 & Polyurethane covered sub-modules & 33 & $\begin{array}{l}\text { Darkening and some flaking of coat- } \\
\text { ing (also noted in earlier DSET } \\
\text { tests). }\end{array}$ \\
\hline
\end{tabular}




\section{MIT LINCOLN LABORATORY}

\section{REAL TIME ENDURANCE TESTING}

A. Component Field Test Sites

MIT Lincoln Laboratory has four Real Time Endurance test sites where PV modules are being tested for their endurance under a range of different environmental conditions.

Two of the test sites are located in New York City which provides an urban environment; one at Columbia University (14-story rooftop), and the other at New York University (6-story rooftop). The third is located on MIT Lincoln Laboratory's 3-story rooftop which provides a rural setting, and the fourth is located on top of Mt. Washington in New Hampshire which provides an arctic alpine environment.

The power outputs of the PV modules were measured at MIT Lincoln Laboratory under standardized conditions prior to and after several months exposure to the prevailing weather conditions at these sites. The results to date can be found on the following pages.

B. System Field Test Sites

MIT Lincoln Laboratory also has three test sites where all the components in a PV system are being tested for their endurance. These systems are located at:

- Mead, Nebraska, which is a $28 \mathrm{~kW}$ system

- Rooftop Test Bed, Massachusett, which is a $10 \mathrm{~kW}$ syslem

- Chicago Museum, which is a $1.5 \mathrm{~kW}$ system

Their testing results can also be found on the following pages. 


\section{CUMULATIVE MODULE FAILURES AT ALL MIT/LL TEST SITES}

DATE

FEBRUARY 1977

MAY 1977

JUNE 1977

JULY 1977

OCTOBER 1977

NOVEMBER 1977

DECEMBER 1977

JANUARY 1978

FEBRUARY 1978

MARCH 1978

APRIL 1978

MAY 1978

JULY 1978

AUGUST 1978

SEPTEMBER 1978
NO. OF MODULES

DEPLOYED

10

46

75

2603

2603

2603

2745

3690

3690

3690

3690

3690

3690

3690

3690
FAILED ELECTRICALLY (\%)
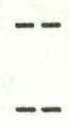

$--$

$--$

0.04

0.12

0.11

0.081

0.22

0.24

0.27

0.35

0.60

0.68

0.79 


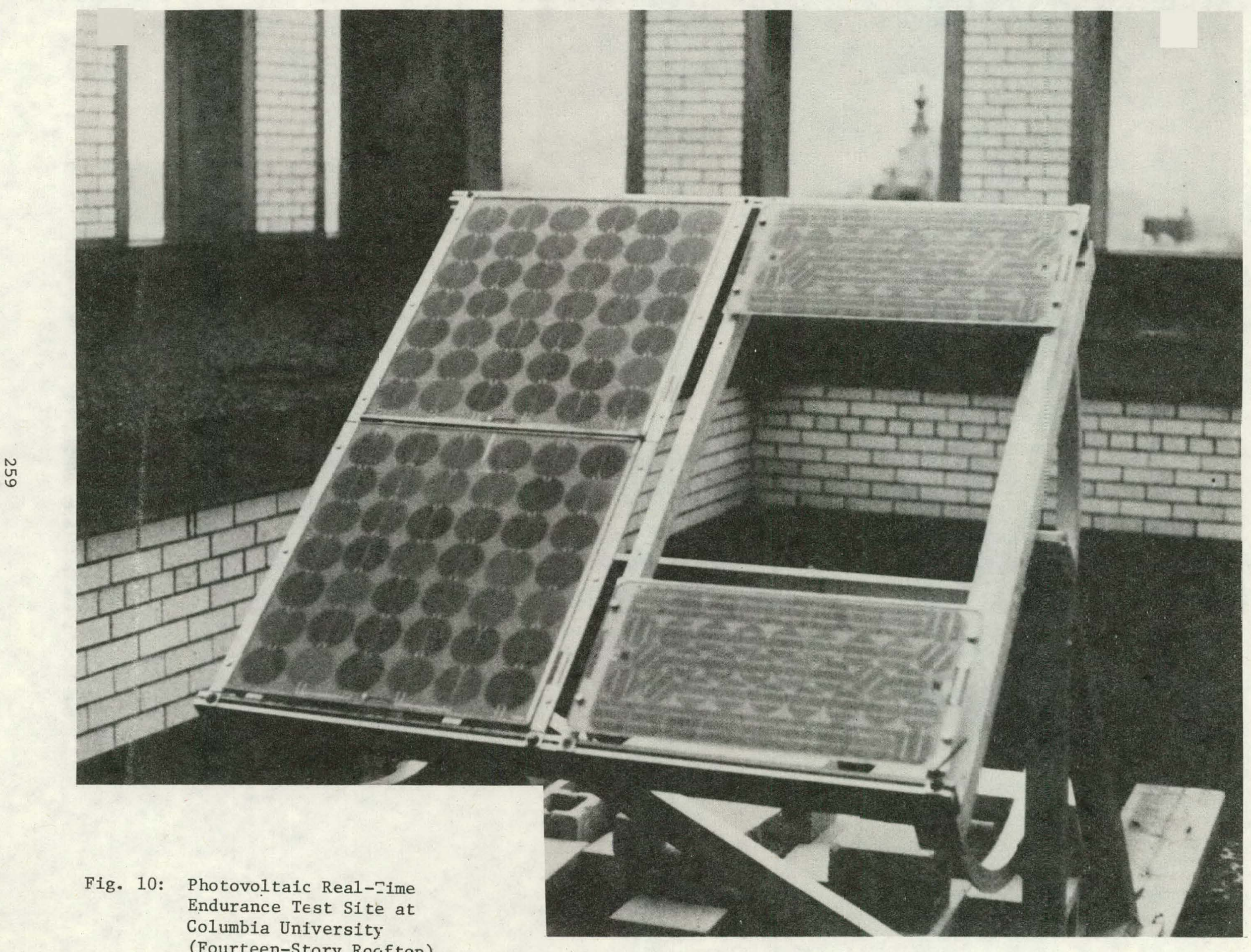
(Fourteen-Story Rocftop) 


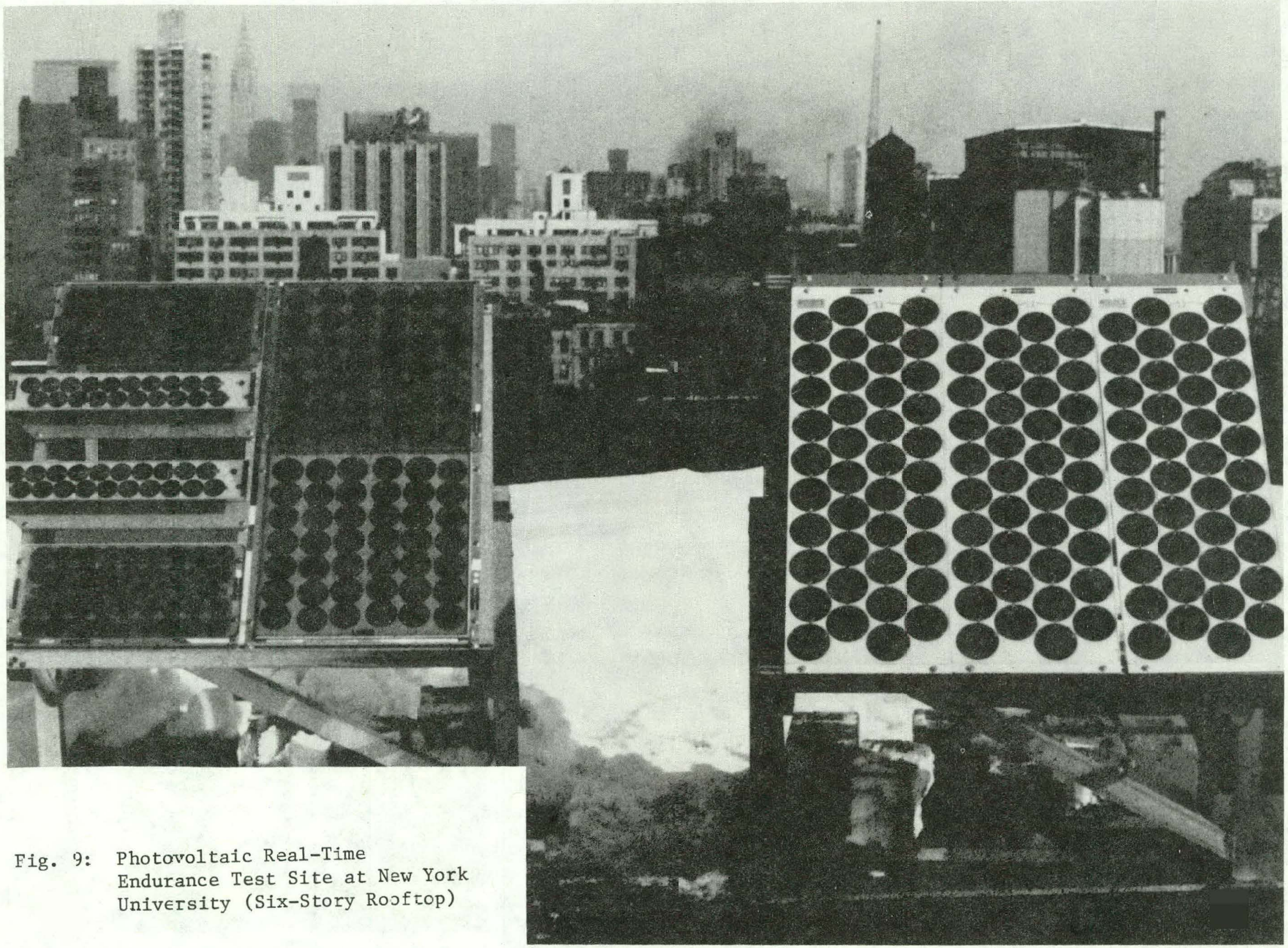


ELECTRICAL DEGRADATION OF NYC MODULES

\begin{tabular}{|c|c|c|c|c|c|}
\hline MODEL & $\begin{array}{l}\text { INITIAL } \\
\text { POWER } \\
\text { (WATTS) }\end{array}$ & $\begin{array}{l}\text { POWER } \\
\text { AT Ó MOS } \\
\text { (WATTS) }\end{array}$ & $\begin{array}{c}\text { LOSS } \\
\%\end{array}$ & $\begin{array}{l}\text { POWER } \\
\text { AT } 1 \text { YR } \\
\text { (WATTS) }\end{array}$ & $\begin{array}{c}\text { LOSS } \\
\%\end{array}$ \\
\hline \multirow[t]{4}{*}{$c$} & 10.61 & 9.84 & $7.26 \%$ & 9.57 & $9.8 \%$ \\
\hline & 9.72 & 9.17 & $5.66 \%$ & 9.57 & $1.5 \%$ \\
\hline & 10.99 & & & 10.04 & $8.64 \%$ \\
\hline & 10.23 & & & 9.67 & $5.47 \%$ \\
\hline \multirow[t]{4}{*}{$D$} & 23.25 & 23 & $1.07 \%$ & 20.64 & $11.22 \%$ \\
\hline & 21.23 & 21.4 & $-.8 \%$ & 19.59 & $7.72 \%$ \\
\hline & 20.3 & & & 20.18 & $.6 \%$ \\
\hline & 22.03 & & & 20.65 & $6.26 \%$ \\
\hline
\end{tabular}

SEF $10 / 17 / 78$ 


\section{MIT/LINCOLN LABORATORY \\ SOIL ACCUMULATION STUDIES \\ SYSTEM TEST FACILITIES}

PERCENT POWER LOSS

MODEL

ENCAPSULANT

LOCATION

START 7/15/77

Nebraska (3 MOS)

NeBRAsKa (5 MOS)

Nebraska (7 mos)

Nebraska (9 mos)

NJEBRASKA (12 MOS)
A

GLASS

B

RTV \&

HARDCOAT
C

RTV

615
D

SYLGARD

184

NOTE: There WAS AN EXCESSive amount of RAIN IN MARCH 1978 WHich is BELIEVED TO BE THE CAUSE OF THE LOWER 9 MONTH READINGS.

START 5/19/77

LL-LEXINGTON (2 MOS)

$1-6.2(15)$

LL-LEXINGTON (5 MOS)

$1-5(3)$

LL-LeXington (7 mos) 1.3-2.8 (9)

LL-LEXINGTON (9 MOS)

$2.8-10.6(15)$

LL-LEXington (11 MOS)

6.2-12 (16) 


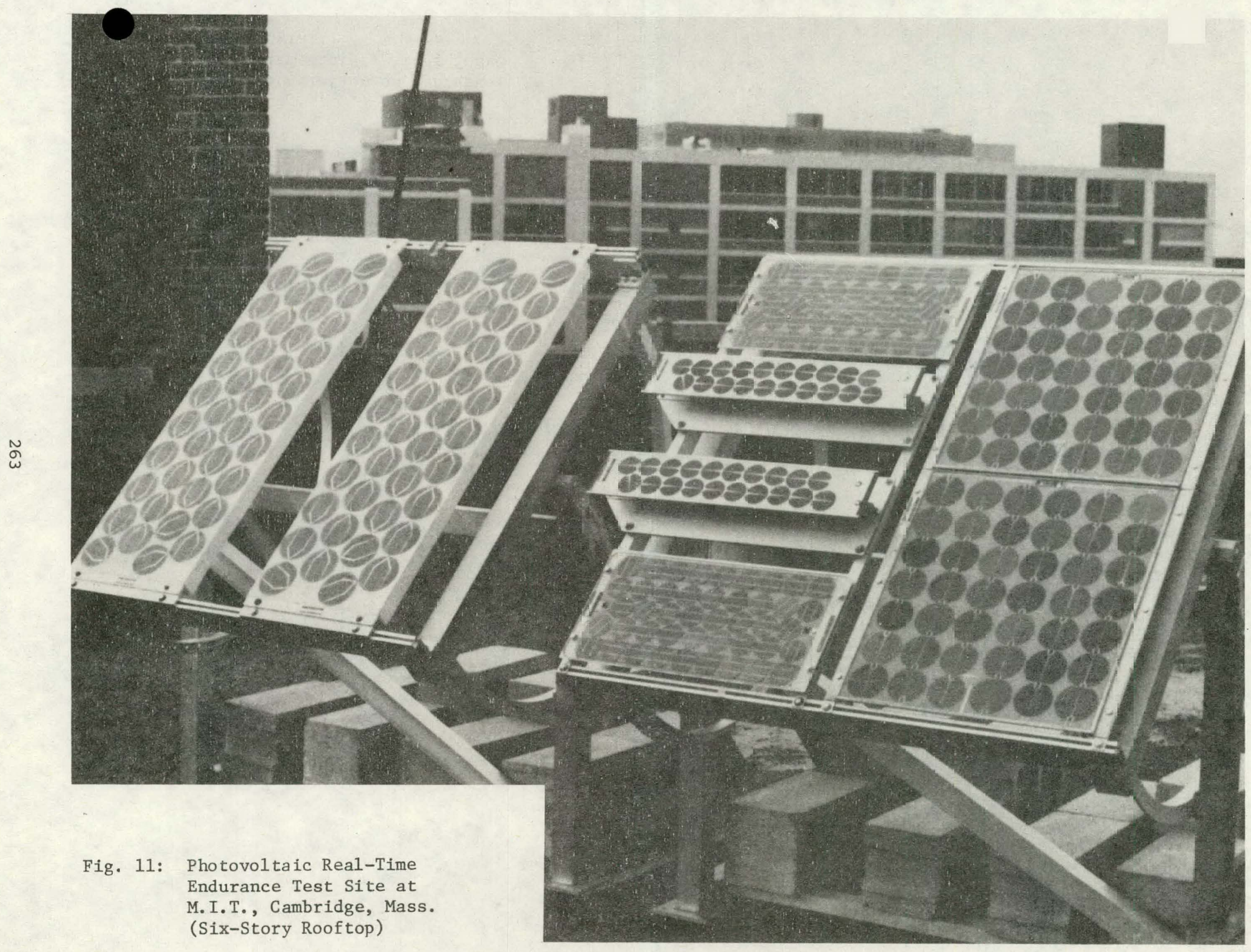




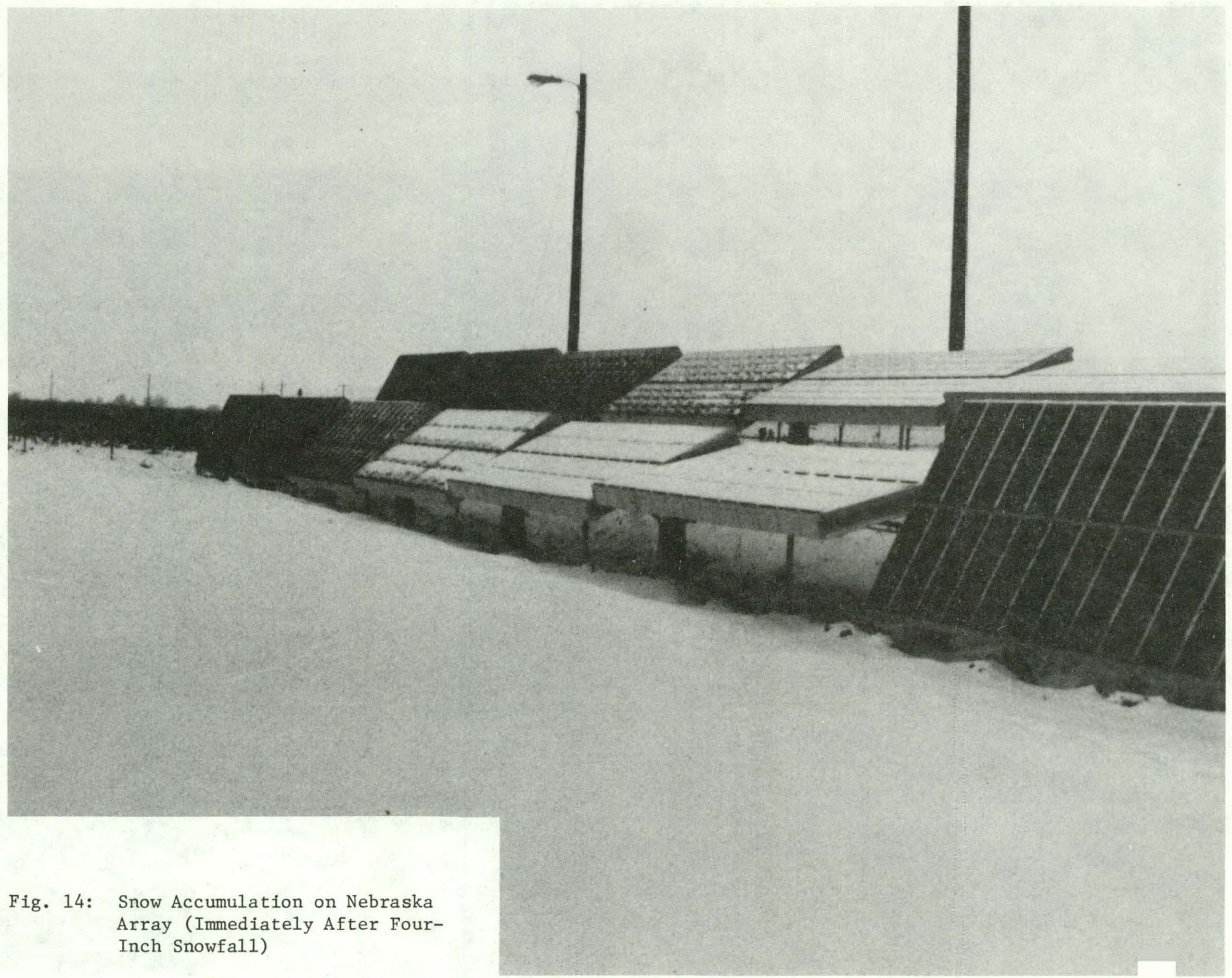


HAIL DAMAGE AT MEAD TEST SITE

LAB AND FIELD INSPECTION OF 44,232 CELLS (OF 97,104) DURING JULY AND SEPTEMBER 1978 INDICATE THAT AT LEAST 136 CELLS HAVE IMPACT CRACKS AND THAT 6 MODULES (OF 2240) FAILED ELECTRICALLY DUE TO THESE CRACKS.

THE CAUSE OF THE IMPACT CRACKS IS BELIEVED TO BE A HAILSTORM WHICH OCCURRED ON MAY 19, 1978. THE CHARACTERISTICS OF THIS STORM ARE AS FOLLOWS:

TIME OF DAY:

TEMPERATURE:

PRECIPITATION:

SIZE OF HAILSTONES: DIAMETER

DENSITY OF HAIL ON GROUND: 10-15 STONES/FT ${ }^{2}$

3:00-3:15 PM (CST) $80^{\circ} \mathrm{F}$

1 INCH OF RAIN IN 15 3-5 MINUTES

$1 / 4$ TO $3 / 4$ INCHES IN MINUTES HAIL LASTED 


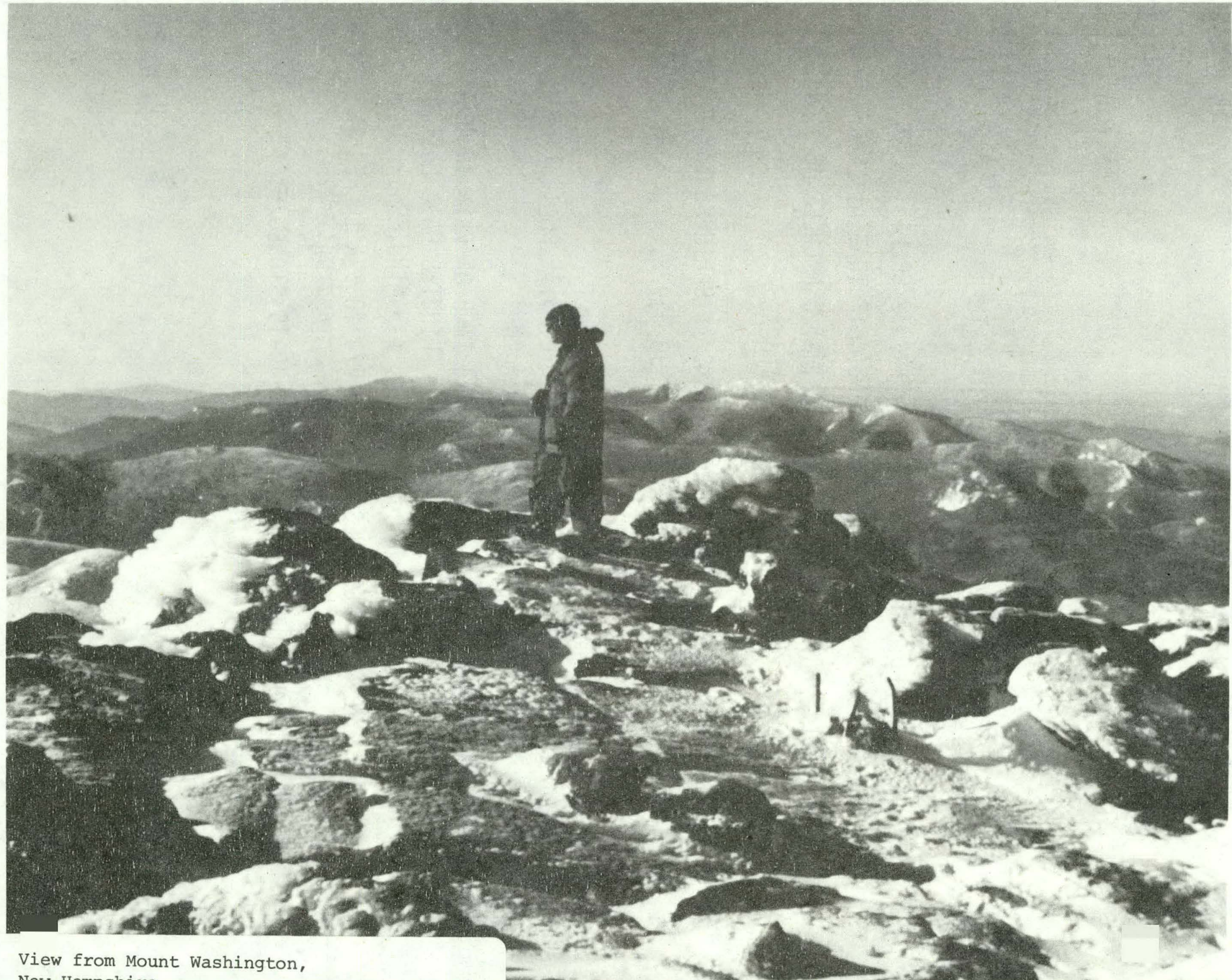


Mt. Washington Test Site

\begin{tabular}{l|l} 
OCATION: Mt. Washington, New Hampshire & OPERATIONAL DATE: October 1977 \\
\hline USER AGENCY: MIT - Lincoln Lab & DESIGNER: MIT - Lincoln Lab \\
$\begin{array}{l}\text { USE: To evaluate performance and survival characteristics of PV panels in an arctic-type } \\
\text { environment }\end{array}$
\end{tabular}

ARRAY POWER (PEAK) :

AMPERAGE (PEAK) :

VOLTAGE. (PEAK) :

EFFICIENCY OF SYSTEM:

STORAGE CAPACITY: $\quad$ Battery was charged at 4.2 amps at 15 volts

SIZE OF ARRAY:

NUMBER OF MODULES: $\quad 6$

MANUFACTURER OF CELLS: ARCO, Motorola, Sensortech (Block III)

COMPOSITION OF CELLS: Silicon

LOAD :

TRACKING SYSTEM TYPE: NOn-tracking

DECLINATION SETTING: One setting, $45^{\circ}$ to horizontal

INSTALLED SYSTEM COST:

COMPONENT COST:

SPECIAL DESIGN FEATURES:

With good sunshine and low ice, the panels charge a battery for an amateur VHF (147 Mhz) epeater furnishing all required power (60 W). 
DATE: Spring 1978

TIME SINCE INSTALLATION: 6 months

CLEANING: No

MODULE FAILURES (if any): None

SYSTEM DEGRADATION (if any):

SPECIAL NOTES :

- Open-circuit voltage measurements indicated continued survival through winter

- The glass encapsulant on one module was shattered but the cells still produced full power (suspect impact from flying ice).

- One RTV encapsulated module had two cracked cells and thus reduced power (suspect same flying ice).

- The other RTV encapsulated module had a bullet hole

DATE: September 1978

TIME SINCE INSTALLATION: 11 months

CLEANING :

MODULE FAILURES (if any):

SYSTEM DEGRADATION (if any):

SPECIAL NOTES :

Last year's modules were taken back to MIT-LL for detailed analysis during the summer. They were replaced with new modules from JPL Block III.

DATE :

TIME SINCE INSTALIATION:

CLEANING :

MODULE FAILURES (if any):

SYSTEM DEGRADATION (if any):

SPECIAL NOTES : 


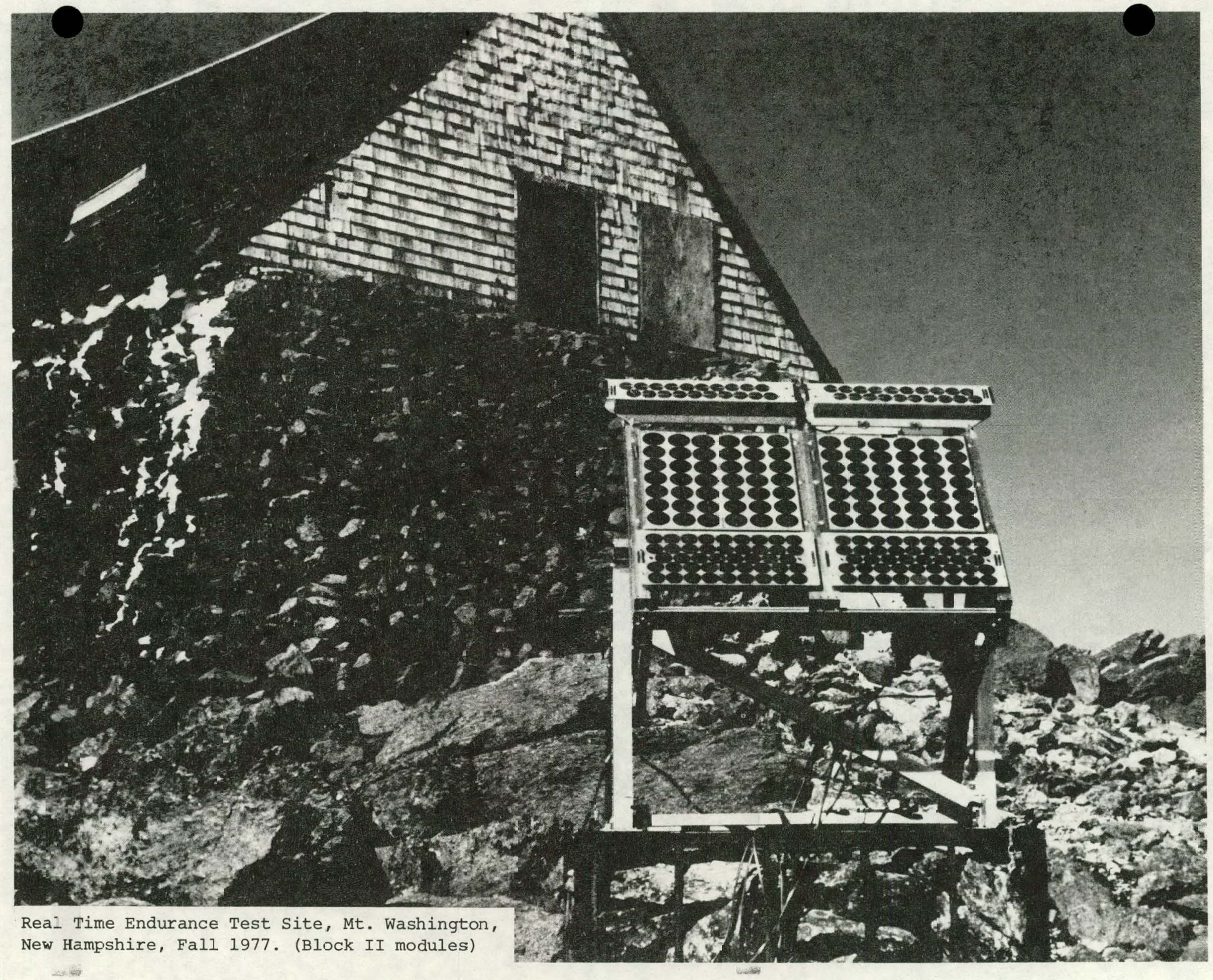




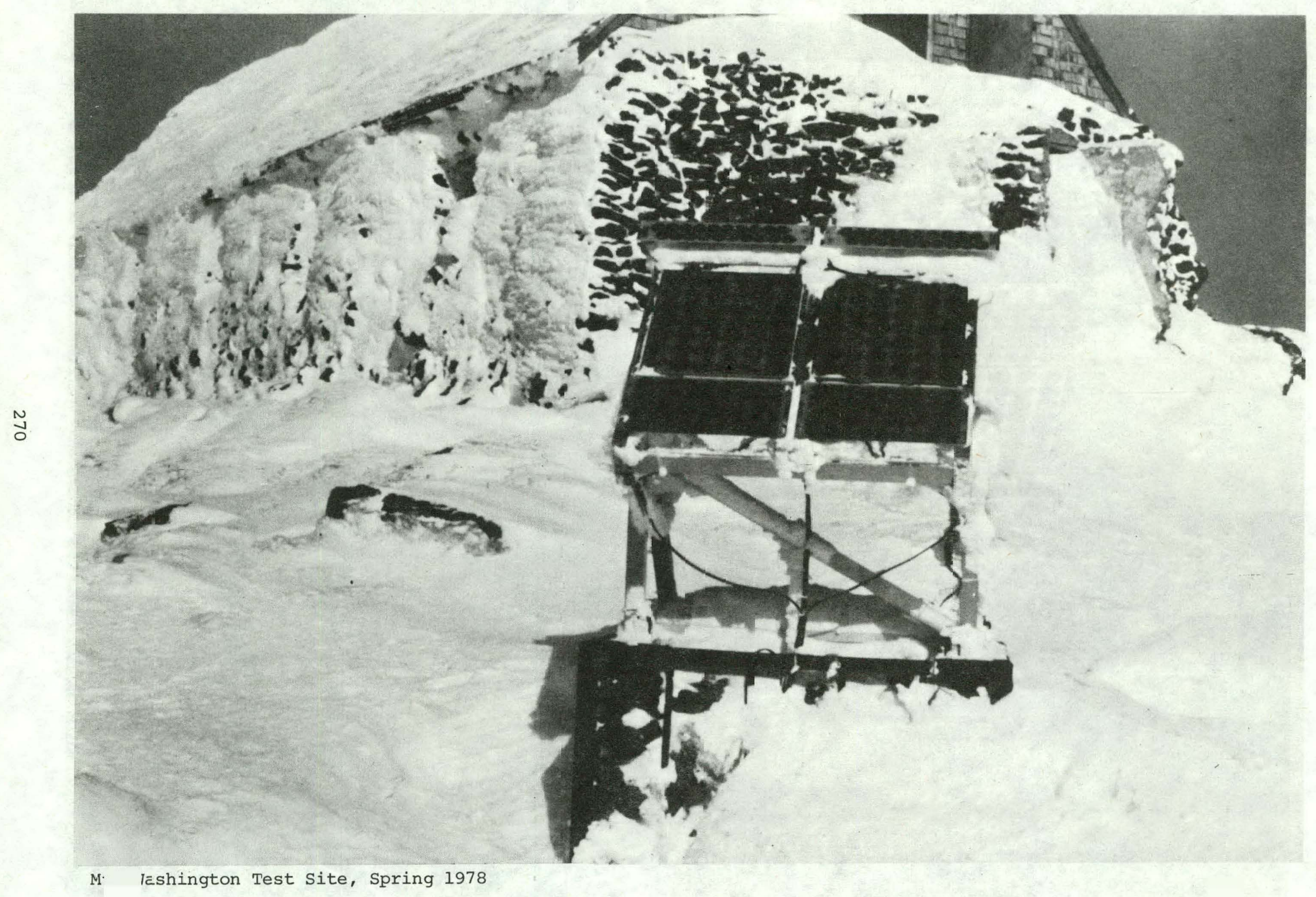


The Mt. Washington Observatory maintains a station on the summit yearround and provides data recording services. Mt. Washington's winters are extremely severe with low temperatures and high winds, even more severe than many far north-latitude military stations, thus affording a convenient location for realistic environmental testing.

During the first month's operation (October 15 - November 15, 1977) full short-circuit currents were obtained from the panels whenever the sun was out at nontime. A battery also was charged at 4.2 amperes at 15 volts. However, rime ice formed over the array in mid-November and for 71 days (November 17 - January 26) no power (zero short-circuit current) was available. Whenever the sun was shining, all of the panels produced some open-circuit voltage indicating survival.

During the blizzard of. February 6-7, 1978, the peak wind gust was $133 \mathrm{mph}$. Open-circuit voltage measurements indicated continued survival. During a thaw on 26 January, all of the ice melted, but there was no sun. From 26 January to 2 February, there was little sun which produced low current, and then the ice reformed. From 3 February - 18 February with some ice on the panels, there was some power available from all panels when there was sunshine.

With good sunshine and low ice, the panels charge a battery for an amateur VHF (147 MHz) repeater furnishing all required power (60 W). Panels set at $45^{\circ}$ to horizontal, pointed south Mt. Washington: $\begin{array}{ll}44^{\circ} & 16^{\prime} \mathrm{N} \\ 71^{\circ} & 18^{\prime} \mathrm{W}\end{array}$

A new set of Block III modules have been installed for the 1978-79 winter season to test the newer modules under Mt. Washington's arctic conditions. 


\title{
MOUNT WASHINGTON WEATHER
}

\author{
6280-FT ALTITUDE \\ WINTER OF 1976-77
}

NOVEMBER TO MARCH (5 months)

AVERAGE TEMPERATURE

MAXIMUM TEMPERATURE

MINIMUM TEMPERATURE

AVERAGE WIND SPEED

MAXIMUM WIND SPEED

MAXIMUM WIND SPEED EVER

(April 12, 1934)

SNOW

MAXIMUM IN 24 HOURS

PERCENT POSSIBLE SUNSHINE

\author{
$6^{\circ} \mathrm{F}$ \\ $47^{\circ} \mathrm{F}$ \\ $-33^{\circ} \mathrm{F}$ \\ $46 \mathrm{smph}$ \\ $154 \mathrm{smph}$
}

$231 \mathrm{smph}$ (a world record)

$400 \mathrm{in.}$

21 in.

23 percent 


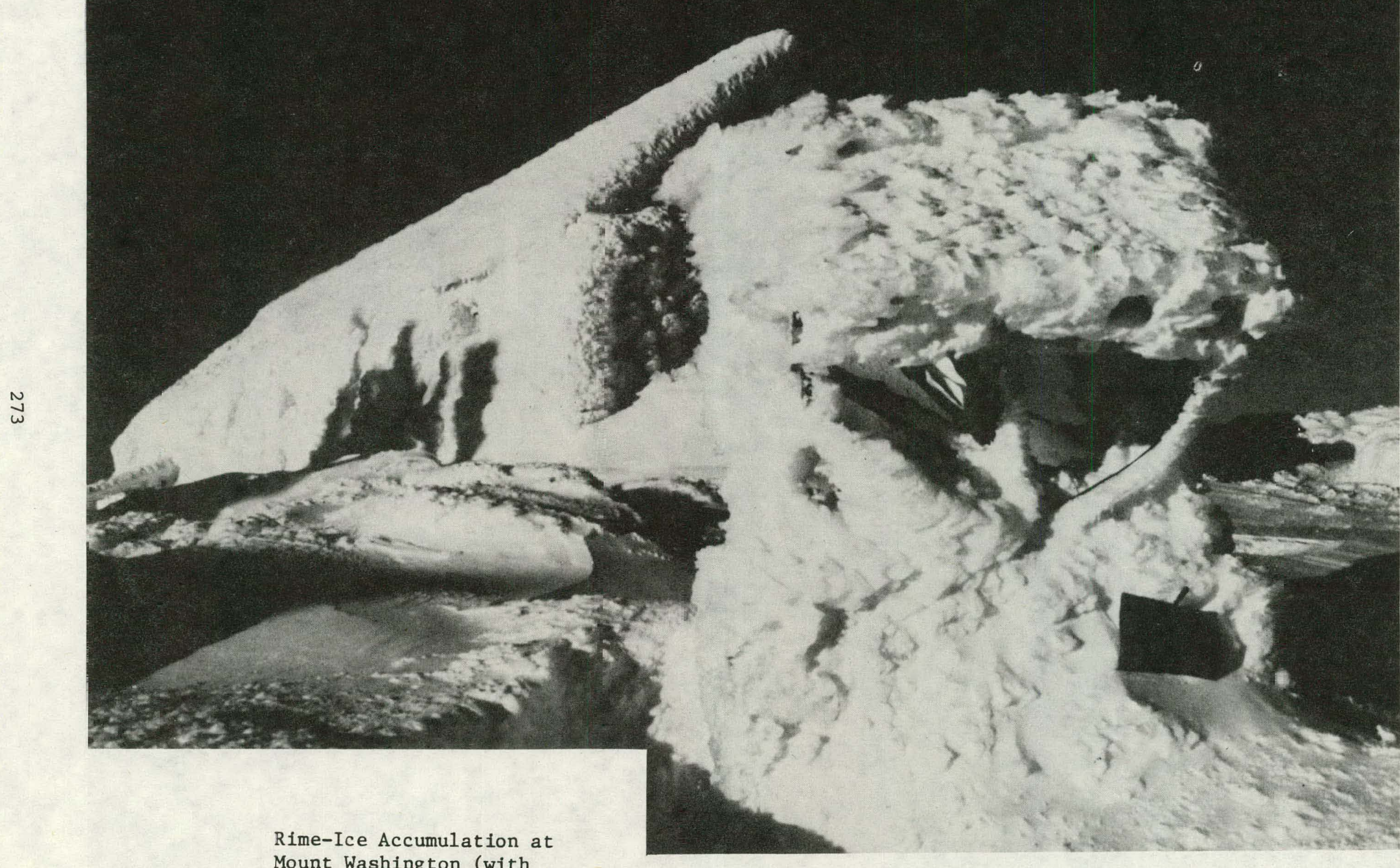

Mount Washington (with

Observatory Building in

background). Jan. 23, 1978 


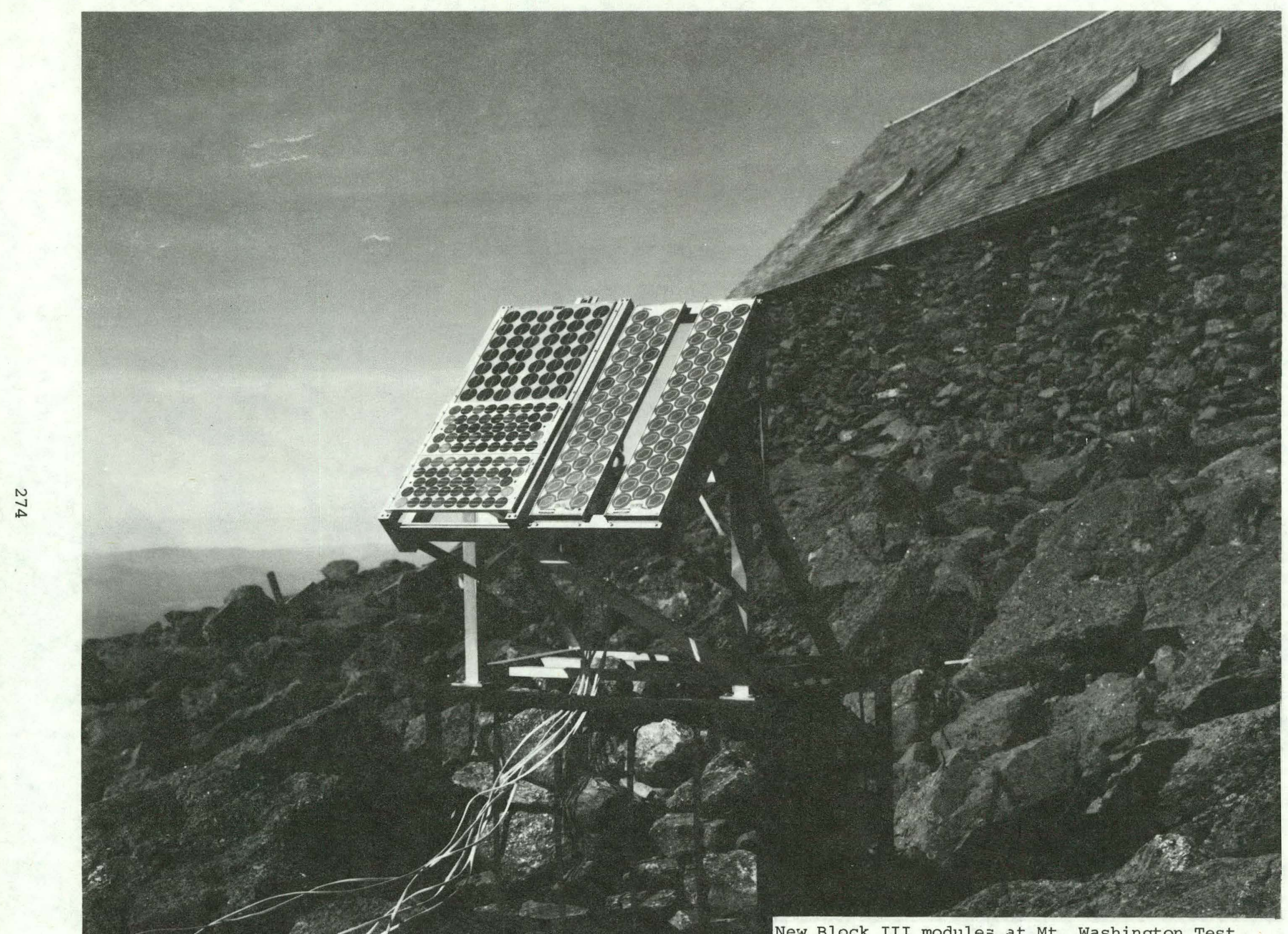

New Block III modules at Mt. Washington Test Site, New Hampshire. Summer 1978 


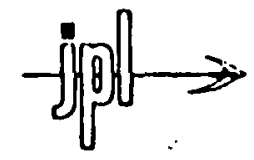

JPL TELEPHONES

213-577-xxxx (UNLESS OTHERWISE NOTED)

FTS: 8-792-xxxx FOR BOTH $577 \& 354$ PREFIXES

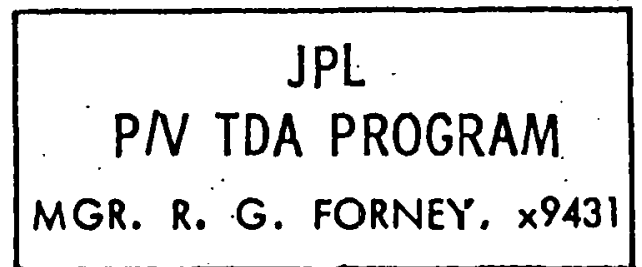

TELECOPIER IN BLDG 506:

AUTO: $354-4964$

DATA CTR: $\quad 354-4289$

MAIL STATIONS:

BLDG 506, RM 418 (UNLESS OTHERWISE NOTED)
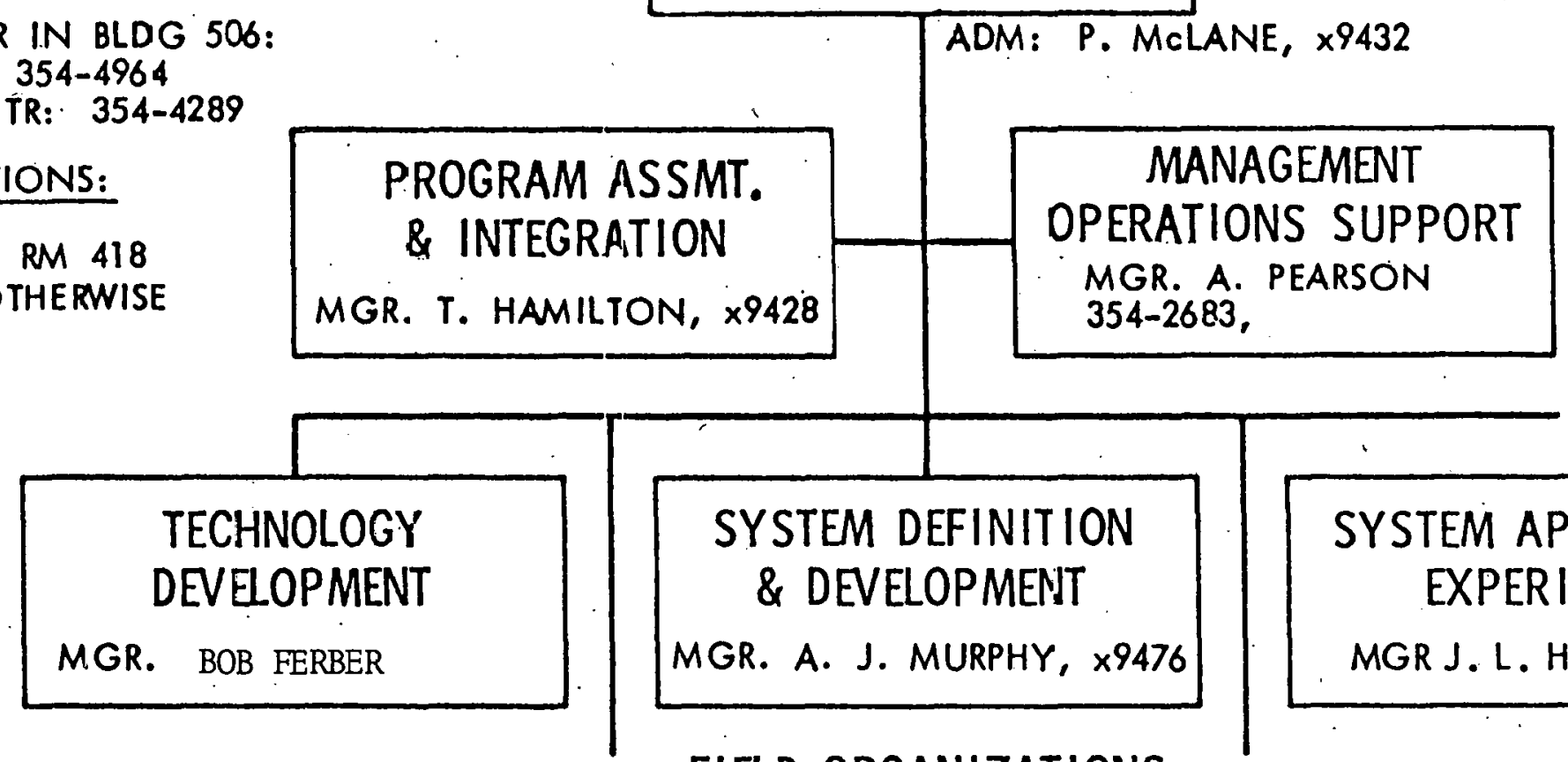

\section{SYSTEM APPLICATION EXPERIMENTS \\ MGR J. L. HESSE, $\times 9428$}

\section{FIELD ORGANIZATIONS}

- aerospace.

- MIT/EL

- MIT/LL

- JPL/LSA

- NASA/LERC

- saNDIa

- SERI
S. I. LEONARD, (213) 648-7040

R. TABORS, (617) 253-3408- (FTS 8-835-3408)

M.. POPE, (617) $862-5500, \times 7785$ (FTS 8-617-862-5500, x7785)

W. T. CALLAGHAN, (213) $577-9517$ (FTS 8-792-9517.)

R. PALMER, (216) 433-4000, x6840 (FTS 8-294-6840)

D. SCHUELER, (505) 264-4041 (FTS 8-475-4041)

D. FEUCHT, (303) 234-1373 (FTS 8-327-1373) 


\section{LOW-COST SOLAR ARRAY PROJECT}

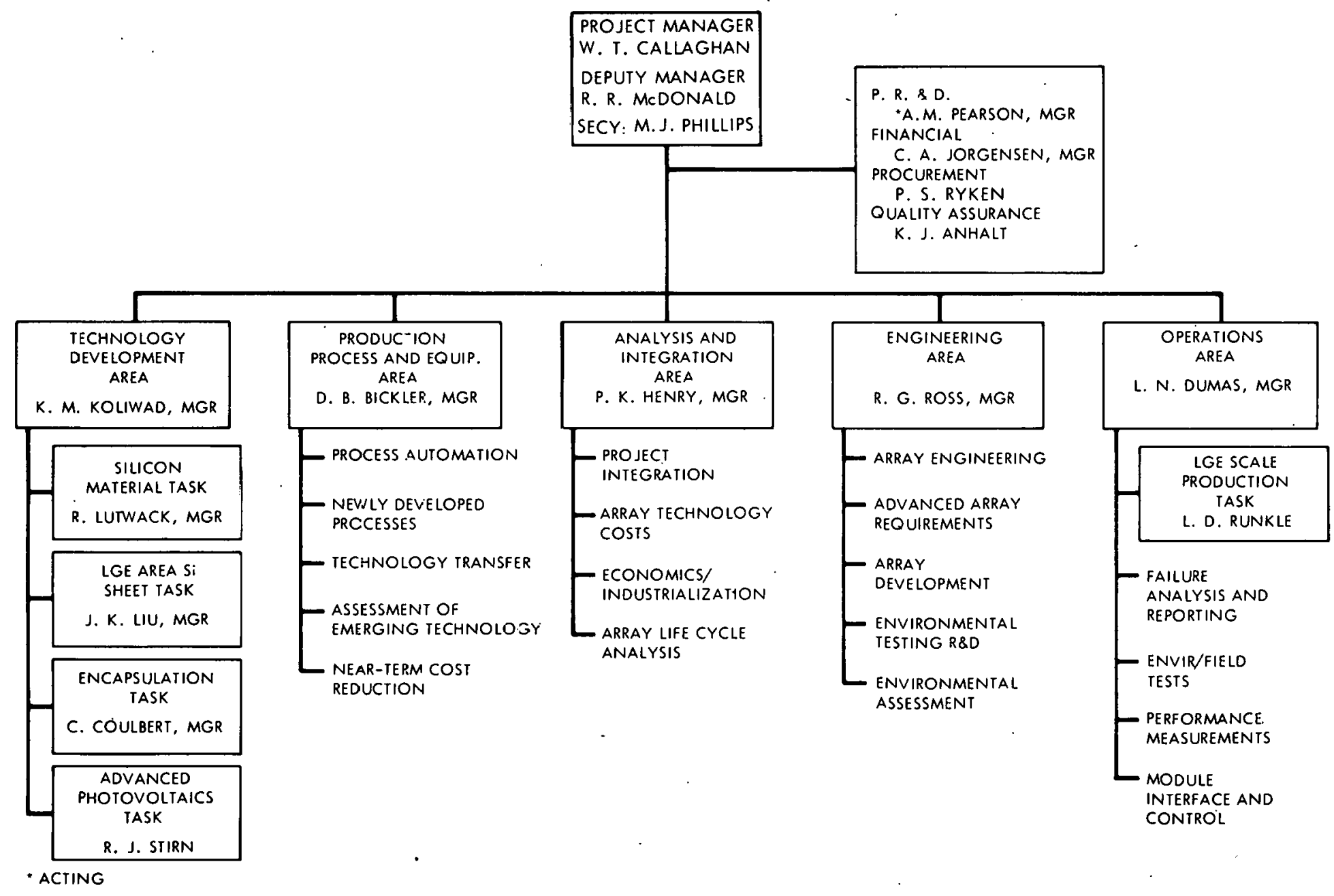


JPL. supports the System Test and Applications program by purchasing and inspecting all modules used by the various DOE Projects. This work is done under the Low-Cost Solar Array Project.

All the modules from the large procurement buys (Biock I-IV) are put through rigorous inspection and testing procedures before they are delivered to insure that they meet all specified design requirements. JPL is just finishing their Block III 200 $\mathrm{kW}$ procurement testing and will soon start testing new Block IV Modules $(60 \mathrm{~kW})$. The Block IV Modules will be used for two general types of applications. Some will be used for intermediate load center applications while the others will be used for residential applications. Each of the applications will have a separate acceptance testing procedure and a brief description of each is given on the following pages. 


\title{
QUALIFICATION AND ACCEPTANCE REQUIREMENTS \\ FOR
}

\author{
RESIDENTIAL APPLICATIONS
}

\section{A. DESIGN QUALIFICATION TEST REQUIREMENTS}

This section specifies the minimum tests that shall be performed in order to verify that the modules will satisfy the design requirements of this specification and to provide confidence that production modules will function within the specified performance requirements. Modules shall be mounted on rigid structural test frames simulating. the selected mounting interface and configuration for all design. qualification testing. The mounting arrangement shall be representative of the rooftop installation shown on the manufacturer's Interface Control Drawing. Modules shall be provided with suitable thermocouple or circuit monitoring instrumentation. As a minimum, the following qualification tests shall be performed in the order described below. For clarification, the test sequence is shown in the flow chart (Figure 1).

(1) Ground Continuity Test - Each module having exposed external conductive surfaces (i.e., frame or structural members) shall be tested using a suitable continuity tester to verify that plertriral rontinuity exists .hetwaen 011 surh surfaces and the module grounding point. The maximum resistance to ground sha1]. be 50 milliohms.

(2) Electrical Isolation Test - Each module shall be subjected to a 'Hi-Pot' test conducted with the output'terminations short-circuited. Test leads from a suitable dc voltage power supply shall be connected with the positive lead on the terminals and the negative lead on the module grounding stud.

In the case of modules not required to provide a grounding stud, the mounting structure shall be used as the second test point. Voltage shall be applied at a rate not to exceed $500 \mathrm{~V} / \mathrm{sec}$ up to the test voltage of $1500 \mathrm{Vdc}$, and then held at the required test voltage for 1 minute. The module shall be observed during the test and there shall be no signs of arcing or flash-over. Leakage current shall be monitored during the test and shall not exceed 50 microamps.

(3) Baseline Electrical Measurement - Subsequent to assembly in the structural test frame, each module shall be remeasured to establish a baseline electrical output power which will serve as the comparison value for determination of the effects of qualification testing on electrical performance. 
(4). Visual Inspection - Each module shall. be visually inspected to obtain a baseline identification of the presence or absence of any defects in the module for purposes of detecting any changes following environmental exposure. Pertinent sections of the applicable acceptance/rejection criteria or workmanship specification shall provide a guide for this inspection.

(5) Environmental Tests - Each module shall be subjected to the following exposures. Module electrical performance measurements and visual inspection shall be conducted after each exposure. The testo ohall be conducted in the order indicated:
(a) Thermal cycling test
(b) Humidity cycling test
(c) Mechanical cycling test, if applicable
(d) Wind resistance test, if applicable
(e) Twisted mounting surface test
(f) Hail impact test

(6) Qualification Pass/Fail Criteria - The output power degradation of each tested module determined after completion of a11. qualification tests, shall not exceed 5 percent of the baseline electrical performance determined per paragraph A:3. The module shall pass the electrical isolation test when retested at completion of qualification tests. There shall be no occurrences of open circuit or. short circuit conditions during tests in which the module circuitry is instrumented. The allowable level of observable cracks or other mechanical degradation (such as delamination of coatings) shall be determined by the JPLapproved manufacturer's module acceptance testing plan. Acceptable performance under the qualification testing requirements is a prerequisite for JPL approval of the module design. 


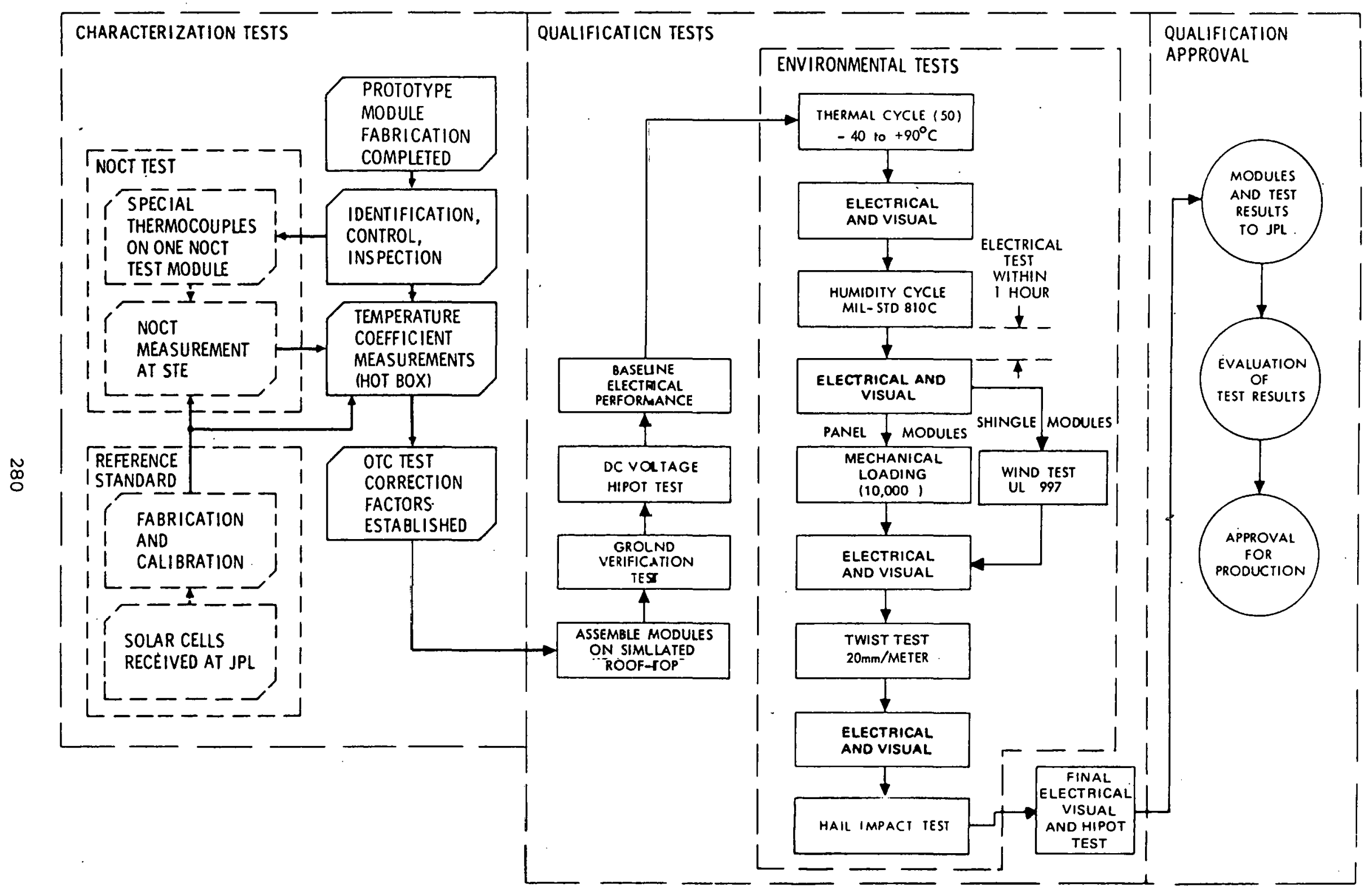

Figure 1. Characterization and Qualification Test Flow Plan for Residential Applications 


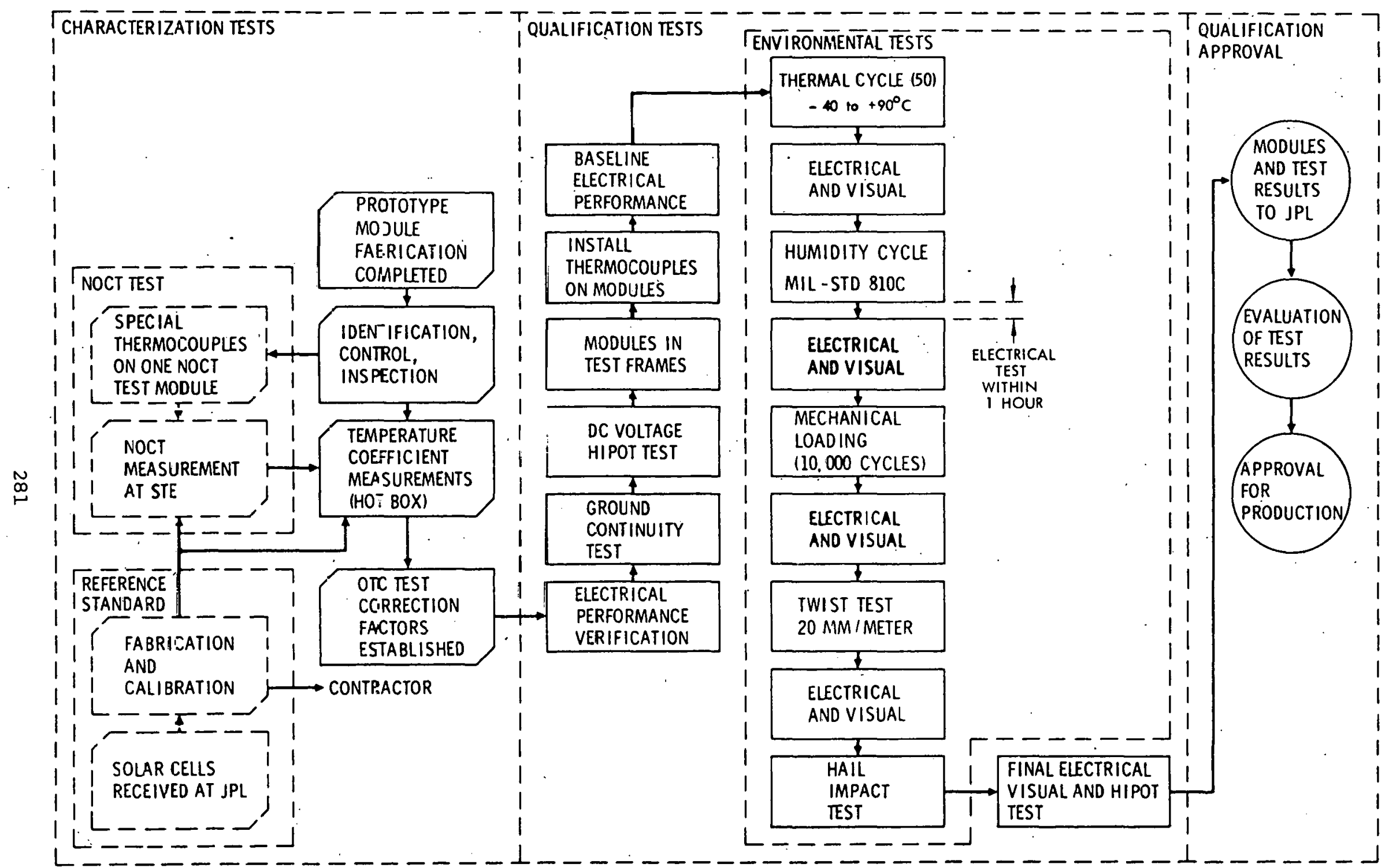

Figure 2. Characterization and Qualification Test Flow Plan

for Intermediate Load Center Applications 
B. MODULE PRODUCTION ACCEPTANCE REQUIREMENTS ments :

Module acceptance shall be based on meeting the following require-

(1) Electrical Performance - Each module shall be measured to determine its current-voltage characteristics (I-V curve). No module shall be accepted for delivery which produces less than 90 percent of the average module output power ( $\mathrm{P}_{\text {avg }}$ ) under Standard Operating Conditions.

(2) Electrical Isolation - Each module shall be subjected to a 1500 vdc Hi-Pot test, per Paragraph A.2, to assure adequate electrical isolation for safety of operating personnel at system operating voltages.

(3) Mechanical and Visual Inspection - Modules shall be mechanically and visually inspected, on the basis of criteria developed by the manufacturer, and approved by JPL, defining acceptable/rejectable levels of workmanship and quality. 


\section{QUALIFICATION AND ACCEPTANCE REQUIREMENTS}

FOR

INTERMEDIATE LOAD CENTER APPLICATIONS

Modules for intermediate load center applications go through almost identical testing procedures as the residential applications do. There are a couple of differences which can be seen easiest by comparing the test flow plan for each (Figure $1 \& 2$ ). The verbal testing requirements are identical word for word except for:

1. The voltage for the "Hi-Pot" test (paragraph 2) is raised to 2000 Vdc vs. 1500 Vdc for residential applications.

2. Environmental testing (paragraph 5) does not include wind resistance testing which is included in the residential tests. 


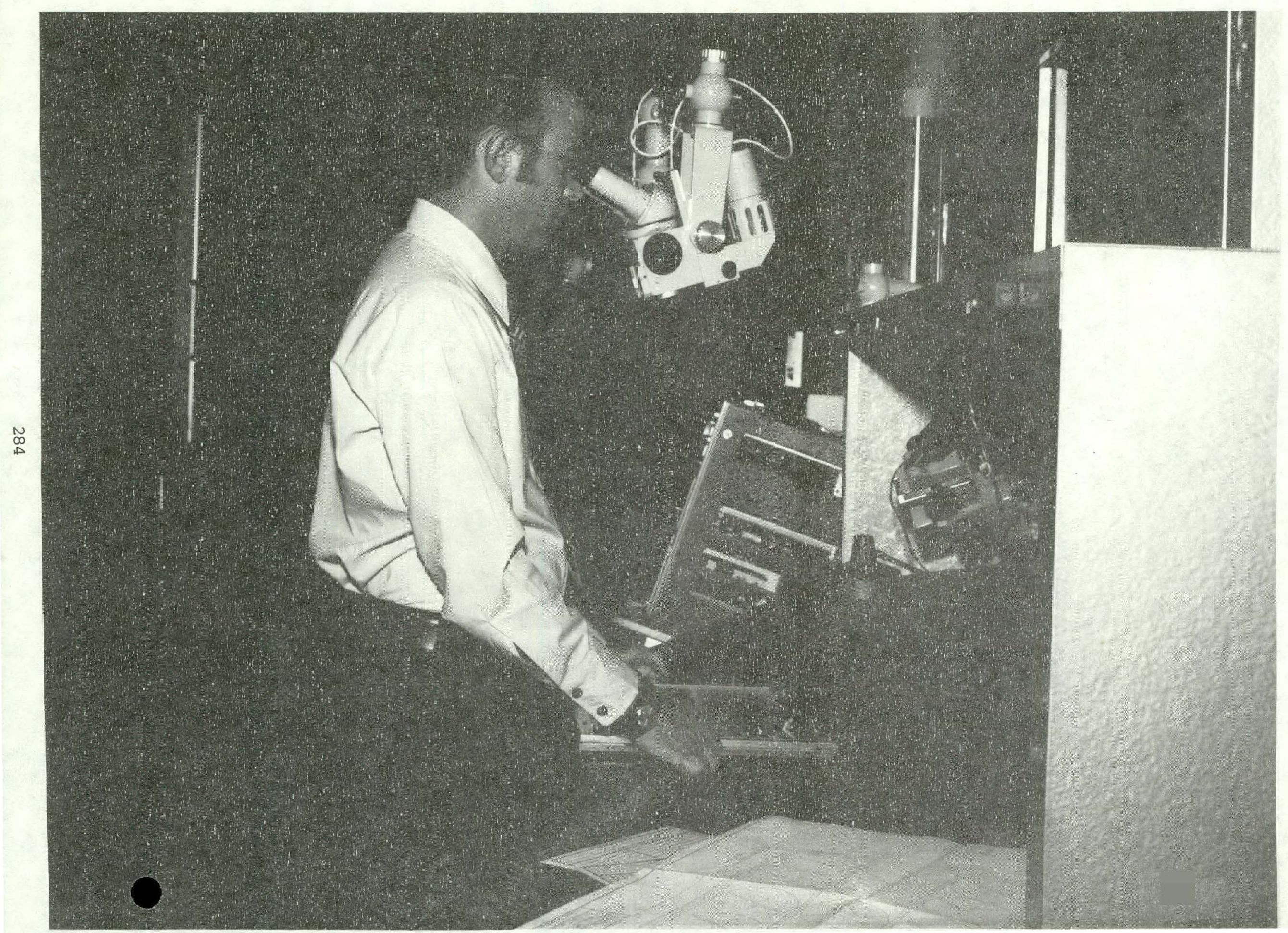




\section{NEW, WALK-IN TEMP/HUMIDITY TEST CHAMBER}

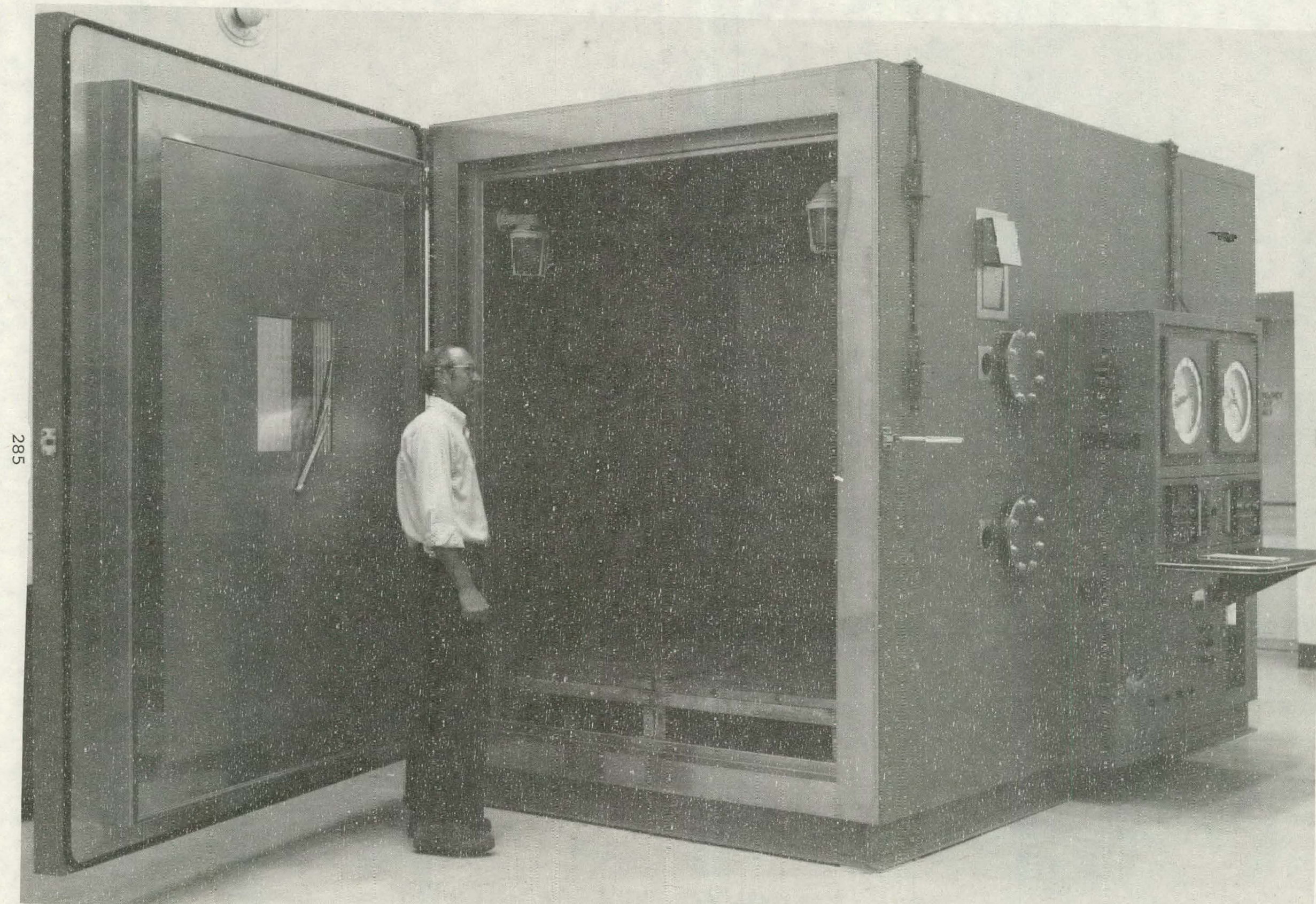


MODULES READY FOR FLASH (ELECTRICAL PERFORMANCE) TEST

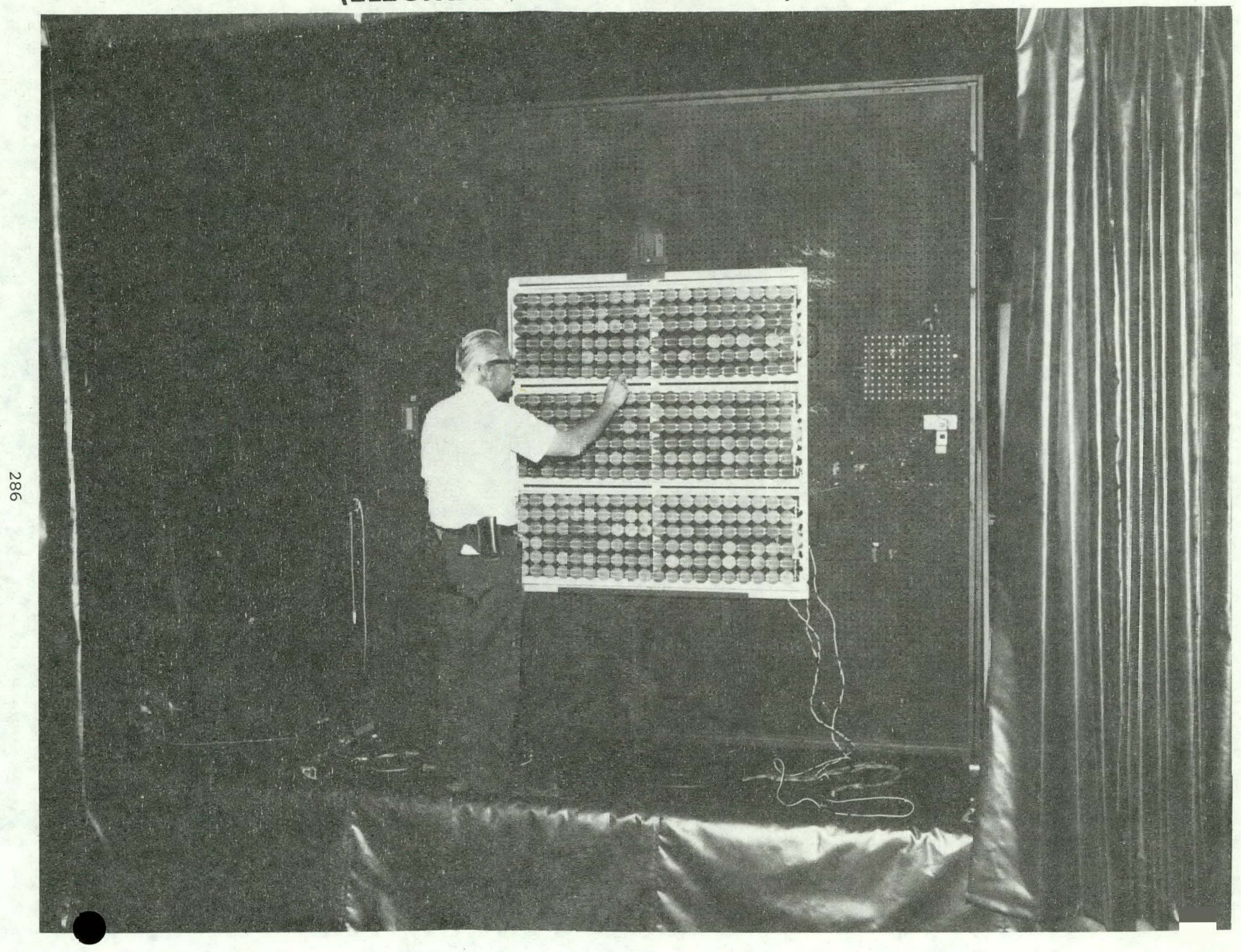




\section{LAPSS CONSOLE}

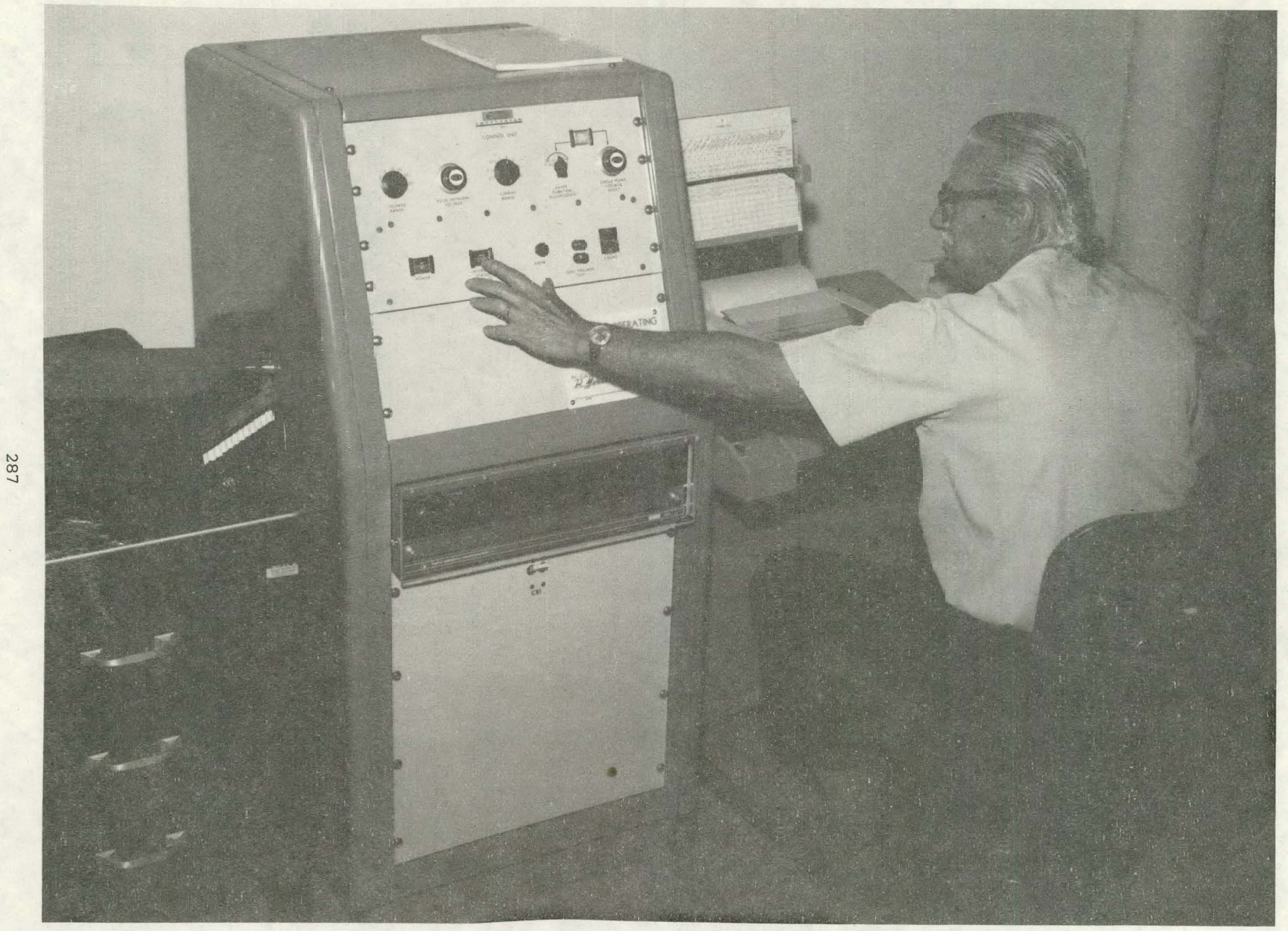




\section{ELECTRICAL ISOLATION (HIPOT) TEST}

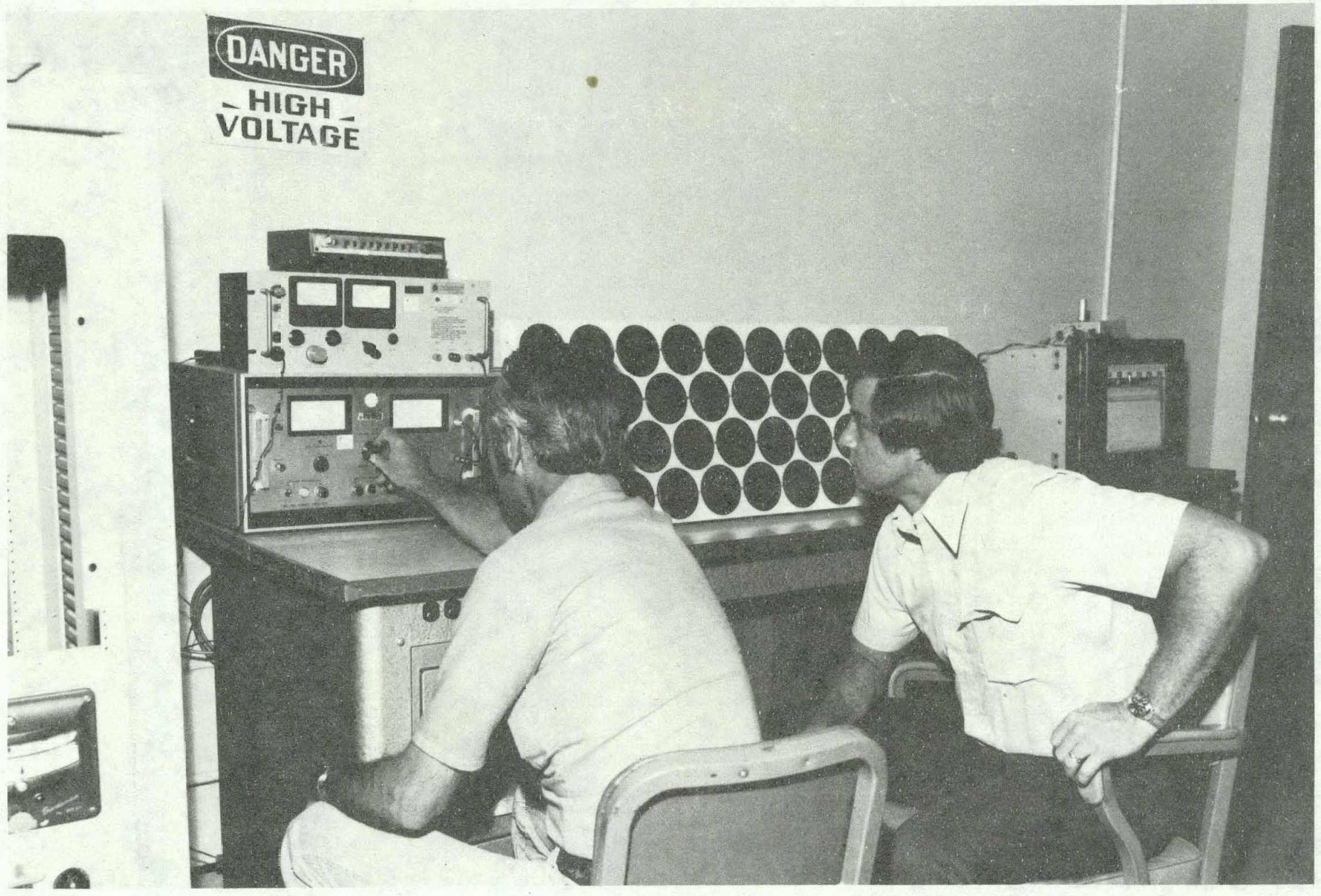


NASA

C-76-1183

\section{REFERENCE CELL}

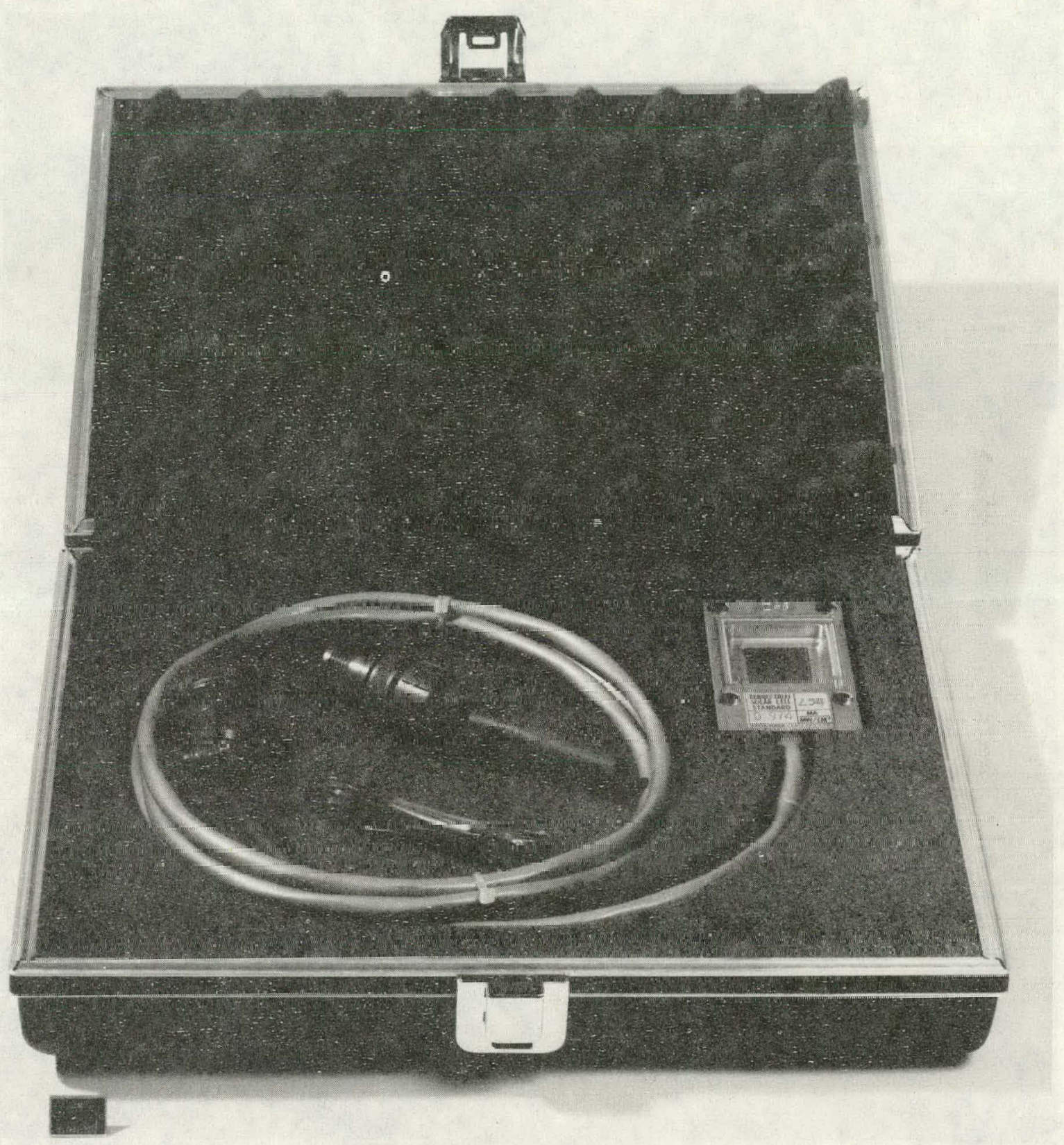




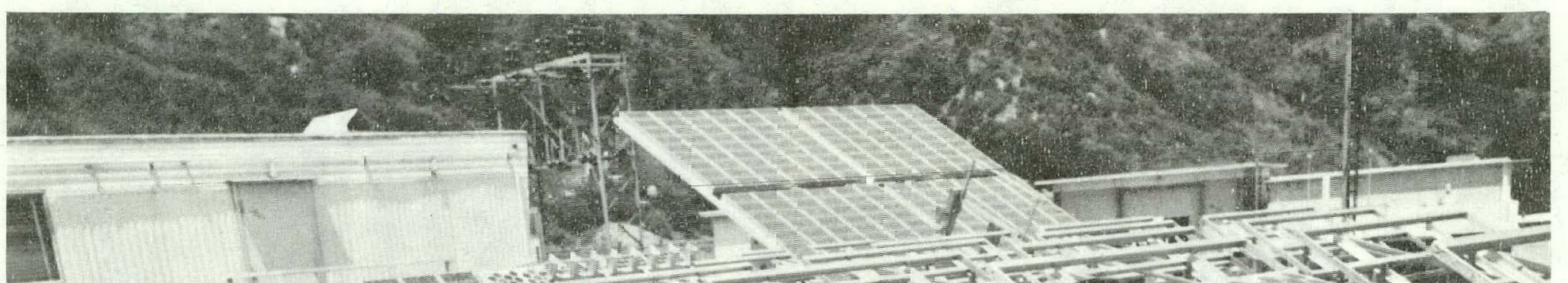

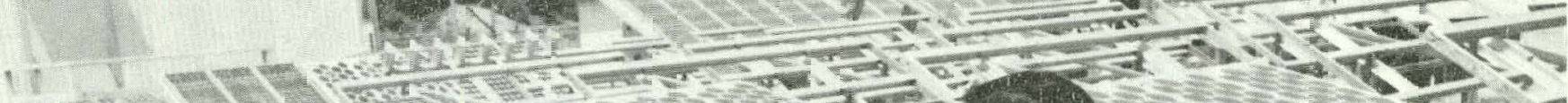
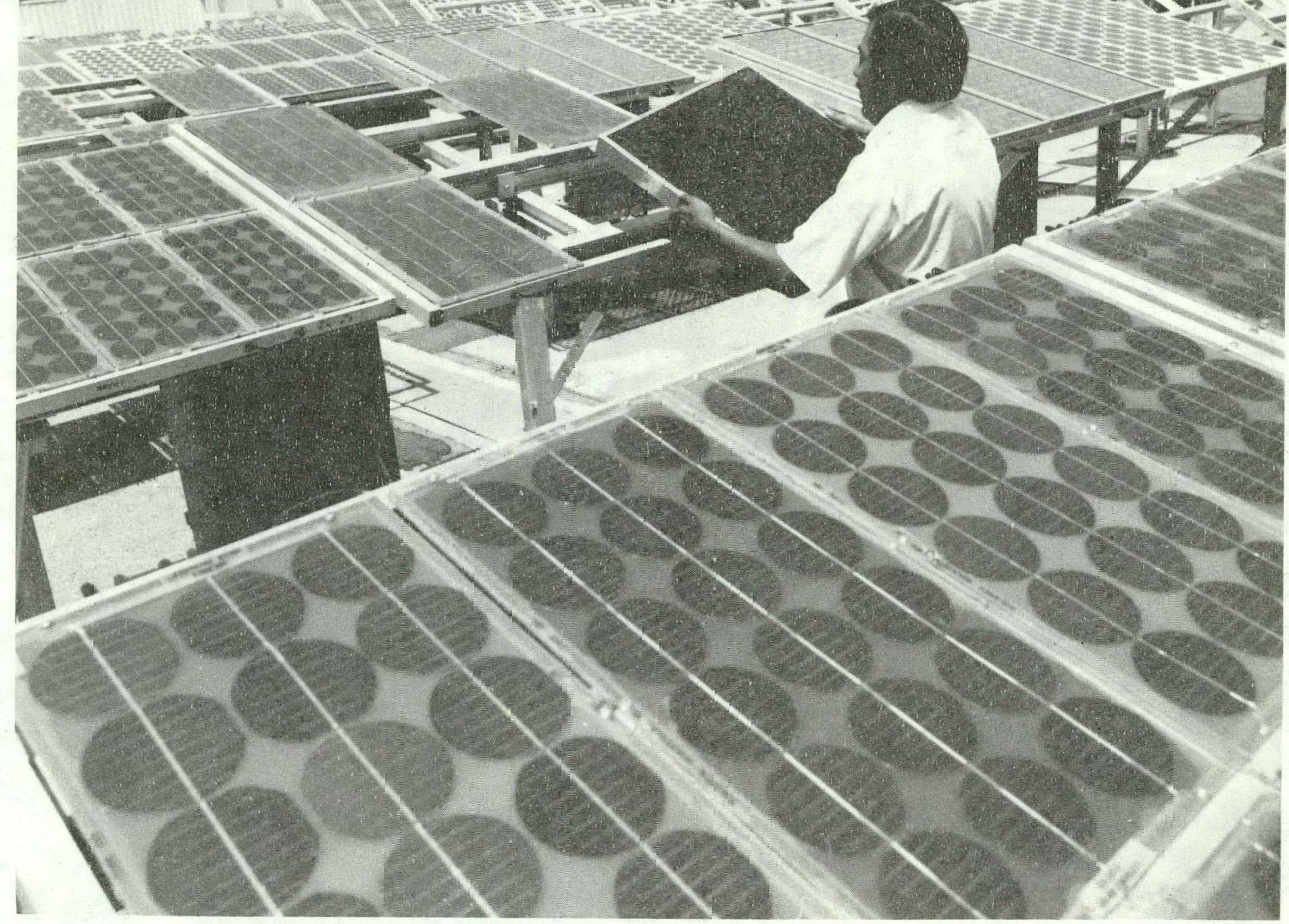

JPL Test Site - Motorola Module being jut in 


\begin{tabular}{|l|l|}
\hline SOCATION: Lexington, Massachusetts & OPERATIONAL DATE: October 1977 \\
\hline USER AGENCY: MIT-Lincoln Lab & DESIGNER: MIT-LinColn Lab \\
\hline
\end{tabular}

USE: Component and subsystem testing

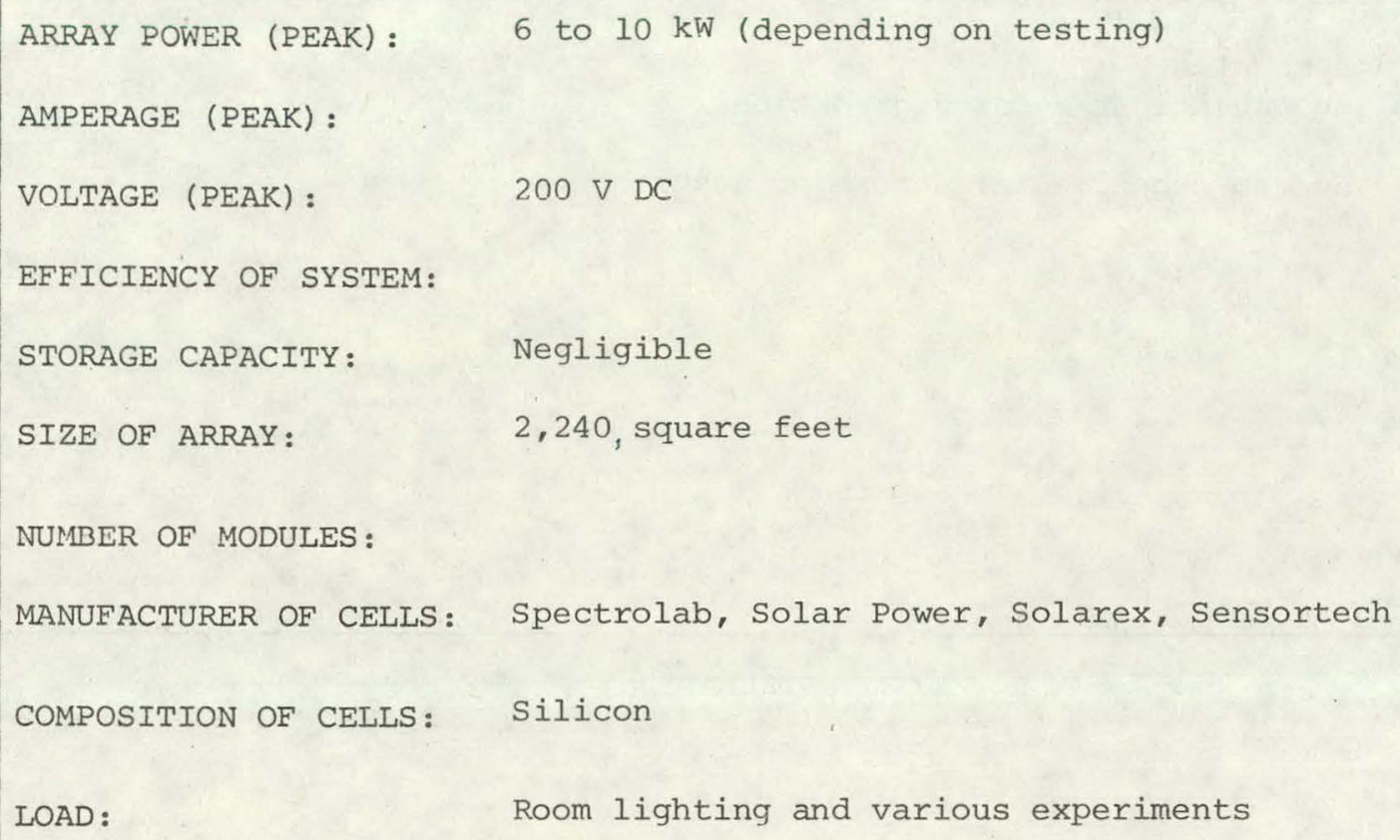

SPECIAL DESIGN FEATURES:

- Can be tilted backward for cleaning

Primarily configured to do component testing on PV related power conditioning and storage devices 
DATE: November 20, 1978

CLEANING : No

MODULE FAILURES (if any):

SYSTEM DEGRADATION (if any):

SPECIAL NOTES :

Do not clean (mostly glass modules)

(non-glass modules being investigated for degradation).

Degradation not measured due to experimental nature of tests.

DATE:

CLEANING :

MODULE FAILURES (if any):

SYSTEM DEGRADATION (if any):

SPECIAL NOTES :

DATE :

TIME SINCE INSTALLATION:

CLEANING :

MODULE FAILURES (if any):

SYSTEM DEGRADATION (if any):

SPECIAL NOTES: 


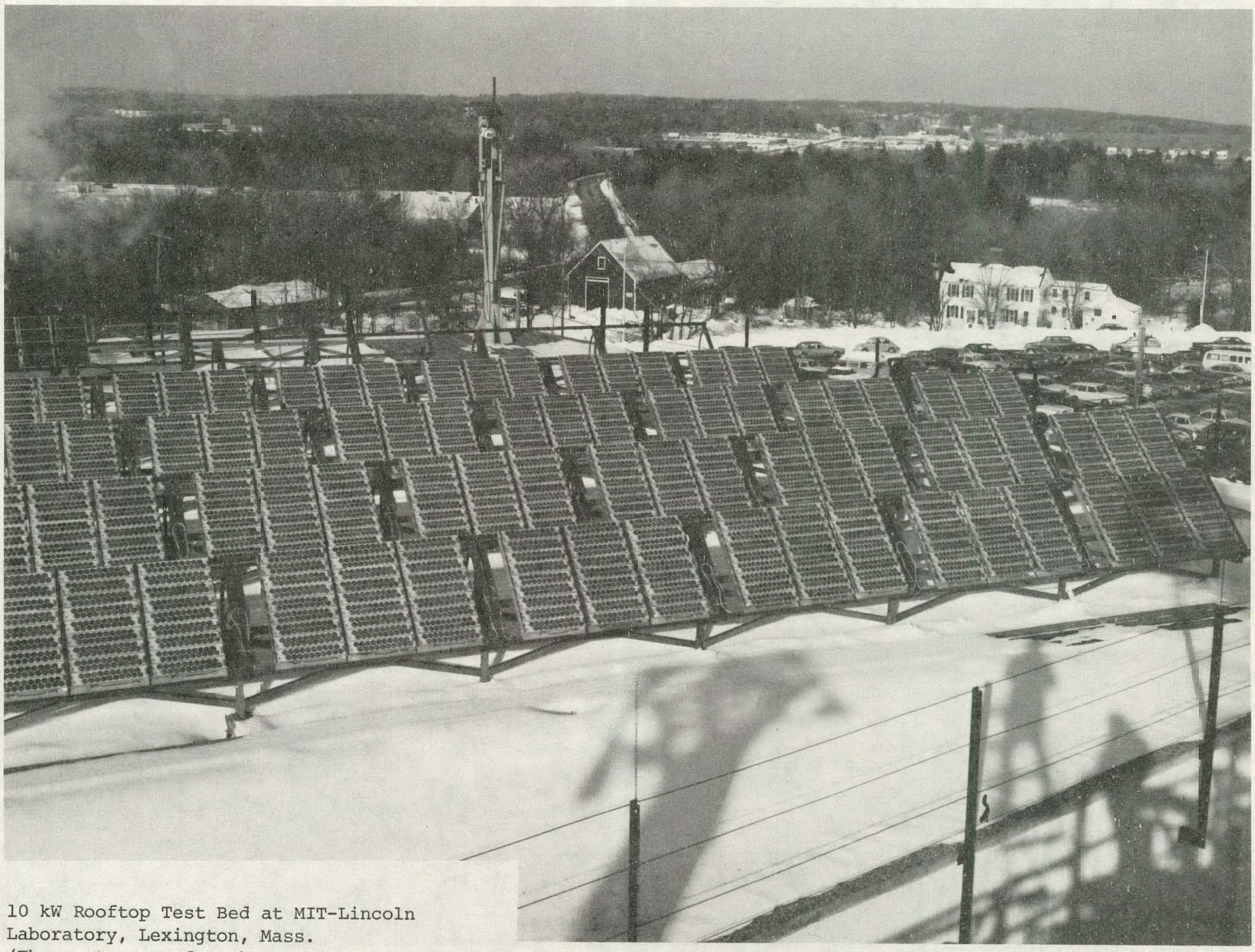

Laboratory, Lexington, Mass.

(Three-story rooftcp.) 


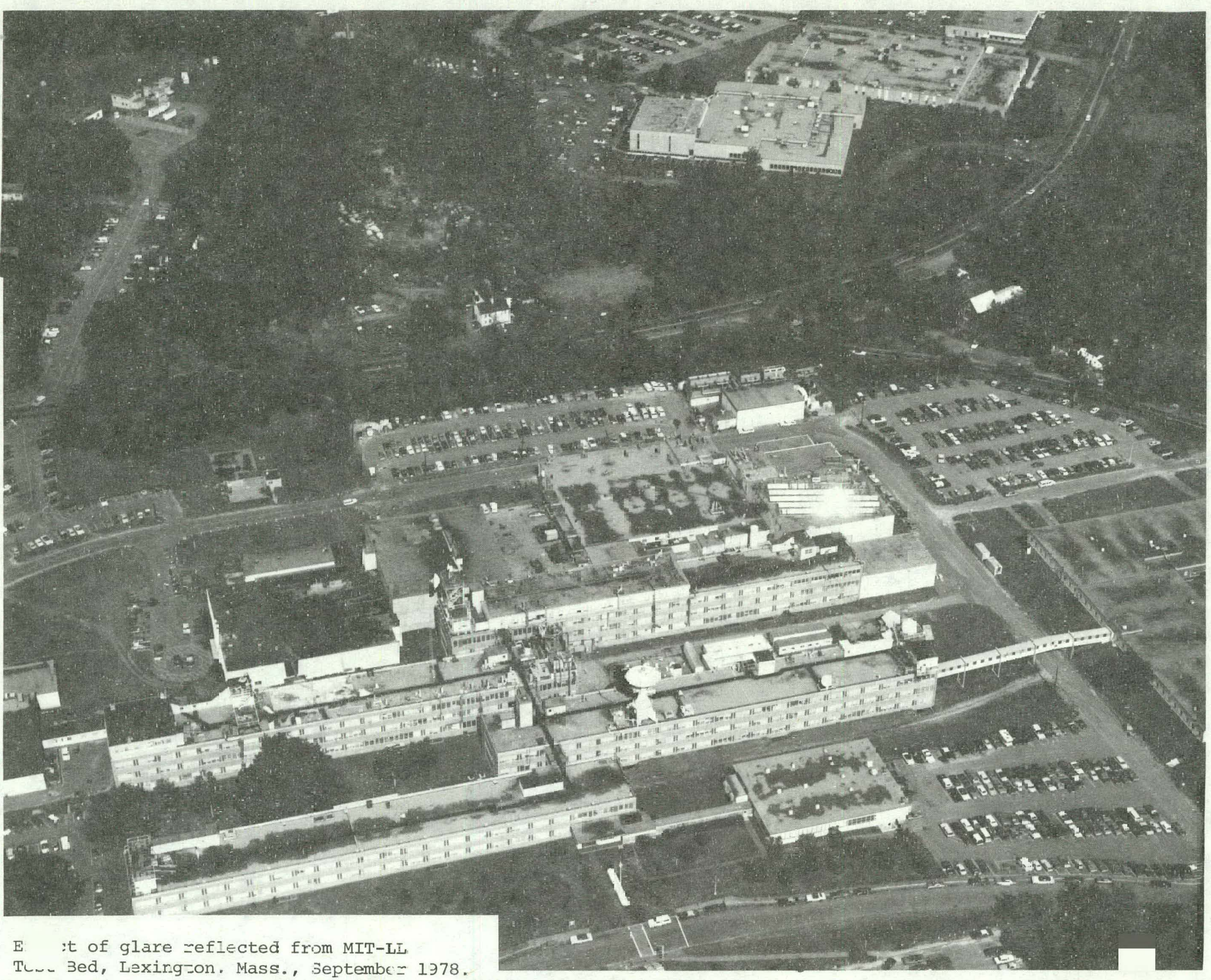




\begin{tabular}{|l|l|}
\hline ITION: Concord, Massachusetts & OPERATIONAL DATE: March 1978 \\
\hline USER AGENCY: MIT/Lincoln Lab & DESIGNER: MIT/Lincoln Lab \\
\hline
\end{tabular}

USE: System Level Testing (primarily residential)

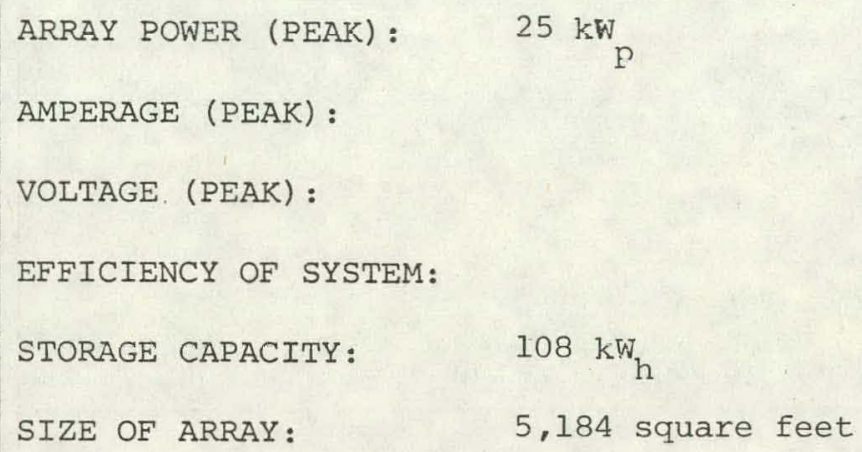

SPECIAL DESIGN FEATURES:

Flexible test facility capable of simple modification to test power systems of various igurations including utility interactive and stand alone systems. 
DATE :

CLEANING :

MODULE FAILURES (if any):

SYSTEM DEGRADATION (if any):

SPECIAT NOTES :
TIME SINCE INSTALLATION:

DATE :

TIME SINCE INSTALLATION:

CLEANING :

MODULE FAILURES (if any):

SYSTEM DEGRADATION (if any):

SPECIAL NOTES:

DATE :

TIME SINCE INSTALLATION:

\section{CLEANING :}

MODULE FAILURES (if any):

SYSTEM DEGRADATION (if anY):

SPECIAL NOTES: 


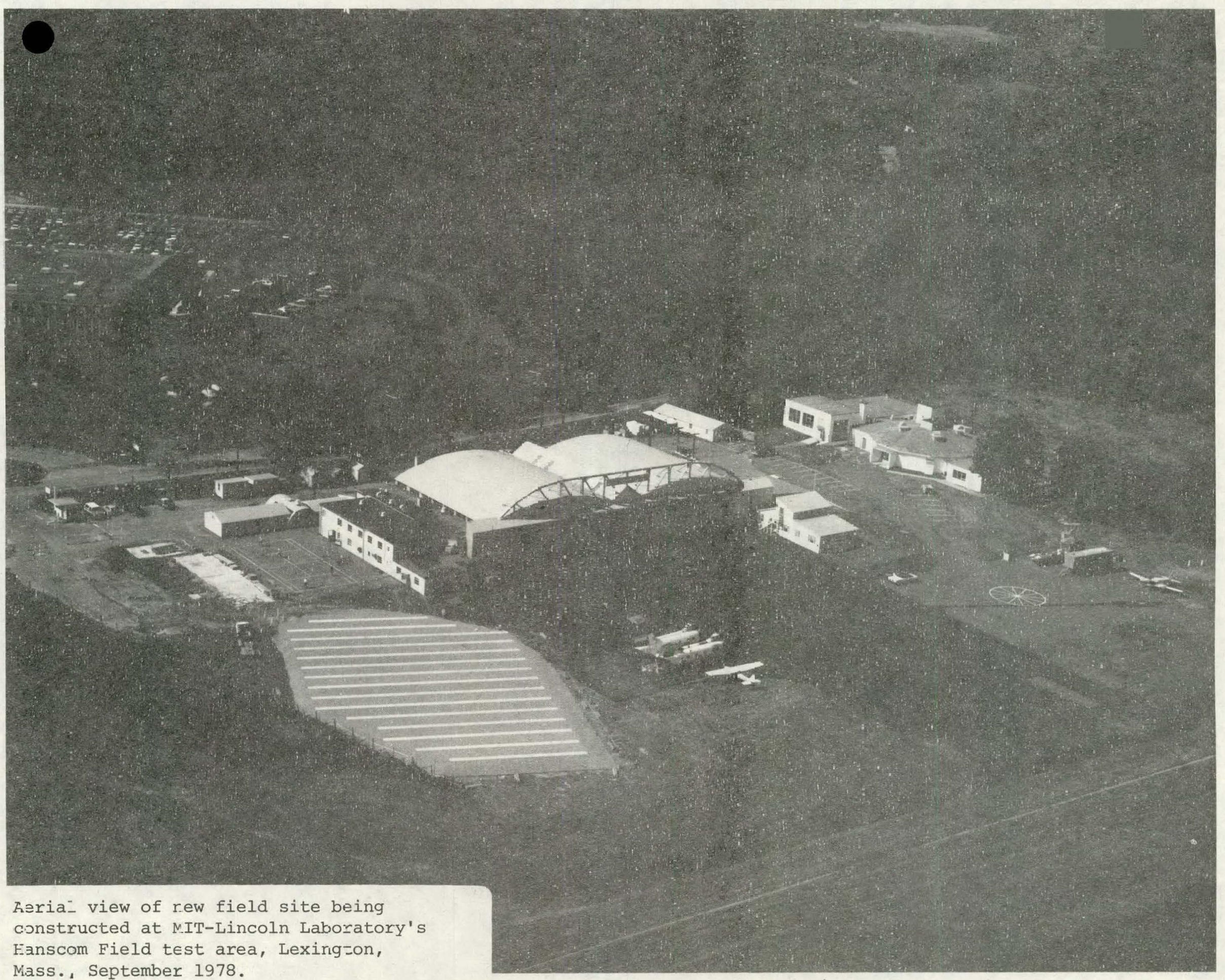




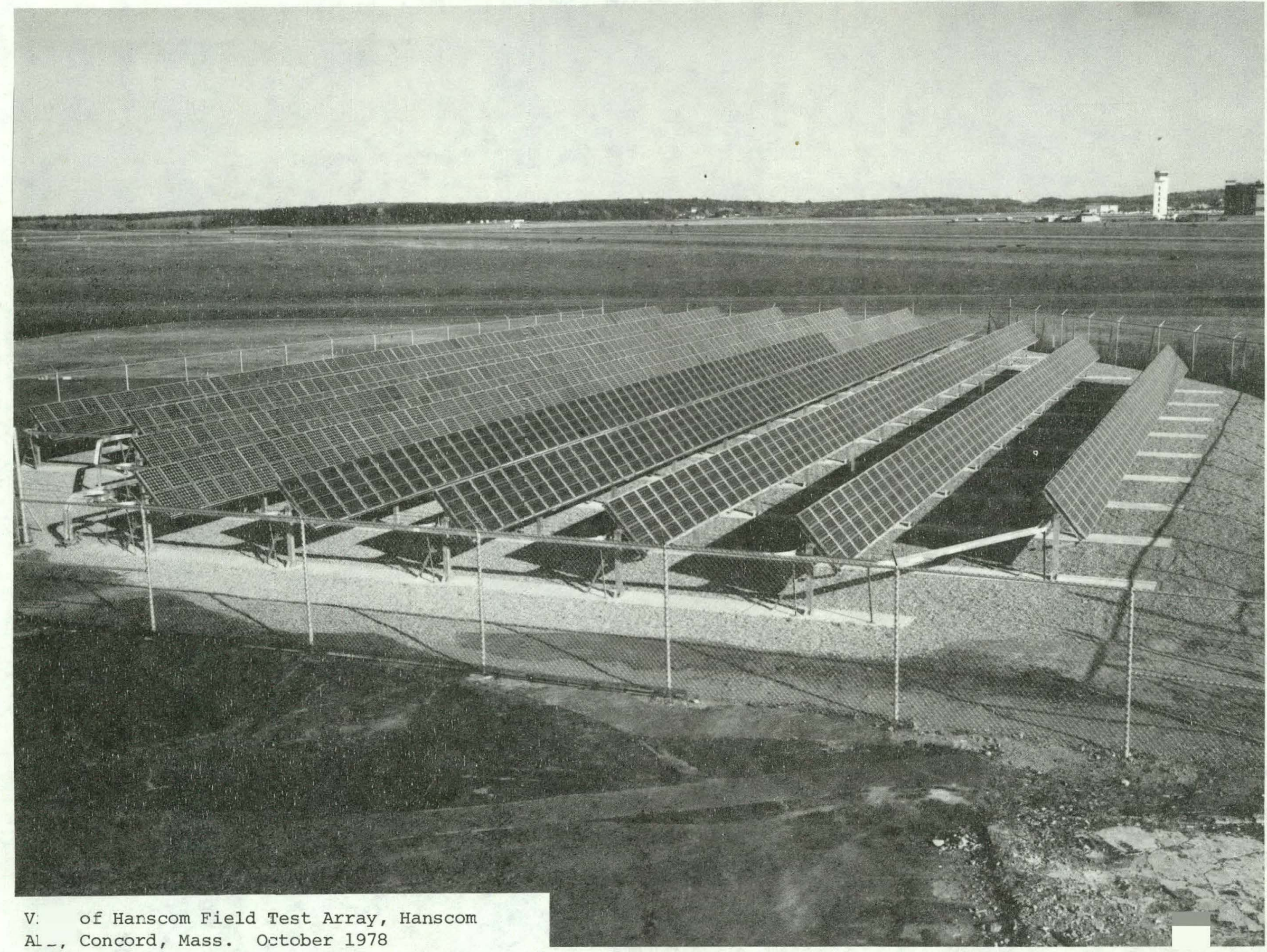


The MIT/Lincoln Laboratory PV Test Facility is being used to test resiciential-size components and loads. This test facility comprises two sectiors: the Component Test Facility (on residence), and the Systems Test Facility (Hanscom Field). The basic ojbectives of these two facilities are different with the Component Test Facility being used to test subscale models of control logic schemes as well as to develop, measure, and characterize the performance of power handling and conversion components, both advarced and off the shelf. The component Test Facility will be used, for example, to obtain performance data on advanced flywheel energy storage systems which promise technical and economic parity with battery storage for residential PV systems. After the unit is measured and characterized, it will be moved to the Systems Test Facility for interfacing and testing in conjunction with an "all-up" PV power system.

The objectives of the Systems Test Facility at Hanscom Field are directed more at evaluating the performance of complete photovoltaic power systems, for example, utilizing advanced components which were developed, evaluated or characterized in the Component Test Facility. The flexibility of this test bed will permit simulation of various sizes and types of residential power systems ranging from a single mobile home or house to a four- or five-family complex. Domestic appliances will serve as loads with special emphasis on devides such as television and radio receivers which may be sensitive to variations in the standard $60 \mathrm{~Hz} \mathrm{AC}$ waveform, and on large loads such as electric stoves and dryers which would place maximum strain on the arrays, batteries and inverters. The testing will also involve hybrid (thermal plus electric) collectors operating in conjunction with a variety of energy conversion devices including heat pumps and air conditioners. 


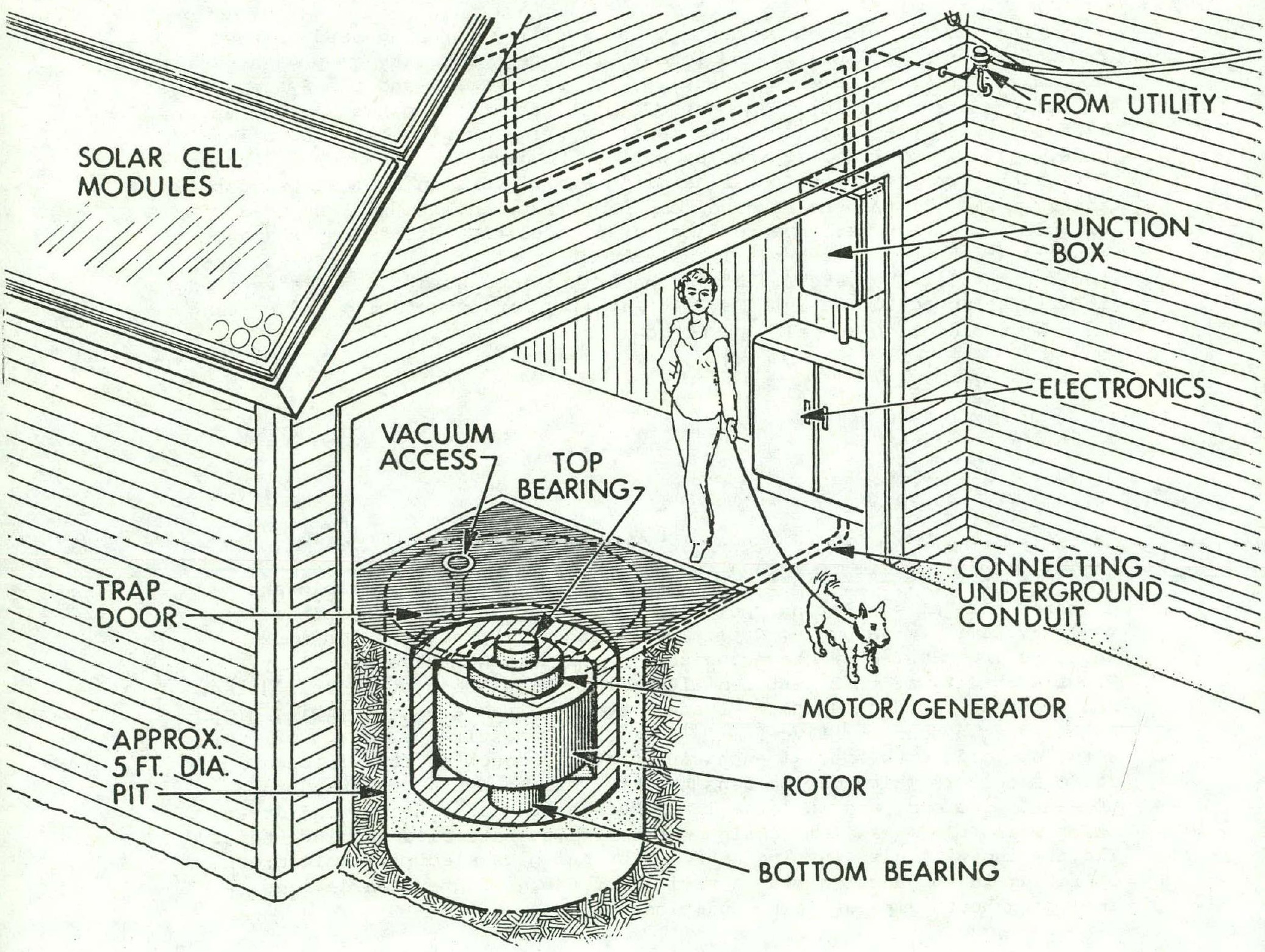

Flywheel Energy Storage System 

LOCATION: Lewis Research Center
Cleveland, Ohio
OPERATIONAL DATE: November 1976

DESIGNER: NASA Lewis Research Center

USE: A national facility for testing experimental photovoltaic systems, subsystems and components.

ARRAY POWER (PEAK) :

AMPERAGE (PEAK) :

VOLTAGE (PEAK) :

EFFICIENCY OF SYSTEM:

STORAGE CAPACITY;

SIZE OF ARRAY:

NUMBER OF MODULES :

MANUFACTURER OF CELLS:

COMPOSITION OF CELLS:

LOAD :

TRACKING SYSTEM TYPE:

DECLINATION SETTING:

INSTALLED SYSTEM COST:

COMPONENT COST:
$10 \mathrm{~kW}$ presently installed ( $30 \mathrm{~kW}$ by mid-1979)

variable, depending on array configuration

variable, up to $300 \mathrm{~V} \mathrm{DC}$

$48 \mathrm{~kW}_{\mathrm{h}}$ lead-acid type batteries (space for $500 \mathrm{~kW}_{\mathrm{h}}$ )

$10 \mathrm{~kW}$ comprises 2 rows of $30,4^{\prime} \times 8^{\prime}$ panels. Total field has a capacity for 8 rows.

Presently 120 Solarex; 644 Sensor Tech; 342 Solar Power

Solarex, Solar Power, Sensor Tech (Block I)

Silicon

Load banks (resistive and reactive) and experimenter provided loads.

Non-tracking variable tilt angle between $5^{\circ}$ and $85^{\circ}$. Array orientation has been established at an optimum angle of $37^{\circ}$ after testing alternative orientations. However, array is set at 410 (latitude angle) for ease of performance calculation.

Design, construction and operation through October 1978: \$1,130 K (not including module cost).

\section{SPECIAL DESIGN FEATURES:}

- The control room houses instruments, data system and power conditioning components (inverters, transformers, etc.)

- Minicomputer system installed with capability of real time display of 16 different parameters. Output available in either millivolts or engineering units on control room CRT display or printed hardcopy.

- Data System: 160 channel data logger, expandable to 1000 channels. 


\section{SYSTEM PERFORMANCE MEASUREMENTS}

A variety of tests have been performed in the STF. These have included:

a. Array transient and shadow effects for MERADCOM.

b. Verification of a module power measurement procedure (NOCT) for JPL.

c. Tests of the Papago Village Power System for Schuchuli, Arizona.

d. Tests of the Upper Volta Power System for the village of Tangaye, U. $\mathrm{V}$.

e. Tests of concepts for system voltage regulation using array string switching.

f. Load sharing with utility power using a line commutated inveter.

9. On-going operating history of the STF array under the daily and seasonal environmental conditions of the local climate.

Results of tests are documented in Project Office or published reports. 
The STF array and associated data system provides a means for obtaining long-term operating history under a variety of environmental conditions. One of these conditions is snowfall. The array output was found to increase up to $6 \%$ due to reflection from a snow field in front of the array. Conversely, a $1 / 4$ inch layer of snow on the array can reduce the output by up to $90 \%$. The depth of snow accumulation and percent of module coverage is a function of the snow type, wind conditions, module surface, and panel tilt.

Snow was found to adhere more to the epoxy-glass substrate modules than to the aluminum substrate modules, even though both types used a silicone rubber encapsulant. The array, for all of these observations, was maintained at an angle of $41^{\circ}$ to the horizontal. From the preliminary data obtained, panel tilt angles greater than $40^{\circ}$ are desired to facilitate self cleaning of the array.

There was no observable damage to the STF array during the blizzard of January 26-27, 1978 (the most intense blizzard in the area for decades during which winds up to $82 \mathrm{mph}$ were recorded). Even during this blizzard the array produced about $20 \%$ of its normal peak power.

The effect of dirt on the solar cell modules was very dependent on the construction of the module cover.

The modules have been exposed to the Cleveland environment for periods ranging from 17 to 24 months. The deterioration of the array has been monitored by physical inspection and electrical measurement. Degradation of the electrical output of the array of approximately $13 \%$ occurred during the first 14 months of array operation. At this point the array was washed resulting in a recovery of about $6 \%$. In the 10-month period since washing, a further power decrease of about $13 \%$ has been experienced.

Delamination has been noted in a majority of the modules. The major delamination has been around the edges of the modules with only a small portion showing delamination over the cells. Cracked and/or hot cells have been noted in approximately 20 modules (approximately $2 \%$ of installation). This cracking has occurred since initial installation and seems to be more pronounced in the last 6 months. Only two modules have failed to an open condition. 


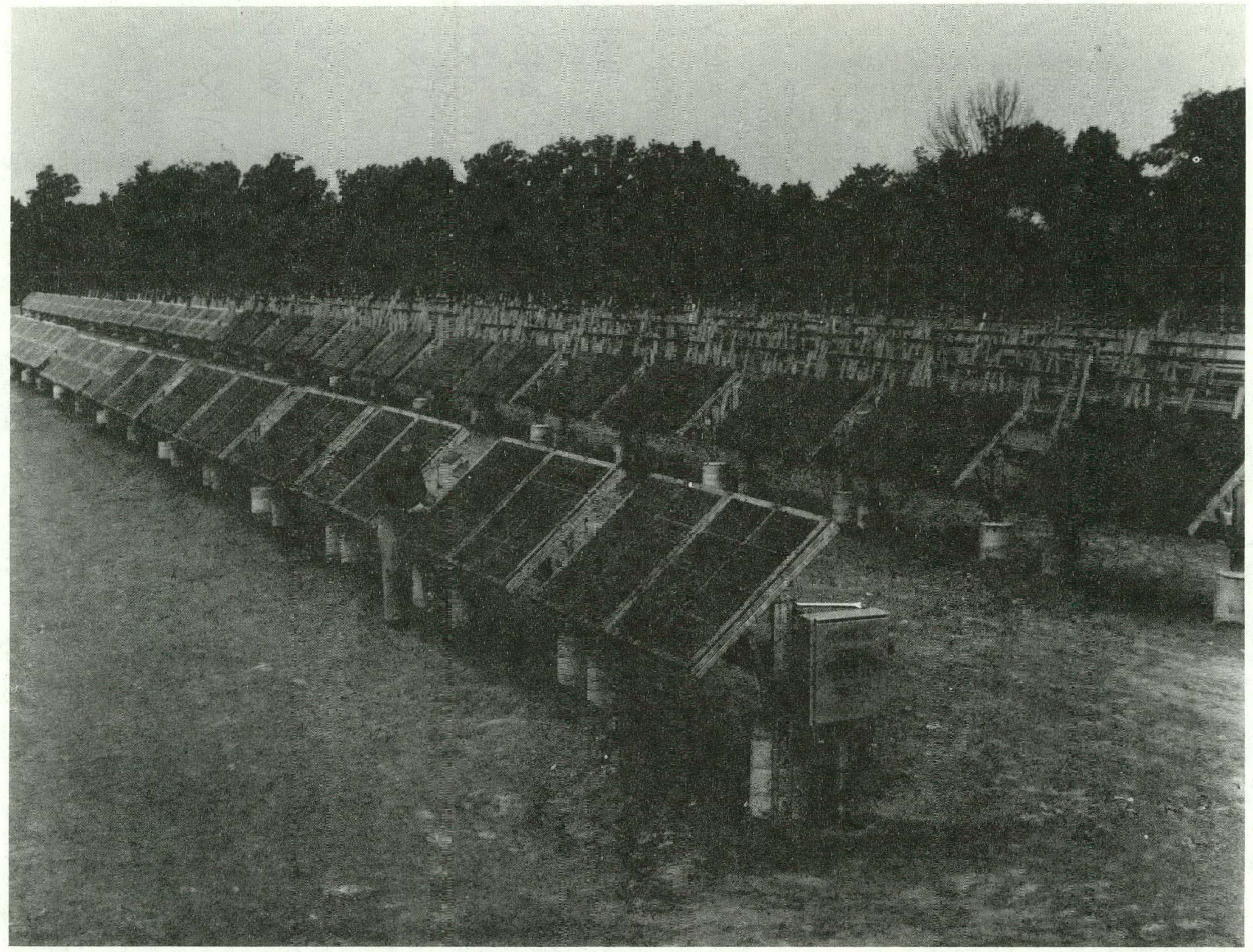

System Test Facility (STF) at NASA Lewis

-search Center, Clevelard, OH. 1977 
By replacing high-cost cell area with lower cost optical area, the cell cost in an array can be reduced significantly. Array cost will then depend on the cost of the sunlight concentrator, its support structure, and tracking mechanism. With this approach, low-cost concentrating devices are essential.

Developing low-cost sunlight concentrators for photovoltaic applications is being done by Sandia as a prime contractor to the DOE/Division of Solar Technology's Photovoltaic Program.

The objective of the concentrator Technology Development Project is to identify, develop, and evaluate sunlight concentrator designs, components, materials, and manufacturing processes that will lead to low-cost, commercially available sunlight concentrators for photovoltaic applications.

The Concentrator Technology Development Project consists of three tasks: Solar Concentrators; Concentrator Array Subsystems; and Concentrator Cell Technology.

Solar Concentrators

The Solar Concentrator Task has as its objectives identifying, developing, and evaluating concentrator designs, components, materials, and manufacturing processes that will lead to array production costs of $\$ 2000 / \mathrm{kW}$ by 1980 and to $\$ 500 / \mathrm{kW}$ in the late 1980s. New concentrating concept's are being sought and developed in a program that includes conceptual design, design optimization, production cost estimation, prototype fabrication, testing, and evaluation. Low concentration arrays, 2 to 10x, are being examined for potential use with low-cost silicon sheet or ribbon cells; medium concentration arrays; 10 to $100 \mathrm{x}$ are being pursued for near-term applications with silicon cells; and highconcentration arrays (100 to 2000x) are being developed for use with compound semiconductor cells and high-efficiency silicon cells. 
Concentrator Array Subsystems

The Concentrator Array Subsystems Task includes designing, optimizing, fabricating, testing, and evaluating full-sized arrays based on designs developed in the preceding task. The objectives of this task are to expose and solve problems associated with fabricating, testing, and operating fullsized, multikilowatt concentrating arrays. Procurement of these arrays will facilitate future array procurements by test and applications programs. Another important feature of this task is array testing and evaluation. Testing includes optical testing, accelerated lifetime testing, severe environment testing for array components and materials, and real-time continuous operation array testing to obtain performance data for the complete array subsystem over long periods of time.

\section{Concentrator Cell Technology}

Euncenllatur Cell Technology ic oonoornod with develnping silicon cells and advanced cells and conversion devices for use in concentrated sunlight. The objectives of this task are to investigate the performance potential of single-crystal silicon solar cells and compound semiconductor solar cells, such as single crystal gallium-arsenide cells, under high illumination and at elevated temperatures, to define cell structures and designs that optimize cell performance for various intensity and temperature conditions; to develop viable cell production methods; to establish commercial sources of reliable cells; and to develop new, high-performance potential conversion concepts. 


\begin{tabular}{|c|c|c|c|c|c|c|}
\hline \multicolumn{2}{|c|}{ Fabricator } & Size & \multicolumn{2}{|r|}{ Tracking } & Performance & Status \\
\hline Sandia & . & $\begin{array}{l}1 \mathrm{~kW} \\
12.6 \mathrm{~m}^{2}\end{array}$ & $\begin{array}{l}13512 \times 12-i n . \\
\text { point focus, } \\
\text { Fresnel lenses } \\
\mathrm{f}=1.0 \\
60 \times \text { concentration }\end{array}$ & $\begin{array}{l}\text { 2-axis, } \\
\text { azimuth-elevation } \\
\text { searchlight mount }\end{array}$ & $\begin{array}{l}7.2 \% \text { with cells at } \\
35^{\circ} \mathrm{C} \\
.\end{array}$ & $\begin{array}{l}\text { Presently testing } \\
\text { in actively cooled } \\
\text { mode. }\end{array}$ \\
\hline Argonne & - & $\begin{array}{l}140 \mathrm{w}_{2} \\
1.5 \mathrm{~m}^{2}\end{array}$ & $\begin{array}{l}\text { Tctal internal } \\
\text { reflection CPC } \\
8 \mathrm{x} \text { concentration }\end{array}$ & $\begin{array}{l}\text { Non-tracking, } \\
\text { seasonal adjust }\end{array}$ & $\begin{array}{l}10.3 \% \\
155 \mathrm{~W}\end{array}$ & $\begin{array}{l}\text { Panel experienced } \\
\text { severe degradation } \\
\text { in } 4 \text { mo. due to } \\
\text { moisture. This is } \\
\text { correctable. }\end{array}$ \\
\hline Argonne & $\cdot$ & $\begin{array}{l}100 \mathrm{w}_{2} \\
1.5 \mathrm{~m}^{2}\end{array}$ & $\begin{array}{l}\text { Reflective } \text { CPC } \\
9 \mathrm{X} \text { concentration }\end{array}$ & $\begin{array}{l}\text { Non-tracking, } \\
\text { seasonal adjust }\end{array}$ & $\begin{array}{l}7.18 \\
107 \mathrm{~W}\end{array}$ & $\begin{array}{l}\text { Panel has been } \\
\text { operating for } 7 \text { mo. }\end{array}$ \\
\hline $\mathrm{RCA}$ & . & $\begin{array}{l}300 \mathrm{w}_{2} \\
3.3 \mathrm{~m}^{2}\end{array}$ & $\begin{array}{l}4 \times 4 \text { in. Fresnel } \\
\text { lenses, } 300 x \\
\text { concentration }\end{array}$ & $\begin{array}{l}\text { 2-axis polar } \\
\text { tracking }\end{array}$ & $\stackrel{9 \%}{\cdot}$ & $\begin{array}{l}\text { Operational since } \\
\text { May } 1978\end{array}$ \\
\hline Boeing & & $\begin{array}{l}1-m \text { and } \\
2-m \text { models }\end{array}$ & $\begin{array}{l}\text { Parabolic dish } \\
\text { air pressure } \\
\text { supported re- } \\
\text { flective film }\end{array}$ & $\begin{array}{l}\text { 2-axis, } \\
\text { aximuth-elevation } \\
\end{array}$ & $\begin{array}{l}83 \% \text { optical } \\
\text { efficiency }\end{array}$ & $\begin{array}{l}\text { Concentrators have } \\
\text { been fabricated. } \\
\text { Laser and solar } \\
\text { simulator tests run. }\end{array}$ \\
\hline Owens-Il] & inois & - & $\begin{array}{l}\text { Lurinescent dye } \\
\text { embedded in } \\
\text { planar sheet }\end{array}$ & None & & $\begin{array}{l}\text { Under } \\
\text { development. }\end{array}$ \\
\hline Acurex & & & $\begin{array}{l}\text { "Headlamp } \\
\text { technology" } \\
\text { concentrator }\end{array}$ & 2-axis & . & $\begin{array}{l}\text { Under } \\
\text { development. }\end{array}$ \\
\hline $\begin{array}{l}\text { Accurex } \\
\text { Commerci }\end{array}$ & & & Parabolic trough & I-axis & & $\begin{array}{l}\text { Under } \\
\text { development. }\end{array}$ \\
\hline Sun Trac & & $\begin{array}{l}50 \cdot \mathrm{W} \\
0.77 \mathrm{~m}\end{array}$ & $\begin{array}{l}\text { Reflective cone, } \\
9 \mathrm{x} \text { concentration }\end{array}$ & $\begin{array}{l}\text { 2-axis, } \\
\text { azimuth-elevation } \\
\text { pedestal \& yoke. }\end{array}$ & $\begin{array}{l}6.5 \% \\
50 \mathrm{~W}\end{array}$ & $\begin{array}{l}\text { Commercially } \\
\text { available. }\end{array}$ \\
\hline
\end{tabular}


Photovoltaic Coricentrator Designs (Cont.)

\section{Fabricator}

Sun Trac

Commercial

Spectrolab

Commercial

Spectrolab

\section{Martin-}

Marietta

$\stackrel{\omega}{\infty}$

Honeywell
Size

8-ft diam.

$500 \mathrm{~W}$

$500-\mathrm{W}$

$1.28 \times 2.64-\mathrm{m}$

troughs

\section{$10 \mathrm{~kW}$ \\ $40 \quad 250-W$ \\ modules}

$9.2 \mathrm{~kW}$

272 lx4-ft

4 lens modules

$12 \times 12-i n$. Fresne
lenses, $f=1.5$

$60 \mathrm{x}$ concentration

Parabolic trough
$20 x$ concentration

2 -axis tracking.

horizontal platform

rotates for aximuth, trough's tilt for

elevation

\section{2 -axis}

rotation around

pedestal for axi-

muth, rotation

about horizontal

beam for elevation

$$
\begin{aligned}
& 10 \mathrm{~kW} \\
& \text { Field: < } 0.15 \\
& \text { acres } \\
& 7 \text { modules }
\end{aligned}
$$

\section{Glass mirror}

reflection

parabolic trough

\section{2-axis}

azimuth-elevation
Performance

\begin{tabular}{l} 
Performance \\
\hline $7.5 \%$ at $73^{\circ} \mathrm{C}$ cell. \\
$12^{\circ} \mathrm{C}$ ambient \\
$8.7 \%$ at cell.
\end{tabular}

\section{7\% at cell \\ temperature \\ $=41^{\circ} \mathrm{C}$}

ambient $=$

$.19^{\circ} \mathrm{C}$

$8.9 \%$

$11.1 \mathrm{~kW}$
Status

Under

development

Under

development.

Module delivered

to Sandia and

tested.

3.1×4-ft modules delivered to Sandia and

tested.

Under

development. 


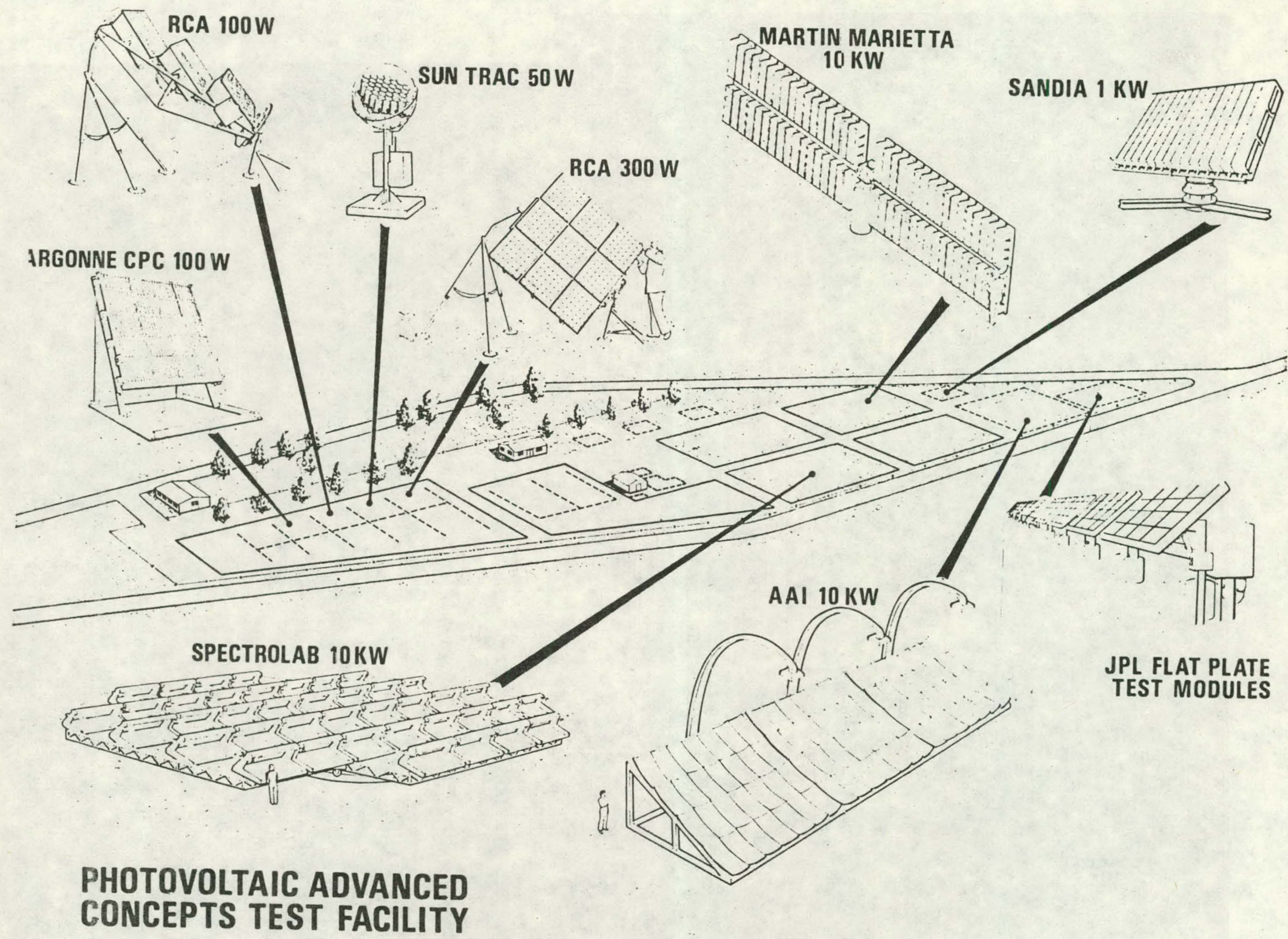




\section{I.}
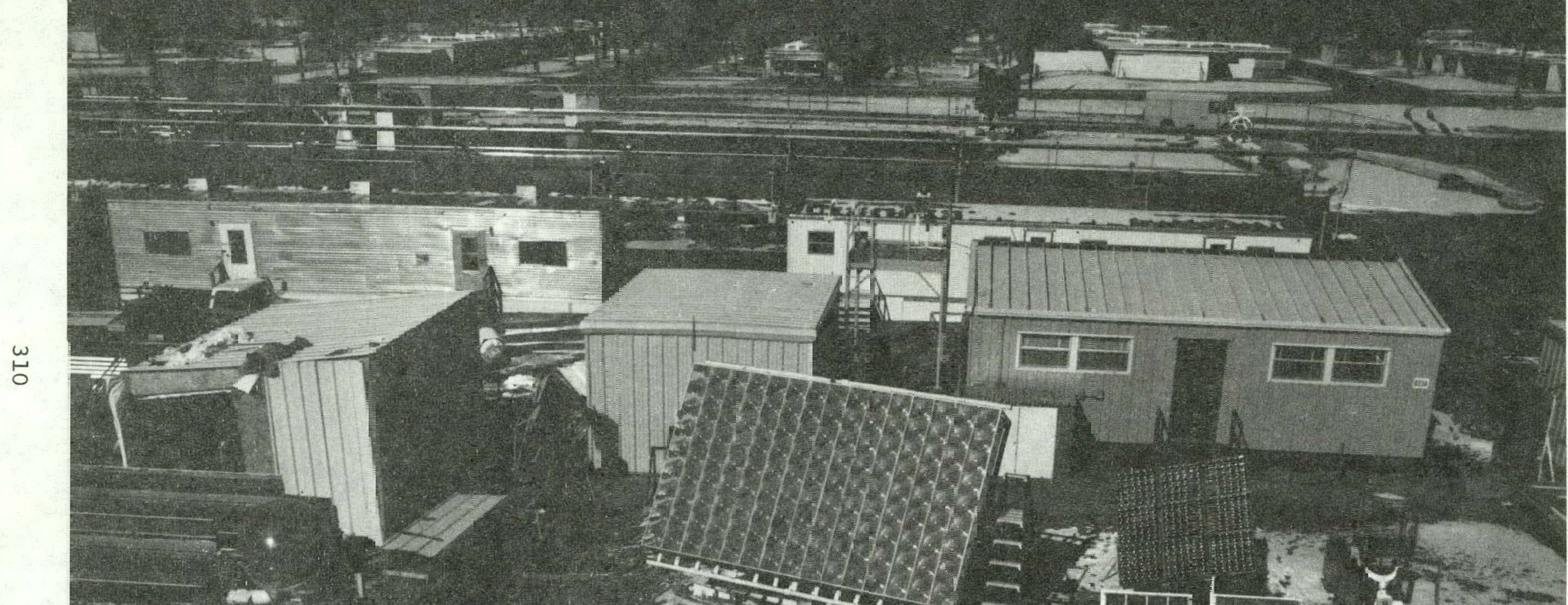

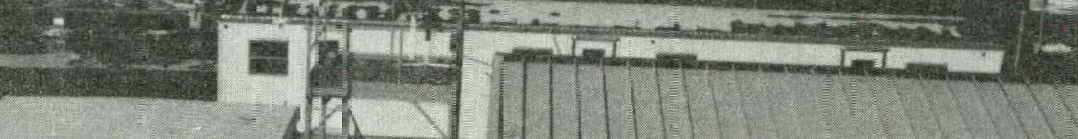

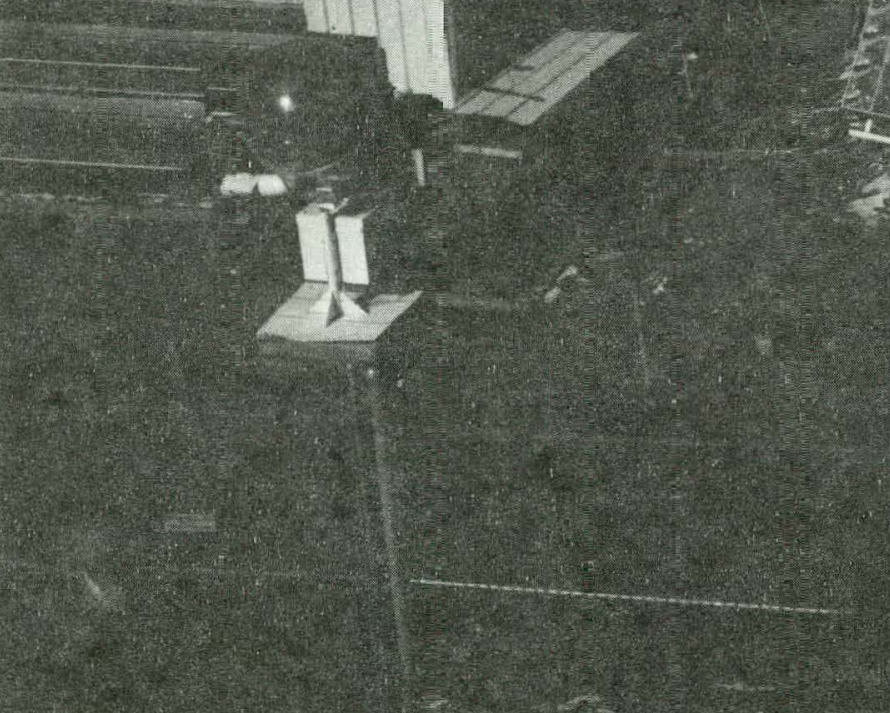


The opposite picture is an aerial view of Sandia's current test facility which illustrates their overcrowded conditions. To alleviate this problem, Sandia is presently constructing a new seven acre test facility on a different section of the laboratory. The new field will have the capability of holding an excess of $50 \mathrm{~kW}$ of arrays. Sandia currently has plans for $35 \mathrm{~kW}$ of arrays which are illustrated in the following pirture. They will have tho ability to dissipatc $50 \mathrm{~kW}$ of electricity and $200 \mathrm{~kW}$ of thermal energy by giving it to the utility grid on the base.

A special feature of the test facility will include $4.5 \mathrm{~kW}$ of JPL flat plate panels (Block III). The significance of this is that it will enable a side-by-side comparison of concentrators versus flat plate, non-tracking panels. 
The illustration of Sandia's new test facility is correct except for the AAI $10 \mathrm{~kW}$ concentrator. It will not be used. Instead, it will be replaced with an actively cooled $10 \mathrm{~kW}$ Honeywell optical concentrating parabolic trough.

Honeywell $10 \mathrm{~kW}$ Characteristics

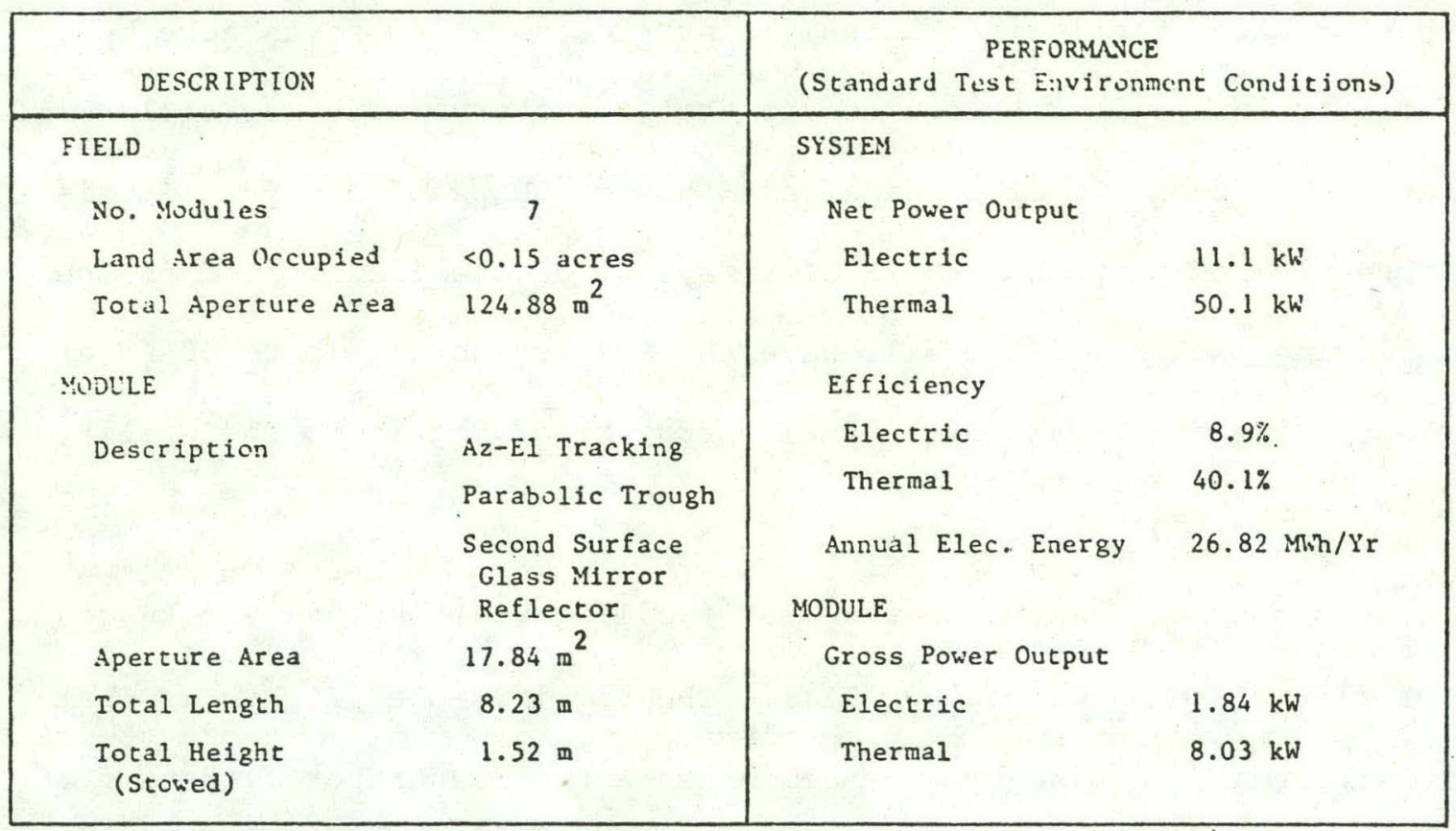

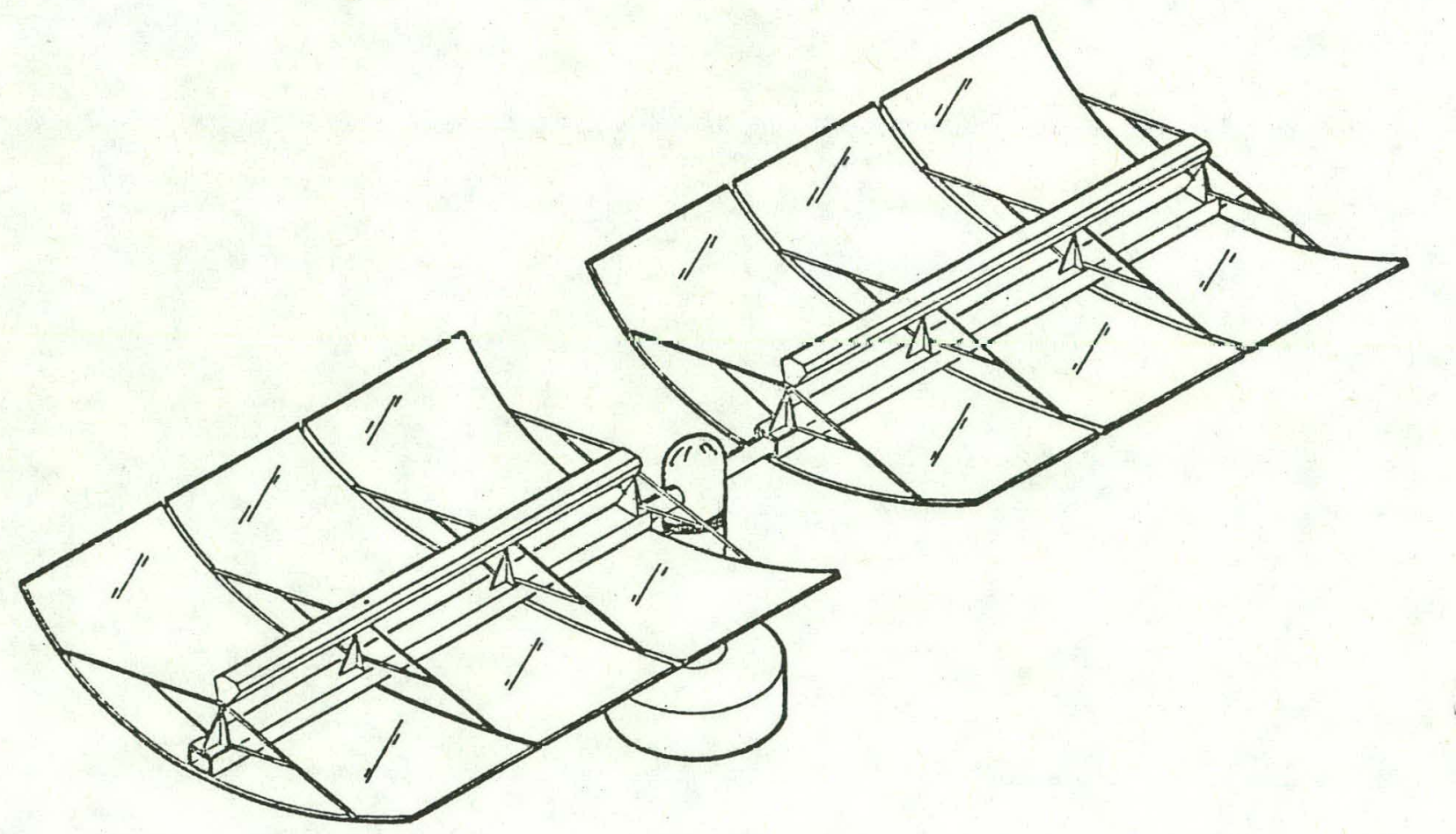




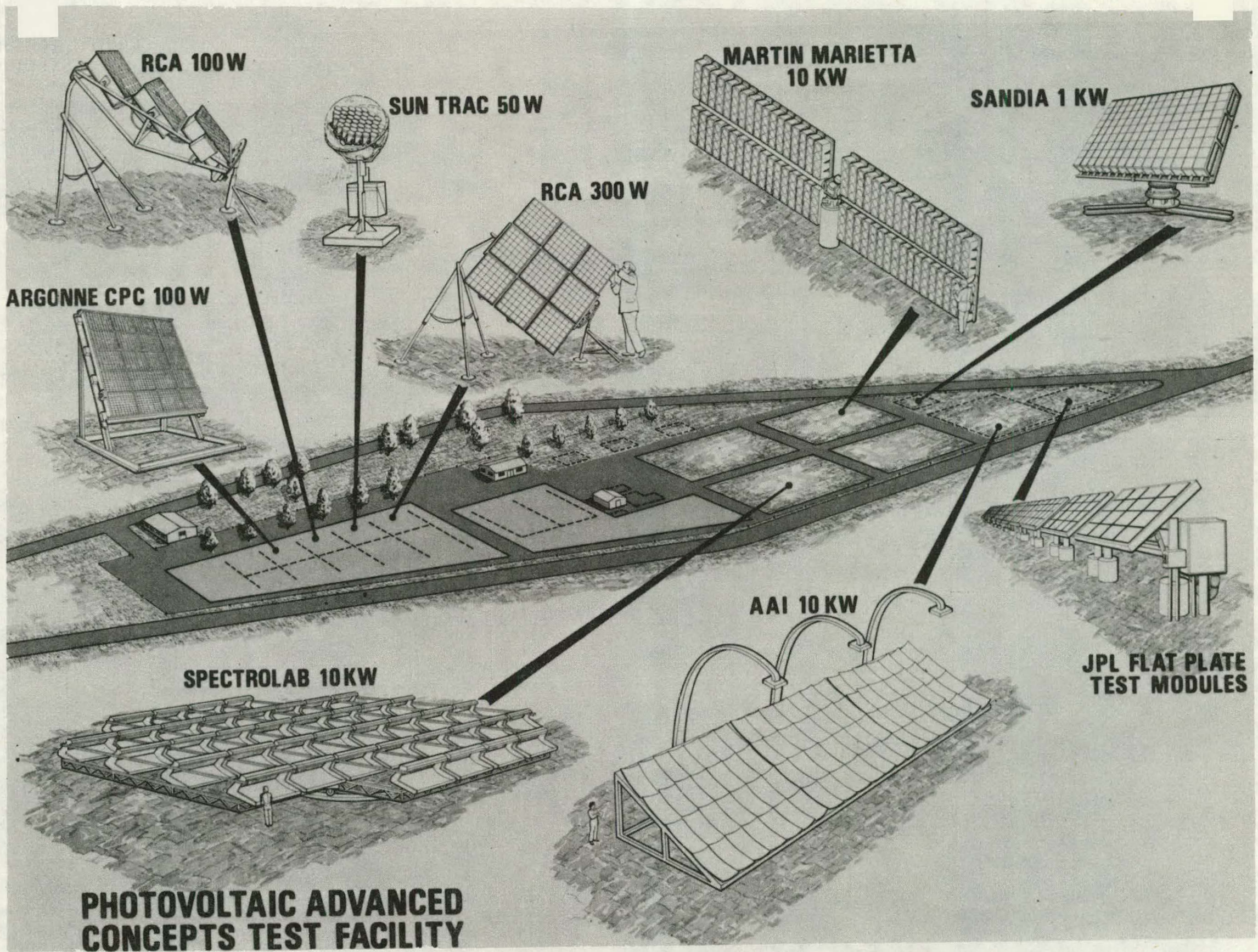




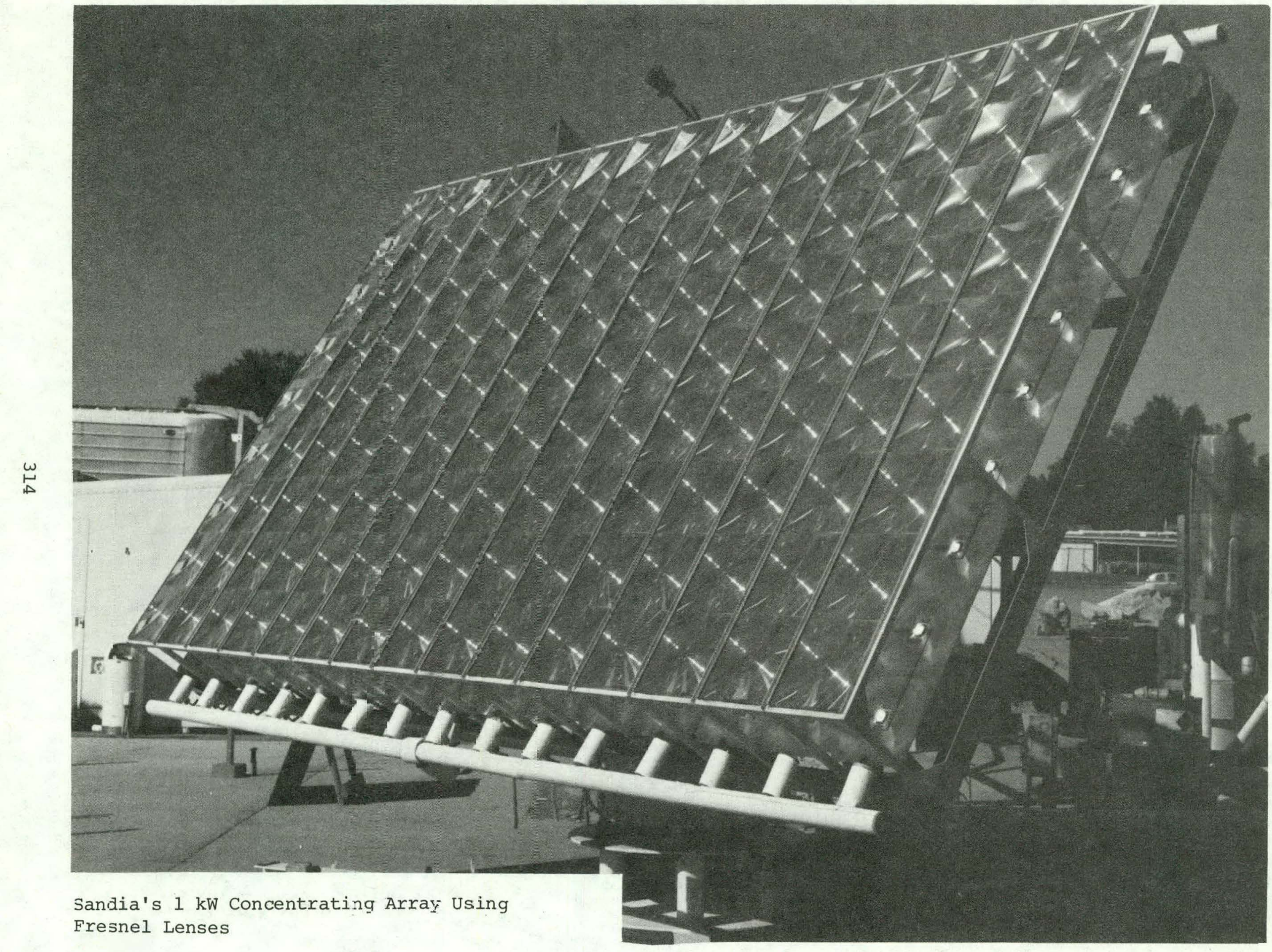




\section{SANDTA}

\section{1-kW Fresnel Lens Array}

Assembly of the 1-kW Fresnel lens array was completed in October 1976. The $12.6-\mathrm{m}^{2}\left(135-\mathrm{ft}^{2}\right)$ array produced only $506 \mathrm{~W}$ because of a high contactresistance problem with $20 \%$ of the cells in the array. One array section was refitted with cells and tested, indicating a projected power of $729 \mathrm{~W}$ without liquid or fin cooling. A new cell assembly has been devised that reduces thermal resistance between the cell and the aluminum substrate. The design conststs of soldering a cell to the pedestals on a copper block, which are formed by cross-cutting the block to a depth of $75 \mathrm{mils}$. The pedestals deform to relieve thermally induced stresses. The block is bolted by insulated attachments to the aluminum substrate with a thin sheet of Kapton between for electrical insulation. The $1-\mathrm{kW}$ array has been refitted with this cell assembly and tested with no active cooling and no fins. At a cell temperature of $135^{\circ} \mathrm{C}$, the array produces $900 \mathrm{w}$. The array is being tested in the actively cooled mode. 


\section{E. Opto-Technology SUNTRAK Array}

The SUNTRAK array from Opto-Technology, Inc. was purchased by Sandia Laboratories and received January 11, 1977. This concentrating array incorporates full two-dimensional tracking and battery storage. Housed in a clear acrylic sphere, it sits upright on a 4-inch diameter support pipe. The tracking and battery-charging electronics are contained in a weather-resistant box mounted on the side of the post.

The peak power output of the array (without battery storage) was approximately 40 watts in initial testing. Present-day output is estimated to be nearly the same as no visible degradation has occurred. Minor problems with inadequate strength of tracking motor gears initially plagued the system. However, retrofit gear motors sent by the manufacturer solved the problem. The array is functioning well as a system, but occasionally gets "lost" as a result of clouds and the large margin in tracking error. 


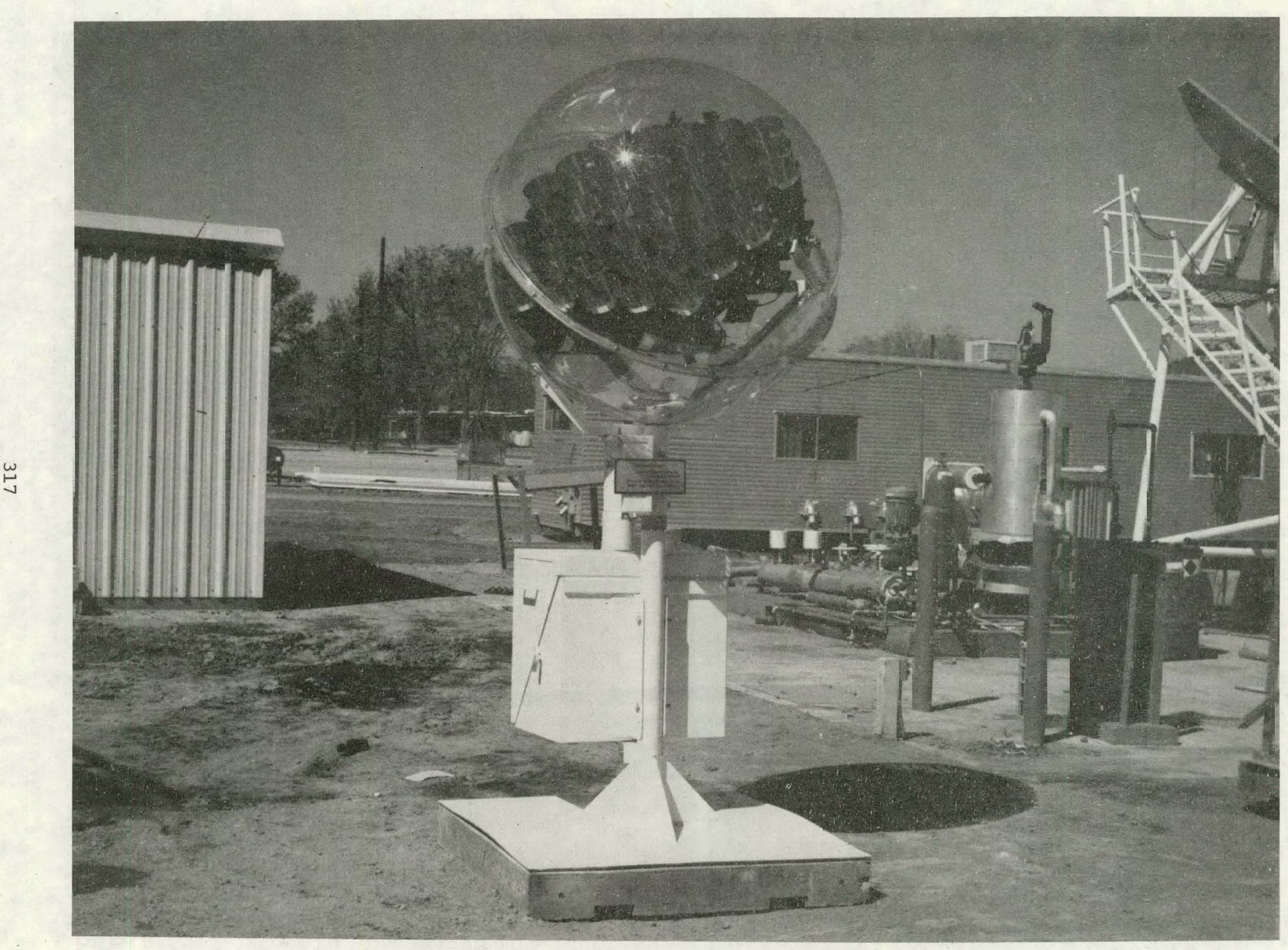

Sun Trac 50 Natt Concentrator Using Circular CPC Concentrators in an Aarylic Bubble 
One Spectrolab 250 Watt Module Which Comprises a $10 \mathrm{~kW}$ Off Axis Parabolic Concentrating Trough (40 Modules in total)

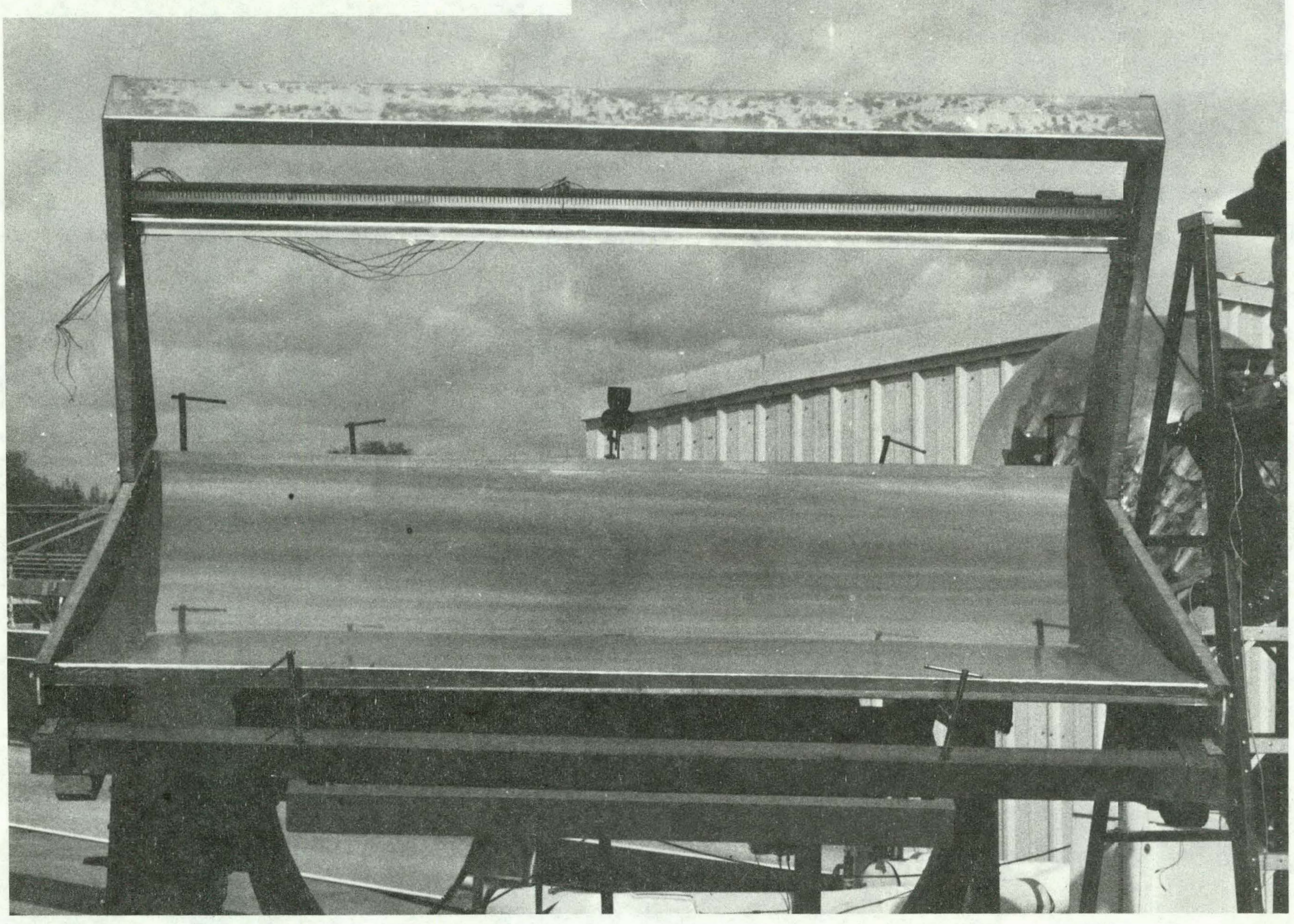




\section{SPECTROLAB}

\section{0-kW Off-Axis Parabolic Trough Concentrator}

Spectrolab's array design consists of $401.28 \times 2.64-\mathrm{m}$ off-axis parabolic troughs mounted on a turntable structure desinged by Ford Aerospace that turns to provide azimuth tracking. The troughs, which rotate for elevation tracking, direct sunlight to extruded aluminum compound elliptical secondaries that concentrate sunlight onto passively cooled linear strings of cells. A single $1.28 \times 2.64-\mathrm{m}$ optical/cell assembly prototype module has been delivered to Sandia and tested. The module produced $229 \mathrm{~W}$ with an illumination of $907 \mathrm{~W} / \mathrm{m}^{2} / \mathrm{s}$, an ambient temperature of $12^{\circ} \mathrm{C}$ and a wind speed of $1 \mathrm{~m} / \mathrm{s}$. The primary concentrator for this module is formed by adhering 2-in. box beams to the two long edges of a reflective-film-covered $0.060-i n$. steel sheet. The box beams are rotated, pushed together slightly, and clamped into two end frames to give the reflective sheet a parabolic shape. This primary concentrator did not provide a uniform image on the secondary cell and string, and design improvements are being investigated by Spectrolab.
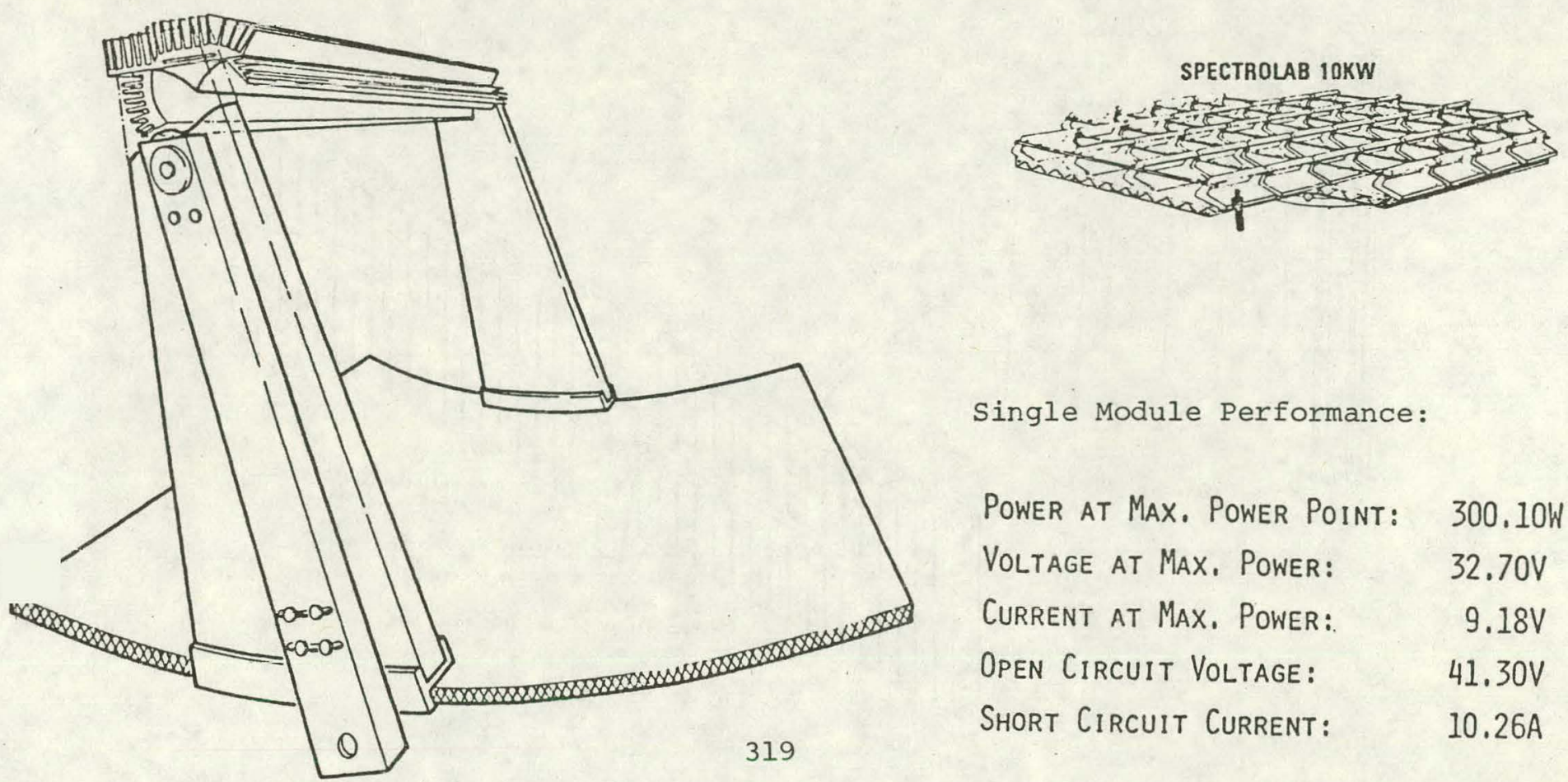

Single Module Performance:

Power at Max. Power Point: $300.10 \mathrm{~W}$ Voltage at Max. Power: $\quad 32.70 \mathrm{~V}$ Current at Max. Power: $9.18 \mathrm{~V}$ Open Circuit Voltage: $\quad 41.30 \mathrm{~V}$ Short Circuit CurRent: $10.26 \mathrm{~A}$ 


\section{Martin-Marietta}

\section{0-kW Fresnel Lens Array}

Martin-Marietta has adopted a module design containing four $1 \mathrm{x}$ 1-ft Fresnel lens with 2-in.-diam cell assemblies. The cell/lens assembly consists of a 1 x 4-ft four-plex Fresnel lens bonded to the opening of a 1-ftdeep vacuum-formed ABS box. OCLI cells are soldered to a metallized alumina substrate that is mechanically attached through the box to an extruded aluminum heat exchanger. The modules are mounted to a steel tube that is rotated about its axis for elevation tracking and is pivoted around a vertical support pedestal for azimuth tracking. Three lens/cell modules were delivered early in FY 78 and tested. The best of the three modules produces $31 \mathrm{w}$ with an illumination of $960 \mathrm{~W} / \mathrm{m}^{2} / \mathrm{s}$, an ambient temperature of $19^{\circ} \mathrm{C}$, and a wind speed of $3 \mathrm{~m} / \mathrm{s}$. The module's efficiency under these conditions was $8.7 \%$.
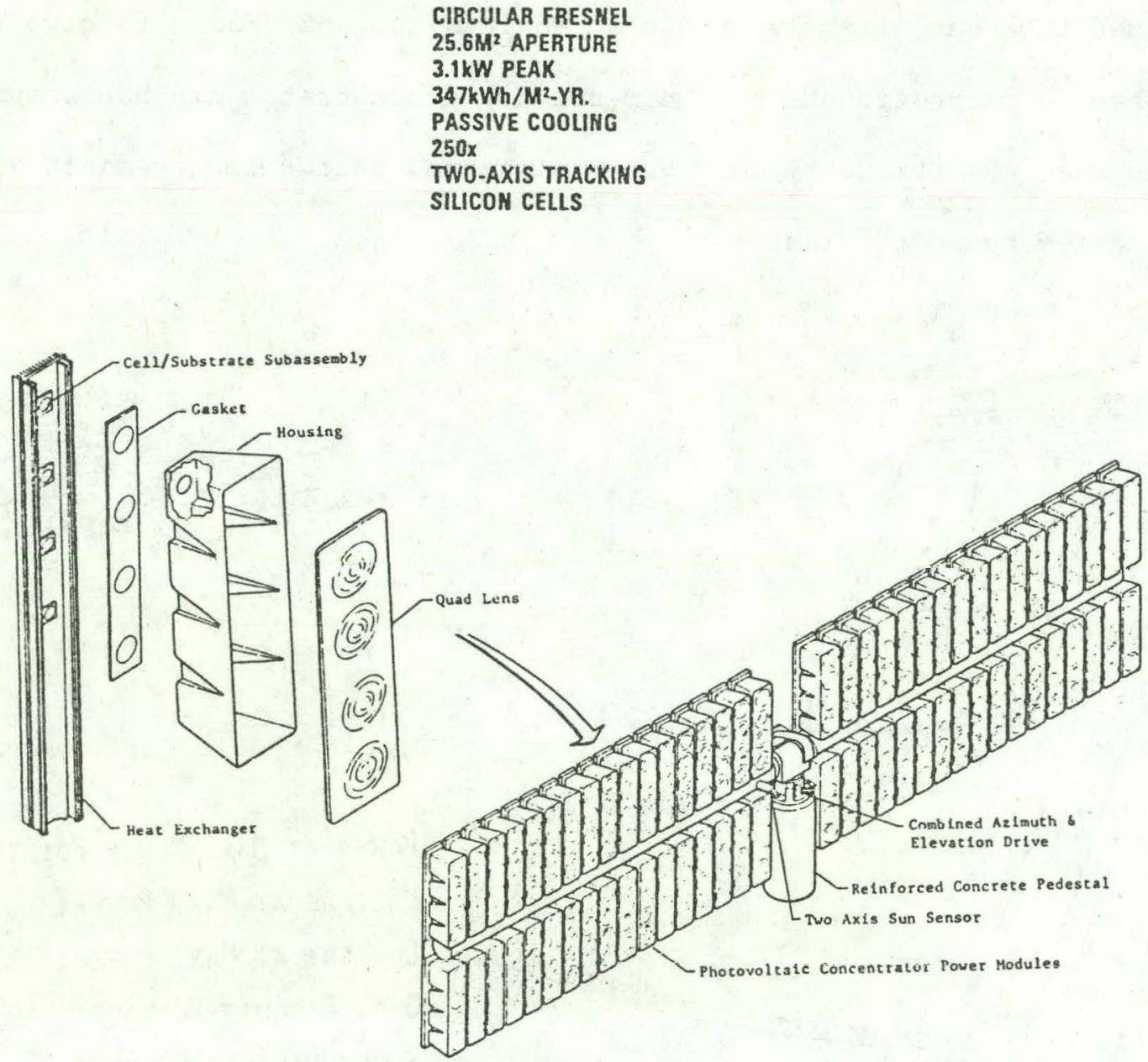
36 Watt Martin Marietta Module for their 2.5

$\mathrm{kW}$ Concentrator. Fresnell Refractive Lens

Concentrate on oCLI Cells (Optical Coating

Laboratories, Inc.)

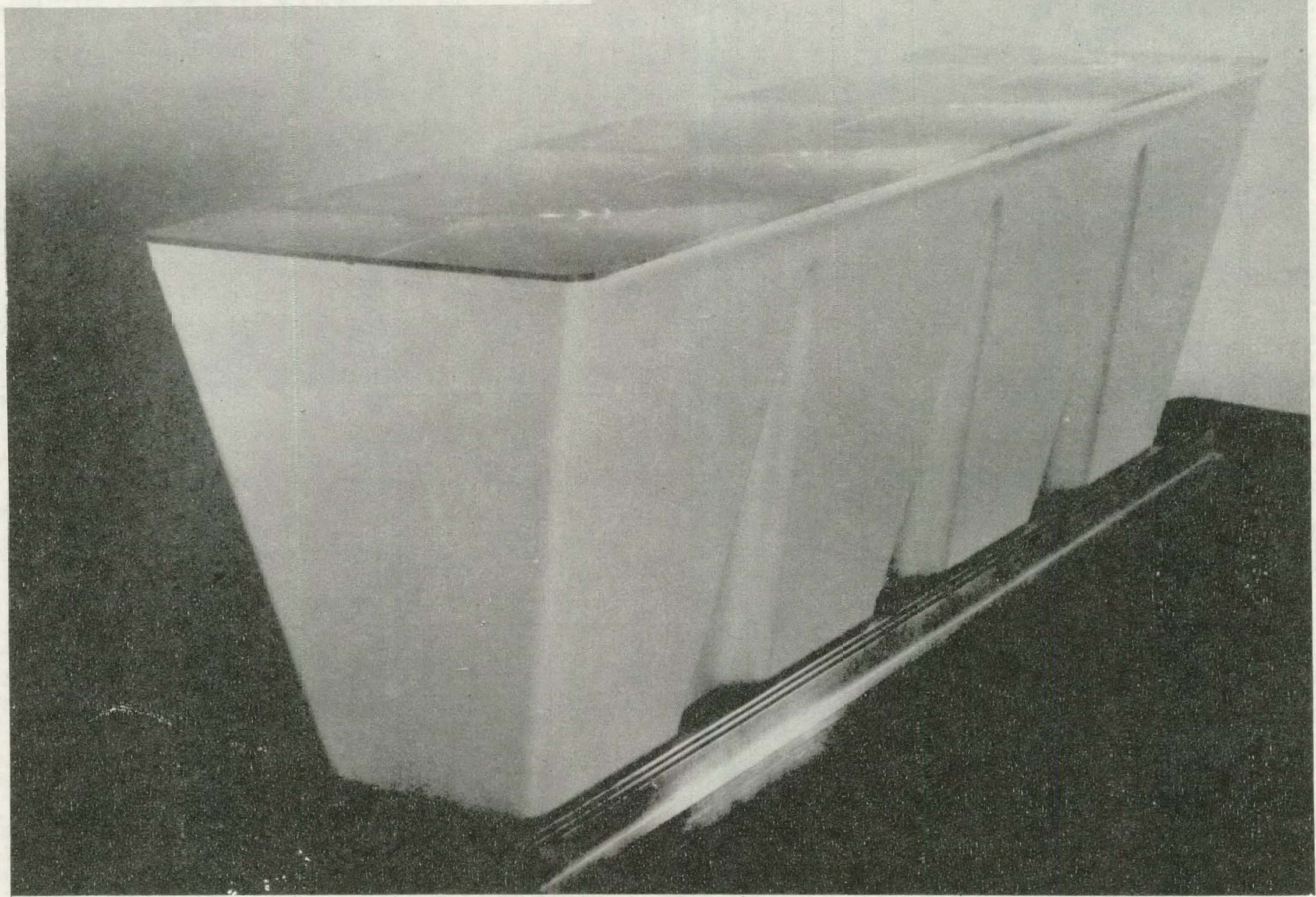




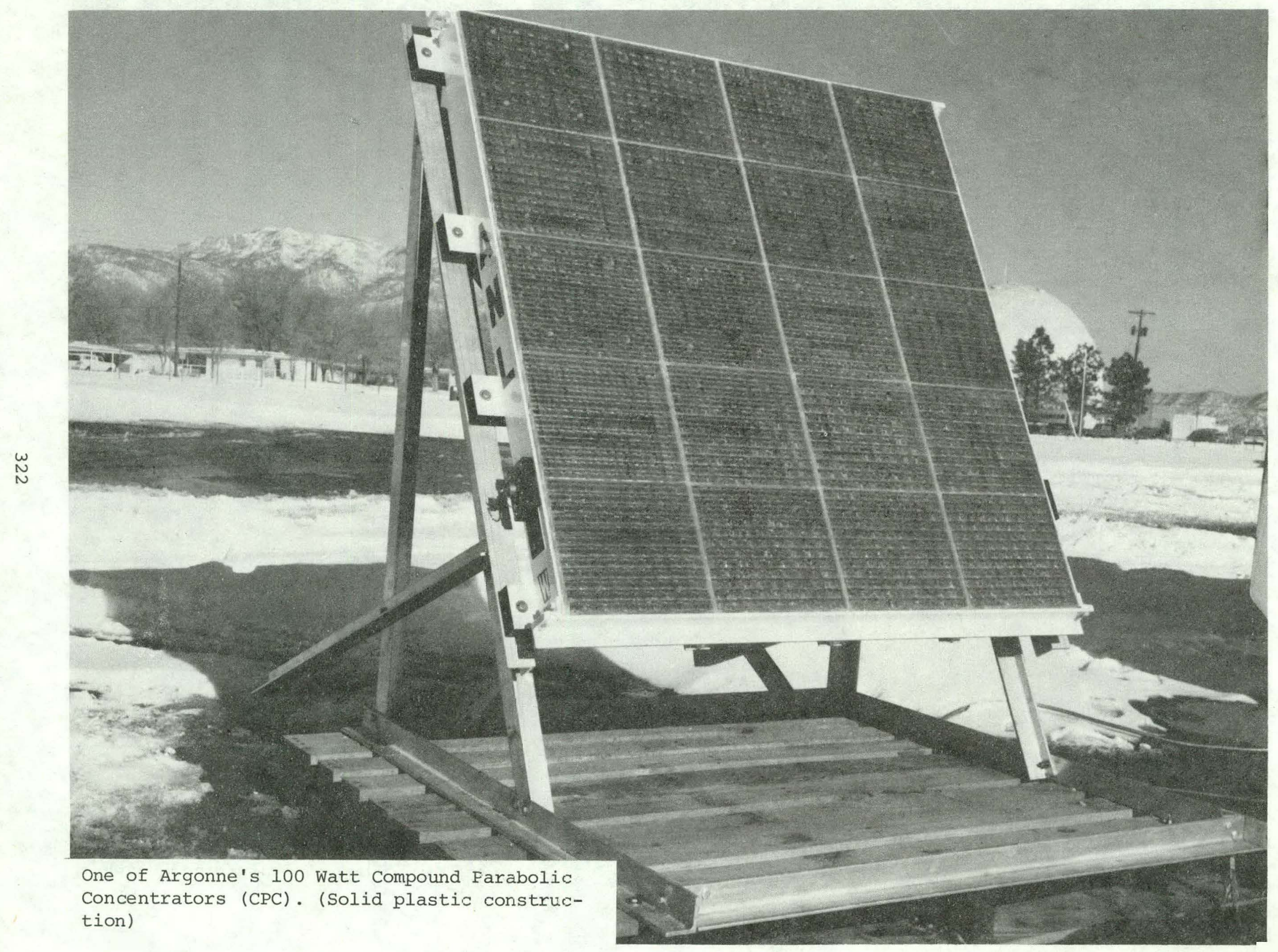




\section{Argonne Labs Dielectric CPC Collector}

Argonne National Labs delivered its dielectric compound-parabolic collector (DCPC) to Sandia Laboratories on December 17, 1976. Typical power output was rated at 100 watts; and this was proven to be the case when actual array evaluation began the first week in January, 1977. Power output reached a peak of 125 watts, resulting in an array efficiency of about 10 percent.

The DCPC array is approximately 48 inches square and mounted on a Sandia-designed framework. The frame allows the array to be reasonably adjusted to the correct tilt angle. The array consists of 20 modules, each having several rows of Winston-type concentrators.

Over the last six months, the performance of the DCPC array has deteriorated to a point where the output is only 50 percent of the initial output. Close examination of individual modules revealed excessive moisture and a general degradation of heat sinks, cells, and coupling between cell and lenses due to corrosion.

Present testing consists of individual module performance evaluation as a function of insolation, tilt angle and module temperature. The array will soon be returned to Argonne National Labs for a closer examination of the failure mechanisms. 


\section{Argonne Labs Hollow CPC Collector}

The Argonne Compound Parabolic Collector (CPC) was delivered on approximately February 2, 1977 and testing began February 24. Peak output power was measured to be 95 watts. The CPC array is similar in overall size to the DCPC array; however, it has only 16 modules. Mounted on duplicate framework, the CPC array has to be adjusted for tilt about twice as often as the DCPC due to the decreased acceptance angle of the hollow winston concentrating troughs.

The CPC array has also weathered poorly, and current output is approximately 50 watts peak. It has suffered from the same environmental effects as the DCPC concentrator, namely, condensation and corrosion. The CPC array is also undergoing extensive single module testing to examine performance at the end of the initial six-month period. 


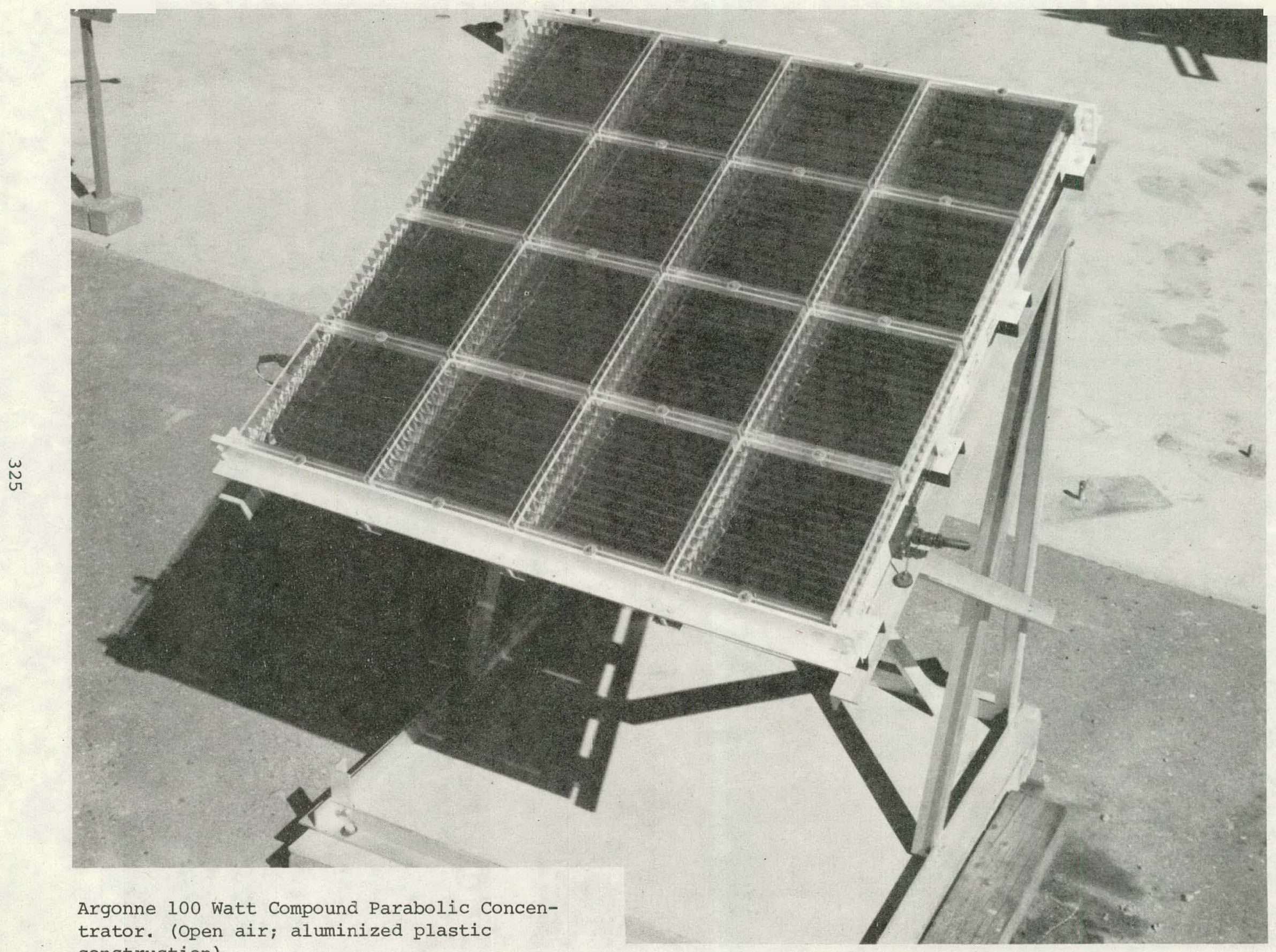
trator. (Open air; aluminized plastic construction) 


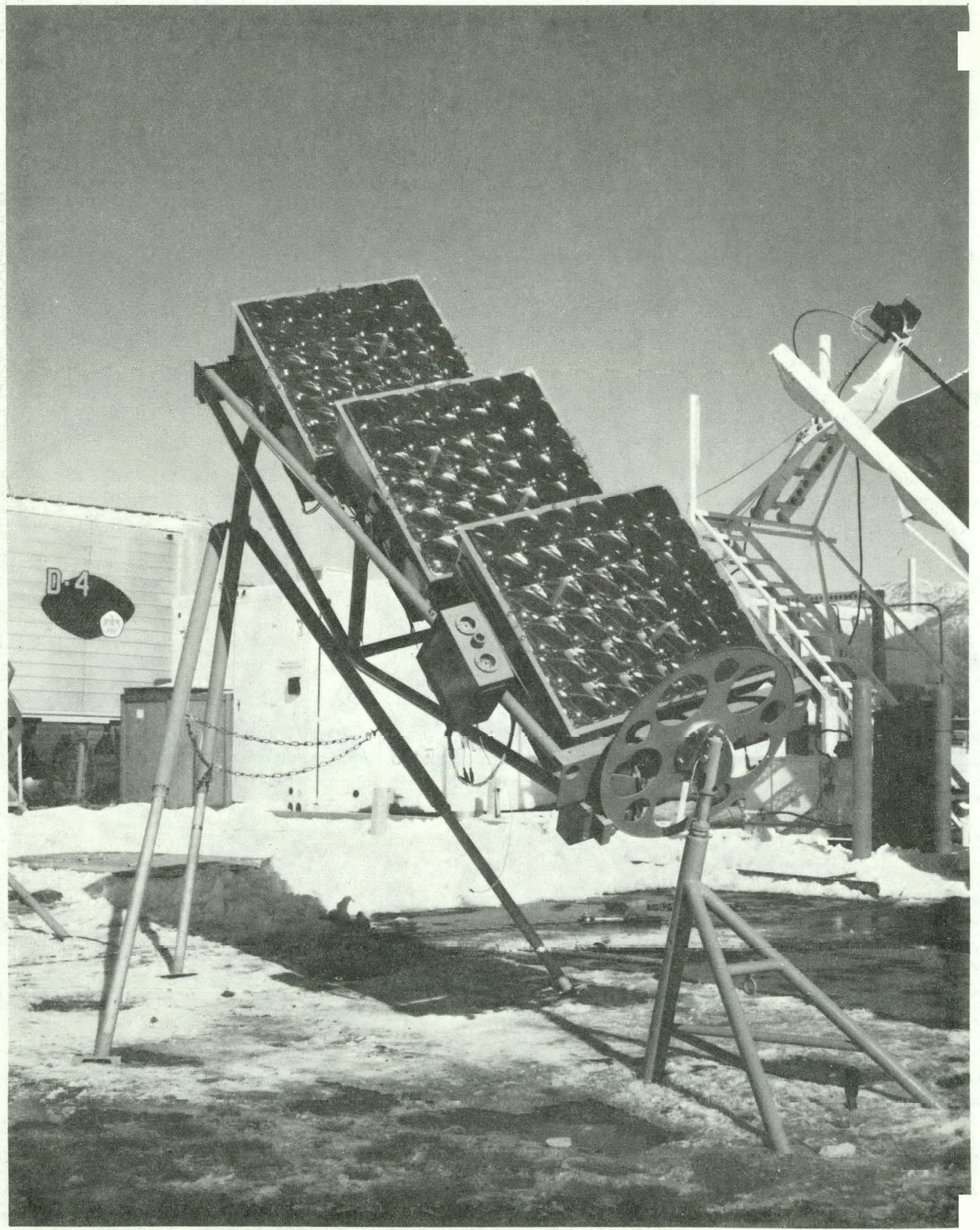

RCA 100 W Concentrating Array 


\section{决 100W Prototype Arrays}

The two prototypes of the RCA concentrating arrays were received and set up during the second week in January, 1977. Initial testing for voltage, current, and power output began approximately February 1. Although the arrays were nominally rated at 100 watts, actual output rarely exceeded $60 \%$ of that value. Difficulty in aligning individual cells was cited as a main obstacle in achieving maximum output.

One array consists of three modules, each with 36 cells and one multiple segment lens. The modules are mounted on a tubular frame supported on a polar axis by two tripods. The entire array is then electro-mechanically rotated about the axis at a speed approximately equal to that of the earth.

The CMOS tracking electronics has been relatively problem free; however, lack of encapsulation of the sensor cells caused deterioration and subsequent temporary failure of both arrays.

Recent testing indicated a decrease in power to approximately $25 \%$ of initial output power. Examination indicated three open cells, one each in three of the four parallel strings of solar cells. Loss of the solder joint between the back of the cell and the mounting plate caused the open circuit. Testing has also shown a general decrease in performance possibly due to several factors such as accumulation of dust, degradation of cells and plastic lenses, and general misalignment. 
300-W Fresnel Lens Silicon Cell Array

RCA has been under contract since May 1976 to design and fabricate fully operational high-concentration arrays using silicon cells. Their modules are $2 \times 2$-ft boxes, each containing $364 \times 4$-in. solid lenses that concentrate sunlight onto a 0.22-in.-diam cell mounted on a transistor heat sink that uses finned surface cooling. Three of the modules are mounted on an equatorial tracking frame made of tubular steel in their 100-W design, and nine modules are used in their 300-W design. The array's declination angle is adjusted three times daily using an active feedback tracker, and diurnal tracking is performed using a clock drive with an active feedback override.

RCA delivered their prototype concentrating array to Sandia Laboratories on July 22, 1977. Similar in structure and tracking methodology to the 100 watt units, this array was nominally rated at 300 watts. This has been the maximum to date. Average array output is near 200 watts. This array has nine modular sections arranged in a rectangular fashion as opposed to the three linear modules in the smaller arrays.

Being three times the size of the 100 watt units also magnifies other problems such as greater backlash in the rotational tracking mechanism. This condition leads to a fluctuation in peak power output over the course of the day. The array as a whole has been performing satisfactorily during the few months it has been operational. None of the problems the 100 watt arrays have been stricken with have affected the 300 watt array; nevertheless, it is not anticipated it will be entirely maintenance-free. 


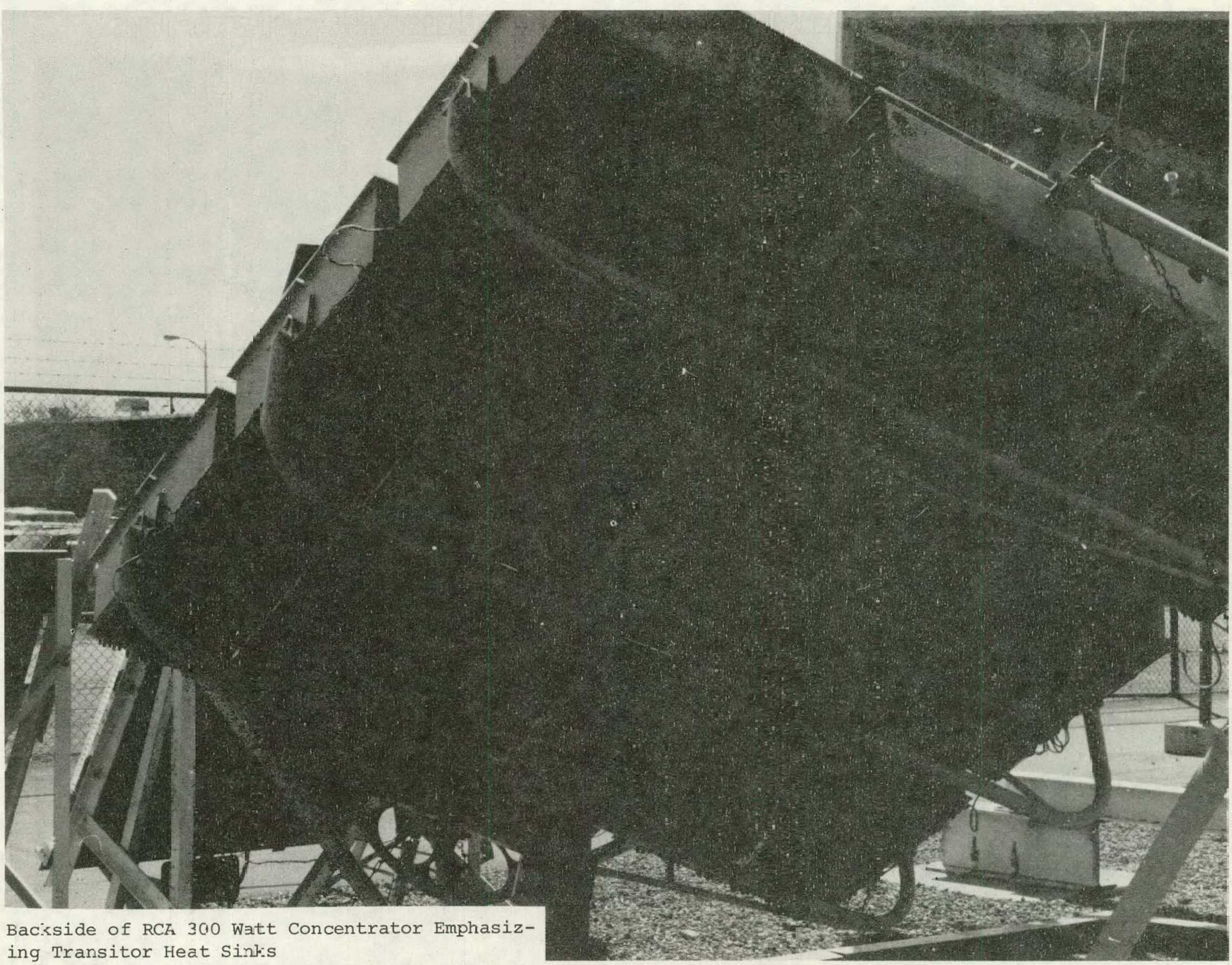




\section{(17) Sandia Laboıatories}

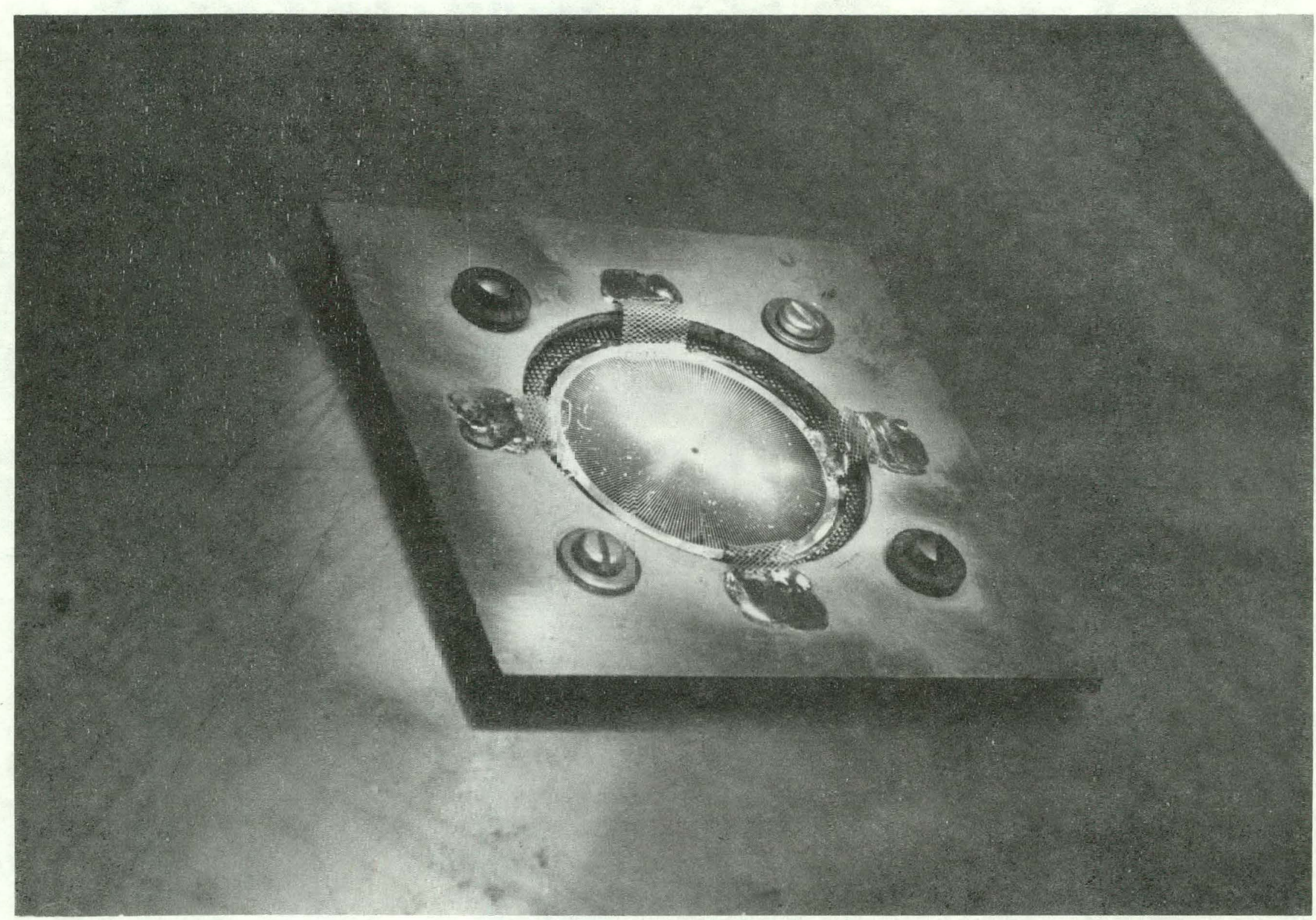

